\title{
Concurrentie, concentratie en rentabiliteit in de glastuinbouw in Nederland
}

Industrial Organisation

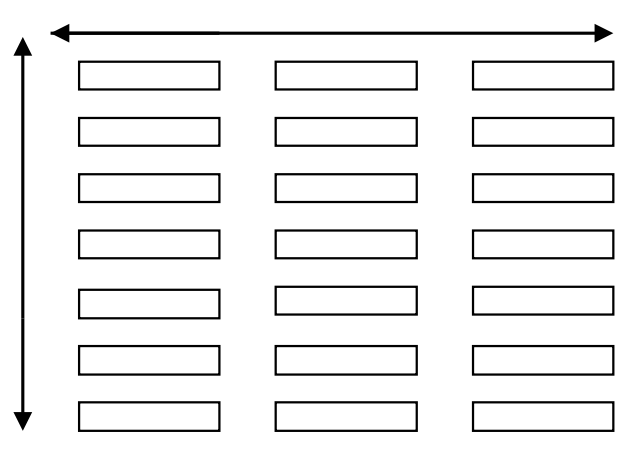

Drs. C.P. (Kees) Veerman 


\section{Promotiecommissie}

\section{Promotor}

Prof. dr. Olaf van Kooten

Hoogleraar Tuinbouwproductieketens

Wageningen University \& Research

\section{Overige leden}

Prof. dr. ir. R.B.M. Huirne, Wageningen University \& Research

Prof. dr. J.H.J.P. Tettero, Universiteit van Amsterdam

Prof. dr. C.P. Veerman, Wageningen University \& Research

Prof. dr. ir. L.C. Zachariasse, Wageningen University \& Research

Dit onderzoek is uitgevoerd binnen de C.T. de Wit Graduate School for Production Ecology and Resource Conservation 


\title{
Concurrentie, concentratie en rentabiliteit in de glastuinbouw in Nederland
}

\author{
Drs. C.P. (Kees) Veerman
}

\section{Proefschrift}

ter verkrijging van de graad van doctor aan Wageningen University op gezag van de rector magnificus,

Prof. dr. ir. A.P.J. Mol,

ten overstaan van een door het

College voor Promoties ingestelde commissie

in het openbaar te verdedigen

op dinsdag 13 februari 2018

des namiddags te vier uur in de Aula. 
Drs. C.P. (Kees) Veerman

Concurrentie, concentratie en rentabiliteit in de glastuinbouw in Nederland 332 pages.

Thesis Wageningen University, Wageningen, NL (2018)

With references, with summaries in Dutch and English

ISBN 978-94-6343-886-5

DOI: https://doi.org/10.18174/434992 


\section{INHOUDSOPGAVE}

Voorwoord 9

Hoofdstuk 1 Inleiding $\quad 11$

1.1 Achtergronden en problemen 13

1.2 Doelstelling onderzoek $\quad 15$

1.3 Te onderzoeken elementen 15

1.4 Opbouw 17

Hoofdstuk 2 Bedrijfstakanalyse 19

2.1 Inleiding 21

2.2 Industrial organisation $\quad 22$

2.2.1 Statische variant $\quad 22$

2.2.2 Dynamische variant 25

2.2.3 Horizontale en verticale concentratie $\quad 26$

2.3 Dynamische markttheorie en het SGR-model 29

2.3.1 Marktcoördinatie $\quad 29$

2.3.2 Productlevenscyclus 31

2.3.3 Structurele concentratie $\quad 34$

2.3.4 Het dynamisch SGR-model 35

2.4 Structurele analyse van de bedrijfstak $\quad 37$

2.5 Voorwaartse verticale integratie 39

2.5.1 De theorie van voorwaartse verticale integratie 39

2.5.2 De Jong 39

2.5.3 Daems en Douma $\quad 40$

2.5.4 Porter 41

2.5.5 Conclusies $\quad 42$

2.5.6 Schematisch analysekader van voorwaartse verticale integratie 43

2.6 Onderzoeksopzet en -methoden 45

2.6.1 Onderzoeksopzet 46

2.6.2 Onderzoeksvragen en te onderzoeken verbanden 48

2.6.3 Deelonderzoeken $\quad 50$ 
3.1 Inleiding 55

3.2 De sectoren (glas)tuinbouw 1980-2010 56

3.2.1 Productiewaarden, export- en importwaarden 56

$\begin{array}{ll}3.2 .2 \text { Concentratie in de glastuinbouw } & 61\end{array}$

3.3 Bedrijfskolom en marktstructuur sector glasgroenten $\quad 62$

$\begin{array}{ll}\text { 3.3.1 Ontwikkeling aanbodzijde markt } & 63\end{array}$

$\begin{array}{ll}\text { 3.3.2 Ontwikkeling vraagzijde markt } & 74\end{array}$

3.4 Bedrijfskolom en marktstructuur sector glassierteelt $\quad 83$

3.4.1 Ontwikkeling aanbodzijde markt $\quad 84$

3.4.2 Ontwikkeling vraagzijde markt $\quad 92$

3.5 Sectorvariabelen en mogelijke verbanden 102

3.5.1 Ontwikkeling sectorvariabelen 2006-2010 102

3.5.2 Ontwikkelingen, analyse en mogelijke verbanden sectorvariabelen 2006-2016 109

Hoofdstuk 4 Onderzoek concurrentiestrategie afzetorganisaties (glas)tuinbouw in Nederland

4.1 Inleiding 115

4.2 Concurrentiestrategie, analyse en resultaten VTN/Coforta/The Greenery 116

4.2.1 Strategie en organisatie periode 1996-2008 116

4.2.2 Strategie en organisatie periode 2009-2011 124

$\begin{array}{ll}\text { 4.2.3 Resultaten periode 1996-2008 } & 127\end{array}$

4.2.4 Resultaten periode 2009-2011 130

4.2.5 Analyse gedragsvariabelen $\quad 132$

4.3 Concurrentiestrategie, analyse en resultaten VBA en FloraHolland 136

4.3.1 Strategie en organisatie periode 2004-2008 137

4.3.2 Strategie en organisatie periode 2009-2011 145

$\begin{array}{ll}\text { 4.3.3 Resultaten periode 2003-2008 } & 149\end{array}$

4.3.4 Resultaten periode 2009-2011 150

4.3.5 Analyse gedragsvariabelen $\quad 152$

4.4 Strategie en resultaten VTN/Coforta/The Greenery, VBA en FloraHolland $\quad 155$

4.4.1 Resultaten 2003-2008 155

4.4.2 Resultaten 2009-2011 158

$\begin{array}{ll}4.4 .3 \text { Voorlopige conclusies } & 161\end{array}$ 
5.1 Inleiding

5.2 Methode bedrijfsonderzoek glasgroenten

5.3 Analyse en resultaten glasgroentebedrijven

5.3.1 Analyse gedrags- en resultaatsvariabelen (microniveau)

5.3.2 Structuur- en resultaatsvariabelen (mesoniveau)

5.4 Voorlopige conclusies

5.4.1 Conclusies marktgedrag en -resultaat

192

5.4.2 Conclusies marktstructuur en -resultaat

197

5.5 Bedrijfs- en marktkarakteristieken sectoren glastuinbouw 2006-2008

Hoofdstuk 6 Bedrijfsonderzoek glastuinbouw in Nederland, deelsector glassnijbloemen

6.1 Inleiding

6.2 Methode bedrijfsonderzoek glassnijbloemen

6.3 Analyse en resultaten glassnijbloemenbedrijven

6.3.1 Analyse gedrags- en resultaatsvariabelen (microniveau)

6.3.2 Structuur- en resultaatsvariabelen sector (mesoniveau)

6.4 Voorlopige conclusies

6.4.1 Marktgedrag en -resultaat

6.5 Bedrijfs- en marktkarakteristieken sectoren glastuinbouw 2006-2008

Hoofdstuk 7 Bedrijfsonderzoek glastuinbouw in Nederland, deelsector glaspotplanten

7.1 Inleiding

7.2 Methode bedrijfsonderzoek glaspotplanten

7.3 Analyse en resultaten glaspotplantenbedrijven

7.3.1 Analyse gedrags- en resultaatsvariabelen (microniveau)

7.3.2 Structuur- en resultaatsvariabelen (mesoniveau)

7.4 Voorlopige conclusies

7.4.1 Conclusies marktgedrag en -resultaat

7.4.2 Conclusies marktstructuur en -resultaat

7.5 Bedrijfs- en marktkarakteristieken sectoren glastuinbouw 2006-2008 in samenhang

7.6 Conceptueel model in de sectoren glasgroenten en glassierteelt 
Hoofdstuk 8 Bedrijfsonderzoek glastuinbouw Nederland, meervoudige econometrische 273 analyse

8.1 Inleiding 275

8.2 Methode onderzoek en analyse $\quad 275$

8.3 Toelichting hypothesen en modelspecificatie $\quad 275$

$\begin{array}{ll}\text { 8.3.1 Hypothesen } & 275\end{array}$

$\begin{array}{ll}\text { 8.3.2 Modelspecificatie } & 278\end{array}$

$\begin{array}{ll}8.4 \text { Resultaten econometrisch onderzoek } & 279\end{array}$

8.5 Samenvatting resultaten $\quad 282$

$\begin{array}{ll}8.6 \text { Conclusies } & 283\end{array}$

8.6.1 Samenvattende conclusie sector glasgroenten 283

8.6.2 Samenvattende conclusie sector glassnijbloemen 283

8.6.3 Samenvattende conclusie sector glaspotplanten 283

Hoofdstuk 9 Conclusies en discussie $\quad 285$

9.1 Conclusies onderzoek sectoren, afzetorganisaties en producenten 287

9.1.1 Conclusies sectoronderzoek voedingstuinbouw en siertuinbouw 287

9.1.2 Conclusies onderzoek afzetorganisaties voedingstuinbouw en siertuinbouw 289

9.1.3 Conclusies bedrijfsonderzoek producenten glastuinbouw 290

9.2 Conclusies econometrisch onderzoek producenten glastuinbouw 292

9.2.1 Producenten glasgroenten 292

9.2.2 Producenten glassnijbloemen $\quad 292$

9.3 Slotconclusie $\quad 292$

9.4 Onderzoeksmethodologie 293

$\begin{array}{ll}9.5 \text { Discussie } & 295\end{array}$

$\begin{array}{ll}\text { Referenties } & 297\end{array}$

$\begin{array}{ll}\text { Literatuur } & 300\end{array}$

Bijlage 1 - SCP-model $\quad 303$

Bijlage 2 - Begripsomschrijvingen $\quad 305$

Bijlage 3 - Meetmethoden horizontale en verticale concentratie 310

Bijlage 4 - Te onderzoeken structurele en strategische elementen uit figuur 1.1 313

Bijlage 5 - Invulling conceptueel model in de sector glasgroenten en glassierteelt 315

Samenvatting $\quad 320$

Summary $\quad 326$

Zie voor Appendices H3 t/m H7: https://proefschrift.online/kees-veerman/ 


\section{Voorwoord}

Vanaf 1980 was er de immer door mijn hoofd suizende opmerking bij het behalen van mijn doctoraal bedrijfseconomie, dat ik me goed moest realiseren wat doctorandus betekent: hij die voor doctor studeert. In andere woorden: je bent er nog niet, je moet echt wel even door!

In dit proefschrift worden de resultaten gepresenteerd van mijn onderzoek in de glastuinbouw naar verbanden tussen marktstructuur, marktgedrag en marktresultaat. Mijn pensionering in 2005 aan de Agrarische Hogeschool Delft, opleiding tuinbouw, was voor mij een van de redenen om aan dit onderzoek te beginnen, niet wetende dat het zo lang zou duren.

Het verschil in afzetstructuur vanaf 1995 tussen de sectoren voedings- en siertuinbouw, dat tot op heden nog steeds bestaat, is opvallend. Als docent marketing kreeg ik vaak de vraag wat ik daarvan vond. Was de positie voor telers in de glasgroenten bij The Greenery nu voordelig of juist nadelig in vergelijking met die in de glassnijbloemen en -potplanten bij FloraHolland? Het blijkt een lastig te beantwoorden vraag die genuanceerd moet worden benaderd en vele jaren onderzoek vergde.

Vanaf 1987 kreeg het HBO toestemming van de Minister van Landbouw om naast het lesgeven praktijkgericht onderzoek te verrichten. Dit is altijd een leerzaam en zeer interessant onderdeel van mijn werk geweest. Na mijn loopbaan wilde ik graag nog 'even' door met onderzoek in de glastuinbouw, in aanvang ook met studenten in projectgroepen, o.a. in opdracht van LTO-Groeiservice en in samenwerking met ir. Cock van Bommel. In 2005 heb ik mij gericht tot de UvA, waar ik prof. dr. Jozef Tettero ontmoette die goed thuis was op het gebied van de Industriële Marketing. Met hem besprak ik mijn eerste onderzoeksvoorstel waaruit tenslotte dit proefschrift is voortgekomen. Hij reageerde enthousiast en kritisch stimulerend en daar ben ik hem zeer dankbaar voor. Vanaf begin 2012 is mijn huidige promotor, prof. dr. Olaf van Kooten bij het onderzoek betrokken geraakt. Hem wil ik bedanken voor de ondersteuning en zijn niet aflatende optimisme ("leuk, leuk, leuk") om dit langdurige project tot een goed einde te brengen. In het laatste traject hebben dr. Frank Bunte en in aanvang ook dr. Erno Kuiper bij de econometrische analyse een belangrijke rol gespeeld en ook hen ben ik zeer erkentelijk.

Van het thuisfront heb ik onmisbare steun ervaren. Hierbij denk ik aan de helpende handen en luisterende oren van zoons Fred, Jitse en Marijn. Onze goede vriendin Yvonne was zeer behulpzaam bij het tot stand brengen van de Engelse samenvatting. Mijn dochter Arja stond altijd direct klaar om mij van advies te dienen, wat tot op het laatst nodig was. Dat is nog steeds het geval, zie haar staan als paranimf, naast mijn vrouw! Marianne was tot het einde toe - meestal geduldig bereid nieuwe versies van het manuscript te beoordelen en te corrigeren. Zij heeft dit proefschrift veelvuldig gelezen en geredigeerd. Zonder deze naasten was dit proefschrift er nooit gekomen!

Woerden, januari 2018 

INLEIDING 



\subsection{Achtergronden en problemen}

De glastuinbouw is een belangrijke en dynamische sector binnen de agrarische bedrijfstak tuinbouw en de Nederlandse economie. In 2009 werkten rond de 7000 bedrijven binnen deze sector aan de productie van glasgroenten (45\%) en glassnijbloemen en -potplanten (50\%). Inclusief zacht fruit en boomkwekerijproducten onder glas omvatte deze sector een oppervlakte glas van rond de 10.500 hectare in Nederland. De totale productiewaarde van de tuinbouw als aandeel van de agrarische sector ligt al jaren op ca. 40\% . In 2009 bedroeg deze 7 mrd. euro waarvan bijna 5 mrd. euro glastuinbouwproducten. In 2015/2016 is het aantal bedrijven onder glas gehalveerd tot 3500 ten opzichte van 2007, is de productiewaarde tuinbouw gestegen tot $10.5 \mathrm{mrd}$. euro en is het aandeel glastuinbouw bijna $6.0 \mathrm{mrd}$. euro. De glasgroenten zijn in ha. glas op het niveau van 4800 ha. gebleven, het areaal glassnijbloemen en -potplanten is vanaf het jaar 2000 gedaald tot ca. 3800 ha. Vooral de kleinere arbeidsintensieve productsoorten roos en chrysant zijn in areaal gekrompen en vervangen door onder andere de import van snijbloemen uit zuidelijk Afrika (Kenia en Ethiopië), vaak door Nederlandse telers geleverd. Het areaal zacht fruit (aardbeien, frambozen, bessen) en kleinere producten uit de boomkwekerij onder glas is groeiende en bedraagt ca. 800 ha. In totaliteit bedraagt het areaal glas in 2015/2016 rond de 9400 ha. (www.agrimatie.nl).

De ontwikkelingen in de glastuinbouw zijn de laatste decennia stormachtig geweest door de grote uitbreiding van het marktgebied van de Europese Unie. In 1986 traden Spanje en Portugal toe tot de Europese markt met een aanzienlijk areaal tuinbouwproducten, gevolgd in 1989/1990 door Oost-Duitsland. Daarna vond een verdere uitbreiding plaats in Noord-, Midden- en OostEuropa met Zweden, Finland, Oostenrijk, Polen, Tsjechië, Hongarije, Slowakije, Slovenië en de Baltische staten (Veldman e.a., 2004). Dit heeft geleid tot enerzijds een toename van het aantal aanbieders (producenten, afzetorganisaties, exporteurs) van tuinbouwproducten op de Europese markt, anderzijds tot een toename van de vraag van Europese detaillisten en consumenten. Een toename van de concurrentie met goedkoper producerende bedrijven uit de nieuwe lidstaten en de nodige veranderingen in de productie- en afzetstructuur van de bedrijven in de sector glastuinbouw waren de gevolgen.

Tot 1996 was in de tuinbouw in Nederland het openbaar veilen van verse tuinbouwproducten favoriet. Deze verkoopmethode voor o.a. verse groenten en bloemen bestaat meer dan 120 jaar. De eerste veilingvereniging werd opgericht in 1887 in Broek op Langedijk, Noord-Holland. Het aantal veilingen rond 1917 bedroeg 166 en in dat jaar werd een vereniging voor groente- en fruitveilingen opgericht, het Centraal Bureau voor de Tuinbouwveilingen (CBT). In de bloemkwekerijsector werd in 1901 de eerste bloemenveiling opgericht in Amsterdam, gevolgd door zeventien bloemenveilingen in Aalsmeer, Rijnsburg, het Westland en andere regio's (Agrarische Hogeschool Delft, 1992). Hoofddoelstelling van de veilingorganisatie was en is het behalen van de hoogste opbrengst voor de producten van de leden. Het dagelijks openbaar via de klok veilen van de producten van de leden geeft bij voldoende vraag en aanbod een transparante prijsvorming en prijzen die tegelijk een referentieprijs zijn voor bemiddelingstransacties. 
De belangrijkste voordelen van deze afzet- en verkoopmethode voor de glastuinder zijn:

- beschikbaarheid van een betrouwbaar en relatief goedkoop afzet- en verkoopsysteem met een goede afhandeling van de transacties, directe betaling en debiteurenbewaking;

- een goede logistieke aan- en afvoer van het bedrijf naar de veiling en de groothandel/exporteur.

In 1996/1997 fuseerden het CBT en de meeste groente- en fruitveilingen (75\% van de totale veilingomzet) tot de afzetcoöperatie VoedingsTuinbouw Nederland U.A. (VTN)/ B.V.The Greenery International, verder te noemen The Greenery. De veilingen ZON te Venlo, fruitveiling Geldermalsen, veiling Zaltbommel en acht kleine veilingen bleven zelfstandig (25\% van de totale veilingomzet). In 1997/1998 werd deze fusie gevolgd door de volledige overname van en integratie in The Greenery van een aantal van de grootste exporteurs en importeurs van groenten en fruit in Nederland, de Van Dijk Delft Groep en de Fresh Produce Divisie van Perkins Foods plc.

Het belangrijkste verkoopsysteem in deze sector was het klokveilen. Dit was echter niet de favoriete keuze van het Europese grootwinkelbedrijf. Het grootwinkelbedrijf wilde vaste weekprijzen in plaats van dagelijks wisselende, zodat wekelijkse acties vroegtijdig gepland konden worden. Het werd op zijn wenken bediend. Het klokveilen werd door The Greenery binnen korte tijd grotendeels vervangen door verkoopteams en bemiddeling (The Greenery International, jaarverslag 1997, p. 14). Het gevolg was een niet doorzichtige prijsvorming voor de leden. Op de eveneens uit fusies voortgekomen bloemenveilingen FloraHolland en Plantion wordt nog steeds een meerderheid van de dagelijkse transacties via de klok gerealiseerd. Dat het verschil in afzetstructuur en transparantie van de prijsvorming tussen The Greenery en FloraHolland tot felle en emotionele discussies leidt tussen leden en het management bleek medio februari en

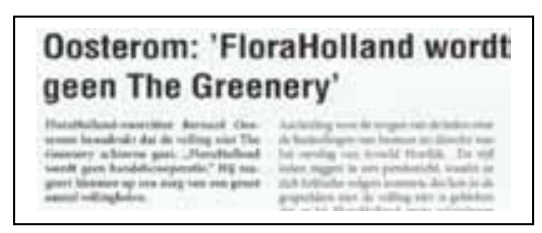
begin maart 2011 in een aantal vakbladartikelen.

De voorzitter van FloraHolland geeft hierin aan dat FloraHolland niet op weg is naar een handelscoöperatie zoals The Greenery. FloraHolland faciliteert de telers, biedt verkoop- en logistieke diensten aan en heeft geen plannen om eigenaar van het product te worden of handelsactiviteiten te gaan integreren in de veilingcoöperatie (Vakblad voor de Bloemisterij, week 6-2011, p. 16).

In maart 2011 pleit een lid van The Greenery voor het ontkoppelen van de afzetorganisatie VTN en het handelsbedrijf The Greenery en voor transparante uitbetaalprijzen. Hij voelt zich steeds meer 'belazerd' door het management. Een week later belooft directeur Philip Smits hem een toelichting te geven op het huidige beleid en de vermeende onverenigbaarheid van belangen tussen telers en handel (Groenten \& Fruit Actueel 2011, week 9, p. 8 en week 10, p. 8). 


\subsection{Doelstelling onderzoek}

Dit promotieonderzoek richt zich op de ontwikkeling van de marktstructuur en -strategie voor verse tuinbouwproducten over de afgelopen 35 jaar in de glastuinbouw, sectoren glasgroenten, glassnijbloemen en glaspotplanten. De doelstelling van het onderzoek is een antwoord te krijgen op de vraag wat de meest effectieve en efficiënte afzetstrategie in deze sectoren is voor verse glastuinbouwproducten op de Europese markt.

\subsection{Te onderzoeken elementen}

Hoofdvraag van het onderzoek is of het verschil in marktstructuur en marktgedrag in de genoemde drie sectoren een significante oorzaak is om het verschil in marktresultaat (brutomarge) voor de leden/bedrijven en hun afzetorganisaties te verklaren. Aanvullende vragen zijn of de keuze van bedrijfs- en ondernemerstype, de gehanteerde afzet- en verkoopmethode of enig ander kenmerk van marktstructuur of marktgedrag een betekenisvol verschil in marktresultaat (brutomarge) oplevert en welke van deze variabelen hieraan het meeste bijdragen.

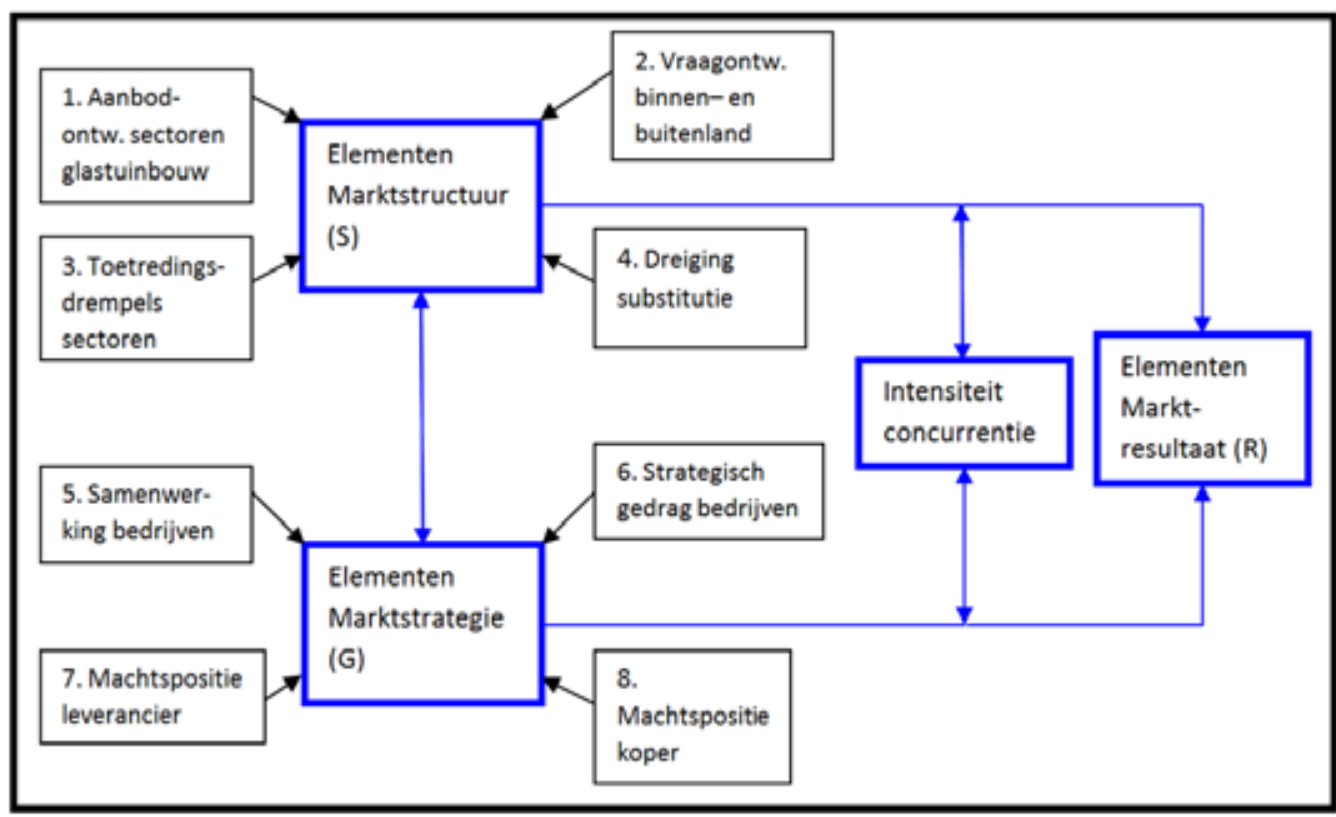

Figuur 1.1 Conceptueel model: concurrentie, concentratie en rentabiliteit sectoren glastuinbouw in Nederland

Het conceptueel model in bovenstaande figuur 1.1 (Daems, 1985, p. 20, figuur 3 met enige aanpassing) geeft het concurrentieproces weer met het bijbehorende krachtenveld. Getoond worden de belangrijkste te onderzoeken elementen van de marktstructuur $(\mathrm{S})$, de marktstrategie $(\mathrm{G})$ en 
het marktresultaat $(\mathrm{R})$, in hun onderling verband. Het onderliggende veld van concurrentiekrachten wordt per hoofdvariabele weergegeven in een aantal boxen. Elementen van de marktstructuur en -strategie beïnvloeden elkaar voortdurend en zorgen voor een bepaalde concurrentie-intensiteit op de markt. Mede afhankelijk van deze intensiteit behalen ondernemingen en sectoren een bepaald marktresultaat.

De op de markt heersende concurrentie bestaat uit interne, externe en potentiële concurrentie. (Daems, 1985, p. 60).

- Interne concurrentie hangt samen met een meer of minder evenwichtige vraag- en aanbodsontwikkeling (box 1 en 2), de bereidheid tot samenwerking (box 5) en het strategisch gedrag van bedrijven (box 6).

- Externe concurrentie betreft de concurrentie veroorzaakt door verschillen in marktmacht tussen de bedrijven en hun toeleveranciers (box 7) en bedrijven en hun kopers (box 8).

- Potentiële concurrentie is de dreiging van nieuwe aanbieders die willen toetreden tot de markt (box 3) en de dreiging van substitutie (box 4) met nieuwe, goedkopere producten of processen of geïmporteerde producten.

Bijlage 4 geeft een overzicht van alle mogelijk te onderzoeken structurele en strategische elementen, ook wel variabelen genoemd. In hoofdstuk 2 paragraaf 2.6 vindt in het kader van de uitwerking van het conceptueel model een selectie van en splitsing naar onafhankelijke en afhankelijke variabelen plaats en een globale inschatting van mogelijke verbanden.

Hieruit volgen de te toetsen hypothesen, de belangrijkste onderzoeksvragen en de te verzamelen gegevens.

De besproken structurele en strategische elementen zijn mede gebruikt ten behoeve van de volgende drie analyses:

- Analyse structuur $(\mathrm{S})$, gedrag $(\mathrm{G})$ en resultaat $(\mathrm{R})$ aan de hand van het SGR-model van De Jong met de vergelijking van de horizontale en verticale concentratie per sector. Tevens het meten en vergelijken van de werkelijke en structurele concentratie in de drie sectoren van de glastuinbouw.

- Analyse en raming van de concurrentie en concentratie en de invloed hiervan op de structurele rentabiliteit van de gemiddelde onderneming in de drie sectoren van de glastuinbouw aan de hand van het bedrijfstakanalysemodel van Porter (1992, p. 4).

- Analyse en raming van de strategische kosten en baten volgens het conceptuele model van voorwaartse verticale integratie(VVI) in de glastuinbouw sector glasgroenten. 


\subsection{Opbouw}

Dit proefschrift beschrijft de ontwikkeling van de marktstructuur en -strategie van verse tuinbouwproducten op de Europese markt, de hierbij optredende concurrentie en concentratie en de invloed hiervan op het structureel marktresultaat van het glastuinbouwbedrijf in Nederland in drie sectoren van de glastuinbouw.

In hoofdstuk 1 worden de achtergronden en problemen van bovenstaande situatie met de onderzoeksdoelstelling, de te onderzoeken elementen en het conceptueel model (figuur 1.1) besproken.

Hoofdstuk 2 begint met de theorie van de 'industrial organisation' en het statische 'Structure Conduct Performance“ (SCP)-model. Vervolgens wordt de dynamische markttheorie van De Jong behandeld met het Structuur Gedrag Resultaat (SGR)-model. Begrippen als horizontale en verticale concentratie komen aan bod met de voor- en nadelen. Hierna volgt de bespreking van de theorie van Porter, die ingaat op de structurele analyse van de bedrijfstak en -sectoren. De theorie van voorwaartse verticale integratie met de conclusies van De Jong, Daems en Douma en Porter wordt besproken in samenhang met een voorbeeld analysekader van kosten- en baten. Het hoofdstuk eindigt met een overzicht van de onderzoeksopzet, de belangrijkste onderzoeksvragen en de deelonderzoeken.

Hoofdstuk 3 beschrijft de positie van de (glas)tuinbouw in de agrarische sector in Nederland met de ontwikkelingen aan de aanbod- en vraagzijde in de sector voedingstuinbouw en siertuinbouw over de periode 1980-2016.

Hoofdstuk 4 beschrijft en analyseert de resultaten van het onderzoek onder de belangrijkste afzetorganisaties in de sector voedingstuinbouw en siertuinbouw over de periode 1996-2016 (VTN/ The Greenery, VBA en FloraHolland).

In hoofdstuk 5, 6 en 7 worden de voornaamste resultaten van drie bedrijfsonderzoeken in 2006, 2007 en 2008 in de glasgroenten, -bloemen en -potplanten beschreven en geanalyseerd. In de laatste paragrafen van hoofdstuk 7 worden de resultaten van de drie sectoren in onderlinge samenhang beschreven.

In hoofdstuk 8 volgt een econometrisch onderzoek naar de meervoudige verbanden tussen verklarende en te verklaren gedrags- en resultaatsvariabelen op bedrijfsniveau (2006-2008), uitgevoerd in 2015/2016 voor de sectoren glasgroenten, glassnijbloemen en -potplanten. De uitbreiding en aanvulling van het bedrijfsonderzoek betreft met name het vaststellen van de omvang en richting van het mogelijke verband tussen kenmerken van het gekozen bedrijfstype, ondernemerstype en organisatie van de afzet en de ontwikkeling van de gerealiseerde brutomarge (Lerner Index). 
In hoofdstuk 9 worden conclusies getrokken op het niveau van de sectoren, de afzetorganisaties en de producenten. Bediscussieerd wordt welke marktstructuur en welk marktgedrag in de glasgroenten en glassierteelt de beste kansen bieden op redelijke marktresultaten voor producenten en hun afzetorganisaties. 



\subsection{Inleiding}

De centrale vraag van dit promotieonderzoek richt zich op marktstructuren, marktgedragingen en marktresultaten in drie sectoren van de bedrijfstak glastuinbouw. Is het verschil in marktstructuur en marktgedrag in de drie sectoren een significante oorzaak om het verschil in marktresultaat (brutomarge) voor de leden/bedrijven en hun afzetorganisaties te verklaren? En welke van de structuur- en gedragsvariabelen leveren hieraan de grootste bijdrage?

Om deze vraag te kunnen beantwoorden is het nodig te bepalen welke variabelen we onderscheiden, welke verbanden we kunnen leggen en wat de verklaringen zijn voor de behaalde resultaten. In het conceptueel model van hoofdstuk 1 (fig. 1.1) is een eerste overzicht gegeven van de belangrijkste variabelen en concurrentiekrachten. Een nadere selectie en uitwerking van de variabelen en onderzoeksvragen volgt aan het eind van dit hoofdstuk. Eerst wordt nu een aantal theorieën en modellen besproken uit de leer van de externe organisatie, in het Engels de industrial organisation theory genoemd. Hierin staat de analyse van bedrijfstakken, bedrijfskolom en bijbehorende markten centraal en wordt het verband tussen marktstructuur, marktgedrag en -resultaat nader onderzocht. De literatuur betreft een aantal vooraanstaande auteurs op het gebied van industrial organisation en bedrijfstakgericht onderzoek. Besproken wordt onder meer het werk van Mason, Bain, Caves, Scherer, Jacquemin, De Jong, Porter en Daems en Douma. Een aantal van deze auteurs heeft bijgedragen aan de ontwikkeling van het zogenaamde SGR-model, dat staat voor: Structuur Gedrag Resultaat. Het SGR-model wordt in het Engels SCP-model genoemd, dat staat voor: Structure Conduct Performance. Een voorbeeld hiervan is opgenomen in bijlage 1 van dit proefschrift (Carlton \& Perloff, 2005, p. 5).

In paragraaf 2.2 van dit hoofdstuk wordt ingegaan op de statische en de dynamische variant van de industrial organisation theorie. De statische variant betreft het werk van Mason, Bain, en Caves, de dynamische variant dat van Scherer, Jacquemin en De Jong. Tevens worden hier de begrippen horizontale en verticale concentratie besproken met de door de verschillende auteurs genoemde voor- en nadelen.

Paragraaf 2.3 behandelt de dynamische markttheorie van De Jong met de theorie van het SGRmodel. Met dit dynamische SGR-model worden de theoretische kenmerken van marktstructuur, -gedrag en -resultaat beschreven gedurende de marktontwikkelingsfasen van een (nieuw) product. Ontwikkelingen van concurrentie en concentratie in deze fasen en de invloed hiervan op het ondernemingsresultaat worden gevolgd.

In paragraaf 2.4 wordt de theorie van de structurele analyse van bedrijfstakken van Porter behandeld en het theoretisch analysemodel.

Paragraaf 2.5 bespreekt de theorie van voorwaartse verticale integratie met de opvattingen van De Jong, Daems en Douma en Porter en het schematisch analysekader. 
In paragraaf 2.6 worden onderzoeksopzet en -methoden besproken met het analysemodel van de geselecteerde variabelen, de belangrijkste onderzoeksvragen en -gegevens en de verschillende deelonderzoeken

\subsection{Industrial organisation}

\subsubsection{Statische variant}

De statische variant van het SGR-model (Bain, 1959) houdt traditioneel in dat de structuur van de markt (het aantal en de omvang van aanbieders en vragers, de concentratiegraad, de mate van homogeniteit van het product, de toetredingsbarrières) het ondernemersgedrag bepaalt (het te voeren ondernemings- en marketingbeleid). Het gedrag bepaalt vervolgens het resultaat van de markt (gerealiseerde prijzen, omzet en rendement). Er vindt geen terugkoppeling plaats van marktgedrag naar marktstructuur.

Een voorbeeld is de marktvorm van volledige mededinging met veel aanbieders, veel vragers, een homogeen product, vrije markttoegang en open en doorzichtige prijsvorming. Iedere ondernemer handelt op praktisch eenzelfde manier. De prijs wordt bepaald door het geheel van vraag en aanbod en een individuele ondernemer is te klein om alleen invloed uit te kunnen oefenen op de marktprijs. Hij is prijsvolger.

Mason wordt gezien als grondlegger van het SGR-model, hoewel dit model niet door hem als zodanig werd omschreven (Mason, 1939). Hij formuleerde de structurele kenmerken van ondernemingen en de markten waarop zij actief waren. Hiermee werd het gedrag en het resultaat verklaard. Hij schrijft over de bedrijfstak het volgende:

"The industry so conceived is a grouping of firms on the basis of a similarity both to products and of production processes." (Mason, 1957, p. 6). Deze definitie leidde tot een statische benadering. Bedrijven met nieuwe gewijzigde productiemethoden die hetzelfde product voortbrengen werden niet als concurrent gezien van de bedrijven met de oude productiemethoden. In de glastuinbouw zou dit betekenen dat bedrijven met rozenteelt in de grond niet concurreren met rozen op substraat (steenwol, kleikorrels e.a.). Hoe nieuwe productiemethoden ontstaan, is vanuit deze benadering onduidelijk en een verklaring voor eventuele dynamiek van de onderneming en keuzevrijheid in handelen, specifiek ondernemersgedrag, lijkt niet aanwezig te zijn.

J.S. Bain was een leerling van Mason en gaf het analyseschema van Mason de naam StructureConduct-Performance-model (Bain, 1959). Bain richtte zich alleen op de kenmerken van de marktstructuur. De belangrijkste kenmerken van de marktstructuur zijn:

- de concentratiegraad van de aanbieders en in mindere mate de afnemers

- de mate van productdifferentiatie

- de toetredingsbarrières 
Vanuit het SCP-model werd verondersteld dat een hoge concentratiegraad (marktstructuur) tot hogere winsten (performance) leidt. Hoge toetredingsbarrières maken een concentratie eenvoudiger en een grote mate van productdifferentiatie leidt tot de creatie van submarkten en daardoor hogere prijzen en winsten (tabel 2.1).

\begin{tabular}{|ll|}
\hline Structure: & $\begin{array}{l}\text { the degree of seller and buyer concentration, the degree of product } \\
\text { differentiation, the condition of entry }\end{array}$ \\
\hline Conduct: & $\begin{array}{l}\text { the price and output decisions, predatory and exclusionary tactics } \\
\text { (established and potential competitors), the determination of sales } \\
\text { promotion outlays and product designs }\end{array}$ \\
\hline Performance: & $\begin{array}{l}\text { the degree of productive efficiency, the price-cost margins and profit } \\
\text { rates, the size of sales-promotion costs }\end{array}$ \\
\hline
\end{tabular}

Tabel 2.1 Het SCP-model (Bain, 1959), (Rogier, 1998)

Bain gaat uit van een causale en afhankelijke relatie: "We may envisage a three-stage sequence of causation from market structure to market conduct to resulting market performance. That is, structure is systematically associated with conduct, or determines what performance will be; therefore, structure is associated to conduct, and of that of conduct to performance."(Bain, 1959, p. 295). Deze benadering betekent dat het marktgedrag wordt bepaald door de marktstructuur en dat de resultaten uiteindelijk alleen worden bepaald door de marktstructuur (Jacquemin \& De Jong, 1977). Op grond van deze causale relatie en op grond van het feit dat marktgedrag empirisch moeilijk te beschrijven is, besluit Bain het empirisch onderzoek te richten op de relatie tussen marktstructuur en performance. Het marktgedrag wordt niet verder uitgewerkt en vormt geen onderwerp van studie.

Ook Caves kan, net als Mason en Bain, een structuralist genoemd worden (Caves, 1964). Evenals Bain beschrijft hij een van de marktstructuur afgeleide relatie voor marktgedrag en -resultaat (zie tabel 2.2). "Market structure is important because it determines the behavior of firms in the industry, and that behavior in turn determines the quality of the industry's performance." (Caves, 1964, p.16). Hij stelt expliciet dat bedrijven vrijwel niet in staat zijn om de marktstructuur te beinvloeden. Hiermee veronderstelt hij weinig keuzevrijheid van de ondernemer en weinig ruimte voor het voeren van een eigen strategie. Caves stelt dat de elementen van de marktstructuur nauwelijks veranderen door de tijd. Is dat wel het geval dan is dat eenvoudig te verklaren. Hij is van mening dat de elementen van de marktstructuur elkaar onderling beïnvloeden. Wanneer vervolgens een element verandert, veranderen andere elementen eveneens en wordt de marktstructuur substantieel gewijzigd. Een verklaring voor deze spaarzame dynamiek wordt gegeven in een artikel uit de serie 'Foundations of modern economics'(Caves, 1964, pp. 32,33). Caves geeft hier via een voorbeeld uit de automobielbranche (U.S.A.1920-1925) aan dat wijziging van 
het marketing element 'productdifferentiatie' leidt tot hogere toetredingsbarrières en een hogere concentratie in de bedrijfstak. "A highly differentiated Chevrolet was introduced, which was sold for about \$ 100 more than the T-Ford, but offered more attractive styling, greater speed and a number of other factors".

Productdifferentiatie als element van de marktstructuur wordt in dit voorbeeld geleid door gewijzigd ondernemersgedrag. Er vindt dus wel degelijk wederzijdse beïnvloeding plaats van marktgedrag en marktstructuur.

\begin{tabular}{ll}
\hline Structure: & concentration, product differentiation, barriers to the entry of new \\
& firms, growth rate of market demand, price elasticity of market \\
& demand, ratio of fixed to variable costs in the short run
\end{tabular}

Conduct: $\quad$ policies toward setting prices, policies toward setting the quality of the product, policies aimed at coercing rivals

Performance: $\quad$ efficiency in the use of resources, maintenance of full employment, growth and progressiveness in enlarging and improving the flow of goods and services, equity in the distribution of income

Tabel 2.2 Het SCP-model volgens Caves (Caves, 1964), (Rogier, 1998)

Met de afbakening van de bedrijfstak heeft Caves grote problemen. Hij beschrijft deze als een groep van gelijksoortige bedrijven die met elkaar concurreren op een markt. Hij geeft aan dat de afbakening op grond van product, ruimte of tijd steeds weer een probleem kan vormen. Hij reikt hiervoor geen oplossing aan, stapt er verder overheen en stelt: "Once we have drawn the industry boundaries, we can use the concept of "seller concentration" to describe each industry's structure." (Caves, 1964).

Samenvattend kunnen we zeggen dat de statische variant van de industrial organisation er vanuit gaat dat de ondernemers in de bedrijfstak zich aanpassen aan de marktstructuur. De vrijheid van keuze is minimaal. De bedrijven hebben hetzelfde doel en handelen op een vergelijkbare wijze. Een verklaring voor veranderingen wordt in de statische variant nauwelijks gegeven. De afbakening van de bedrijfstak en de markt met de concurrenten die daarop actief zijn, blijkt moeilijk te formuleren te zijn. De statische benadering van de industrial organisation lijkt, evenals bij Bain, op het eerste gezicht weinig bij te kunnen dragen aan de modellen van deze studie.

Toch is het SGR-model in zijn structuralistische vorm toe te passen op de te onderzoeken variabelen van de afzetorganisaties VTN/The Greenery en FloraHolland. Het verschil in afzetstructuur tussen The Greenery en FloraHolland vanaf 1997/1998 tot heden veroorzaakt een verschil in marktstructuur tussen de sectoren glasgroenten en glassierteelt. Met dit model kan worden bezien of er een betekenisvol verband is tussen elementen van marktstructuur (wel of geen verticale in- 
tegratie) en behaalde marktresultaten bij de belangrijkste afzetorganisaties en leden/bedrijven in deze sectoren. In paragraaf 2.6 wordt de onderzoeksopzet en de methode van onderzoek hiervan beschreven. In de hoofdstukken $3 \mathrm{t} / \mathrm{m} 8$ vindt een uitwerking van de resultaten plaats.

\subsubsection{Dynamische variant}

De dynamische variant van de industrial organisation is de opvolger van de statische theorie. De statische theorie wordt bekritiseerd door de dynamische markttheoretici. Zij wijzen op het bestaan van eigen initiatieven zoals marketing met advertentiecampagnes, onderzoek en ontwikkeling met als mogelijk resultaat octrooien en patenten. Deze initiatieven worden verricht vanuit de gedachte dat de markt wel te beïnvloeden is. Jacquemin (1987) maakt hierbij een onderscheid naar de Classical Industrial Organisation en de New Industrial Organisation. Scherer spreekt over de structuralistische en de behavioristische benadering (Scherer, 1980). De Jong besteedt in Dynamische Markttheorie (De Jong, 1989) aandacht aan het strategische gedrag van ondernemingen en hoe dit gedrag de marktstructuur kan beïnvloeden. In de behavioristische benadering worden de behaalde resultaten afhankelijk gesteld van marktstructuur én marktgedrag. De Jong noemt dit een voluit dynamische, wederkerige betrekking, waarbij marktstructuur en marktproces elkaar wederzijds beïnvloeden (De Jong, 1989, p. 5). De concentratiegraad van het aanbod is bijvoorbeeld te beïnvloeden door bepaalde samenwerkingsvormen, fusies en overnames. Productdifferentiatie is door middel van reclame en verpakkingsvormen te beïnvloeden. Toetredingsbarrières tot de bedrijfstak zijn te verhogen door patenten op nieuwe producten of productiemethoden waardoor toetreding tot de bedrijfstak aanzienlijk wordt bemoeilijkt voor potentiële concurrenten. In principe kan elk bedrijf via zijn markt- en marketingstrategie de marktstructuur beïnvloeden. Dit geldt niet alleen voor omvangrijke of kapitaalkrachtige bedrijven maar ook voor kleinere bedrijven. Zij hebben bijvoorbeeld invloed op de marktstructuur door een relatief uniek product of levering aan een uniek marktsegment.

De dynamische variant van de industrial organisation is de stroming die ingaat op markten en concurrentie. Het concurrerend gedrag van de ondernemers wordt beschouwd vanuit een welvaartstheoretisch perspectief op bedrijfstakniveau. Deze concurrentie is verbonden aan de schaarste waarin ondernemers ondernemen bij het streven naar verhoging van hun welvaart. Deze behavioristische benadering wordt in de literatuur ook wel Industrial Economics, Industrial Dynamics (Carlsson, 1989) of Dynamische markttheorie genoemd. De oorspronkelijke titel van de Dynamische markttheorie van De Jong luidde Dynamische concentratietheorie (De Jong, 1972). De reden die De Jong geeft voor wijziging van de titel van zijn boek is het gegroeide inzicht dat concentratie slechts een van de coördinatiewijzen van de markt is, naast concurrentie en samenwerking (De Jong, 1989, p. 2). Daarnaast geeft de term 'Dynamische Markttheorie' duidelijker dan voorheen aan dat naast analyse van het aanbod ook analyse van de vraag onderwerp van studie is. De aandacht voor concurrentie is erg groot in deze benadering. Concurrentie kan twee richtingen opgaan. Enerzijds kunnen er door innovaties ongelijkheden ontstaan. Anderzijds kunnen ondernemers handelingen verrichten waarbij er weer gelijkheid ontstaat en waardoor prijsverschillen verdwijnen (De Jong, 1989, pp. 162-177). Mededinging is per definitie 
dynamisch van aard en vormt de basis voor een dynamische beschouwing. Rivaliteit door het behalen van een concurrentievoordeel en het tenietgaan van een dergelijke ongelijkheid is enkel denkbaar in een dynamische setting. Statische markttheorie kan niet zinvol over concurrentie spreken (De Jong, 1989, p. 7). Door het erkennen van de gedragscomponent wordt een dynamische beschouwing beter en meer uitgewerkt. De auteurs van de dynamische variant baseren zich in belangrijke mate op de ideeën van Schumpeter. Hij ziet de neoklassieke theorieën uit zijn tijd zoals de statische variant 'of static equilibrium that excluded strategy'(Schumpeter, 1954, p. 972). Het zijn vooral de innovatieve gedragingen van ondernemers die de economische ontwikkeling voortstuwen door de realisatie van grote en kleinere innovaties. Dit marktgedrag is van invloed op zowel de marktstructuur als het marktresultaat (Rogier, 1998, p. 80).

\subsubsection{Horizontale en verticale concentratie}

De Jong gebruikt bij de uitwerking van het dynamische SGR-model veelvuldig de begrippen horizontale en verticale concentratie.

Horizontale concentratie is het op bedrijfstakniveau samenvoegen van verschillende economische handelingen of ondernemingen onder gemeenschappelijke beslissingsmacht (De Jong, 1989, pp. 24-25).

Verticale concentratie is de combinatie van opeenvolgende economische handelingen of ondernemingen onder gemeenschappelijke beslissingsmacht, in dit geval een vereniging van een reeks stadia in de bedrijfskolom tot één geheel. Verticale concentratie wordt vaak verticale integratie genoemd en kan voorwaarts of achterwaarts in de bedrijfskolom plaatsvinden (De Jong, 1989, pp. 190-193). Onderstaande figuur 2.1 geeft van beide een voorbeeld. In de linkerkolom een voorbeeld van voorwaartse verticale concentratie (zie verticale pijl) in de bedrijfskolom glasgroenten tussen groentekwekers, veilingorganisatie en groothandel/exporteur (VTN/The Greenery en Van Dijk Delft in 1997/1998). In de rechterkolommen glassnijbloemen en -potplanten een voorbeeld van horizontale concentratie (zie horizontale pijl), te weten de fusie in september 2007 tussen twee grote bloemenveilingen (FloraHolland in Naaldwijk en VBA in Aalsmeer).

Concentratie kan zowel van toepassing zijn op een bereikte situatie (hoogte concentratiegraad op bepaald tijdstip) als op het proces om deze situatie te bereiken (toename concentratie over een bepaalde periode). Een beschrijving van de meetmethoden van horizontale en verticale concentratie is opgenomen in bijlage 3 van dit proefschrift.

\subsubsection{Voor- en nadelen van horizontale concentratie}

Horizontale concentratie van ondernemingen in de bedrijfstak heeft voor- en nadelen. De meeste argumenten, genoemd door de verschillende auteurs, liggen in elkaars verlengde of overlappen elkaar. De belangrijkste uit het werk van De Jong, Porter en Daems en Douma zijn hieronder samengevat (De Jong, 1989, pp. 16-20, 90, 108-109; Porter, 1992, pp.162-188; Daems en Douma, 1985, pp. 19-23). 


\begin{tabular}{|c|c|c|}
\hline $\begin{array}{l}\text { bedrijfskolom } \\
\text { glasgroenten }\end{array}$ & $\begin{array}{l}\text { bedrijfskolom } \\
\text { glassnijbloemen }\end{array}$ & $\begin{array}{l}\text { bedrijfskolom } \\
\text { glaspotplanten }\end{array}$ \\
\hline zaadveredelaar & plantveredelaar & plantveredelaar \\
\hline plantenkweker & Plantvermeerderaar & Plantvermeerderaar \\
\hline groentekweker & snijbloemenkweker & potplantenkweker \\
\hline $\begin{array}{l}\text { veiling / } \\
\text { bemiddeling } \\
\text { i.c. VTN/The } \\
\text { Greenery, ZON, }\end{array}$ & $\begin{array}{l}\text { veiling / } \\
\text { bemiddeling } \\
\text { i.c. FloraHolland, } \\
\text { Plantion }\end{array}$ & $\begin{array}{l}\text { veiling / } \\
\text { bemiddeling } \\
\text { i.c. FloraHolland, } \\
\text { Plantion }\end{array}$ \\
\hline $\begin{array}{l}\text { binnenlandse } \\
\text { groothandel - } \\
\text { exporteur i.c VDD } \\
\text { e.a. }\end{array}$ & $\begin{array}{l}\text { binnenlandse } \\
\text { groothandel - } \\
\text { exporteur }\end{array}$ & $\begin{array}{l}\text { binnenlandse } \\
\text { groothandel - } \\
\text { exporteur }\end{array}$ \\
\hline $\begin{array}{l}\text { buitenlandse } \\
\text { groothandel - } \\
\text { importeur }\end{array}$ & $\begin{array}{l}\text { buitenlandse } \\
\text { groothandel - } \\
\text { importeur }\end{array}$ & $\begin{array}{l}\text { buitenlandse } \\
\text { groothandel - } \\
\text { importeur }\end{array}$ \\
\hline detailhandel & detailhandel & detailhandel \\
\hline consument & consument & consument \\
\hline
\end{tabular}

Figuur 2.1 Bedrijfskolom en bedrijfstak sectoren glastuinbouw in Nederland met horizontale en verticale concentratie 
Argumenten voor kunnen zijn:

- minder concurrentie van een kleiner aantal ondernemingen met gemiddeld een hoger marktaandeel, een hogere omzet, meestal een hogere winstvoet en meer continuïteit;

- een grotere schaalgrootte van productie, distributie en verkoop. Dit resulteert vaak in een lagere kostprijs ten gevolge van lagere vaste kosten en meer financiële middelen om te investeren in kansrijke innovaties. Dit geldt bijvoorbeeld voor nieuwe omvangrijke investeringen en de kosten en risico's hiervan (bijvoorbeeld onderzoek en exploitatie van alternatieve energiebronnen, proefboringen naar aardwarmte);

- een betere marktpositie en meer mogelijkheden tot machtsvorming (countervailing power) tegenover machtige klanten of leveranciers dat tot een gemiddeld hoger prijsniveau of een lager kostenniveau voor te leveren of te ontvangen producten leidt (Galbraith, 1952, p. 31);

- meer mogelijkheden voor gezamenlijke inkoop en verkoop via op te richten aan- en verkoopcoöperaties, vooral voor de kleinere ondernemingen, waarbij kosten en risico's over meer ondernemingen worden verdeeld.

Argumenten tegen kunnen zijn:

- het ontstaan van gemiddeld grotere ondernemingen met meer productie op grote schaal, kans op meer bureaucratie en een tragere besluitvorming;

- een daling van de concurrentie voor de onderneming waardoor het management vaak minder alert reageert op nieuwe ontwikkelingen en minder snel handelt richting klant en innovaties;

- een minder goede marktwerking voor het totale aanbod van goederen en diensten, een minder goede allocatie met meer verspilling en voor de eindafnemer gemiddeld hogere prijzen;

- teveel macht bij een kleiner aantal ondernemingen wat bij een gelijkblijvend aantal vragers kan leiden tot prijsopdrijving;

- een integratie van de diverse functies van samenwerkende of fuserende ondernemingen met een kans op afname van de soepelheid, flexibiliteit en productiviteit van de nieuwe organisatie. Productie op te grote schaal kan zelfs leiden tot meer monotone arbeid, milieuverontreiniging en minder kwaliteit van processen en producten.

\subsubsection{Voor- en nadelen van verticale concentratie}

Verticale concentratie van ondernemingen in de bedrijfstak heeft eveneens voor- en nadelen. Net als bij horizontale concentratie liggen de meeste argumenten, genoemd door de auteurs, in elkaars verlengde. De belangrijkste uit het werk van De Jong, Porter en Daems en Douma zijn hieronder samengevat (De Jong, 1989, pp. 183-190; Porter, 1992, pp. 305-327; Daems en Douma, 1985, pp. 131-143).

Argumenten voor kunnen zijn:

- realisatie van mogelijke besparingen door het integreren van diverse functies in de bedrijfsprocessen zoals inkoop, productie, verkoop en distributie;

- bij achterwaartse integratie een grotere zekerheid van de aanvoer van benodigde grond- en 
hulpstoffen. Bij voorwaartse integratie een grotere zekerheid van de afzet van producten en diensten. De schakels van de bedrijfskolom zijn nu in eigen beheer;

- een uitbreiding van de ondernemingsactiviteiten met een hogere omzet, een eventueel hogere winstvoet, meer concurrentiekracht en continuïteit;

- meer informatie, kennis en zeggenschap over de kwaliteit en specificaties aan de leverancierszijde en de eisen en wensen aan de afnemerszijde. Dit geeft meer marktinformatie, mogelijkheden tot productdifferentiatie en marktmacht;

- meestal kortere logistieke lijnen en beter op elkaar afgestemde kwaliteitseisen, hoeveelheden en maatvoering wat kostenvoordelen kan opleveren.

Argumenten tegen kunnen zijn:

- een kostennadeel van deze nieuwe schakel ten opzichte van de toeleverancier of afnemer op een competitieve markt door de lagere schaalgrootte, het gemis aan kennis en het gemis aan marktwerking van deze activiteit;

- een toename van de vaste kosten waaronder managementkosten en een stijging van de bureaucratie en het financieel risico. Bij voorwaartse integratie van de groothandels- en exportfunctie is er tevens het risico van niet-verkopen en derving bij de leverantie van versproducten;

- minder mogelijkheden om uit te wijken naar alternatieve leveranciers dan wel afnemers met aantrekkelijker prijs- en leveringsvoorwaarden. Hierdoor zijn er minder onderhandelingsmogelijkheden wat tot minder aantrekkelijke transactievoorwaarden kan leiden, een eventueel lagere winstvoet en een lager rendement;

- minder mogelijkheden voor horizontale samenwerking met bedrijfstakgenoten en het organiseren van 'marktmacht' tegenover machtige klanten dan wel leveranciers (countervailing power). Het gevolg voor vooral de kleinere onderneming is minder aantrekkelijke prijs- en leveringsvoorwaarden, een lagere winstvoet en rendement;

- het financieel risico van overcapaciteit in de geïntegreerde schakels van de bedrijfskolom en eventueel hogere uitstapkosten bij conjuncturele neergang van de economie.

\subsection{Dynamische markttheorie en het SGR-model}

\subsubsection{Marktcoördinatie}

De dynamische markttheorie van De Jong wordt gerangschikt onder de theorie van de externe organisatie (De Jong, 1989). Deze theorie behandelt de bedrijfshuishoudingen van bijvoorbeeld toeleveranciers, producenten en handel in hun onderlinge relaties alsmede die met de overheid. Uit deze relaties kunnen economische organisatievormen ontstaan van uiteenlopende aard, motieven en doelstellingen. Het gaat hier om de ordening van betrekkingen ten behoeve van het bereiken van bepaalde doelstellingen. Bijvoorbeeld het wel of niet samenwerken tussen ondernemingen bij de export van goederen en diensten, bij de inkoop van grondstoffen ten behoeve van het bereiken van een zeker resultaat. Deze ordening tot een bepaalde organisatievorm of -structuur gebeurt volgens bepaalde coördinatieprincipes (De Jong, 1989, pp. 6-8). De Jong 
beschrijft drie grondvormen van marktcoördinatie te weten concurrentie, samenwerking en concentratie. Deze drie coördinatievormen zijn de verbindende schakels tussen marktstructuur en marktgedrag. Een belangrijk verschil tussen deze coördinatievormen betreft het gedrag van de deelnemende partijen (aanbieders en vragers) op de markt. De keuze voor de ene of de andere coördinatievorm wordt meestal gemaakt met als doel tot betere resultaten te komen. Hieronder volgt een overzicht van deze vormen:

- Concurrentie is het onderling rivaliserende gedrag tussen aan de markt deelnemende partijen. Er is steeds sprake van onzekerheid over de vorm van het gedrag van deze partijen.

- Samenwerking staat voor een zekere mate van gedragsregulering bij het bundelen van middelen en gedragingen van verder zelfstandig handelende bedrijfshuishoudingen.

- Concentratie staat eveneens voor gedragsregulering, maar dan wel met de overdracht van de zeggenschap van de ene onderneming aan de andere. Concentratie manifesteert zich in veel verschillende vormen.

De overheid zorgt via de coördinatievormen voor de randvoorwaarden waarbinnen de vrije markt kan functioneren. Zo wordt concurrentie bevorderd door antitrustpolitiek, minimumprijzen bevorderen samenwerking en octrooiverlening bevordert concentratie (De Jong, 1989, p. 162). De afzonderlijke ondernemer ondervindt voorts de invloed van de overheid via wet- en regelgeving, heffingen en subsidies. De Jong betrekt geen direct overheidsingrijpen in de marktstructuur.

Bij de hiervoor genoemde drie coördinatievormen doet zich een aantal paradoxale verschijnselen voor. Geen enkele coördinatievorm blijkt duurzaam te zijn (De Jong, 1989, pp. 16-18).

- Concurrentie neigt naar opheffing door het ontstaan van monopoloïde situaties.

- Samenwerking gaat aan eigen zwakheden ten onder door factoren zoals eigenbelang, menselijke fouten, informatie- en communicatietekorten, te geringe motivatie. ${ }^{1}$

- Bij hoge concentraties dreigen monopoloïde situaties waartegen de overheid optreedt.

- Dit paradoxale karakter van de coördinatievormen leidt tot een dynamische beweging van de markt. Het is een komen en gaan van regels en organisatievormen. Deze vormen betreffen in beginsel niet alleen de horizontale relaties tussen bedrijven in een markt, maar ook de verticale relaties tussen bedrijven uit opeenvolgende schakels van een bedrijfskolom. De dynamische beweging verbindt De Jong met de verschillende fasen van de productlevenscyclus. Dit wordt besproken in paragraaf 2.3.2. Horizontale (de)concentratie in een bedrijfstak en verticale (des) integratie in een bedrijfskolom worden op deze manier verklaard.

De Jong (1989) hanteert in zijn theorie vijf kernbegrippen, te weten: marktsituatie, marktstructuur en marktontwikkeling (1989, pp. 100-101), bedrijfstak en parameterinterdependentie (1989, pp. 76-78).

1 Williamson, O.E., Markets and hierarchies: analysis and antitrust implications. A study in the economics of internal organization. New York, London 1975, pp. 20-41 
- Marktsituatie wordt omschreven als het samenhangend geheel van vraag- en aanbodfactoren dat op een gegeven moment of gedurende een korte periode de kenmerken van de markt van een bepaald product weergeeft (1989, pp. 100-102). Dit betekent dat kwesties als productdifferentiatie, schaalvoordelen, toegangsbarrières e.d. als elementen van de marktsituatie worden gezien. In de statische theorieën spelen de toetredingsbarrières een rol bij de begrenzing van de markt. De barrières kunnen onderhevig zijn aan veranderingen, zonder dat onderlinge verhoudingen zich wijzigen. De Jong gaat uit van barrières als onderdeel van de marktsituatie.

- Marktstructuur is het geheel van kenmerken dat bij een gegeven marktsituatie de geleding, opbouw en onderlinge betrekkingen van marktpartijen aan de aanbod- en vraagzijde van de markt voorstelt. Het betreft het aantal ondernemingen, de onderlinge grootte, verhoudingen en verbindingen tussen de ondernemingen en de mate van concurrentie, samenwerking en concentratie. De marktstructuur wordt gezien als een onderdeel van de marktsituatie. De marktstructuur kan door ondernemers voortdurend worden gevormd en omgevormd, terwijl de marktsituatie conditionerend werkt. De opeenvolgende marktsituaties conditioneren het gedrag van ondernemers zonder dat het gedrag wordt gedetermineerd. De marktsituatie kan beperkingen opleggen aan het effectief gebruik van bepaalde parameters (zoals prijs, kwaliteit, reclame en verpakking).

- Marktontwikkeling is het dynamische element van de dynamische markttheorie. Marktontwikkeling definieert De Jong als de opeenvolging van verschillende marktsituaties in de groeicyclus. Marktsituaties zijn dwarsdoorsneden van de marktontwikkeling. Zij stellen daarin momenten voor die geen permanent karakter, maar wel een zekere eenheid van karakter hebben. Een bepaalde levensfase van het product en bedrijf kan uiteenlopende marktsituaties bevatten.

- Bedrijfstak definieert De Jong als het geheel van de ondernemingen die op directe wijze met elkaar in horizontale relatie treden, concurrerend en anderszins. Met het begrip relatie doelt De Jong op parameterinterdependentie. Dit is het al dan niet optreden van reacties van onafhankelijke ondernemingen op wijzigingen in de parameters (zoals prijs, kwaliteit, reclame en verpakking) van initiërende ondernemingen. Deze parameterinterdependentie fungeert als criterium voor de afbakening van een gelijksoortig product en van de bedrijfstak.

\subsubsection{Productlevenscyclus}

Het dynamische SGR-model van De Jong (zie tabel 2.4) vormt de theoretische beschrijving van de structuurveranderingen in de bedrijfstak in samenhang met de marktontwikkeling in de marktfasen van de productlevenscyclus (De Jong, 1989, p. 121). In deze paragraaf worden de belangrijkste kenmerken van de vier marktfasen in de productlevenscyclus beschreven. Er worden vier marktfasen onderscheiden: introductie-, groei-, rijpheids- en teruggangsfase. Elke marktfase wordt gekenmerkt door specifieke knelpunten. Gezien de afstemmings-problematiek van aanbod en vraag is het interessant te weten welke knelpunten dat zijn en welke oplossingen denkbaar zijn. 
I. De introductiefase in het model bestaat uit een voorfase proefproductie. Door optredende knelpunten in de toelevering van materialen of de afzet van het product vindt vaak een zekere verticale concentratie plaats met toeleveranciers of afnemers. De productie is kleinschalig en arbeidsintensief. Kennis van zaken is belangrijk. Wijzigingen in product en productieproces komen veel voor en product- en procesontwikkeling spelen een belangrijke rol. Afnemers zijn aanvankelijk onbekend met het product en er moet veel gebeuren om het product bekend en geaccepteerd te krijgen. De marketinguitgaven per product zijn in deze fase hoog. Als de proefproductie aanslaat bij de klant en er voldoende (potentiële) klanten klaarstaan met een vraag naar het product, volgt de fase van de commerciële productie. Mogelijk is dat in deze fase ook horizontale samenwerking plaatsvindt op het gebied van markt- en klantbenadering bij gebrek aan kennis van deze materie.

II. De groeifase, ook wel expansiefase genoemd, bestaat in dit model ook uit twee fasen: een beginnende fase en een gevorderde fase. In de beginnende fase is een deconcentratie te constateren van verticale en horizontale concentratie. Deze vindt plaats omdat ondernemers op eigen kracht betere resultaten verwachten dan bij concentratie. Er vindt een brede ontwikkeling van de markt plaats door toetredende en imiterende concurrenten. De ondernemingen zijn vooral bezig met het verkrijgen van een goede marktpositie, de inrichting van processen (inkoop, productie en verkoop) en specialisatie in verschillende richtingen. Knelpunten zijn toename van de concurrentie en druk op het prijsniveau. Deze prijsdaling kan echter weer tot aanzienlijke marktverbreding leiden, wat ruimte geeft voor nieuwe toetreders. Ook stimuleert prijsdaling de productie op grotere schaal met mogelijke kostenverlaging, omzet- en winstvergroting. In de gevorderde groeifase ontstaat er een tendens die karakteristiek is voor de volgende fase: marktverzadiging. Er zijn geen belangrijke vernieuwingen meer bij het product en het proces. De mogelijkheden tot standaardisatie en grootschalige productie nemen toe en zorgen voor een verlaging van de productiekosten. De afzetkosten (transportkosten, reclame) nemen toe doordat de markt steeds groter wordt. Er ontstaat overlapping met afzetgebieden van concurrenten en het kost steeds meer om de laatste potentiële kopers over de streep te trekken. Het eigen marktaandeel groeit langzaam en kan slechts worden vergroot ten koste van anderen. Er ontstaat een kleinere winstmarge en scherpere prijsconcurrentie. Tenslotte ontstaat er overcapaciteit. Het productbeleid is gericht op productdifferentiatie en het marketingbeleid op marktsegmentatie, ter profilering en bescherming van het eigen product ten opzichte van dat van de concurrent. De concentratiebewegingen in deze fase zijn vooral horizontaal gericht. Oorzaak is de bijna verzadigde markt en geringe groei. Teruglopende marges zorgen ervoor dat kleinere bedrijven het financieel niet meer redden en zoeken naar samenwerking en mogelijke fusie met andere.

III. De rijpheidsfase wordt gekenmerkt door een verdere concentratie van de diverse ondernemingen. Knelpunten zijn een verzadigde markt, dalende groeicijfers en een toenemende concurrentie van buiten en binnen de bedrijfstak. De technologie is volledig doordacht. Er ontstaat een capaciteitsoverschot. De beheersing van de kosten gaat een belangrijke rol spelen. Er wordt gestreefd naar standaardisatie, terwijl vooral reclame, verpakking, vormgeving en verkoopfacilitei- 
ten worden aangewend voor differentiatie. De kosten hiervan nemen dan ook toe. De winstmarges staan onder druk door de concurrentie, met als gevolg dat de prijs als concurrentiemethode een ondergeschikte rol speelt. De nadruk komt meer te liggen op concurrentie met kwaliteit, reclame en productdifferentiatie. Concentratie in deze fase is vooral horizontaal gericht. Als er sprake is van verticale concentratie, dan is dat vaak voorwaarts gericht om de afstand tot de klant te verkleinen.

IV. De teruggangsfase kent een verdere toename van de horizontale concentratie en een afname van verticale concentratie. De marktvorm verandert in een monopolie of oligopolie. Knelpunten in deze fase zijn stagnatie van de marktgroei en een nog scherpere concurrentie. Veel ondernemingen fuseren, worden overgenomen, stoppen of verlaten de bedrijfstak.

In aanvang valt de daadwerkelijke teruggang in de afzet mee door de invloed van de vervangingsvraag. Later krimpt de markt en is er negatieve groei doordat de vraag daalt of ophoudt te bestaan. Er is weinig productdifferentiatie en meer massaproductie. De winsten zijn laag en de concurrentie is fel. Het is mogelijk dat de prijzen dalen beneden de integrale kostprijs, het assortiment wordt smaller, de reserves worden aangesproken en de financiële posities van de ondernemingen dalen. Er is verder sprake van onderbezetting en de kosten per eenheid product stijgen. Onderdelen van het bedrijf worden verkocht, waarmee men liquiditeitszorgen wil oplossen. De beheersing van de kosten wordt primair opgelost door horizontale concentratie. In de bedrijfskolom vindt wel samenwerking en afstemming plaats, maar de schakels desintegreren veelal gezien de risicoparadox. Deze vormt in elke marktfase een belemmering voor verticale integratie, maar in de stagnatiefase speelt de risicoparadox de deelnemers aan verticale integratie vooral parten. Wie van de verticaal samenwerkende partners neemt een eventueel negatieve uitkomst van de verticaal geïntegreerde ondernemingen voor zijn rekening? In de stagnatiefase doen zich horizontale concentratie en verticale deconcentratie voor.

In onderstaande tabel 2.3 staan de (de)concentratiebewegingen in relatie tot de fase van de productlevenscyclus volgens De Jong weergegeven (De Jong, 1989). Hier is alleen de standaardcyclus weergegeven. Door de handelingsvrijheid van de ondernemer wordt het verloop van de cyclus beïnvloed en zijn vele cyclusvormen denkbaar.

\begin{tabular}{|l|c|c|c|c|}
\hline \multicolumn{2}{|c|}{ Horizontaal } & & Desintegratie \\
\hline Marktfase & Concentratie & Deconcentratie & Integratie & ++ \\
\hline Introductie & + & & + & + \\
\hline Groei & & + & & + \\
\hline Rijpheid & ++ & & & + \\
\hline Teruggang & + & & & + \\
\hline
\end{tabular}

Tabel 2.3 Concentratiebewegingen in de bedrijfstak op basis van de standaardcyclus van de productlevenscyclus, volgens H.W. de Jong. ++ betekent dat op deze (de)concentratievorm meer nadruk ligt dan op + (Rogier, 1998). 
Met de productlevenscyclus verklaart De Jong de dynamiek. Doordat er een wederzijdse beïnvloeding bestaat tussen ondernemingen en markt kan de productlevenscyclus een ander verloop hebben dan het standaardpatroon met de S-curve (De Jong, 1989, p. 84). De Jong vooronderstelt dat ondernemers de markt en de S-curve kunnen beïnvloeden door allerlei innovaties. De markt is ook te beïnvloeden door handelingen in de vorm van concurrentie, samenwerking of concentratie. Voorts zijn er conditionerende factoren, bijvoorbeeld de situationele vraag- en aanbodverhoudingen in de verschillende fasen van de productlevenscyclus. Ondernemingen maken hierbij strategische keuzen. Deze keuzen worden door De Jong niet verder uitgewerkt. Hij beschrijft de ontwikkeling op bedrijfstakniveau en geeft geen strategisch te voeren beleid voor de individuele ondernemer.

\subsubsection{Structurele concentratie}

De Jong probeert de bepalende factoren van de markontwikkeling in hun onderlinge samenhang vast te leggen en komt hierbij tot een nieuw begrip: structurele concentratie.

In bijlage 3 van dit proefschrift wordt de formule hiervan en de berekeningswijze uitgebreid toegelicht, hieronder wordt vooral de toepassing in het dynamisch SGR-model beschreven.

De bepalende factoren van de marktontwikkeling zijn: "de techniek, de marktverzadiging, de gedragingen van de collectiviteit van ondernemers en de handelingen van individuele, anticiperende ondernemers" (De Jong, 1989, pp. 114-125).

De techniek staat voor de technische ontwikkeling van het bedrijfsproces tot een optimale bedrijfsomvang van mensen en middelen door de individuele en collectieve ondernemers.

Deze optimale ondernemingsomvang $(\mathrm{O})$ heeft de neiging te stijgen met de ontwikkeling in de bedrijfstak als de groei van de markt meer productiemiddelen vereist.

Een ander begrip dat De Jong definieert is de verzadigingsgraad (V). Deze geeft de verhouding weer van de actuele marktomvang $\left(\mathrm{M}_{\mathrm{a}}\right)$ en de relevante marktomvang $\left(\mathrm{M}_{\mathrm{p}}\right)$.

Deze actuele marktomvang is de werkelijke marktomvang in de verschillende fasen van de productlevenscyclus. De relevante marktomvang is de maximaal te bereiken marktomvang gedurende deze fasen. Het verschil tussen actuele en relevante marktomvang noemt De Jong de resterende potentiële marktomvang $\sum d$. Hieruit volgen twee gelijkheden:

- de relevante marktomvang $\mathrm{M}_{\mathrm{r}}: \quad \mathrm{M}_{\mathrm{r}}=\mathrm{M}_{\mathrm{a}}+\sum \mathrm{d}$

- de verzadigingsgraad $\mathrm{V}: \quad \mathrm{V}=\mathrm{M}_{\mathrm{a}} / \mathrm{M}_{\mathrm{r}}=\mathrm{M}_{\mathrm{a}} /\left(\mathrm{M}_{\mathrm{a}}+\sum \mathrm{d}\right)$

Met het verloop van de marktontwikkeling kan V zowel stijgen als dalen, maar op den duur stijgt $\mathrm{V}$ nauwelijks door de vermindering van de groei van de potentiële markt $\sum \mathrm{d}$.

De groei van de potentiële marktomvang is van belang voor de marktontwikkeling in de verschillende stadia van de productlevenscyclus. De waarde van V ligt tussen 0 en 1, afhankelijk van de waarde van $\sum \mathrm{d}$ en zal zijn maximum 1 bereiken als $\sum \mathrm{d}$ nadert tot nul. 
De Jong definieert nu met behulp van de zojuist omschreven begrippen structurele concentratie $\left(C_{\mathrm{x}}\right)$. (De Jong, 1989, pp. 116-117).

In formule weergegeven:

- $\mathrm{C}_{\mathrm{x}}=\mathrm{O} / \mathrm{M}_{\mathrm{r}}=\mathrm{O} . \mathrm{V} / \mathrm{M}_{\mathrm{a}}$

In woorden: de structurele concentratie is de verhouding van de optimale ondernemings-omvang en de relevante marktomvang of te wel voor hoeveel ondernemingen met een optimale omvang is er ruimte in de relevante marktomvang.

Confrontatie van de werkelijke concentratiegraad $\left(\mathrm{C}_{\mathrm{w}}\right)$ met deze $\mathrm{C}_{\mathrm{x}}$ geeft inzicht in:

- de over- of onderschrijding van de structurele concentratie in de bedrijfstak

- het verloop van de mogelijke concentratie- en deconcentratieprocessen.

In de introductiefase van de productlevenscyclus bijvoorbeeld is $\mathrm{C}_{\mathrm{w}}$ meestal zeer hoog en veelal gelijk aan 1: de innovatiemonopolist treedt op met een nieuw product. $\mathrm{C}_{\mathrm{x}}$ is middelmatig hoog tot gering, zodat er een inherente spanning ontstaat in de bedrijfstak om tot deconcentratie te komen. Deze spanning wordt veroorzaakt door de imiterende ondernemers gedurende de groeifase die kansen zien in de markt van de pionierende vernieuwer. Voortzetting hiervan vindt plaats in het tweede deel van de groeifase, want $\mathrm{C}_{\mathrm{x}}$ blijft laag door nieuwe toepassingsgebieden die naar voren komen. Door prijsverlaging en productverbetering krijgt de potentiële markt impulsen en nieuwe marktsegmenten dienen zich aan.

In de rijpheidsfase groeit de potentiële markt minder snel en stijgt de verzadigingsgraad V. De structurele concentratie $\mathrm{C}_{\mathrm{x}}$ heeft de neiging te stijgen doordat $\mathrm{V}$ stijgt en ook de optimale ondernemingsomvang $\mathrm{O}$ waarschijnlijk zal stijgen door een toenemende schaalgrootte.

In het tweede deel van de rijpheidsfase en het eerste deel van de teruggangsfase zet deze werking zich versterkt voort en $\mathrm{C}_{\mathrm{x}}$ stijgt scherp. De hierop anticiperende ondernemers gaan over tot horizontale of verticale concentratie. De schaalgrootte van de optimale ondernemersomvang en de marktverzadiging die zijn bereikt, laten geen ruimte voor de bestaande aantallen ondernemingen. Er dient een noodzakelijke aanpassing plaats te vinden van de werkelijke concentratie $\mathrm{C}_{\mathrm{w}}$ aan de structurele concentratie $\mathrm{C}_{\mathrm{x}}$.

Gebeurt dit niet, dan is de kans op instabiele oligopolies met prijsoorlogen het gevolg, een leerproces om in te zien dat $\mathrm{C}_{\mathrm{x}}$ duurzaam is verhoogd.

\subsubsection{Het dynamisch SGR-model}

Het dynamisch SGR-model van De Jong, zie tabel 2.4 op de volgende pagina, toont op een compacte en overzichtelijke manier de belangrijkste theoretische kenmerken van de marktstructuur $(S)$, het marktgedrag van de ondernemers $(G)$ en het bereikte marktresultaat $(R)$ in de zes fasen van de marktontwikkeling van een product.

De fasen zijn achtereenvolgens de introductiefase (proef- en commerciële productie), de groeifase (beginnend en gevorderd/aflopend), de rijpheidsfase en de teruggangsfase. 


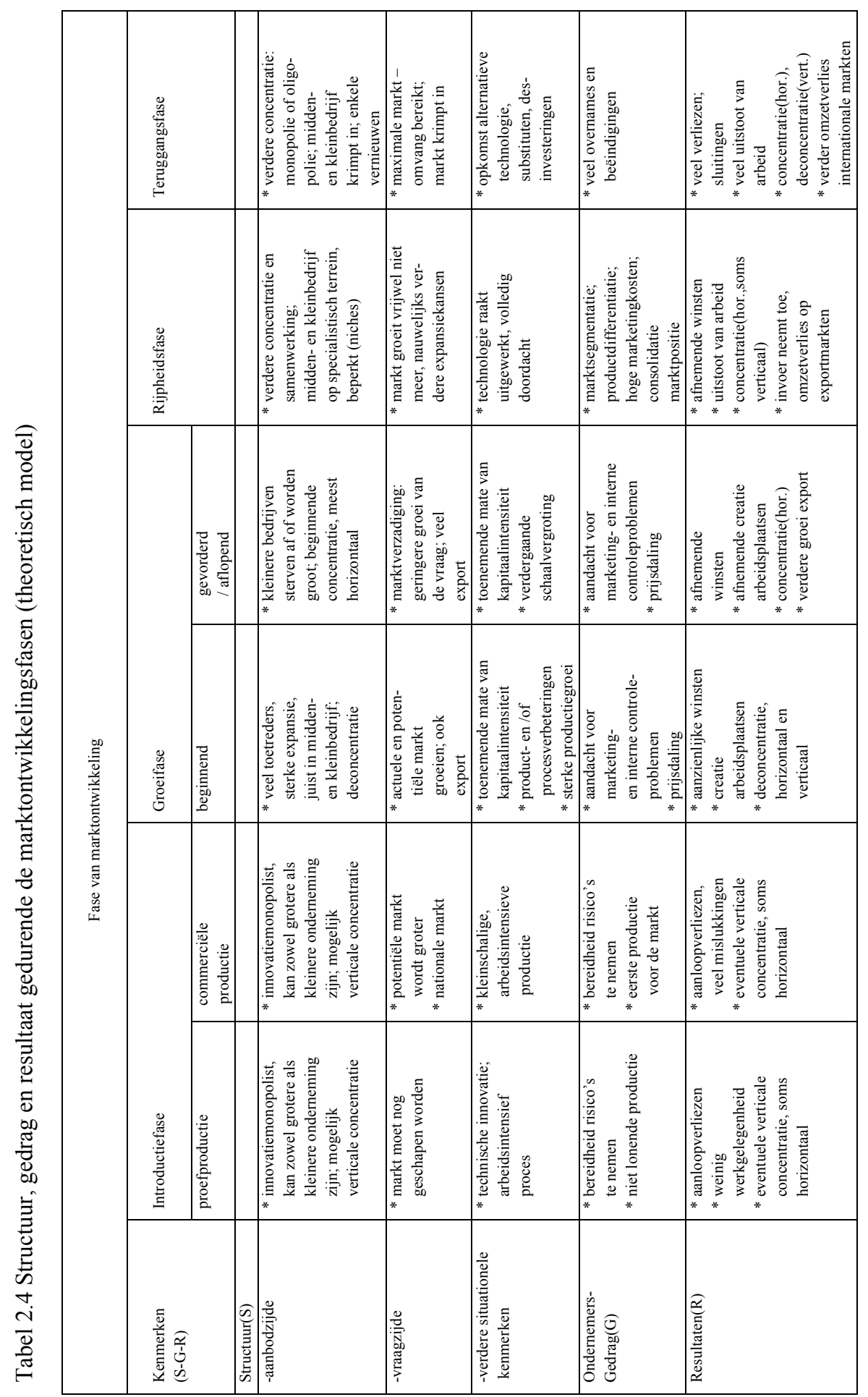


- De marktstructuur(S) geeft de kenmerken weer van de aanbod- en vraagzijde van de markt en de situationele factoren in de te onderscheiden fasen.

- Het ondernemersgedrag $(\mathrm{G})$ geeft de hoofdzaken van het te voeren strategisch beleid in de te onderscheiden fasen weer.

- Het resultaat(R) geeft informatie over het verloop van concurrentie, concentratie, omzet en verlies/winst van de ondernemingen in de te onderscheiden fasen.

\subsection{Structurele analyse van de bedrijfstak}

In dit promotieonderzoek staat het volgen van de ontwikkelingen in concurrentie, samenwerking en concentratie in de sectoren van de bedrijfstak glastuinbouw centraal. Welke ontwikkelingen zijn te constateren in de deelsectoren glasgroenten, -snijbloemen en -potplanten? Leiden deze ontwikkelingen tot een verschil in marktstructuur, marktgedrag en -resultaat? De dynamische markttheorie van De Jong volgt en analyseert hiertoe vooral de marktontwikkeling gedurende de levensfasen van het product. Hij richt zich in het bijzonder op het verloop van horizontale en verticale (de)concentratie. Porter zoekt vanuit een structurele analyse van de bedrijfstak naar het verloop van de concurrentie-intensiteit en het daarachter liggende krachtenveld. In deze paragraaf wordt de kern van de theorie van structurele analyse van de bedrijfstak (Porter, 1992) behandeld met de aansluiting op het conceptueel model (figuur 1.1). Hiermee kan de mate van concurrentie, concentratie en rentabiliteit in de drie sectoren van de glastuinbouw worden geanalyseerd.

Evenals De Jong in zijn Dynamische Markttheorie gaat ook Porter uit van een wederzijdse beinvloeding van marktstructuur en marktgedrag. Porter hanteert als analyseniveau de individuele ondernemer. Hij onderscheidt vijf concurrentiekrachten, ook wel sleutel-kenmerken genoemd (Porter, 1992, p. 4). Het zijn deze sleutelkenmerken en de onderliggende bronnen die gezamenlijk de grootte van de concurrentie-intensiteit en de winstmogelijkheden van de bedrijfstak of sector bepalen. De vijf sleutelkenmerken zijn:

1.bedrijfsconcurrenten: rivaliteit tussen bestaande bedrijven in de sector;

2.mogelijke toetreders: bedreiging van nieuwe toetreders tot de sector;

3. substituten: bedreiging van substituutproducten of -diensten;

4. leveranciers: onderhandelingspositie van leveranciers en bedrijven in de sector;

5. kopers: onderhandelingspositie van de kopers en bedrijven in de sector;

De sterkte van deze vijf krachten varieert over de tijd. Een belangrijke verklaring hiervoor is een van de basisconcepten van de bedrijfstakontwikkeling, de levenscyclus van de bedrijfstak. Evenals De Jong gebruikt ook Porter het levenscyclusconcept voor een dynamische beschouwing (Porter, 1992, pp. 160-165). Hij geeft een aantal gangbare voorstellingen van de wijzigingen die de bedrijfstak gedurende de levenscyclus kan ondergaan en wat het effect daarvan zou moeten zijn op een te voeren strategie. Hij geeft direct de nodige kritiek op dit concept, met name als 
hulpmiddel bij planning, en acht het onjuist het concept te gebruiken in voorspellende zin (Porter, 1992, pp. 161, 165). Een alternatief voor het gebruik van de levenscyclus van de bedrijfstak is het concept voor bedrijfstakontwikkeling dat Porter schetst. Dit concept is een methode voor ontwikkelingsprognoses, in dit geval het volgen van de belangrijkste ontwikkelingsprocessen in de bedrijfstak zoals veranderingen in groei, kopersegmenten, kennis en ervaring, schaalgrootte, inputkosten en wisselkoersen, product-, marketing- en procesvernieuwing, wijzigingen in het overheidsbeleid en toe- en uittreding van bedrijven (Porter, 1992, pp. 167-186). Hij is voorts van mening dat zowel het individuele bedrijf als de collectiviteit van bedrijven de structuur van de bedrijfstak kan beïnvloeden en veranderen (Porter, 1992, pp. 187-190). Hij noemt hiervoor drie strategieën: kostenleiderschap, differentiatie en marktsegmentatie. Marktsegmentatie wordt door Porter ook wel focus genoemd. Hiermee wordt bedoeld dat de onderneming met zijn marketingbeleid is 'gefocust' op een specifieke doelgroep bijvoorbeeld jongeren in de leeftijd van 12-18 jaar.

Porter neemt evenals De Jong afstand van de statische variant van industrial organisation (1981, pp. 615-616). In industrial organisation spelen de begrippen bedrijfstak en markt een centrale rol. Porter ziet een bedrijfstak als een groep van ondernemingen die producten voortbrengen die elkaar kunnen vervangen. Hij gebruikt de markt hier als criterium. Het begrip markt wordt niet gedefinieerd. De definitie van de bedrijfstak geeft veel ruimte (Porter, 1992, pp. 5, 32). Voor de bepaling van de strategie acht Porter het niet van belang waar de grens van de bedrijfstak precies ligt. Voor de ontwikkeling van een strategie zijn alleen de concurrentiekrachten van belang. Porter besteedt veel aandacht aan strategische groepen, terwijl hij de bedrijfstak nauwelijks omschrijft. De strategische groep wordt door Porter gezien als een groep van bedrijven die binnen een bedrijfstak eenzelfde of vergelijkbare strategie volgen op basis van strategische dimensies (Porter, 1992, p. 129). Deze strategische dimensies zijn: specialisatie, merkidentificatie, 'push' versus 'pull' strategie, kanaalkeuze, productkwaliteit, technologische voorsprong, verticale integratie, kostenpositie, service, prijsbeleid, 'leverage', verhouding met het moederbedrijf en verhouding tussen eigen en gastregering (Porter, 1992, pp. 127-129). Porter geeft niet aan waarom hij voor deze dimensies kiest. De visie van Porter op de bedrijfstakontwikkeling en de markt is evenals bij De Jong een dynamische. Er is keuzevrijheid voor de ondernemer en wederzijdse beïnvloeding van marktstructuur en marktgedrag. De definiëring van het begrip bedrijfstak is summier. De markt wordt niet gedefinieerd. De strategische groep wordt vooral gekenmerkt door aanbodkarakteristieken.

De bijdrage van de theorie van Porter aan dit onderzoek betreft met name het volgende:

- een grondige structurele analysemethode voor het vaststellen van de concurrentiekrachten en -intensiteit in de bedrijfstak en de sectoren glastuinbouw;

- een methode voor het meten en vergelijken van concurrentie en concentratie in deze sectoren en het inzichtelijk maken van de gevolgen, veroorzaakt door een strategie van voorwaartse verticale integratie;

- een methode voor het opzetten van een strategische kosten- en batenanalyse van voorwaartse verticale integratie (zie paragraaf 2.5). 


\subsection{Voorwaartse verticale integratie}

\subsubsection{De theorie van voorwaartse verticale integratie}

Een onderneming kan proberen haar concurrentiepositie te versterken door een strategie te voeren van voorwaartse of achterwaartse verticale integratie. Bij een voorwaartse integratie neemt de onderneming tevens de afwerking van haar producten op zich of verzorgt zelf de distributie en verkoop van deze producten in plaats van een onafhankelijke groothandel.

Bij achterwaartse verticale integratie legt de onderneming zich tevens toe op de levering van grondstoffen en materialen die ze voor haar productie nodig heeft. Hier wordt het schematisch analysekader van voorwaartse verticale integratie besproken.

In paragraaf 2.2.3 van dit hoofdstuk zijn het begrippenkader en de voor- en nadelen van horizontale en verticale concentratie behandeld aan de hand van de literatuur van De Jong (1989), Daems en Douma (1985) en Porter (1992). In de volgende paragrafen 2.5.2 t/m 2.5.5 bespreek ik de belangrijkste conclusies van deze auteurs uit de theorie van voorwaartse verticale integratie. Daarna volgt de invulling van het voorbeeld schematisch analysekader (2.5.6).

\subsubsection{De Jong}

In Dynamische Markttheorie (De Jong, 1989, pp. 183-218) gaat de Jong uitgebreid in op de vele aspecten van verticale integratie. Naast de in paragraaf 2.3 genoemde voor- en nadelen komt hij tot een aantal opvallende conclusies. Het blijkt in de praktijk van het ondernemen erg moeilijk te zijn om tot werkelijk effectieve technische integratie te komen. Hij geeft een voorbeeld van de Engelse textielindustrie waar in de zestiger jaren van de vorige eeuw een grootscheeps proces van voorwaartse verticale integratie is ondernomen door een aantal belangrijke kunstvezelproducenten, van spinnen tot kleinhandelsafzet. Ondanks het streven naar minimalisatie van de kosten per deelfase, leidde dit in zijn geheel tot een belangrijke kostenverhoging en winstdaling (De Jong, 1989, pp. 185-186). Concerns met de meest directe marktverbindingen presteerden hier nog het beste. In zijn algemeenheid vindt De Jong het moeilijk de vraag te beantwoorden of een strategie van verticale integratie zodanige voordelen geeft dat de nadelen tenminste worden gecompenseerd (De Jong, 1989, p. 189). Het is vooral in de introductiefase en beginnende groeifase van een nieuw product dat verticale integratie van belang kan zijn. De tijd dringt en het innoverende bedrijf kan niet altijd wachten tot leveranciers en afnemers voldoende zijn meegegroeid. De (potentiële) concurrentie staat klaar om marktaandeel over te nemen. Ook kunnen overwegingen van geheimhouding een rol spelen en kunnen specifieke bedrijfsgeheimen door integratie van opeenvolgende stadia in de bedrijfskolom beter worden beschermd (De Jong, 1989, p. 195). De Jong wijst nog op de centrale rol van de ondernemersfunctie in de ontwikkeling van de bedrijfstak. Het volgen van en anticiperen op structuurwijzigingen in bedrijfstakken en markten behoort tot een wezenlijk bestanddeel van de ondernemersfunctie (De Jong, 1989, p. 199). Voorwaartse verticale integratie in de rijpheidsfase is pas dan van belang als voorwaarts gelegen schakels knelpunten opleveren in de distributie naar de eindafnemer. Functioneel gezien is er minder reden voor als er een goed handelsapparaat beschikbaar is (De Jong, 1989, p. 200). Verticale integratie kan behalve door kostenafweging (de integrerende producent kan de te 
koppelen functie zelf goedkoper verrichten) en dynamische overwegingen (innovaties en tempowinst) ook door machtsfactoren worden gestimuleerd. De Jong geeft hiervan een voorbeeld. Als een verticaal geïntegreerde onderneming in een bedrijfstak een marktbeheersende positie inneemt (hoge horizontale concentratie) en haar integratiegraad ligt tussen 0 en 1 (een deel van de levering of afzet gaat via de markt), dan heeft zij de mogelijkheid de van haar afhankelijke leveranciers of afnemers te manipuleren of hiermee te dreigen door het hanteren van verschillende inkoop- of verkoopprijzen. Hij trekt hierbij de volgende conclusies (De Jong, 1989, p. 211):

1. Monopolie of marktbeheersing in een der schakels levert het vermogen tot machtsuitoefening (prijsdiscriminatie, prijstangeffecten, uitsluiting e.a.) in andere schakels.

2. Marktstructuur en de aard van de concurrentie verandert bij voortgezette (verticale) integratieprocessen in een bedrijfstak.

Hierna behandelt De Jong uitgebreid de effecten van verticale integratie tussen ondernemingen in een concurrerende marktstructuur, verticale integratie tussen ondernemingen in een monopoloïde en concurrerende marktstructuur en verticale integratie van monopolisten. Zijn algemene conclusie luidt (De Jong, 1989, p. 218): verticale integratie behoeft bij ongewijzigde kostenfuncties na integratie geen voordelen op te leveren en heeft des te meer nadelen naarmate de macht van de geïntegreerde marktbeheersende ondernemingen de concurrentie meer uitschakelt. Als zij tot kostenbesparingen voert, zal zij maatschappelijk gezien slechts dan voordelen geven als de prijzen van de eindproducten dalen en vergrote winsten tot innovaties leiden.

\subsubsection{Daems en Douma}

Daems en Douma behandelen in Concurrentie: Analyse en Strategie (1985, pp. 131-134) de voor- en nadelen van verticale integratie als onderdeel van positieverbeterende strategieën. Zij beperken zich tot een opsomming van deze voor- en nadelen. Ook noemen zij een alternatief voor verticale integratie door middel van het afsluiten van langetermijncontracten van het bedrijf met zijn distributeurs, agenten en leveranciers. Deze contracten verminderen de investeringen die de onderneming zelf moet verrichten, maar houden het risico in van niet-naleving. Dit risico achten zij bijzonder groot als correcte naleving van de beschikkingen van het contract vatbaar is voor juridische betwisting. Het risico van een contractuele integratie zal moeten worden afgewogen tegen de voor- en nadelen van verticale integratie met eigen investeringen. Als belangrijkste evaluatiepunt noemen zij dat de onderneming door het zelf uitvoeren van de te integreren activiteiten een kostenvoordeel of een strategisch en concurrentieel voordeel kan krijgen dat haar zou ontglippen als ze op onafhankelijke leveranciers of afnemers een beroep doet. Onderzoek heeft volgens hen uitgewezen dat deze voordelen vaker worden verkregen bij voorwaartse dan bij achterwaartse integratie. Vooral hoogtechnologische ondernemingen en producenten van gedifferentieerde producten zouden baat hebben bij voorwaartse verticale integratie. 


\subsubsection{Porter}

In Porters Concurrentiestrategie (Porter, 1992, pp. 305-328) worden de economische en bestuurlijk organisatorische gevolgen van verticale integratie van bedrijfstakken in de bedrijfskolom onderzocht. Het doel is om managers te helpen bij het vaststellen van de juiste mate van verticale integratie in een strategische context en een brede afweging te maken van alle te voorziene kosten en baten. Deze kosten- en batenanalyse kan zowel voor de betreffende bedrijfstak als voor het individuele bedrijf aanmerkelijke verschillen opleveren. Een en ander is afhankelijk van de specifiek strategische situatie van deze bedrijfstak en de positie van het bedrijf hierin. Porter geeft duidelijk aan dat deze afweging veel verder dient te gaan dan een louter financiële beslissing over het 'zelf doen' dan wel 'uitbesteden' van de nieuwe verticale activiteit. De kosten en baten worden mede beïnvloed door de vraag of het bedrijf een beleid voert van getemperde integratie of dat het direct kiest voor volledige integratie. Getemperde verticale integratie houdt in dat men ervoor kiest in aanvang een deel van de te integreren activiteiten in eigen beheer te verrichten en een ander deel uit te besteden.

Veel baten van verticale integratie kunnen voorts ook worden verkregen zonder grote investeringen door middel van schijnintegratie via bijv. participatie in ondernemingen of het creëren van verticale verbindingen tussen bedrijven zonder volledige eigendom na te streven.

Porter beschrijft deze brede strategische afweging door middel van het opzetten van een schematisch kader dat gecombineerd moet worden met een zorgvuldige analyse van de bedrijfstak en de concurrentie. Er dient een analyse van de specifiek te bestuderen situatie plaats te vinden en een nauwgezette strategische taxatie door het bedrijf dat de beslissing moet nemen (Porter, 1992, p. 307). Porter begint met een bespreking van de algemene baten en kosten en eindigt met een aantal specifieke aspecten van voorwaartse en achterwaartse verticale integratie. In paragraaf 2.2.3.2 zijn de meeste van deze aspecten uitgebreid behandeld. Porter besteedt expliciet aandacht aan het belang van de optimale schaalgrootte van een achterwaarts of voorwaarts nieuw te integreren activiteit. Als het integrerende bedrijf hier geen kans toe ziet, zal een minder efficiënte eenheid moeten worden opgezet (met mogelijk hogere kosten dan die van de markt) of een 'efficiënte' eenheid die een deel aan de markt levert. De vraag is dan wel hoe de concurrentie hierop reageert. Porter heeft veel aandacht voor de vergroting van de concurrentiekracht van de verticaal integrerende bedrijven en bedrijfstak. Zowel het vergroten van het vermogen om te differentiëren als het verhogen van toetredingsbarrières en onderhandelingsmacht met leveranciers en kopers kan de posities en concurrentiekracht van de bedrijven en de bedrijfstak(ken) aanmerkelijk versterken (Porter, 1992, pp. 312-313). Soms kan een bedrijf gedwongen zijn te integreren op defensieve gronden, omdat het anders te maken krijgt met een nadeel van uitsluiting dat zwaarder weegt naarmate het percentage onbereikbare klanten of leveranciers toeneemt. Dezelfde overwegingen houden in dat een nieuwe toetreder tot de bedrijfstak op geïntegreerde basis moet toetreden. Deze noodzaak van integratie zal de barrières van toe- en uittreding doen toenemen op een vergelijkbare manier als de vereiste schaalgrootte of kapitaalomvang (Porter, 1992, p. 314).

Een belangrijk aandachtspunt waar Porter bij de behandeling van de strategische kosten nog op wijst, is het probleem van handhaving van het evenwicht in productiecapaciteit van de schakels in de verticale keten. De schakel met overcapaciteit (of -vraag) moet een gedeelte van zijn output 
verkopen (of iets van zijn input kopen) op de vrije markt op straffe van opoffering van de marktpositie. Een dergelijke stap in zo'n situatie is misschien moeilijk, omdat de verticale relatie het bedrijf vaak dwingt van zijn concurrenten te kopen of aan hen te verkopen. Deze concurrenten kunnen onwillig zijn om met het bedrijf handel te drijven uit angst om op de tweede plaats te komen of om versterking van de positie van de concurrent te vermijden. Als daarentegen het outputoverschot gemakkelijk op de vrije markt kan worden verkocht of als het tekort daar gemakkelijk kan worden aangevuld, zijn de risico's van evenwichtsverstoring niet al te groot. Verticale fasen raken om een aantal redenen vaak uit balans. Ten eerste verschillen de efficiënte capaciteitsuitbreidingen van de verschillende schakels doorgaans waardoor zelfs in een groeiende markt perioden van evenwichtsverstoring kunnen optreden. Ook kunnen technologische veranderingen in de verticale schakels deze capaciteiten doen verschillen. Tenslotte moet bij deze problematiek rekening worden gehouden met de aard en waarde van de te verhandelen goederen. Oplopende (incourante) voorraden en snelle veroudering van bederfelijke waar kunnen een groot financieel risico inhouden.

\subsubsection{Conclusies}

De Jong komt ten aanzien van voorwaartse verticale integratie tot de volgende deelconclusies:

- Het volgen van en anticiperen op structuurwijzigingen als horizontale en verticale samenwerkingsverbanden en eventuele concentraties in bedrijfstakken en markten behoort tot een wezenlijk bestanddeel van de ondernemersfunctie.

- Het blijkt in de praktijk van het ondernemen erg moeilijk te zijn om tot werkelijk effectieve technische integratie te komen.

- Het is moeilijk in algemene zin de vraag te beantwoorden of een strategie van verticale integratie zodanige voordelen geeft dat de nadelen tenminste worden gecompenseerd. Het is vooral in de introductiefase en beginnende groeifase van een nieuw product dat verticale integratie van belang kan zijn.

- Voorwaartse verticale integratie in de rijpheidsfase is pas dan van belang als voorwaarts gelegen schakels knelpunten opleveren in de distributie naar de eindafnemer. Functioneel gezien is er minder reden voor als er een goed handelsapparaat beschikbaar is.

Zijn eindconclusie luidt (De Jong, 1989, p. 218):

- Verticale integratie behoeft bij ongewijzigde kostenfuncties na integratie geen voordelen op te leveren en heeft des te meer nadelen naarmate de macht van de geïntegreerde marktbeheersende ondernemingen de concurrentie meer uitschakelt. Als zij tot kostenbesparingen voert, zal zij maatschappelijk gezien slechts dan voordelen geven als de prijzen van de eindproducten dalen en vergrote winsten tot innovaties leiden.

Daems en Douma komen ten aanzien van voorwaartse verticale integratie tot de volgende conclusie:

- De strategische afweging van een wel of niet verticaal te integreren activiteit heeft als belangrijkste evaluatiepunt het concurrentieel voordeel (aan kosten- of opbrengstzijde) dat de 
onderneming kan verkrijgen bij integratie en dat ze zou mislopen als ze op onafhankelijke leveranciers of afnemers een beroep doet. Dit voordeel wordt volgens hen vaker verkregen bij voorwaartse dan bij achterwaartse integratie. Vooral hoogtechnologische ondernemingen en producenten van gedifferentieerde producten zouden baat hebben bij voorwaartse verticale integratie.

Porter pleit bij voorwaartse verticale integratie voor een brede afweging van financieel-economische en bestuurlijk organisatorische aspecten. Hij trekt geen harde conclusies, maar wijst op de volgende aandachtspunten:

- De handhaving van evenwicht in productiecapaciteit en vraagomvang in de achtereenvolgende schakels in de verticale keten blijft een probleem.

- Verticale fasen raken om een aantal redenen vaak uit balans. Ten eerste verschillen de efficiente capaciteitsuitbreidingen van de verschillende schakels doorgaans waardoor zelfs in een groeiende markt perioden van evenwichtsverstoring kunnen optreden. Ook kunnen technologische veranderingen in de verticale schakels deze capaciteiten doen verschillen.

- Bij deze problematiek moet rekening worden gehouden met de aard en waarde van de te verhandelen goederen. Oplopende (incourante) voorraden en snelle veroudering van bederfelijke waar kunnen een groot financieel risico inhouden.

De conclusies van bovengenoemde auteurs geven aan dat er risico's zijn verbonden aan een strategie van voorwaartse verticale integratie. Productsoort en -type, nieuwheid en marktontwikkeling in de productlevensfasen spelen hierbij een belangrijke rol. Bij verkleining of afsluiting van een deel van de markt door deze strategie moet rekening worden gehouden met scherpe reacties van de concurrentie. Een aanzienlijke vermindering van vertrouwen in elkaar is het gevolg. De bereidheid tot horizontale samenwerking zoals extra levering bij tekorten of afname bij overschotten zal flink afnemen. Dit laatste kan juist in de vaak moeilijk te plannen sector van verse (glas)tuinbouwproducten extra nadelige gevolgen hebben voor het bedrijfsresultaat.

\subsubsection{Schematisch analysekader van voorwaartse verticale integratie}

\section{Inleiding}

Bijgaande voorbeeldoverzichten op de volgende pagina's geven het schematisch analysekader met de invulling van de belangrijkste strategische kosten en baten van voorwaartse verticale integratie. Het gaat hierbij om een brede afweging van alle pro's en contra's dus naast de economische zijn ook de organisatorische en eventueel andere aspecten op hun merites beoordeeld en opgenomen. De onderstaande conclusie is een voorbeeld. Op basis van onderzoeksuitkomsten kunnen wegingscoëfficienten en scores nader worden gemotiveerd en ingevuld.

\section{Voorbeeldconclusie}

De afweging van de verschillende strategische kosten en baten bij deze voorwaartse verticale integratie van de productiebedrijven annex hun verkoopcoöperatie met de groothandels/export- 
functie laten zien dat de strategische kosten enigszins hoger worden ingeschat dan de baten. De raming van de gemiddelde score van de kosten van verticale integratie komt uit op 3.6 en die van de baten op 3.3. (zie de scoreformulieren op de volgende pagina's).

Voorbeeld strategische kosten- en batenanalyse van voorwaartse verticale integratie

\section{Strategische kosten}

Hieronder volgen puntsgewijs de af te wegen strategische kosten met een raming van de scores ( 5-puntsschaal, 1= laag--------> 5 = hoog ) en wegingscoëfficient.

\begin{tabular}{|c|c|c|c|c|c|}
\hline Nr. & Strategische kostenveroorzakende factoren & $\begin{array}{l}\text { Sub- } \\
\text { nr. }\end{array}$ & Strategische kostensoorten & $\begin{array}{l}\text { Sco- } \\
\text { re } \\
(1-5)\end{array}$ & $\begin{array}{l}\text { We- } \\
\text { ging } \\
\text { in } \%\end{array}$ \\
\hline \multirow[t]{8}{*}{1.} & Toetredingsdrempel kosten en investeringen & a. & Verhoging inkoopkosten & & \\
\hline & (overwinnen van mobiliteitsbarrières) & $\mathrm{b}$. & Idem productiekosten & & \\
\hline & & c. & Idem logistieke kosten & 5 & \\
\hline & & d. & Idem verkoopkosten & 5 & \\
\hline & & e. & Idem materiaalkosten & 5 & \\
\hline & & f. & Idem vaste / variabele kosten & 5 & \\
\hline & & g. & Hoogte Investeringen & 5 & \\
\hline & & $\begin{array}{l}\text { a.t } / \mathrm{m} \\
\text { g. }\end{array}$ & Gemiddelde score: & 5 & 20 \\
\hline 2. & $\begin{array}{l}\text { Toetredingsdrempel productietechniek en - } \\
\text { technologie (overwinnen van mobiliteits- } \\
\text { barrières) }\end{array}$ & a. & $\begin{array}{l}\text { Beschikbare toegang en } \\
\text { kostenvereisten techniek- en } \\
\text { technologie ( incl. kennis, } \\
\text { vaardigheden, vakbekwaam personeel) }\end{array}$ & 0 & 0 \\
\hline 3. & $\begin{array}{l}\text { Toetredingsdrempel grondstoffen en } \\
\text { materialen (overwinnen van mobiliteits- } \\
\text { barrières) }\end{array}$ & a. & $\begin{array}{l}\text { Beschikbare toegang en } \\
\text { kostenvereisten grondstoffen en } \\
\text { materialen }\end{array}$ & 0 & 0 \\
\hline 4. & $\begin{array}{l}\text { Toetredingsdrempel Distributiekanalen } \\
\text { (overwinnen van mobiliteitsbarrières) }\end{array}$ & a. & $\begin{array}{l}\text { Beschikbare toegang en } \\
\text { kostenvereisten distributiekanalen }\end{array}$ & 5 & 20 \\
\hline 5. & $\begin{array}{l}\text { Afname flexibiliteit en concurrentievermogen } \\
\text { tov (nieuwe) marktpartijen ( leveranciers, } \\
\text { afnemers en concurrenten) } \\
\text {-te vast geklonken keten; }\end{array}$ & $\begin{array}{l}\text { la. } \\
\mathrm{t} / \mathrm{m} \\
1 \mathrm{~g}\end{array}$ & $\begin{array}{l}\text { Correctie verhoging diverse kosten en } \\
\text { investeringen }\end{array}$ & 3 & 5 \\
\hline 6. & $\begin{array}{l}\text { Algehele verhoging uittredingsdrempel bij } \\
\text { eventueel verlaten bedrijfstak / sector }\end{array}$ & a. & $\begin{array}{l}\text { Hogere uittredingskosten, risico van } \\
\text { kapitaalvernietiging, zie } 1 \mathrm{at} / \mathrm{m} \mathrm{g} \text {. }\end{array}$ & 3 & 5 \\
\hline \multirow[t]{2}{*}{7.} & $\begin{array}{l}\text { Kapitaalbehoeften Eigen en Vreemd } \\
\text { vermogen }\end{array}$ & a. & Kapitaalkosten E.V. & 3 & 5 \\
\hline & & $\mathrm{b}$. & Idem V.V. & 3 & 5 \\
\hline 8. & $\begin{array}{l}\text { Afsluiting informatiebronnen (voormalige) } \\
\text { leveranciers resp. afnemers }\end{array}$ & a. & $\begin{array}{l}\text { Kosten informatieverlies, verlies know- } \\
\text { how, technische kennis e.a. }\end{array}$ & 3 & 10 \\
\hline 9. & $\begin{array}{l}\text { Evenwicht aanbod van en vraag naar goederen } \\
\text { / diensten 'ketenlang' vereist meer inspanning }\end{array}$ & a. & $\begin{array}{l}\text { Risico van toename voorraadkosten en } \\
\text { kosten incourantie en / of derving. } \\
\text { Verlies aan 'countervailing power' }\end{array}$ & 3 & 10 \\
\hline 10. & $\begin{array}{l}\text { Verminderde concurrentie door interne } \\
\text { levering kan kostenverhogend werken }\end{array}$ & a. & $\begin{array}{l}\text { Risico van minder efficiency en } \\
\text { zakelijkheid }\end{array}$ & 2 & 10 \\
\hline \multirow[t]{2}{*}{11.} & $\begin{array}{l}\text { Verschillen in organisatie en } \\
\text { managementstructuur vereist aanpassingen }\end{array}$ & a. & $\begin{array}{l}\text { Kosten aanpassing organisatie en } \\
\text { managementstructuur }\end{array}$ & 2 & 10 \\
\hline & & & Gemiddelde score kosten 1. $t / m 11$ & $\begin{array}{c}360 / \\
100= \\
3.6\end{array}$ & \\
\hline
\end{tabular}




\section{Strategische baten}

Hieronder volgen puntsgewijs de af te wegen strategische baten met een raming van de scores ( 5-puntsschaal, $1=$ laag--------> 5 = hoog ) en wegingscoëfficient.

\begin{tabular}{|c|c|c|c|c|c|}
\hline $\mathrm{Nr}$ & Strategische batenveroorzakende factoren & $\begin{array}{l}\text { sub- } \\
\text { nr. }\end{array}$ & Strategische batensoorten & $\begin{array}{l}\text { Sco- } \\
\text { re } \\
(1-5)\end{array}$ & $\begin{array}{l}\text { We- } \\
\text { ging } \\
\text { in } \%\end{array}$ \\
\hline \multirow[t]{8}{*}{1.} & $\begin{array}{l}\text { Besparingsaspecten v.i. door betere } \\
\text { aansluiting / afstemming / maatvoering / } \\
\text { coördinatie / (markt) informatie }\end{array}$ & a. & Verlaging inkoopkosten & 2 & 5 \\
\hline & Idem & b. & Idem productiekosten & 2 & 5 \\
\hline & Idem & c. & Idem logistieke kosten & 5 & 10 \\
\hline & $\begin{array}{l}\text { Verlaging transactiekosten door interne } \\
\text { levering }\end{array}$ & d. & Idem verkoopkosten & 5 & 10 \\
\hline & & e. & Idem materiaalkosten & 3 & 5 \\
\hline & & f. & Idem vaste / variabele kosten & 0 & \\
\hline & & g. & Hoogte Investeringen & 5 & 5 \\
\hline & & $\begin{array}{l}\text { a.t } / \mathrm{m} \\
\text { g. }\end{array}$ & Gemiddelde score: & 3.75 & 40 \\
\hline \multirow[t]{2}{*}{2.} & $\begin{array}{l}\text { Kennis en informatie (nieuwe) } \\
\text { productietechniek en -technologie, veilig } \\
\text { stellen van de productie / dienstverlening. }\end{array}$ & a. & $\begin{array}{l}\text { Toegang tot techniek- en technologie ( } \\
\text { incl. kennis, inzicht en vaardigheden). }\end{array}$ & 3 & 5 \\
\hline & & b. & Verhoging kwaliteit producten / diensten & 3 & 5 \\
\hline \multirow[t]{2}{*}{3.} & $\begin{array}{l}\text { Kennis en informatie grondstoffen en } \\
\text { materialen, veilig stellen van de aanvoer van } \\
\text { benodigde grondstoffen en materialen. }\end{array}$ & a. & $\begin{array}{l}\text { Toegang tot grondstoffen en materialen ( } \\
\text { incl. kennis, inzicht en vaardigheid } \\
\text { toegepaste techniek en technologie). }\end{array}$ & & \\
\hline & & b. & Verhoging kwaliteit producten / diensten & & \\
\hline \multirow[t]{2}{*}{4.} & $\begin{array}{l}\text { Kennis en informatie distributiekanalen, veilig } \\
\text { stellen van de vraag naar de te leveren } \\
\text { producten / diensten. }\end{array}$ & a. & $\begin{array}{l}\text { Toegang tot distributiekanalen ( incl. } \\
\text { kennis, inzicht en vaardigheden } \\
\text { toegepaste techniek en technologie). }\end{array}$ & 3 & 10 \\
\hline & & $\mathrm{b}$. & Verhoging kwaliteit producten / diensten & 4 & 10 \\
\hline 5. & $\begin{array}{l}\text { Neutraliseren onderhandelingsmacht } \\
\text { leverancier }\end{array}$ & a. & $\begin{array}{l}\text { Verlaging (te) hoge leveringskosten } \\
\text { grondstoffen en materialen }\end{array}$ & & \\
\hline 6. & $\begin{array}{l}\text { Neutraliseren onderhandelingsmacht } \\
\text { Koper }\end{array}$ & a. & $\begin{array}{l}\text { Verhoging (te) lage afzetprijzen } \\
\text { producten / diensten }\end{array}$ & 3 & 5 \\
\hline \multirow[t]{2}{*}{7.} & $\begin{array}{l}\text { Vergroting breedte en diepte van het } \\
\text { assortiment producten / diensten }\end{array}$ & a. & $\begin{array}{l}\text { Verhoging omzet en resultaat door } \\
\text { productontwikkeling en marktsegmentatie }\end{array}$ & 3 & 5 \\
\hline & & b. & Verbetering marktpositie & 1 & 5 \\
\hline \multirow[t]{3}{*}{8.} & $\begin{array}{l}\text { (Nieuwe) toetredingsdrempel voor } \\
\text { concurrenten }\end{array}$ & a. & $\begin{array}{l}\text { Door nieuwe strategie van v.i. } \\
\text { bedrijfstakken van de bedrijfskolom } \\
\text { verhogen toetredingsdrempel ( hogere } \\
\text { kosten en investeringen) voor } \\
\text { concurrentie }\end{array}$ & 3 & 10 \\
\hline & & b. & $\begin{array}{l}\text { Verhoging omzet- en ondernemings- } \\
\text { resultaat door toevoegen nieuwe } \\
\text { activiteiten }\end{array}$ & 3 & 5 \\
\hline & & & Gemiddelde score baten $1 \mathrm{t} / \mathrm{m} 8$ & $\begin{array}{l}330 / \\
100= \\
3.3\end{array}$ & \\
\hline
\end{tabular}


Beschrijving onderzoeksopzet

- Onder literatuurstudie(A) staat vermeld wat eerdere paragrafen van dit hoofdstuk aan theorieën en modellen ter verdere uitwerking en toetsing aan de praktijk heeft opgeleverd. De toe te passen theorie, de modellen en de te onderzoeken variabelen geven mogelijk aanknopingspunten voor het beantwoorden van de hoofdvraag van dit onderzoek. Het onderzoek richt zich op de belangrijkste kenmerken van en mogelijke verbanden tussen marktstructuur (S), marktgedrag $(\mathrm{G})$ en marktresultaat $(\mathrm{R})$. Toegelicht zijn het statisch SGR-model van Bain, het dynamisch SGR-model van De Jong en de analysemodellen van Porter. De theorie van voorwaartse verticale integratie met de conclusies van De Jong, Daems en Douma en Porter is besproken in samenhang met het schematisch kader van kosten- en batenanalyse. In hoofdstuk 3 en 4 vindt de analyse plaats van de geselecteerde sectorvariabelen en die van de afzetorganisaties. In hoofdstuk 5, 6 en 7 staat de analyse van de structuur-, gedrags- en resultaatsvariabelen op producentenniveau. Het onderzoeksmodel dat hiervoor is ontworpen, is het conceptueel model van figuur 1.1, een samenvoeging van het concurrentiemodel van Daems, het bedrijfstakanalysemodel van Porter en het dynamisch SGR-model van De Jong. Met dit model wordt op basis van de verschillende onderzoeksuitkomsten tevens een inschatting gemaakt van markttypering, marktontwikkeling en concurrentie intensiteit in de glasgroente- en glassierteeltsector. Aan het einde van hoofdstuk 7 wordt dit toegelicht en wordt verwezen naar de invulling van het conceptueel model in bijlage 5 .

- Het gehouden vooronderzoek(B1) geeft een overzicht van voorlopige conclusies van een aantal autoriteiten over de (nieuwe) afzetstrategie van voorwaartse verticale integratie van handelscoöperatie VTN/The Greenery en de mogelijke gevolgen in de sector glasgroenten.

- Het praktisch onderzoek(B2) behelst een drietal bedrijfsonderzoeken in drie sectoren van de glastuinbouw. Aan de hand van de literatuurstudie en het vooronderzoek zijn vragenlijsten opgesteld. Hiermee worden gegevens van bedrijven en meningen van glastuinders geïnventariseerd betreffende de marktstructuur, het marktgedrag en het marktresultaat en de gevolgen van de veranderde afzetstrategie in de sector glasgroenten. Gelijktijdig vindt een sectoronderzoek plaats naar de gegevens en ontwikkeling van de productie en afzet, de belangrijkste afzetorganisaties en de groothandel/export van verse (glas)tuinbouwproducten. In de volgende paragraaf 2.6.2 worden in het analysemodel van figuur 2.4 de relevante nader te onderzoeken variabelen getoond en de onderzoeksvragen en mogelijke verbanden op meso- en microniveau beschreven. In paragraaf 2.6.3 volgt een beschrijving van de aanpak van de verschillende deelonderzoeken.

- De analyse $(C)$ geeft op bedrijfsniveau inzicht in de belangrijkste variabelen van marktstructuur, marktgedrag en marktresultaat met de onderzochte enkelvoudige verbanden in de drie sectoren glastuinbouw. Een econometrisch onderzoek en analyse naar meervoudige verbanden in de glasgroenten en -snijbloemen zijn toegevoegd. Op het niveau van de sector, de afzetorganisaties en de groothandel/export zijn de belangrijkste variabelen, voor zover mogelijk, op een vergelijkbare manier onderzocht en geanalyseerd. 
- De conclusies $(D)$ volgen uit analyse en toetsing van de onderscheiden variabelen op het niveau van de sectoren, de afzetorganisaties en de producenten aan de hand van het conceptueel onderzoeksmodel van figuur 1.1.

\subsubsection{Onderzoeksvragen en te onderzoeken verbanden}

In onderstaande figuur 2.4 worden de meest relevante variabelen van marktstructuur (S), marktgedrag $(\mathrm{G})$ en marktresultaat $(\mathrm{R})$ getoond. Deze variabelen zijn geselecteerd uit het overzicht van nader te onderzoeken elementen in hoofdstuk 1. Basis voor de keuze is de veronderstelde dynamische marktwerking van deze variabelen in het concurrentie- en concentratieproces van de bedrijfstak en de sectoren (zie ook Marijs en Hulleman, 2003, p. 112).

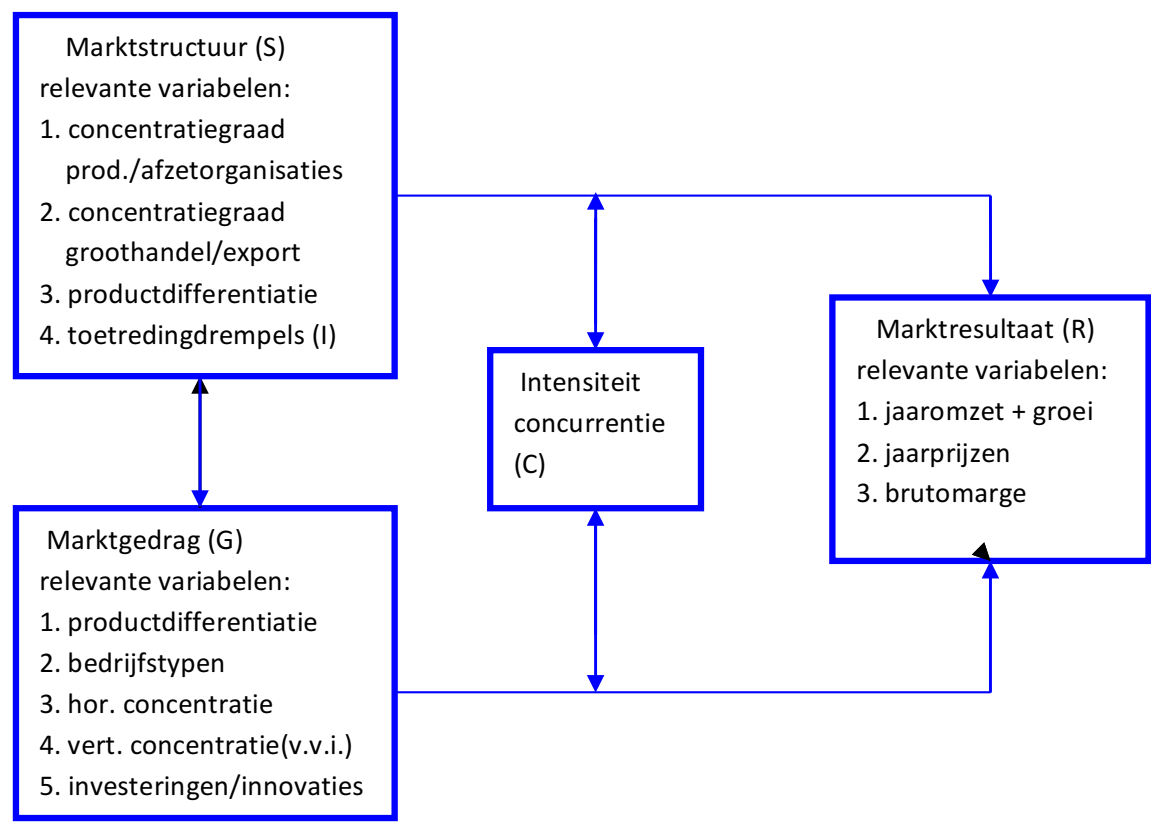

Figuur 2.4 Analysemodel variabelen marktstructuur (S), marktgedrag (G) en marktresultaat (R) met modererende variabele concurrentie-intensiteit sectoren glastuinbouw in Nederland 
Hieronder volgen de belangrijkste te verzamelen gegevens en te stellen onderzoeksvragen op mesoniveau en op microniveau. Met mesoniveau wordt het bedrijfstak- en sectorniveau bedoeld. Het gaat om die onderzoeksvariabelen en -resultaten die het geheel of het grootste deel van een sector in de (glas)tuinbouw vertegenwoordigen. Hierop is het sectoronderzoek afzet, afzetorganisaties en groothandel/export gericht.

Microniveau is het niveau van het glastuinbouwbedrijf waarop het bedrijfs- en econometrisch onderzoek in de glasgroenten, -snijbloemen en -potplanten is gericht.

\section{Onderzoeksvragen op mesoniveau}

Hieronder volgen de voornaamste vragen op mesoniveau.

1. Wat is de hoogte van de concentratiegraad van de producenten resp. verkooporganisaties van de deelsectoren en/of productgroepen en hoe ontwikkelen zich deze? Is er een verband van de concentratiegraad met de per sector of productgroep gerealiseerde jaarprijzen, jaaromzet en het rendement?

2. Wat is de hoogte van de structurele concentratiegraad van de producenten van de deelsectoren en is er een betekenisvol verschil met de werkelijke concentratiegraad?

3. Wat is de hoogte van de concentratiegraad van de groothandel/export van de deelsectoren en hoe ontwikkelt deze zich? Is er een verband met gerealiseerde jaarprijzen, jaaromzet en rendement?

4. Is er een verband tussen de mate van productdifferentiatie van de deelsectoren en gerealiseerde jaarprijzen, jaaromzet en rendement?

5. Wat is de gemiddelde hoogte van de toetredingsdrempel van de sectoren (gem. bedrijfsopp. glas in ha. incl. WKK) en hoe ontwikkelt zich deze? Is er een verband met de in deze sectoren gerealiseerde jaarprijzen, jaaromzet en rendement?

6. Is er een verband tussen de hoogte van het binnenlands marktaandeel (in \%) per sector en gerealiseerde jaarprijzen, jaaromzet en rendement?

7. Is er een verband tussen de hoogte van het importaandeel (in \%) per sector en gerealiseerde jaarprijzen, jaaromzet en rendement?

8. Is er een verband tussen de hoogte van het exportaandeel (in \%) per sector en gerealiseerde jaarprijzen, jaaromzet en rendement?

9. Is er een verband tussen de variabelen van het marktgedrag van de afzetorganisaties en telersverenigingen/producenten en de marktstructuur van de sectoren (vice versa) en zo ja, wat is de invloed hiervan op het marktresultaat?

Onderzoeksvragen op microniveau

Hieronder volgen de voornaamste vragen op microniveau.

1. Welke productsoorten worden onderscheiden, wat is de gemiddelde jaarprijs, -omzet en brutomarge en hoe is de ontwikkeling? Is er een verband tussen productsoorten/-differentiaties en gerealiseerde jaarprijzen, jaaromzet en rendement? 
2. Welke bedrijfstypen worden onderscheiden, wat is de gemiddelde jaarprijs, -omzet en brutomarge en hoe is de ontwikkeling? Is er een verband tussen bedrijfstype en gerealiseerde jaarprijzen, jaaromzet en rendement?

3. Bij welke afzetorganisatie/telersvereniging is het bedrijf aangesloten (horizontale concentratie)? Welke verkoopstrategie wordt gehanteerd en is er een verband tussen deze strategie en gerealiseerde jaarprijzen, jaaromzet en rendement?

4. Bij welke afzetorganisatie/telersvereniging is het bedrijf aangesloten (verticale concentratie)? Is er een verband tussen de gehanteerde verkoopstrategie (voorwaartse verticale integratie) en gerealiseerde jaarprijzen, jaaromzet en rendement?

5. Wat is de hoogte van de gem. jaarlijkse investeringen per bedrijf in vernieuwingen per sector en hoe is de ontwikkeling hiervan? Is er een verband tussen de moderniteit van het bedrijf en gerealiseerde jaarprijzen, jaaromzet en rendement?

6. Wat is de hoogte van de gem. bedrijfsomvang (in ha. glas) per sector en hoe is de ontwikkeling hiervan? Is er een verband tussen deze gemiddelde bedrijfsomvang en gerealiseerde jaarprijzen, jaaromzet en rendement?

7. Is er een verband tussen de jaarlijkse mutatie in toe- of uittreding (in \%) van bedrijven per sector en gerealiseerde jaarprijzen, jaaromzet en rendement?

\subsubsection{Deelonderzoeken}

Hieronder volgt een overzicht van de verschillende deelonderzoeken.

\subsubsection{Vooronderzoek}

Het vooronderzoek bestaat uit een autoriteitenonderzoek, gehouden in de sector glasgroenten in de periode december 2005 - maart 2006. Er vonden dertien interviews plaats met vertegenwoordigers van productiebedrijven, handelsbedrijven en koepelorganisaties uit de sector. Aanpak en onderzoeksresultaten zijn te vinden in het rapport 'Autoriteitenonderzoek glasgroenten' (Veerman, 2006). In appendix 5A van hoofdstuk 5 zijn de voorlopige conclusies van dit onderzoek opgenomen.

\subsubsection{Sectoronderzoek en onderzoek afzetorganisaties (glas)tuinbouw}

Via deskresearch zijn diverse beleidsplannen, onderzoeksrapporten en vakbladen bestudeerd over de ontwikkeling van de productie en afzet van verse (glas)tuinbouwproducten, de afzetorganisaties en de groothandel/export over de periode 1985-2010. Naast internet zijn de bibliotheken van de belangrijkste koepelorganisaties en onderzoeksinstituten in de Tuinbouw geraadpleegd zoals het Productschap Tuinbouw, het LEI , DPA, VBN, HBAG, Frugi Venta, VGB, VTN/The Greenery en VBN/FloraHolland. Aparte studies zijn gemaakt van de jaarverslagen van de grote afzetorganisaties in de voedingstuinbouw en de siertuinbouw. (Veerman, 2010). De resultaten van het sectoronderzoek en het onderzoek afzetorganisaties worden in hoofdstuk 3 en 4 nader toegelicht. 


\subsubsection{Bedrijfsonderzoeken en aanvullend econometrisch onderzoek}

Vanaf het najaar $2005 \mathrm{t} / \mathrm{m}$ eind 2008 is een aantal bedrijfsonderzoeken gehouden in de glasgroenten, de -snijbloemen en -potplanten (Veerman, 2007, 2008 en 2009). Elk onderzoek bestaat uit een vooronderzoek (kwalitatief) en een bedrijfsonderzoek (kwantitatief).

- Bedrijfsonderzoek glasgroenten

$\mathrm{Na}$ de rapportage in de eerste helft van 2006 van het vooronderzoek en het autoriteiten-onderzoek in de glasgroenten is een breder onderzoek opgesteld. Hierin zijn vooral kwantitatief gerichte vragen verwerkt over onder meer (afzet)kosten, opbrengsten en behaalde uitbetaalprijzen om meer inzicht te verkrijgen op de resultaten op individueel bedrijfsniveau.

- Bedrijfsonderzoek glassnijbloemen en -potplanten

De bedrijfsonderzoeken glassnijbloemen en -potplanten zijn in 2007/2008 en 2008/2009 op een vergelijkbare wijze als in de glasgroentesector uitgevoerd.

- Aanvullend econometrisch onderzoek glasgroenten en -snijbloemen

Het aanvullend econometrisch onderzoek glasgroenten en -snijbloemen vond plaats in 2016/2017 als aanvulling op de bedrijfsonderzoeken.

De voornaamste onderzoeksresultaten van het bedrijfsonderzoek worden besproken in hoofdstuk 5, 6 en 7. In deze rapportages en de bij deze hoofdstukken behorende appendices staat de onderzoeksverantwoording. De uitkomsten van het econometrisch onderzoek in de sectoren glasgroenten en glassnijbloemen zijn opgenomen in hoofdstuk 8 . 


IN NEDERLAND 



\subsection{Inleiding}

Het promotieonderzoek richt zich op de bedrijfs- en marktontwikkeling van 1980-2010 in de bedrijfskolom glasgroenten en glassierteelt (snijbloemen en potplanten) met drie belangrijke schakels: de producenten, de afzetorganisaties en de groothandelaren/exporteurs (zie figuur 3.1, afgeleid van figuur 2.1 hoofdstuk 2).

\begin{tabular}{|l|l|l|}
\hline $\begin{array}{l}\text { bedrijfskolom } \\
\text { glasgroenten }\end{array}$ & $\begin{array}{l}\text { bedrijfskolom } \\
\text { glassierteelt } \\
\text { (snijbloemen) }\end{array}$ & $\begin{array}{l}\text { bedrijfskom } \\
\text { glassierteel } \\
\text { (potplanten) }\end{array}$ \\
\hline glasgroentekweker & glassnijbloemenkweker & glaspotplantenkweker \\
\hline $\begin{array}{l}\text { afzetorganisatie } \\
\text { groenten en fruit }\end{array}$ & $\begin{array}{l}\text { afzetorganisatie/ } \\
\text { bloemenveiling }\end{array}$ & $\begin{array}{l}\text { afzetorganisatie/ } \\
\text { bloemenveiling }\end{array}$ \\
\hline $\begin{array}{l}\text { groothandel/exporteur } \\
\text { groenten en fruit }\end{array}$ & $\begin{array}{l}\text { groothandel/exporteur } \\
\text { bloemen en planten }\end{array}$ & $\begin{array}{l}\text { groothandel/exporteur } \\
\text { bloemen en planten }\end{array}$ \\
\hline
\end{tabular}

Figuur 3.1 Schakels sectoronderzoek (glas)tuinbouw

Het sectoronderzoek probeert van deze schakels de belangrijkste onderzoeksvariabelen van de marktstructuur (S) en het marktresultaat $(\mathrm{R})$ op te sporen en de mogelijke verbanden hiertussen aan te geven. Het gaat om die onderzoeksvariabelen en -resultaten die het geheel of het grootste deel van een sector in de glastuinbouw vertegenwoordigen. In het analysemodel (figuur 2.4) van vorig hoofdstuk zijn de volgende variabelen genoemd:

\section{Marktstructuur (S)}

- Concentratieontwikkeling producenten, afzetorganisaties en groothandels/exporteurs

- Productdifferentiatie

- Toetredingsdrempels

- Binnenlands aandeel

- Importaandeel

- Exportaandeel

Marktresultaat (R)

- Jaaromzet + groei

- Jaarafzet + groei (nieuw)

- Jaarprijzen

- Rendement 
Om een goed beeld te krijgen van de ontwikkeling van deze sectorvariabelen is aan de hand van gegevens en kerncijfers uit jaarverslagen, studies en rapporten van (koepel)organisaties uit de tuinbouw sectoronderzoek verricht. De belangrijkste organisaties zijn het Productschap Tuinbouw (PT), het Landbouwkundig Economisch Instituut (LEI), het Hoofdbedrijfsschap Agrarische Groothandel (HBAG) met handelskoepels Frugi Venta en VGB en de afzetorganisaties VTN/The Greenery en FloraHolland. De resultaten van het sectoronderzoek worden in dit en volgend hoofdstuk beschreven. Paragraaf 3.2 toont aan de hand van de tabellen $3.1 \mathrm{t} / \mathrm{m} 3.7$ de sectorale ontwikkeling van een aantal resultaatsvariabelen en de concentratie in de glastuinbouw. We behandelen achtereenvolgens de productiewaarden, de export- en importwaarden, de belangrijkste exportmarkten en het areaal glas met aantal en omvang glastuinbouwbedrijven. Bij het volgen en vergelijken van de cijfermatige ontwikkeling in de tabellen zijn, voor zover mogelijk en beschikbaar, de volgende jaren gekozen: 1980, 1990, 2000, 2005-2010. Soms was dit niet mogelijk. Het Productschap Tuinbouw heeft in zijn jaarpublicaties bij sommige overzichten bepaalde jaren weggelaten.

Paragraaf 3.3 en 3.4 beschrijven de ontwikkeling van de bedrijfskolom en marktstructuur in de glasgroenten en -sierteelt, de belangrijkste productgroepen en de mate van concurrentie en concentratie bij de producenten, de afzetorganisaties en de groothandel/exporteur. In paragraaf 3.5.1 volgt de toetsing van de eerder genoemde sectorvariabelen 2006-2010, behalve die van productdifferentiatie en toetredingsdrempels. Deze komen bij het bespreken van de onderzoeksresultaten en toetsing van de gedragsvariabelen in hoofdstuk $4 \mathrm{t} / \mathrm{m} 7$ aan de orde. In paragraaf 3.5.2 sluiten we het hoofdstuk af met de belangrijkste ontwikkelingen 2006-2016 die van invloed kunnen zijn op de behandelde structuur- en resultaatsvariabelen.

\subsection{De sectoren (glas)tuinbouw 1980-2010}

\subsubsection{Productiewaarden, export- en importwaarden}

Het belang van de bedrijfstak tuinbouw als onderdeel van de agrarische sector en onze nationale economie is groot. De afgelopen tien jaar heeft de productiewaarde van de tuinbouw zich in stijgende lijn ontwikkeld van $6.7 \mathrm{mrd}$. euro in 2000 tot $7.9 \mathrm{mrd}$. euro in 2010 . Het aandeel van de tuinbouw in procenten van de agrarische sector van Nederland staat de afgelopen jaren op bijna $40 \%$. Alhoewel er een terugval was in 2008/2009, veroorzaakt door de kredietcrisis, is er in de jaren erna sprake van een aanmerkelijk herstel. De productiewaarde van de tuinbouw wordt voor ongeveer twee derde gecreëerd in de sector siertuinbouw en één derde in de voedingstuinbouw. Onderstaand worden deze sectoren nader uitgesplitst. 
Tabel 3.1 Productiewaarden sectoren in de tuinbouw (x $1 \mathrm{mln}$. euro)

\begin{tabular}{|l|c|c|c|c|c|l|l|l|l|l|}
\hline & 1980 & 1990 & 2000 & 2005 & 2006 & 2007 & 2008 & 2009 & $\left.2010^{*}\right)$ & $\left.\mathbf{0}^{* *}\right)$ \\
\hline Siertuinbouw & $\mathbf{1 . 4 9 4}$ & $\mathbf{2 . 9 5 2}$ & $\mathbf{4 . 3 9 4}$ & $\mathbf{4 . 8 2 3}$ & $\mathbf{5 . 0 4 7}$ & $\mathbf{5 . 2 8 5}$ & $\mathbf{5 . 2 0 6}$ & $\mathbf{4 . 8 9 8}$ & $\mathbf{5 . 2 3 5}$ & $\mathbf{7}$ \\
\hline Bloemisterij & 1.079 & 2.204 & 3.241 & 3.711 & 3.901 & 4.062 & 4.034 & 3.789 & 4.110 & 8 \\
\hline -snijbloemen & 840 & 1.480 & 2.085 & 2.199 & 2.277 & 2.294 & 2.172 & 1.887 & 2.110 & 12 \\
\hline -potplanten & 239 & 724 & 1.155 & 1.512 & 1.624 & 1.768 & 1.862 & 1.902 & 2.000 & 5 \\
\hline Bloembollen/bomen & 415 & 748 & 1.153 & 1.112 & 1.146 & 1.223 & 1.172 & 1.109 & 1.125 & 1 \\
\hline Voedingstuinbouw & $\mathbf{1 . 2 8 7}$ & $\mathbf{2 . 2 1 8}$ & $\mathbf{2 . 2 9 7}$ & $\mathbf{2 . 1 8 5}$ & $\mathbf{2 . 4 8 0}$ & $\mathbf{2 . 4 7 5}$ & $\mathbf{2 . 4 6 5}$ & $\mathbf{2 . 1 1 7}$ & $\mathbf{2 . 6 6 0}$ & $\mathbf{2 6}$ \\
\hline Verse groenten & 1.100 & 1.909 & 1.971 & 1.850 & 2.105 & 2.105 & 1.995 & 1.722 & 2.255 & 31 \\
\hline -onder glas & 677 & 1.172 & 1.259 & 1.215 & 1.345 & 1.340 & 1.270 & 1.095 & 1.455 & 33 \\
\hline -volle grond+overige & 423 & $\mathbf{7 3 7}$ & 712 & 635 & 760 & 765 & 725 & 627 & 800 & -2 \\
\hline Vers fruit & 187 & 309 & 326 & 335 & 375 & 370 & 470 & 395 & 405 & 3 \\
\hline & & & & & & & & & \\
\hline Tuinbouw totaal & $\mathbf{2 . 7 8 2}$ & $\mathbf{5 . 1 7 0}$ & $\mathbf{6 . 6 9 1}$ & $\mathbf{7 . 0 0 8}$ & $\mathbf{7 . 5 2 7}$ & $\mathbf{7 . 7 6 0}$ & $\mathbf{7 . 6 7 1}$ & $\mathbf{7 . 0 1 5}$ & $\mathbf{7 . 8 9 5}$ & $\mathbf{1 3}$ \\
\hline
\end{tabular}

Bron: C.B.S., PT *) Voorlopige cijfers, $\left.{ }^{* *}\right)$ groei 2010 t.o.v. 2009

Tabel 3.1 geeft aan dat in de tuinbouw vooral de siertuinbouw in de periode 1980-2000 sterk is gegroeid. Vanaf 2005 stabiliseert de productiewaarde van de siertuinbouw zich door een stabilisatie resp. enige daling van de deelsectoren snijbloemen, bloembollen en boomkwekerij. De deelsector potplanten groeit nog steeds door, zelfs tijdens de kredietcrisis in 2008/2009 (+ 2 \%).

Tabel 3.2 Exportwaarden sectoren in de tuinbouw, incl. re-export (x $1 \mathrm{mln}$. euro)

\begin{tabular}{|l|c|c|c|c|c|c|c|c|c|c|}
\hline & 1980 & 1990 & 2000 & 2005 & 2006 & 2007 & 2008 & 2009 & $2010^{*}$ & $\left.\%{ }^{* *}\right)$ \\
\hline Siertuinbouw totaal & $\mathbf{1 . 2 6 4}$ & $\mathbf{2 . 9 6 8}$ & $\mathbf{5 . 1 0 9}$ & $\mathbf{5 . 8 8 2}$ & $\mathbf{6 . 2 8 8}$ & $\mathbf{6 . 3 5 5}$ & $\mathbf{6 . 1 6 3}$ & $\mathbf{5 . 8 8 4}$ & $\mathbf{6 . 2 0 0}$ & $\mathbf{5}$ \\
\hline Bloemisterij & 853 & 2.269 & 4.019 & 4.859 & 5.225 & 5.231 & 5.097 & 4.880 & 5.180 & 6 \\
\hline -snijbloemen & 692 & 1.600 & 2.844 & 3.144 & 3.237 & 3.373 & 3.243 & 2.991 & 3.190 & 7 \\
\hline -potplanten & 161 & 669 & 1.175 & 1.715 & 1.777 & 1.858 & 1.854 & 1.888 & 1.990 & 5 \\
\hline Overige & 411 & 699 & 1.090 & 1.023 & 1.063 & 1.124 & 1.066 & 1.004 & 1.020 & 2 \\
\hline & & & & & & & & & & \\
\hline Voedingstuinbouw tot. & $\mathbf{1 . 5 4 6}$ & $\mathbf{3 . 4 0 8}$ & $\mathbf{5 . 8 3 1}$ & $\mathbf{6 . 9 6 8}$ & $\mathbf{7 . 8 1 8}$ & $\mathbf{8 . 9 1 2}$ & $\mathbf{9 . 4 7 0}$ & $\mathbf{8 . 8 9 1}$ & $\mathbf{9 . 3 4 0}$ & $\mathbf{5}$ \\
\hline Groenten & 1.118 & 2.290 & 3.358 & 3.532 & 4.020 & 4.328 & 4.490 & 4.230 & 4.640 & 10 \\
\hline -vers & 909 & 1.777 & 2.695 & 2.885 & 3.420 & 3.620 & 3.718 & 3.511 & 3.900 & 11 \\
\hline -verwerkt & 209 & 513 & 663 & 647 & 600 & 708 & 772 & 719 & 740 & 3 \\
\hline Fruit totaal & 372 & 971 & 2.110 & 2.844 & 3.180 & 3.866 & 4.251 & 3.914 & 3.900 & 0 \\
\hline -vers & 196 & 570 & 1.157 & 1.824 & 2.000 & 2.303 & 2.664 & 2.420 & 2.500 & 3 \\
\hline -verwerkt & 176 & 401 & 953 & 1.020 & 1.180 & 1.563 & 1.587 & 1.491 & 1.400 & -6 \\
\hline Overige & 56 & 147 & 363 & 592 & 618 & 718 & 729 & 747 & 800 & 7 \\
\hline Tuinbouw totaal & $\mathbf{2 . 8 1 0}$ & $\mathbf{6 . 3 7 6}$ & $\mathbf{1 0 . 9 4 0}$ & $\mathbf{1 2 . 8 5 0}$ & $\mathbf{1 4 . 1 0 6}$ & $\mathbf{1 5 . 2 6 7}$ & $\mathbf{1 5 . 6 3 3}$ & $\mathbf{1 4 . 7 7 5}$ & $\mathbf{1 5 . 5 4 0}$ & $\mathbf{5}$ \\
\hline
\end{tabular}

Bron: C.B.S., PT, HBAG, Eurostat *) Voorlopige cijfers, **) groei 2010 t.o.v. 2009 
De voedingstuinbouw, in 1980 kleiner in omvang dan de siertuinbouw, groeit minder hard dan de siertuinbouw. Die stabiliseert vanaf 1990-2005 en toont in de jaren 2006-2008 een aanmerkelijk hogere productiewaarde dan in 2005 (10-15\%). In 2009 laten beide sectoren door de gevolgen van de kredietcrisis een terugval zien (- 6 resp. -15\%). In 2010 komt de siertuinbouw weer op het niveau van 2008 en de voedingstuinbouw zelfs erboven. De exportwaarde in de twee tuinbouwsectoren laat in tabel 3.2 een vergelijkbare ontwikkeling zien.

Vooral de groei van de export van bloemisterijgewassen van 1980-2000 is spectaculair, bijna vervijfvoudigd. De laatste jaren is deze groei een stuk minder. De oorzaak hiervan is een toenemende concurrentie vanuit het buitenland, een verzadiging van onze belangrijkste exportmarkten in Europa en de hoge koers van de euro ten opzichte van de U.S. dollar en het Engelse pond. Ook hier laten in 2009 beide sectoren door de gevolgen van de kredietcrisis een flinke terugval in export zien en toont de potplantensector hier minder last van te hebben. In 2010 is de siertuinbouw weer terug op het niveau van 2008. De voedingstuinbouw herstelt zich eveneens, maar blijft door de lagere export van fruit onder dit niveau. Onderstaand volgt een nadere uitsplitsing van de belangrijkste exportmarkten voor beide sectoren.

Tabel 3.3 geeft een overzicht van onze belangrijkste exportmarkten van snijbloemen en potplanten. Ondanks de terugval van de totale exportwaarde van 2008 naar 2009 met 4\% laat onze belangrijkste exportmarkt Duitsland (aandeel 33\% vanaf 2005) in het crisisjaar 2009 een plus zien van 4\%. Het Verenigd Koninkrijk dat sinds 2000 op gelijke hoogte met of net boven Frankrijk staat, laat na de top in 2007 een terugval zien. De oorzaak hiervan is de dure euro ten opzichte

Tabel 3.3 Belangrijkste exportmarkten bloemisterij (snijbloemen en potplanten, x $1 \mathrm{mln}$. euro)

\begin{tabular}{|l|c|c|c|c|c|c|c|c|c|}
\hline & 1980 & 1990 & 2000 & 2005 & 2007 & 2008 & 2009 & $2010^{*}$ & $\left.\%^{* *}\right)$ \\
\hline Bloemisterij totaal & $\mathbf{8 5 3}$ & $\mathbf{2 . 2 6 9}$ & $\mathbf{4 . 0 1 9}$ & $\mathbf{4 . 8 5 9}$ & $\mathbf{5 . 2 3 1}$ & $\mathbf{5 . 0 9 7}$ & $\mathbf{4 . 8 8 0}$ & $\mathbf{5 . 1 8 0}$ & $\mathbf{6}$ \\
\hline -Duitsland & 574 & 998 & 1.470 & 1.531 & 1.513 & 1.475 & 1.528 & 1.610 & 5 \\
\hline -V.K. & 29 & 234 & 566 & 810 & 908 & 745 & 656 & 710 & 8 \\
\hline -Frankrijk & 90 & 339 & 563 & 650 & 680 & 665 & 647 & 675 & 4 \\
\hline -Italië & 15 & 154 & 221 & 333 & 337 & 330 & 323 & 332 & 3 \\
\hline -België & 22 & 55 & 133 & 187 & 206 & 216 & 212 & 237 & 12 \\
\hline -Zwitserland & 32 & 88 & 122 & 132 & 139 & 137 & 135 & 147 & 9 \\
\hline -Denemarken & 10 & 51 & 93 & 135 & 145 & 143 & 135 & 125 & -7 \\
\hline -Rusland & $\cdot$ & $\cdot$ & 46 & 100 & 151 & 177 & 136 & 152 & 12 \\
\hline -Oostenrijk & 28 & 72 & 116 & 135 & 138 & 135 & 133 & 142 & 7 \\
\hline -Polen & $\cdot$ & $\cdot$ & 46 & 73 & 109 & 143 & 128 & 140 & 9 \\
\hline -Overige landen & & & 643 & 773 & & 931 & 847 & 910 & 7 \\
\hline & & & & & & & & & \\
\hline
\end{tabular}

Bron: HBAG, ${ }^{*}$ ) voorlopige cijfers, ${ }^{* *}$ ) groei 2010 t.o.v. 2009. Opmerking: het jaar 2006 is niet opgenomen in de PT Tuinbouwcijfers 2009 en 2010 
van het in waarde dalende Engelse pond en de verminderde vraag door de gevolgen van de kredietcrisis. Van de nieuwe markten in Oost-Europa scoort Rusland in 2008 de hoogste omzet (177 mln. euro), maar valt in 2009 terug tot 136 mln. euro. In 2010 stijgt de omzet weer met 12\%. Polen blijft hier iets onder (140 mln. euro) en bereikt in 2010 een exportwaarde die 3x zo hoog is als bij de start in 2000 .

Tabel 3.4 toont de belangrijkste marktontwikkelingen voor verse groenten en fruit met een plus van $4 \%$ ondanks de kredietcrisis. Het PT verstrekt deze cijfers tot op heden alleen in $\mathrm{kg}$.

Ook hier toont de Duitse markt een stabiele marktontwikkeling met eveneens vanaf 2005 een vergelijkbaar aandeel van ongeveer 33\%. Het Verenigd Koninkrijk staat ook hier op de tweede plaats met Frankrijk op de derde tot het jaar 2005. Rusland doet vanaf 2000 mee en streeft Frankrijk in 2005 voorbij. In 2009 valt Rusland terug, maar in 2010 volgt een herstel met een plus van 44\%. Italië laat in het crisisjaar 2009 een grote plus zien van 40\%. In 2010 volgt een min van $18 \%$. Polen, dat de laatste twee jaar in opmars is, scoort in 2010 een grote plus van $34 \%$.

Tabel 3.4 Belangrijkste exportmarkten voedingstuinbouw verse groenten en fruit (Nederlands product), vanaf 2000 excl. producten voor de industrie (x $1 \mathrm{mln} . \mathrm{kg})$

\begin{tabular}{|l|c|c|c|c|c|c|c|c|}
\hline & 1980 & 1990 & 2000 & 2005 & 2008 & 2009 & $2010^{*}$ & $\left.\%^{* *}\right)$ \\
\hline $\begin{array}{l}\text { Verse groenten en } \\
\text { fruit van Nederlandse } \\
\text { bodem }\end{array}$ & $\mathbf{1 . 5 5 0}$ & $\mathbf{2 . 3 8 8}$ & $\mathbf{2 . 4 7 5}$ & $\mathbf{2 . 7 3 0}$ & $\mathbf{2 . 8 8 4}$ & $\mathbf{3 . 0 1 0}$ & $\mathbf{3 . 1 2 0}$ & $\mathbf{4}$ \\
\hline -Duitsland & & & & & & & & \\
\hline -V.K. & 898 & 1.010 & 868 & 894 & 867 & 892 & 930 & 4 \\
\hline -Frankrijk & 195 & 371 & 402 & 452 & 449 & 457 & 460 & 1 \\
\hline -Rusland & 147 & 264 & 146 & 157 & 153 & 156 & 168 & 8 \\
\hline -België/Luxemburg & 107 & 261 & 79 & 87 & 87 & 87 & 81 & -7 \\
\hline -Italië & & & 45 & 81 & 79 & 112 & 92 & -18 \\
\hline -Zweden & 41 & 61 & 104 & 113 & 119 & 105 & 120 & 14 \\
\hline -Polen & & & 46 & 28 & 67 & 70 & 94 & 34 \\
\hline -Tsjechië & & & 30 & 44 & 61 & 60 & 62 & 3 \\
\hline -Overige landen & & & 140 & 162 & 210 & 160 & 230 & 44 \\
\hline
\end{tabular}

Bron: PT/KCB, *) voorlopige cijfers, ${ }^{* *}$ ) groei 2010 t.o.v. 2009. Opmerking: het jaar 2006 en 2007 is niet opgenomen in de PT Tuinbouwcijfers 2009 en 2010

De import in tabel 3.5 toont voor de siertuinbouw en de voedingstuinbouw grote verschillen.

De import in de siertuinbouw begint pas vanaf 2000 van meer betekenis te worden dan daarvoor en verloopt in de jaren tachtig en negentig vooral via de importerende en exporterende groothandel. $\mathrm{Er}$ is in die jaren veel verzet van Nederlandse snijbloemen- en potplantentelers tegen een te grote aanvoer van buitenlandse producten via de bloemenveilingen, vooral in het hoogseizoen (april september). Alleen in de winterperiode is de invoer welkom als aanvulling op het eigen assorti- 
Tabel 3.5 Importwaarden sectoren van de tuinbouw (x $1 \mathrm{mln}$. euro)

\begin{tabular}{|c|c|c|c|c|c|c|c|c|}
\hline & 1980 & 1990 & 2000 & 2005 & 2008 & 2009 & $2010^{*}$ & $\% * *)$ \\
\hline Siertuinbouw totaal & 138 & 366 & 885 & 982 & 1.285 & 1.174 & 1.120 & -5 \\
\hline Bloemisterij & 108 & 319 & 836 & 924 & 1.206 & 1.106 & 1.050 & -5 \\
\hline -snijbloemen & 68 & 196 & 650 & 646 & 827 & 748 & 710 & -5 \\
\hline -potplanten & 40 & 123 & 186 & 278 & 379 & 358 & 340 & -5 \\
\hline Bloembollen & 16 & 26 & 29 & 31 & 40 & 38 & 38 & 0 \\
\hline Boomkwekerij & 14 & 21 & 20 & 27 & 39 & 30 & 32 & 6 \\
\hline Voedingstuinbouw totaal & 1.110 & 2.118 & 4.285 & 5.269 & 7.062 & 6.675 & 7.080 & 6 \\
\hline Groenten & 226 & 545 & 1.031 & 1.244 & 1.450 & 1.435 & 1.520 & 6 \\
\hline -vers & 122 & 287 & 659 & 839 & 985 & 975 & 1.040 & 7 \\
\hline -verwerkt & 104 & 259 & 372 & 405 & 465 & 460 & 480 & 4 \\
\hline Fruit & 724 & 1.315 & 2.641 & 3.243 & 4.655 & 4.310 & 4.580 & 6 \\
\hline -vers & 449 & 805 & 1.397 & 2.083 & 2.927 & 2.740 & 2.870 & 5 \\
\hline -verwerkt & 275 & 510 & 1.244 & 1.160 & 1.728 & 1.570 & 1.710 & 9 \\
\hline Overige & 160 & 258 & 613 & 782 & 957 & 931 & 980 & 5 \\
\hline Tuinbouw Totaal & 1.248 & 2.484 & 5.170 & 6.251 & 8.347 & 7.850 & 8.200 & 4 \\
\hline
\end{tabular}

Bron: C.B.S., PT, HBAG, Eurostat *) Voorlopige cijfers, **) groei 2010 t.o.v. 2009. Opmerking: het jaar 2006 en 2007 is niet opgenomen in de PT Tuinbouwcijfers 2009 en 2010

ment om toch zoveel mogelijk jaarrond te kunnen leveren aan de groothandel. Felle discussies zijn gevoerd en scherpe afspraken gemaakt over de perioden van aanvoer en de percentages van toegestane invoer (in aanvang 5 tot $10 \%$ van de totale aanvoer), om de Nederlandse aanvoer te beschermen tegen ongebreidelde concurrentie en te lage prijzen. De afgelopen tien jaar (2000-2010) zijn de mogelijkheden voor buitenlandse aanvoer via de veilingen aanzienlijk verruimd. Ook de fusies tussen de bloemenveilingen, de overname van importveiling TFA door FloraHolland en de nieuwe mogelijkheden voor het buitenlands lidmaatschap hebben hieraan meegewerkt (Jaarverslag FloraHolland, 2008 en 2009).

De import van voedingstuinbouwproducten is vanaf de jaren zeventig veel omvangrijker geweest dan van siertuinbouwproducten. Vooral de invoer van groente en fruit uit Zuid-Europa (Spanje, Italië) en landen van het zuidelijk halfrond als Zuid-Afrika, Argentinië en Brazilië zorgde voor een groot aandeel van importproducten op de binnenlandse en (via re-export) de aan Nederland grenzende exportmarkten. In 1980 was het aandeel geïmporteerd fruit $65 \%$ van de totale import die toen $1.1 \mathrm{mrd}$. euro bedroeg. De totale export van de voedingstuinbouw was in dat jaar 1.5 mrd. euro. In de jaren daarna verdubbelt de import vanaf 1980 tot ruim 2 mrd. euro in 1990. Tien jaar later vindt nogmaals een verdubbeling plaats tot ruim 4 mrd. euro. In 2010 is de import gestegen tot ruim $7 \mathrm{mrd}$. euro, een stijging van $2.8 \mathrm{mrd}(65 \%)$. De verhouding tussen de invoer van verse groenten en vers fruit ligt in deze jaren op ca. 1:3. 


\subsubsection{Concentratie in de glastuinbouw}

In de glastuinbouw bestaat de voedingstuinbouw voor ongeveer 95\% uit vruchtgroenten (voornamelijk tomaat, paprika en komkommer) en 5\% uit zacht fruit. De siertuinbouw bestaat voor ongeveer $90 \%$ uit bloemisterijgewassen (snijbloemen, pot- en perkplanten en uitgangsmateriaal) en $10 \%$ boomkwekerijgewassen inclusief vaste planten.

Tabel 3.6 Verdeling opp. tuinbouw onder glas over sectoren (ha.)

\begin{tabular}{|c|c|c|c|c|c|c|c|c|c|c|}
\hline & 1980 & 1990 & 2000 & 2005 & 2006 & 2007 & 2008 & 2009 & $2010^{*}$ & $\% * *$ \\
\hline Voedingstuinbouw & 4.714 & 4.485 & 4.230 & 4.617 & 4.715 & 4.746 & 4.888 & 4.993 & 5.041 & +1 \\
\hline Groenten & 4.508 & 4.361 & 4.037 & 4.344 & 4.421 & 4.420 & 4.553 & 4.558 & 4.732 & +1 \\
\hline Fruit & 206 & 124 & 193 & 273 & 294 & 326 & 335 & 329 & 309 & -6 \\
\hline Siertuinbouw & 4.041 & 5.283 & 6.296 & 6.032 & 5.783 & 5.743 & 5.452 & 5.437 & 5.270 & -3 \\
\hline Bloemisterij & 3.976 & 5.140 & 5.927 & 5.599 & 5.381 & 5.327 & 5.047 & 5.005 & 4.779 & -5 \\
\hline -snijbloemen & 2.896 & 3.593 & 3.727 & 3.250 & 3.093 & 3.003 & 2.809 & 2.690 & 2.446 & -9 \\
\hline -potplanten & 554 & 984 & 1.261 & 1.377 & 1.386 & 1.397 & 1.431 & 1.464 & 1.383 & -6 \\
\hline -overige gewassen & 527 & 564 & 939 & 972 & 902 & 927 & 807 & 851 & 950 & +12 \\
\hline $\begin{array}{l}\text { Boomkwekerij incl. } \\
\text { vaste planten }\end{array}$ & 65 & 143 & 369 & 433 & 402 & 416 & 405 & 432 & 491 & +14 \\
\hline Totaal & 8.755 & 9.768 & 10.526 & 10.649 & 10.498 & 10.489 & 10.340 & 10.430 & 10.311 & 0 \\
\hline
\end{tabular}

Bron: C.B.S, PT. *)Voorlopige cijfers, **) groei 2010 t.o.v. 2009

Tabel 3.7 Aantal bedrijven met glastuinbouw naar areaal per bedrijf per sector in Nederland $1980-2010$

\begin{tabular}{|c|c|c|c|c|c|c|c|c|}
\hline & \multicolumn{2}{|c|}{$\begin{array}{l}\text { Totaal aantal } \\
\text { bedrijven en opp. in ha. }\end{array}$} & \multicolumn{3}{|c|}{$\begin{array}{l}\text { Sector voedingstuinbouw (groenten } \\
\text { en fruit**) onder glas }\end{array}$} & \multicolumn{3}{|c|}{$\begin{array}{l}\text { Sector siertuinbouw (snijbloemen en } \\
\text { potplanten) onder glas }\end{array}$} \\
\hline & $\begin{array}{l}\text { Aantal } \\
\text { bedrijven }\end{array}$ & In ha. & $\begin{array}{l}\text { Aantal } \\
\text { bedrijven }\end{array}$ & $\begin{array}{l}\text { Areaal in } \\
\text { ha. }\end{array}$ & $\begin{array}{l}\text { gem. in } \\
\text { ha. }\end{array}$ & $\begin{array}{l}\text { Aantal } \\
\text { bedrijven }\end{array}$ & $\begin{array}{l}\text { Areaal in } \\
\text { ha. }\end{array}$ & $\begin{array}{l}\text { gem. in } \\
\text { ha. }\end{array}$ \\
\hline 1980 & 15.923 & 8.755 & 8000 & 4714 & 0,6 & 7923 & 4041 & 0,5 \\
\hline 1990 & 13.610 & 9.768 & 5652 & 4485 & 0,8 & 7958 & 5283 & 0,7 \\
\hline 2000 & 11.417 & 10.526 & 3575 & 4230 & 1,2 & 7842 & 6296 & 0,8 \\
\hline 2005 & 7.733 & 10.649 & 2662 & 4617 & 1,7 & 5071 & 6032 & 1,1 \\
\hline 2006 & 7.235 & 10.498 & 2520 & 4715 & 1,9 & 4715 & 5783 & 1,1 \\
\hline 2007 & 7.018 & 10.489 & 2344 & 4746 & 2,0 & 4674 & 5743 & 1,1 \\
\hline 2008 & 6.475 & 10.340 & 2139 & 4888 & 2,3 & 4336 & 5452 & 1,3 \\
\hline 2009 & 5.537 & 10.430 & 1878 & 4993 & 2,6 & 3659 & 5437 & 1,5 \\
\hline $2010 *)$ & 5.015 & 10.311 & 1765 & 5041 & 2,9 & 3250 & 5270 & 1,6 \\
\hline
\end{tabular}

Bron: C.B.S, PT, *) voorlopige cijfers, **) vanaf 2000 gem. 300 bedrijven met 300 ha. fruit 
In tabel 3.6 is te zien dat het glasareaal van 1980-2000 steeg met bijna 2000 ha tot 10.526 ha. en sindsdien op dat niveau is gebleven. De sector glasgroenten is in het verleden de belangrijkste sector binnen de glastuinbouw geweest. In 1960 werd op 4500 ha. groenten en zacht fruit geteeld en op 500 ha. bloemen en planten. Tegen $1970 \mathrm{kwam}$ een trend op gang waarbij werd overgeschakeld op de snijbloementeelt en vanaf 1980 tevens op de teelt van potplanten. De groentesector heeft sinds 1970800 ha. ingeleverd (Agrarische Hogeschool Delft, 1992).

Het huidige glasareaal omvat 4800 ha. snijbloemen en potplanten en 4.700 ha. groenten.

Minder belangrijk is de boom- en fruitteelt onder glas met een oppervlakte van 400 en 300 ha. vanaf 2000. De boomkwekerij onder glas bestaat uit pot- en containerteelt met vooral vaste planten; de fruitteelt onder glas bestaat voornamelijk uit aardbeien.

Tabel 3.7 schetst de ontwikkeling van het aantal glastuinbouwbedrijven en de omvang van het glasareaal in Nederland (in ha.) en de gemiddelde omvang per bedrijf over de periode 19802010. De daling van het aantal bedrijven in de voedingstuinbouw (75\%) is groter dan in de siertuinbouw (60\%) en de gemiddelde bedrijfsomvang is bijna vijf keer zo groot geworden, van 0,6 naar 2,9 ha. In de siertuinbouw verloopt dit proces langzamer, van 0,5 naar 1,6 ha.

\subsection{Bedrijfskolom en marktstructuur sector glasgroenten}

We geven eerst een schets van de bedrijfskolom glasgroenten met de structuur van de afzet van de belangrijkste producten. Daarna volgen de spelers van de marktstructuur: aan de aanbodzijde de producenten en afzetorganisaties, aan de vraagzijde de groothandel/export.

Figuur 3.2 geeft de voor dit onderzoek belangrijke schakels van de bedrijfskolom. De eerste schakel betreft het binnen- en buitenlandse aanbod van de producenten van vruchtgroenten. In de tweede schakel bevinden zich de afzetorganisaties en telersverenigingen, in de derde de exporteurs, de importeurs en de (binnenlandse) groot- en tussenhandel. Deze schakels zijn gescheiden door een stippellijn waarmee wordt aangegeven dat een aantal afzetorganisaties de groothandels- en exportfunctie hebben geïntegreerd in hun bedrijf en feitelijk opereren in één schakel. De vierde schakel betreft de detailhandel buitenland en de detailhandel en foodservice binnenland. Tomaten, paprika's en komkommers zijn de belangrijkste vruchtgroenten, op afstand gevolgd door aubergines en courgettes. Het aandeel van de glasgroenten in de productiewaarde van de Nederlandse voedingstuinbouw bedraagt in de periode 2006-2008 ruim 60\%. Meer dan 80\% van de Nederlandse glasgroenten is bestemd voor de export. De import van vruchtgroenten is beperkt. De import bedraagt 20\% van het binnenlandse aanbod. De import is voornamelijk gericht op de re-export (Bunte, 2009).

Het in kaart brengen en volgen van de marktstructuur en sectorvariabelen van de deelsector glasgroenten richt zich enerzijds op het aanbod van verse glasgroenten, anderzijds op de vraag naar deze producten op de relevante binnen- en buitenlandse markten (zie figuur 3.2). 
Figuur 3.2 De bedrijfskolom glasgroenten in Nederland (2007)

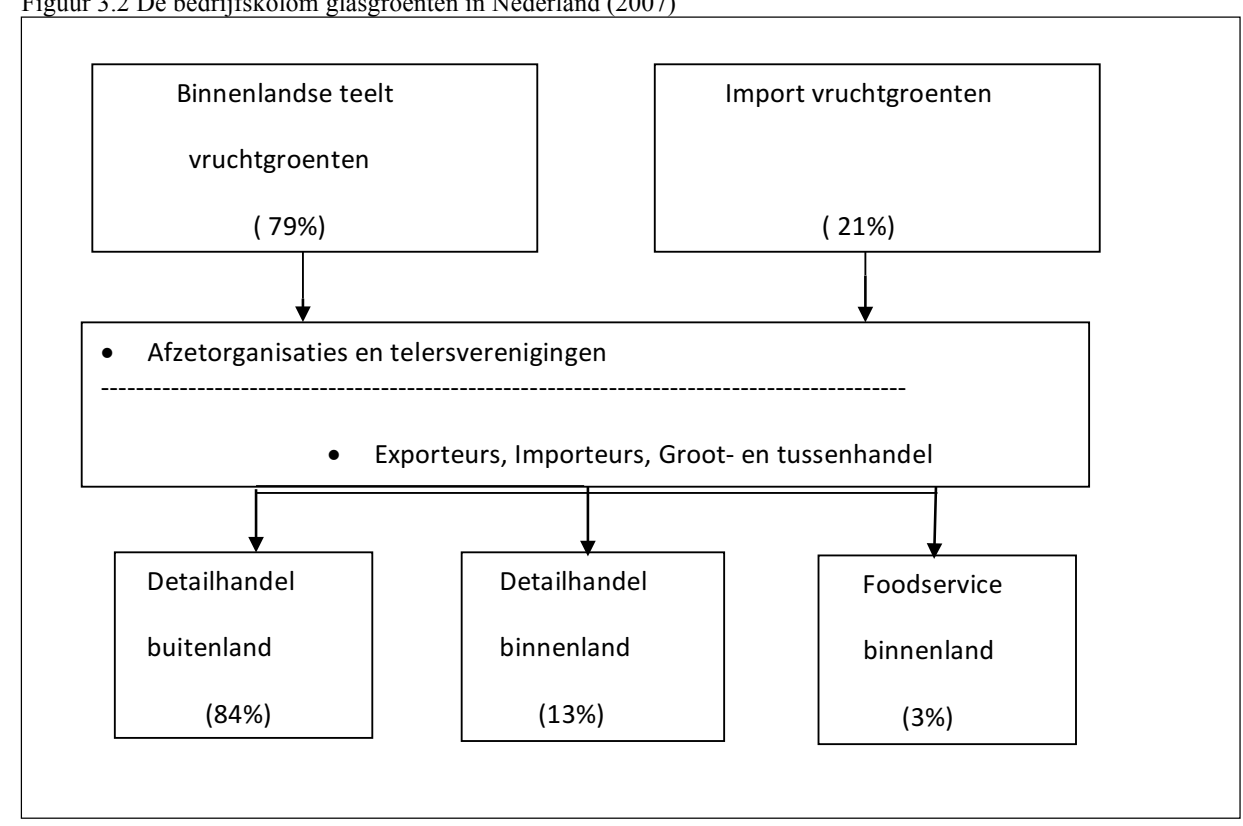

Bron: FAO, LEI 09-02 met enige aanpassing

De belangrijkste kenmerken aan de aanbodzijde zijn bedrijfstype en -omvang van de producenten en hun afzetorganisatie, de posities op de markten, de onderscheiden productgroepen met de uniekheid, breedte en diepte van het assortiment, de toegepaste methoden en technieken en de kostprijs. Dit betreft zowel de eigen productie als de import.

Aan de vraagzijde treffen we als eerste schakel meestal de groothandel/exporteur of importeur van verse groenten en fruit en als tweede de detailhandel. De belangrijkste kenmerken aan de handelszijde zijn het spiegelbeeld van die van het aanbod. Bedrijfstype en -omvang, positie op de markt, gevraagde productgroepen, assortiment, methoden en technieken, kostprijs en specifieke klantwensen spelen hier een rol. Hieronder behandelen we eerst de ontwikkeling aan de aanbodzijde, daarna die aan de vraagzijde.

\subsubsection{Ontwikkeling aanbodzijde markt}

\subsubsection{Producenten}

In tabel 3.7 is al aangegeven hoe snel de schaalvergroting in de sector glasgroenten gaat. Als we de periode 2005-2010 hier uitlichten (tabel 3.8), dan is te zien dat er in een periode van vijf à zes jaar een vergroting van de bedrijfsomvang plaatsvindt van gemiddeld 1.8 ha. tot meer dan 3 ha. glasoppervlakte. Jaarlijks stopt 10 tot $15 \%$ van de bedrijven. Nog nooit eerder is deze schaalvergroting zo snel gegaan als in deze periode. In 2006 zijn in de glasgroenten 2200 bedrijven actief op een oppervlakte van 4415 hectare met een productiewaarde van ruim 1,3 mld. euro. De productiewaarde bedraagt dan gemiddeld 604.000 euro op 2.0 ha. glas. Tot 2008 groeit 
deze productiewaarde met ruim 14\% tot gemiddeld 691.000 euro, om in 2009 te stabiliseren op 694.000. In 2010 volgt een grote stijging van de productiewaarde tot bijna $1 \mathrm{mln}$. euro, inmiddels wel met $30 \%$ minder bedrijven dan in 2006. Uit de concurrentiemonitor glasgroenten is op te maken dat in 2008 en 2009 minder goede resultaten zijn geboekt door glasgroentebedrijven. Met name in 2009, het jaar van de kredietcrisis, waren de financiële resultaten uitzonderlijk slecht (LEI-rapport 2010-051, p. 23).

Tabel 3.8 Schaalvergroting producenten in de sector glasgroenten 2000-2010

\begin{tabular}{|l|l|l|l|l|l|}
\hline Jaar & $\begin{array}{l}\text { Productie } \\
\text { waarde (x euro } \\
1 \text { mrd.) }\end{array}$ & $\begin{array}{l}\text { Bedrijfsopp. } \\
\text { glas in ha. }\end{array}$ & $\begin{array}{l}\text { Aantal } \\
\text { bedrijven } \\
\text { glasgroenten }\end{array}$ & $\begin{array}{l}\text { Gem. prod. } \\
\text { waarde(x } \\
\text { euro 1 mln.) }\end{array}$ & $\begin{array}{l}\text { Gem. } \\
\text { opp. }\end{array}$ \\
\hline 2000 & 1.259 & 3930 & 3275 & 0.384 & 1,2 \\
\hline 2005 & 1.215 & 4344 & 2362 & 0.514 & 1,8 \\
\hline $\mathbf{2 0 0 6}$ & $\mathbf{1 . 3 4 0}$ & $\mathbf{4 4 1 5}$ & $\mathbf{2 2 2 0}$ & $\mathbf{0 . 6 0 4}$ & $\mathbf{2 , 0}$ \\
\hline 2007 & 1.345 & 4446 & 2044 & 0.658 & 2,2 \\
\hline 2008 & 1.270 & 4588 & 1839 & 0.691 & 2,5 \\
\hline $\left.2009^{* *}\right)$ & 1.095 & 4693 & 1578 & 0.694 & 3,0 \\
\hline $\mathbf{2 0 1 0}$ ) & $\mathbf{1 . 4 5 5}$ & $\mathbf{4 7 4 1}$ & $\mathbf{1 4 6 5}$ & 0.993 & $\mathbf{3 , 2}$ \\
\hline
\end{tabular}

Bron: CBS/PT, *) voorlopig **) kredietcrisis

\subsubsection{Productgroepen}

Als aanvulling op de eerder gegeven informatie over de bedrijfskolom (figuur 3.2) en de belangrijkste glasgroenten wordt hieronder een overzicht gegeven van de ontwikkeling van het areaal groentegewassen onder glas vanaf 2000-2009 en de prijsvorming van de belangrijkste glasgroenten van 2005-2009.

Uit tabel 3.9 is te constateren dat het areaal tomaat in de periode $2000-2009$ met ruim $40 \%$ is toegenomen tot ruim 1600 ha. Het areaal komkommer is in dezelfde periode met $7 \%$ gedaald tot 626 ha. Het areaal paprika is van 2000-2005 licht gestegen en schommelt tot 2008 rondom de 1200 ha. Ondanks de terugval van de productiewaarde in 2009, het jaar van de kredietcrisis, is het areaal van dit gewas juist gestegen tot 1331 ha $(+12 \%)$. Aubergine blijft vrij stabiel net onder de 100 ha., aardbei onder glas is bijna verdubbeld (van 110 naar 210 ha.) en de overige groenten zijn met bijna 100 ha. gedaald (van 550 ha. naar 467 ha.). 
Tabel 3.9 Areaal in ha. van een aantal groentegewassen onder glas van 2000-2009*)

\begin{tabular}{|c|r|r|r|r|r|c|}
\hline & 2000 & 2005 & 2006 & 2007 & 2008 & 2009 \\
\hline$\bullet \quad$ Tomaat & 1134 & 1396 & 1481 & 1545 & 1600 & 1628 \\
\hline -ronde en vleestomaat & 455 & 376 & 386 & 413 & 422 & 481 \\
\hline -trostomaat & 628 & 936 & 1007 & 1034 & 1078 & 1047 \\
\hline -cherry tomaat & 51 & 84 & 88 & 98 & 100 & 100 \\
\hline$\bullet \quad$ Paprika & 1155 & 1236 & 1214 & 1187 & 1184 & 1331 \\
\hline$\bullet \quad$ Komkommer & 663 & 638 & 617 & 622 & 626 & 626 \\
\hline$\bullet \quad$ Aubergine & 76 & 90 & 90 & 96 & 97 & 95 \\
\hline$\bullet \quad$ Radijs & 165 & & & & & \\
\hline$\bullet \quad$ Aardbei onder glas & 110 & 161 & 177 & 194 & 211 & 210 \\
\hline$\bullet \quad$ Oardbeitunnels & 53 & 66 & 68 & 71 & 58 & 58 \\
\hline$\bullet \quad$ Opkweekmateriaal & 171 & 191 & 206 & 220 & 213 & 235 \\
\hline Totaal areaal & 4200 & 4445 & 4548 & 4571 & 4647 & 4826 \\
\hline
\end{tabular}

Bron: CBS Landbouwtelling, *) cijfers 2010 nog niet beschikbaar

Tabel 3.10 Aandeel productiewaarde tomaat, paprika en komkommer in totaal van de glasgroenten en gemiddelde productiewaarde per bedrijf in 2008

\begin{tabular}{|l|l|l|l|}
\hline & Aantal bedrijven & $\begin{array}{l}\text { Productiewaarde } \\
\text { (x euro 1 mln. })\end{array}$ & $\begin{array}{l}\text { Gem. per bedrijf } \\
\text { (x euro 1 mln.) }\end{array}$ \\
\hline Tomaat & 400 & 500 & 1.25 \\
\hline Paprika & 350 & 425 & 1.21 \\
\hline Komkommer & 250 & 250 & 1.00 \\
\hline & & & \\
\hline Totaal & 1000 & $1.175(92.5 \%)$ & \\
\hline Glasgroenten totaal & \multicolumn{2}{|l}{} \\
\hline
\end{tabular}

Bron: PT, Kwin Glastuinbouw 2010

Bovenstaande tabel 3.10 laat nog eens het belang zien van de drie grote vruchtgroenten in de totale glasgroenten. Met een productiewaarde van $1.175 \mathrm{mln}$. euro hebben ze in 2008 een aandeel van $92.5 \%$ in de totale glasgroenten is Nederland.

Tabel 3.11 toont het prijsverloop in de jaren 2005-2009 van komkommer, paprika en tomaat met het berekende gemiddelde over deze periode en de prijsrange. De komkommer, die als een homogeen product kan worden beschouwd, laat een laag maar stabiel prijsniveau zien met een kleine prijsrange. De afwijking ten opzichte van het vijfjaargemiddelde van 23.5 eurocent is $10 \%$. Paprika is een minder homogeen product en laat met haar vier kleurenassortiment veel grotere prijsschommelingen zien met afwijkingen ten opzichte het vijfjaargemiddelde van 25 tot $30 \%$. Bij de tomaat is de cherrytomaat te beschouwen als een 'specialty' met een hoog prijsniveau terwijl de 'convenience' ronde tomaat en trostomaat dicht bij elkaar in de buurt zitten met een gelijk vijfjaargemiddelde van laag niveau. De trostomaat lijkt zich hier weinig te onderscheiden van de ronde tomaat en wordt door de klant steeds meer als inwisselbaar hiervoor beschouwd. 
Tabel 3.11 Prijsverloop 2005-2009 komkommer, paprika en tomaat (eurocent per st./kg)

\begin{tabular}{|l|l|l|l|l|l|l|l|}
\hline & 2005 & 2006 & 2007 & 2008 & $2009 *)$ & $\begin{array}{l}\text { Gem. } \\
05 / 09\end{array}$ & $\begin{array}{l}\text { Prijs- } \\
\text { range }\end{array}$ \\
\hline Komkommer gem. jaarprijs/st. & 26 & 25 & 23 & 22 & 21 & 23.5 & $21-26$ \\
\hline & & & & & & & \\
\hline Paprika geel gem. jaarprijs/kg & 102 & 141 & 138 & 125 & 87 & 114 & $87-141$ \\
\hline Paprika groen gem. jaarprijs/kg & 88 & 115 & 113 & 107 & 76 & 96 & $76-115$ \\
\hline Paprika oranje gem. jaarprijs/kg & 133 & 140 & 171 & 141 & 88 & 115 & $88-141$ \\
\hline Paprika rood gem. jaarprijs/kg & 98 & 144 & 149 & 132 & 77 & 123 & $98-149$ \\
\hline & & & & & & & \\
\hline Tomaat cherry gem. jaarprijs/kg & 168 & 225 & 193 & 181 & 192 & 196 & $168-225$ \\
\hline Tomaat rond gem. jaarprijs/kg & 75 & 76 & 72 & 64 & 55 & 66 & $55-76$ \\
\hline Tomaat tros gem. jaarprijs/kg & 74 & 76 & 75 & 71 & 55 & 66 & $55-76$ \\
\hline & & & & & & & \\
\hline
\end{tabular}

Bron: Kwin Glastuinbouw 2010, *) cijfers 2010 nog niet beschikbaar

\subsubsection{Afzetorganisaties}

Afzetorganisaties in de groente- en fruitsector zijn van huis uit coöperatieve veilingen met meer dan 100 jaar ervaring in het openbaar veilen van verse tuinbouwproducten. In hoofdstuk 1 is aangegeven dat deze verkoopmethode na de fusie van 1996 grotendeels is vervangen door verkoopteams en bemiddeling. In het jaaroverzicht 1996 van VTN/The Greenery wordt over de reden tot fuseren het volgende vermeld: "Begin jaren negentig verslechtert de inter-nationale marktpositie van de Nederlandse voedingstuinbouw in snel tempo. De veilingen zien hun omzetten dalen en het rendement van veel teeltbedrijven staat onder druk. Het Nederlandse verkoopsysteem sluit niet meer aan op de eisen en wensen van vooral grote afnemers. Een groep Nederlandse veilingen zoekt de oplossing in verregaande samenwerking en een marktgerichte aanpak van de verkoop. Zij streven naar een fusie tussen alle Nederlandse veilingen.” (The Greenery International, jaarverslag 1996, p. 28).

Als je de resultaten van tabel 3.12 hieronder bekijkt, dan valt op dat de ontwikkeling van de totale veilingomzet van 1980 tot 1996 toch redelijk op niveau is gebleven.

Inmiddels zijn de meeste van de nog bestaande groente- en fruitveilingen omgevormd tot logistieke dienstverleners, bemiddelaars en handelshuizen. Zelfstandig of onder de vlag van de coöperatieve veilingen zijn op grote schaal telersverenigingen opgericht, georganiseerd rondom een of meer productgroepen. In samenwerking met de veiling of zelfstandig voeren zij de onderhandelingen met en verrichten de verkoop aan de groothandel/export. Anno 2010 zijn er in Nederland nog slechts een paar organisaties die groenten veilen. De grootste groenteveiling is ZON in Grubbenvorst, maar ook bij de Veiling Zaltbommel en bij The Greenery worden groenten geveild. Bij The Greenery worden de meeste producten via bemiddeling verkocht. Hier fungeert de veilingklok vooral als middel om optimaal te profiteren van de marktomstandigheden in tijden van tekort of om overschotten af te zetten. De afzetorganisaties en de veilingen leveren 
vooral diensten aan telersverenigingen en kopers, maar worden zelf meestal geen eigenaar van de producten, hoewel zij steeds meer ook een rol als groothandel vervullen (Bunte, 2009 en Van Galen et al., 2010).

In paragraaf 3.2 is behandeld hoe snel de ontwikkeling in schaalvergroting gaat bij producenten in de glastuinbouw. Tabel 3.12 schetst de ontwikkeling van het aantal groente- en fruitveilingen en de veilingomzet, eerst van 1980 tot aan het fusieproces in 1995/1996. Daarna volgt de periode 2000-2010 op basis van de productiewaarde van de sector met de vernieuwde veilingen/ afzetorganisaties en de zelfstandig opererende telersverenigingen. Deze telersverenigingen zijn ontstaan in de negentiger jaren voor de organisatie van gezamenlijke inkoop, verpakking, distributie en afzet. Hierdoor kon op de kosten aan inkoop- en verkoopzijde worden bespaard en beter worden voldaan aan de wensen van de afnemers. Tevens probeerde men in aanmerking te komen voor door de EU verstrekte GMO-subsidies (Gemeenschappelijke Marktordening Groenten en Fruit). Deze subsidies worden verstrekt aan leden van door de EU erkende telersverenigingen, die gericht zijn op een verbetering van de afzetpositie op de Europese markt (Van Galen et al., 2010).

Tabel 3.12 Ontwikkeling van het aantal veilingen/afzetorganisaties met de totale omzet in de sector groenten en fruit in Nederland in de jaren 1980-2010

\begin{tabular}{|l|c|c|c|c|c|c|}
\hline & 1980 & 1990 & $1995 / ' 96$ & 2000 & 2005 & 2010 \\
\hline $\begin{array}{l}\text {-Aantal veilingen/afzetorg. } \\
\text {-zelfst. telersverenigingen }\end{array}$ & 55 & 28 & 20 & $\begin{array}{l}10 \\
\left.25^{* *}\right)\end{array}$ & $\begin{array}{l}10 \\
\left.45^{* *}\right)\end{array}$ & $\begin{array}{l}10 \\
50^{* *} \text { ) }\end{array}$ \\
\hline \begin{tabular}{l} 
Veilingomzet in fl. (x 1 mln.) \\
\hline $\begin{array}{l}\text { Veilingomzet/ productiewaarde } \\
\text { sector in euro (x 1 mln.) }\end{array}$
\end{tabular} & 3.678 & 3.828 & 3.670 & & & \\
\hline
\end{tabular}

Bron: PT/VTN (1996), *) vanaf 2000 productiewaarde sector voedingstuinbouw(zie tabel 3.1) **) Schatting op

basis van bijlage Teelt in Beeld bij vakblad Groenten \& Fruit, maart 2004, 2006, 2008 en 2009, zie ook de tabellen $3.14 / 3.15$ en $3.18 / 3.19$

In de periode van 1980-1995 daalt het aantal veilingen met ruim 60\%, van 55 naar 20, onder een min of meer gelijkblijvende veilingomzet. Deze veilingomzet is $20 \%$ lager dan de productiewaarde van de sector. Een aantal producten van de vollegrond, champignons en fruit werden rechtstreeks van de teler aan de groothandel verkocht. Na de fusie in 1996 van negen veilingen tot VTN/The Greenery (75\% van de veilingomzet) gaan in 1997 twaalf veilingen zelfstandig door. Tabel 3.13 geeft een overzicht van de veilingen die in 1996 zijn gefuseerd tot VTN/The Greenery en degene die zelfstandig zijn gebleven of later zijn gefuseerd.

Aanvullende opmerkingen bij het veilingoverzicht van tabel 3.13:

- Tot op heden is veiling ZON zelfstandig gebleven met over de laatste jaren wisselende resultaten. De productomzet van ZON schommelde van 2005-2010 tussen de 200 en 300 mln. euro. Fusievoorstellen met veiling Geldermalsen zijn eind mei 2010 afgeblazen. De onderhandelaars denken te verschillend over de toekomstige ontwikkelingen en het te voeren beleid. De 
veilingklok wordt bij ZON nog steeds gebruikt, gemiddeld wordt $60 \%$ van de afzet verkocht via bemiddeling, $30 \%$ via de klok en $10 \%$ via voorverkoop aan de retail (Jaarverslagen ZON Coöperatie, 2005-2010).

Tabel 3.13 Overzicht omzet ( $€$ x 1000) groente- en fruitveilingen in Nederland, aangesloten bij het CBT en wel of geen deelname aan VTN/The Greenery*)

\begin{tabular}{|c|c|c|c|}
\hline \multicolumn{2}{|c|}{$\begin{array}{l}\text { Aangesloten bij nieuwe veiling Verenigde Tuinbouwveiling } \\
\text { Nederland (VTN/The Greenery) }\end{array}$} & \multicolumn{2}{|l|}{ Niet-aangesloten veilingen } \\
\hline - Westland-Poeldijk & - 958.410 & - $\quad$ ZON-Grubbenvorst & - $\quad 563.441$ \\
\hline - De Kring-Bleiswijk & - 472.909 & - Geldermalsen & - 108.644 \\
\hline - RBT-Breda & - 338.655 & - $\quad$ Zaltbommel & - $\quad 86.186$ \\
\hline $\begin{array}{l}\text { - } \quad \text { HZ-Barendrecht en } \\
\text { Kapelle }\end{array}$ & • $\quad 318.151$ & - $\quad$ RWM-Ochten & • 49.179 \\
\hline - WFO-Wervershoof & - 222.705 & - Margraten & $\begin{array}{ll} & 14.479\end{array}$ \\
\hline - Veldhoven & - 140.479 & - $\quad$ Katwijk & • 13.558 \\
\hline - Utrecht & - 134.931 & - Groningen & • $\quad 10.977$ \\
\hline - $\quad$ KZIJ-Ijsselmuiden & - 130.572 & - Zundert & 9.800 \\
\hline - VON-Bemmel & - $\quad 68.360$ & - St. Annaland & 9.261 \\
\hline & & - $\quad$ Zetten & 8.945 \\
\hline & & - Wijk bij Duurstede & 8.274 \\
\hline & $==========$ & & $=========$ \\
\hline Totaal & $\begin{array}{ll}\text { - } & 2.785 .172(\mathrm{fl}) \\
\text { - } & 1.265 .987(€)\end{array}$ & & $\begin{array}{ll}\text { - } & 882.744(\mathrm{fl}) \\
\text { - } & 401.247(€)\end{array}$ \\
\hline
\end{tabular}

Bron: Kolkman, W.A., Dynamiek in de groente- en fruitsector van 1990 tot 1998, Een nieuw logistiek concept, Productschap Tuinbouw, december $1999 ; *$ ) Veiling Bunnik, opgeheven per 1 oktober 1995 en Minnertsga, opgeheven per 29 oktober 1995, zijn hierin niet opgenomen.

- Fruitveiling Geldermalsen, tegenwoordig Koninklijke FruitmastersGroep geheten, is in 1999 gefuseerd met RWM-Ochten en Wijk bij Duurstede. In 2001 is handelsbedrijf Nico de Jong b.v. uit Bunnik en in 2003 importbedrijf Citronas uit Rotterdam overgenomen. De omzet schommelt vanaf 2006 tussen de 200 en $230 \mathrm{mln}$. euro. Ook hier is de veilingklok nog steeds in gebruik (20\% van de omzet), het resterende deel (> 50\%) wordt via bemiddeling verkocht, een kleiner deel via de koelcel of op het hout (Jaarverslagen Koninklijke FruitmastersGroep, 2005-2010).

- In 1997 is door VTN, ZON en Geldermalsen een nieuwe koepelorganisatie opgericht, de Dutch Produce Association (D.P.A.) te Breda, met als andere leden de veilingen Zaltbommel en Zuid-Limburg en de coöperatieve telersvereniging Unistar. Inmiddels is het traditionele veilingsysteem grotendeels omgevormd tot commerciële afzetorganisaties. Zij opereren als handelsbedrijf, als dienstverlener aan en als bemiddelaar tussen producent en eindafnemer. Bij DPA zijn in de loop der jaren de volgende zelfstandige coöperatieve telersverenigingen toegetreden: Best Growers Benelux (BGB), FresQ, Fossa Eugenia, Funghi, Komosa, Nautilus 
en Vers Direct Nederland (VDN). Unistar is uitgetreden. DPA behartigt de belangen van haar leden bij de nationale overheid in Den Haag en bij de Europese Commissie in Brussel (www. dpa.eu).

De afzetorganisaties zoals VTN/The Greenery (de nieuwe naam van de telerscoöperatie is in 2010 Coöperatie Coforta U.A.), ZON, Zaltbommel en Fruitmasters zijn opgericht als coöperatieve veilingen, maar vervullen momenteel tevens een rol als handelshuis en/of bemiddelaar. Daarnaast zijn er de nieuw opgezette zelfstandige afzetorganisaties zoals FresQ, VDN/VDT, BGB/Haluco en andere. Onder de afzetorganisaties ressorteren verschillende telersverenigingen. De afzetorganisaties vervullen verschillende functies. Zij zijn coöperaties van telers (met telersverenigingen) waarvoor zij diensten uitvoeren zoals debiteurenbewaking, kwaliteitszorg en veiling, zij bemiddelen tussen telers en klanten over vraag en aanbod en zij handelen via hun handelshuis. De afzetorganisaties kopen bijvoorbeeld via hun handelshuis producten van buitenlandse aanvoerders als de binnenlandse aanvoer onvoldoende is. In december 2007 is het selectief lidmaatschap van The Greenery opengesteld voor buitenlandse telers (jaarverslag The Greenery, 2007). De telers(verenigingen) en afzetorganisaties (via handelshuis, bemiddeling of veiling) leveren aan de groothandel en detailhandel in binnen- en buitenland. De groothandel verhandelt voor eigen rekening en risico producten en vervult een rol als intermediair tussen aanbieders en vragers (vooral detailhandel) in binnen- en buitenland. De groothandel en de handelshuizen van de afzetorganisaties zijn in die zin concurrenten van elkaar (Bunte, 2009 en Van Galen et al., 2010).

De onderstaande tabellen 3.14 en 3.15 geven een globale indeling van de posities van de diverse afzetorganisaties bij de productgroepen tomaat en paprika. Onder elke tabel staan de belangrijkste ontwikkelingen aangegeven.

In tabel 3.14 zijn de volgende ontwikkelingen te zien:

- In 2004 heeft het areaal glastomaat in Nederland een omvang van bijna 1000 ha. 45\% hiervan is aangesloten bij The Greenery, 23\% bij FresQ, 12\% bij Greenery/ZON en ZON Ver-

Tabel 3.14 Posities en aandelen afzetorganisaties in het geschat areaal glastomaat in ha.

\begin{tabular}{|l|c|c|c|c|c|c|}
\hline Afzetorganisatie & $\begin{array}{l}\text { ha. } \\
2004\end{array}$ & $\begin{array}{l}\text { aandeel } \\
\text { in } \%\end{array}$ & $\begin{array}{l}\text { ha. } \\
2006\end{array}$ & $\begin{array}{l}\text { aandeel } \\
\text { in } \%\end{array}$ & $\begin{array}{l}\text { ha. } \\
2008\end{array}$ & $\begin{array}{l}\text { aandeel } \\
\text { in } \%\end{array}$ \\
\hline 1. The Greenery & 437 & 45 & 466 & 39 & 341 & 27 \\
\hline 2. FresQ & 225 & 23 & 207 & 18 & 330 & 26 \\
\hline 3. Vers Direct Nederland (VDN) & 84 & 9 & 170 & 15 & 118 & 9 \\
\hline 4. Greenery/ZON & 66 & 7 & 53 & 4 & 83 & 6 \\
\hline 5. ZON Verkoopdiensten & 49 & 5 & 114 & 10 & 103 & 8 \\
\hline 6. Overig & 106 & 11 & 170 & 14 & 311 & 24 \\
\hline Totaal & 967 & 100 & 1180 & 100 & 1286 & 100 \\
\hline Aandeel 1. t/m 5. (C4) & & $89 \%$ & & $86 \%$ & & $76 \%$ \\
\hline
\end{tabular}

Bron: Bijlage Teelt in beeld bij Vakblad Groenten \& Fruit, maart 2004/2006/2008, LTO Groeiservice 
Tabel 3.15 Posities en aandelen afzetorganisaties in het geschat areaal glaspaprika in ha.

\begin{tabular}{|c|c|c|c|c|c|c|}
\hline Afzetorganisatie & $\begin{array}{l}\text { ha. } \\
2004\end{array}$ & $\begin{array}{l}\text { aandeel } \\
\text { in } \%\end{array}$ & $\begin{array}{l}\text { ha. } \\
2006\end{array}$ & $\begin{array}{l}\text { aandeel } \\
\text { in } \%\end{array}$ & $\begin{array}{l}\text { ha. } \\
2008\end{array}$ & $\begin{array}{l}\text { aandeel } \\
\text { in } \%\end{array}$ \\
\hline 1. ZON Verkoopdiensten & 149 & 18 & 207 & 24 & 207 & 18 \\
\hline 2. Vers Direct Nederland (VDN) & 136 & 16 & 156 & 18 & 151 & 13 \\
\hline 3. The Greenery & 89 & 11 & 65 & 8 & 137 & 12 \\
\hline 4. FresQ & 85 & 10 & 112 & 13 & 135 & 12 \\
\hline 5. Haluco BV & 105 & 13 & 115 & 13 & 110 & 10 \\
\hline 6. Rainbow Internationaal & 80 & 10 & 66 & 8 & 110 & 10 \\
\hline 7. Greenery / FreshQ / VDN / ZON & 52 & 6 & 59 & 7 & 63 & 6 \\
\hline 8. Overige, niet gespecificeerd & 115 & 14 & 81 & 9 & 93 & 8 \\
\hline $\begin{array}{ll}\text { 8. Overige met spec.: } & \text {-Tradition } \\
& \text {-Batavia } \\
& \text {-Westveg }\end{array}$ & 19 & 2 & & & $\begin{array}{l}68 \\
32 \\
30\end{array}$ & $\begin{array}{l}6 \\
3 \\
2\end{array}$ \\
\hline Totaal & 830 & 100 & 861 & 100 & 1136 & 100 \\
\hline Aandeel $1 \mathrm{t} / \mathrm{m} 4+7(\mathrm{C} 4)$ & & $61 \%$ & & $70 \%$ & & $61 \%$ \\
\hline
\end{tabular}

Bron: Bijlage Teelt in beeld bij Vakblad Groenten \& Fruit, maart 2004/2006/2008, LTO Groeiservice

koopdiensten en $9 \%$ is aangesloten bij VDN. De concentratiegraad van deze vier grootste afzetorganisaties(C4) bedraagt $89 \%$.

- In 2008 is het totale areaal gegroeid tot bijna 1300 ha. De posities van de vier grootste afzetorganisaties zijn nu gewijzigd: het aandeel van The Greenery is gedaald naar 27\% (- 96 ha.), het aandeel van FresQ is gestegen naar 26\% (+ 105 ha.), het aandeel van Greenery/ZON en ZON Verkoopdiensten bedraagt 14\% (+ 71 ha.) en dat van VDN 9\% (+ 34 ha.). Na de daling van de $\mathrm{C} 4$ in 2006 tot $86 \%$ is deze nu verder gezakt naar 76\%. Meer tomatentelers (verenigingen) kiezen voor een zelfstandig verkoopmodel of andere afzetorganisatie en zeggen hun lidmaatschap bij The Greenery op (zie Teelt in beeld 2004/2006/2008 en de ontwikkelingen volgens tabel 3.16).

- VDN is na een sterke groei van 2004-2006 (+86 ha.) in de periode van 2006-2008 teruggevallen van 170 ha. tot 118 ha. Dit is veroorzaakt door het verlies van een van de vier in VDN participerende groothandelsbedrijven, Valstar (Teelt in beeld, maart 2006/2008).

- Onder de overige afzetorganisaties hebben in 2008 Haluco en Rainbow Growers Group het grootste aandeel, beide $8 \%$ (Teelt in beeld, maart 2008).

In tabel 3.15 zijn de volgende ontwikkelingen te zien:

- In 2004 heeft het areaal glaspaprika in Nederland een omvang van 830 ha. Hiervan is $18 \%$ aangesloten bij ZON Verkoopdiensten, 16\% bij VDN, 11\% bij The Greenery en 10\% bij FresQ. Een aantal telers doet met alle vier deze afzetorganisaties zaken (zie 7, 6\% van het areaal). De concentratiegraad van de vier grootste afzetorganisaties(C4) bedraagt aldus $61 \%$. 
- In 2008 is het totale areaal gegroeid tot 1136 ha. Het aandeel van ZON is met $18 \%$ gelijk gebleven ( +58 ha.), het aandeel van VDN bedraagt nu 13\% (+ 15 ha.), dat van The Greenery $12 \%$ (+ 48 ha.) en van FresQ eveneens 12\% (+ 50 ha.). Nog steeds doet $6 \%$ van het areaal(+ 11 ha.) met alle vier de afzetorganisaties zaken (zie 7.).

- De concentratiegraad van de vier grootste afzetorganisaties (C4) is van 61\% in 2004 gestegen naar $70 \%$ in 2006 en daarna gedaald naar $61 \%$ in 2008 . Evenals bij de tomaten is ook hier de ontwikkeling dat meer paprikatelers (verenigingen) kiezen voor een ander verkoopmodel en hun lidmaatschap bij ZON, The Greenery of andere afzetorganisaties heroverwegen of opzeggen (Teelt in beeld, maart 2004/2006/2008).

- Het areaal paprika is gelijkmatiger verdeeld over de verschillende afzetorganisaties dan het areaal tomaten.

Verondersteld mag worden dat de daling van de hiervoor genoemde concentratiegraden bij de afzetorganisaties van glastomaten en -paprika's in combinatie met de grote uitbreiding van het areaal de onderhandelingspositie van deze organisaties ten opzichte van de groothandel/export en de detailhandel verzwakt. Hetzelfde geldt voor de veelvuldig voorkomende heroverwegingen en veranderingen in de organisatie van de afzet en het verkoopproces bij telers(verenigingen).

Met het vrijwel verdwijnen van de veilingklok is de markt voor groenten een stuk minder transparant geworden. Daarnaast is ruimte ontstaan voor heronderhandelingen. In plaats van een steeds eenmalig treffen van vraag en aanbod en het via de klok sluiten van de verkoopovereenkomst, wordt nu continu onderhandeld over prijzen, kortingen, voorwaarden en dergelijke. Partijen hebben daarbij ook de mogelijkheid om terug te komen op gemaakte afspraken. Hoewel telers wellicht gehoopt hadden op langetermijnafspraken met grootwinkelbedrijven, is dat in de praktijk vrijwel uitgebleven. Onderhandelingen hebben voornamelijk een kortetermijnkarakter en de contracten worden afgesloten voor hooguit een paar weken. Uitzondering is de keten Albert Heijn - Bakker Barendrecht - A.C. Hartman, waarbij via service-provider Bakker Barendrecht (dochteronderneming Univeg) voor langere tijd de leveringen van de producent Hartman zijn vastgelegd (Bunte, 2009).

Het dochterbedrijf Holland Crop van Bakker Barendrecht heeft vergelijkbare overeenkomsten met ca. 200 telers in binnen- en buitenland wier productie op maat gekoppeld wordt aan de vraag van Bakker-Albert Heijn. Ook de keten Plus - Hollander Barendrecht - The Greenery/Coforta U.A. is een voorbeeld van service-providing met langetermijncontracten.

Maar ook deze langetermijnafspraken worden regelmatig geëvalueerd, vergeleken met prijsaanbiedingen van concurrenten en zo laag mogelijk vastgesteld (Bunte, 2009).

De traditionele afzetorganisaties die voorheen vooral zorgden voor het veilen van de producten, zoals (de voorlopers van) The Greenery en ZON, hebben zich in de loop der jaren ontwikkeld tot allround dienstverleners en handelaren. Toch is met het afnemen van het belang van de veilingklok en de opkomst van andere afzetorganisaties de rol van deze partijen afgenomen. Dit komt het meest tot uitdrukking in het afnemende marktaandeel van The Greenery bij bepaalde glasgroenten, zoals bijvoorbeeld de tomaat (tabel 3.16). 
Tabel 3.16 Verdeling marktaandelen in verkoop tomaten (1996-2008)

\begin{tabular}{|l|c|c|c|c|c|c|c|c|c|}
\hline & \multicolumn{3}{|l|}{ The Greenery } & \multicolumn{3}{l|}{ ZON } & \multicolumn{3}{l|}{ Overige (FresQ e.a.) } \\
\hline & 1996 & 1998 & 2008 & 1996 & 1998 & 2008 & 1996 & 1998 & 2008 \\
\hline Tomaten & 76 & 57 & 40 & 14 & 8 & 11 & 10 & 42 & 49 \\
\hline
\end{tabular}

Bron: LEI, The Greenery, ZON, Bunte (2009)

Het gaat daarbij om het marktaandeel in de afzet van Nederlandse tomaten naar zowel binnenals buitenlandse afnemers. In 1996 werd 76\% van de tomaten via The Greenery afgezet, in 2008 was dat nog $40 \%$. De groep 'overige' heeft betrekking op de overige afzet van Nederlandse tomaten, via andere afzetorganisaties en veilingen, bijvoorbeeld de veiling in het Belgische Mechelen of rechtstreekse verkoop aan groot- of detailhandel. Inmiddels hebben zich wederom verschuivingen voorgedaan. Het marktaandeel van de grootste vier afzetorganisaties in de afzet van tomaten van Nederlandse telersverenigingen (op basis van areaal van die telersverenigingen) bedroeg in 2009 naar schatting ongeveer 60-65\% (Groenten \& Fruit, 2009). Aangezien de telersverenigingen ongeveer $90 \%$ van het Nederlandse aanbod bundelen, is het totale marktaandeel van de grootste vier afzetorganisaties ongeveer $60 \%$. Deze grootste vier afzetorganisaties waren in 2009 FresQ, The Greenery, Komosa en ZON (Groenten \& Fruit, 2009).

Op dit moment (2010/2011) kunnen binnen de telerscoöperatie Coforta U.A. (de nieuwe naam voor VTN) telers en aangesloten telersverenigingen kiezen voor toetreding tot Coforta Verkoop of toetreding tot handelsonderneming The Greenery. In het eerste geval kiest men voor het zogenaamde transactiemodel (t-model), in het tweede geval voor het 'preferred supplier' (p-model). In het t-model is het de teler of telersvereniging toegestaan een zelfstandig beleid voeren ten aanzien van de verkoop aan binnenlandse groothandel en exporteurs. Directe handel met buitenlandse afnemers is niet toegestaan. In het p-model is deze rol neergelegd bij het handelshuis en krijgen de telers de rol van 'preferred supplier'. De meeste telers hebben gekozen voor het p-model. Bemiddeling als verkoopmechanisme, waarbij de afzetorganisatie geen eigenaar wordt van het product, maar bemiddelt voor de telers, zal in het p-model waarschijnlijk geen rol meer spelen (Bunte, 2009 en Van Galen et al., 2010).

Omdat in het t-model geen directe verkoop aan buitenlandse klanten mogelijk is, zijn in 2011 toch een flink aantal 'prominente' telers uitgetreden en overgestapt naar een andere afzetorganisatie, waaronder FresQ. FresQ had tot 2014 het grootste marktaandeel in de productie en afzet van de tomaat (zie ook tabel 3.16).

Bovengenoemde ontwikkelingen geven aan dat er weinig stabiliteit is in de organisatie van de afzet en verkoop van verse groenten en fruit vanuit Nederland. Dit is nadelig voor de concurrentiepositie van de sector op de Europese markt en geeft concurrerende marktpartijen aan aanbod- en vraagzijde veel kansen om Nederlandse telers(verenigingen) en afzetorganisaties tegen elkaar uit te spelen. 


\subsubsection{Concentraties}

Schaalvergroting vindt in de gehele bedrijfskolom van de deelsectoren glastuinbouw plaats: het aantal ondernemingen neemt af en het marktaandeel van de grootste bedrijven neemt gestaag toe. De concentratie(graad) in een markt wordt doorgaans bepaald op basis van het cumulatieve marktaandeel van de vier grootste ondernemingen (C4) of de Hirschmann Herfindahl Index (HHI) (zie bijlage 2, begripsomschrijvingen). Een gezamenlijk marktaandeel van $60 \%$ of meer voor de top 4 is een indicatie van een sterke concentratie.

Tabel 3.17 Concentratie in de glasgroenteteelt (aantal producenten; marktaandeel C4)

\begin{tabular}{|l|r|r|r|r|r|r|}
\hline Product & \multicolumn{3}{|c|}{ Aantal producenten } & \multicolumn{3}{c|}{ C4*) } \\
\hline & 1980 & 2005 & 2008 & 1980 & 2003 & 2008 \\
\hline Komkommers & 1.133 & 399 & 250 & 2.9 & 6.1 & 5.0 \\
\hline Paprika & 381 & 544 & 350 & 7.7 & 4.4 & 5.0 \\
\hline Tomaten & 2.955 & 531 & 404 & 1.1 & 6.5 & 10.0 \\
\hline$\bullet \quad$ Tros & n.b & 275 & 223 & n.b & 7.9 & 11.0 \\
\hline$\bullet \quad$ Rond/vl. & n.b & 218 & 174 & n.b & 18.0 & 22.0 \\
\hline$\bullet \quad$ Cherry & n.b & 38 & 44 & n.b & 48.3 & 55.0 \\
\hline Alle bedrijven & 7.862 & 2547 & 1839 & n.b & n.b. & 6.5 \\
\hline
\end{tabular}

Bron: LEI, Bunte (2009), *) C4= Concentratiegraad vier grootste producenten

In de glasgroenten gaan concentratie, differentiatie en specialisatie gelijk op. Het aantal ondernemingen neemt versneld af en de grootste ondernemingen krijgen een steeds groter gewicht in de markt (tabel 3.17). Het aantal glasgroentebedrijven is in de periode 1980-2008 met ruim driekwart gedaald. De concentratie in de glasgroenten is tot op heden beperkt met een $\mathrm{C} 4$ voor alle productiebedrijven (1839 in 2008) van maximaal 6,5\%. Echter, als rekening gehouden wordt met een toenemende productdifferentiatie, is de concentratie een stuk groter. Het gezamenlijk marktaandeel van de top vier van producenten van cherrytomaten bedroeg in 2003 reeds $48 \%$. Ook op het niveau van de afzetorganisaties (zie tabel 3.14 en 3.15) en de telersverenigingen (zie tabel $3.18,3.19)$ is de concentratie in de tuinbouw aanmerkelijk groter. Het verschil in concentratiegraad (C4) tussen afzetorganisatie en telersvereniging wordt veroorzaakt doordat er meer telersverenigingen onder eenzelfde afzetorganisatie vallen.

Tabel 3.18 Telersverenigingen van tomaten

\begin{tabular}{|l|c|c|}
\hline & 2004 & 2008 \\
\hline Aantal telersverenigingen met merken & 19 & 19 \\
\hline Aantal leden & 560 & 404 \\
\hline Cumm. marktaandeel (in \%) op basis areaal (C4) & 46 & 52 \\
\hline Cumm. marktaandeel (in \%) op basis ledenaant. (C4) & 56 & 58 \\
\hline
\end{tabular}

Bron: Groenten \& Fruit 2004 en 2008, LEI en Bunte (2009) 
Tabel 3.19 Overige telersverenigingen

\begin{tabular}{|l|c|c|}
\hline & 2004 & 2008 \\
\hline Aantal telersverenigingen met merken & 24 & 28 \\
\hline Aantal leden & 598 & 814 \\
\hline Cumm. marktaandeel (in \%) op basis areaal (C4) & 35 & 49 \\
\hline Cumm. marktaandeel (in \%) op basis leden (C4) & 43 & 47 \\
\hline
\end{tabular}

Bron: Groenten \& Fruit 2004 en 2008, LEI en Bunte (2009)

\subsubsection{Ontwikkeling vraagzijde markt}

$\mathrm{Na}$ de behandeling van producenten en afzetorganisaties aan de aanbodzijde van de sector volgt nu de groot- en detailhandel aan de vraagzijde. De te volgen sectorvariabelen zijn de concentratieontwikkeling bij de exporteurs, de importeurs en de binnenlandse groothandel en de gerealiseerde export- en importwaarden. In de volgende paragrafen worden deze over een langere periode gevolgd. Eerst wordt specifiek gekeken naar de ontwikkeling van de export en import in de periode rondom het bedrijfsonderzoek (2006-2010). Samen met de ontwikkeling van het saldo van de handelsbalans, het volume en de prijzen zijn die in kaart gebracht. Daarna volgt de bespreking van de omzet- en concentratieontwikkeling in de exportgroothandel, de import en de binnenlandse groothandel. Van de binnenlandse groothandel worden tevens de verschillende bedrijfsvormen besproken en van de exportgroothandel afzonderlijk de exporteurs van glasgroenten. Als laatste volgt een korte beschrijving van de ontwikkeling bij het grootwinkelbedrijf en de overige detailhandel.

\subsubsection{Sectorale export- en importwaarde 2006-2010}

Onderstaande tabellen $3.20 \mathrm{t} / \mathrm{m} 3.23$ geven een overzicht van de ontwikkeling van de sectorale waarde, het volume en het prijspeil van export en import van verse groenten en vers fruit over de periode 2006-2010. Ook de ruilvoet $\left(\mathrm{p}_{\mathrm{x}}=\right.$ exportprijspeil $/ \mathrm{p}_{\mathrm{i}}=$ importprijspeil) en het exportsaldo over deze jaren wordt berekend en vergeleken.

Tabel 3.20 toont een aanmerkelijk herstel van de exportwaarde in 2010, in het bijzonder die van de sector groenten $(+11 \%)$. Zowel het volume als het prijspeil namen toe, het laatste zelfs ver boven het prijspeil van 2008 .

Ook de importwaarde steeg in 2010, voor verse groenten met $12 \%$, zie tabel 3.21. De ontwikkeling van de ruilvoet in 2010 was in de min, voor groenten $-3 \%$ en voor fruit $-1 \%$ (tabel 3.22 ).

Op basis van de cijfers van tabel 3.23 (export- en importwaarde) is het exportoverschot op de handelsbalans voor verse groenten en fruit in 2010 met $374 \mathrm{mln}$. euro gestegen van $2.217 \mathrm{mln}$. euro (jaar van de kredietcrisis) naar $2.490 \mathrm{mln}$. euro (+12\%). Ook ten opzichte van de jaren 2006-2008 is een hoger positief exportsaldo gerealiseerd. 
Tabel 3.20 Ontwikkeling exportwaarde, -volume en -prijspeil verse groenten en fruit incl. re-export (x1 mln. euro/kg/eurocent) periode 2006-2010

\begin{tabular}{|l|l|l|l|l|l|c|}
\hline Exportwaarde (x 1 mln. euro) & 2006 & 2007 & 2008 & $2009 *)$ & $2010 \mathrm{~V}$ & $* *)$ \\
\hline Groenten & 3.335 & 3.620 & 3.718 & 3.511 & 3.900 & 11 \\
\hline Fruit & 1.965 & 2.303 & 2.664 & 2.420 & 2.500 & 3 \\
\hline Totaal & 5.300 & 5.923 & 6.382 & 5.931 & 6.400 & 8 \\
\hline & & & & & & \\
\hline Exportvolume (x l mln. kg) & & & & & & \\
\hline Groenten & 3.450 & 3.500 & 3.700 & 3.850 & 3.900 & 1 \\
\hline Fruit & 2.500 & 2.700 & 2.600 & 2.450 & 2.500 & 2 \\
\hline Totaal & 5.950 & 6.200 & 6.300 & 6.300 & 6.400 & 2 \\
\hline & & & & & & \\
\hline Exportprijspeil (per kg/eurocent) & & & & & & \\
\hline Groenten & 0,97 & 1,03 & 1,00 & 0,91 & 1,05 & 15 \\
\hline Fruit & 0,79 & 0,85 & 1,02 & 0,99 & 1,04 & 5 \\
\hline
\end{tabular}

Bron: Eurostat/PT, V=voorlopige cijfers, *) kredietcrisis, **)groei t.o.v. 2009 in $\%$

Tabel 3.21 Ontwikkeling importwaarde, -volume en -prijspeil verse groenten en fruit incl. re-export (x1 mln. euro/kg/eurocent) periode 2006-2010

\begin{tabular}{|l|l|l|l|l|l|c|}
\hline Importwaarde (x I mln. euro) & 2006 & 2007 & 2008 & $2009 *)$ & $2010 \mathrm{~V}$ & $* *)$ \\
\hline Groenten & 964 & 1.066 & 985 & 975 & 1.095 & 12 \\
\hline Fruit & 2.396 & 2.594 & 2.927 & 2.740 & 3.014 & 10 \\
\hline Totaal & 3.359 & 3.660 & 3.912 & 3.715 & 4.109 & 11 \\
\hline & & & & & & \\
\hline Importvolume (x I mln. kg) & & & & & & \\
\hline Groenten & 1.046 & 1.012 & 981 & 1.047 & 989 & -6 \\
\hline Fruit & 2.934 & 3.156 & 3.301 & 3.125 & 3.256 & 4 \\
\hline Totaal & 3.980 & 4.168 & 4.282 & 4.172 & 4.245 & 2 \\
\hline & & & & & & \\
\hline Importprijspeil (per kg/eurocent) & & & & & & \\
\hline Groenten & 0,92 & 1,05 & 1,00 & 0,93 & 1,11 & 19 \\
\hline Fruit & 0,82 & 0,82 & 0,89 & 0,88 & 0,93 & 6 \\
\hline
\end{tabular}

Bron: Eurostat/PT, V=voorlopige cijfers, *) kredietcrisis, **)groei t.o.v. 2009 in \%

Tabel 3.22 Ontwikkeling ruilvoet $\left(\mathrm{p}_{\mathrm{x}} / \mathrm{p}_{\mathrm{i}}\right)$ verse groenten en vers fruit incl. re-export

\begin{tabular}{|l|l|l|l|l|l|l|}
\hline & 2006 & 2007 & 2008 & $2009 *)$ & $2010 *)$ & $* *)$ \\
\hline Groenten & $0,97 / 0,92=$ & $1,03 / 1,05=$ & $1,00 / 1,00=$ & $0,91 / 0,93=$ & $1,05 / 1,11=$ & \\
& 1.05 & 0.98 & 1.00 & 0.98 & 0.95 & -3 \\
\hline Fruit & $0,79 / 0,82=$ & $0,85 / 0,82=$ & $1,02 / 0,89=$ & $0,99 / 0,88=$ & $1,04 / 0,93=$ \\
& 0.96 & 1.04 & 1.15 & 1.13 & 1.12 & -1 \\
\hline
\end{tabular}

Bron: Eurostat/PT, V= voorlopige cijfers, ${ }^{*}$ ) kredietcrisis, ${ }^{* *}$ )groei t.o.v. 2009 in $\%$

Tabel 3.23 Ontwikkeling exportsaldo verse groenten en fruit (x mln. euro)

\begin{tabular}{|l|l|l|l|l|l|c|}
\hline & 2006 & 2007 & 2008 & $2009 *)$ & $2010 \mathrm{~V}$ & $* *)$ \\
\hline Exportwaarde & 5.300 & 5.923 & 6.382 & 5.931 & 6.400 & 8 \\
\hline Importwaarde & 3.359 & 3.660 & 3.912 & 3.715 & 3.910 & 5 \\
\hline Exportsaldo handelsbalans & 1.941 & 2.263 & 2.470 & 2.217 & 2.490 & 12 \\
\hline
\end{tabular}

Bron: Eurostat/PT, V= voorlopige cijfers, *) kredietcrisis, **)groei t.o.v. 2009 in \% 


\subsubsection{Groothandelsbedrijven en concentraties}

De groothandel in groenten en fruit bestaat uit exporteurs, importeurs en binnenlandse groothandelaren. Zij verzorgen de collectie en distributie van verse tuinbouwproducten van telers en afzetorganisaties naar de detailhandel in binnen- en buitenland. Hun specialisme is de kennis van de internationale markten en de dagelijkse afstemming van het aanbod van groenten en fruit op de vraag en wensen van de detailhandel en consumenten. Het grootste deel van het aanbod van verse groenten en fruit gaat naar de ons omringende lidstaten van de EU, inclusief de re-export van de import. De groothandel is een breed begrip en kent verschillen in aangeboden diensten. Ze variëren van transport- en verkoopdiensten tot de organisatie van een complete versketen met opslag en bevoorrading van winkels in binnen- en buitenland, ook wel product- en category management genoemd. Hiervoor is specifieke kennis van de detailhandel vereist en vermogen tot investeren. Zoals in de paragraaf hiervoor is beschreven, is slechts een paar van de grote handelsbedrijven, zoals The Greenery en Univeg (tegenwoordig "GreenYard" geheten), hiertoe in staat. Meestal is een bijzondere strategie van samenwerking van de productie- en handelsschakels vereist.

Van de groothandel in groenten en fruit in Europa zijn voor een aantal EU-lidstaten vanaf 2000 t/m 2007 bepaalde kengetallen beschikbaar. Het betreft het aantal bedrijven, de omzet en de bruto toegevoegde waarde per medewerker. Van het laatste kengetal wordt tevens de gemiddelde jaarlijkse groei aangegeven (Concurrentiemonitor glasgroente, LEI-rapport 2010-051, tabel 5.2 en 5.3, pp. 62 en 63). Tabel 3.24 geeft van 2003-2007 voor een aantal Europese landen, tevens belangrijke exportmarkten voor Nederland, een vergelijking van de Nederlandse met de buitenlandse groothandel.

Tabel 3.24 Ontwikkeling aantal bedrijven, omzet en bruto toegevoegde waarde groothandel in groenten en fruit van een aantal Europese landen van 2003-2007

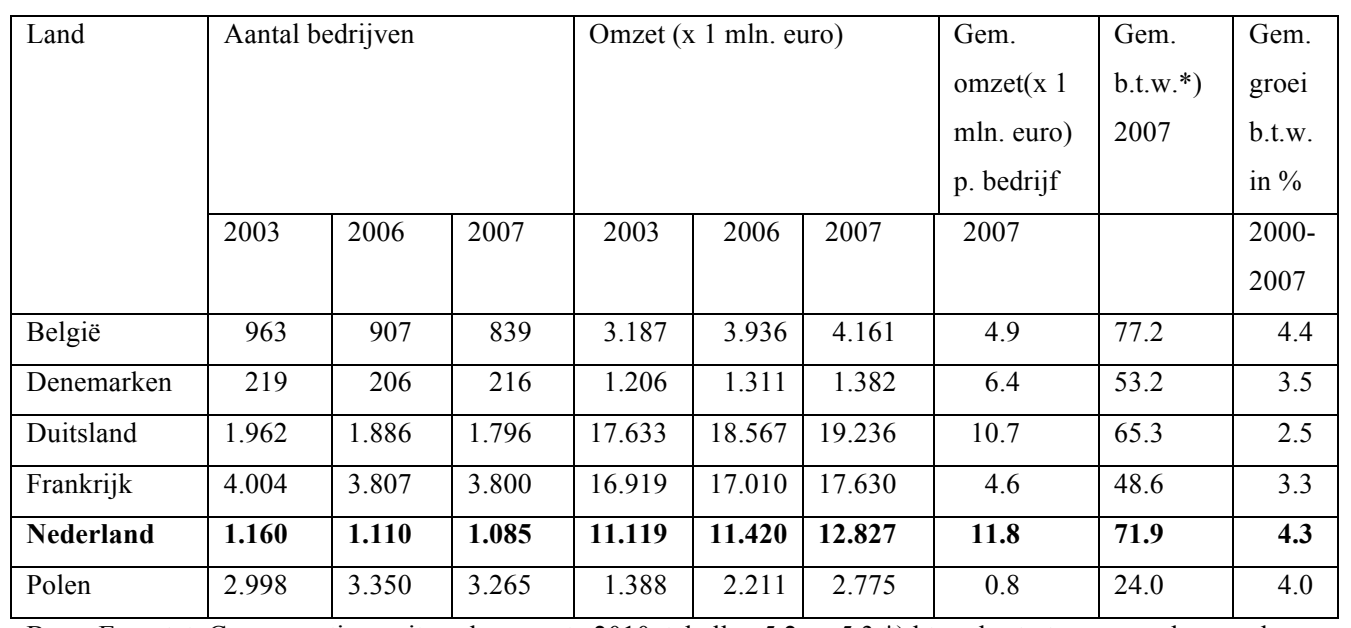

Bron: Eurostat, Concurrentiemonitor glasgroente 2010, tabellen 5.2 en $5.3 *$ ) btw= bruto toegevoegde waarde per medewerker in \% 
Het aantal groothandelsbedrijven in Nederland is tussen 2003 en 2007 gedaald van 1.160 naar 1.085. De gemiddelde omzet per bedrijf bedroeg in 2007 bijna $12 \mathrm{mln}$. euro. Hiermee zijn de Nederlandse bedrijven de grootste in omzetwaarde. In Duitsland bedraagt de gemiddelde groothandelsomzet $10.7 \mathrm{mln}$. euro. In de overige lidstaten zijn de bedrijven gemiddeld veel kleiner: Denemarken $6.4 \mathrm{mln}$. euro, België $4.9 \mathrm{mln}$. euro en Frankrijk $4.6 \mathrm{mln}$. euro. De groothandelsbedrijven in Oost-Europa zoals in Polen liggen in gemiddelde handelsomzet in 2007 lager dan $1 \mathrm{mln}$. euro. Ten aanzien van de groei van de gemiddelde toegevoegde waarde per medewerker per bedrijf ontlopen de landen elkaar niet veel. De Nederlandse groothandel presteert met een gemiddelde jaarlijkse groei van 4.3\% in de periode van 2000-2007 relatief goed. In Duitsland, Frankrijk en Denemarken werd minder groei in arbeidsproductiviteit gerealiseerd.

\section{Frugi Venta}

De overkoepelende organisatie in de groothandel van groenten en fruit in Nederland is Frugi Venta (onderdeel van het huidige Groente en Fruithuis). Deze organisatie is ontstaan in 2001 uit een fusie tussen drie organisaties die de exporteurs, de importeurs en de binnenlandse groothandelaren vertegenwoordigden.

Tabel 3.25 Groothandelsbedrijven totaal en per handelsfunctie

\begin{tabular}{|l|l|l|l|l|l|}
\hline & 2006 & 2007 & 2008 & 2009 & 2010 \\
\hline Aantal groothandelsbedrijven $(>€ 0.5 \mathrm{mln})$. & 768 & 804 & 780 & 789 & 782 \\
\hline Te verdelen in: & & & & & \\
\hline Aantal exporteurs ( $>€ 0.5 \mathrm{mln})$. & 320 & 324 & 322 & 335 & 351 \\
\hline Aantal groothandelaren binnenland $(>€ 0.5 \mathrm{mln})$. & 468 & 455 & 453 & 455 & 434 \\
\hline Aantal importeurs $(>€ 0.5 \mathrm{mln})$. & 128 & 130 & 137 & 143 & 133 \\
\hline
\end{tabular}

Bron: HBAG groenten en fruit

In 2010 zijn er 782 groothandelsbedrijven met een omzet boven de $€$ 0,5 mln.(zie tabel 3.25). Dit aantal blijft de laatste vijf jaar op een stabiel niveau. De bedrijven kunnen meer handelsfuncties hebben. Omzetontwikkeling en concentratie wordt voor de drie typen groothandelsbedrijven in de tabellen $3.25 \mathrm{t} / \mathrm{m} 3.27$ toegelicht.

In de discussie over horizontale of verticale samenwerking en concentratie door telers, telersverenigingen en afzetorganisaties enerzijds en groothandelaren anderzijds kiest Frugi Venta als vertegenwoordiger van de groothandel duidelijk positie. Onderstaand volgt een overzicht van een aantal argumenten van Frugi Venta voor vooral verticale samenwerking en integratie. Zie hiervoor ook het beleidsplan 2005-2008 en de jaarverslagen 2005-2011.

- De invoering per 1 januari 2005 van de Algemene Levensmiddelen Wet (General Food Law) met dwingende markteisen ten aanzien van kwaliteit en voedselveiligheid geeft een verplich- 
ting aan de bedrijven in de bedrijfskolom van voorwaartse en achterwaartse traceerbaarheid van producten. Frugi Venta heeft hiervoor in 2003, samen met het PT, de Stichting Monitoring Voedingstuinbouw 'Foodcompass' opgezet. Foodcompass zorgt landelijk voor een onafhankelijke, op risicoanalyse gebaseerde uitvoering van residu-onderzoek (Beleidsplan Frugi Venta 2005-2008).

- Eveneens in 2003 is het platform Frug I Com ingesteld, ter bevordering van de ontwikkeling en het gebruik van electronische standaardberichten (EDI) voor informatie-uitwisseling bij (internationale) transacties tussen partijen in de bedrijfskolom (Beleidsplan Frugi Venta 20052008).

- De internationalisering van de handel is versterkt door de uitbreiding van de EU, de opkomst van China als exporteur en consumptiemarkt en de internationale concentratie van supermarktorganisaties en de levensmiddelenindustrie. Ook aan producentenzijde zijn internationale afzetorganisaties aan het ontstaan. Een groeiend aantal Frugi Venta-leden manifesteert zich als verticaal geïntegreerd Europees handelshuis met vestigingen in het buitenland of met buitenlandse eigenaren (Beleidsplan Frugi Venta 2005-2008).

- Verticale samenwerking en integratie heeft bij de handelsbedrijven veel aandacht gekregen door de behoefte aan versterking van de concurrentiepositie en leveringszekerheid. In tegenstelling tot de verwachtingen heeft de structuurwijziging in de bedrijfskolom omstreeks 1995/1996 door de oprichting van The Greenery en de snelle afbouw van de klokverkoop, niet geleid tot een massale sanering van de groot- en tussenhandel. De functie van de handelsbedrijven tussen teler en eindafnemer in binnen- en buitenland is overeind gebleven. 'Er zijn meer dan genoeg eindafnemers die de toegevoegde waarde van de handelsbedrijven erkennen' (Jaarverslag Frugi Venta 2007, p. 8). Ook de behoefte aan voedselveiligheidsgaranties, klantgerichtheid en kostenbesparingen spelen een rol (Beleidsplan Frugi Venta 2005-2008, p. 4).

- Frugi Venta geeft de voorkeur aan vaste verticale ketensamenwerking waarbij de teler via zijn afzetorganisatie en/of handelaar specifieke afspraken met de retailer maakt over de innerlijke en uiterlijke kwaliteit, verpakking, gebruik van gewasbeschermingsmiddelen, aanvoerprognoses, levertijden en prijscalculaties. 'De retailer wil in verbinding staan met de bron. De producent wordt extra gemotiveerd, wanneer deze weet voor wie zijn product is bestemd. Horizontale bundeling is dan geen werkbare oplossing, vooral niet als het bedoeld is om de markt te dwingen.' (Jaarverslag Frugi Venta 2010, p. 13).

De ontwikkeling van omzet en concentratie over de periode 2006-2009 wordt hieronder toegelicht voor exporteurs, importeurs en binnenlandse groothandel. 
Tabel 3.26 Indeling exporteurs naar omzetgrootte inclusief re-export

\begin{tabular}{|c|c|c|c|c|c|c|c|c|}
\hline \multirow[t]{2}{*}{ Exportomzetklassen } & \multicolumn{4}{|c|}{ Aantal exporteurs per omzetklasse } & \multicolumn{4}{|c|}{ Exportaandeel in $\%$} \\
\hline & 2006 & 2007 & 2008 & $2009 *)$ & 2006 & 2007 & 2008 & $2009 *)$ \\
\hline Euro & & & & & $\%$ & $\%$ & $\%$ & $\%$ \\
\hline meer dan $50 \mathrm{mln}$. & 22 & 27 & 29 & 30 & 50 & 53 & 55 & 55 \\
\hline 25 tot $50 \mathrm{mln}$. & 22 & 26 & 26 & 25 & 19 & 18 & 17 & 17 \\
\hline 15 tot $25 \mathrm{mln}$. & 27 & 23 & 19 & 22 & 10 & 9 & 7 & 8 \\
\hline 7.5 tot $15 \mathrm{mln}$. & 47 & 53 & 53 & 50 & 10 & 11 & 11 & 10 \\
\hline 5 tot $7.5 \mathrm{mln}$. & 29 & 23 & 32 & 30 & 4 & 2 & 4 & 3 \\
\hline 2.5 tot $5 \mathrm{mln}$. & 33 & 45 & 43 & 47 & 3 & 3 & 3 & 3 \\
\hline 1 tot $2.5 \mathrm{mln}$. & 67 & 69 & 69 & 73 & 2 & 2 & 2 & 2 \\
\hline 0.5 tot $1 \mathrm{mln}$. & 73 & 58 & 51 & 58 & 2 & 2 & 1 & 2 \\
\hline $\begin{array}{l}\text { Totaal aantal bedrijven } \\
\text { vanaf } 0.5 \mathrm{mln} \text {. euro }\end{array}$ & 320 & 324 & 322 & 335 & 100 & 100 & 100 & 100 \\
\hline $\begin{array}{l}\text { Totale exportomzet- } \\
\text { opgave bij HBAG } \\
\text { Groenten en Fruit }\end{array}$ & $\begin{array}{c}4.696 \\
\text { mln. }\end{array}$ & $\begin{array}{l}5.283 \\
\text { mln. }\end{array}$ & $\begin{array}{r}5.386 \\
\text { mln. }\end{array}$ & $\begin{array}{l}5.309 \\
\text { mln. }\end{array}$ & & & & \\
\hline
\end{tabular}

Bron: HBAG groenten en fruit, ${ }^{*}$ ) kredietcrisis

Tabel 3.26 geeft de volgende informatie. Het aantal exportbedrijven met een omzet van minstens $0,5 \mathrm{mln}$. euro is van 2006-2009 gestegen met bijna 5\% tot 335. De exportomzet over 2009 is ten opzichte van 2008 met 2\% gedaald tot $5.309 \mathrm{mln}$. euro. Ten opzichte van 2007 ligt deze omzet praktisch gelijk en ten opzichte van 2006 bijna 13\% hoger. De export inclusief re-export van groenten en fruit blijft ook in het jaar van de kredietcrisis op peil, wat mede wordt bewerkstelligd door het op niveau blijven van de import. In tabel 3.28 wordt een nadere verdeling van de concentratie onder exporteurs vermeld op basis van de KCB exporthoeveelheden tot en met 2010.

In 2006 hebben de 44 grootste bedrijven (14\%) een exportaandeel van 69\%. In 2007 zijn dit 53 bedrijven (16\%) die 71\% exportaandeel hebben. In 2008 en in 2009 zijn het de 55 grootste exportbedrijven (17\% en 16\%) die een gezamenlijk aandeel van $72 \%$ in de exportomzet hebben. De concentratie in de exporthandel ligt op een hoog en stabiel niveau. 
De bij het HBAG geregistreerde omzet van de importhandel is met $1.678 \mathrm{mln}$. euro in 200920 $\mathrm{mln}$. euro meer dan in 2008. Ten opzichte van 2006 is er een toename van $6 \%$. Het aantal importbedrijven boven de omzetgrens van $0.5 \mathrm{mln}$. euro bedraagt in 2009143.

De eigen import van de binnenlandse groothandel en supermarktorganisaties blijft hierbij buiten beschouwing.

In 2006 hebben de 18 grootste bedrijven (14\%) een importaandeel van 66\%. In 2007 en 2008 zijn dit 17 bedrijven (13\% en $12 \%$ ) die 63\% en 64\% importaandeel hebben. In 2009 zijn het de 19 grootste importbedrijven (13\%) die een gezamenlijk aandeel van $65 \%$ in de importomzet hebben. De concentratie in de importhandel ligt iets lager dan in de exporthandel, maar heeft ook hier een hoog en stabiel niveau (tabel 3.27).

Tabel 3.27a toont de ontwikkeling van de binnenlandse groothandel van 2006-2009. Het aantal bedrijven daalt enigszins bij een op peil blijvende omzet, ondanks de recessie in 2009. Er zijn in dat jaar 455 groothandelaren bij het HBAG groenten en fruit geregistreerd met een verkoopomzet van minstens $0,5 \mathrm{mln}$. euro aan binnenlandse afnemers. De totale omzet van de groothandel aan binnenlandse afnemers daalde in 2009 met 2,5\% tot $4.409 \mathrm{mln}$. euro onder invloed van de economische recessie. In verhouding tot de daling met $15 \%$ van de productiewaarde van de Nederlandse voedingstuinbouw is de daling bij de groothandel beperkt gebleven.

Tabel 3.27a Binnenlandse groothandel (incl. citrus- en bananenomzet)

\begin{tabular}{|c|c|c|c|c|c|c|c|c|}
\hline \multirow[t]{2}{*}{ Omzetklassen } & \multicolumn{4}{|c|}{ Aantal bedrijven per omzetklasse } & \multicolumn{4}{|c|}{$\begin{array}{l}\% \text { aandeel van totale binnenlandse } \\
\text { groothandelsomzet }\end{array}$} \\
\hline & 2006 & 2007 & 2008 & $2009 *)$ & 2006 & 2007 & 2008 & $2009 *)$ \\
\hline Euro & & & & & $\%$ & $\%$ & $\%$ & $\%$ \\
\hline meer dan $50 \mathrm{mln}$. & 16 & 20 & 20 & 20 & 42 & 49 & 51 & 52 \\
\hline 25 tot $50 \mathrm{mln}$. & 19 & 14 & 13 & 13 & 18 & 12 & 11 & 10 \\
\hline 15 tot $25 \mathrm{mln}$. & 20 & 21 & 20 & 19 & 10 & 10 & 9 & 9 \\
\hline 10 tot $15 \mathrm{mln}$. & 19 & 23 & 24 & 29 & 6 & 6 & 6 & 8 \\
\hline 5 tot $10 \mathrm{mln}$. & 54 & 54 & 59 & 48 & 9 & 8 & 9 & 8 \\
\hline 2.5 tot $5 \mathrm{mln}$. & 94 & 86 & 86 & 83 & 8 & 8 & 8 & 8 \\
\hline 0.5 tot $2.5 \mathrm{mln}$ & 246 & 237 & 231 & 243 & 7 & 7 & 6 & 5 \\
\hline $\begin{array}{l}\text { Totaal aantal bedrijven } \\
\text { vanaf } 0.5 \mathrm{mln} \text {. euro }\end{array}$ & 468 & 455 & 453 & 455 & 100 & 100 & 100 & 100 \\
\hline $\begin{array}{l}\text { Totale binnenlandse } \\
\text { groothandelsomzet }\end{array}$ & $\begin{array}{c}4.268 \\
\text { mln. }\end{array}$ & $\begin{array}{r}4.415 \\
\text { mln. }\end{array}$ & $\begin{array}{l}4.525 \\
\text { mln. }\end{array}$ & $\begin{array}{r}4.409 \\
\text { mln. }\end{array}$ & & & & \\
\hline
\end{tabular}

Bron: HBAG groenten en fruit, *) kredietcrisis 
De 52 bedrijven (11\%) in de omzetgroepen boven de $15 \mathrm{mln}$. euro vertegenwoordigen $71 \%$ van de landelijke omzet in 2009. Ter vergelijking: in 2006 waren er 55 bedrijven (12\%) boven de omzetgrens van $15 \mathrm{mln}$. euro met een gezamenlijk marktaandeel van $69 \%$. De concentratie in de binnenlandse groothandel ligt evenals bij de export en import op een hoog en stabiel niveau.

\subsubsection{Bedrijfsvormen binnenlandse groothandel}

Onder de 455 groothandelaren in groenten en fruit met binnenlandse afzet bevinden zich geheel verschillende bedrijfsvormen (zie bijlage bij het jaarverslag Frugi Venta 2010).

De volgende zes categorieën worden onderscheiden:

1. de algemene levensmiddelen- of horecagroothandel, die tevens verse groenten en fruit verkopen. Hieronder valt ook de omzet van supermarktconcerns aan franchiseondernemers.

Deze omzet wordt geraamd op $700 \mathrm{mln}$. euro.

2. de gespecialiseerde groenten- en fruitgroothandelaren die zich voornamelijk richten op de Nederlandse supermarktorganisaties. Deze bedrijven bevinden zich in de hoogste omzetgroepen. Zij vervullen de functie van logistieke dienstverlener.

3. de groentebewerkingsbedrijven die leveren aan supermarkten en foodserviceafnemers (horeca, zorgsector, cateraars, maaltijdfabrikanten). De gezamenlijke omzet van deze 48 bedrijven boven de 0,5 mln. euro bedraagt in $2009520 \mathrm{mln}$. euro.

4. de in een bepaalde productgroep gespecialiseerde groothandel, die voornamelijk aan de collega-groothandel verkoopt (bijv. uien, Nederlands fruit, champignons, grove tuinbouw).

Het aandeel van deze onderlinge verkoop wordt geraamd op 20 à $25 \%$ van de totale omzet.

5. de groep grote of middelgrote exporteurs, die een deel van hun ingekochte producten afzetten aan binnenlandse afnemers. Deze grootschalige exporteurs tellen in deze statistiek mee als binnenlandse groothandelaren.

6. grossiers die zich hoofdzakelijk richten op de AGF-speciaalzaken, allochtone en ambulante detailhandel. HBAG raamt hun aantal tussen de 100 en 125, verdeeld over alle omzetgroepen. Dit aantal daalt sterk door de daling van het marktaandeel van deze winkels, behalve van de allochtone bedrijven. Volgens het Hoofdbedrijfsschap Detailhandel is de gezamenlijk omzet van de groentespeciaalzaken in 2009 gedaald naar $433 \mathrm{mln}$. euro, dat is $6 \%$ lager dan in 2008 . Het aantal winkels is sinds 2005 met 340 gedaald tot 1210 . Daarnaast zijn er nog 1100 ambulante handelaren in AGF-producten actief. Dit aantal blijft redelijk constant.

\subsubsection{Exporteurs van glasgroenten}

Onderstaande tabel 3.28 toont de ontwikkeling van de concentratie bij de tien grootste exporteurs van glasgroenten, gericht op Duitsland in vergelijking met de tien grootste exporteurs van alle producten (groenten en fruit) en die van de specifiekere glasgroenten, gericht op alle landen. 
Tabel 3.28 Positie van de tien grootste exporteurs *)

\begin{tabular}{|l|l|l|l|l|l|}
\hline Exportaandeel van de 10 grootste exporteurs & 2006 & 2007 & 2008 & 2009 & 2010 \\
\hline & $\%$ & $\%$ & $\%$ & $\%$ & $\%$ \\
\hline Alle producten (groenten en fruit) & $\mathbf{4 7 . 3}$ & $\mathbf{4 7 . 2}$ & $\mathbf{4 4 . 0}$ & $\mathbf{4 6 . 2}$ & $\mathbf{4 6 . 4}$ \\
\hline Tomaten, kropsla, komkommers, paprika naar Duitsland & 72.3 & 71.4 & 67.3 & 66.4 & 65.9 \\
\hline $\begin{array}{l}\text { Tomaten, kropsla, komkommers, paprika naar alle } \\
\text { landen }\end{array}$ & 65.0 & 63.8 & 58.2 & 56.4 & 57.6 \\
\hline
\end{tabular}

Bron: KCB/HBAG groenten en fruit; *) Dit betreft de tien grootste exporteurs in het betreffende kalenderjaar op basis van alle producten en alle bestemmingen (exclusief België/Luxemburg)

Gevolgd wordt de ontwikkeling van het exportaandeel (de concentratiegraad) van de tien grootste exporteurs bij de belangrijkste glasgroenten over de periode 2006-2010.

De concentratie van de exporthandel van glasgroenten met bestemming Duitsland ligt op een hoog niveau vergeleken met andere productgroepen en bestemmingen. Het exportaandeel laat echter van 2006-2010 een dalend verloop zien van ruim 6 procentpunt (72.3 naar 65.9).

In 2006 zijn er in Nederland 83 exporteurs van glasgroenten (jaarverslag Frugi Venta 2009 en 2010). Het gaat dan om bij de brancheorganisatie aangesloten groothandelsbedrijven die exporteren. Het aantal exporteurs daalt van 2006-2010 van 83 tot 77. De grootste negen exporteurs nemen in 2006 bijna $70 \%$ van de export naar Duitsland voor hun rekening. In 2010 zijn dit negen bedrijven met $64.5 \%$ aandeel. Naast de grote exporteurs met een afzetgrootte op jaarbasis van boven de $40 \mathrm{mln}$. $\mathrm{kg}$ bestaat er een 40-tal kleine exporteurs met een afzetgrootte beneden de $2 \mathrm{mln}$. kg per jaar. De toetredingsdrempels tot de tussenhandel in groente en fruit zijn laag. Fysiek is slechts een telefoon en een vrachtwagen nodig (Bunte, 2009). De handel in groenten is een dynamische wereld waarin naast de grote ondernemingen zeer veel Nederlandse en internationale bedrijven opereren, die dagelijks door koop en verkoop een gat in de markt proberen te vullen. Het begrip groothandel is echter een breed begrip en er zijn gradaties in de soorten groothandelaren en de drempels die gelden om als groothandel in een bepaalde markt te opereren. Het opbouwen van vaste relaties met afnemers is kostbaar en naarmate de volumes groter worden en de assortimenten breder en dieper, is bijvoorbeeld meer opslag en koelruimte nodig. Sommige groothandelsbedrijven (inclusief de handelshuizen van de afzetorganisaties) voeren product- en category management uit voor afnemers, wat specifieke kennis en investeringen vergt. Enkele grote supermarkten werken met preferred suppliers of zelfs exclusieve service providers (zie Grootwinkelbedrijf).

\subsubsection{Grootwinkelbedrijf}

De belangrijkste afnemers van de Nederlandse vruchtgroenten zijn de grootwinkelbedrijven in Nederland, Duitsland en het Verenigd Koninkrijk. De afgelopen decennia heeft een sterke concentratie plaatsgevonden van grootwinkelbedrijven in Europa. Het marktaandeel (totaal aan levensmiddelen) van de vijf grootste supermarktorganisaties in Nederland bedraagt in 2007 onge- 
veer $66 \%$. Aan de inkoopzijde werken veel supermarkten samen in, soms grensoverschrijdende inkoopcombinaties. In Nederland hebben de drie grootste inkoop-combinaties, te weten Albert Heijn, Superunie en TSN, in 2004 73\% marktaandeel (OESO, 2006; Bunte, 2009). Tegelijkertijd neemt de betekenis van andere distributiekanalen af. Gezamenlijk hebben de andere distributiekanalen zoals de groentespeciaalzaken en de markten in 2005 een marktaandeel voor groenten en fruit van circa $24 \%$, waaronder $9 \%$ voor AGF-speciaalzaken en $9 \%$ voor de markt (EIM, 2007). Het aantal AGF-speciaalzaken is in de periode 1994-2005 meer dan gehalveerd van ruim 3.000 tot minder dan 1.400 (EIM, 2007; PT, 2005). De omzet in groentespeciaalzaken is in de periode 2000-2005 met 30\% afgenomen (EIM, 2007; Bunte, 2009).

\subsection{Bedrijfskolom en marktstructuur sector glassierteelt}

We bespreken in deze paragraaf eerst de ontwikkeling van de bedrijfskolom in de sector glassierteelt aan de hand van de afzetstructuur van snijbloemen. In tegenstelling tot de afzetstructuur in de voedingstuinbouw staat hier de positie van de coöperatieve bloemenveiling als organisator van de dagelijkse markt van (glas)snijbloemen, pot- en tuinplanten nog steeds centraal. Hierna schenken we aandacht aan de belangrijkste spelers van de marktstructuur, eerst aan de aanbodzijde, de producenten en afzetorganisaties, daarna aan de vraagzijde, de groothandel/export.

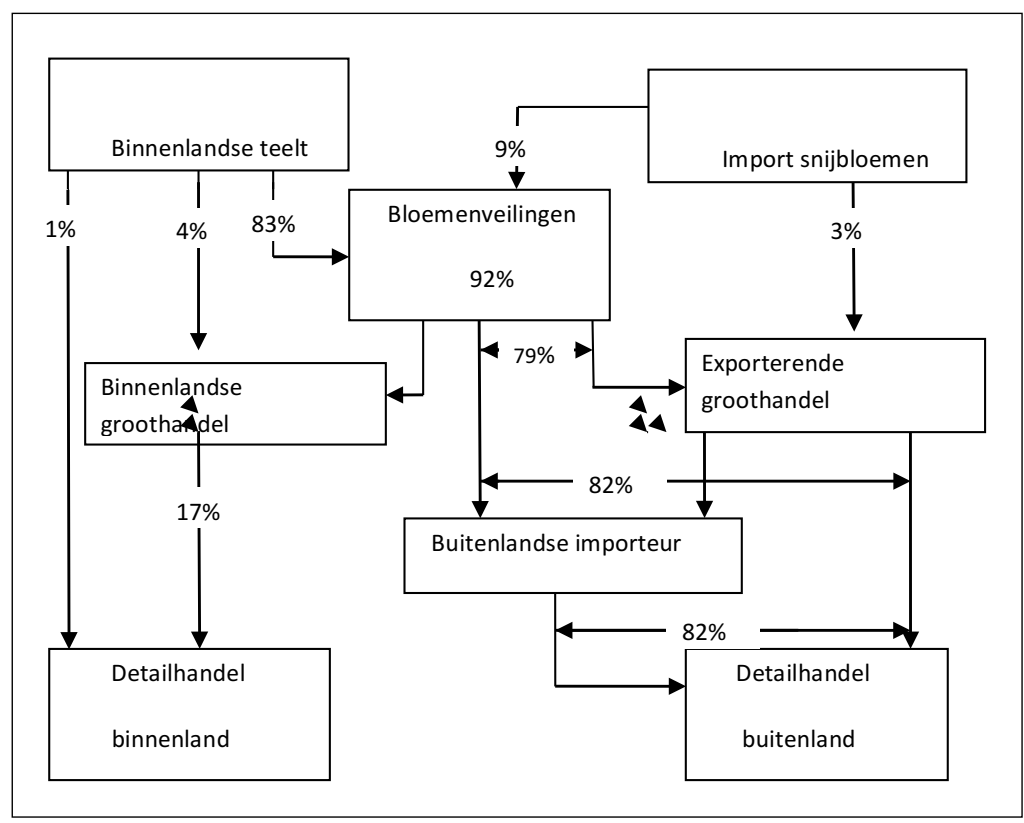

Figuur 3.2 De bedrijfskolom glassierteelt (snijbloemen) in Nederland in 2000 (Uitgerekend De Tuinbouw, 2002) 
Figuur 3.2 hierboven geeft de voor dit onderzoek belangrijke schakels van de bedrijfskolom glassnijbloemen aan. De eerste schakel betreft het binnen- en buitenlandse aanbod van (glas) snijbloemen met een verdeling over het jaar 2000 in een verhouding van $88: 12$.

De tweede schakel toont de bloemenveilingen die dagelijks de B2B-markt organiseren voor binnen- en buitenlandse aanvoerders enerzijds en binnen- en buitenlandse groothandel/export (de derde schakel) anderzijds. De binnen- en buitenlandse groothandel/export zet in 2000 de snijbloemen af aan de detailhandel in een verhouding van $18: 82$. Evenals de voedings-tuinbouw is de siertuinbouw zeer export georiënteerd. Meer dan $80 \%$ van de Nederlandse snijbloemen zijn bestemd voor de export. Het gemiddelde aandeel van de Nederlandse siertuinbouw in de EU exporthandel bedraagt sinds 2000 ongeveer 70\% (PT, Uitgerekend De Tuinbouw, 2002). Voor snijbloemen ligt dit percentage rond de 80 , voor potplanten op $50 \%$.

De import van snijbloemen bedraagt in 2000 24\% van het binnenlandse aanbod. In 2010 ligt dit op 25\% (zie ook tabellen 3.1 en 3.5 van paragraaf 2). De import is, evenals bij de vruchtgroenten, voornamelijk gericht op de re-export. De import van pot- en perkplanten ligt op een iets lager niveau dan de snijbloemen, namelijk op $15 \%$.

Het in kaart brengen en volgen van de marktstructuur en sectorvariabelen van de deelsector glassierteelt richt zich enerzijds op het aanbod van verse snijbloemen en potplanten, anderzijds op de vraag naar deze producten op de relevante binnen- en buitenlandse markten (zie figuur 3.2). De belangrijkste kenmerken aan de aanbodzijde zijn bedrijfstype en -omvang van de producenten en hun afzetorganisatie, de positie op de markt, de onderscheiden productgroepen met de uniekheid, breedte en diepte van het assortiment en de toegepaste methoden en technieken en de kostprijs. Dit betreft zowel de eigen productie als de import uit het buitenland. Aan de vraagzijde treffen we als eerste schakel meestal de groothandel/ exporteur of importeur van verse snijbloemen en potplanten aan en als tweede de detailhandel. De belangrijkste kenmerken aan de handelszijde zijn het spiegelbeeld van die van het aanbod. Bedrijfstype en -omvang, positie op de markt, gevraagde productgroepen, assortiment, methoden en technieken, kostprijs en specifieke klantwensen spelen ook hier een rol. Hieronder behandelen we eerst de ontwikkeling aan de aanbodzijde, daarna die aan de vraagzijde.

\subsubsection{Ontwikkeling aanbodzijde markt}

\subsubsection{Producenten}

In tabel 3.7 van paragraaf 3.2 is aangegeven hoe de schaalvergroting van de bedrijven in de sector glassierteelt verloopt. Als we de periode 2000-2010 voor glassnijbloemen en -potplanten hier uitlichten (zie onderstaande tabellen 3.29 en 3.30), dan is te zien dat er in een periode van tien jaar een vergroting van de bedrijfsomvang plaatsvindt van gemiddeld 0.9 ha. naar 1.5 en 1.6 ha. glasoppervlakte. Bij de snijbloemen verloopt dit echter anders dan bij de potplanten. Het areaal van de snijbloemen laat een daling zien van $30 \%$, terwijl bij de potplanten sprake is van enige stijging van het areaal. Eerst bespreken we het verloop bij de snijbloemen, daarna bij de potplanten. 
Tabel 3.29 Schaalvergroting producenten snijbloemen 2000-2010

\begin{tabular}{|l|l|l|l|c|c|}
\hline Jaar & $\begin{array}{l}\text { Productie- } \\
\text { waarde (x euro } \\
1 \text { mrd.) }\end{array}$ & $\begin{array}{l}\text { Bedrijfsopp. } \\
\text { Glas in ha. }\end{array}$ & $\begin{array}{l}\text { Aantal } \\
\text { bedrijven }\end{array}$ & $\begin{array}{l}\text { Gem. prod. } \\
\text { waarde (x } \\
\text { euro 1 mln.) }\end{array}$ & $\begin{array}{l}\text { Gem. } \\
\text { opp. }\end{array}$ \\
\hline 2000 & 2.085 & 3923 & 4112 & 0.507 & 0,9 \\
\hline 2005 & 2.199 & 3414 & 3026 & 0.727 & 1,1 \\
\hline 2006 & 2.277 & 3248 & 2818 & 0.808 & 1,2 \\
\hline 2007 & 2.294 & 3165 & 2548 & 0.900 & 1,2 \\
\hline 2008 & 2.172 & 2953 & 2399 & 0.905 & 1,2 \\
\hline $2009 * *)$ & 1.887 & 2856 & 2113 & 0.893 & 1,4 \\
\hline $\left.2010^{*}\right)$ & 2.110 & 2612 & 1674 & 1.260 & 1,6 \\
\hline
\end{tabular}

Bron: $\mathrm{CBS} / \mathrm{PT}, *)$ voorlopig **) kredietcrisis

Uit tabel 3.29 is op te maken dat vanaf 2000-2008 jaarlijks 5-10\% van de bedrijven stopt, in 2009 en 2010 ligt dit percentage zelfs op 12\% en $20 \%$. De gevolgen van de kredietcrisis zijn ook hier zichtbaar. Een daling van 30\% van het areaal en $60 \%$ van het aantal bedrijven over de gehele periode van tien jaar zorgt voor een versnelling van de schaalvergroting. In het jaar van het bedrijfsonderzoek glassnijbloemen (2007) zijn 2548 bedrijven actief op een oppervlakte van 3165 ha. met een sectorproductiewaarde van bijna $2.3 \mathrm{mrd}$. euro. De productiewaarde van het bedrijf bedraagt dan gemiddeld 900.000 euro op 1.2 ha. glas. In 2008 en 2009 daalt de sectorproductiewaarde met 5 en 13\%. In 2010 volgt een herstel tot ruim $2.1 \mathrm{mrd}$. euro. Er is dan ruim $34 \%$ minder bedrijven dan in 2007. Evenals in de glasgroentesector is in 2008 en 2009 in de glassierteelt het netto bedrijfsresultaat van het gemiddelde bedrijf negatief (Binternet, LEI, 2008 en 2009).

Tabel 3.30 Schaalvergroting producenten potplanten 2000-2010

\begin{tabular}{|l|c|c|c|c|c|}
\hline Jaar & $\begin{array}{c}\text { Productie- } \\
\text { waarde (x euro } \\
1 \mathrm{mrd} .)\end{array}$ & $\begin{array}{c}\text { Bedrijfsopp. } \\
\text { glas in ha. }\end{array}$ & $\begin{array}{c}\text { Aantal } \\
\text { bedrijven } \\
\text { prod.waarde } \\
\text { (x euro 1 } \\
\text { mln.) }\end{array}$ & $\begin{array}{c}\text { Gem. } \\
\text { opp. }\end{array}$ \\
\hline 2000 & 1.155 & 2200 & 2463 & 0.525 & 0,9 \\
\hline 2005 & 1.512 & 2349 & 2045 & 0.739 & 1,1 \\
\hline 2006 & 1.624 & 2300 & 1896 & 0.857 & 1,2 \\
\hline 2007 & 1.768 & 2288 & 1768 & 1.000 & 1,3 \\
\hline 2008 & 1.862 & 2238 & 1605 & 1.160 & 1,4 \\
\hline $\left.2009^{* *}\right)$ & 1.902 & 2315 & 1641 & 1.159 & 1,4 \\
\hline $\left.2010^{*}\right)$ & 2.000 & 2333 & 1576 & 1.269 & 1,5 \\
\hline
\end{tabular}

Bron: CBS/PT, *) voorlopig **) kredietcrisis 
Tabel 3.30 laat zien dat bij de sector glaspotplanten geen daling maar een stijging van het areaal van 2000-2010 plaatsvindt. Het aantal bedrijven daalt met 36\%, dus in mindere mate dan de glassnijbloemen. Opvallend is dat de sectorale productiewaarden van de glassnijbloemen en -potplanten in 2009 en 2010 steeds dichter bij elkaar in de buurt komen.

Er lijkt een verschuiving plaats te vinden van minder Nederlandse productie van glassnijbloemen naar meer productie van glaspotplanten.

De verhoogde aanvoer van snijbloemen door buitenlandse aanvoerders (met lage productiekosten en toegenomen kwaliteit) en grotere concurrentie kan hiervoor mede een reden zijn.

\subsubsection{Productgroepen}

$\mathrm{Na}$ de informatie over de bedrijfskolom (figuur 3.2) en de schaalvergroting bij de producenten van glassnijbloemen en -potplanten volgt hieronder in de tabellen 3.31 en 3.32 een overzicht van de ontwikkeling van het areaal snijbloemen en potplanten onder glas vanaf 2000-2009.

In tabel 3.31 is te zien dat het areaal snijbloemen in negen jaar tijd met 1067 ha. is gedaald. Het zijn vooral de productgroepen roos (- 400 ha.) en chrysant (- 281 ha.) die het meest hieraan bijdragen. Deze gewassen ondervinden de meeste concurrentie van producten uit andere landen. De kwaliteit van de importrozen wordt steeds beter. Naast de kleinbloemige roos neemt nu ook de grootbloemige uit Afrika (Kenia en Ethiopië) en Zuid-Amerika (Ecuador en Colombia) een groter deel van de marktposities van Nederland in Europa over (Vakblad voor de Bloemisterij, staalkaart, 22 mei 2009, p. 19). De concurrentie bij de chrysant komt evenals bij de roos deels door directe aanvoer uit Zuid-Amerika, deels door directe aanvoer uit Italië op Europese markten.

Tabel 3.31 Areaal in ha. van snijbloemen onder glas van 2000-2009

\begin{tabular}{|l|r|r|r|r|r|r|}
\hline & 2000 & 2005 & 2006 & 2007 & 2008 & 2009 \\
\hline Roos & 932 & 780 & 754 & 652 & 583 & 532 \\
\hline Chrysant & 774 & 598 & 597 & 566 & 523 & 493 \\
\hline Freesia & 221 & 167 & 152 & 155 & 129 & 116 \\
\hline Gerbera & 253 & 212 & 205 & 206 & 208 & 217 \\
\hline Lelie & 276 & 255 & 232 & 220 & 222 & 221 \\
\hline Alstroemeria & 119 & 83 & 77 & 93 & 79 & 68 \\
\hline Orchidee & 212 & 214 & 210 & 240 & 206 & 209 \\
\hline Anthurium & 90 & 95 & 111 & 120 & 78 & 95 \\
\hline Anjer & 86 & 31 & 32 & 32 & 18 & 21 \\
\hline Gypsophila & 30 & & & & & 678 \\
\hline Overige snijbloemen & 196 & 164 & 154 & 162 & 144 & 166 \\
\hline Opkweekmateriaal snijbloemen & 3923 & 3414 & 3248 & 3165 & 2953 & 2856 \\
\hline Totaal areaal & & & & & & \\
\hline Bron: CBS Landbouwtling & & & & & & \\
\hline
\end{tabular}

Bron: CBS Landbouwtelling 
Tabel 3.32 Areaal in ha. van perk- en potplanten onder glas van 2000-2009

\begin{tabular}{|l|r|r|r|r|r|r|}
\hline & 2000 & 2005 & 2006 & 2007 & 2008 & 2009 \\
\hline Perk- en kuipplanten & 497 & 550 & 489 & 486 & 459 & 475 \\
\hline Potplanten bladplanten & 582 & 589 & 548 & 551 & 489 & 511 \\
\hline waarvan ficus & 89 & 75 & 59 & 59 & 61 & 57 \\
\hline waarvan dracaena & 25 & 30 & 23 & 25 & 33 & 27 \\
\hline Potplanten bloeiend & 679 & 788 & 838 & 846 & 941 & 953 \\
\hline waarvan begonia & 24 & 22 & & & & \\
\hline waarvan kalanchoë & 44 & 58 & 52 & 46 & 54 & 52 \\
\hline waarvan phalaenopsis & & 76 & 99 & 148 & 188 & 215 \\
\hline waarvan anthurium & & 47 & 56 & 58 & 67 & 74 \\
\hline waarvan spathiphylum & & 27 & 33 & 22 & 24 & 22 \\
\hline Overige bloemkwekerij producten & 160 & 168 & 167 & 162 & 143 & 161 \\
\hline Totaal areaal perk- en potplanten & 2004 & 2095 & 2042 & 2045 & 2032 & 2099 \\
\hline
\end{tabular}

Bron: CBS Landbouwtelling

Van de gewassen die volgen op de roos en de chrysant blijven het areaal lelie, gerbera en orchidee redelijk op niveau, freesia verliest ruim 100 ha. van 2000-2009. Anthurium blijft de gehele periode op een niveau van rond de 100 ha.. De productie van de anjer is flink gedaald. Gypsophila wordt sinds begin 2000 alleen nog geïmporteerd. De grote groep overige snijbloemen geeft aan dat het assortiment nog zeer divers is over de gehele periode met een stabiel areaal van ca. 700 ha. De restpost van 150 - 200 ha. betreft de opkweek van uitgangsmateriaal voor snijbloemen.

Het areaal perk- en potplanten onder glas blijft in de periode 2000-2009 stabiel op een niveau van 2000 tot 2100 ha. Ook de aandelen areaal perk- en kuipplanten (25\%) en areaal bladplanten (25-30\%) ontwikkelen zich stabiel. Bloeiende potplanten geven een groei in areaal te zien, vanaf 2000-2009 zo'n 40\%. Bij de bloeiende potplanten valt de opmars van phalaenopsis op, van 76 ha. in 2005 tot 215 ha. in 2009. Anthurium stijgt in deze periode van 50 tot 75 ha. en kalanchoë blijft stabiel rond de 50 ha.

Het lijkt erop dat nadelige gevolgen van de kredietcrisis zoals vermindering van de vraag, vraaguitval of prijsverlagingen, aan de potplantensector, met name de bedrijven met bloeiende potplanten, zonder al teveel schade zijn voorbijgegaan.

\subsubsection{Afzetorganisaties}

Afzetorganisaties in de sierteeltsector zijn tot op heden de coöperatieve bloemenveilingen met meer dan 100 jaar ervaring in het openbaar veilen van verse tuinbouwproducten. In deze sector werd in 1901 de eerste bloemenveiling opgericht in Amsterdam, gevolgd door zeventien bloemenveilingen in Aalsmeer, Rijnsburg, het Westland en andere regio's (zie hoofdstuk 1 en bijlage 2, overzicht verkoopmethoden verse tuinbouwproducten). 
Inmiddels zijn de bloemenveilingen via horizontale fusies teruggebracht tot één zeer grote veilingorganisatie, FloraHolland met de hoofdvestiging te Naaldwijk, en één kleinere veiling, Plantion te Ede. FloraHolland heeft nevenvestigingen in Aalsmeer, Rijnsburg, Bleiswijk, Eelde en Herongen (joint-venture veiling Rhein-Maas). Evenals in de voedingstuinbouw zijn er in de sierteeltsector telersverenigingen opgericht, zowel bij de snijbloemen als bij de potplanten. Dit zijn horizontale samenwerkingsverbanden van individuele telers/leden van de veiling die in bepaalde productgroepen een nauwere samenwerking zoeken bij de inkoop, verkoop of andere activiteiten. De bloemenveiling biedt hiervoor faciliteiten aan en transacties worden gemeld of lopen rechtstreeks via de veiling. Omdat in de sierteeltsector geen zelfstandige, los van de veiling optredende telersverenigingen zijn, worden deze niet afzonderlijk behandeld. Onderstaand volgt een cijfermatig overzicht van het (horizontaal) fusieproces van de bloemenveilingen over de periode 1980-2010.

Tabel 3.33 Omzet VBN-veilingen 1980-2008 + export/importcijfers HBAG (x 1 mln. euro)

\begin{tabular}{|c|c|c|c|c|c|c|c|c|c|}
\hline $\begin{array}{l}\text { Verloop aantal } \\
\text { Bloemenveilingen }\end{array}$ & $\begin{array}{r}1980 \\
(12) \\
\end{array}$ & $\begin{array}{r}1990 \\
(8) \\
\end{array}$ & $\begin{array}{r}2000 \\
(6) \\
\end{array}$ & $\begin{array}{r}2005 \\
(4) \\
\end{array}$ & $\begin{array}{r}2006 \\
(4) \\
\end{array}$ & $\begin{array}{r}2007 \\
(4) \\
\end{array}$ & $\begin{array}{r}2008 \\
(2) \\
\end{array}$ & $\begin{array}{r}2009 \\
(2) \\
\end{array}$ & $\begin{array}{c}2010 \\
(2)\end{array}$ \\
\hline CCWS/BVW/BVH/FH & 310 & 740 & 1.293 & 2.004 & 2.136 & 2.240 & 4.074 & 3.861 & 4.130 \\
\hline VBA & 394 & 922 & 1.471 & 1.690 & 1.755 & 1.823 & & & \\
\hline Flora Rijnsburg & 94 & 213 & 433 & & & & & & \\
\hline $\begin{array}{l}\text { Overige veilingen (vanaf } \\
2009 / 2010 \text { Plantion) }\end{array}$ & 137 & 240 & 156 & 85 & 84 & 92 & 96 & 95 & 105 \\
\hline Totaal veilingomzet & 935 & 2.115 & 3.353 & 3.779 & 3.975 & 4.155 & 4.170 & 3.956 & 4.235 \\
\hline Jaargroei veilingomzet(\%) & 15.2 & 8.6 & 10.1 & 4.3 & 5.2 & 4.5 & 0.3 & -5.1 & 7.0 \\
\hline Import & 53 & 195 & 492 & 569 & 604 & 642 & 667 & 639 & 673 \\
\hline Jaargroei import (\%) & 18.1 & 12.4 & 11.3 & 3.7 & 6.1 & 6.4 & 3.9 & $-4,2$ & 5.3 \\
\hline Aandeel import (\%) & 5.7 & 9.2 & 14.7 & 15.1 & 15.2 & 15.5 & 16.4 & 16.6 & 16.3 \\
\hline Export snijbl_potpl. & 882 & 2.360 & 4.188 & 5.061 & 5.226 & 5.451 & 5.298 & 4.880 & 5.180 \\
\hline Duitsland & 585 & 1.022 & 1.509 & 1.575 & 1.552 & 1.557 & 1.521 & 1529 & 1.599 \\
\hline Frankrijk & 93 & 349 & 579 & 674 & 679 & 706 & 691 & 646 & 671 \\
\hline Engeland & 32 & 244 & 585 & 832 & 871 & 935 & 766 & 656 & 704 \\
\hline Overig & 172 & 745 & 1.515 & 1.980 & 2.124 & 2.253 & 2.320 & 2.050 & 2.019 \\
\hline Aantal exporteurs & & & 1.218 & 1.082 & 1.012 & 930 & 923 & & \\
\hline Bloemist/winkelier & & & 5.784 & 4.797 & 4.846 & 4.836 & 4.843 & & \\
\hline Markt- en straathandel & & & 1.652 & 1.419 & 1.410 & 1.298 & 1.222 & & \\
\hline Tuincentra & & & 1.091 & 947 & 944 & 896 & 895 & & \\
\hline
\end{tabular}

Bron: Gegevens VBN jaarverslagen 1980, 1990, 2000, 2005-2007, idem jaarverslagen FloraHolland en VBA 2003-2008 
Tabel 3.33 laat de (horizontale) concentratieontwikkelingen en het omzetverloop zien bij de afzet van sierteeltproducten, verkocht via de bloemenveilingen in Nederland en aangevoerd door glassierteeltbedrijven in binnen- en buitenland. Hieronder volgt een toelichting op de ontwikkeling van de coöperatieve afzetorganisaties, op de afzetstromen en op het veilproces.

\section{- Veilingcoöperaties}

De vereniging bloemenveilingen in Nederland (VBN) bestaat in 1980 uit twaalf veilingen. Het is een drietal grote exportveilingen in Noord- en Zuid-Holland: VBA Aalsmeer, CCWS uit Honselersdijk en Flora uit Rijnsburg. Daarnaast zijn er negen regionale veilingen, verspreid over diverse regio's in Nederland: Veiling Berkel te Bleiswijk, EEM te Roelofarendsveen, 't Noorden te Eelde, VV'70 te Bemmel, U. en O. te Vleuten, CVV te Grubbenvorst, NCB te Tilburg, BGVB te Beverwijk en CFT te Leeuwarden. In de periode tot 1990 resp. 2000 zoekt meer dan de helft van deze regionale veilingen samenwerking met de grotere exportveilingen. De zuidelijke veilingen in Nederland zoeken aansluiting bij Bloemenveilingen Holland uit Naaldwijk en de noordelijke bij de VBA te Aalsmeer. Veiling Flora aarzelt en lijkt te kiezen voor de VBA. Bloemenveilingen Holland is echter de VBA te snel af en fuseert met Flora Rijnsburg in 2004/2005. De nieuwe naam wordt FloraHolland en daarna vindt in 2007 een nieuwe fusie plaats tussen de twee veilingreuzen FloraHolland te Naaldwijk en de VBA uit Aalsmeer. Er zijn dan nog twee 'kleintjes' over, Veiling Oost Nederland (VON) te Bemmel en Veiling Vleuten. In 2009/2010 gaan deze samen op in de nieuwe regionale veiling Plantion te Ede. FloraHolland heeft een marktaandeel van bijna $98 \%$ in het Nederlandse aanbod en participeert voor een derde in het nieuwe Plantion (ca. 2\%). FloraHolland heeft voorts begin 2010 de importveiling Tele Flower Aalsmeer (TFA) overgenomen en is eind 2011 een joint venture aangegaan met de Duitse afzetcoöperatie Landgard. Samen hebben zij in de EU-regio rondom Venlo een nieuwe (klok)veiling Rhein-Maas in Herongen opgezet vanuit de bestaande veilingen te Venlo, Lüllingen en Herongen.

\section{- Ontwikkeling afzetstromen snijbloemen en potplanten}

In de tabel valt naast de voortdurende daling van het aantal bloemenveilingen de enorme groei in omzet en in aantallen aangevoerde snijbloemen en potplanten op. In de eerste twee perioden van tien jaar (1980-1990 en 1990-2000) vindt een toename in omzet plaats per tien jaar van ruim $€ 1$ mrd. euro (een jaarlijkse omzetgroei van 10\% of meer). Vanaf 2000-2007 tempert deze groei tot een gemiddelde van 5\% per jaar om in 2008 door de gevolgen van de kredietcrisis tot bijna nul terug te vallen. Naast een toename van de vraag in de ons omringende EU-landen en Engeland als spectaculaire groeimarkt, is de grote uitbreiding van het EU-marktgebied een belangrijke reden voor deze groei. Door de val van de muur in Berlijn in 1989/1990, de hereniging van Oost- en West-Duitsland en de toetreding van nieuwe Oost-Europese lidstaten verruimt het EU-marktgebied enorm. Tevens zorgt de verruiming van de buitenlandse aanvoer van vooral snijbloemen op de bloemenveilingen voor het binden van meer jaarrond koopkracht op de veiling. In tabel 3.33 is de groei van het importaandeel van 5.7\% in 1980 naar $16.3 \%$ in 2010 opvallend. Inmiddels behoort een volledig lidmaatschap voor buitenlandse aanvoerders (onder gelijke voorwaarden als geldend voor de Nederlandse aanvoer) bij het gefuseerde FloraHolland tot de mogelijkheden. 


\section{- Klokveilen en beeldveilen}

Bij FloraHolland staat het klokveilen nog steeds centraal bij de prijsvorming van verse snijbloemen en potplanten. In 2010 ligt het aandeel van de kloktransacties rond de $60 \%$ en bemiddeling via FloraHolland Connect op 40\% (kengetallen bij het jaarverslag 2010).

De virtualisering van de afzet zet door, ook via webshops. Kopen op Afstand(KOA) via de virtuele klok groeit snel. Eind 2010 zijn er 2200 KOA-systemen uitgegeven en gaat $40 \%$ van de klokomzet via KOA. Het aantal grote handelsbedrijven dat zijn inkopers in een eigen dealingroom laat inkopen en niet meer op de tribunes, groeit en is eind 2010 ongeveer veertig (FloraHolland, jaarverslag 2010, p. 13). De bezwaren van de groothandel tegen een te snelle invoering van beeldveilen blijven echter bestaan. Hierover is het volgende afgesproken. Een productgroep wordt pas dan gebeeldveild als er bij belanghebbenden draagvlak voor is. De betrouwbaarheidsindex van de productgroep moet hoog genoeg zijn en voldoende telers moeten goed beeldmateriaal met het product meegeven. De uniforme beeldbank die is opgezet en de speciale workshops voor telers die hiertoe worden gehouden, zijn hierbij van belang.

\subsubsection{Concentraties}

De toename van schaalgrootte in bedrijfsomvang van de glassnijbloemen en -potplanten is in het voorgaande duidelijk aangetoond (zie tabellen 3.29 en 3.30), maar blijft gering als je het vergelijkt met die van de afzetorganisatie FloraHolland. De laatste heeft een horizontale concentratie van bijna $100 \%$ als landelijke aanbieder van snijbloemen en potplanten. Wel moet hierbij in ogenschouw worden genomen dat FloraHolland geen eigenaar van het product wordt. Zij organiseert de verkoop en streeft naar de hoogst mogelijke opbrengst voor de producten van de leden/ aanvoerders die bij het klokveilen de beslissing over de prijsvorming en -zetting uitbesteden. Uiteindelijk bepaalt bij elke transactie het geheel van vraag en aanbod de optimale prijs voor het geveilde product. Wel kan de veilingmeester in overleg met de aanvoerder van het product een bodemprijs bepalen waaronder er niet wordt verkocht. Hieronder wordt eerst de ontwikkeling van de concentratie getoond in de rozen- en chrysantenteelt, daarna in de groene en bloeiende potplanten.

Ook in de glassnijbloemen zet de concentratie van bedrijven gestaag door, zij het in een wat lager tempo dan in de glasgroenten. Het gemiddeld areaal stijgt van 2007-2009 van 1.8 ha. naar 2.0 ha. (zie tabel 3.34 en 3.35). De rozentelers hebben het hierbij moeilijker dan de chrysantencollega's door de scherpe en toenemende concurrentie van de import. De arbeidsintensieve kleinbloemige roos wordt in Nederland nauwelijks nog geteeld, maar ook de grootbloemige roos heeft het zwaar. Het aantal ondernemingen neemt, mede door de gevolgen van de kredietcrisis, versneld af en er wordt ook op areaal ingeleverd. De grootste ondernemingen krijgen een steeds groter gewicht in de markt. De concentratie in de glassnijbloemen is nog beperkt met een concentratiegraad van de vier grootste bedrijven (C4) van 5\% tot $10 \%$. Echter, als rekening gehouden wordt met een toenemende differentiatie van het product, alsmede de import uit Afrika en Zuid-Amerika van een aantal ook in Nederland producerende rozenbedrijven is de concentratie waarschijnlijk nog een stuk groter. 
Tabel 3.34 Raming concentratieontwikkeling glasrozen

\begin{tabular}{|l|c|c|c|}
\hline & 2007 & 2008 & 2009 \\
\hline Aantal bedrijven & 356 & 310 & ca. 270 \\
\hline Areaal roos & 652 & 583 & 532 \\
\hline Gemiddeld areaal per bedrijf & 1.8 ha. & 1.9 ha. & 2.0 ha. \\
\hline Marktaandeel op basis areaal (C4) & $6 \%$ & $8 \%$ & $10 \%$ \\
\hline
\end{tabular}

Bron: CBS/PT, bedrijfsonderzoek glassnijbloemen (juli 2008)

Tabel 3.35 Raming concentratieontwikkeling glaschrysanten

\begin{tabular}{|l|c|c|c|}
\hline & 2007 & 2008 & 2009 \\
\hline Aantal bedrijven & 304 & 275 & ca. 250 \\
\hline Areaal chrysant & 566 & 523 & 493 \\
\hline Gemiddeld areaal per bedrijf & 1.9 ha. & 1.9 ha. & 2.0 ha. \\
\hline Marktaandeel op basis areaal (C4) & $5 \%$ & $6 \%$ & $7 \%$ \\
\hline
\end{tabular}

Bron: CBS/PT, bedrijfsonderzoek glassnijbloemen (juli 2008)

Tabel 3.36 Raming concentratieontwikkeling groene potplanten onder glas

\begin{tabular}{|l|c|c|c|}
\hline & 2007 & 2008 & 2009 \\
\hline Aantal bedrijven & 491 & 407 & ca. 350 \\
\hline Areaal groene planten (bladplanten) & 551 & 489 & 511 \\
\hline Gemiddeld areaal per bedrijf & 1.1 ha. & 1.2 ha. & 1.5 ha. \\
\hline Marktaandeel op basis areaal (C4) & $6 \%$ & $6 \%$ & $6 \%$ \\
\hline
\end{tabular}

Bron: CBS/PT, bedrijfsonderzoek glaspotplanten (mei 2009)

Tabel 3.37 Raming concentratieontwikkeling bloeiende potplanten onder glas

\begin{tabular}{|l|c|c|c|}
\hline & 2007 & 2008 & 2009 \\
\hline Aantal bedrijven & 673 & 694 & ca. 700 \\
\hline Areaal bloeiende planten & 846 & 941 & 953 \\
\hline Gemiddeld areaal per bedrijf & 1.3 ha. & 1.4 ha. & 1.4 ha. \\
\hline Marktaandeel op basis areaal (C4) & $7 \%$ & $6.5 \%$ & $6 \%$ \\
\hline
\end{tabular}

Bron: CBS/PT, bedrijfsonderzoek glaspotplanten (mei 2009) 
In de groene en bloeiende glaspotplanten verloopt het concentratieproces over deze periode verschillend. Bij de groene planten daalt het aantal bedrijven flink (van 2007-2009 met 30\%) en neemt het areaal minder af. De gemiddelde bedrijfsomvang komt in 2009 op 1.5 ha., precies het gemiddelde van de gehele glassierteelt. Bij de bloeiende potplanten stijgt het aantal bedrijven en stijgt ook het areaal. De gemiddelde bedrijfsomvang komt hier uit op 1.4 ha. De geschatte concentratiegraad (C4) ligt zowel bij de groene als de bloeiende potplanten tussen de $6 \%$ en de $7 \%$. Ook hier geldt dat door productdifferentiatie de werkelijke concentratiegraad aanmerkelijk hiervan kan afwijken.

\subsubsection{Ontwikkeling vraagzijde markt}

$\mathrm{Na}$ de behandeling van de aanbodzijde volgt nu de vraagzijde van de markt van snijbloemen en potplanten met de sectorale export- en importwaarde 2006-2010 als eerste. Daarna wordt de groot- en detailhandel besproken. De te volgen sectorvariabelen zijn concentratieontwikkeling en gerealiseerde export- en importwaarden met tevens volume- en prijsontwikkeling. Gegevens over het verloop van het saldo handelsbalans en de ruilvoet worden in deze sector niet geregistreerd. Hetzelfde geldt voor de ontwikkeling van de binnenlandse groothandel. De gegevens over de exportontwikkeling zijn verkregen via jaarverslag, jaarberichten en kengetallen van het Hoofdbedrijfschap Agrarische Groothandel (HBAG Bloemen en planten) en studies van de Vereniging van Groothandelaren in Bloemkwekerijproducten (VGB). De gegevens van de binnenlandse marktontwikkeling, met name die van groot- en detailhandel, zijn verkregen via FloraHolland, concernmanagement binnenlandse markt.

\subsubsection{Sectorale export- en importwaarde 2006-2010}

- Exportwaarde snijbloemen en potplanten

In onderstaande tabellen 3.38 en 3.39 wordt een overzicht gegeven van de ontwikkeling van de exportwaarde, het volume en het prijspeil van de export, en de importwaarde van snijbloemen en potplanten over de periode 2006-2009/2010. Daarna volgt op basis van de gegevens van het HBAG Bloemen en planten het soort en aantal bedrijven per groothandelsfunctie, de verdeling in de omzetgroepen en de ontwikkeling van de concentratie van 2006-2010.

Tabel 3.38 Exportwaarde snijbloemen en potplanten uit Nederland 2006-2010 (x 1 mln. euro)

\begin{tabular}{|l|l|l|l|l|l|l|}
\hline Exportwaarde in mln. euro's & 2006 & 2007 & 2008 & $2009 *)$ & 2010 & $* *)$ \\
\hline Snijbloemen & 3.237 & 3.374 & 3.243 & 2.992 & 3.151 & 5 \\
\hline Potplanten & 1.780 & 1.860 & 1.854 & 1.888 & 1.994 & 6 \\
\hline Totaal & 5.017 & 5.234 & 5.097 & 4.880 & 5.145 & 5 \\
\hline
\end{tabular}

Bron: Eurostat/PT, HBAG Bloemen en planten, *) kredietcrisis, **)groei t.o.v. 2009 in \% 
De Nederlandse exportwaarde van snijbloemen en potplanten groeide in de periode 2006-2010 van 5 mrd. naar 5.2 mrd. euro met een duidelijke dip in het jaar 2009 door de gevolgen van de kredietcrisis (tabel 3.38). In 2010 was er sprake van een aanmerkelijk herstel met een groei van $6 \%$ voor de potplanten en $5 \%$ voor de snijbloemen.

De exportwaarde wordt bepaald door aantallen en prijs. Om een beter inzicht te krijgen in de ontwikkeling van de exportwaarde wordt in tabel 3.39 gekeken naar de prijsontwikkeling van de productgroepen. De prijsvorming van bloemen en planten vindt plaats op de veiling, waar vraag en aanbod bij elkaar komen. De periode betreft 2006-2009, omdat de gegevens van 2010 nog niet beschikbaar waren.

Tabel 3.39 Aanvoer (aantal) en gemiddelde prijs bloemkwekerijproducten op veilingen in Nederland 2006-2009

\begin{tabular}{|c|c|c|c|c|c|}
\hline & 2006 & 2007 & 2008 & $2009 *)$ & $* *)$ \\
\hline Aanvoer snijbloemen (x $1 \mathrm{mln}$.) & 11.394 & 11.372 & 11.428 & 11.235 & -2 \\
\hline Gem. prijs snijbloemen (eurocent) & 22 & 23 & 22 & 20 & -9 \\
\hline Aanvoer potplanten (x $1 \mathrm{mln})$ & 1.276 & 1.287 & 1.313 & 1.361 & 4 \\
\hline Gem. potplanten (eurocent) & 117 & 127 & 129 & 129 & 0 \\
\hline
\end{tabular}

Bron: VBN 2009, *) kredietcrisis, **)groei t.o.v. 2008 in \%

De gemiddelde prijs per bloem schommelt in de periode 2006-2009 tussen de 20 en 23 eurocent en laat in 2009, het jaar van de kredietcrisis, een daling zien van 9\%. Het aantal verkochte snijbloemen daalt met 2\%. De omzet is hierdoor fors lager dan in 2008.

Voor potplanten is de prijsvorming in deze periode een stuk gunstiger. Vanaf 2006 vindt een stijging plaats van de gemiddelde prijs per potplant, ook in aantal aangevoerde planten. Door de stijging van prijs en aanvoer is de totale veilingomzet van potplanten de afgelopen jaren flink gestegen. In het crisisjaar 2009 worden zelfs meer potplanten verkocht dan de jaren ervoor. Misschien dat de langere houdbaarheid van de potplant ten opzichte van de snijbloem juist in tijden van crisis hier de reden voor is.

- Importwaarde snijbloemen en potplanten

In paragraaf 3.2 bij tabel 3.5 is besproken dat de import van snijbloemen en potplanten pas vanaf 2000 van grotere betekenis voor de sierteeltsector is geworden dan de jaren daarvoor. De belangrijkste importlanden voor snijbloemen zijn in volgorde van belangrijkheid: Kenia, Israël, Ethiopië en Ecuador (FloraHolland, jaarverslag 2008, kengetallen). De Nederlandse plantenimport komt uit een aantal Europese landen, uit Midden-Amerika, Afrika en het Verre Oosten. De belangrijkste zijn: Duitsland, Denemarken, België, Italië, Spanje, Kenia, China en Costa Rica. Zoals is te zien in onderstaande tabel 3.40, verhoudt het aandeel snijbloemen en planten zich vanaf 2005 ongeveer als $2: 1$. Opvallend is de verdere terugval in 2010 met 5\% voor zowel snijbloemen als planten na het crisisjaar 2009. 
Tabel 3.40 Importwaarde snijbloemen en potplanten (x $1 \mathrm{mln}$. euro)

\begin{tabular}{|l|c|c|c|c|c|c|}
\hline & 2000 & 2005 & 2008 & $2009 *)$ & $2010 * \mathrm{~V}$ & $* *)$ \\
\hline Snijbloemen & 650 & 646 & 827 & 748 & 710 & -5 \\
\hline Potplanten & 186 & 278 & 379 & 358 & 340 & -5 \\
\hline Totaal & 836 & 924 & 1.206 & 1.106 & 1.050 & -5 \\
\hline
\end{tabular}

Bron: Eurostat/PT, V= voorlopige cijfers, *) kredietcrisis, **)groei t.o.v. 2009 in \%

\subsubsection{Groothandelsbedrijven en concentraties}

- De groothandel, plaats en functie in de bedrijfskolom

Binnen de sierteeltsector is een grote verscheidenheid in typen groothandelaren. De bedrijven bestaan uit verzendexporteurs, lijnrijders, importeurs, handelskwekers, commissionairs en Cash \& Carry's. De verzendexporteur verstuurt bestelde producten naar de afnemer in binnen- en buitenland en is verantwoordelijk voor ongeveer $85 \%$ van de exportwaarde. De lijnrijder biedt niet verkochte producten letterlijk 'op de stoep' van zijn klanten aan. De importeur haalt zijn handel uit het buitenland en verhandelt deze voornamelijk weer via de veilingen of groothandelaren. De exportwaarde die de importeur zelf genereert, is klein. In verschillende studies krijgt de ontwikkeling van het ongespecialiseerde kanall $^{2}$ als afzetpunt voor bloemkwekerijproducten veel aandacht. Verondersteld wordt dat dit kanaal de laatste jaren een fors aandeel heeft verworven. De sterke focus rond dit afzetkanaal en de veronderstelde hoge groeicijfers blijken niet terecht (Typisch Groothandel, Van Willegen e.a., 2010).

\section{- Concentraties}

In 2005 staan 1014 exporterende groothandelaren geregistreerd bij het HBAG. Dit aantal neemt met $20 \%$ af tot 808 bedrijven in 2009. Van deze 808 bedrijven leveren 501 exporteurs aan Duitsland, 248 aan Frankrijk en 226 aan het Verenigd Koninkrijk. Wanneer het aantal exporteurs wordt gesplitst per productgroep (zie tabel 3.41), is te zien dat de daling vooral plaatsvindt bij de snijbloemenhandelaren en de groep 'mix'.

In de gehele handel is sprake van schaalvergroting. Bij snijbloemen is de daling van het aantal handelaren procentueel groter dan de daling van de exportwaarde. De gemiddelde exportwaarde per snijbloemenhandelaar is in de periode 2002-2009 gegroeid van $3.4 \mathrm{mln}$. euro naar $4.6 \mathrm{mln}$. euro. Ook bij de potplanten is het aantal handelaren verminderd en de exportwaarde in dezelfde periode toegenomen. Hier is de gemiddelde exportwaarde per bedrijf gegroeid van $1.7 \mathrm{mln}$. euro naar $3 \mathrm{mln}$. euro. De jaarlijkse omzetgroei per bedrijf bedraagt in deze periode bijna $8 \%$.

2 Ongespecialiseerd kanaal, ook aangeduid als retailkanaal of grootwinkelbedrijf. Bron: Dynamiek in perspectief (De visie op de sierteeltgroothandel 2010-2020) 
Tabel 3.41 Ontwikkeling aantal exporteurs, ingedeeld naar productgroep, 2005-2009

\begin{tabular}{|l|r|r|c|}
\hline & 2005 & 2009 & Verandering in \% \\
\hline Snijbloemen & 714 & 547 & -23 \\
\hline Potplanten & 249 & 219 & -12 \\
\hline Mix & 51 & 42 & -18 \\
\hline Totaal & 1014 & 808 & -20 \\
\hline
\end{tabular}

Voor zowel het snijbloemen- als het potplantensegment geldt dat een relatief klein aantal groothandelsbedrijven een groot deel van de totale exportwaarde vertegenwoordigt.

35 snijbloemenbedrijven (4.4\% van het totaal) en 18 potplantenbedrijven ( $2.2 \%$ van het totaal) vertegenwoordigen $50 \%$ van de exportwaarde van het betreffende segment.

Onderstaand overzicht geeft de ontwikkeling van de concentratie bij de exporteurs in de sierteeltsector over de periode 2008-2011.

In tabel 3.42 zijn de volgende ontwikkelingen van belang:

- In de periode 2008-2011 daalt het aantal exporteurs van 857 naar 724 (bijna 16\%) en stijgt de totale exportomzet met bijna $3 \%$.

- De gemiddelde exportomzet stijgt van bijna $6 \mathrm{mln}$. euro in 2008 naar $7.2 \mathrm{mln}$. euro $(+20 \%)$ in 2011.

- De concentratiegraad stijgt met 5 procentpunten over 4 jaar bij een stijging van 2 procentpunten van het aantal bedrijven: 7\% van de bedrijven realiseert in $200859 \%$ van de exportomzet ten opzichte van 9\% van de bedrijven die 64\% realiseert in 2011.

- Het aantal kleinste exporteurs ( 0 - 2mln. euro omzet) daalt met bijna 100 van 520 in 2008 naar 421 in 2011.

Tabel 3.42 Aantal exporteurs ingedeeld naar omzetcategorie 2008-2011

\begin{tabular}{|c|c|c|c|c|c|c|c|c|}
\hline & \multicolumn{2}{|c|}{2008} & \multicolumn{2}{|c|}{2009} & \multicolumn{2}{|c|}{2010} & \multicolumn{2}{|c|}{2011} \\
\hline $\begin{array}{l}\text { Omzetcategorie } \\
\text { (x } 1 \mathrm{mln} \text {. euro) }\end{array}$ & $\begin{array}{l}\text { aantal } \\
\text { cumm. } \\
\text { in } \%\end{array}$ & $\begin{array}{l}\text { omzetaan- } \\
\text { deel cumm. } \\
\text { in } \%\end{array}$ & $\begin{array}{l}\text { aantal } \\
\text { cumm. } \\
\text { in } \%\end{array}$ & $\begin{array}{l}\text { omzetaan- } \\
\text { deel cumm. } \\
\text { in } \%\end{array}$ & $\begin{array}{l}\text { aantal } \\
\text { cumm. } \\
\text { in } \%\end{array}$ & $\begin{array}{l}\text { omzetaan- } \\
\text { deel cumm. } \\
\text { in } \%\end{array}$ & $\begin{array}{l}\text { aantal } \\
\text { cumm. } \\
\text { In } \%\end{array}$ & $\begin{array}{l}\text { omzetaan- } \\
\text { deel cumm. } \\
\text { in } \%\end{array}$ \\
\hline$>40 \mathrm{mln}$. & 3 & 37 & 3 & 35 & 3 & 40 & 4 & 42 \\
\hline $20-40 \mathrm{mln}$. & 7 & 59 & 8 & 60 & 8 & 61 & 9 & 64 \\
\hline $10-20 \mathrm{mln}$. & 14 & 74 & 15 & 75 & 16 & 77 & 16 & 79 \\
\hline $5-10 \mathrm{mln}$. & 23 & 85 & 23 & 84 & 25 & 86 & 25 & 87 \\
\hline $2-5 \mathrm{mln}$ & 39 & 93 & 40 & 94 & 42 & 94 & 42 & 95 \\
\hline $0-2 \mathrm{mln}$. & 100 & 100 & 100 & 100 & 100 & 100 & 100 & 100 \\
\hline Aantal totaal & 857 & & 801 & & 765 & & 724 & \\
\hline Omzet totaal & & $\begin{array}{l}5.096 \\
(x 1 m \ln .)\end{array}$ & & $\begin{array}{l}4.880 \\
(x 1 \mathrm{mln} .)\end{array}$ & & $\begin{array}{l}5.144 \\
(x 1 \mathrm{mln} .)\end{array}$ & & $\begin{array}{l}5.243 \\
(x 1 \mathrm{mln} .)\end{array}$ \\
\hline
\end{tabular}

Bron: HBAG, kengetallen 2011 


\subsubsection{Positie van Nederland op de Europese markt}

In 2009 heeft Nederland nog altijd een leidende positie als het gaat om de exporthandel in sierteeltproducten. Hierbij gaat het alleen om de exportstromen van sierteeltproducten tussen Europese landen. Wanneer de lokale binnenlandse handel wordt meegenomen in de cijfers is het Nederlandse marktaandeel vele malen kleiner. Dit komt omdat een groot aantal Europese landen zelfvoorzienend zijn. De rol van de Nederlandse handel in sierteeltproducten binnen de totale Europese Unie is groot. In 2008 vindt 77\% van alle EU exporthandel plaats via Nederland (tabel 3.43). Opvallend is dat het aandeel potplanten in 2008 met $4 \%$ is toegenomen ten opzichte van 2007, terwijl de exportwaarde gelijk is gebleven. Hieruit kan worden geconcludeerd dat de overige EU-landen minder hebben geëxporteerd dan het jaar ervoor. Het betreft hier niet de totale handel in bloemen en planten, maar enkel de exporthandel.

Tabel 3.43 Het aandeel van de Nederlandse export van de uitvoer binnen de Europese Unie ${ }^{3}$ in de periode $2002-2008$

\begin{tabular}{|l|l|l|l|l|l|l|l|}
\hline & 2002 & 2003 & 2004 & 2005 & 2006 & 2007 & 2008 \\
\hline Bloemkwekerijproducten & 74 & 74 & 75 & 75 & 75 & 75 & 77 \\
\hline Snijbloemen & 82 & 82 & 85 & 85 & 85 & 86 & 86 \\
\hline Potplanten & 53 & 51 & 58 & 58 & 58 & 58 & 62 \\
\hline
\end{tabular}

Bron: Productschap Tuinbouw 2009

De binnenlandse handel en verkoop zijn niet meegenomen in deze cijfers. Belangrijk is daarom in acht te nemen dat sommige Europese landen door eigen productie behoorlijk zelfvoorzienend zijn en daardoor minder afhankelijk van het Nederlandse exportproduct. Ook is de noodzaak tot export voor die landen minder aanwezig vanwege een grote thuismarkt (Duitsland, Spanje, Italië). De conclusies uit eerdere onderzoeken bevestigen dit. Hieruit blijkt dat de positie van Nederland in de totale potplantenhandel (export en lokale afzet) slechts $27 \%$ is (Florilogregie, 2006).

\subsubsection{Afzetkanalen drie grootste exportlanden}

Door de buitenlandse afnemers in te delen naar de belangrijkste distributiekanalen kan de afzet per klantsegment en de verschuiving hierin worden gevolgd. De afnemersstatistiek is een 'business to business'-statistiek (Kengetallen 2011, HBAG Bloemen en planten) en geeft een beeld van het eerst ontvangende afnemerstype. Het uiteindelijk verkooppunt kan verder in de keten liggen. Een importerende groothandel die op zijn beurt de detailhandel of het grootwinkelbedrijf levert, is daarvan een voorbeeld. Hieronder wordt de afzet via de diverse distributiekanalen van de drie belangrijkste exportmarkten weergegeven: Duitsland, Frankrijk en het Verenigd Koninkrijk.

3 Het aantal landen dat lid was van de EU verschilt: 2002, 2003 EU 15 landen; 2004, 2005, 2006 EU 25 landen; 2007, 2008 EU 27 landen; het betreft hier alleen de uitvoerhandel van alle EU-landen. 
Tabel 3.44 Aandeel afzetkanalen (\%) Duitsland

\begin{tabular}{|c|c|c|c|c|c|c|c|c|}
\hline Duitsland & & \multicolumn{3}{|c|}{ Snijbloemen } & \multicolumn{4}{|c|}{ Potplanten } \\
\hline & 2008 & 2009 & 2010 & 2011 & 2008 & 2009 & 2010 & 2011 \\
\hline Importerend groothandel & 25 & 24 & 23 & 22 & 17 & 18 & 19 & 18 \\
\hline Supermarkt/warenhuis & 24 & 28 & 29 & 27 & 29 & 24 & 20 & 21 \\
\hline Cash \& Carry & 18 & 18 & 18 & 21 & 4 & 4 & 5 & 7 \\
\hline Bloemenwinkel & 22 & 20 & 19 & 20 & 10 & 10 & 9 & 10 \\
\hline Tuincentrum/bouwmarkt & 2 & 2 & 2 & 1 & 20 & 21 & 24 & 24 \\
\hline Veiling Inkoop & 7 & 7 & 7 & 7 & 16 & 20 & 19 & 15 \\
\hline Overige & 2 & 1 & 2 & 2 & 4 & 3 & 4 & 5 \\
\hline & 100 & 100 & 100 & 100 & 100 & 100 & 100 & 100 \\
\hline \multicolumn{5}{|c|}{$\begin{array}{l}\text { Rangorde afzetkanalen snijbloemen 2011: } \\
\text { 1.Supermarkt/warenhuis } \\
\text { 2.Importerende groothandel } \\
\text { 3.Cash \& Carry } \\
\text { 4.Bloemenwinkel }\end{array}$} & \multicolumn{4}{|c|}{$\begin{array}{l}\text { Rangorde afzetkanalen potplanten } 2011 \\
\text { 1.Tuincentrum/bouwmarkt } \\
\text { 2.Supermarkt/warenhuis } \\
\text { 3.Importerende groothandel } \\
\text { 4.Veiling inkoop } \\
\text { 5.Bloemenwinkel }\end{array}$} \\
\hline
\end{tabular}

Opmerkelijk bij de snijbloemen in Duitsland in 2011 is de daling van het supermarktkanaal van $29 \%$ naar $27 \%$ terwijl dit percentage juist stijgende was vanaf 2008. In 2009 overtrof de supermarkt de importerende groothandel voor het eerst. De groothandel moest in 2011 ook een procentpunt prijsgeven tot $22 \%$, terwijl de Cash \& Carry met drie procentpunt klom tot $21 \%$. Bij de potplanten is het aandeel van de supermarkten flink gedaald van $29 \%$ in 2008 naar $21 \%$ in 2011 , terwijl het aandeel van het tuincentrum in deze periode is gestegen van $20 \%$ tot $24 \%$. Opvallend bij de potplanten is ook het hogere aandeel van de directe veilinginkoop in 2009 en 2010 ten opzichte van 2008 en 2011.

Ook in Frankrijk is bij de snijbloemen in 2010 en 2011 een daling van het supermarktkanaal te constateren van $22 \%$ naar $20 \%$. De importerende groothandel gaat hier aan kop met een hoog en stabiel aandeel van $36 \%$, met op de tweede plaats de bloemenwinkel met eveneens een stabiel aandeel van 29\%. Bij de potplanten staat, evenals in Duitsland, het tuincentrum op kop met een aandeel van $26 \%$. De tweede plaats is voor de importerende groothandel met $24 \%$ en de derde is de supermarkt met $22 \%$. 
Tabel 3.45 Aandeel afzetkanalen (\%) Frankrijk

\begin{tabular}{|c|c|c|c|c|c|c|c|c|}
\hline Frankrijk & \multicolumn{4}{|c|}{ Snijbloemen } & \multicolumn{4}{|c|}{ Potplanten } \\
\hline & 2008 & 2009 & 2010 & 2011 & 2008 & 2009 & 2010 & 2011 \\
\hline Importerend groothandel & 36 & 34 & 35 & 36 & 27 & 25 & 25 & 24 \\
\hline Supermarkt/warenhuis & 22 & 22 & 21 & 20 & 19 & 21 & 21 & 22 \\
\hline Cash \& Carry & 7 & 8 & 8 & 8 & 4 & 3 & 4 & 5 \\
\hline Bloemenwinkel & 28 & 29 & 30 & 29 & 14 & 14 & 15 & 16 \\
\hline Tuincentrum/bouwmarkt & 3 & 3 & 3 & 3 & 26 & 26 & 26 & 26 \\
\hline Veiling Inkoop & 1 & 1 & 1 & 1 & 2 & 2 & 2 & 2 \\
\hline \multirow[t]{2}{*}{ Overige } & 3 & 3 & 2 & 3 & 7 & 7 & 7 & 6 \\
\hline & 100 & 100 & 100 & 100 & 100 & 100 & 100 & 100 \\
\hline \multicolumn{5}{|c|}{$\begin{array}{l}\text { Rangorde afzetkanalen snijbloemen } 2011 \text { : } \\
\text { 1.Importerende groothandel } \\
\text { 2.Bloemenwinkel } \\
\text { 3.Supermarkt/warenhuis }\end{array}$} & \multicolumn{4}{|c|}{$\begin{array}{l}\text { Rangorde afzetkanalen potplanten } 2011 \\
\text { 1.Tuincentrum/bouwmarkt } \\
\text { 2.Importerende groothandel } \\
\text { 3.Supermarkt/warenhuis } \\
\text { 4.Bloemenwinkel }\end{array}$} \\
\hline
\end{tabular}

Tabel 3.46 Aandeel distributiekanalen (\%) Verenigd Koninkrijk

\begin{tabular}{|c|c|c|c|c|c|c|c|c|}
\hline Verenigd Koninkrijk & & \multicolumn{3}{|c|}{ Snijbloemen } & \multicolumn{4}{|c|}{ Potplanten } \\
\hline & 2008 & 2009 & 2010 & 2011 & 2008 & 2009 & 2010 & 2011 \\
\hline Importerend groothandel & 31 & 33 & 34 & 30 & 27 & 28 & 26 & 25 \\
\hline Supermarkt/warenhuis & 38 & 39 & 40 & 45 & 21 & 20 & 31 & 32 \\
\hline Cash \& Carry & 13 & 12 & 12 & 12 & 7 & 7 & 6 & 7 \\
\hline Bloemenwinkel & 15 & 12 & 11 & 10 & 5 & 5 & 5 & 5 \\
\hline Tuincentrum/bouwmarkt & 2 & 2 & 1 & 1 & 27 & 28 & 23 & 20 \\
\hline Veiling Inkoop & & & & & 4 & 3 & 2 & 2 \\
\hline \multirow[t]{2}{*}{ Overige } & 2 & 2 & 2 & 2 & 9 & 9 & 7 & 9 \\
\hline & 100 & 100 & 100 & 100 & 100 & 100 & 100 & 100 \\
\hline \multicolumn{5}{|c|}{$\begin{array}{l}\text { Rangorde afzetkanalen snijbloemen 2011: } \\
\text { 1.Supermarkt/warenhuis } \\
\text { 2.Importerende groothandel } \\
\text { 3. Cash \& Carry } \\
\text { 4. Bloemenwinkel }\end{array}$} & \multicolumn{4}{|c|}{$\begin{array}{l}\text { Rangorde afzetkanalen potplanten } 2011 \\
\text { 1.Supermarkt/warenhuis } \\
\text { 2.Importerende groothandel } \\
\text { 3.Tuincentrum/bouwmarkt } \\
\text { 4.Cash \& Carry }\end{array}$} \\
\hline
\end{tabular}

In het Verenigd Koninkrijk krijgt de supermarkt een steeds groter aandeel in de distributie van snijbloemen en potplanten. In de periode 2008-2011 neemt dit aandeel bij snijbloemen toe van $38 \%$ naar $45 \%$, bij potplanten van $21 \%$ naar $32 \%$. Op de tweede plaats staat zowel bij snijbloemen als potplanten de importerende groothandel. Op de derde plaats staat bij snijbloemen de Cash \& Carry en bij potplanten het tuincentrum. Het aandeel van de laatste is aanmerkelijk gedaald van $27 \%$ aandeel in 2008 naar $20 \%$ in 2011. 


\subsubsection{Binnenlandse groothandel, detailhandel en concentraties}

Binnenlandse groothandel bloemen en planten

Betrouwbare cijfers over de omvang van de sierteeltmarkt in Nederland en de positie en ontwikkeling van de binnenlandse groothandel in bloemen en planten zijn bij het Productschap Tuinbouw, het HBAG Bloemen en planten en de koepelorganisatie VGB niet beschikbaar. Deze binnenlandse groothandel wordt niet (meer) geregistreerd. In 2010 is door een projectgroep van FloraHolland, onder leiding van het concernmanagement binnenlandse markt, een onderzoek gedaan naar de belevering van de Nederlandse markt, gericht op het vergroten van de opbrengst en marge voor de leden van FloraHolland (Visie op belevering van de Nederlandse markt, FloraHolland, november 2011). Uit dit onderzoek blijkt in 2010 een veilingomzet aan binnenlandse afnemers van ca. $730 \mathrm{mln}$. euro met een geschat aandeel van $70 \%$. De binnenlandse marktomvang is als volgt opgebouwd:

-Inkoopaandeel Nederlandse groothandel

-Inkoopaandeel Nederlandse detailhandel

-Totale veilingomzet FH binnenlandse markt

-Totale omzet binnenlandse markt
$450 \mathrm{mln}$. euro

$280 \mathrm{mln}$. euro

$730 \mathrm{mln}$. euro $(=70 \%)$

$1.042 \mathrm{mln}$. euro $(=100 \%)$

De omvang van de binnenlandse markt bedraagt volgens bovenstaande berekening ruim $1 \mathrm{mrd}$. euro. Dit is ongeveer 25\% van de productiewaarde in Nederland (2010: $4.1 \mathrm{mrd}$. euro).

Nederland telde in 1990/1991 ongeveer 220 binnenlandse groothandelaren en ruim 1900 exporteurs (Afzet van Nederlandse Tuinbouwproducten, Agrarische Hogeschool Delft, november 1992). Twintig jaar later zijn deze aantallen meer dan gehalveerd. In 2010/2011 zijn er ongeveer 130 groothandelaren actief op de binnenlandse markt (FloraHolland, afdeling binnenlandse markt) en 724 exporteurs in het buitenland (Kengetallen 2011, HBAG Bloemen en planten).

De binnenlandse groothandel bestaat uit de volgende bedrijfstypen:

- 50 binnenlandse groothandelaren/verzendbedrijven

- 20 binnenlandse lijnrijders

- 60 groothandelaren, gevestigd op een 'Cash \& Carry' lokatie

De jaaromzet van de binnenlandse groothandel in 2010 wordt als volgt berekend:

- Totale veilingomzet FH binnenlandse groothandel

$450 \mathrm{mln}$. euro $(=70 \%)$

- Totale inkoopwaarde binnenlandse groothandel

$643 \mathrm{mln}$. euro $(=100 \%)$

- Totale omzet binnenlandse groothandel (aankoop x 1.25)

804 mln. euro

4 Deze 'Cash \& Carries' bevinden zich op 20 huidige en voormalige bloemenveilinglokaties, verspreid over de meeste provincies van Nederland. Zie ook paragraaf 3.4.1.3 veilingcoöperaties. 
Uit bovenstaande gegevens volgt een gemiddelde handelsomzet van $6.2 \mathrm{mln}$. euro in 2010 . Ter vergelijking: in 1990 lag deze op basis van gelijke veronderstellingen omtrent veilingaandeel en verkoopmarge op $3.8 \mathrm{mln}$. euro. In 20 jaar tijd is de gemiddelde handelsomzet voor de binnenlandse groothandel met ruim $60 \%$ gestegen. Er zijn geen exacte gegevens bekend over het verloop van de concentratie. Verondersteld mag worden dat deze, evenals bij de exporteurs, tamelijk hoog is en dat er een grote spreiding in de groothandelsomzet is met veel kleine en een klein aantal grote bedrijven. In de berekening hierboven is voor het inschatten van de waarden van de binnenlandse marktomvang een groothandelsmarge gehanteerd van $25 \%$ op de inkoopwaarde. Deze gehanteerde marge verschilt niet veel van de marge verkregen uit het onderzoek Nederlandse marktomvang van FloraHolland op consumenten- en producentenniveau (ca. 22\%). De marktomvang op eindafnemersniveau (tabel 3.47) wordt geschat op $2.2 \mathrm{mrd}$. euro. Een bekende vuistregel is dat de producentenwaarde op consumentenniveau ongeveer verdubbelt, hetgeen ook in deze berekening redelijk klopt (Visie FloraHolland, november 2011).

Tabel 3.47 Marktomvang binnenlandse markt siertuinbouw 2009 (x 1 mln. euro)

\begin{tabular}{|l|c|c|c|}
\hline & Consumentenwaarde & Bedrijvenmarkt & Marktomvang \\
\hline Snijbloemen & $€ 800$ & $€ 200$ & $€ 1.000$ \\
\hline Kamerplanten & $€ 290$ & $€ 270$ & $€ 560$ \\
\hline Tuinplanten & $€ 450$ & $€ 200$ & $€ 650$ \\
\hline & & & \\
\hline Totaal & $€ 1.540$ & $€ 670$ & $€ 2.210$ \\
\hline
\end{tabular}

Bron: Visie FloraHolland, PT Hoveniersonderzoek, Groen Kennisnet, VHG

Bij bovenstaande tabel zijn de volgende opmerkingen te maken:

- De Nederlandse markt kent een vrij stabiele marktomvang. De verwachte Nederlandse groei van de sierteeltconsumptie ligt iets lager dan de Europese groei (2\% per jaar).

- Tot en met 2020 zal de marktomvang maar zeer gering groeien. Verwachte groei snijbloemen $1 \%$, pot- en tuinplanten $2 \%$ per jaar.

Detailhandel bloemen en planten

Onderstaande tabellen 3.48, 3.49 en 3.50 tonen de ontwikkeling aan de verkoop- en inkoopzijde van de detailhandel in bloemen en planten.

Tabel 3.48 toont de ontwikkeling in 2009/2010 van de belangrijkste afzetkanalen voor snijbloemen en potplanten in Nederland, bezien vanuit de bestedingen van de consument.

Het belangrijkste kanaal bij snijbloemen is de bloemist en bij kamerplanten het tuincentrum. Bij snijbloemen is het laatste jaar de supermarkt ten koste van de markt- en straathandel een paar procent gegroeid. De consument in Nederland heeft de meeste voorkeur voor de bloemist als verkoopkanaal, ondanks de opkomst van supermarkten. 
Tabel 3.48 Aandeel verkoopkanalen snijbloemen en kamerplanten in percentage consumentenbestedingen 2009/2010

\begin{tabular}{|l|r|r|r|r|}
\hline \multirow{2}{*}{ Verkoopkanalen } & \multicolumn{2}{|c|}{$\begin{array}{l}\text { Snijbloemen } \\
\text { (aandeel in \%) }\end{array}$} & \multicolumn{2}{c|}{$\begin{array}{l}\text { Potplanten } \\
\text { (aandeel in \%) }\end{array}$} \\
\hline & 2009 & 2010 & 2009 & 2010 \\
\hline Bloemist & 57 & 57 & 25 & 23 \\
\hline Tuincentrum & 4 & 4 & 50 & 51 \\
\hline Supermarkt & 15 & 17 & 11 & 12 \\
\hline Markt + straat & 13 & 11 & 3 & 2 \\
\hline Bouwmarkt & 4 & 4 & 5 & 5 \\
\hline Benzinestation & 6 & 6 & & 4 \\
\hline Kiosk & & & & \\
\hline Kwekerij & 1 & 1 & 2 & 100 \\
\hline Internet & 100 & 100 & 100 & \\
\hline Overig & & & & \\
\hline & & & & \\
\hline
\end{tabular}

Bron: PT, consumentenpanel

Tabel 3.49 laat van 2005-2007 een jaarlijkse daling zien van het aantal bloemenwinkels in Nederland met gemiddeld $3 \%$ tot $4 \%$. In de kleinste en de grootste gemeenten ligt dit percentage aanmerkelijk hoger.

Tabel 3.49 Aantal en spreiding bloemisten in Nederland 2005/2007

\begin{tabular}{|r|r|r|r|}
\hline Omvang woonplaats & $\begin{array}{c}\text { Aantal } \\
\text { winkels } \\
2005\end{array}$ & $\begin{array}{r}\text { Aantal } \\
\text { winkels } \\
2007\end{array}$ & $\begin{array}{r}\text { Mutatie in } \\
\%\end{array}$ \\
\hline tot 2000 inwoners & 163 & 144 & -12 \\
\hline $2.000-5.000$ & 430 & 416 & -3 \\
\hline $5.000-10.000$ & 525 & 497 & -5 \\
\hline $10.000-50.000$ & 1.340 & 1.281 & -4 \\
\hline $50.000-100.000$ & 527 & 471 & -11 \\
\hline $100.000-175.000$ & 407 & 347 & -15 \\
\hline 175.000 of meer & 636 & 568 & -11 \\
\hline Totaal & 4.028 & 3.727 & -7 \\
\hline
\end{tabular}

Bron: CBS/PT

Tabel 3.50 Inkoopkanalen van de bloemist

\begin{tabular}{|l|c|}
\hline & $\begin{array}{l}\text { Aandeel (in \%) } \\
\text { inkoopkanalen } \\
\text { bloemist } \\
\text { (VBW 2010) }\end{array}$ \\
\hline & 2010 \\
\hline Veiling/Klok & 31 \\
\hline Cash \& Carry/zelfbedienend & 16 \\
\hline Groothandel/bezorgend & 32 \\
\hline Lijnrijder & 12 \\
\hline Commissionair & 9 \\
\hline Kwekerij & \\
\hline Overig & 100 \\
\hline
\end{tabular}

Bron: VWB Bloemistendata 2010 
Tabel 3.50 geeft de aandelen in 2010 van de belangrijkste inkoopkanalen van de bloemist. Hierbij zijn de volgende opmerkingen te maken (Visie FloraHolland, november 2011):

- De bloemist maakt gebruik van meerdere kanalen. Er zijn ook veel kanalen, zelf inkopen is populair.

- Er is een lage organisatiegraad onder de bloemisten. Samenwerking neemt wel toe, inkoop bij de veiling (o.a. klok) is de afgelopen jaren toegenomen.

- Bij de leverancierskeuze spelen de volgende argumenten een belangrijke rol: persoonlijk contact/klantgevoel, wijze van klachtafhandeling, leverfrequentie, aanbod van nieuwe producten.

\subsection{Sectorvariabelen en mogelijke verbanden}

Paragraaf 3.5.1 toont de ontwikkeling van de structuur- en resultaatsvariabelen 2006-2010, in 3.5.2 wordt tevens de ontwikkeling 2011-2016 besproken met de mogelijke verbanden.

\subsubsection{Ontwikkeling sectorvariabelen 2006-2010}

In 3.5.1.1 t/m 3.5.1.3 zijn de sectorvariabelen binnenlands aandeel, import- en exportaandeel van de glasgroenten (tabel 3.51), de glassnijbloemen (tabel 3.52) en de glaspotplanten (tabel 3.53) met de gerealiseerde resultaten geanalyseerd.

In 3.5.2.1 en 3.5.2.2 is gekeken naar de ontwikkeling van de horizontale concentratie bij producenten, afzetorganisaties en groothandel/exportbedrijven in de glasgroenten en -sierteelt (C4 of $\mathrm{Cx}$ ) en de gerealiseerde resultaten (tabel 3.54 en 3.55).

Van de hierna vermelde sectorvariabelen betreffen de eerste vijf de sectorstructuur en de drie laatste het sectorresultaat:

1. Binnenlands aandeel

2. Importaandeel

3. Exportaandeel

4. Horizontale concentratie

5. Productdifferentiatie

6. Productiewaarde

7. Exportwaarde

8. Gemiddelde uitbetaalprijzen

3.5.1.1 Sectorvariabelen verse groenten van 2006-2010

In tabel 3.51 zijn de sectorvariabelen berekend van de posities van de Nederlandse groentesector en de buitenlandse invoer. 
Tabel 3.51 Sectorvariabelen verse groenten van 2006-2010

\begin{tabular}{|l|r|r|r|r|r|}
\hline & 2006 & 2007 & 2008 & $2009 * *)$ & 2010 \\
\hline Binnenlands aandeel verse groenten (\%) & $\left.82^{*}\right)$ & 82 & 89 & 89 & 94 \\
\hline Importaandeel verse groenten (\%) & $\left.18^{*}\right)$ & 18 & 11 & 11 & 6 \\
\hline Totaal binnenlandse aanbod (\%) & 100 & 100 & 100 & 100 & 100 \\
\hline & & & & & 72.2 \\
\hline Exportaandeel verse groenten (\%) & $\left.68^{*}\right)$ & 68.3 & 69.6 & 71.1 & 3.900 \\
\hline $\begin{array}{l}\text { Exportwaarde (glas)groenten } \\
\text { (x 1 mln. euro) }\end{array}$ & 3.420 & 3.620 & 3.718 & 3.511 & 1.040 \\
\hline $\begin{array}{l}\text { Importwaarde (glas)groenten } \\
\text { (x 1 mln. euro) }\end{array}$ & n.b. & n.b. & 985 & 975 & \\
\hline & 1.350 & 1.340 & 1.270 & 1.080 & 1.455 \\
\hline $\begin{array}{l}\text { Productiewaarde glasgroenten } \\
\text { (x 1 mln. euro) }\end{array}$ & 430 & 400 & 400 & 330 & 380 \\
\hline $\begin{array}{l}\text { Idem vollegrondsgroenten } \\
\text { (x 1 mln. euro) }\end{array}$ & 0.97 & 1.03 & 1.01 & 0.91 & 1.05 \\
\hline Gem. gewogen prijzen verse groenten p.kg & & & & \\
\hline
\end{tabular}

Bron : PT, HBAG, Marktmonitor Groenten en Fruit Nederland deel II 2007-2010, aandelen op basis volume in $\mathrm{kg}$ verse groenten $*$ ) raming op basis van extrapolatie 2010-2007, **) jaar van de kredietcrisis

Als we de ontwikkeling van bovenstaand berekende sectorvariabelen nader beschouwen, kunnen we het volgende vaststellen:

1. Er is een toename van meer dan tien procentpunten van het binnenlandse aandeel en een even grote daling van het importaandeel over de periode 2006-2010. Dit veronderstelt een verbetering van de positie van het Nederlands product op de binnenlandse markt en een verslechtering van het importproduct. Het snelle herstel in 2010 na de kredietcrisis wijst op een mogelijk positief verband tussen het hogere binnenlands aandeel en de gestegen productiewaarde, exportwaarde en prijzen in dit jaar.

2. Er is een toename van meer dan vier procentpunten van het exportaandeel van verse (vrucht) groenten over de periode 2006-2010. Dit veronderstelt een verbetering van de positie van het Nederlands product op de buitenlandse markt. Evenals bij punt 1 wijst dit op een mogelijk positief verband tussen de groei van het exportaandeel en de behaalde resultaten in 2010 .

3. De exportwaarde (glas)groenten groeit in 2007 en 2008 met 6 en 3\% ten opzichte van het voorafgaande jaar. In 2009 daalt de export met 6\% (kredietcrisis) om in 2010 weer te stijgen tot bijna 4 mrd. euro (+ 11\% ten opzichte van 2009$)$.

4. De productiewaarde glasgroenten blijft in de periode 2006-2008 op een stabiel niveau. In 2009 valt deze met $15 \%$ terug door de gevolgen van de kredietcrisis om in 2010 op een recordhoogte van bijna $1.5 \mathrm{mrd}$. euro uit te komen ( $+15 \%$ ten opzichte van 2008$)$.

5. De productiewaarde vollegrondsgroenten daalt in de periode 2006-2008 met 7\%. In 2009 valt deze met een daling van $18 \%$ nog lager uit tot $330 \mathrm{mln}$. euro (kredietcrisis) om in 2010 op 380 mln. euro te komen ( $-5 \%$ ten opzichte van 2008$)$.

6. De ontwikkeling van het gemiddelde prijsniveau schommelt in de periode 2006-2008 rond één euro. In 2009 daalt dit met 10\% (kredietcrisis) om in 2010 uit te komen op een 5\% hoger niveau ten opzichte van de jaren 2006-2008. 


\subsubsection{Sectorvariabelen verse snijbloemen van 2006-2010}

In tabel 3.52 zijn de sectorvariabelen berekend van de posities van de Nederlandse snijbloemensector en de buitenlandse invoer.

Tabel 3.52 Sectorvariabelen verse snijbloemen van 2006-2010

\begin{tabular}{|l|r|r|r|r|r|}
\hline & 2006 & 2007 & 2008 & $2009 *)$ & 2010 \\
\hline Binnenlands aandeel verse snijbloemen (\%) & 77.4 & 76.6 & 72.4 & 71.6 & 74.8 \\
\hline Importaandeel verse snijbloemen (\%) & 22.6 & 23.4 & 27.6 & 28.4 & 25.2 \\
\hline Totaal binnenlandse aanbod (\%) & 100 & 100 & 100 & 100 & 100 \\
\hline $\begin{array}{l}\text { Productiewaarde snijbloemen Nederland (x 1 } \\
\text { mln. euro) }\end{array}$ & 2.277 & 2.294 & 2.172 & 1.887 & 2.110 \\
\hline $\begin{array}{l}\text { Importwaarde snijbloemen } \\
\text { (x 1 mln. euro) }\end{array}$ & 664 & 702 & 827 & 748 & 710 \\
\hline $\begin{array}{l}\text { Totaal binnenlands aanbod snijbloemen } \\
\text { productiewaarde + importwaarde } \\
\text { (x 1 mln. euro) }\end{array}$ & 2.941 & 2.996 & 3.000 & 2.635 & 2.820 \\
\hline & & & & & \\
\hline $\begin{array}{l}\text { Raming verkoopwaarde binnenlands aanbod } \\
\text { (productie + import) x 1.25] }\end{array}$ & 3.676 & 3.745 & 3.750 & 3.294 & 3.525 \\
\hline $\begin{array}{l}\text { Exportwaarde snijbloemen } \\
\text { (x 1mln. euro) }\end{array}$ & 3.237 & 3.373 & 3.243 & 2.991 & 3.190 \\
\hline $\begin{array}{l}\text { Omvang binnenlandse markt snijbloemen } \\
\text { (verkoopwaarde bi. aanbod - exportwaarde } \\
\text { groothandelswaarde) (x 1 mln. euro) }\end{array}$ & 439 & 372 & 507 & $303(?)$ & $335(?)$ \\
\hline Exportaandeel verse snijbloemen (\%) & & & & & \\
\hline
\end{tabular}

Bron : PT, VBN/FloraHolland, HBAG, *) jaar van de kredietcrisis

Als we de ontwikkeling van bovenstaand berekende sectorvariabelen nader beschouwen, kunnen we het volgende vaststellen:

1. Er is een afname van het binnenlands aandeel van verse snijbloemen over de periode 20062010 en een verhoging van de import van snijbloemen. Dit veronderstelt een verslechtering van de positie van het Nederlands (glas)product op de binnenlandse markt. Dit lijkt niet het geval. De terugval van het Nederlands product in 2009 is procentueel groter dan die van de import, maar er is in 2010 een opvallend herstel van het Nederlands product en een verdere daling van de import.

2. Er is een toename van ruim twee procentpunten van het exportaandeel van verse snijbloemen over de periode 2006-2010. Dit veronderstelt een verbetering van de positie van het Nederlands (glas)product op de buitenlandse markt. Het herstel in 2010 ten opzichte van 2009 lijkt dit te onderschrijven.

3. De productiewaarde glassnijbloemen blijft in de periode 2006-2007 op een stabiel niveau. In 2008 en 2009 valt deze met 5\% en 15\% terug door de gevolgen van de kredietcrisis om in 2010 te herstellen tot het niveau van $2.1 \mathrm{mrd}$. euro (-3\% ten opzichte van 2008). 
4. De ontwikkeling van het gemiddelde prijsniveau ligt in de periode 2006-2008 rond 0.22 eurocent per stuk. In 2009 daalt dit met 10\% (kredietcrisis) om in 2010 uit te komen op een 5\% hoger niveau ten opzichte van het jaar 2009.

\subsubsection{Sectorvariabelen verse potplanten van 2006-2010}

In tabel 3.53 zijn de sectorvariabelen berekend van de posities van de Nederlandse potplantensector en de buitenlandse invoer.

Tabel 3.53 Sectorvariabelen verse potplanten van 2006-2010

\begin{tabular}{|c|c|c|c|c|c|}
\hline & 2006 & 2007 & 2008 & $2009 * *)$ & 2010 \\
\hline Binnenlands aandeel potplanten (\%) & 83.6 & 83.5 & 83.1 & 84.2 & 85.5 \\
\hline Importaandeel potplanten (\%) & 16.4 & 16.5 & 16.9 & 15.8 & 14.5 \\
\hline Totaal binnenlandse aanbod (\%) & 100 & 100 & 100 & 100 & 100 \\
\hline $\begin{array}{l}\text { Productiewaarde potplanten Nederland (x } 1 \\
\text { mln. euro) }\end{array}$ & 1.624 & 1.768 & 1.862 & 1.902 & 2.000 \\
\hline $\begin{array}{l}\text { Importwaarde potplanten } \\
\text { (x } 1 \mathrm{mln} \text {. euro) }\end{array}$ & $\left.318^{*}\right)$ & $348 *)$ & 379 & 358 & 340 \\
\hline $\begin{array}{l}\text { Binnenlands aanbod potplanten }= \\
\text { productiewaarde }+ \text { importwaarde } \\
(\mathrm{x} 1 \mathrm{mln} \text {. euro) }\end{array}$ & 1.942 & 2.116 & 2.241 & 2.260 & 2.340 \\
\hline $\begin{array}{l}\text { Raming verkoopwaarde binnenlands aanbod } \\
\text { [(productie + import) } \times 1.25]\end{array}$ & 2.428 & 2.645 & 2.801 & 2.825 & 2.925 \\
\hline $\begin{array}{l}\text { Exportwaarde potplanten } \\
\text { (x } 1 \mathrm{~m} l \mathrm{ln} \text {. euro) }\end{array}$ & 1.777 & 1.858 & 1.854 & 1.888 & 1.990 \\
\hline $\begin{array}{l}\text { Omvang binnenlandse markt (verkoopwaarde } \\
\text { bi. aanbod - exportwaarde = } \\
\text { groothandelswaarde) (x } 1 \mathrm{mln} \text {. euro) }\end{array}$ & 651 & 787 & 947 & 937 & 935 \\
\hline Exportaandeel potplanten (\%) & 73.2 & 70.2 & 66.2 & 66.8 & 68.0 \\
\hline Gem. prijzen potplanten (eurocent/st.) & 1.17 & 1.27 & 1.29 & 1.29 & \\
\hline
\end{tabular}

Bron : PT, VBN/FloraHolland, HBAG, *) extrapolatie 2010-2008, **) jaar van de kredietcrisis

Als we de ontwikkeling van bovenstaand berekende sectorvariabelen nader beschouwen, kunnen we het volgende vaststellen:

1. Er is eerst een stabilisatie en daarna een toename in de periode 2006-2010 van het binnenlands aandeel van verse potplanten en een verlaging van de import van potplanten in 2009 en 2010 . Dit veronderstelt een verbetering van de positie van het Nederlands product op de binnenlandse markt. Dit lijkt het geval.

2. Er is een daling van vijf procentpunten van het exportaandeel van verse potplanten over de periode 2006-2010. Dit veronderstelt een verslechtering van de positie van het Nederlands (glas)product op de buitenlandse markt. Dit is niet het geval. Er is juist sprake van een minder grote gevoeligheid voor de problemen van de kredietcrisis bij de export van potplanten en geen terugval in 2009 en 2010. 
3. De productiewaarde glaspotplanten toont over de gehele periode 2006-2010 een stabiele groei van 3 tot $6 \%$ per jaar.

4. Het gemiddelde prijsniveau ligt in 2006 op $€ 1.17$. Ondanks de kredietcrisis stijgt het prijsniveau in 2007-2009 naar $€ 1.27-1.29(+10 \%)$.

\subsubsection{Ontwikkeling concentraties sector glasgroenten}

Onderstaande tabel laat de ontwikkeling zien van de horizontale concentratie(graad) bij glasgroentebedrijven, afzetorganisaties/telersverenigingen en groothandels-/exportbedrijven in relatie tot behaalde sectorresultaten over de onderzoeksperiode 2004-2008/2010.

Tabel 3.54 Concentraties (in \%) bij productiebedrijven, afzetorganisaties en groothandels/exportbedrijven in glasgroenten 2004-2010 (op basis aandeel 4 of 10 grootste bedrijven)

\begin{tabular}{|c|c|c|c|c|c|c|}
\hline & 2004 & 2006 & 2007 & 2008 & $2009 * *)$ & 2010 \\
\hline $\begin{array}{l}\text { Producenten glasgroenten (C4) } \\
\text {-Tomaat } \\
\text {-Paprika } \\
\text {-Komkommer } \\
\text {-Glasgroenten } \\
\text { (alle bedrijven op basis areaal) }\end{array}$ & $\begin{array}{l}6.5 \\
4.4 \\
6.1 \\
5.7\end{array}$ & $\begin{array}{l}5.0 \\
4.0 \\
5.0\end{array}$ & & $\begin{array}{r}10.0 \\
5.0 \\
5.0 \\
6.5\end{array}$ & & \\
\hline $\begin{array}{l}\text { Afzetorganisaties glasgroenten (C4) } \\
\text {-Tomaaat } \\
\text {-Paprika } \\
\text {-Komkommer } \\
\text {-Glasgroenten (gemiddeld) }\end{array}$ & $\begin{array}{l}89.0 \\
61.0 \\
46.0 \\
70.0\end{array}$ & $\begin{array}{l}86.0 \\
70.0 \\
72.0\end{array}$ & & $\begin{array}{l}76.0 \\
61.0 \\
52.0 \\
66.0\end{array}$ & & \\
\hline $\begin{array}{l}\text { Groothandel/export (aandeel } 10 \\
\text { grootste exporteurs kasgroenten op } \\
\text { basis omzet) }\end{array}$ & & 72.3 & 71.4 & 67.3 & 66.4 & 65.9 \\
\hline Exportaandeel verse groenten (\%) & & $\left.68.0^{*}\right)$ & 68.3 & 69.6 & 71.1 & 72.2 \\
\hline $\begin{array}{l}\text { Exportwaarde (glas)groenten } \\
\text { (x } 1 \mathrm{mln} \text {. euro) }\end{array}$ & & 3.420 & 3.620 & 3.718 & 3.511 & 3.900 \\
\hline $\begin{array}{l}\text { Productiewaarde glasgroenten } \\
\text { (x } 1 \mathrm{mln} \text {. euro) }\end{array}$ & & 1.350 & 1.340 & 1.270 & 1.080 & 1.455 \\
\hline $\begin{array}{l}\text { Gem. jaarprijzen (eurocent p. kg) } \\
\text {-tomaat } \\
\text {-paprika } \\
\text {-komkommer }\end{array}$ & $\begin{array}{r}57 \\
125 \\
48\end{array}$ & $\begin{array}{r}80 \\
136 \\
56\end{array}$ & $\begin{array}{r}80 \\
138 \\
53\end{array}$ & $\begin{array}{r}72 \\
118 \\
48\end{array}$ & $\begin{array}{l}64 \\
78 \\
43\end{array}$ & $\begin{array}{r}85 \\
110 \\
56\end{array}$ \\
\hline
\end{tabular}

Bron : LEI, Bunte(2006), Bunte (2009), Groenten en Fruit 2004, 2006 en 2008, PT, HBAG, Kwin Glastuinbouw $2010, *)$ raming op basis van extrapolatie 2010-2007, **) jaar van de kredietcrisis

Als we de ontwikkeling van bovenstaand berekende concentraties en sectorresultaten nader beschouwen, kunnen het volgende vaststellen:

1. De concentratiegraad van de vier grootste producenten $(\mathrm{C} 4)$ in de glasgroenten ligt op een laag niveau. Er is een geringe toename bij de producenten van glasgroenten van $5.7 \%$ naar $6.5 \%$ over de periode 2003-2008 met de hoogste concentratie in het gewas tomaat (10\%). Deze toename is van weinig invloed op het sectorresultaat (productiewaarde en prijzen glasgroenten). 
2. De concentratiegraad van de vier grootste afzetorganisaties (C4) in de (glas)groenten ligt op een hoog niveau. $\mathrm{Er}$ is een grote daling van deze $\mathrm{C} 4 \mathrm{bij}$ de tomaat, met dertien procentpunten (van $89 \%$ naar $76 \%$ ) over de periode 2003-2008. Gemiddeld is de daling over de drie vruchtgroenten minder (vier procentpunten). Een en ander veronderstelt een verslechtering van het gemiddelde bedrijfsresultaat in 2008/2009. Inderdaad is er sprake van een verlaging van de productiewaarde en de prijzen in 2008 en 2009.

3. De concentratiegraad van de tien grootste groothandels-/exportbedrijven (C10) in de groenten en fruit ligt op een hoog niveau. Er is een daling van deze $\mathrm{C} 10$ met ruim zes procentpunten (van 72.3\% naar 65.9\%) over de periode 2006-2010. De daling van de concentratiegraad veronderstelt een verbetering van het sectorresultaat aan de producentenzijde hetgeen niet in 2008/2009 (kredietcrisis), maar eerst in 2010 het geval is. Wel is er sprake van een toename van meer dan vier procentpunten van het exportaandeel van verse (glas)groenten over de periode 2006-2010 hetgeen een verbetering van de positie van het Nederlandse (glas)product veronderstelt op de buitenlandse markt. Dit is in 2010 het geval met een grote toename van de productiewaarde en de exportwaarde. Het niveau van de uitbetaalprijzen 2010 is nog niet beschikbaar (Kwin Glastuinbouw 2010).

Tabel 3.55 Concentraties, marktaandelen en sectorresultaten in de glassierteelt (snijbloemen en potplanten) 2007-2011

\begin{tabular}{|c|c|c|c|c|c|}
\hline & 2007 & 2008 & $2009 *)$ & 2010 & 2011 \\
\hline $\begin{array}{l}\text { Snijbloementelers (C4 in \%) } \\
\text {-Roos } \\
\text {-Chrysant } \\
\text { Potplantentelers (C4 in \%) } \\
\text {-Groene planten } \\
\text {-Bloeiende planten } \\
\text { (alle bedrijven op basis areaal) }\end{array}$ & $\begin{array}{l}6.0 \\
7.0\end{array}$ & $\begin{array}{l}6.0 \\
6.5\end{array}$ & $\begin{array}{r}10.0 \\
7.0\end{array}$ & & \\
\hline $\begin{array}{l}\text { Afzetorganisaties } \\
\text {-FloraHolland (m.a. in \%) } \\
\text {-Plantion resp. Vleuten/VON (idem) }\end{array}$ & & $\begin{array}{r}98.0 \\
2.0\end{array}$ & $\begin{array}{r}98.0 \\
2.0\end{array}$ & $\begin{array}{r}98.0 \\
2.0\end{array}$ & $\begin{array}{r}98.0 \\
2.0\end{array}$ \\
\hline $\begin{array}{l}\text { Groothandel/export (aandeel in \% } \\
\text { van } 7-9 \text { grootste exporteurs op basis } \\
\text { omzet) }\end{array}$ & & 59.0 & 60.0 & 61.0 & 64.0 \\
\hline $\begin{array}{l}\text { Exportaandeel verse snijbloemen } \\
(\%)\end{array}$ & 90.0 & 86.5 & 90.8 & 90.5 & \\
\hline $\begin{array}{l}\text { Productiewaarde snijbloemen } \\
\text { Nederland (x } 1 \mathrm{mln} \text {. euro) }\end{array}$ & 2.294 & 2.172 & 1.887 & 2.110 & 2.040 \\
\hline $\begin{array}{l}\text { Productiewaarde potplanten } \\
\text { Nederland (x } 1 \mathrm{mln} \text {. euro) }\end{array}$ & 1.768 & 1.862 & 1.902 & 2.000 & 1.970 \\
\hline $\begin{array}{l}\text { Gemiddelde jaarprijzen } \\
\text { (eurocent p. } \mathrm{kg} / \mathrm{st} \text {.) } \\
\text {-snijbloemen } \\
\text {-kamerplanten }\end{array}$ & $\begin{array}{r}23 \\
153\end{array}$ & $\begin{array}{r}22 \\
153\end{array}$ & $\begin{array}{r}20 \\
149\end{array}$ & $\begin{array}{r}21 \\
153\end{array}$ & $\begin{array}{r}21 \\
153\end{array}$ \\
\hline
\end{tabular}

Bron : PT, HBAG, Jaarverslag FloraHolland 2010, bedrijfsonderzoeken glassnijbloemen en glaspotplanten juli 2008 en mei $2009, *)$ jaar van de kredietcrisis 


\subsubsection{Ontwikkeling concentraties sector glassierteelt}

Tabel 3.55 toont de concentraties, berekend van de snijbloemen- en potplantentelers, de afzetorganisaties en de groothandels/exportbedrijven over de onderzoeksperiode 2007-2011.

Als we de ontwikkeling van bovenstaande berekende concentraties en sectorresultaten nader beschouwen, kunnen we het volgende vaststellen:

1. De concentratiegraad van de vier grootste producenten $(\mathrm{C} 4)$ in de glassnijbloemen en -potplanten ligt op een laag niveau. Er is een toename van de $\mathrm{C} 4 \mathrm{bij}$ de producenten van rozen van $6 \%$ naar $10 \%$ en bij de chrysanten van $5 \%$ naar $7 \%$ over de periode $2007-2009$. De C4 bij de groene potplanten blijft in deze periode op een niveau van $6 \%$ en de $\mathrm{C} 4$ bij de bloeiende planten daalt van $7 \%$ naar $6 \%$. De toename van de concentratie lijkt van weinig invloed op het behaalde sectorresultaat.

2. Het marktaandeel van FloraHolland bedraagt sinds de fusie in 2007 tussen FloraHolland Naaldwijk en de VBA Aalsmeer bijna 98\%. FloraHolland heeft aldus een bijna monopolie in Nederland ten aanzien van de (organisatie van de) verkoop van sierteeltproducten. Haar invloed op de prijsvorming is echter indirect, zij organiseert in eerste instantie de markt en in tweede instantie de verkoop. Met als voornaamste doel het verkrijgen van de hoogste opbrengst voor de producten van de leden. De veiling Plantion te Ede, die in 2009/2010 ontstond uit de fusie van bloemenveilingen Vleuten en Bemmel (VON) heeft ruim 2\% marktaandeel. Bij de sector snijbloemen is sprake van een daling van de productiewaarde in 2008 van $5 \%$ en in 2009 van 13\% ten opzichte van het voorafgaande jaar. Bij de sector potplanten is juist sprake van een groei van de productiewaarde van 5\% in 2008 en 3\% in 2009. In 2010 is sprake van een flink herstel in de sector snijbloemen $(+12 \%)$. De sector potplanten groeit in 2010 door met 5\%. Mede gezien de turbulente situatie veroorzaakt door de kredietcrisis in 2008 en 2009 , is niet vast te stellen wat de invloed van de hoge concentratie van de afzetorganisaties in de sierteeltsector is op het sectorresultaat. Dat deze hoge concentratie een belangrijke rol speelt bij de snelheid van het herstel in 2010 is evident.

3. De concentratieontwikkeling bij de groothandel/export betreft de periode 2008-2010, aangezien de sectorresultaten 2011 nog niet beschikbaar zijn. De concentratiegraad van de 7-8 grootste groothandelsbedrijven (C7/8) in deze handelsschakel ligt op een hoog niveau. Er is kleine stijging van de concentratiegraad van twee procentpunten (van 59\% naar 61\%) bij een stijging van 7 naar 8 bedrijven over de periode 2008-2010. De invloed hiervan op het (dalende) sectorresultaat in 2008 en 2009 is evenals bij punt 2. hiervoor niet in te schatten. Ook bij de groothandel/export is een hoge concentratie van belang voor de snelheid van handelen als de markt ten goede keert. 


\subsubsection{Ontwikkelingen, analyse en mogelijke verbanden sectorvariabelen 2006-2016}

Uit de ontwikkelingen en analyse van dit hoofdstuk, aangevuld met de cijfers van 2011-2016, (zie ook appendix 3A) kan het volgende worden opgemaakt. We bespreken eerst de ontwikkeling van de resultaatsvariabelen productiewaarde, export- en importwaarde en daarna de variabelen van de sectorstructuur. Dit zijn achtereenvolgens de concentratie, de productdifferentiatie, het binnenlands aandeel en het import- en exportaandeel.

\section{Ontwikkeling productiewaarde en export- en importwaarden}

De productiewaarden en de export- en importwaarden van de voedingstuinbouw en siertuinbouw laten over de laatste 30 - 35 jaar een positieve ontwikkeling zien. Ondanks de kredietcrisis in 2008/2009 en de EHEC-crisis in 2011 tonen beide sectoren zowel in 2010 als in 2012-2016 een snel en krachtig herstel met een dip in de groentesector in 2014 (Jaarverslag Productschap Tuinbouw 2012, p. 8, jaarverslagen Frugi Venta/Groenten Fruithuis 2013-2015 en FloraHolland 2011-2015, rapport VGB Typisch Groothandel 2014). Over de gehele periode toont de siertuinbouw gemiddeld hogere groeicijfers en een stabielere ontwikkeling dan de voedingstuinbouw, mede veroorzaakt door de sterke groei van de potplanten. Beide sectoren profiteren in ruime mate van de groeiende import-/re-exportfunctie van fruit en snijbloemen vanuit Nederland naar de aangrenzende landen en handelspartners in Europa.

\section{Ontwikkeling concentraties sectoren voedings- en siertuinbouw}

De schaalgrootte van de glastuinbouw- en groothandelsbedrijven neemt al jaren sterk toe, enerzijds door de groei van het Europese marktgebied, anderzijds door de toenemende concurrentie van buitenlandse productie. De ontwikkeling is de afgelopen jaren versneld door de economische gevolgen van de krediet- en EHEC-crisis. Het aantal bedrijven in de groenten is van 2008-2015 gedaald van 2000 naar 1385 en het gemiddelde productiebedrijf is met ongeveer 3.5 ha. glas *) inmiddels zes keer zo groot als in 1980. Bij de snijbloemen en potplanten gaat deze concentratie minder snel. Het aantal bedrijven in 2015 ligt hier op 1132 en 850 met een gem. oppervlakte rond de 2 ha. (CBSLandbouwtelling, bewerking WER).

Het totale areaal glas in Nederland, dat jaren schommelde rond de 10.000 ha., is na 2010 gedaald tot 9200 ha. in 2015 . Het bestaat momenteel uit ca. 4800 ha. glasgroenten, 2000 ha. glassnijbloemen en 1800 ha. pot- en perkplanten en ongeveer 600 ha. producten in de boomkwekerij inclusief zacht fruit. Het areaal groenten is de laatste jaren gestegen, onder andere door een flinke toename van de tomaat, en stabiliseert momenteel.

Het areaal snijbloemen in de sierteelt is fors gedaald, vooral door daling van de roos, die concurrentie ondervindt van de import (Jaarverslag PT 2012, p. 9). De concentratie onder de glastuinbouwbedrijven is tot op heden laag met een concentratiegraad van de vier grootste bedrijven van $6-10 \%$. Als rekening wordt gehouden met een toenemende differentiatie van het product, is deze concentratie groter. Dat geldt ook voor de belangrijkste afzetorganisaties. Met marktaandelen in 2010 van 98 en 2\% nemen in de sector siertuinbouw de bloemenveiling FloraHolland en het 
veel kleinere Plantion te Ede bijzondere posities in (C2 is 100\%). (Typisch Groothandel 2014, Vergelijking 2008-2013, p. 7).

In de voedingstuinbouw hebben de vier grootste afzetorganisaties een concentratiegraad tussen de 50 en $60 \%$. In de glasgroenten waren dit in 2009 FresQ, The Greenery, Komosa en ZON. In 2012/2013 is de positie van FresQ en haar voormalige leden drastisch veranderd door de ontvangst van diverse NMa-boetes voor overtreding van de GMO-regels, met name op het gebied van individuele prijsafspraken. Verlies van de GMO-erkenning vond plaats, evenals deconcentratie van het aanbod door het uiteenvallen van telersverenigingen of opzegging van prominente leden (Jaarverslag Frugi Venta 2012, p. 19).

Inmiddels zijn er door voormalige leden/bedrijven van FresQ nieuwe telersverenigingen opgezet (Harvest House, Door Partners, Van Nature en andere) en is in 2015 de Stichting FVO (Federatie Vruchtgroenteorganisaties) opgericht door de zes grootste Nederlandse afzetorganisaties/(glasgroente-)telersverenigingen met als belangrijkste doelstelling het verzekeren van een toekomstbestendige en leidende positie van de Nederlandse glastuinbouw op de Europese markt. (www. vruchtgroente.nl)

Dit betekent dat de horizontale concentratiegraad in de glasgroentesector voor de zes grootste bedrijven (C6) momenteel ruim 60\% bedraagt (zie appendix $3 \mathrm{~A}$ ).

\section{Ontwikkeling productdifferentiatie}

In de sector glasgroenten is de productdifferentiatie van de belangrijkste vruchtgroenten laag. De komkommer, als tamelijk homogeen product, heeft het op de Europese markt het zwaarst. De tomaat en de paprika, die een breder assortiment hebben en zich gemakkelijker kunnen onderscheiden, ondervinden toch bijna evenveel concurrentie als de komkommer. Dit blijkt uit de gerealiseerde uitbetaalprijzen 2005-2009 waar duidelijk wordt dat de trostomaat zich nauwelijks meer onderscheidt van de ronde tomaat. Toch heeft de Nederlandse tomaat in de EU de afgelopen jaren aan marktaandeel gewonnen door de mogelijkheid van jaarrond aanbod (belichting), voorsprong in kwaliteit op Spanje en Marokko en het creëren van toegevoegde waarde door middel van een breed assortiment producten, verpakkingen en merken [Vruchtgroenten Nederland (2015), Concurrentiedruk neemt toe, (www.vruchtgroente.nl )].

In de glassierteelt is de productdifferentiatie van snijbloemen en potplanten veel groter dan in de glasgroenten. Dit grotere onderscheid tussen producten zorgt voor minder scherpe concurrentie die van invloed is op de resultaten. Zowel bij snijbloemen als bij potplanten levert dit een stabielere en vaak hogere prijsvorming op.

4. Ontwikkeling en verbandsanalyse structuur- en resultaatsvariabelen sectoren

Onderstaande onderzoeksresultaten betreffen de uitkomsten van de toetsing van de sectorvariabelen binnenlands aandeel, import- en exportaandeel per sector.

De resultaatsvariabelen in de sector glasgroenten laten een snel herstel zien in 2010 en 2012 na de kredietcrisis en de EHEC-crisis en tonen behalve een kleine dip in 2014 een stabiele ontwik- 
keling tot 2016. Dit wijst op een positief verband tussen het hoge binnenlandse aandeel verse groenten en de weer stijgende productiewaarde, exportwaarde en prijzen. Hetzelfde geldt voor de toename van het exportaandeel verse groenten. Dit wijst op een verbetering van de positie van het Nederlands product op de buitenlandse markt en een positief verband tussen groei van het exportaandeel en behaalde resultaten in 2010. In 2012-2015 zet deze groei zich op een wat lager niveau voort, vergelijkbaar met 2007/2008 (Jaarverslagen Frugi Venta 2012 -2015). Bij de snijbloemen is de terugval van het Nederlands product in 2009 groter dan die van de import, maar er is in 2010 een opvallend herstel van het Nederlands product en een verdere daling van de import. Dit herstel zet zich in 2011 en 2012 voort (Jaarverslag PT 2012, p. 8). De toename van het exportaandeel wijst op een verbetering van de positie van het Nederlands product op de buitenlandse markt. Het herstel in 2010 ten opzichte van 2009 onderschrijft dit. Dit herstel zet zich eveneens in 2011 en 2012 en de volgende jaren tot 2016 voort (Typisch Groothandel 2014, jaarverslagen FloraHolland 2013-2015).

Bij de potplanten is er sprake van een stabilisatie en daarna een toename van het binnenlands aandeel. De verlaging van de import in 2009 en 2010 wijst op een verbetering van de positie van het Nederlands product op de binnenlandse markt. In 2011 en 2012 is er sprake van een stabilisatie (Jaarverslag FloraHolland 2012, kengetallen). De daling van het exportaandeel lijkt te wijzen op een verslechtering van de positie van het Nederlands product op de buitenlandse markt, maar dit is niet het geval. Er is juist sprake van een minder grote gevoeligheid voor de problemen van de kredietcrisis bij de export en geen terugval in 2009 en 2010. In 2011 en 2012 stabiliseert de export. De productiewaarde glaspotplanten toont een stabiele ontwikkeling. Dit zet zich ook in 2011 en 2012 en de daarna volgende jaren tot en met 2016 voort (Typisch Groothandel 2014, jaarverslagen FloraHolland 2013-2016). 


AFZETORGANISATIES (GLAS)TUINBOUW IN NEDERLAND 



\subsection{Inleiding}

$\mathrm{Na}$ het sectoronderzoek en -analyse in hoofdstuk 3 bespreken we hier het onderzoek naar de concurrentiestrategie en resultaten van de belangrijkste afzetorganisaties in de glasgroenten en de glassierteelt, te weten VTN/The Greenery, VBA en FloraHolland. VTN/The Greenery is inmiddels van naam veranderd en heet Coforta/The Greenery. De centrale onderzoeksvraag is of het verschil in marktstructuur en marktgedrag in de sectoren glasgroenten en de glassierteelt een significante oorzaak is om het verschil in marktresultaat (brutomarge) van de leden/bedrijven en hun afzetorganisatie te verklaren en welke structuur- en gedragsvariabelen hieraan de grootste bijdrage leveren. Het betreft hier de volgende variabelen uit het analysemodel van figuur 2.4 in hoofdstuk 2:

Marktgedrag

- Horizontale concentratie

- Voorwaartse verticale concentratie

Productdifferentiatie

- Investeringen/innovaties

Marktresultaat

- Jaaromzet + groei

- Jaarafzet + groei

- Jaarprijzen

- Rendement

Marktstructuur

- Concentratieontwikkeling

- Productdifferentiatie

- Toetredingsdrempels

In hoofdstuk 2 paragraaf 2.6.2 zijn de te beantwoorden onderzoeksvragen op mesoniveau hiertoe geformuleerd (vraag 1, 4 en 5). Het onderzoek afzetorganisaties richt zich op het volgende:

1. Hoe ontwikkelen zich de horizontale en verticale concentratie van de afzetorganisaties in de sector glasgroenten en glassierteelt en is er een betekenisvol verband tussen de hoogte van deze concentratie en de gerealiseerde jaarprijzen, jaaromzet en het rendement?

2. Is er een verband tussen de mate van productdifferentiatie in de deelsectoren respectievelijk bij de afzetorganisaties en de gerealiseerde jaarprijzen, jaaromzet en het rendement?

3. Is er een verband tussen de hoogte van de (innovatieve) investeringen in de deel-sectoren respectievelijk de afzetorganisaties en de gerealiseerde jaarprijzen, jaaromzet en het rendement?

Afzonderlijke studies zijn gemaakt van beleidsplannen en jaarverslagen van de grote afzetorganisaties in de voedingstuinbouw en de siertuinbouw, VTN/Coforta/The Greenery, VBA en FloraHolland. De hoofdzaken van strategie, organisatieontwikkeling en resultaten van de deelonderzoeken worden beschreven in de paragrafen 4.2 en 4.3. In de sub-paragrafen vindt de analyse van de geselecteerde variabelen plaats. In paragraaf 4.4 volgt de vergelijking van de resultaten van de drie afzetorganisaties en in 4.5 volgen de voorlopige conclusies. 


\subsection{Concurrentiestrategie, analyse en resultaten VTN/Coforta/The Greenery}

Paragraaf 4.2.1 beschrijft de belangrijkste resultaten van het beleidsonderzoek VTN/The Greenery 1996-2008. Het betreft de gehanteerde (concurrentie-)strategieën, de bestuurlijke structuren van de organisatie en de bereikte resultaten. De onderscheiden perioden zijn 1996- 1999 (startfase), 2000-2005 (structureringsfase) en 2006-2008 (herstructureringfase). In paragraaf 4.2.2 is een beschouwing over 2009-2011 opgenomen. De resultaatsvariabelen staan in sub-paragraaf 4.2.3 en 4.2.4 vermeld. In sub-paragraaf 4.2.5 worden de geselecteerde strategische variabelen van het marktgedrag, voor zover mogelijk, geanalyseerd en besproken. De ontwikkeling van organisatiestructuur en organigram is opgenomen in appendix A.

In appendix B is de ontwikkeling van de gedrags- en resultaatsvariabelen 2012-2016 te zien.

\subsubsection{Strategie en organisatie periode 1996-2008}

Startfase 1996-1999

- Strategisch beleid

In het jaaroverzicht 1996 van de nieuwe afzetorganisatie worden vijf speerpunten van het (nieuwe) strategische beleid genoemd: schaalvergroting, marktgerichtheid, toegevoegde waarde, ketenintegratie en efficiency (Jaaroverzicht 1996, pp. 6 en 7). The Greenery wil een gerespecteerd partner worden van het Europese grootwinkelbedrijf en heeft daar veel voor over. Een belangrijk doel is het terugdringen van de klokverkopen ten gunste van contract-bemiddeling en weekverkopen en het maken van langduriger leverings- en prijsafspraken. Zij wil verkoopsystemen hanteren die tegemoetkomen aan de wensen van alle kopers en die tevens passen binnen het streven naar ketenregie. Leveringszekerheid, stabiele marktprijzen en garanties zijn voor kopers de belangrijkste argumenten om niet via de klok te kopen (Jaarverslag VTN, 1997, p. 14). Volgens het management is hiervoor een nauwere samenwerking nodig met de Greenery Service Providers en de overname en integratie van een aantal vooraanstaande internationale groentenen fruitgroothandelaren en export/importbedrijven zoals de Van Dijk Delftgroep (VDD) en de 'Fresh Produce' Divisie van Perkins Foods plc.

\section{- Organisatieontwikkeling}

The Greenery International kent in de startfase een Raad van Bestuur, bestaande uit een voorzitter en een viertal directeuren, verantwoordelijk voor de divisies Producten, Financiën \& Administratie, Marketing \& Verkoop en Logistiek (zie figuur 4.1 in appendix 4A). Onder de directie Producten vallen de productdivisies, die de schakels zijn tussen telers en afnemers. Aan het hoofd staan de productmanagers, die tevens verantwoordelijk zijn voor kennisuitwisseling en productinnovaties. Onder Marketing \& Verkoop vallen de landendivisies die de relatie onderhouden met (potentiële) afnemers, de groot- en detailhandel. Verkopers en accountmanagers van deze divisies maken plannen en afspraken met kleine en grote afnemers op binnen- en buitenlandse markten, waaronder het grootwinkelbedrijf (GWB). Intensief onderling contact tussen product- en accountmanager moet zorgen voor de juiste afstemming van klantwensen. Daarnaast functioneert een aantal stafdiensten waaronder een nieuwe afdeling 
Marketing Research, ter ondersteuning van het geheel (zie figuur 1 en Jaaroverzicht 1996, pp. 14,15).

Koerswijziging strategisch beleid en organisatiestructuur 1997/1998/1999

De beginfase van The Greenery verliep niet zonder slag of stoot. De nieuwe organisatie-opbouw eiste veel aandacht van het management voor de invulling van nieuwe functies en het herplaatsen of aantrekken van personeel (Jaarverslag VTN 1997, p. 9). In 1997/1998 wordt het landenmanagement, dat is gericht op Duitsland, Nederland, Engeland, Scandinavië en USA/Japan, uitgebreid met business development managers naast de accountmanagers. Bij de productdivisies komen aanbodmanagers nieuwe stijl (een 50-tal nieuw benoemd) die gaan samenwerken met de Product Markt Advies Commissie's (PMAC's) per productgroep. In deze PMAC's worden de productplannen doorgesproken met de vertegenwoordigers van de telers en definitieve afspraken gemaakt over levering en prijs (Jaarverslag VTN 1997, p. 21).

In maart 1998 vond de overname plaats van de Van Dijk Delftgroep en de 'Fresh Produce' Divisie van Perkins Food plc. Klimatologisch was 1998 een slecht jaar voor de vruchtgroenten. Door het ontbreken van zichtbare successen op commercieel en organisatorisch gebied traden in mei 758 telers uit. In juli/augustus 1998 werd besloten tot een herstructureringsprogramma. Doel hiervan was de uitvoering van het ondernemingsplan dichter bij de markt te laten plaatsvinden, met name dichter bij de telers en kopers, en zich meer te concentreren op de operationele zaken en de strategie een lagere prioriteit te geven (Jaarverslag VTN 1998, pp. 7, 8).

Dit leidde tot het opzetten van vijf nieuwe Business Units (BU), zie appendix 4A, figuur 4.2. Deze BU's zijn zelfstandige profitcenters, met een rapportageverplichting aan een driehoofdige Raad van Bestuur, vanaf april 1999 geleid door een nieuwe voorzitter.

De samenwerking met telers werd aangepakt, er kwam een nieuw tarievenstelsel en een onderscheidend systeem van uitbetaalprijzen, een duidelijkere invulling van de relatie teler - verkoopbedrijf met individuele leveringsplannen (service providing) en voor de kleinere kopers een programma 'kopen op maat'. Verdere opmerkingen van de Raad van Bestuur over het strategisch beleid (Jaarverslag VTN 1999, p. 14) waren:

- de gekozen strategie van voorwaartse verticale integratie is de juiste richting voor een goede inkomensbijdrage voor de leden;

- het veranderingsproces van The Greenery International verkeert nog in het beginstadium (proces van aanbodgestuurd naar vraaggestuurd);

- men streeft een procesmatige aanpak van de probleemonderwerpen na, met een verdere aanpassing van de organisatiestructuur in de BU Greenery Operations.

Als relevante beleidszaken werden aangegeven:

- de bundeling van fruit tussen Fruitmasters Geldermalsen en The Greenery is mislukt door een negatief besluit van de Nederlandse Mededingingsautoriteit (NMa);

- het ontwikkelen van een centrale fruitlocatie Greenery Barendrecht en centrale champignonlocatie Greenery Zaltbommel gaat van start; 
- de ontbundeling van productgroepen in de sector wordt tegengegaan door een actief bundelingsbeleid na te streven.

Structureringsfase 2000-2005

In het jaar 2000 is een aantal wijzigingen doorgevoerd in de management- en organisatiestructuur (Jaarverslag VTN 2000, pp. 5, 6). De relatief zelfstandige Business Units veranderden in een lijnorganisatie, direct aangestuurd door een vierhoofdige Raad van Bestuur (zie figuur 4.3, organisatiestructuur 2000, appendix 4A).

Overige organisatorische aanpassingen (horizontaal en verticaal) waren:

- De herstructurering van Greenery Operations en een vermindering van het aantal fte's met 175 wordt uitgevoerd en een nauwere (verticale) samenwerking komt tot stand met de handelshuizen en Greenery Operations. Verkopers van Greenery Operations en inkopers van de handelshuizen werken samen onder de naam 'Verkoop Operations' en hebben als taak het verkopen van de producten van The Greenery-telers en de commerciële coördinatie van de handelsactiviteiten (Jaarverslag VTN 2000, p. 6).

- Met Waling van Geest en de UK desks van Disselkoen en VDD wordt de BU Greenery UK opgezet, gevestigd in Maasland (Jaarverslag VTN 2000, p. 10).

- Met Hagè International, C. den Hollander, Greenery Retail en Crop Top Quality Packers wordt de BU Greenery Nederland opgezet die zich met name richt op het grootwinkelbedrijf in de Benelux (Jaarverslag VTN 2000, p. 11).

- De overnames in 2001/2002 van Minnaar, Hoogsteder, Boers, Jover en Fresh Produce Services (FPS) moeten de positie van The Greenery op onder andere de markt van het Verenigd Koninkrijk versterken, zijn een verdere integratie van de groothandels-functie en leggen kortere lijnen naar het grootwinkelbedrijf (Jaarverslag VTN 2001, p. 13).

- In november 2001 wordt de BU Greenery International opgericht door een samengaan van grote delen van VDD, Boers en Disselkoen. De naam van de Holding verandert hierdoor in The Greenery (Jaarverslag VTN 2001, p. 13).

\section{0-2003}

De ondernemingsstrategie in 2000 noemt als voornaamste doelstellingen het komen tot een optimale uitbetaalprijs voor de telers en een redelijk rendement op het geïnvesteerd vermogen (Jaarverslag VTN 2000, p.12). The Greenery International wil zich positioneren als een marketing- en verkooporganisatie, in eigendom van de tuinders, die in staat is binnen een gesloten keten een versproduct op efficiënte wijze bij de klant te krijgen. Duurzaamheid, voedselveiligheid, traceerbaarheid en kwaliteit zijn hierbij de bepalende uitgangspunten. In het kader van het commercieel beleid is de ontwikkeling van Verkoop Operations, de plaats waar coördinatie van in- en verkoop plaatsvindt, essentieel. Dit geldt ook voor het nadrukkelijk profileren van The Greenery naar retailers toe als 'zaken doen met de bron'. Het commercieel beleid, waarvan key account management en category management belangrijke onderdelen zijn, vormt de leidraad voor product- en verkoopplannen (Jaarverslag VTN 2000, p. 14). Een opmerking van de Raad 
van Bestuur op 20 maart 2001 te Breda bij de presentatie van het jaarverslag over The Greenery geeft aan in welke strategische richting men denkt: 'Het concept van The Greenery is gebaseerd op een coördinatie van activiteiten die voorheen door veiling of handelshuis werden uitgeoefend. Op deze wijze kan efficiënt binnen een gesloten keten worden gewerkt als zijnde een geïntegreerd bedrijf.' (Jaarverslag VTN 2000, p. 17).

Bij de presentatie van het jaarverslag 2001 stelt de Raad van Bestuur vast dat de behaalde resultaten over 2001 in lijn zijn met de eerder uitgesproken verwachtingen. Belangrijke zaken die hieraan hebben bijgedragen zijn:

- het kostenreductieprogramma binnen Greenery Operations;

- aanpassing van de tarievenstructuur aan de werkelijke kosten;

- betere commerciële coördinatie tussen The Greenery-bedrijven.

Tevens heeft men een succesvol begin kunnen maken met de implementatie van het strategisch plan. De komende jaren zal het zogenaamde 'Greenhouse project' verder worden uitgerold, wat de realisatie van een nieuwe logistieke infrastructuur met planning- en besturingssysteem inhoudt. Een en ander moet leiden tot een optimale logistiek, voedselveiligheid, meer aandacht voor het milieu en ketenverkorting (Jaarverslag VTN 2001, p. 8).Volgens de Raad van Bestuur zijn de resultaten over 2002/2003 bemoedigend, worden budgetten gehaald en verwachtingen gerealiseerd. Verdere intensivering van het kosten-reductieprogramma vindt plaats evenals stroomlijning van de activiteiten binnen en tussen de BU's en toenemende samenwerking. De organisatie heeft een plattere structuur gekregen, er worden nu zes Business Units onderscheiden, direct vallend onder een driehoofdige Raad van Bestuur (zie figuur 4.4, organisatiestructuur 2002/2003, appendix 4A).

Interne samenwerking en telersbeleid

Belangrijk is een verdere intensivering van de samenwerking tussen de BU's van The Greenery en de VTN-telers om een directe koppeling tussen producent - afnemer tot stand te brengen. Er vindt een herijking plaats van het telersbeleid om van aanbodmanagement naar relatiemanagement te komen. Telers moeten kleur bekennen. Dat wil zeggen, vanuit speciale klanteisen en -wensen strategische productkeuzen maken, inclusief services ten aanzien van soort product, kwaliteit, kwantiteit, verpakking en andere leveringsafspraken (Jaarverslag VTN 2003, p. 61). De telersprovisie blijft op het niveau 2002 en gaat voor 2003 niet omhoog, zoals eerder voorgesteld. De meeste commerciële teams gaan vanuit Barendrecht werken. Marketing wordt meer onderdeel van de commerciële strategie en er vindt een organisatieaanpassing plaats waarbij de afdeling productmanagement wordt omgezet in 'category management' en 'brand management' Een groot deel van de category management-activiteiten is per 1 januari 2003 georganiseerd binnen de commerciële business units (Jaarverslag VTN 2003, p. 6). Het is hierbij de bedoeling om in samenspraak met klanten uit de retail (discount en full-service retailers) alsook de buitenhuishoudelijke markt en de industrie, verkoopbevorderende plannen op te stellen. Brand management heeft een nieuw internationaal pakket 'point of sales'- materiaal ontwikkeld en bij diverse retailers productdemonstraties georganiseerd. Voor 2004 zijn de uitbetaalprijzen 'af tuin' en zijn de logistieke kosten van het collectietransport voor rekening van The Greenery. Er wordt 
een clustering van de ProductMarktAdviesCommissie's (PMAC's) doorgevoerd (van 35 naar 20) en de voorverkoopcommissies krijgen een formele status (Jaarverslag VTN 2003, p. 11).

Er is vreugde over het tot staan brengen van de sinds 2000 dalende veilingomzet. Deze stijgt in 2003 van $881 \mathrm{mln}$. naar $890 \mathrm{mln}$. euro (Jaarverslag VTN 2003, p. 11).

Een jaar later keldert deze omzet naar $706 \mathrm{mln}$. euro.

\section{4}

Ten opzichte van 2003 heeft The Greenery in 2004 minder omzet en ook minder winst gemaakt. Beide ontwikkelingen zijn vooral toe te schrijven aan de lage verkoopprijzen. Een grote Europese oogst zorgt voor overschotten waardoor de marktprijzen lager uitvallen. Tegelijkertijd staan de marges onder druk doordat de retail zeer op prijs concurreert om de gunst van de consument. Het volume groeit daarentegen met $6 \%$ door een grotere aanvoer van de eigen telers, terugkomst van toekomstgerichte telers naar The Greenery en een grotere importstroom (Jaarverslag VTN 2004, p. 1). Door hiervoor ook afzet te vinden, versterkt The Greenery haar positie in 2004 op verschillende markten. De aansluiting van tien nieuwe lidstaten bij de EU blijkt bedreigingen en kansen op te leveren. Fruit- en paddenstoelentelers merken dat Oost-Europeanen goedkoop produceren en dat Nederlandse telers andere wapens moeten ontwikkelen in de concurrentiestrijd. Anderzijds vergemakkelijken de wegvallende grenzen de export. Bestaande handelsrelaties kunnen worden uitgebouwd. Zo kopen de Baltische Staten en Tsjechië aanzienlijk meer groenten en fruit in 2004. Ook Rusland was een groeiende markt totdat het zonder duidelijke redenen zijn grenzen sluit voor producten uit Nederland. Ook de export naar overzeese landen krimpt. De lage dollarkoers maakt importeren voor de Amerikanen uit de EU erg kostbaar en stimuleert tegelijkertijd de import van fruit van het zuidelijk halfrond (Jaarverslag VTN 2004, p. 5).

Op de Nederlandse markt wordt resultaat geboekt bij het beleveren van retailers. Hollander Barendrecht krijgt van een Nederlandse franchise keten opdracht om de logistiek van het totale koelverssegment te verzorgen (Jaarverslag VTN 2004, p. 5).

Deze laatste activiteit is tamelijk ver verwijderd van de corebusiness van The Greenery en vereist de nodige investeringen. Deze investeringen zijn risicovol en het is de vraag of ze voldoende rendement opleveren.

\section{Herstructurering organisatie}

In april 2004 treedt de voorzitter van de Raad van Bestuur af. Weer vindt een herstructurering plaats van de organisatie. Men streeft naar een meer operationele directie met een nog directere aansturing. De structuur met een Raad van Bestuur en Business Units per landengroep wordt ingeruild voor een operationele directie met drie bedrijfskolommen te weten Sales, Sourcing en Bedrijfsvoering (zie figuur 4.5, organisatiestructuur 2004/2005, appendix 4A). Een nog betere aansluiting op de markt in 2005 wordt een belangrijke doelstelling. Eind januari 2005 wordt een nieuwe directie benoemd die aan de slag gaat om deze structuur in te vullen (Jaarverslag VTN 2004, p. 11). 


\section{5}

Ten opzichte van 2004 heeft The Greenery in 2005 een lichte stijging van de omzet en ook de winst gerealiseerd. De samenwerking met een aantal belangrijke afnemers en The Greenery werd geïntensiveerd. De relatie tussen aandeelhouder VTN en The Greenery is versterkt door het gezamenlijk opstellen en deels realiseren van de strategische opdracht genoemd in het in april 2005 vastgestelde positioneringspaper 'Snoeien-Groeien-Bloeien'(Jaarverslag VTN 2005, p. 1). Hierin zijn drie doelstellingen voor The Greenery vastgelegd:

- de uitbetaalprijs voor de aangesloten telers zit in de top twee van vergelijkbare marktpartijen (zie hoofdstuk 3 tabel 3.14 en 3.15);

- het afzetvolume groeit met 3\% per jaar;

- de verhouding eigen vermogen ten opzichte van het balanstotaal verbetert met 2 procentpunten per jaar.

Naar aanleiding hiervan heeft The Greenery een strategisch businessplan voor 2005 tot 2007 gemaakt met de volgende vier pijlers: innovatie, kostenreductie, samenwerking en marktgerichtheid. Bij het opstellen van dit plan zijn de leden via de Greenery Ondernemers Platforms intensief betrokken (Jaarverslag VTN 2006, p. 32). Per 1 februari 2006 treedt een nieuwe algemeen directeur aan en wordt de BU-structuur nogmaals aangepast met een aansturing vanuit de directie naar de bedrijfsonderdelen Commercie, Bedrijfsvoering en Sourcing (zie figuur 4.6, organisatiestructuur 2005/2006, appendix 4A).

Herstructureringsfase 2006-2008

In 2006 is er evenals in 2005 sprake van een lichte stijging van de omzet en winst. Het volume voor het Nederlandse product blijft achter (3,3\% lagere aanvoer) door sterk wisselende weersomstandigheden, maar dit wordt gecompenseerd door betere uitbetaalprijzen $(+17 \%)$ en een hogere omzet ( $+42 \mathrm{mln}$. euro). Door veel aandacht te besteden aan service, logistiek en kwaliteit kan een marktconforme prijs voor de leden worden gerealiseerd. De solvabiliteit stijgt met 3,0 procentpunt, boven de doelstelling van 2 procentpunt (Jaarverslag VTN 2006, pp. 10, 17, 19). Volgens bestuur en management is de waardering bij de leden voor de eigen afzetorganisatie gegroeid. Dit wordt zichtbaar door de toetreding van 44 nieuwe leden en uitbreiding van activiteiten en areaal van reeds aangesloten leden, dit ondanks een daling van het totaal aantal leden van ca. 1700 tot 1400 . The Greenery wil in 2007 een nieuw concept van individuele uitbetaalprijzen invoeren met een differentiatie al naar gelang de geleverde producten en prestaties. Vanwege de verbondenheid en samenwerking van coöperatie en bedrijf is besloten beide onder dezelfde naam The Greenery te laten opereren (Jaarverslag VTN 2006, p. 9). In het strategisch businessplan voor 2006 en 2007 wordt de missie als volgt verwoord: The Greenery is gericht op betrouwbaarheid, samenwerking en permanente innovatie. Zij wil een zo kort mogelijke marktgerichte keten organiseren waarvan telers, afnemers en uiteindelijk de consument profiteren (Jaarverslag VTN 2006, p. 5).

De doelstellingen van The Greenery zijn:

- het realiseren per product van een marktconforme uitbetaalprijs

- het bereiken van een autonome volumegroei (excl. acquisities) van jaarlijks 3\% 
- het behalen van een gemiddelde groei van het eigen vermogen van 2 procentpunten; acquisities mogen deze doelstelling niet belemmeren.

Genoemde doelstellingen zijn geen van drie klantgericht. De eerste is telers- respectievelijk leveranciersgericht en de twee overige bedrijfsgericht.

2007

In 2007 dalen de omzet (-2,3\%) en de winst. Het bedrijfsresultaat is lager door een lagere verkoopmarge (hoge uitbetaalprijzen aan de leden en lage verkoopprijzen van de detailhandel) en hogere bedrijfskosten. Het volume van de verkochte AGF-producten daalt met 1\% ten opzichte van 2006. Door veel aandacht te besteden aan service, logistiek en kwaliteit kan een marktconforme prijs voor de leden worden gerealiseerd. De solvabiliteit stijgt met 2,7 procentpunt, boven de doelstelling van 2 procentpunt. Het eigen vermogen stijgt van 7,8 naar 10,5\% van het balanstotaal en het aansprakelijk vermogen van 38,4 naar $41.1 \%$, onder andere door een groei van de ledenlening van 90 naar 96 mln. euro (Jaarverslag VTN 2007, p. 18-21). Er treden 59 nieuwe leden toe en er vindt een uitbreiding van activiteiten en areaal plaats door de nieuwe en reeds aangesloten leden ondanks een daling van het totaal aantal leden van ca. 1400 tot 1250 (Jaarverslag VTN 2007, p. 16).

In de ledenraad van 30 maart 2007 wordt goedkeuring verkregen voor het nieuwe concept van individuele uitbetaalprijzen met differentiatie naar kwaliteit en typering van de geleverde producten en diensten. Eveneens keurt de ledenraad het selectief buitenlands lidmaatschap en het in te voeren full service logistiek dienstverleningsconcept voor een van de grootste Nederlandse retailers goed (Jaarverslag VTN 2007, pp. 8, 26).

\section{Wijziging organisatiestructuur}

In de hoofdstructuur van de organisatie is in 2007 het volgende gewijzigd: Het bedrijfs-onderdeel Sourcing is gesplitst in Sourcing Nederland en Import en bedrijfsonderdeel Commercie is veranderd in Sales (zie figuur 4.7, organisatiestructuur 2007, appendix 4A).

\section{Relevante marktontwikkelingen zijn (Jaarverslag VTN 2007, p. 23-29):}

- door verkoop in het Verenigd Koninkrijk van vier groothandelsstandplaatsen aan een belangrijke afnemer wordt toegang verkregen tot tien extra groothandelsmarkten met een (veel) grotere geografische verspreiding van het Nederlandse product: een voorbeeld van verticale deconcentratie op de Engelse markt dat positief uitwerkt voor VTN/The Greenery.

- sterke concentratie van de retail op de EU-markt zorgt voor een voortdurende prijzenslag, vooral op de Duitse markt. Op de Engelse markt zijn eveneens minder gunstige ontwikkelingen te zien door een groeiende voorkeur voor het eigen product (Buy British) en door de discussies over 'foodmiles' en de dure euro ten opzichte van het Engelse pond.

- Nederland is koploper in de EU voor wat betreft de groei van de vraag naar convenience producten. In 2007 bestaat een derde van de groenteomzet uit voorverpakte producten.

- in Oost-Europa en Rusland ontwikkelen retailers zich snel, traditionele kleine groentewinkels moeten plaatsmaken voor grote supermarkten (vaak winkelketens uit West-Europa) met een breed en volledig assortiment groenten en fruit uit West-Europa en andere werelddelen. 
Belangrijke innovaties van producten en diensten zijn (Jaarverslag VTN 2007, p. 23-36):

- opzet en ontwikkeling versdistributiecentrum Plus Retail via C. den Hollander: The Greenery als versprovider inclusief maaltijden en zuivel (Jaarverslag VTN 2007, p. 26);

- ontwikkeling en invoering van het programma Fit4Future en de aankoop inclusief de automatiseringssoftware SAP (Jaarverslag VTN 2007, pp. 8, 34, 36);

- investeringen in een nieuw distributiecentrum te Barendrecht en modernisering van het vrachtwagenpark voor binnen- en buitenlandse distributie;

- ontwikkeling schaalgrootte glastuinbouwbedrijf bij de leden: het gemiddeld tomatenbedrijf 2002 van 2,3 ha. groeit naar 4,3 ha. in 2007, het gemiddeld paprikabedrijf 2002 van 1,9 ha. groeit naar 3,5 ha. in 2007. Deze steeds groter wordende professionele teeltbedrijven staan open voor nieuwe vormen van samenwerking in telersverenigingsverband of soms zelfstandig met of zonder handelsorganisatie (Jaarverslag VTN 2007, pp. 30, 31).

\section{8}

Concentratie van het aanbod en mogelijke vorming van Associaties van Producenten Organisaties (APO's) is een centraal thema in 2008. Voor producenten, toeleveranciers, afzetorganisaties en retailers is het een moeilijk jaar (Jaarverslag VTN 2008, p. 6). De devaluatie van het Britse pond, de productieschommelingen in diverse landen, stijgende energieprijzen, oplopende kosten en toenemende concurrentie zijn ontwikkelingen die het voor alle spelers in de AGF-sector noodzakelijk maken kostenbesparende maatregelen te treffen. De effecten en gevolgen van de kredietcrisis worden eind 2008 sterker voelbaar. Resultaten lopen terug. Ook voor The Greenery vindt in 2008 een flinke daling van de omzet (- 7,5\%) en van de winst plaats ten opzichte van 2007. Een lagere verkoopmarge door relatief hoge uitbetaalprijzen aan de leden en lage verkoopprijzen van de detailhandel (vergelijkbaar met 2007) en hogere bedrijfskosten door onder meer de ontwikkelingen bij het importbedrijf zijn hier debet aan. Het volume van de verkochte AGF-goederen daalt met 5\% ten opzichte van 2006. De oorzaak ligt voor een deel aan de lagere fruitoogst en voor een ander deel aan de dure euro ten opzichte van het Britse pond en de dollar waardoor de exportomzet in euro's naar deze landen achterblijft. De solvabiliteit is nagenoeg gelijk aan 2007. Het E.V. in procenten van het balanstotaal blijft gelijk (10,3\%) en het aansprakelijk vermogen daalt enigszins (van 41.1 naar 38,7\%) door een toename van het balanstotaal ten gevolge van nieuwe investeringen (Jaarverslag VTN 2008, pp. $6,7,24,25)$.

In 2008 is de ledenomzet gedaald met $7 \%$ en er vindt een daling van het aantal leden plaats van ca. 1250 naar 1150. Het gemiddeld areaal per lid is gegroeid (Jaarverslag VTN 2008, p. 22).

\section{Strategisch beleid}

Er is een operational-excellence beleid uitgewerkt en er is sterk geïnvesteerd in zowel de automatisering van verschillende bedrijfsprocessen als in het versdistributiecentrum Hollander Barendrecht. Tevens is er een kostenbesparingsprogramma (Fit4Future) van 12 miljoen euro gerealiseerd. Diensten op het gebied van category management zijn uitgebreid en aan klanten kan een full-service verslogistiek dienstenpakket worden aangeboden. Voor telers is een nieuw 
tarieven- en heffingenstelsel opgezet, een nieuwe productgroepgerichte organisatie ingericht en voor de meeste producten is een marktconforme prijs uitbetaald.

De titel op het jaarverslag 2008 Samenwerken aan het Beste Vers verwoordt de nieuwe visie van The Greenery voor de komende jaren. De nieuwe missie 'Succes in vers' luidt:

The Greenery ziet het als haar opdracht om met gezonde ideeën haar succes tot het succes van haar partners te maken. Kernwaarden van het bedrijf die hierbij worden genoemd, zijn kwaliteit, ondernemend, weloverwogen, fris en toonaangevend (Jaarverslag VTN 2008, pp. 12, 13).

\section{Relevante marktontwikkeling:}

- de uitbetaalprijzen voor AGF staan in 2008 zeer onder druk wat aanleiding geeft tot hernieuwde discussies over aanbod- en afzetbundeling en eventuele deelname aan de vorming van een Associatie van Producenten Organisaties. The Greenery staat achter de doelstelling van een aanbod- en afzetbundeling zolang het gaat om structurele samenwerkingsverbanden die niet ondermijnend zijn voor The Greenery of haar strategie (Jaarverslag VTN 2008, p. 23).

Herstructurering organisatie

In 2008 volgt weer een herstructurering van de organisatie. Er worden vijf businessunits (BU's) onderscheiden: twee sourcingunits (Sourcing-NL en Sourcing Import) en drie verkoopunits (Benelux, UK en Europa). Deze units werken vanuit de drie hoofdvestigingen, Barendrecht, Maasland en Bleiswijk. Per vestiging zijn de voorheen aparte afdelingen commercie en logistiek nu samengevoegd. Elke vestiging is vanaf 1 juli 2008 een zelfstandige commerciële businessunit die geleid wordt door een commercieel directeur (zie figuur 4.8, organisatiestructuur 2008, appendix 4A).

\subsubsection{Strategie en organisatie periode 2009-2011}

2009

2009 is het jaar van de kredietcrisis met een daling van het consumentenvertrouwen en een vermindering van de vraag naar AGF-producten. Prijzen staan sterk onder druk en de netto-omzet van The Greenery daalt met $12 \%$. Door een kostenverlaging via het interne verbeteringsprogramma Fit4Future komt het bruto bedrijfsresultaat hoger uit dan in 2008. De netto winst daalt van 9 mln. in 2008 naar 7 mln. euro (Jaarverslag VTN 2009, pp. 7-9).

\section{Nieuw samenwerkingsmodel}

In 2009 is ook een nieuw samenwerkingsmodel tussen teler en The Greenery voorgesteld. Hierin worden handelshuis en coöperatie apart gepositioneerd. Telers krijgen de keuze uit verschillende samenwerkingsvormen met het handelshuis The Greenery. Dat kan een nauwe vorm zijn met het handelshuis (partnerschap) of een zakelijker handelsrelatie (transactie) waarbij de afzet zowel via het handelshuis als de Nederlandse groothandel en exporteurs kan plaatsvinden. In december 2009 kiest een meerderheid van de ledenraad voor dit nieuwe samenwerkingsmodel. In februari 2010 maken de leden hun keuze bekend. Ongeveer 86\% kiest voor de partnerschapsrelatie, 14\% voor de transactierelatie (Jaarverslag VTN 2009, pp. 3, 23). 
De lage prijzen voor de teler leidt tot een groeiende groep telers die pleit voor een verdere bundeling van het aanbod ten behoeve van een betere prijsvorming. The Greenery deelt deze mening op hoofdlijnen en is actief betrokken bij de vorming van samenwerkingsverbanden met producentenorganisaties. Zij meent wel dat een bundeling van het aanbod niet de enige actie moet zijn, maar dat alleen een blijvende focus op de klant en een continue verbetering van de prestaties zal leiden tot een betere prijsvorming. De nieuwe strategie die eind 2008 wordt geformuleerd, is in 2009 geïmplementeerd. 'Gezonde business creëren door excellente samenwerking' is wat The Greenery probeert te bereiken middels vijf speerpunten: kostenbesparing, marktgerichtheid, ketenoptimalisatie, volumegroei en cultuur. Volgens The Greenery heeft de implementatie van deze strategie een vergroting van het marktaandeel bij de Europese retail tot gevolg gehad. Meer dan de helft van het huidige volume gaat hier naar toe. Het doel is om dit percentage nog verder te laten groeien (Jaarverslag VTN 2009, p. 17).

\section{0}

Op 10 februari 2010 heeft Coöperatie The Greenery U.A. haar naam gewijzigd in Coöperatie Coforta U.A. en het nieuwe samenwerkingsmodel ingevoerd. Hiermee biedt zij haar leden op productniveau een keuzemogelijkheid voor het afzetkanaal voor hun producten: via handelsonderneming The Greenery naar met name de Europese retail of via het nieuwe verkoop-bedrijf Coforta Verkoop b.v. naar de Nederlandse groothandel en exporteur.

Het productassortiment van The Greenery omvat een totaalassortiment groenten en fruit: glasgroenten, vollegrondsgroenten, zacht en hard fruit, paddenstoelen, exoten en convenience. Het productassortiment van Coforta Verkoop b.v. bestaat in 2010 uit de glasgroenten komkommer, tomaat, paprika en aubergine (Jaarverslag VTN 2010, pp. 3, 4, 23). Voor elk productsegment wordt een apart verkoopbeleid ontwikkeld door de verkoper van Coforta Verkoop b.v. in overleg met een Verkoop Advies Commissie (VAC) van telers uit het segment. Deze commissie is mede verantwoordelijk voor een optimale aanbodprognose.

Handelsonderneming The Greenery zegt dat haar positie bij de internationale retailers is versterkt en dat Coforta Verkoop als nieuwe speler een stevige positie in de markt heeft verworven, gericht op de Nederlandse groothandel en exporteurs (Jaarverslag VTN 2010, pp. 6, 7). In een intensieve samenwerking met de telers benaderen de twee verkoopbedrijven de markt. Tesamen hebben de verkoopbedrijven iets meer volume verkocht $(+0.3 \%)$ en is de netto-omzet ten opzichte van 2009 met 10\% gestegen door een gemiddeld hoger prijsniveau. De omzet uit producten van de leden stijgt met 18\% (Jaarverslag VTN 2010, p. 9). Het hoger gemiddeld inkoopprijsniveau kan met name in de zomermaanden onvoldoende in de verkoopprijzen worden doorberekend. Het bedrijfsresultaat en de nettowinst vallen daardoor lager uit en het rendement op het gemiddeld geïnvesteerd vermogen daalt van 4.5 naar $1.1 \%$. Brutomarge en prijsvorming blijven onder druk staan. De solvabiliteit stijgt van 12.4 naar $14.3 \%$ en het aansprakelijk vermogen neemt toe van 40 tot $41 \%$. 
Prioriteiten 2011 (Jaarverslag VTN 2010, p. 7)

Voor 2011 worden de volgende prioriteiten voor de twee verkoopdochters genoemd: handelsonderneming The Greenery:

- aanscherpen van de strategie van operationele excellentie en toegevoegde waarde;

- versterken van de marktbenadering vanuit productspecialisme;

- intensiveren van kostenbesparende maatregelen;

- implementatie SAP;

- logistieke visie uitvoeren waaronder de sluiting van een Distributie Centrum (DC). verkoopbedrijf Coforta verkoop b.v.:

- onverminderd aandacht voor optimalisatie van het verkoopproces;

- inhoud geven aan productmarketing.

\section{1}

Voor de groenten- en fruitsector is 2011 een turbulent jaar met een crisis van ongekende invloed op de afzet van vooral vruchtgroenten en sla: de EHEC-crisis. Daarnaast is er de Moerdijkbrand met flinke schade voor de vollegrondsproducten en heeft ook de slechte zomer in NoordwestEuropa de consumptie negatief beïnvloed. De opbrengst per $\mathrm{m}^{2}$ voor telers van vruchtgroenten komt dit jaar zo'n 30\% lager uit dan in 2010. In de top van de productiemaanden in Nederland (juni/juli) komt de (Duitse) marktvraag naar komkommers, tomaten, paprika en verschillende slasoorten bijna tot stilstand. Ook Rusland sloot in deze maanden haar grenzen voor het Nederlands product. Marge en prijsvorming blijven onder druk staan en het bedrijfsresultaat in 2011 is negatief. Ook de volumeontwikkeling is negatief (-6\%) en de netto-omzet ligt $15 \%$ lager dan in 2010. De omzet uit producten van de leden daalt met 18\% (Jaarverslag VTN 2011, p. 9). De nettowinst daalt van 5 naar $2 \mathrm{mln}$. euro en het rendement op het gemiddeld geïnvesteerd vermogen daalt van 1.1 naar $-1.2 \%$. Positief zijn de stijging van de solvabiliteit van 14.3 naar $15 \%$ en het aansprakelijk vermogen van 41 tot bijna 42\% (Jaarverslag VTN 2011, p. 9).

Integratie van de commerciële en logistieke activiteiten van vestiging Maasland en Bleiswijk vinden plaats (Sales UK $\leftarrow$ Sales Europe, zie figuur 8). Vanaf december 2011 is Maasland niet meer in gebruik en ook ALC Venlo wordt in 2012 verkocht. Door deze logistieke aanpassingen dalen de kosten structureel met ca. $5 \mathrm{mln}$. euro op jaarbasis. Het aantal vaste medewerkers is gedaald van 1631 naar 1507 (Jaarverslag VTN 2011, p. 13).

Het aantal lidbedrijven daalt van 1007 in 2010 naar 885 bedrijven in 2011.

Een aanzienlijke groep glasgroentetelers wier producten door Coforta Verkoop b.v. aan de Nederlandse groothandel worden verkocht, heeft het lidmaatschap per 1 januari 2012 opgezegd. Het gaat hierbij om een gezamenlijk geraamde omzet van $216 \mathrm{mln}$. euro in 2011 . Volgens het bestuur van Coöperatie Coforta is er een langdurig en intensief proces van onderling overleg en afstemming geweest tussen telers, bestuur, directie en Raad van Commissarissen. Dat heeft echter niet tot overeenstemming geleid. De commerciële positie en productbeschikbaarheid van verkooporganisatie The Greenery blijven volgens het bestuur ongewijzigd (Jaarverslag VTN 2011, p. 33). Het vakblad Groenten \& Fruit actueel van 11 oktober 2011 geeft over deze uit- 
treding de volgende informatie: het betreft de vier telersverenigingen Prominent, Paprika NL, Green Diamonds en Purple Pride met 81 glasgroentetelers (216 mln. omzet) die per 1 januari 2012 de overstap maken naar afzetorganisatie FresQ. Ze verwachten daar commercieel meer ruimte te krijgen als zelfstandige verkoopdochters en direct supermarkten te kunnen beleveren. Binnen Coforta kunnen ze dat alleen via handelshuis The Greenery. FresQ krijgt hierdoor het grootste aandeel in de arealen glastomaten en glaspaprika's in Nederland (ca. 40\%), terwijl het aandeel van Coforta daalt naar $26 \%$ bij de glastomaat en $11 \%$ bij de glaspaprika (Groenten \& Fruit actueel, pp. 1, 7).

Er treden in 2011 ook nieuwe leden toe tot Coöperatie Coforta. Hieronder bevinden zich buitenlandse leden in het Verenigd Koninkrijk (VK) en Frankrijk. In het VK is een samenwerking aangegaan met Cornerways Nursery, een tweede Engelse producent van vrucht-groenten, na John Baarda Ltd. uit Billingham, lid sinds 2010. The Greenery is nu goed voor een aanzienlijk aandeel van het totale volume aan tomaten in het VK (Jaarverslag VTN 2011, p. 16).

\subsubsection{Resultaten periode 1996-2008}

In tabel 4.1 hierna wordt een overzicht gegeven van de belangrijkste resultaten van de negen in 1996 gefuseerde groenten- en fruitveilingen in VTN/The Greenery. In tabel 4.2 wordt vanaf de overname en integratie in 1998 van de handelsbedrijven (VDD e.a.) de omzetontwikkeling naar

Tabel 4.1 Resultaten en kerncijfers VTN/The Greenery 1996-2008

\begin{tabular}{|c|c|c|c|c|c|c|c|c|c|c|}
\hline \multirow[t]{2}{*}{ Jaar } & \multirow[t]{2}{*}{$\begin{array}{l}\text { Omzet x } \\
€ 1 \mathrm{mln} .\end{array}$} & \multirow[t]{2}{*}{$\begin{array}{l}\text { Provisie } x \\
€ 1 \mathrm{mln} .\end{array}$} & \multirow{2}{*}{$\begin{array}{l}\text { Veiling- } \\
\text { omzet } \\
x € 1 \mathrm{mln} .\end{array}$} & \multirow{2}{*}{$\begin{array}{l}\text { Resultaat x } \\
€ 1 \mathrm{mln} \text {. } \\
\text { voor/na } \\
\text { belasting }\end{array}$} & \multirow{2}{*}{$\begin{array}{l}\text { Rendement } \\
\% \text { Omzet of } \\
\text { TV }\end{array}$} & \multirow[t]{2}{*}{$\begin{array}{l}\text { Aantal } \\
\text { fte's }\end{array}$} & \multirow[t]{2}{*}{$\begin{array}{l}\text { Aantal } \\
\text { Leden }\end{array}$} & \multicolumn{3}{|c|}{$\begin{array}{l}\text { Gem. veilingprijs in } \\
\text { eurocent } / \mathrm{kg} \text { excl. BTW }\end{array}$} \\
\hline & & & & & & & & $\begin{array}{l}\text { Kom- } \\
\text { kommer }\end{array}$ & $\begin{array}{l}\text { To- } \\
\text { maat }\end{array}$ & $\begin{array}{l}\text { Pa- } \\
\text { prika }\end{array}$ \\
\hline 1996 & 1.294 & & 1.182 & $-/ 2.8$ & $\begin{array}{l}0.2 \% \\
\text { Omzet }\end{array}$ & 1200 & 12000 & 45 & 91 & 1.25 \\
\hline 1997 & 1.282 & 111.5 & 1.225 & $-/-9.9$ & $\begin{array}{l}-0.7 \% \\
\text { Omzet }\end{array}$ & 1027 & 9000 & 48 & 79 & 1.54 \\
\hline 1998 & 1.140 & 106.8 & 1.127 & $-/ 4.5$ & & $\begin{array}{l}3204 / \\
2786 *)\end{array}$ & & 50 & 81 & 1.50 \\
\hline 1999 & 1.426 & 95.9 & 910 & $-/ 2.7$ & $2.3 \% \mathrm{TV}$ & 2702 & & 43 & 72 & 1.25 \\
\hline 2000 & 1.523 & 82.7 & 998 & $-7.3 /-2.6$ & $-2.1 \%$ TV & 2712 & 4000 & 57 & 91 & 1.45 \\
\hline 2001 & 1.523 & 88.0 & 920 & $12 / 4.1$ & $1.7 \%$ TV & 2530 & & 52 & 73 & 1.34 \\
\hline 2002 & 1.515 & 88.0 & 881 & $21 / 7.6$ & $3.0 \% \mathrm{TV}$ & 2174 & 2500 & 48 & 88 & 1.17 \\
\hline 2003 & 1.570 & 89.0 & 890 & $15 / 9.1$ & $2.4 \%$ TV & 2083 & 2200 & 53 & 89 & 1.38 \\
\hline 2004 & 1.426 & 80.5 & 706 & $5 / 4$ & $0.8 \%$ TV & 1775 & 2000 & 48 & 57 & 1.25 \\
\hline 2005 & 1.434 & 73.9 & 736 & $7.5 / 13$ & $1.4 \%$ TV & 1699 & 1700 & 57 & 75 & 1.00 \\
\hline 2006 & 1.448 & 59.0 & 778 & $15 / 14$ & $2.8 \% \mathrm{TV}$ & 1693 & 1400 & 56 & 80 & 1.36 \\
\hline 2007 & 1.414 & 53.9 & 810 & $9 / 10$ & $1.8 \% \mathrm{TV}$ & 1638 & 1250 & 53 & 80 & 1.38 \\
\hline 2008 & 1.308 & 52.1 & 763 & $2 / 9$ & $0.4 \%$ TV & 1661 & 1150 & 48 & 72 & 1.18 \\
\hline
\end{tabular}

*) jaarverslag 1998 geeft 3204 fte's op jaareinde, jaarverslag 1999 geeft over 19982786 fte's op jaareinde (1020 bij The Greenery, 1766 bij de handelsbedrijven); 
geografische marktsegmenten en productgroepen getoond en de margeontwikkeling. Na analyse hiervan en van het in de voorgaande paragrafen beschreven strategisch beleid worden onder de tabel de belangrijkste ontwikkelingen aangegeven.

\section{Ontwikkelingen}

In bovenstaande tabel 4.1 is een aantal ontwikkelingen te constateren.

- De totale omzet van VTN/The Greenery schommelt sinds de overname van de handelshuizen in 1998 tussen de 1.1 en 1.6 mld. euro.

- De provisie van de door de telers aangevoerde producten is vanaf de veilingfusie in 1996 met bijna 60 mln. euro gedaald (ruim 50\%).

- De omzet van de door de eigen leden aangevoerde producten daalt eveneens vanaf de fusiedatum met ruim $400 \mathrm{mln}$. euro (ca. $35 \%$ ).

- Het rendement op het totale vermogen ligt tussen 1999-2008 gemiddeld op 1.45\% en schommelt tussen -2.1 en $3.0 \%$.

- Het aantal fte's is vanaf de overname/integratie van de handelshuizen in 1998 bijna gehalveerd (van 3204 naar 1661).

- Het aantal leden/aanvoerders is vanaf de fusie met ca. 10.000 gedaald, van ca. 12.000 in 1996 tot ca. 4000 in 2000 naar ca. 1150 in 2008 . In deze periode is de gemiddelde veilingomzet per lid gestegen van ongeveer 100.000 naar 650.000 euro.

- De gemiddelde veilingprijs voor komkommers ligt vóór de veilingfusie in 1996 tussen 59 (1991) en 44 eurocent (1993), na de fusie tussen de 43 (1999) en 57 eurocent (2000). De minimum- en maximumprijs en het prijsverschil zijn voor en na de fusie praktisch gelijk gebleven. *)

- De gemiddelde veilingprijs voor tomaten ligt vóór de veilingfusie in 1996 tussen de 86 (1991) en 60 eurocent (1993), na de fusie tussen de 57 (2004) en 91 eurocent (2000). De minimumprijs ligt na de fusie iets lager en de maximumprijs hoger. Het prijsverschil is gestegen van 26 naar 34 eurocent. *)

- De gemiddelde veilingprijs voor paprika's ligt vóór de veilingfusie in 1996 tussen de 175 (1989) en 108 eurocent (1993), na de fusie tussen de 117 (2002) en 154 eurocent (1997). De minimumprijs ligt na de fusie hoger en de maximumprijs lager. Het prijsverschil is gedaald van 67 naar 37 eurocent. *)

*) De gemiddelde veilingprijzen glasgroenten in de jaren 1989 t/m 1995 zijn verkregen via het PT. 
Tabel 4.2 Omzet- en brutomargeontwikkeling van VTN/The Greenery van 1998-2008, tevens ingedeeld naar geografische marktsegmenten en productgroepen

\begin{tabular}{|c|c|c|c|c|c|c|c|c|c|c|c|c|}
\hline \multirow[t]{2}{*}{ Jaar } & \multirow{2}{*}{$\begin{array}{l}\text { Omzet } \\
\mathrm{x} € \\
1 \mathrm{mln} .\end{array}$} & \multirow{2}{*}{$\begin{array}{l}\text { Inkoop } \\
\text { handels- } \\
\text { product }+ \\
\text { uitbesteed } \\
\text { werk }\end{array}$} & \multirow{2}{*}{$\begin{array}{l}\text { Inkoop } \\
\text { in \% } \\
\text { omzet }\end{array}$} & \multicolumn{5}{|c|}{$\begin{array}{l}\text { Omzet } \mathrm{x} € 1 \mathrm{mln} \text {. verdeeld naar } \\
\text { marktsegmenten }\end{array}$} & \multicolumn{4}{|c|}{$\begin{array}{l}\text { Omzet } \mathrm{x} € 1 \mathrm{mln} \text {. verdeeld naar } \\
\text { Productgroepen }\end{array}$} \\
\hline & & & & Ned. & Du. & Eng. & $\begin{array}{l}\text { Rest } \\
\text { EU }\end{array}$ & $\begin{array}{l}\text { Rest } \\
\text { Wereld }\end{array}$ & $\begin{array}{l}\text { Groenten } \\
\quad+ \\
\text { Fruit }\end{array}$ & \begin{tabular}{|c} 
Bloemen \\
+ \\
Planten
\end{tabular} & $\begin{array}{l}\text { Trans- } \\
\text { port }\end{array}$ & $\begin{array}{l}\text { Provi- } \\
\text { sie }\end{array}$ \\
\hline 1998 & \begin{tabular}{|l|}
1.140 \\
\end{tabular} & 920 & $\begin{array}{l}80.7 \\
*)\end{array}$ & 280.7 & 362.6 & 224.4 & 224.1 & 48.3 & 995 & 95.6 & 49.5 & \\
\hline 1999 & 1.426 & 1.254 & 87.9 & 468.7 & 397.5 & 184.7 & 293.1 & 82.0 & 1.159 & \begin{tabular}{|l|}
106.4 \\
\end{tabular} & 161.0 & \\
\hline 2000 & 1.523 & 1.344 & 88.2 & 461.2 & 452.5 & 224.6 & 239.2 & 142.7 & 1.245 & \begin{tabular}{|l|}
101.8 \\
\end{tabular} & 173.6 & \\
\hline 2001 & 1.523 & 1.326 & \begin{tabular}{|l|}
87.1 \\
\end{tabular} & 571.9 & \begin{tabular}{|l|}
388.7 \\
\end{tabular} & 240.0 & 200.2 & 122.8 & 1.283 & 105.7 & 134.3 & \\
\hline 2002 & 1.515 & 1.315 & 86.8 & 511.3 & 372.0 & 268.1 & 281.6 & 131.9 & 1.349 & 26.8 & 139.3 & \\
\hline 2003 & 1.570 & 1.280 & \begin{tabular}{|l|}
81.8 \\
$* *)$ \\
\end{tabular} & 556.4 & 320.9 & 262.6 & 316.6 & 108.2 & 1.287 & 28.7 & 160.2 & 88.5 \\
\hline 2004 & 1.426 & 1.148 & $\begin{array}{l}80.5 \\
* *) \\
\end{array}$ & 508.2 & 243.8 & 267.7 & 296.9 & 109.7 & 1.168 & 26.0 & 151.3 & 80.6 \\
\hline 2005 & 1.434 & 1.230 & \begin{tabular}{|l|}
82.1 \\
$* *)$
\end{tabular} & 555.7 & 260.3 & 271.5 & 300.6 & 109.6 & 1.248 & 27.4 & 147.9 & 73.9 \\
\hline 2006 & \begin{tabular}{|l|}
1.448 \\
\end{tabular} & 1.203 & 83.1 & 431.8 & \begin{tabular}{|l|}
307.7 \\
\end{tabular} & 258.2 & 365.2 & 85.6 & 1.272 & 28.9 & 78.9 & 69.2 \\
\hline 2007 & \begin{tabular}{|l|}
1.414 \\
\end{tabular} & 1.171 & 82.8 & $\begin{array}{l}438.4 \\
* * *)\end{array}$ & $\begin{array}{l}285.4 \\
* * *)\end{array}$ & $\begin{array}{l}243.3 \\
* * *)\end{array}$ & $\begin{array}{l}380.9 \\
* * *)\end{array}$ & $\begin{array}{l}66.0 \\
* * *)\end{array}$ & 1.255 & 0.4 & 105.0 & 53.9 \\
\hline 2008 & \begin{tabular}{|l|}
1.308 \\
\end{tabular} & 1.088 & 83.2 & 416.5 & 239.6 & 219.1 & 376.2 & 57.0 & 1.163 & 0.0 & 92.8 & 52.2 \\
\hline
\end{tabular}

*) maart 1998 integratie/overname VDD e.a., ${ }^{* *}$ ) excl. uitbesteed werk, ${ }^{* * *}$ ) correctie in jaarverslag 2008

Ontwikkelingen omzet en brutomarge

In tabel 4.2 is een aantal ontwikkelingen te constateren.

- De brutomarge (omzet - inkoop) schommelt tussen de 10 en 20\% van de omzet en is mede afhankelijk van het wel of niet uitbesteden van specifieke logistieke activiteiten (transport, sorteren, verpakken).

- De omzetontwikkeling naar marktsegmenten sinds 1998 laat het volgende zien:

- de positie van de Greenery op de Nederlandse markt is redelijk stabiel tot licht stijgend van 1999-2005, vanaf 2006 daalt de omzet;

- de positie op de Duitse markt is wisselend en teruglopend (veel concurrentie van eigen producenten en import uit andere EU-lidstaten);

- de positie op de Engelse markt en Rest EU is redelijk stabiel tot groeiende;

- de positie Rest Wereld (VS en Japan) is wisselend. De dure euro, veel concurrentie van eigen producenten en import vanuit andere landen zijn oorzaken hiervan.

- De omzetontwikkeling naar productgroepen sinds 1998 geeft het volgende aan:

de productgroep Bloemen en Planten is erg klein ten opzichte van Groenten en Fruit en valt van 2002-2006 terug tot 25 - $30 \mathrm{mln}$. euro. Daarna daalt deze omzet tot nul.

- De productgroep Transport varieert van 1999-2005 in omzet tussen de $130 \mathrm{mln}$. en $175 \mathrm{mln}$. euro. Vanaf 2006 daalt deze omzet tot ca. $100 \mathrm{mln}$. euro per jaar. 
- De dienst veilen/verkopen is hiervoor ook genoemd (zie tabel 4.1) en laat een grote terugval zien door de verminderde aanvoer dan wel uittreding van leden. Gemiddeld ligt de provisie op ca. $10 \%$ van de verkoopwaarde aanvoer, een en ander is mede afhankelijk van de gevraagde dienstverlening aan The Greenery.

\subsubsection{Resultaten periode 2009-2011}

Onderstaand volgen de resultaten van de jaren 2009-2011 in tabel 4.3 en 4.4. Zij zijn niet opgenomen in tabel 4.1 en 4.2, maar worden apart getoond en besproken.

De resultaten van het beleids- en bedrijfsonderzoek in de periode 2006, 2007 en 2008 moeten afzonderlijk kunnen worden beoordeeld, los van de kredietcrisis in 2009 en de EHEC-crisis in 2011. Om toch aansluiting te houden met een aantal voorafgaande jaren zijn 2005-2008 in tabel 4.3 en 4.4 opgenomen.

Tabel 4.3 Aanvulling omzet- en prijsontwikkeling VTN/Coforta*)/The Greenery 2009-2011

\begin{tabular}{|c|c|c|c|c|c|c|c|c|c|c|}
\hline \multirow[t]{2}{*}{ Jaar } & \multirow[t]{2}{*}{$\begin{array}{l}\text { Omzet } x \\
€ 1 \mathrm{mln}\end{array}$} & \multirow[t]{2}{*}{$\begin{array}{l}\text { Provisie } x \\
€ 1 \mathrm{mln} .\end{array}$} & \multirow{2}{*}{$\begin{array}{l}\text { Veiling- } \\
\text { omzet } \\
x € 1 \mathrm{mln} .\end{array}$} & \multirow{2}{*}{$\begin{array}{l}\text { Resultaat x } \\
€ 1 \mathrm{mln} \text {. } \\
\text { voor/na } \\
\text { belasting }\end{array}$} & \multirow{2}{*}{$\begin{array}{l}\text { Rendement } \\
\% \text { Omzet, } \% \\
\text { TV of } \% \mathrm{GV}\end{array}$} & \multirow[t]{2}{*}{$\begin{array}{l}\text { Aantal } \\
\text { fte's }\end{array}$} & \multirow{2}{*}{$\begin{array}{l}\text { Aantal } \\
\text { leden / } \\
\text { bedrij- } \\
\text { ven }\end{array}$} & \multicolumn{3}{|c|}{$\begin{array}{l}\text { Gem. veilingprijs in } \\
\text { eurocent } / \mathrm{kg} \text { excl. BTW }\end{array}$} \\
\hline & & & & & & & & $\begin{array}{l}\text { Kom- } \\
\text { kommer }\end{array}$ & $\begin{array}{l}\text { To- } \\
\text { maat }\end{array}$ & $\begin{array}{l}\text { Pa- } \\
\text { prika }\end{array}$ \\
\hline 2005 & 1.434 & 73.9 & 736 & $7.5 / 13$ & $1.4 \% \mathrm{TV}$ & 1699 & 1700 & 57 & 75 & 1.00 \\
\hline 2006 & 1.448 & 59.0 & 778 & $15 / 14$ & $2.8 \% \mathrm{TV}$ & 1693 & 1400 & 56 & 80 & 1.36 \\
\hline 2007 & 1.414 & 53.9 & 810 & $9 / 10$ & $1.8 \% \mathrm{TV}$ & 1638 & 1250 & 53 & 80 & 1.38 \\
\hline 2008 & 1.308 & 52.1 & 763 & $2 / 9$ & $0.4 \% \mathrm{TV}$ & 1661 & 1150 & 48 & 72 & 1.18 \\
\hline 2009 & 1.149 & 64.6 & 633 & $4.5 / 7$ & $0.9 \% \mathrm{TV}$ & 1655 & $\left.1006^{* *}\right)$ & 43 & 64 & 0.78 \\
\hline 2010 & 1.263 & $-* * *)$ & 749 & $4 / 5$ & $0.7 \% \mathrm{TV}$ & 1631 & $1007 * *)$ & 56 & 85 & 1.10 \\
\hline 2011 & 1.099 & - & 636 & $-4 / 2$ & $-0.8 \% \mathrm{TV}$ & 1507 & $\left.885^{* *}\right)$ & 43 & 65 & 1.02 \\
\hline
\end{tabular}

*) Vanaf maart 2010 is de naam van VTN U.A. gewijzigd in Coforta U.A., eigenaar van The Greenery b.v. Onder The Greenery b.v. vallen de twee afzetbedrijven Coforta b.v. en handelsonderneming The Greenery en een aantal dochterondernemingen (Jaarverslag VTN 2010, pp. 3, 23); **) aantal bedrijven; ***) - geen gegevens.

\section{Omzet- en prijsontwikkelingen}

In tabel 4.3 zijn van 2008-2011 de volgende ontwikkelingen in resultaat te constateren:

1. De netto-omzet van Coforta/The Greenery loopt van 2008-2011 verder terug van 1.3 mld. naar 1.1 mld. euro. Tussen krediet- en EHEC-crisis geeft 2010 een herstel tot $1.263 \mathrm{mln}$;

2. De provisie van de door de telers aangevoerde producten is van 2008-2009 met $12.5 \mathrm{mln}$. euro gestegen. De provisie van 2010 en 2011 is niet apart geregistreerd;

3. De omzet van de door de eigen leden aangevoerde producten daalt van 2008-2011 met 127 mln. euro;

4. Het rendement op het totaal vermogen daalt van $2007-2011$ van 1.8 tot $-0.8 \%$; 
5. Het aantal fte's daalt van 2008-2011 van 1661 naar 1507;

6. Het aantal leden/aanvoerders daalt van 1150 leden/bedrijven in 2008 naar 885 leden/bedrijven in 2011. In deze periode is de gemiddelde omzet per lid/bedrijf gestegen van 650.000 naar 720.000 euro;

7. De gemiddelde uitbetaalprijzen voor de drie vruchtgroenten gaan in 2009 en 2011 door de gevolgen van krediet- en EHEC-crisis flink naar beneden. In 2010 is er sprake van een aanmerkelijk herstel, vooral voor de tomaat.

Tabel 4.4 Omzet- en brutomargeontwikkeling van VTN/Coforta*)/The Greenery 2009-2011, ingedeeld naar geografische marktsegmenten en productgroepen.

\begin{tabular}{|c|c|c|c|c|c|c|c|c|c|c|c|c|}
\hline \multirow[t]{2}{*}{ Jaar } & \multirow[t]{2}{*}{$\begin{array}{l}\text { Omzet } x \\
€ 1 \mathrm{mln}\end{array}$} & \multirow{2}{*}{$\begin{array}{l}\text { Inkoop } \\
\text { handels- } \\
\text { product } \\
+ \text { uitbe- } \\
\text { steed } \\
\text { werk }\end{array}$} & \multirow{2}{*}{$\begin{array}{l}\text { Inkoop } \\
\text { in \% } \\
\text { omzet }\end{array}$} & \multicolumn{5}{|c|}{$\begin{array}{l}\text { Omzet } x € 1 \mathrm{mln} \text {. verdeeld naar } \\
\text { marktsegmenten }\end{array}$} & \multicolumn{4}{|c|}{$\begin{array}{l}\text { Omzet } \mathrm{x} € 1 \mathrm{mln} \text {. verdeeld naar } \\
\text { productgroepen }\end{array}$} \\
\hline & & & & Ned. & Du. & Eng. & $\begin{array}{l}\text { Rest } \\
\text { EU }\end{array}$ & $\begin{array}{l}\text { Rest } \\
\text { Wereld }\end{array}$ & $\begin{array}{l}\text { Groenten } \\
+ \\
\text { Fruit }\end{array}$ & $\begin{array}{c}\text { Bloemen } \\
+ \\
\text { Planten }\end{array}$ & $\begin{array}{l}\text { Trans- } \\
\text { port }\end{array}$ & $\begin{array}{l}\text { Provi- } \\
\text { sie }\end{array}$ \\
\hline 2005 & 1.434 & 1.230 & $\begin{array}{l}82.1 \\
* *)\end{array}$ & 555.7 & 260.3 & 271.5 & 300.6 & 109.6 & 1.248 & 27.4 & 147.9 & 73.9 \\
\hline 2006 & 1.448 & 1.203 & 83.1 & 431.8 & 307.7 & 258.2 & 365.2 & 85.6 & 1.272 & 28.9 & 78.9 & 69.2 \\
\hline 2007 & 1.414 & 1.171 & 82.8 & $\begin{array}{l}438.4 \\
* * *)\end{array}$ & $\begin{array}{l}285.4 \\
* * *) \\
\end{array}$ & \begin{tabular}{|l|}
243.3 \\
$* * *)$ \\
\end{tabular} & $\begin{array}{l}380.9 \\
* * *)\end{array}$ & $\begin{array}{l}66.0 \\
* * *) \\
\end{array}$ & 1.255 & 0.4 & 105.0 & 53.9 \\
\hline 2008 & 1.308 & 1.088 & 83.2 & 416.5 & 239.6 & 219.1 & 376.2 & 57.0 & 1.163 & - & 93.3 & 52.2 \\
\hline 2009 & 1.149 & 918 & 79.9 & 326.7 & $\mid 179.1$ & 213.5 & 346.1 & 83.4 & 983 & - & 101.4 & 64.6 \\
\hline 2010 & 1.263 & 1.050 & 83.1 & 285.2 & 242.4 & 252.8 & 388.0 & \begin{tabular}{|l|}
94.8 \\
\end{tabular} & - & - & - & - \\
\hline 2011 & 1.099 & 899 & 81.8 & 292.0 & 210.4 & 185.1 & 321.8 & 89.2 & - & - & - & - \\
\hline
\end{tabular}

*) Vanaf maart 2010 is de naam van VTN U.A. gewijzigd in Coforta U.A, zie tabel 4.3, **) excl. uitbesteed werk, ***) correc in jaarverslag 2008

Ontwikkelingen omzet marktsegmenten en brutomarge

In tabel 4.4 zijn in de periode $2008-2011$ de volgende ontwikkelingen in resultaat te constateren:

1. De brutomarge (omzet - inkoop) ligt tussen de 17 en $20 \%$ van de omzet;

2. De omzetontwikkeling naar marktsegmenten sinds 2008 laat het volgende zien:

a. de positie van The Greenery op de Nederlandse markt loopt verder terug van ruim $400 \mathrm{mln}$. omzet in 2008 naar krap $300 \mathrm{mln}$. euro in 2011;

b. de omzet op de Duitse markt loopt in 2009 terug door de gevolgen van de kredietcrisis, maar herstelt zich in 2010. In 2011 is er de terugval, veroorzaakt door de EHEC-crisis. In vergelijking met 2009 valt deze terugval mee;

c. de omzet op de Engelse markt toont ook een terugval in 2009 en 2011, maar de gevolgen van de EHEC-crisis laten zich hier zwaarder voelen dan die van de kredietcrisis (zie ook Jaarverslag 2011, p. 18);

d. de Rest EU laat een met Engeland vergelijkbare terugval van de omzet zien, maar deze stijgt in 2010 tot een hoog niveau (388 mln. euro); 
e. de omzet Rest Wereld (vnl. VS en Japan) lijkt enigszins te verbeteren door de waardevermindering van de euro ten opzichte van de dollar en de yen.

3. De omzetontwikkeling naar productgroepen sinds 2008 geeft alleen voor 2009 nog enige informatie. De overige gegevens worden niet meer getoond in het jaarverslag.

\subsubsection{Analyse gedragsvariabelen}

De analyse van de gedragsvariabelen, ook wel strategische variabelen genoemd, richt zich als eerste op de ontwikkeling van de horizontale en verticale concentratie van VTN/The Greenery. Horizontale concentratie wordt gevolgd van 2004-2008 en vergeleken met de concentratie direct voor en na de horizontale fusie van 1995/1996. Verticale concentratie wordt gevolgd vanaf de verticale fusie in 1997/1998-2008. Daarna worden productdifferentiatie en investering/innovatie behandeld.

\subsubsection{Horizontale concentratie}

Horizontale concentratie aan de aanbodzijde van de sector glasgroenten is in hoofdstuk 3 uitgebreid besproken, voor zowel de productiebedrijven, de telersverenigingen als de afzetorganisaties. Tabel 4.5 toont de concentratieontwikkeling (C4) bij de afzetorganisaties glasgroenten in de onderzoekperiode 2004-2008 per productgroep en totaal met tevens de behaalde productiewaarden en gemiddelde jaarprijzen uit tabel 3.54 van hoofdstuk 3.

Tabel 4.5 Horizontale concentratieontwikkeling (in \%) afzetorganisaties in glasgroenten 2004-2008 (op basis van de vier grootsten in het glasareaal $=\mathrm{C} 4$ )

\begin{tabular}{|c|c|c|c|c|}
\hline Afzetorganisaties glasgroenten & 2004 & 2006 & 2007 & 2008 \\
\hline$\bullet \quad$ C4 tomaat(\%) & 89.0 & 86.0 & & 76.0 \\
\hline$\quad$ C4 paprika(\%) & 61.0 & 70.0 & & 61.0 \\
\hline C4 komkommer(\%) & 46.0 & & & 52.0 \\
\hline$\quad$ C4 glasgroenten gemiddeld (\%) & 70.0 & 72.0 & & 66.0 \\
\hline Productiewaarden glasgroenten & 1.100 & 1.350 & 1.340 & 1.270 \\
(x 1 mln. euro) & & & & \\
\hline $\begin{array}{l}\text { Gemiddelde jaarprijzen (eurocent p. kg) } \\
\text {-tomaat }\end{array}$ & 57 & 80 & 80 & 72 \\
-paprika & 425 & 136 & 138 & 118 \\
-komkommer & 48 & 56 & 53 & 48 \\
\hline
\end{tabular}

Bron : LEI, Bunte (2009), Teelt in beeld 2004, 2006 en 2008 (bijlage vakblad Groenten \& Fruit), PT

De horizontale concentratiegraad van de vier grootste afzetorganisaties in de glasgroenten is in de periode 2004-2008 gedaald van 70 naar $66 \%$ en het aandeel van leden/telers van VTN/The Greenery in het areaal Nederlandse glasgroenten is flink afgenomen. Voor de fusie van mei 1996 bedroeg de concentratiegraad van de vier grootste van 20 veilingen (C4) ongeveer $64 \%$ (zie tabel 3.13 hoofdstuk 3). Vlak na de fusie van 9 groente- en fruitveilingen bedroeg de concentratiegraad van de vier grootste van 12 afzetorganisaties (C4) $96 \%$. Deze vier grootste zelfstandige 
afzetorganisaties waren VTN, ZON, Geldermalsen en Zaltbommel. De horizontale concentratie is in 2008 weer op het niveau van voor de fusie terechtgekomen en de beoogde grotere samenwerking en horizontale bundeling van de afzet tussen de afzetorganisaties in groenten en fruit in Nederland is tot op heden niet behaald. Als we de ontwikkelingen bij de overgebleven afzetorganisaties en coöperatieve telersverenigingen momenteel volgen, ziet het er niet naar uit dat dit binnenkort wel behaald zal worden. Zolang de twee grootste overgebleven afzetorganisaties/ voormalige veilingen Coforta/The Greenery en ZON 'verticale concentratie en groothandelsbelang' voorrang geven op 'horizontale concentratie en maximale prijzen voor de producten van de leden' zullen de meer zelfstandigheid nastrevende telers en telersverenigingen zich niet bij hen aansluiten, maar hun eigen plan trekken. Een evenwichtiger ontwikkeling van vraag en aanbod met redelijke uitbetaalprijzen voor glasgroentetelers komt dan niet snel dichterbij.

\subsubsection{Voorwaartse verticale concentratie}

In maart 1998 vond de overname en integratie plaats van de Van Dijk Delftgroep en de 'Fresh Produce' Divisie van Perkins Food plc. Hiermee verkleinde VTN/The Greenery de groothandelsmarkten in Nederland en de naburige Europese landen aanmerkelijk. Exacte cijfers over de verticale concentratiegraad ${ }^{5}$ in dat jaar zijn niet voorhanden, maar vanuit het aandeel van de VTN-leden in de jaarlijkse productiewaarde groenten en fruit gerekend, lag dat percentage in Nederland in aanvang op 50\% of meer (zie tabel 4.6). Het was voor de concurrenten/exporteurs van The Greenery van groot belang deze deels gesloten markt open te krijgen om voldoende telers/leveranciers en afnemers/grootwinkelbedrijven over te houden. Daar zijn ze goed in geslaagd. Zij benaderden op grote schaal de leden van The Greenery met alternatieve uitbetaalprijzen en klanten/retailers met aantrekkelijke verkoopvoorwaarden. Het gevolg hiervan was dat de horizontale en verticale concurrentie op de groothandels- en detailhandelsmarkten - die al groot was - extra werd aangewakkerd. In korte tijd zegden veel leden van The Greenery hun lidmaatschap op en sloten zich aan bij een telersvereniging of gingen een nieuwe relatie aan met een of meer groothandelaren/exporteurs. Voorbeelden hiervan zijn FresQ, VDN/VDT, Haluco/BGB en vele andere. In onderstaande tabel 4.6 is, mede op basis van een aantal gegevens van tabel 4.1, de ontwikkeling van de verticale integratiegraad met de resultaatsvariabelen over de periode 1998-2008 in kaart gebracht.

5 De verticale integratiegraad meet de mate van uitschakeling van de markt door verticale integratie. Transacties (T) verlopen via eigen geïntegreerde schakels van de ondernemingen, verkopen $(\mathrm{S})$ lopen via de groothandelsmarkt. De verticale integratiegraad $\mathrm{VI}_{2}=\mathrm{T} / \mathrm{S}+\mathrm{T}$ berekent het aandeel van de markt dat is afgesloten voor concurrenten. 
Tabel 4.6 Ontwikkeling verticale integratiegraad, omzet- en rendementsverloop VTN/The Greenery na de overname van VDD-groep en 'Fresh Produce' Divisie 1998-2008

\begin{tabular}{|c|c|c|c|c|c|c|c|c|c|}
\hline \multirow[t]{2}{*}{ Jaar } & \multirow{2}{*}{$\begin{array}{l}\text { VTN/The } \\
\text { Greenery } \\
\text { Omzet (x } \\
€ 1 \mathrm{mln} .)\end{array}$} & \multirow[t]{2}{*}{$\begin{array}{l}\text { Rendement } \\
\text { in } \% \text { Omzet } \\
\left.\text { of } \mathrm{TV}^{* *}\right)\end{array}$} & \multirow[t]{2}{*}{$\begin{array}{l}\text { Aantal } \\
\text { Leden }\end{array}$} & \multirow{2}{*}{$\begin{array}{l}\text { (Veiling) } \\
\text { Omzet } \\
\text { producten } \\
\text { leden } \\
(\mathrm{x} \in 1 \mathrm{mln} .)\end{array}$} & \multirow{2}{*}{$\begin{array}{l}\text { Productie- } \\
\text { waarden } \\
\text { sector } \\
(\mathrm{x} \in 1 \\
\text { mln.) }\end{array}$} & \multirow[t]{2}{*}{$\begin{array}{l}\text { Verticale } \\
\text { integratie- } \\
\text { graad } *)\end{array}$} & \multicolumn{3}{|c|}{$\begin{array}{l}\text { Gem. veilingprijs sector } \\
\text { glasgroenten in eurocent/ } \\
\text { excl. BTW (bron:PT) }\end{array}$} \\
\hline & & & & & & & $\begin{array}{l}\text { Kom- } \\
\text { kommer }\end{array}$ & Tomaat & $\mathrm{Pa}$ \\
\hline 1996 & 1.294 & $0.2 \%$ Omzet & 12000 & 1.182 & & & 45 & 91 & 1.2 \\
\hline 1997 & 1.282 & $-0.7 \%$ Omzet & 9000 & 1.225 & & & 48 & 79 & 1.5 \\
\hline 1998 & 1.140 & & & 1.127 & 2.378 & 0.47 & 50 & 81 & 1.5 \\
\hline 1999 & 1.426 & $2.3 \% \mathrm{TV}$ & & 910 & 2.174 & 0.42 & 43 & 72 & $\overline{1.2}$ \\
\hline 2000 & 1.523 & $-2.1 \% \mathrm{TV}$ & 4000 & 998 & 2.297 & 0.43 & 57 & 91 & 1.4 \\
\hline 2001 & 1.523 & $1.7 \%$ TV & & 920 & 2.366 & 0.39 & 52 & 73 & 1.3 \\
\hline 2002 & 1.515 & $3.0 \% \mathrm{TV}$ & 2500 & 881 & & & 48 & 88 & 1.1 \\
\hline 2003 & 1.570 & $2.4 \% \mathrm{TV}$ & 2200 & 890 & 2.445 & 0.36 & 53 & 89 & 1.3 \\
\hline 2004 & 1.426 & $0.8 \%$ TV & 2000 & 706 & 2.155 & 0.33 & 48 & 57 & $\overline{1.2}$ \\
\hline 2005 & 1.434 & $1.4 \%$ TV & 1700 & 736 & 2.185 & 0.34 & 57 & 75 & 1.0 \\
\hline 2006 & 1.448 & $2.8 \% \mathrm{TV}$ & 1400 & 778 & 2.480 & 0.31 & 56 & 80 & 1.3 \\
\hline 2007 & 1.414 & $1.8 \% \mathrm{TV}$ & 1250 & 810 & 2.475 & 0.33 & 53 & 80 & 1.3 \\
\hline 2008 & 1.308 & $0.4 \%$ TV & 1150 & 763 & 2.465 & 0.31 & 48 & 72 & 1.1 \\
\hline & & $\begin{array}{l}\text { Gem.2001/ } \\
2008= \\
1.45 \% \mathrm{TV}\end{array}$ & & & & & $\begin{array}{l}\operatorname{Max} . / \\
\min .= \\
1.3\end{array}$ & $\begin{array}{l}\text { Max./ } \\
\min .= \\
1.6\end{array}$ & $\begin{array}{r}\overline{\mathrm{M}} \mathrm{s} \\
\mathrm{mi} \\
1.1\end{array}$ \\
\hline
\end{tabular}

*) verticale integratiegraad = ledenomzet/productiewaarde sector (maatstaf voor voorwaartse verticale integratie)

**) TV $=$ Totaal Vermogen

In tabel 4.6 is het volgende te constateren:

1. De verticale concentratie, ingezet door de verticale fusie van VTN/The Greenery met de VDDgroep en 'Fresh Produce' in 1998 op een niveau van ongeveer 50\% is gedaald tot ca. 30\% in 2008. Dit is met name veroorzaakt door het vertrek van een groot aantal leden/bedrijven en een terugloop van de ledenomzet van 30-35\%;

2. De netto-omzet van VTN/The Greenery ligt tussen 1999 en 2007 op een redelijk stabiel niveau rond de $€ 1.5$ mld. euro. De jaren 1998 en 2003 zijn uitersten naar beneden en naar boven (1.1 en 1.6 mld. euro);

3. Het rendement over het totale vermogen over de jaren 1999-2008 ligt op een laag niveau tussen -2.1 en $+3.0 \%$. Het gemiddelde bedraagt $1.45 \%$.

\subsubsection{Productdifferentiatie}

De gedragsvariabele productdifferentiatie betreft het product- en productontwikkelingsbeleid in brede zin dat sinds de start in 1996 is gevoerd door de afzetorganisatie VTN/The Greenery. Onderzocht wordt of met dit beleid de positie op de Nederlandse en Europese markten van verse groenten, fruit en paddenstoelen wordt versterkt. In het Jaarverslag 1996 staat onder het strategisch speerpunt schaalvergroting het volgende vermeld: "The Greenery International biedt het hele jaar door een breed en diep assortiment groenten, fruit en paddenstoelen en kan hechte relaties aanknopen met grote afnemers." (Jaaroverzicht 1996, pp. 6 en 7). Samenwerken aan het 'beste vers' geeft aan dat The Greenery zich wil onderscheiden met het aanbod van een uniek assortiment verse tuinbouwproducten van hoog kwaliteitsniveau, duurzaam en veilig geteeld. 
$\mathrm{Zij}$ probeert hierbij synergie te bereiken tussen de levering van verse groenten en fruit en andere versproducten. Bij productdifferentiatie gaat het dus niet alleen om het aanbod van nieuwe producten maar ook nieuwe verkoop- en logistieke diensten die extra waarde toevoegen aan het geheel van de transactie. De vraag is nu wat de invloed is van het (nieuwe) assortiment producten en diensten op de concurrentiepositie, het onderscheidend vermogen en het resultaat van VTN/ The Greenery. Is er een betekenisvol verband tussen de inzet van (nieuwe) producten /diensten en behaalde resultaten? Hieronder wordt een aantal voorbeelden gegeven uit diverse jaarverslagen over de periode 1996-2008 van nieuw ontwikkelde producten en/of diensten. Er zijn op dit moment onvoldoende (financiële) gegevens van VTN/The Greenery of derden beschikbaar om over een eventueel verband betrouwbare uitspraken te kunnen doen.

\section{Voorbeeld 2004}

- Op de Nederlandse markt werd resultaat geboekt bij het beleveren van retailers. Hollander Barendrecht kreeg van een Nederlandse franchiseketen opdracht om de logistiek van het totale koelverssegment te verzorgen (Jaarverslag VTN 2004, p. 5).

Voorbeelden 2007

- Accountmanagement en category management-activiteiten incl. voorlichting en opleiding AGF-personeel, zie ook het AGF-handboek van The Greenery wordt verder ontwikkeld.

- Versdistributiecentrum Plus Retail met dochterbedrijf C. den Hollander wordt opgezet: The Greenery als versprovider inclusief maaltijden en zuivel (Jaarverslag VTN 2007, p. 26).

Voorbeelden 2008

- Er is een operational-excellence beleid uitgewerkt en er is sterk geïnvesteerd in zowel de automatisering van verschillende bedrijfsprocessen als in het versdistributiecentrum Hollander Barendrecht.

- Diensten op het gebied van category management zijn uitgebreid en aan klanten kan een fullservice verslogistiek dienstenpakket worden aangeboden (Jaarverslag VTN 2008, pp. 12, 13).

\subsubsection{Investering/innovatie}

De gedragsvariabele investering/innovatie betreft het investerings- en innovatiebeleid dat door VTN/The Greenery vanaf 1996-2008 is gevoerd. Dit beleid is meer gericht op het eigen bedrijfsgebeuren en probeert met doelgerichte interne investeringen en innovaties de concurrentiepositie te versterken. Ook hier is het de vraag wat de invloed is van deze (nieuwe) investeringen en innovaties op de concurrentiepositie en het resultaat van de onderneming en of er een betekenisvol verband is te constateren. Er zijn onvoldoende (financiële) gegevens beschikbaar om betrouwbare uitspraken te kunnen doen. Een aantal verwijzingen naar voorbeelden uit de jaarverslagen van (nieuwe) investeringen en innovaties volgt hieronder. 
Voorbeeld 2001

- De komende jaren zal het zogenaamde 'Greenhouse project' verder worden uitgerold, wat de realisatie inhoudt van een nieuwe logistieke infrastructuur met planning- en besturingssysteem. Een en ander moet leiden tot een optimale logistiek, voedselveiligheid, meer aandacht voor het milieu en ketenverkorting (Jaarverslag VTN 2001, p. 8).

Voorbeeld 2003

- Marketing wordt meer onderdeel van de commerciële strategie en er vindt een organisatieaanpassing plaats waarbij de afdeling productmanagement wordt omgezet in category management en brand management. Een groot deel van de category managementactiviteiten is per 1 januari 2003 georganiseerd binnen de commerciële businessunits (Jaarverslag VTN 2003, p. $6)$.

Voorbeeld 2007

- Het programma Fit4Future wordt ingevoerd inclusief voorbereiding en implementatie van de automatiseringssoftware SAP.

- Investeringen zijn gedaan in een nieuw distributiecentrum Barendrecht en in modernisering van het vrachtwagenpark voor binnen- en buitenlandse distributie (Jaarverslag VTN 2007, pp. $8,34,36)$.

\section{Voorbeelden 2008}

- Er is een kostenbesparingsprogramma (Fit4Future) van 12 miljoen euro gerealiseerd.

- Innovatieve projecten zijn gerealiseerd via de afdeling 'Kwaliteit en Milieu' op het gebied van gewasbescherming, teeltoptimalisatie en duurzaamheid (Jaarverslag VTN 2008, pp. 46, 47).

\subsection{Concurrentiestrategie, analyse en resultaten VBA en FloraHolland}

Deze paragraaf beschrijft de belangrijkste resultaten van het beleidsonderzoek Bloemenveilingen in Nederland 1980-2008 vanaf 2004-2008 (Veerman, 2010). Het betreft de ontwikkeling van de (concurrentie)strategieën, de organisatie en de bereikte resultaten van de VBA en FloraHolland apart en gezamenlijk vanaf de fusie in september 2007. Toegevoegd is een beschouwing van 2009-2011. In 4.3.5 worden de geselecteerde strategische variabelen van het marktgedrag (G), voor zover mogelijk, geanalyseerd en besproken. De resultaatsvariabelen (R) zijn opgenomen in 4.3.3 en 4.3.4.

In appendix 4B is de ontwikkeling van de gedrags- en resultaatsvariabelen 2012-2016 te zien. 


\subsubsection{Strategie en organisatie periode 2004-2008}

VBA 2004

Het verslagjaar 2004 is voor de VBA en de gehele bloemisterijsector een moeilijk jaar. Het consumentenvertrouwen is laag en de euro/dollarverhouding ongunstig. Prijzen staan onder druk evenals de marges in de keten en als meest negatieve gebeurtenis geldt de sluiting van de grenzen in Rusland (het snelst groeiende exportland tot dan toe) met een importstop vanaf juni 2004. De uitvoer naar Duitsland stabiliseert en de Engelse markt groeit minder dan voorgaande jaren. De export naar dollarlanden blijft achter door ongunstige valutaverhou-dingen. Door de stagnerende markt komen ook de opbrengsten van bloemenveiling Aalsmeer lager uit. Door bestuur en directie is besloten het kostenniveau op korte en langere termijn te verlagen. Dit laatste door invoering van het reorganisatieprogramma Turbo, dat gericht is op een efficiënter en effectiever functionerende organisatie (VBA Jaarverslag 2004, pp. 1, 7, 12). Ten opzichte van 2003 heeft de VBA in 2004 toch nog een lichte stijging van de omzet $(+2.1 \%)$ gerealiseerd, maar een daling van de winst (winst voor aftrek van belastingen van $€ 3.2 \mathrm{mln}$. in 2003 naar $€ 2.8 \mathrm{mln}$. in 2004).

De omzet is lager dan begroot, maar de groei ligt boven de gemiddelde marktgroei hetgeen leidt tot een hoger marktaandeel, van $44.4 \%$ in 2003 naar $45.0 \%$ in 2004 . Er is stevig bezuinigd op de bedrijfskosten die in 2004 ruim onder het gebudgetteerde niveau uitkomen en ook op langere termijn lager zullen uitkomen. De directie heeft volgens het jaarverslag het volste vertrouwen in deze plannen en denkt reeds in 2005 hiervan de (financiële) vruchten te kunnen plukken.

\section{Strategisch beleid}

De door bestuur en directie in het Jaarverslag 2004 geformuleerde visie luidt:

"Bloemenveiling Aalsmeer wil haar positie als toonaangevende marktplaats voor sierteelt-producten continu waarmaken en verder versterken. Door excellente dienstverlening aan aanvoerders en kopers, door het vermarkten van sierteeltproducten en het verzorgen van de logistiek, kan Bloemenveiling Aalsmeer een optimale prijsvorming realiseren voor haar leden." (VBA Jaarverslag 2004, pp. 12-17).

Op basis van deze visie (2004-2008) zijn vijf strategische speerpunten geformuleerd:

1. het versterken van de coöperatie;

2. het versterken van de commerciële slagkracht;

3. het versterken van de logistiek;

4. het versterken van het fysieke centrum;

5. het verbeteren van de kwaliteit van de organisatie.

Belangrijke markt- en bedrijfsontwikkelingen in 2004 zijn:

- opkomst van nieuwe bloemisterijverkooppunten in de vorm van ketens van bouwmarkten, tuincentra, grootwinkelbedrijven en benzinestations op de West- en Oost-Europese markt;

- invoering van het internationaal lidmaatschap (VBA Jaarverslag 2004, p. 10);

- ontwikkeling van een virtuele marktplaats Kopen op Afstand (KOA), inmiddels 10\% van de transacties omvattend, en de invoering van een electronisch ordersysteem voor de potplanten- 
handel via LAB/ Florecom (VBA Jaarverslag 2004, pp. 11, 15);

- financiële bijdrage van de VBA aan de omlegging N 201 (VBA Jaarverslag 2004, p. 9);

- 5\% participatie in Chinese sierteeltveiling in Kunming (VBA Jaarverslag 2004, p. 2).

FloraHolland 'oud' (FH) 2004

Ten opzichte van 2003 heeft FH in 2004 een lichte daling van de omzet en een stijging van de winst gerealiseerd. Evenals voor de VBA en de gehele bloemisterijsector is 2004 een moeilijk en turbulent jaar. Het consumentenvertrouwen is laag, de euro/dollarverhouding ongunstig en prijzen en marges staan onder druk. Ook de importstop in Rusland in juni 2004 zorgt voor een stagnerende vraag. Het marktaandeel van FH loopt terug van 53.3 tot 52.7 procent (FH Jaarverslag 2004, p. 20). Schaalvergroting, samenwerking, internationalisering en een tegenvallende prijsvorming voor veel producten zijn de thema's van 2004. Ondanks een iets hogere waarde van de siergewassenexport zetten een toegenomen aanbod en lagere prijzen druk op de exploitatie van FloraHolland (FH Jaarverslag 2004, p. 17).

\section{Strategisch beleid}

Vanuit de strategische visie van FloraHolland blijven onder meer de volgende vier aandachtspunten gelden:

1. uitbreiding van de afzet van snijbloemen via bemiddeling;

2. verbeteren van de plantendaghandel en het waarborgen van de positie van de plantenklok;

3. ontwikkeling van handelscentra bij de veilingen en zonodig in de nabijheid van de afzetcentra met de daarbij behorende investeringen;

4. ontwikkeling van relatievormen die passen bij de bedrijfsstructuren van grote productiebedrijven in binnen- en buitenland.

Belangrijke bedrijfsontwikkelingen (FH Jaarverslag 2004, pp. 20-22) zijn:

- een groei van de bemiddelingsomzet van snijbloemen en potplanten bij een stabiele klokomzet;

- een reorganisatie van het bemiddelingsbureau met de introductie van product-/marktteams met accountmanagement voor kwekers en kopers;

- een verbetering van de ordersystematiek Florecom en LAB voor potplanten;

- de introductie Florconcepting als nieuwe dienstverlening voor innovatieve producten;

- verdere harmonisering van electronische aanvoerbrieven, logistieke middelen en kwaliteitsborging middels zelfkeur en toename betrouwbaarheidsindex (BI) tot max. 100.

\section{VBA 2005}

Bloemenveiling Aalsmeer realiseert in 2005 een omzet van bijna $€ 1.7 \mathrm{mrd}$. Dat is een groei van $3.7 \%$. Deze groei is nagenoeg volledig te danken aan de hogere prijzen die afnemers van bloemen en planten hebben betaald. De omzet via de veilingklokken stijgt met $2 \%$, de omzet via bemiddeling (MVA) met $8 \%$. Zowel de toename van de omzet als die van de winst is hoger dan begroot. Het marktaandeel dat begroot was op een toename van $0.2 \%$, laat echter een daling zien 
van $0.3 \%$ (van 45.0 naar $44.7 \%$ ). Er wordt dus achtergebleven op de gemiddelde marktgroei en de groei van FloraHolland (VBA Jaarverslag 2005, pp. 21-22).

Relevante ontwikkelingen (VBA Jaarverslag 2005, pp. 16, 18, 19) zijn:

- volgens bestuur en directie in de toekomst een blijvende behoefte aan kleinschalige kwekers die zich specialiseren in één onderscheidend product;

- introductie vast basistarief van 1.6\% voor bemiddelingsactiviteit (MVA) en aanpassing en verlaging staffeltarieven;

- introductie klokinnovaties en proef beeldveilen voor een aantal producten;

- invoering van internationaal lidmaatschap per 1 januari 2006.

FloraHolland 'oud'( FH) 2005

2005 verloopt positiever dan de jaren 2003 en 2004 waarin de veilingomzet stagneerde. Ten opzichte van 2004 heeft $\mathrm{FH}$ in 2005 een stijging van de omzet $(+5 \%)$ en van de winst $(+$ $7 \%$ ) gerealiseerd. Dit wordt voornamelijk veroorzaakt door hogere prijzen, waarbij FH zich vooral versterkt bij de productgroepen tulp, roos en potorchidee. Voor het eerst in haar geschiedenis wordt door FH meer dan $€ 2$ mrd. jaaromzet in bloemisterijproducten door de aanvoerders gerealiseerd. Het marktaandeel gaat met $0.5 \%$ omhoog tot $53.2 \%$ (FH Jaarverslag 2005, p. 13).

\section{Bedrijfsstrategie (zie ook beleid 2004)}

FloraHolland wil de afzetketen van bloemisterijbedrijven beter laten presteren. Om dit te bereiken, wil FH een breed aanbod van bloemisterijproducten uit binnen- en buitenland aan de veilingklokken en aan het bemiddelingsbureau binden (FH Jaarverslag 2005, p. 15).

Bestuur en directie van FH zien hiertoe de volgende middelen en mogelijkheden:

- nationaal en internationaal relatiebeheer, acquisitie en accountmanagement;

- ontwikkeling van logistieke diensten in binnen- en buitenland;

- actieve benadering (met ketenpartners) van de grootschalige retail en nieuwe markten in Oosten Zuid-Europa;

- actief introductiebeleid van nieuwe producten en de ontwikkeling van verkoopbevorderende concepten;

Relevante bedrijfsontwikkelingen (FH Jaarverslag 2005, pp. 16-20) zijn:

- samenvoeging concernunit ProductMarktRelatie (PMR) management met unit Klok Naaldwijk tot Commerciële Zaken FH met focus op direct commerciële klokprocessen;

- naast een toename van de bemiddelingsomzet tevens versterken van de plantenklok door verbreden plantenassortiment (FH is inmiddels de grootste plantenveiling);

- aanscherpen dienstenpakket en tarieven bemiddelingsbureau in basis-, service- en 'dienstverlening op maat'-pakket;

- aanpassen van veilschema's en verder versterken van het electronisch KOA-systeem;

- deelname onderzoek en ontwikkeling landelijke uniforme stapelwagen (LUS) met VBA en 
VGB; medeontwikkeling logistieke standaarden, geautomatiseerd volgsysteem, oprichting en deelname aan Stichting Florilog;

- verdere ontwikkeling en uitbreiding handelsaccomodaties op de diverse FH-vestigingen.

\section{VBA 2006}

Bloemenveiling Aalsmeer realiseert in 2006 een omzet van $€ 1.756 \mathrm{mrd}$. Dat is een groei van $3.9 \%$ ten opzichte van 2005 ondanks de daling van de aanvoer met $6 \%$. Deze groei is dus volledig te danken aan de hogere prijzen die afnemers van bloemen en planten hebben betaald. Bij de verkopen via de veilingklokken groeit de omzet met $0.8 \%$, via MVA stijgt de omzet met bijna $12 \%$. De winst voor belastingen komt uit op $€ 5.6 \mathrm{mln}$. en komt nagenoeg overeen met de begroting. Het marktaandeel laat wederom een daling zien van $0.5 \%$ (van 44.7 naar 44.2\%) hetgeen duidelijk maakt dat er wordt achtergebleven op de gemiddelde marktgroei en de groei van FloraHolland (+ 6.5\%) (VBA Jaarverslag 2006, pp. 12, 13).

\section{Onderzoek fusie}

Gezien de sterk verschuivende productie- en handelsstromen in de internationale bloemisterijsector gedurende de afgelopen jaren, de toenemende schaalgrootte van productie- en handelsbedrijven en de wens van de (grote) bloemenveilingen om de functie van mondiale draaischijf van bloemisterijproducten voor Nederland te behouden, hebben de besturen van de VBA en FH per 26 oktober 2006 de intentie uitgesproken te willen fuseren en in 2007 een onderzoek naar de mogelijkheden hiervan op te starten (VBA Jaarverslag 2006, p. 1).

Strategisch beleid (VBA Jaarverslag 2006, pp. 6-11)

De VBA stelt zich ten doel zo goed mogelijk in te spelen op de behoeften van aanvoerders en klanten. De veiling biedt aanvoerders een zo sterk mogelijke marktplaats waar ze de beste prijs krijgen voor hun producten. Handelaren en exporteurs kopen hun producten in Aalsmeer, omdat ze daar een keus kunnen maken uit een zeer breed en diep assortiment. Naast een optimale match van vraag en aanbod, wil de VBA aanvoerders en klanten excellente logistieke faciliteiten bieden, zodat de producten op het juiste moment en met behoud van kwaliteit bij de klanten worden afgeleverd. Het beleid in 2006 was erop gericht om, gegeven de snel veranderende internationale context, de marktpositie van de VBA te versterken.

Belangrijke ontwikkelingen (VBA Jaarverslag 2006, pp. 6-13):

- introductie nieuw certificaat (pot)phalaenopsis Aalsmeer Quality;

- oprichting Kissit (Keten Informatie Systeem Sierteelt Transport) met FH, VGB en collectieve vervoerders;

- aanpassing dienstverlening via bemiddeling met introductie basispakket, servicepakket en diensten op maat. Belangstelling voor het servicepakket is groot $(80 \%$ van de kwekers kiest hiervoor). Hetzelfde geldt voor Persoonlijke Verkoop;

- nieuw structuurplan VBA-Centrum met diverse verbeteringen waaronder brandveiligheid;

- introductie internationaal lidmaatschap (220 leden/bedrijven). 
FloraHolland 'oud' (FH) 2006

Voor FH is 2006 een prima jaar. De omzet van FH groeit met $6.5 \%$ tot 2.136 mrd. euro. Het financieel resultaat komt met $6.2 \mathrm{mln}$. euro boven het begrote bedrag van $5 \mathrm{mln}$. De omzetstijging is voornamelijk toe te schrijven aan de positieve prijsontwikkeling van $8 \%$. Hier staat een volumedaling tegenover van ca. $1 \%$. De klokomzet is in 2006 gestegen met $4 \%$ naar $€ 1.458$ mln. en de omzet van het bemiddelingsbureau stijgt met $13 \%$ en bedraagt $€ 678 \mathrm{mln}$. (verhouding omzet klok : omzet BB als $69: 31$ ). Tevens vergroot FH wederom haar marktaandeel met $0.6 \%$ tot $53.8 \%$ (FH Jaarverslag 2006, pp. 12-15).

Vanuit de strategische visie (zie 2004 en 2005) en de ontwikkelingen staan bestuur en directie positief tegenover het voornemen tot fusie van FH en de VBA. Beide veilingen hechten aan de Nederlandse rol in de internationale afzet van siergewassen. Behoud en versterking van het Nederlandse systeem als draaischijf in de wereld waarborgen de positie van Nederlandse producenten en handelaren, maar zetten ook buitenlandse telers sterker in de markt. Een sterke cooperatieve afzet is de kern van het Nederlandse veilingsysteem. Versterking van de marktplaats en verbetering van de marktwerking, mede door het ontwikkelen van nieuwe diensten, kunnen aldus zorgen voor lagere ketenkosten, nodig om de internationale marktpositie en regiefunctie in de sector te kunnen handhaven (VBA Jaarverslag 2006, pp. 10, 21).

Als speerpunten in het beleid voor 2007 worden genoemd: (1) differentiatie van diensten en tarieven, (2) marketing, (3) dienstverlening aan de retail (samen met telers en groothandel), (4) persoonlijke verkoop en (5) internationale sourcing.

Relevante markt- en bedrijfsontwikkelingen (VBA Jaarverslag 2006, pp. 12-19):

- overname activiteiten Boskoopse veiling per 1 november 2006 (VBA Jaarverslag 2006, p. 10);

- tarieven provisie klokveilen verlaagd van $2.9 \%$ naar $2.6 \%$, tarieven bemiddelen gedifferentieerd naar basistarief van $1.6 \%$ en tarief actieve bemiddeling van $2.1 \%$;

- Europees marktaandeel Nederlandse veilingen (op basis groothandelswaarde) is $37.9 \%$ en daalt licht;

- groei omzet buitenlandse aanvoer $+8 \%$ ( $>$ concurrenten), extra aanvoerbegeleiding via VBB (Verwerking Buitenlandse Bloemen), vrachtconsolidatie en actieve sourcing;

- groei van KOA (Kopen Op Afstand) naar 305 aansluitingen en omzet van $€ 150$ mln.(50\% stijging in 2006), aandeel in klokafzet 11.6\%, uitbreiding naar veiling Rijnsburg in 2007.

\section{VBA en FH}

2007

VBA en FH zetten in 2007 totaal voor ruim 4 mrd. euro aan siergewassen om, een groei ten opzichte van 2006 met 4.4\%. Het omzetaandeel 2007 voor snijbloemen : potplanten : tuinplanten is $61.5: 31.0: 7.5$ (in 2006 was dit $63: 30: 7$ ). De groeipercentages liggen voor de snijbloemenomzet op bijna $2 \%$, voor kamerplantenomzet op bijna $9 \%$ en voor tuinplantenomzet op bijna $10 \%$. De omzetverhouding klok : bemiddeling komt voor de totale omzet van beide veilingen op 68 : 32. De sierteeltsector verwacht te blijven groeien, Bloemenbureau Holland heeft voor de 
komende tien jaar een jaarprognose opgesteld van 3 à 4 procent internationale marktgroei, hetgeen kansen biedt aan alle ketenpartners inclusief het nieuwe FH om door te groeien en te blijven innoveren. De afzet van siergewassen ontwikkelt zich in 2007 voorspoedig en de Nederlandse export groeit met $4.4 \%$. Tegenover stabilisatie in de Duitstalige landen en Zuid-Europa staat een flinke groei in Frankrijk en nog meer groei in het Verenigd Koninkrijk, Ierland en Oost Europa. Rusland blijft de grootste Oost-Europese markt, maar Polen, Tsjechië, Hongarije en Roemenië worden snel belangrijker. Opvallend is dat de snijbloemenexport bijna even snel groeit als de plantenexport. Betere prijzen dragen meer bij aan de exportgroei dan volumegroei. De rol van de grootschalig inkopende winkelketens (supermarkten, tuincentra maar ook ketens van bouwmarkten en woonwinkels) blijft in belang toenemen. De internationalisering van de sector zet onverminderd door. Nederlandse producenten zetten steeds vaker een bedrijf op in het buitenland. Voor FloraHolland betekent dit een verhoogde inspanning op het gebied van de internationale sourcing. Nederlandse producenten hebben baat bij het sterk houden van de Nederlandse handel. Om internationaal aantrekkelijk te zijn, moet de handel kunnen beschikken over een jaarrond internationaal (wereld)aanbod. Daar moet FloraHolland voor zorgen. Het fusieproces heeft de focus op de internationale product sourcing verder versterkt en er kunnen nu diensten vanuit één organisatie worden aangeboden. Buitenlandse telers die aan de lidmaatschapsvoorwaarden voldoen, krijgen bij het nieuwe FH de mogelijkheid zich aan te melden als volwaardig lid (FH Jaarverslag 2007, pp. 15-19).

In oktober 2006 is het voornemen tot fusie aangekondigd en in 2007 is dit voorbereid en uitgewerkt. Het proces verloopt volgens twee sporen: goedkeuring van de fusie door de leden van beide coöperaties en vergunningverlening door de Nederlandse Mededingingsautoriteit (NMa). Deze vergunningverlening door de NMa vereist van de bloemenveilingen een goede onderbouwing van hun positie op de internationale sierteeltmarkt waarbij duidelijkheid verschaft moet worden over een mogelijke vermindering van de concurrentie door deze fusie en een eventueel te grote economische machtspositie van het nieuwe FloraHolland op deze markt. In de loop van 2007 wordt goedkeuring verkregen van de NMa en stemmen ook de leden van VBA en FH in overgrote meerderheid in met het fusierapport (19 september 2007).

Per 1 januari 2008 kan het nieuwe FloraHolland voortvarend van start onder leiding van een nieuw bestuur, nieuwe raad van commissarissen en directie (FH Jaarverslag 2007, pp. 10, 15). Hieronder worden de (nieuwe) missie, doelstellingen en strategie van de twee fuserende bloemenveilingen voor de komende jaren aangegeven (FH Jaarverslag 2007, pp. 5, 6).

Missie en doelstellingen

Het nieuwe FloraHolland brengt telers tegen zo laag mogelijke kosten in een optimale marktpositie. Het beoogde financiële resultaat, minimaal tien mln. euro per jaar, waarborgt de continuïteit van de afzetcoöperatie en maakt vereiste investeringen mogelijk. Voor een gezonde financiële positie streeft het nieuwe FloraHolland naar een solvabiliteit van tenminste twintig procent en een risicodragend vermogen van tenminste veertig procent van het balanstotaal. FloraHolland bindt meer dan $95 \%$ van de totale Nederlandse productie van bloemen en planten. FH beoogt de 
aanvoer van buitenlandse bloemen tenminste gelijke tred te laten houden met de ontwikkelingen van de bloemenproductie buiten Nederland. De aanvoer van buitenlandse planten groeit sneller dan de plantenproductie buiten Nederland groeit. FH is marktgericht, flexibel, slagvaardig en sterk dankzij gemotiveerde, betrokken medewerkers en aantrekkelijk voor aanvoerders en kopers door de kosten/batenverhouding van haar diensten.

\section{Strategie}

Kern van de nieuwe strategie van FH is dat ze opereert met meer vestigingen. FH heeft een netwerk van exportveilingen in Aalsmeer, Naaldwijk en Rijnsburg en regionale veilingen in Venlo, Bleiswijk en Eelde. De bemiddelingsorganisatie FloraHolland Connect werkt vanuit de vestigingen en het handelscentrum Boskoop. Dit geheel vormt voor klanten één commercieel en logistiek netwerk tussen de teelt- en handelscentra van siergewassen. Telers en handelaren uit de hele wereld kunnen op de marktplaatsen van FH voor het complete assortiment siergewassen terecht. Dankzij de nieuwe omvang van FH kan ze beter inspelen op de trends van internationalisering, schaalvergroting en druk op de ketenkosten. Het uniformeren en vernieuwen van systemen, middelen, diensten en regelingen levert meer ketenefficiency en lagere kosten op. FH werkt daarin samen met haar partners voor haar bedrijfsprocessen, voor haar klanten en voor de bloemisterijsector als geheel.

Aan de hand van een zogenaamde 'SWOT-analyse' is de voorgenomen strategie vertaald naar de verschillende te ondernemen acties op korte en langere termijn (FH Jaarverslag 2007, pp. 6, 7). Omdat er in 2007 nog twee coöperaties actief waren, zijn de jaarrekeningen 2007 van VBA en FH apart verantwoord. Hieronder volgen de voornaamste (financiële) resultaten van de VBA en FH afzonderlijk.

\section{VBA 2007}

Bloemenveiling Aalsmeer realiseert in 2007 een omzet van $€ 1.823 \mathrm{mrd}$. Dat is een groei van $3.8 \%$ ten opzichte van 2006 en is voornamelijk toe te schrijven aan de positieve prijsontwikkeling met een kleine volumedaling. Bij de verkopen via de veilingklokken groeit de omzet met $1.5 \%$ naar een totaal omzet van $€ 1.236 \mathrm{mrd}$., via MVA stijgt de omzet met bijna $9.3 \%$ tot een totaalomzet van $€ 587 \mathrm{mln}$. De omzetverhouding klok : bemiddeling komt aldus op $68: 32$. De winst voor belastingen is negatief door de (extra) aftrekpost fusiegerelateerde lasten van - $€ 7.4$ mln en komt uit op - $€ 2.3 \mathrm{mln}$. Het marktaandeel laat een daling zien van $0.2 \%$ (van 44.2 naar $44.0 \%$ ) hetgeen duidelijk maakt dat er enigszins wordt achtergebleven op de gemiddelde marktgroei en de groei van FloraHolland (+ 4.9\%) (FH Jaarverslag 2007, pp. 68-71).

FloraHolland 'oud'( FH) 2007

Voor FloraHolland is 2007 zowel commercieel als financieel een goed jaar geweest. De omzetstijging bedraagt $4.9 \%$. Dit resulteert in een totaalomzet van $€ 2.240 \mathrm{mln}$., hetgeen is toe te schrijven aan een positieve prijsontwikkeling van $3.8 \%$ en een volumestijging van $1 \%$.

De omzet via de veilingklokken groeit in 2007 met $1.0 \%$ naar een totaalomzet van $€ 1.472 \mathrm{mln}$, 
via het BB stijgt de omzet met bijna $13 \%$ tot in totaal $€ 768 \mathrm{mln}$. De omzetverhouding klok : bemiddeling komt aldus op $66: 34$. De winst voor belastingen komt uit op $€ 6.7 \mathrm{mln}$, rekening houdend met de bijzondere last vanwege de fusie $(-€ 7.4 \mathrm{mln})$ en een herwaardering grondverkoop Rijnsburg en Bleiswijk van $€ 3.3 \mathrm{mln}$. Het marktaandeel laat een stijging zien van $0.2 \%$ (van 53.8 naar 54.0\%) (FH Jaarverslag 2007, pp. 42, 45).

\section{Het nieuwe FloraHolland}

\section{Resultaten}

Voor het 'nieuwe' FloraHolland is 2008 een woelig jaar met de kredietcrisis en tegenvallende omzetten. Groeimarkten krimpen als gevolg van valutaproblemen en ook het weer is een negatieve factor. De export van bloemisterijproducten uit Nederland daalt in 2008 met 3\%. Vooral de export naar het Verenigd Koninkrijk valt terug, onder meer door de waardedaling van het pond, en laat een grote daling zien van 18\%. Toch is 2008 voor FH afgesloten met een lichte plus in de omzet: deze groeit met $€ 11 \mathrm{mln}$. van $€ 4.063$ naar $€ 4.074(+0.27 \%)$. De totale opbrengsten aan provisie, heffingen en overige opbrengsten over 2008 bedragen $€ 387.3 \mathrm{mln}$. en zijn eveneens iets hoger dan in 2007 (€ 386.6 mln.) (FH Jaarverslag 2008, pp. 5, 7, 8, 9).

\section{Strategie en organisatie}

Gebundelde kracht in een open markt wordt de nieuwe strategische visie die directie en bestuur in de eerste helft 2008 ontwikkelt en in het najaar met de leden op regio-bijeenkomsten wordt besproken en ondersteund. Binding met de leden blijft het leidend beginsel voor de coöperatie. FloraHolland ontwikkelt voor haar leden marktplaatsen. Zij bundelt aanbod aan de coöperatie via (verkoop)diensten die voor leden waarde toevoegen tegen tarieven en andere voorwaarden die voor leden gunstiger zijn dan voor niet-leden (FH Jaarverslag 2008, pp. 18, 19, 20).

Nieuwe diensten zijn:

- internationale dienstverlening zoals logistiek, marktinformatie, productkwaliteit;

- maatwerk voor directe afzet in de vorm van conceptontwikkeling voor kwekersgroepen in samenwerking met retailorganisaties;

- virtualisering van de marktplaats bijvoorbeeld via KOA, beeldondersteunend veilen, FloraHolland e-Trade, Plantconnect.nl met electronische aanbodsbank potplanten e.a.

Direct na 1 januari 2008 begint de integratie van de organisatie. Op commercieel gebied werken de exportmarktplaatsen Aalsmeer, Naaldwijk en Rijnsburg en de bemiddelings-organisatie FloraHolland Connect steeds meer samen. Dat geldt eveneens voor de regionale marktplaatsen die zich op de binnenlandse markt richten. De verschillende vestigingen opereren in het belang van de kweker en de klant, niet in het belang van de eigen marktplaats. Dat leidt steeds vaker tot horizontale samenwerking. Nieuwe diensten, systemen en ontwikkelingen worden tussen de verschillende onderdelen van FloraHolland uitgewisseld.

Belangrijk onderdeel van de nieuwe samenwerking is het samen opstellen van veilschema's. FloraHolland wil voor alle leden de hoogst mogelijke prijs tegen de laagst mogelijke kosten realiseren. Afstemming van veilschema's kan een bijdrage leveren om tot maximale opbrengsten te komen. Een beter afgestemd veilschema draagt bij aan een gelijkmatiger prijsvorming op de 
marktplaatsen, zodat de productstromen tussen de veilingen krimpen, wat ketenkosten bespaart. Tenslotte zijn goed afgestemde veilschema's een eerste stap richting landelijk virtueel veilen. In 2009 wordt dit nader onderzocht. Traditionele waarden zoals afzetzekerheid en betalingszekerheid blijven daarbij gekoesterd. De omvangrijke uniformeringstrajecten rondom de stapelwagen en de integratie van de aanvoerders- en kopersbestanden zijn in 2008 begonnen en worden resp. in 2012 en januari 2010 afgerond (FH Jaarverslag 2008, p. 5).

Andere relevante zaken in het jaarverslag 2008 zijn:

- hernieuwde discussie 2009 over transparant tarievenstelsel en invoering marktplaatsbijdrage;

- samenwerking in de keten volgens nieuwe ketenstandaarden op ICT- en logistiek gebied via FlorEcom en Florilog en het verder uitrollen van het transportvolgsysteem KISSit waarin FH mede participeert (FH Jaarverslag 2008, p. 20);

- verdere invoering beeldveilen exportvestigingen, beeldondersteunend veilen regionale vestigingen, invoering virtuele klok Aalsmeer (FH Jaarverslag 2008, p. 18).

\subsubsection{Strategie en organisatie periode 2009-2011} 2009

De problemen van de kredietcrisis treffen ook de sierteeltsector. De omzetten van veiling, telers en handelaren liggen flink onder het niveau van 2008. Bij een vrijwel gelijkblijvend aanbod, dalen de prijzen sterk. De omzet in 2009 is uitgekomen op $€ 3.861$ miljoen (2008: $€ 4$ 4.074) wat neerkomt op een daling van 5,2\%. De verhouding omzet klok : omzet BB komt in 2009 uit op 62 : 38 (in 2008 op $65: 35$ ). De export daalt met 4\% vooral door de economische situatie en het slechte weer begin van het jaar. De omzetdaling begin 2009 maakt bijstelling van de begroting 2009 al vroeg in het jaar noodzakelijk. Uitgegaan wordt van een daling met $10 \%$. Om dit op te vangen worden de kostenbudgetten met $€ 17$ miljoen verlaagd. Ook een groot aantal investeringen wordt doorgeschoven waardoor het investeringsbudget van $€ 104$ miljoen wordt gehalveerd. De uiteindelijke daling van de omzet is minder groot dan verwacht. Door de uitgevoerde besparingsoperaties is het financiële resultaat zelfs gestegen van $€ 5.5$ in 2008 naar $€ 7.6 \mathrm{mln}$. in 2009 (FH Jaarverslag 2009, p. 31).

Analyse van de omzet- en exportcijfers laat zien dat de consumenten bloemen en planten blijven kopen. De internationale consumptie blijft redelijk op peil. De prijsdaling (snijbloemen min tien procent) was deels een gevolg van een sterke waardedaling van de voor de export van Nederlandse sierteeltgewassen belangrijke valuta, zoals het Britse pond, de Russische roebel en de Poolse zloty. Deze drie landen zijn goed voor dertig procent van de export van sierteeltgewassen. De prijsvorming van kamerplanten staat onder druk, al is dat door verschuiving in het aanbod in de cijfers minder goed zichtbaar (FH Jaarverslag 2009, p. 7).

De kosten van het afzetapparaat kunnen fors worden teruggedrongen waardoor kostenverhogingen uitblijven. Hier en daar worden zelfs kostenverlagingen voor de leden en kopers doorgevoerd. Ondanks de recessie wordt er een aantal belangrijke stappen gezet, zoals de verdere virtualisering van het veilproces, de focus op het product-/marktmanagement vanuit een centrale 
visie van FloraHolland, versterkt risicobeheer en duurzaam ondernemen. Ook de aankondiging van de joint venture tussen FloraHolland en het Duitse Landgard, die leidt tot Veiling RheinMaas, en de integratie van TFA in FloraHolland horen hierbij. Dit alles met het doel vraag en aanbod optimaal te verbinden (FH Jaarverslag 2009, p. 5).

\section{Strategisch beleid}

In 2008 stelt FloraHolland haar strategische visie 'Gebundelde kracht in een open markt' vast.

Die visie benoemt de kerngebieden van het beleid:

- het zo veel mogelijk binden van omzet via het lidmaatschap;

- het ontwikkelen van diensten om internationaal aanbod te binden;

- het creëren van maatwerkdiensten om directe stromen te binden;

- het benutten van mogelijkheden van virtualisering in de afzet.

Op elk van deze punten wordt in 2009 goede voortgang geboekt (FH Jaarverslag 2009, p. 11).

Virtualisering van het veilproces

Om de voordelen van virtualisering te benutten, harmoniseert FloraHolland veilschema's en zijn er meer klokken op de exportvestigingen beschikbaar in 2009. Met name in Naaldwijk en Rijnsburg worden de veilingklokken gemoderniseerd. In Aalsmeer is dat proces al gaande. FloraHolland schat in dat in 201065 tot $75 \%$ van alle bloemen via beeldveilen zal worden verkocht en dat 55 à $60 \%$ van de bloemen via KOA zal gaan. Beide inschattingen zijn op basis van omzet (FH Jaarverslag 2009, p. 14).

2010

In 2010 herstelt de sector sierteelt zich snel van het crisisjaar 2009. Voor FloraHolland is 2010 een goed jaar, voor veel telers en handelaren is het herstel echter onvoldoende voor een gezonde bedrijfsvoering. De exportveilingen van FloraHolland worden met op elkaar afgestemde veilschema's, diensten en systemen steeds meer één marktplaats. Het draagvlak voor beeldveilen is door goed overleg verbreed en maakt verdere invoering mogelijk. FloraHolland Connect heeft haar werkwijze beter aangepast aan de specifieke producten, concepten en marktvragen van kwekers en klanten (FH Jaarverslag 2009, p. 7).

In 2010 is de omzet uitgekomen op $€ 4.130$ ten opzichte van $€ 3.861$ in 2009 ( $+7 \%$, waarvan $6 \%$ prijs- en 1\% afzetstijging). Het financiële resultaat stijgt van $€ 7.6 \mathrm{mln}$. in 2009 naar $€ 11.9 \mathrm{mln}$. in 2010. De verhouding omzet klok : omzet BB komt in 2010 uit op $60: 40$ (in 2009 op $62: 38$ ). De export stijgt met 5.4\%, voornamelijk naar Midden- en Oost-Europa en de kernlanden België, Duitsland en het Verenigd Koninkrijk (FH Jaarverslag 2010, p. 37).

Kernwaarden, toekomst en strategie FloraHolland

FloraHolland wil een duidelijke koers varen en voortdurend werken aan verbetering van haar diensten volgens de wensen van de klant. Zij hanteert hierbij de vier kernwaarden: dienstverlenend, durf, duidelijkheid en duurzaamheid (FH Jaarverslag 2010, p. 9).

FH is gericht op een duurzame toekomst met een gezonde groei, oog voor mens en milieu en 
zorg voor werkgelegenheid. Daarin ligt de focus op de volgende strategische activiteiten:

- basis- en maatwerkdiensten;

- versterken internationale productie- en afzetbevordering;

- moderniseren verkoop via veilingklokken (virtualisering);

- intensiveren directe verkoop;

- stroomlijnen ketenprocessen;

- verhogen kwaliteit;

- verrijken assortiment;

- verstevigen product- en conceptontwikkeling;

- ontwikkelen medewerkers;

- toonaangevend werkgeverschap.

\section{1}

Het jaar 2011 is een bijzonder jaar voor FloraHolland in verband met de viering van het honderd jaar coöperatief ondernemerschap. Ter ere hiervan ontvangt zij het predicaat Koninklijk uit handen van koningin Beatrix (FH Jaarverslag 2011, pp. 4, 5). Commercieel gezien is 2011 een lastig jaar. Druk op de prijzen, hoge lasten en strengere eisen van de banken maken het ondernemen voor leden en klanten niet gemakkelijk. De aanhoudende Europese schuldencrisis tast het vertrouwen van consumenten aan en tempert de vraag. Toch groeit de omzet van FloraHolland licht. In 2011 komt de productomzet uit op $€ 4.158 \mathrm{mln}$. (2010: $€ 4.130 \mathrm{mln}$.). Dit betekent een groei van $0.7 \%$ met een verlaging van het gemiddeld prijsniveau en een verhoging van het afzetniveau (-1.8\% prijs- en $+2.5 \%$ afzetstijging). De verhouding omzet klok : omzet BB komt in 2011 uit op $57: 43$ (in 2010 op $60: 40$ ). Het exploitatieresultaat van FH bedraagt $€ 13.2 \mathrm{mln}$. euro hetgeen $€ 1.3 \mathrm{mln}$. hoger is dan in 2010. De export stijgt met $1.9 \%$, voornamelijk naar de kernlanden Frankrijk en het Verenigd Koninkrijk en daarnaast naar Midden- en Oost-Europa en Scandinavië. De export naar Duitsland groeit in 2011 met 1.7\%. De solvabiliteitsratio is met $0.2 \%$ gestegen naar $23.1 \%$ en de ratio risicodragend vermogen komt uit op $47.3 \%$.

\section{Strategisch beleid}

In 2011 heeft Koninklijke FloraHolland haar missie en strategische doelstellingen opnieuw vastgesteld (FH Jaarverslag 2011, p. 8). Koninklijke FloraHolland is een dienstverlenend bedrijf, waarvan telers van bloemen en planten uit de hele wereld lid zijn. De coöperatie wil voor haar leden optimaal rendement realiseren, door het organiseren van een geheel van marktplaatsen en daarmee samenhangende diensten en voorzieningen, met hoge verkoopopbrengsten tegen lage afzetkosten.

De strategische doelstellingen voor de komende jaren zijn:

1. behoud van de centrale positie van het Nederlandse cluster;

2. binden van aanbod en vraag door middel van een internationaal servicenetwerk;

3 . versterken van toegevoegde waarde en onderscheidend vermogen van afzet via KFH. 
Tabel 4.7 Ontwikkeling omzet, veilingprijzen en overige kerncijfers vanaf 2003-2008 bloemenveilingen FloraHolland (FH) te Naaldwijk en VBA te Aalsmeer voor en na de fusie van september 2007

\begin{tabular}{|c|c|c|c|c|c|c|c|c|c|c|c|c|c|c|}
\hline \multirow[t]{2}{*}{ Jaar } & \multirow[t]{2}{*}{$\begin{array}{l}\text { Om- } \\
\text { zet } \\
x \in 1 \\
\text { mln. }\end{array}$} & \multicolumn{2}{|c|}{$\begin{array}{l}\text { Markt- } \\
\text { aandeel } \\
\text { in } \%\end{array}$} & \multirow[t]{2}{*}{$\begin{array}{l}\text { Provisie } \\
/ \\
\text { Heffing } \\
x \\
€ 1 \mathrm{mln} .\end{array}$} & \multirow[t]{2}{*}{$\begin{array}{l}\text { Veiling- } \\
\text { omzet x } \\
€ 1 \mathrm{mln} \text {. } \\
\text { verhou- } \\
\text { ding } \\
\text { klok/ } \\
\text { bemid- } \\
\text { deling }\end{array}$} & \multirow[t]{2}{*}{$\begin{array}{l}\text { Resul } \\
\text { taat x } \\
€ 1 \\
\text { mln. } \\
\text { voor/ } \\
\text { na } \\
\text { belast } \\
\text { ing }\end{array}$} & \multirow[t]{2}{*}{$\begin{array}{l}\text { Ren- } \\
\text { de- } \\
\text { ment } \\
\text { in \% } \\
\text { T.V. }\end{array}$} & \multicolumn{2}{|c|}{$\begin{array}{l}\text { Solvabiliteits- } \\
\text { ratio's Eigen } \\
\text { Vermogen en } \\
\text { Risicodragend } \\
\text { Vermogen; } \\
\text { E.V. en R.V. } \\
\text { in \% balans- } \\
\text { totaal }\end{array}$} & \multirow[t]{2}{*}{$\begin{array}{l}\text { Aan- } \\
\text { tal } \\
\text { fte's }\end{array}$} & \multirow[t]{2}{*}{$\begin{array}{l}\text { Aan- } \\
\text { tal } \\
\text { leden }\end{array}$} & \multicolumn{3}{|c|}{$\begin{array}{l}\text { Gemiddelde } \\
\text { (theoretische) veiling- } \\
\text { prijs in eurocent/st. } \\
\text { excl. BTW; } \\
\text {-omzet in } € \text { x } 1 \mathrm{mln} \text {. } \\
\text {-afzet in st. x } 1 \mathrm{mln} \text {. }\end{array}$} \\
\hline & & $\mathrm{FH}$ & $\begin{array}{l}\mathrm{VB} \\
\mathrm{A}\end{array}$ & & & & & $\begin{array}{l}\text { ratio } \\
\text { E.V. } \\
\text { in } \%\end{array}$ & $\begin{array}{l}\text { Ratio } \\
\text { R.V. } \\
\text { in } \%\end{array}$ & & & Roos & $\begin{array}{l}\text { Chry- } \\
\text { sant } \\
\text { ( tros) }\end{array}$ & $\begin{array}{l}\text { Phae } \\
\text { la- } \\
\text { nop- } \\
\text { sis }\end{array}$ \\
\hline 2003 & $\begin{array}{l}\text { FH } \\
206.8 \\
\\
\text { VBA } \\
182.8\end{array}$ & $\begin{array}{l}53 . \\
3\end{array}$ & $\begin{array}{l}44 . \\
4\end{array}$ & $\begin{array}{l}\text { FH } \\
105.0 \\
(62+43) \\
\text { VBA } \\
100.1 \\
(54+46)\end{array}$ & $\begin{array}{l}\text { FH } \\
1.919 \\
(71: 29) \\
\\
\text { VBA } \\
1.598\end{array}$ & $\begin{array}{l}\text { FH } \\
6.1 / \\
4.4 \\
\\
\text { VBA } \\
3.3 / \\
2.4\end{array}$ & $\begin{array}{l}\text { VBA } \\
0.7\end{array}$ & $\begin{array}{l}\text { VBA } \\
15.8\end{array}$ & $\begin{array}{l}\text { VBA } \\
37.2\end{array}$ & $\begin{array}{l}\text { VBA } \\
1699\end{array}$ & $\begin{array}{l}\text { FH } \\
3996 \\
\\
\text { VBA } \\
3000\end{array}$ & $\begin{array}{l}\text { VBA } \\
0,20\end{array}$ & $\begin{array}{l}\text { VBA } \\
0,21\end{array}$ & $\begin{array}{l}\text { VBA } \\
4,57\end{array}$ \\
\hline 2004 & $\begin{array}{l}\text { FH } \\
213.6 \\
\text { VBA } \\
185.3\end{array}$ & $\begin{array}{l}52 . \\
7\end{array}$ & $\begin{array}{l}45 . \\
0\end{array}$ & $\begin{array}{l}\text { FH } \\
107.3 \\
(61+46) \\
\text { VBA } \\
103.7 \\
(54+50) \\
\end{array}$ & $\begin{array}{l}\text { FH } \\
1.910 \\
(71: 29) \\
\text { VBA } \\
1.630\end{array}$ & $\begin{array}{l}\text { FH } \\
7.1 / \\
5.0 \\
\text { VBA } \\
3.0 / \\
2.6 \\
\end{array}$ & $\begin{array}{l}\text { FH } \\
1.3 \\
\text { VBA } \\
0.6\end{array}$ & $\begin{array}{l}\text { FH } \\
19.9 \\
\text { VBA } \\
15.7\end{array}$ & $\begin{array}{l}\text { FH } \\
42.4 \\
\text { VBA } \\
36.6\end{array}$ & $\begin{array}{l}\text { FH } \\
2209 \\
\\
\text { VBA } \\
1651\end{array}$ & $\begin{array}{l}\text { FH } \\
3803 \\
\\
\text { VBA } \\
2800\end{array}$ & $\begin{array}{l}\text { VBN } \\
0,21\end{array}$ & $\begin{array}{l}\text { VBN } \\
0,20\end{array}$ & $\begin{array}{l}\text { VBN } \\
4,61\end{array}$ \\
\hline 2005 & $\begin{array}{l}\text { FH } \\
213.0 \\
\text { VBA } \\
181.3\end{array}$ & $\begin{array}{l}53 . \\
2\end{array}$ & $\begin{array}{l}44 . \\
7\end{array}$ & $\begin{array}{l}\text { FH } \\
108.5 \\
(63+45) \\
\text { VBA } \\
104.5 \\
(54+51)\end{array}$ & $\begin{array}{l}\text { FH } \\
2.005 \\
(70: 30) \\
\text { VBA } \\
1.690\end{array}$ & $\begin{array}{l}\text { FH } \\
7.6 / \\
5.4 \\
\text { VBA } \\
9.0 / \\
5.9 \\
\end{array}$ & $\begin{array}{l}\text { FH } \\
1.4 \\
\text { VBA } \\
1.9\end{array}$ & $\begin{array}{l}\text { FH } \\
19.5 \\
\\
\text { VBA } \\
14.3\end{array}$ & $\begin{array}{l}\text { FH } \\
41.3 \\
\\
\text { VBA } \\
38.4\end{array}$ & $\begin{array}{l}\text { FH } \\
2123 \\
\\
\text { VBA } \\
1524\end{array}$ & $\begin{array}{c}\text { FH } \\
+ \\
+ \\
\text { VBA } \\
6000\end{array}$ & $\begin{array}{l}\text { VBN } \\
€ 729 / \\
3.552 \\
\text { st. }= \\
0.21\end{array}$ & $\begin{array}{l}\mathrm{VBN} \\
€ 293 / \\
1.361 \\
\text { st. }= \\
0.22\end{array}$ & $\begin{array}{l}\text { VBN } \\
€ 144 \\
/ 29 \\
\text { st. }= \\
4,90\end{array}$ \\
\hline 2006 & $\begin{array}{l}\text { FH } \\
212.3 \\
\text { VBA } \\
182.0 \\
\\
394.3\end{array}$ & $\begin{array}{l}53 . \\
8\end{array}$ & $\begin{array}{l}44 . \\
2\end{array}$ & $\begin{array}{l}\text { FH } \\
101.8 \\
(57+45) \\
\text { VBA } \\
103.0 \\
(53+50)\end{array}$ & $\begin{array}{l}\text { FH } \\
2.136 \\
(69: 31) \\
\text { VBA } \\
1.756 \\
(69: 31) \\
3.892 / \\
69: 31 \\
\end{array}$ & $\begin{array}{l}\text { FH } \\
8.8 / \\
6.2 \\
\text { VBA } \\
6.4 / \\
5.6\end{array}$ & $\begin{array}{l}\text { FH } \\
1.6 \\
\text { VBA } \\
1.3\end{array}$ & $\begin{array}{l}\text { FH } \\
19.7 \\
\\
\text { VBA } \\
14.8\end{array}$ & $\begin{array}{l}\text { FH } \\
40.9 \\
\\
\text { VBA } \\
40.7\end{array}$ & $\begin{array}{l}\text { FH } \\
2090 \\
\\
\text { VBA } \\
1523 \\
\\
\text { tot. } \\
3613 \\
\end{array}$ & $\begin{array}{l}\text { FH+ } \\
\text { VBA } \\
5450\end{array}$ & $\begin{array}{l}\text { VBN } \\
€ 758 / \\
3.346 \\
\text { st. }= \\
0.23\end{array}$ & $\begin{array}{l}\text { VBN } \\
€ 300 / \\
1.318 \\
\text { st. }= \\
0.23\end{array}$ & $\begin{array}{l}\text { VBN } \\
€ 174 \\
/ 34 \\
\text { st. }= \\
5,11\end{array}$ \\
\hline 2007 & $\begin{array}{l}\text { FH } \\
216.7 \\
\text { VBA } \\
182.8 \\
*) \\
\\
399.5\end{array}$ & $\begin{array}{l}54 . \\
0\end{array}$ & $\begin{array}{l}44 . \\
0\end{array}$ & $\begin{array}{l}\text { FH } \\
103.0 \\
(57+46) \\
\text { VBA } \\
102 \\
(51+51)\end{array}$ & $\begin{array}{l}\text { FH } \\
2.240 \\
+\mathrm{VBA} \\
1.823= \\
4.063 / \\
67: 33\end{array}$ & $\begin{array}{l}\text { FH } \\
7.3 / \\
6.2 \\
\text { VBA } \\
-2.2 / \\
-1.7 \\
\text { gem. } \\
3.4 / \\
5.5 \\
\end{array}$ & $\begin{array}{l}\text { FH } \\
1.3 \\
\text { VBA } \\
-0.5\end{array}$ & $\begin{array}{l}\text { FH } \\
19.5 \\
\text { VBA } \\
12.3\end{array}$ & $\begin{array}{l}\text { FH } \\
40.0 \\
\\
\text { VBA } \\
37.2\end{array}$ & $\begin{array}{l}\text { FH } \\
2114 \\
\text { VBA } \\
1515 \\
\text { tot. } \\
3629\end{array}$ & $\begin{array}{l}\text { FH+ } \\
\text { VBA } \\
5323\end{array}$ & $\begin{array}{l}\text { VBN } \\
€ 781 / \\
3.219 \\
\text { st. }= \\
0.24\end{array}$ & $\begin{array}{l}\text { VBN } \\
€ 295 / \\
1.300 \\
\text { st. }= \\
0.23\end{array}$ & $\begin{array}{l}\text { VBN } \\
€ 219 \\
/ 45 \\
\text { st. }= \\
4.87\end{array}$ \\
\hline 2008 & $\begin{array}{l}\text { FH } \\
\text { nieuw } \\
387.3\end{array}$ & & & $\begin{array}{l}209(97 \\
+112.0)\end{array}$ & $\begin{array}{l}4.074 / \\
65: 35\end{array}$ & $\begin{array}{l}5.5 / \\
3.3\end{array}$ & $\begin{array}{l}5.8 / \\
961= \\
0.58\end{array}$ & $\begin{array}{l}205 / \\
961= \\
21.4\end{array}$ & $\begin{array}{l}451 / \\
961= \\
47.0\end{array}$ & 3555 & 5124 & $\begin{array}{l}€ 785 / \\
3.365 \\
\text { st. }= \\
0.23 \\
\end{array}$ & $\begin{array}{l}268 / \\
1.279 \\
\text { st. }= \\
0.21 \\
\end{array}$ & $\begin{array}{l}€ 288 \\
/ 71 \\
\text { st. }= \\
4.06\end{array}$ \\
\hline
\end{tabular}

*) volgens geconsolideerde winst- en verliesrekening VBA incl. Hobaho Hortigroep en koelhuisactiviteiten 
Versterken Nederlandse afzetmodel

FH liet onderzoek doen naar waardeontwikkeling in de sierteeltsector tot 2020. De uitkomsten hiervan geven aan dat de Europese consumptie van bloemen en planten tussen 2010 en 2020 groeit van $25 \mathrm{mrd}$. naar $32 \mathrm{mrd}$. euro. Die groei betreft vooral Oost-Europa en de grootschalig inkopende retailbedrijven. Nederland laat kansen liggen, omdat er in de keten nog te weinig wordt samengewerkt, het Nederlandse afzetsysteem te weinig toegankelijk is en de veilingklok verdere versterking nodig heeft. Consortia van telers, handelaren, andere partijen en de veiling moeten de positie van de gebruikers van het Nederlandse afzetmodel versterken. Eind 2011 zijn al twee van deze consortia opgezet. Eind 2012 moeten dat er vijf zijn (FH Jaarverslag 2011, p. 22).

\subsubsection{Resultaten periode 2003-2008}

In tabel 4.7 wordt een overzicht gegeven van de belangrijkste resultaten van VBA en FloraHolland over de periode 2003-2008. Na analyse hiervan en het in de voorgaande paragrafen beschreven strategisch beleid worden onder de tabel de belangrijkste ontwikkelingen aangegeven.

\section{Ontwikkelingen}

In bovenstaande tabel is een aantal ontwikkelingen te constateren.

- De omzet van FH groeit van 2003-2007 van $€ 1.919$ mln. naar $€ 2.240 \mathrm{mln}$. dus $16.7 \%$ over 5 jaar (gemiddeld 5.3\% per jaar). De verhouding klok : bemiddeling verschuift van 71 : 29 naar 67 : 33. Het marktaandeel daalt in 2005 met $0.6 \%$ ( van 53.3 naar $52.7 \%$ ) en stijgt daarna weer tot $54.0 \%$ in 2007.

De omzet van de VBA groeit van 2003-2007 van $€ 1.598 \mathrm{mln}$. naar $€ 1.823 \mathrm{mln}$.dus $14 \%$ over 5 jaar (= gemiddeld 2.8\% per jaar). De verhouding klok : bemiddeling is in $200669: 31$ en in 200767 : 33. Van de andere jaren zijn geen gegevens bekend. Het marktaandeel stijgt in 2005 met $0.6 \%$ (van 44.4 naar $45.0 \%$ ) en daalt daarna tot $44.0 \%$ in 2007 .

- De verkoopprovisie ligt bij FH en de VBA in 2003/2004 op gemiddeld 3 - 3,5\% en verschuift bij beide veilingen naar een lager niveau in 2006/2007 (2,5 - 3\%). In 2008 ligt het bij het nieuwe FH op $2.4 \%$. Het percentage heffingen ligt hier in 2003/2004 ca. 1\% onder en wordt in 2007/2008 op een enigszins hoger niveau gebracht evenals de overige inkomsten. Gemiddeld liggen de totale jaarinkomsten voor beide veilingen op 10 - 11\% van de jaarlijkse productopbrengst.

- Het resultaat voor belastingen ligt bij FH in bijna alle jaren (2005 niet) boven dat van de VBA en schommelt tussen de $€ 6.1 \mathrm{mln}$. en $€ 7.8 \mathrm{mln}$. Bij de VBA ligt dit tussen de - $€ 2.3 \mathrm{mln}$. en $€ 9.0 \mathrm{mln}$. In 2008 ligt het gezamenlijk resultaat op $€ 5.5 \mathrm{mln}$. Voor het rendement op totaal vermogen (RTV) geldt dit eveneens: voor FH schommelt dit tussen 1.4 en $1.2 \%$ en voor de VBA tussen -0.5 en $1.9 \%$. In 2008 is het RTV voor het nieuwe F.H. $0.6 \%$.

- De solvabiliteitsratio's Eigen Vermogen (E.V.) en Risicodragend Vermogen (R.V.) liggen voor FH van 2003-2007 tussen 18.6 - 19.9\% resp. tussen 40.4 - 42.4\%. Voor de VBA zijn deze cijfers 12.3 - $15.8 \%$ resp. $36.6-40.7 \%$. 
- Zowel voor FH als voor de VBA is er een voortdurende daling van het aantal werknemers op fte-basis: voor FH van 2003-2007 van 2287 naar 2114 en voor de VBA van 1699 naar 1515. In 2008 ligt het totale aantal werknemers voor het nieuwe FH op 3555.

- Het aantal leden daalt voor FH van 2003-2007 van ca. 4000 naar ca. 3000 en voor de VBA van ca. 3000 naar ca. 2000. In 2008 ligt het totale aantal leden voor het nieuwe FH op 5124. De gemiddelde veilingomzet per lid is voor alle bloemenveilingen in Nederland (VBN) van 1990 -2000 gestegen van ca. $€ 240.000$ naar ca. $€ 365.000$ en daarna meer dan verdubbeld tot in 2008 ruim $€ 800.000$.

- De gemiddelde veilingprijs voor de roos (alle soorten incl. import) ontwikkelt zich in de aanloop naar de veilingfusie tamelijk stabiel en ligt van 2003-2005 op 0.20/ 0.21 eurocent en stijgt naar 0.23/0.24 eurocent in 2006, 2007 en 2008. Bedacht moet worden dat deze prijs het gemiddelde is van de kleinbloemige, de grootbloemige en de (tros)roos. Voorts vindt er een aanmerkelijke verschuiving plaats bij de Nederlandse rozenkwekers naar de teelt van grootbloemige rozen en verdwijnen de arbeidsintensieve soorten (waaronder kleinbloemige) naar importlanden (Kenia e.a.).

- De gemiddelde veilingprijs voor de chrysant (alle soorten) ontwikkelt zich in de aanloop naar de veilingfusie tamelijk stabiel en ligt van 2003-2005 op 0.21/0.22 eurocent en stijgt naar 0.23 eurocent in 2006 en 2007. In het fusiejaar 2008 daalt deze prijs tot 0.21 eurocent.

- De gemiddelde veilingprijs voor de phalaenopsis schommelt in de aanloop naar de fusie tussen $€ 4.57$ en $€ 5.11$. In 2008 zakt de prijs tot een historisch dieptepunt door enerzijds een teruglopende vraag ten gevolge van de kredietcrisis, anderzijds een (te) groot aanbod van phalaenopsistelers in Nederland.

\subsubsection{Resultaten periode 2009-2011}

Onderstaand volgen de resultaten van de jaren 2009, 2010 en 2011 in tabel 4.8. Zij zijn niet opgenomen in tabel 4.7 maar worden apart getoond en besproken. De resultaten van het beleids- en bedrijfsonderzoek in de periode 2006, 2007 en 2008 moeten afzonderlijk kunnen worden beoordeeld, los van de kredietcrisis in 2009 en de EHEC-crisis in 2011. Om aansluiting te houden met het voorafgaande jaar is 2008 in tabel 4.8 opgenomen. 
Tabel 4.8 Ontwikkeling omzet, veilingprijzen en overige kerncijfers vanaf 2008-2011

FloraHolland (FH) te Aalsmeer na de fusie van september 2007.

\begin{tabular}{|c|c|c|c|c|c|c|c|c|c|c|c|c|c|}
\hline \multirow[t]{2}{*}{ Jaar } & \multirow[t]{2}{*}{$\begin{array}{l}\text { Omzet } \\
\mathrm{x} € 1 \\
\text { mln. }\end{array}$} & \multirow[t]{2}{*}{$\begin{array}{l}\text { Markt- } \\
\text { aan- } \\
\text { deel in } \\
\%\end{array}$} & \multirow[t]{2}{*}{$\begin{array}{l}\text { Provisie } \\
/ \\
\text { Heffing } \\
\mathrm{x} \\
€ 1 \mathrm{mln} \text {. }\end{array}$} & \multirow[t]{2}{*}{$\begin{array}{l}\text { Veiling- } \\
\text { omzet x } \\
€ 1 \mathrm{mln} \text {. } \\
\text { verhou- } \\
\text { ding } \\
\text { klok/ } \\
\text { bemid- } \\
\text { deling }\end{array}$} & \multirow[t]{2}{*}{$\begin{array}{l}\text { Resul } \\
\text { taat } x \\
€ 1 \\
\text { mln. } \\
\text { voor/ } \\
\text { na } \\
\text { belas- } \\
\text { ting }\end{array}$} & \multirow[t]{2}{*}{$\begin{array}{l}\text { Ren- } \\
\text { de- } \\
\text { ment } \\
\text { in \% } \\
\text { T.V. }\end{array}$} & \multicolumn{2}{|c|}{$\begin{array}{l}\text { Solvabiliteits- } \\
\text { ratio's Eigen } \\
\text { Vermogen en } \\
\text { Risicodragend } \\
\text { Vermogen; } \\
\text { E.V. en R.V. } \\
\text { in \% balans- } \\
\text { totaal }\end{array}$} & \multirow[t]{2}{*}{$\begin{array}{l}\text { Aan- } \\
\text { tal } \\
\text { fte's }\end{array}$} & \multirow[t]{2}{*}{$\begin{array}{l}\text { Aan- } \\
\text { tal } \\
\text { leden }\end{array}$} & \multicolumn{3}{|c|}{$\begin{array}{l}\text { Gemiddelde } \\
\text { (theoretische) veiling- } \\
\text { prijs in eurocent/st. } \\
\text { excl. BTW; } \\
\text {-omzet in } € \text { x } 1 \mathrm{mln} \text {. } \\
\text {-afzet in st. x } 1 \mathrm{mln} \text {. }\end{array}$} \\
\hline & & & & & & & $\begin{array}{l}\text { ratio } \\
\text { E.V. } \\
\text { in \% }\end{array}$ & $\begin{array}{l}\text { Ratio } \\
\text { R.V. } \\
\text { in } \%\end{array}$ & & & Roos & $\begin{array}{l}\text { Chry- } \\
\text { sant } \\
\text { ( tros) }\end{array}$ & $\begin{array}{l}\text { Pha- } \\
\text { lae- } \\
\text { nop- } \\
\text { sis }\end{array}$ \\
\hline 2008 & $\begin{array}{l}\text { FH } \\
\text { nieuw } \\
390.6 \\
*)\end{array}$ & 97.7 & $\begin{array}{l}209(97 \\
+112)\end{array}$ & $\begin{array}{l}4.074 / \\
65: 35\end{array}$ & $\begin{array}{l}5.5 / \\
3.3\end{array}$ & $\begin{array}{l}5.6 / \\
953= \\
0.59\end{array}$ & $\begin{array}{l}205 / \\
953= \\
21.6\end{array}$ & $\begin{array}{l}451 / \\
953= \\
47.4\end{array}$ & 3555 & 5124 & $\begin{array}{l}€ 785 / \\
3.365 \\
\text { st. }= \\
0.23\end{array}$ & $\begin{array}{l}€ 268 / \\
1.279 \\
\text { st. }= \\
0.21\end{array}$ & $\begin{array}{l}€ 288 \\
/ 71 \\
\text { st. }= \\
4.06\end{array}$ \\
\hline 2009 & 382.0 & 97.6 & $\begin{array}{l}200(87 \\
+113)\end{array}$ & $\begin{array}{l}3.861 \\
62: 38\end{array}$ & $\begin{array}{l}7.6 / \\
5.7\end{array}$ & $\begin{array}{l}8.0 / \\
923= \\
0.87\end{array}$ & 22.4 & 47.9 & 3386 & 4900 & $\begin{array}{l}€ 679 / \\
3.373 \\
\text { st. }= \\
0.20\end{array}$ & $\begin{array}{l}€ 232 / \\
1.232 \\
\text { st. }= \\
0.19\end{array}$ & $\begin{array}{l}€ 328 \\
/ 95 \\
\text { st. }= \\
3.45\end{array}$ \\
\hline 2010 & 378.0 & 97.5 & $\begin{array}{l}200(91 \\
+109)\end{array}$ & $\begin{array}{l}4.130 \\
60: 40\end{array}$ & $\begin{array}{l}11.9 / \\
12.3\end{array}$ & $\begin{array}{l}14.9 / \\
941= \\
1.6\end{array}$ & 22.9 & 46.8 & 3279 & 4949 & $\begin{array}{l}743 / \\
3.466 \\
\text { st. }= \\
0.21 \\
\end{array}$ & $\begin{array}{l}257 / \\
1.211 \\
\text { st. }= \\
0.21 \\
\end{array}$ & $\begin{array}{l}€ 374 \\
/ 100 \\
\text { st. }= \\
3.74\end{array}$ \\
\hline 2011 & 375.0 & 97.3 & $\begin{array}{l}188(89 \\
+99)\end{array}$ & $\begin{array}{l}4.158 \\
57: 43\end{array}$ & $\begin{array}{l}13.2 / \\
11.3\end{array}$ & $\begin{array}{l}15.1 / \\
960= \\
1.6\end{array}$ & 23.1 & 47.3 & 3218 & 4908 & $\begin{array}{l}€ 761 / \\
3.708 \\
\text { st. }= \\
0.21\end{array}$ & $\begin{array}{l}€ 267 / \\
1.205 \\
\text { st. }= \\
0.22\end{array}$ & $\begin{array}{l}€ 415 \\
/ 105 \\
\text { st. }= \\
3.95\end{array}$ \\
\hline
\end{tabular}

*)aanpassing aan jaarverslag 2009

Ontwikkelingen

In bovenstaande tabel 4.8 is een aantal ontwikkelingen te constateren.

- De omzet van het nieuwe FH daalt in 2009 (jaar van de kredietcrisis) met 5.2\%. In 2010 en 2011 komt het juist boven het niveau van 2008 uit met $€ 4.130 \mathrm{mln}$. en $€ 4.158 \mathrm{mln}$. ( +1 en $0.5 \%$ ). De verhouding klok : bemiddeling verschuift van $65: 35$ naar $57: 43$. Het marktaandeel daalt van 2008-2011 met 0.4\%. De inkomsten uit dienstverlening van FH dalen van 2008-2011 van $€ 391 \mathrm{mln}$. naar $€ 375 \mathrm{mln}$, een daling van ca. $4 \%$ over 4 jaar.

- In 2008 ligt de verkoopprovisie bij het nieuwe FH op 2.4\%. Het percentage heffingen is in 2008 op een enigszins hoger niveau gebracht evenals de overige inkomsten. Van 2008-2011 daalt de verkoopprovisie naar $2.1 \%$ en de totale jaarinkomsten van $\mathrm{FH}$ van ca. $10 \%$ naar $9 \%$ van de jaaromzet.

- Het resultaat voor belastingen bij FH groeit van 2008-2011 van $€ 5.5$ naar $€ 13.2 \mathrm{mln}$. Het rendement op Totaal Vermogen (RTV) stijgt van 0.6 naar $1.6 \%$.

- De solvabiliteitsratio's Eigen Vermogen (E.V.) en Risicodragend Vermogen (R.V.) ontwikkelen zich van 2008-2011 van 21.6 naar 23.1\% resp. van 47.4 naar $47.3 \%$. Het plan is het E.V. op termijn te verhogen naar een niveau van 25 - 30\% van het balanstotaal (FH Jaarverslag 2009, p. 34). 
- Van 2008-2011 daalt het aantal werknemers op fte-basis voor FH van 3555 naar 3218. In 2008 ligt het totale aantal leden voor het nieuwe FH op 5124 en in 2011 op 4908 . Hieronder bevindt zich inmiddels zo'n 10\% buitenlandse leden. De gemiddelde veilingomzet per lid is van 2008 2011 gestegen van ruim $€ 800.000$ naar $€ 850.000$.

- De gemiddelde veilingprijs voor de roos (alle soorten incl. import) daalt van 2008 naar 2009 van 0.23 naar 0.20 eurocent (kredietcrisis). De afzet stijgt iets (0.3\%). In 2010 en 2011 stijgt de prijs naar 0.21 eurocent terwijl de afzet met 3 en $7 \%$ stijgt.

- De gemiddelde veilingprijs voor de chrysant (alle soorten) daalt van 2008 naar 2009 van 0.21 naar 0.19 eurocent (kredietcrisis). Ook de afzet daalt in 2009, met 4\%. In 2010 en 2011 stijgt de prijs naar 0.21 resp. 0.22 eurocent terwijl de afzet daalt met 2 en $0.5 \%$.

- De gemiddelde veilingprijs voor de phalaenopsis is in 2008 aanmerkelijk lager dan in 2007 (een daling van $€ 4.87$ naar $€ 4.06$ onder een toename van de afzet van ruim 50\%). In 2009 daalt de prijs verder tot $€ 3.45$ bij een toename van de afzet van $30 \%$. In 2010 stijgt de prijs weer naar $€ 3.74$ met een toename van de afzet van 5\% en in 2011 naar $€ 3.95$ terwijl de afzet weer toeneemt met $5 \%$.

\subsubsection{Analyse gedragsvariabelen}

\subsubsection{Horizontale concentratie}

Horizontale concentratie aan de aanbodzijde van de sector glassierteelt is eveneens in hoofdstuk 3 besproken, voor de productiebedrijven, de afzetorganisaties en de groothandel/export (zie tabel 3.55). Tabel 4.9 toont hieruit de horizontale concentratieontwikkeling van de afzetorganisaties (FloraHolland en Plantion) met de resultaatsvariabelen uit tabel 3.55 over de periode 2007-2011.

Tabel 4.9 Concentraties, marktaandelen en sectorresultaten bij de afzetorganisaties in de glassierteelt (snijbloemen en potplanten) 2007-2011

\begin{tabular}{|l|r|r|r|r|r|}
\hline & 2007 & $\left.2008^{*}\right)$ & $2009 *)$ & 2010 & 2011 \\
\hline Afzetorganisaties & & & & & \\
-FloraHolland (m.a. in \%) & & 97.7 & 97.6 & 97.5 & 97.3 \\
-Plantion resp. Vleuten/VON (idem) & & 2.3 & 2.4 & 2.5 & 2.7 \\
\hline Productiewaarde snijbloemen & 2.294 & 2.172 & 1.887 & 2.110 & 2.040 \\
Nederland (x 1 mln. euro) & & & & & \\
\hline Productiewaarde potplanten & 1.768 & 1.862 & 1.902 & 2.000 & 1.970 \\
Nederland (x 1 mln. euro) & & & & & \\
\hline $\begin{array}{l}\text { Gemiddelde jaarprijzen } \\
\text { (eurocent p. kg/st.) }\end{array}$ & & & & & \\
-snijbloemen & 23 & 22 & 20 & 21 & 21 \\
-kamerplanten & 153 & 153 & 149 & 153 & 153 \\
& & & & & \\
\hline
\end{tabular}

Bron : PT, HBAG, Jaarverslag FloraHolland 2010, *) jaren van de kredietcrisis 
De ontwikkeling van de horizontale concentratie bij de afzetorganisaties en sectorresultaten leidt tot de volgende conclusie: zowel bij de sector snijbloemen als potplanten is niet vast te stellen wat de invloed is van de hoge horizontale concentratie van de afzetorganisaties in de sierteeltsector op het sectorresultaat, mede gezien de turbulente situatie, veroorzaakt door de kredietcrisis in 2008 en 2009. Wel speelde deze hoge concentratie in de sector en het adequaat functionerende (veiling)verkoopsysteem voor de afzet van de dagelijks aangevoerde verse snijbloemen en potplanten een belangrijke rol bij de snelheid van het herstel in 2010.

\subsubsection{Voorwaartse verticale concentratie}

In de sector glassierteelt zijn tot op heden nauwelijks concrete voorbeelden te geven van producenten/glastuinbouwbedrijven of afzetorganisaties die verticaal geïntegreerd zijn of plannen hebben om op kortere termijn te integreren met groothandelsbedrijven/exporteurs in de bloemisterijsector. De opvattingen zijn veelal: schoenmaker, houd je bij je leest!

Wel zijn er vele voorbeelden van verticale samenwerking tussen producenten, afzetorganisatie, groothandel/export en grootschalige detaillisten, vooral bij de grotere potplantenbedrijven. In aanverwante sectoren zoals de bloembollen- en bomenteelt komt de integratie van productie en groothandel/export (de handelskweker) wel meer voor. Vaak is dit uit nood geboren om markten te (leren) kennen en ontwikkelingen te kunnen volgen. Ook is van belang voldoende jaarrond vraag uit de markt te genereren om de geteelde producten kwijt te raken.

\subsubsection{Productdifferentiatie}

De gedragsvariabele productdifferentiatie betreft het product- en productontwikkelingsbeleid in brede zin dat vanaf 2004 is gevoerd door de twee grootste bloemenveilingen FloraHolland en VBA. In 2004 zegt FloraHolland het volgende over haar bedrijfsstrategie:

'FloraHolland wil de afzetketen van bloemisterijbedrijven beter laten presteren. Om dit te bereiken wil FH een breed aanbod van bloemisterijproducten uit binnen- en buitenland aan de veilingklokken en aan het Bemiddelingsbureau binden.' (VBA Jaarverslag 2005, p. 15).

$\mathrm{Zij}$ somt een reeks van strategische maatregelen op om haar marktplaatsen en dienstverlening (veilen en bemiddelen) te versterken door middel van enerzijds het aanbieden van een breed en diep assortiment aantrekkelijke bloemisterijproducten , anderzijds het aantrekken van een jaarrond koopkrachtige vraag voor deze producten. FloraHolland is een dienstverlenend bedrijf dat met name verkoop- en logistieke diensten aanbiedt. Het gaat evenals bij VTN/The Greenery om het aanbod van aantrekkelijke (nieuwe) producten en (nieuwe) verkoop- en logistieke diensten die extra waarde toevoegen aan het geheel van de transactie. De vraag is ook hier wat de invloed is van het (nieuwe) assortiment producten en diensten op de concurrentiepositie van FloraHolland, het onderscheidend vermogen ten opzichte van de VBA en het resultaat. Is er een betekenisvol verband tussen de inzet van (nieuwe) producten en diensten en de behaalde resultaten? Hierna wordt verwezen naar een aantal voorbeelden uit diverse jaarverslagen over de periode 2004-2008 van nieuw ontwikkelde producten en/of diensten door FloraHolland en de VBA, alleen of in samenwerking met derden. Er zijn momenteel te weinig (financiële) gegevens van FloraHolland beschikbaar om over een eventueel verband betrouwbare uitspraken te kunnen doen. 
Voorbeelden VBA 2004

- ontwikkeling van een virtuele marktplaats Kopen op Afstand (KOA), inmiddels 10\% van de transacties omvattend, en de invoering van een electronisch ordersysteem voor de potplantenhandel via LAB/ Florecom (VBA Jaarverslag 2004, pp. 11, 15).

Voorbeeld VBA 2005

- invoering van internationaal lidmaatschap per 1 januari 2006

(VBA Jaarverslag 2005, p. 19).

Voorbeeld VBA 2006

- introductie nieuw certificaat (pot)phalaenopsis Aalsmeer Quality;

(VBA Jaarverslag 2006, p. 7).

Voorbeelden FloraHolland 2005

- actieve benadering (met ketenpartners) van de grootschalige retail en nieuwe markten in Oosten Zuid-Europa;

- aanpassen van veilschema's en verder versterken van het electronisch KOA-systeem

(VBA Jaarverslag 2005, p. 15, 16-20).

\subsubsection{Investering/innovatie}

De gedragsvariabele investering/innovatie betreft het investerings- en innovatiebeleid dat vanaf 2004 is gevoerd door de twee grootste bloemenveilingen FloraHolland en VBA.

Dit beleid is gericht op het eigen bedrijfsgebeuren en probeert met doelgerichte investeringen en innovaties de concurrentiepositie te versterken. Ook hier is het de vraag wat de invloed is van deze (nieuwe) investeringen en innovaties op de concurrentiepositie en het resultaat van de onderneming en of er een betekenisvol verband is te constateren. Er zijn onvoldoende (financiële) gegevens beschikbaar om betrouwbare uitspraken te kunnen doen. Een aantal verwijzingen naar voorbeelden uit de jaarverslagen van (nieuwe) investeringen en innovaties volgt hieronder.

Voorbeelden VBA 2004

- financiële bijdrage van de VBA aan de omlegging N 201 (VBA Jaarverslag 2004, p. 9);

- 5\% participatie in Chinese sierteeltveiling in Kunming (VBA Jaarverslag 2004, p. 2).

Voorbeelden VBA 2005

- introductie klokinnovaties en proef beeldveilen voor een aantal producten; (VBA Jaarverslag 2005, pp. 16, 18, 19).

Voorbeeld FloraHolland 2004

- introductie Florconcepting als nieuwe dienstverlening voor innovatieve producten. 
Voorbeeld FloraHolland 2006

- groei van KOA naar 305 aansluitingen en omzet van $150 \mathrm{mln}$. euro (50\% stijging in 2006), aandeel in klokafzet $11.6 \%$, uitbreiding naar veiling Rijnsburg in 2007 (VBA Jaarverslag 2006, pp. 12-19).

\subsection{Strategie en resultaten VTN/Coforta/The Greenery, VBA en FloraHolland}

In deze paragraaf worden de eerder besproken resultaatsvariabelen van de drie, later twee grootste afzetorganisaties van glastuinbouwproducten in Nederland naast elkaar geplaatst, worden markt- en bedrijfsontwikkelingen geanalyseerd en onderzocht op mogelijke verbanden met de door de afzetorganisaties en hun leden gevoerde strategieën en/of de structuur van de markt. In paragraaf 4.4.1 wordt in tabel 4.10 een overzicht gegeven van de behaalde resultaten in de periode 2003-2008, in paragraaf 4.4.2 in tabel 4.11 een overzicht van de resultaten in de periode 2009-2011. In paragraaf 4.4.3 volgen de voorlopige conclusies. Deze conclusies zijn ingedeeld naar bestuurlijk-organisatorische, commerciële en financieel-economische aspecten per sector glasgroenten en glassierteelt volgens de SGR-methodiek (zie het analysemodel, figuur 2.4, in hoofdstuk 2).

\subsubsection{Resultaten 2003-2008}

Onderstaand worden de resultaten en kerncijfers 2003-2008 van de drie afzetorganisaties overzichtelijk getoond en ontwikkelingen geanalyseerd en besproken.

\section{Ontwikkelingen}

In bovenstaande tabel 4.10 is een aantal ontwikkelingen te constateren (de prijs-ontwikkelingen onder punt 8 zijn overgenomen uit de tabellen 4.1 en 4.7 ).

1 a. De inkomsten uit dienstverlening van FH groeit van 2003-2007 (fusie per september 2007) van $€ 207 \mathrm{mln}$. naar $€ 217 \mathrm{mln}$. dus een stijging van ca. $5 \%$ over 5 jaar.

b. De inkomsten uit dienstverlening van de VBA blijft gelijk van 2003-2007 en bedraagt $€ 183$ mln. In 2008 zijn deze inkomsten van het nieuwe FH $€ 387 \mathrm{mln}$.

c. De inkomsten uit dienstverlening + netto marge verkoop producten van VTN daalt van 2003-2008 van $€ 290 \mathrm{mln}$. naar $€ 220 \mathrm{mln}$. dus een daling van ca. $24 \%$ over 6 jaar. De inkomsten aan provisie/heffingen dalen van 2003-2008 van $€ 88.5 \mathrm{mln}$. naar $€ 52.2 \mathrm{mln}$, dus een daling van $41 \%$ over 6 jaar.

2. De veilingomzet (totale productomzet op jaarbasis) ontwikkelt zich van 2003-2007 voor de drie organisaties als volgt:

a. De veilingomzet van FH groeit van $2004-2007$ van $€ 1.910 \mathrm{mln}$. naar $€ 2.240 \mathrm{mln}$., dus een stijging van ca. $17 \%$ over 4 jaar. 
Tabel 4.10 Ontwikkeling resultaten en kerncijfers van 2003-2008 van FloraHolland 'oud' te Naaldwijk, VBA Aalsmeer, FloraHolland 'nieuw' en VTN/The Greenery

*) VTN/The Greenery, incl. winstmarge verkochte producten; VTN= Voedingstuinbouw Nederland, VBA=

\begin{tabular}{|c|c|c|c|c|c|c|c|c|c|}
\hline \multirow[t]{2}{*}{ Jaar } & \multirow{2}{*}{$\begin{array}{l}\text { Inkomsten uit } \\
\text { diensten x } € \\
1 \text { mln. ( + netto } \\
\text { marge van } \\
\text { verkoop } \\
\text { producten door } \\
\text { VTN) }\end{array}$} & \multirow[t]{2}{*}{$\begin{array}{l}\text { Provisie/ } \\
\text { Heffing } x \\
€ 1 \mathrm{mln} .\end{array}$} & \multirow[t]{2}{*}{$\begin{array}{l}\text { Veiling- } \\
\text { omzet } x \\
€ 1 \mathrm{mln} .\end{array}$} & \multirow[t]{2}{*}{$\begin{array}{l}\text { Resultaat } x \\
€ 1 \mathrm{mln} \text {. voor } \\
\text { belasting }\end{array}$} & \multirow[t]{2}{*}{$\begin{array}{l}\text { Rende- } \\
\text { ment } \\
\text { in \% } \\
\text { T.V. }\end{array}$} & \multicolumn{2}{|c|}{$\begin{array}{l}\text { Solvabiliteits- } \\
\text { ratio's E.V./ } \\
\text { Risicodragend } \\
\text { vermogen }\end{array}$} & \multirow[t]{2}{*}{$\begin{array}{l}\text { Aantal } \\
\text { fte's }\end{array}$} & \multirow[t]{2}{*}{$\begin{array}{l}\text { Aantal } \\
\text { leden }\end{array}$} \\
\hline & & & & & & $\begin{array}{l}\text { ratio } \\
\text { E.V. } \\
\text { in \% }\end{array}$ & $\begin{array}{l}\text { ratio } \\
\text { R.V. } \\
\text { in \% }\end{array}$ & & \\
\hline 2003 & $\begin{array}{l}\text { FH } \\
206.8 \\
\text { VBA } \\
182.8 \\
\text { VTN }^{*} \text { ) } \\
290.0\end{array}$ & $\begin{array}{l}\text { FH } \\
105.0 \\
\text { VBA } \\
100.1 \\
\text { VTN } \\
88.5\end{array}$ & $\begin{array}{l}\text { FH } \\
1.919 \\
\text { VBA } \\
1.598 \\
\text { VTN } \\
1.570\end{array}$ & $\begin{array}{l}\text { FH } \\
6.1 \\
\text { VBA } \\
3.3 \\
\text { VTN } \\
15.0\end{array}$ & $\begin{array}{l}\text { FH } \\
1.2 \\
\text { VBA } \\
0.7 \\
\text { VTN } \\
2.4\end{array}$ & $\begin{array}{l}\text { FH } \\
18.6 \\
\text { VBA } \\
15.8 \\
\text { VTN } \\
4.2\end{array}$ & $\begin{array}{l}\text { FH } \\
40.7 \\
\text { VBA } \\
37.2 \\
\text { VTN } \\
29.5\end{array}$ & $\begin{array}{l}\text { FH } \\
2287 \\
\text { VBA } \\
1699 \\
\text { VTN } \\
2083\end{array}$ & $\begin{array}{l}\text { FH } \\
3996 \\
\text { VBA } \\
3000 \\
\text { VTN } \\
2200\end{array}$ \\
\hline 2004 & $\begin{array}{l}\text { FH } \\
213.6 \\
\text { VBA } \\
185.3 \\
\text { VTN*) }^{*} \text { 278.0 }\end{array}$ & $\begin{array}{l}\text { FH } \\
107.3 \\
\text { VBA } \\
103.7 \\
\text { VTN } \\
80.6\end{array}$ & $\begin{array}{l}\text { FH } \\
1.910 \\
\text { VBA } \\
1.630 \\
\text { VTN } \\
1.426\end{array}$ & $\begin{array}{l}\text { FH } \\
7.1 \\
\text { VBA } \\
3.0 \\
\text { VTN } \\
5.0\end{array}$ & $\begin{array}{l}\text { FH } \\
1.3 \\
\text { VBA } \\
0.6 \\
\text { VTN } \\
0.8\end{array}$ & $\begin{array}{l}\text { FH } \\
19.9 \\
\text { VBA } \\
15.7 \\
\text { VTN } \\
5.5\end{array}$ & $\begin{array}{l}\text { FH } \\
42.4 \\
\text { VBA } \\
36.6 \\
\text { VTN } \\
30.9\end{array}$ & $\begin{array}{l}\text { FH } \\
2209 \\
\text { VBA } \\
1651 \\
\text { VTN } \\
1775\end{array}$ & $\begin{array}{l}\text { FH } \\
3803 \\
\text { VBA280 } \\
0 \\
\text { VTN } \\
2000\end{array}$ \\
\hline 2005 & $\begin{array}{l}\text { FH } \\
213.0 \\
\text { VBA } \\
181.3 \\
\text { VTN*) } \\
204.0\end{array}$ & $\begin{array}{l}\text { FH } \\
108.5 \\
\text { VBA } \\
104.5 \\
\text { VTN } \\
73.9\end{array}$ & $\begin{array}{l}\text { FH } \\
2.005 \\
\text { VBA } \\
1.690 \\
\text { VTN } \\
1.434\end{array}$ & $\begin{array}{c}\text { FH } \\
7.6 \\
\text { VBA } \\
9.0 \\
\text { VTN } \\
7.5\end{array}$ & $\begin{array}{l}\text { FH } \\
1.4 \\
\text { VBA } \\
1.9 \\
\text { VTN } \\
1.4\end{array}$ & $\begin{array}{l}\text { FH } \\
19.5 \\
\text { VBA } \\
14.3 \\
\text { VTN } \\
4.8\end{array}$ & $\begin{array}{l}\text { FH } \\
41.3 \\
\text { VBA } \\
38.4 \\
\text { VTN } \\
38.0\end{array}$ & $\begin{array}{l}\text { FH } \\
2123 \\
\text { VBA } \\
1524 \\
\text { VTN } \\
1699 \\
\end{array}$ & $\begin{array}{l}\text { FH + } \\
\text { VBA } \\
6000 \\
\\
\text { VTN } \\
1700\end{array}$ \\
\hline 2006 & $\begin{array}{l}\text { FH } \\
212.3 \\
\text { VBA } \\
182.0 \\
\text { VTN*) } \\
245\end{array}$ & $\begin{array}{l}\text { FH } \\
101.8 \\
\text { VBA } \\
103.0 \\
\text { VTN } \\
69.2\end{array}$ & $\begin{array}{l}\text { FH } \\
2.136 \\
\text { VBA } \\
1.756 \\
\text { VTN } \\
1.448\end{array}$ & $\begin{array}{l}\text { FH } \\
8.8 \\
\text { VBA } \\
6.4 \\
\text { VTN } \\
15.0\end{array}$ & $\begin{array}{l}\text { FH } \\
1.6 \\
\text { VBA } \\
1.3 \\
\text { VTN } \\
2.8\end{array}$ & $\begin{array}{l}\text { FH } \\
19.7 \\
\text { VBA } \\
14.8 \\
\text { VTN } \\
7.6\end{array}$ & $\begin{array}{l}\text { FH } \\
40.9 \\
\text { VBA } \\
40.7 \\
\text { VTN } \\
38.4\end{array}$ & $\begin{array}{l}\text { FH } \\
2090 \\
\text { VBA } \\
1523 \\
\text { VTN } \\
1695\end{array}$ & $\begin{array}{l}\text { FH+ } \\
\text { VBA } \\
5450 \\
\\
\\
\text { VTN } \\
1400\end{array}$ \\
\hline 2007 & $\begin{array}{l}\text { FH } \\
216.7 \\
\text { VBA } \\
182.8 \\
\text { VTN*) } \\
243\end{array}$ & $\begin{array}{l}\text { FH } \\
103.0 \\
\text { VBA } \\
101.9 \\
\text { VTN } \\
53.9\end{array}$ & $\begin{array}{l}\text { FH } \\
2.240 \\
\text { VBA } \\
1.823 \\
\text { VTN } \\
1.414\end{array}$ & $\begin{array}{c}\text { FH } \\
7.3 \\
\text { VBA } \\
-2.2 \\
\text { VTN } \\
9.0\end{array}$ & $\begin{array}{l}\text { FH } \\
1.3 \\
\text { VBA } \\
-0.5 \\
\text { VTN } \\
1.8\end{array}$ & $\begin{array}{l}\text { FH } \\
19.5 \\
\text { VBA } \\
12.3 \\
\text { VTN } \\
10.3\end{array}$ & $\begin{array}{l}\text { FH } \\
40.0 \\
\text { VBA } \\
37.2 \\
\text { VTN } \\
41.1\end{array}$ & $\begin{array}{l}\text { FH } \\
2114 \\
\text { VBA } \\
1515 \\
\text { VTN } \\
1638\end{array}$ & $\begin{array}{l}\text { FH+ } \\
\text { VBA } \\
5323 \\
\\
\text { VTN } \\
1250\end{array}$ \\
\hline 2008 & $\begin{array}{l}\text { FH-n. } \\
387.3 \\
\text { VTN*) } \\
220 \\
\end{array}$ & $\begin{array}{l}\text { FH-n. } \\
208.7 \\
\text { VTN } \\
52.2\end{array}$ & $\begin{array}{l}\text { FH-n. } \\
4.074 \\
\text { VTN } \\
1.308\end{array}$ & $\begin{array}{c}\text { FH-n. } \\
5.5 \\
\text { VTN } \\
2.0\end{array}$ & $\begin{array}{l}\text { FH-n. } \\
0.6 \\
\text { VTN } \\
0.4\end{array}$ & $\begin{array}{l}\text { FH-n. } \\
21.6 \\
\text { VTN } \\
10.3 \\
\end{array}$ & $\begin{array}{l}\text { FH-n. } \\
47.4 \\
\text { VTN } \\
38.7 \\
\end{array}$ & $\begin{array}{l}\text { FH-n. } \\
3555 \\
\text { VTN } \\
1661\end{array}$ & $\begin{array}{l}\text { FH-n. } \\
5124 \\
\text { VTN } \\
1150\end{array}$ \\
\hline
\end{tabular}

Verenigde Bloemenveilingen Aalsmeer, FH= FloraHolland. 
b. De veilingomzet van de VBA groeit van $2003-2007$ van $€ 1.598 \mathrm{mln}$. naar $€ 1.823 \mathrm{mln}$., dus een stijging van ca. $14 \%$ over 5 jaar .

c. De omzet van VTN/The Greenery (incl. groothandelsmarge) daalt van 2003-2007 van € $1.570 \mathrm{mln}$. naar $€ 1.414 \mathrm{mln}$., dus een daling van ca. $10 \%$ over 5 jaar.

3. Het rendement op totaal vermogen ontwikkelt zich als volgt:

a. Voor FH ligt dit in de jaren 2003-2007 tussen 1.2 en 1.6\%.

b. Voor de VBA ligt dit in de jaren 2003-2007 tussen -0.5 en $1.9 \%$.

c. Voor VTN ligt dit in de jaren 2003-2007 tussen 0.8 en $2.8 \%$.

Opmerkingen:

* In 2008 is het rendement totale vermogen voor het nieuwe FH $0.6 \%$ en VTN $0.4 \%$.

* Voor VTN lag het rendement op het totale vermogen vanaf 1996-2002 tussen de -2.1 en 3.0\%; van 2001-2008 is het rendement aanmerkelijk verbeterd en ligt tussen de 0.4 en $2.8 \%$.

4. De solvabiliteitsratio's eigen vermogen en risicodragend vermogen liggen:

a Voor FH van 2003-2007 tussen 18.6 - 19.9\% resp. tussen $40.4-42.4 \%$.

b. Voor de VBA zijn deze cijfers 12.3 - 15.8\% resp. 36.6 - 40.7\%.

c. Voor VTN zijn deze cijfers 4.2 - 10.3\% resp. 29.5 - $41.1 \%$.

5.Zowel voor FH, als voor de VBA en VTN is er een voortdurende daling van het aantal werknemers op fte- basis:

a. Voor FH van 2003-2007 van 2287 naar 2090 (-9\%).

b. Voor de VBA van 2003-2007 van 1699 naar 1515 (-11\%).

c. Voor VTN van 2003-2007 van 2083 naar 1638 (-21\%).

Opmerking: in 2008 ligt het totale aantal werknemers voor het nieuwe FH op 3555.

6. De daling van het aantal leden/bedrijven verloopt voor de drie organisaties als volgt:

a. Voor FH van 2003-2007 van ca. 4000 naar ca. 3000 (-25\%).

b. Voor de VBA van 2003-2007 van ca. 3000 naar ca. 2000 (-33.3\%).

c. Voor VTN van 2003-2007 van ca. 2200 naar ca. 1150 ( $-48 \%)$.

Opmerking: in 2008 ligt het totale aantal leden/bedrijven voor het nieuwe FH op 5124.

7. De gemiddelde veilingomzet per lid ontwikkelt zich voor de bloemenveilingen resp. VTN/The Greenery als volgt:

a. De gemiddelde veilingomzet per lid is voor alle bloemenveilingen in Nederland van 19902000 gestegen van ca. $€ 240.000$ naar ca. $€ 365.000$ en daarna meer dan verdubbeld tot in 2008 ruim $€ 800.000$.

b. De gemiddelde veilingomzet per lid van VTN/The Greenery is gestegen van ca. $€ 100.000$ (1996) via $€ 250.000$ (2000) naar ca. € 650.000 (2008). 
8. De prijsvorming voor de belangrijkste sierteeltproducten van de bloemenveilingen resp. de belangrijkste vruchtgroenten bij VTN/The Greenery ontwikkelt zich over de afgelopen jaren als volgt (zie tabellen 4.7 en 4.1 ):

a.1 De gemiddelde veilingprijs voor de roos (alle soorten incl. import) ontwikkelt zich in de aanloop naar de veilingfusie tamelijk stabiel en ligt van 2003-2005 op 0.20/ 0.21 eurocent en stijgt naar 0.23/0.24 eurocent in 2006, 2007 en 2008. Bedacht moet worden dat deze prijs het gemiddelde is van de kleinbloemige, de grootbloemige en de (tros)roos. Voorts vindt er een aanmerkelijke verschuiving plaats bij de Nederlandse rozenkwekers naar de teelt van grootbloemige rozen en verdwijnen de arbeidsintensieve soorten (waaronder kleinbloemige) naar importlanden (Kenia e.a.).

a.2 De gemiddelde veilingprijs voor de chrysant (alle soorten) ontwikkelt zich in de aanloop naar de veilingfusie tamelijk stabiel en ligt van 2003-2005 op $0.21 / 0.22$ eurocent en stijgt naar 0.23 eurocent in 2006 en 2007. In het fusiejaar 2008 daalt deze prijs tot 0.21 eurocent. a.3 De gemiddelde veilingprijs voor de phalaenopsis schommelt in de aanloop naar de fusie tussen $€ 4.57$ en $€ 5.11$. In 2008 zakt de prijs tot een historisch dieptepunt door enerzijds een teruglopende vraag ten gevolge van de kredietcrisis, anderzijds een (te) groot aanbod van phalaenopsistelers in Nederland.

b.1 De gemiddelde veilingprijs voor komkommers ligt voor de veilingfusie in 1996 tussen de 44 (1993) en 59 eurocent (1991), na de fusie tussen de 43 (1999) en 57 eurocent (2000).

b.2 De gemiddelde veilingprijs voor tomaten ligt voor de veilingfusie in 1996 tussen de 60 1993) en 86 eurocent (1991), na de fusie tussen de 57 (2004) en 91 eurocent (2000).

b.3 De gemiddelde veilingprijs voor paprika ligt voor de veilingfusie in 1996 tussen de 108 1993) en 175 eurocent (1989), na de fusie tussen de 117 (2002) en 154 eurocent (1997).

Een voorzichtige conclusie op basis van de onder de punten b.1, b.2 en b.3 geconstateerde ontwikkeling kan zijn dat de veilingfusie in 1996 geen of nauwelijks invloed heeft op de hoogte van de uitbetaalprijs.

\subsubsection{Resultaten 2009-2011}

Onderstaand worden de resultaten en kerncijfers 2009-2011 van de twee afzetorganisaties getoond en ontwikkelingen geanalyseerd en besproken. Zij zijn niet opgenomen in tabel 4.10 maar apart toegevoegd uit een oogpunt van actualiteit. Om aansluiting te houden met het voorafgaande jaar is 2008 ook in deze tabel opgenomen. 
Tabel 4.11 Ontwikkeling resultaten en kerncijfers van 2009-2011 van FloraHolland 'nieuw' en VTN/Coforta/The Greenery

\begin{tabular}{|c|c|c|c|c|c|c|c|c|c|}
\hline \multirow[t]{2}{*}{ Jaar } & \multirow{2}{*}{$\begin{array}{l}\text { Inkomsten } \\
\text { uit diensten x } \\
€ 1 \mathrm{mln} . \text { ( }^{+} \\
\text {netto marge } \\
\text { van verkoop } \\
\text { producten } \\
\text { door VTN } \\
\text { /Coforta) }\end{array}$} & \multirow[t]{2}{*}{$\begin{array}{l}\text { Provisie/ } \\
\text { Heffing } x \\
€ 1 \mathrm{mln} .\end{array}$} & \multirow[t]{2}{*}{$\begin{array}{l}\text { Veiling- } \\
\text { omzet } x \\
€ 1 \mathrm{mln} .\end{array}$} & \multirow[t]{2}{*}{$\begin{array}{l}\text { Resultaat } \mathrm{x} \\
€ 1 \mathrm{mln} \text {. voor } \\
\text { belasting }\end{array}$} & \multirow[t]{2}{*}{$\begin{array}{l}\text { Rende- } \\
\text { ment } \\
\text { in \% } \\
\text { T.V. }\end{array}$} & \multicolumn{2}{|c|}{$\begin{array}{l}\text { Solvabiliteits- } \\
\text { ratio's E.V./ } \\
\text { Risicodragend } \\
\text { vermogen }\end{array}$} & \multirow[t]{2}{*}{$\begin{array}{l}\text { Aantal } \\
\text { fte's }\end{array}$} & \multirow[t]{2}{*}{$\begin{array}{l}\text { Aantal } \\
\text { leden }\end{array}$} \\
\hline & & & & & & $\begin{array}{l}\text { ratio } \\
\text { E.V. } \\
\text { in } \%\end{array}$ & $\begin{array}{l}\text { ratio } \\
\mathrm{R} . \mathrm{V} \text {. } \\
\text { in } \%\end{array}$ & & \\
\hline 2008 & $\begin{array}{l}\text { FH } \\
387.3 \\
\text { VTN*) }^{*} 20\end{array}$ & $\begin{array}{l}\text { FH } \\
208.7 \\
\text { VTN } \\
52.2\end{array}$ & $\begin{array}{l}\text { FH } \\
4.074 \\
\text { VTN } \\
1.308\end{array}$ & $\begin{array}{l}\text { FH } \\
5.5 \\
\text { VTN } \\
2.1\end{array}$ & $\begin{array}{l}\text { FH } \\
0.6 \\
\text { VTN } \\
0.4\end{array}$ & $\begin{array}{l}\text { FH } \\
21.6 \\
\text { VTN } \\
10.3\end{array}$ & $\begin{array}{l}\text { FH } \\
47.4 \\
\text { VTN } \\
38.7\end{array}$ & $\begin{array}{l}\text { FH } \\
3555 \\
\text { VTN } \\
1661\end{array}$ & $\begin{array}{l}\text { FH } \\
5124 \\
\text { VTN } \\
1150\end{array}$ \\
\hline 2009 & $\begin{array}{l}\text { FH } \\
382 \\
\text { VTN } \\
231\end{array}$ & $\begin{array}{l}\text { FH } \\
200 \\
\text { VTN } \\
64.6\end{array}$ & $\begin{array}{l}\text { FH } \\
3.861 \\
\text { VTN } \\
1.149\end{array}$ & $\begin{array}{l}\text { FH } \\
7.6 \\
\text { VTN } \\
4.5 \\
\end{array}$ & $\begin{array}{c}\text { FH } \\
0.9 \\
\text { VTN } \\
0.9\end{array}$ & $\begin{array}{l}\text { FH } \\
22.4 \\
\text { VTN } \\
12.4 \\
\end{array}$ & $\begin{array}{l}\text { FH } \\
47.9 \\
\text { VTN } \\
40.0\end{array}$ & $\begin{array}{l}\text { FH } \\
3386 \\
\text { VTN } \\
1655\end{array}$ & $\begin{array}{l}\text { FH } \\
4900 \\
\text { VTN } \\
1006\end{array}$ \\
\hline 2010 & $\begin{array}{l}\text { FH } \\
378 \\
\text { VTN } \\
213 \\
\end{array}$ & $\begin{array}{l}\text { FH } \\
200 \\
\text { VTN } \\
-* *)\end{array}$ & $\begin{array}{l}\text { FH } \\
4.130 \\
\text { VTN } \\
1.263 \\
\end{array}$ & $\begin{array}{l}\text { FH } \\
11.9 \\
\text { VTN } \\
4.0 \\
\end{array}$ & $\begin{array}{c}\text { FH } \\
1.6 \\
\text { VTN } \\
0.7 \\
\end{array}$ & $\begin{array}{l}\text { FH } \\
22.9 \\
\text { VTN } \\
14.3 \\
\end{array}$ & $\begin{array}{l}\text { FH } \\
46.8 \\
\text { VTN } \\
41.0 \\
\end{array}$ & $\begin{array}{l}\text { FH } \\
3279 \\
\text { VTN } \\
1631 \\
\end{array}$ & $\begin{array}{l}\text { FH } \\
4949 \\
\text { VTN } \\
1007 \\
\end{array}$ \\
\hline
\end{tabular}

*) VTN/Coforta/The Greenery, incl. winstmarge verkochte producten; **) - geen gegevens;

$\mathrm{VTN}=$ Voedingstuinbouw Nederland, $\mathrm{FH}=$ FloraHolland.

\section{Ontwikkelingen}

In bovenstaande tabel is een aantal ontwikkelingen te constateren (de prijsontwikkelingen onder punt 8 zijn overgenomen uit de tabellen 4.3 en 4.8 ).

1. De inkomsten uit dienstverlening ontwikkelen zich van 2008-2011 voor de twee organisaties als volgt:

a. De inkomsten uit dienstverlening van FH dalen van $€ 387 \mathrm{mln}$. naar $€ 375 \mathrm{mln}$., dus een daling van ca. $3 \%$ over 3 jaar. De inkomsten uit provisie/heffingen dalen sterker, van $€ 209$ mln. naar $€ 188 \mathrm{mln}$., dus een daling van $10 \%$ over 3 jaar.

b. De inkomsten uit dienstverlening + netto marge verkoop producten van VTN dalen van $€ 220 \mathrm{mln}$. naar $€ 200 \mathrm{mln}$., dus een daling van $11 \%$ over 3 jaar. De inkomsten aan provisie/ heffingen stijgen van 2008-2009 van $€ 52.2 \mathrm{mln}$. naar $€ 64.6 \mathrm{mln}$., een stijging van bijna 24\%. In 2010 en 2011 zijn geen gegevens gevonden in de jaarverslagen.

2. De veilingomzet (totale productomzet op jaarbasis) ontwikkelt zich van 2008-2011 voor de twee organisaties als volgt:

a. De veilingomzet van $\mathrm{FH}$ groeit van $€ 4.074 \mathrm{mln}$. naar $€ 4.158 \mathrm{mln}$., dus een stijging van ca. $2 \%$ over 3 jaar.

b. De omzet van VTN/The Greenery (incl. groothandelsmarge) daalt van $€ 1.308 \mathrm{mln}$. naar $€ 1.099 \mathrm{mln}$., dus een daling van bijna $20 \%$ over 3 jaar. 
3. Het rendement op totaal vermogen ontwikkelt zich als volgt:

a. Voor FH ligt dit in de jaren 2008-2011 tussen 0.6 en $1.6 \%$

b. Voor VTN ligt dit in de jaren 2008-2011 tussen -0.8 en $0.9 \%$.

4. De solvabiliteitsratio's eigen vermogen en risicodragend vermogen liggen:
a. Voor FH van 2008-2011 tussen 21.6 - 23.1\% resp. tussen $46.8-47.9 \%$.
b. Voor VTN zijn deze cijfers 10.3 - 15.0\% resp. 38.7 - 42.0\%.

5. Zowel voor FH, als voor de VBA en VTN is er een voortdurende daling van het aantal werknemers op fte-basis:
a. Voor FH van 2008-2011 van 3555 naar 3218 (- ca. 10\%).
b. Voor VTN van 2008-2011 van 1661 naar 1507 (- ca. 10\%).

6. De daling van het aantal leden/bedrijven verloopt voor de drie organisaties als volgt:
a. Voor FH van 2008-2011 van 5124 naar 4908 (-4.5\%).
b. Voor VTN van 2008-2011 van 1150 naar 885 (- 23\%).

7. De gemiddelde veilingomzet per lid ontwikkelt zich van 2008-2011 als volgt:
a. Bij FH is deze gestegen van $€ 795.000$ naar $€ 847.000$ (6.5\%).
b. Bij VTN is deze gestegen van $€ 663.000$ naar $€ 719.000(8.5 \%)$.

8. De gemiddelde veilingprijs voor de belangrijkste sierteeltproducten bij FH resp. de vruchtgroenten bij VTN ontwikkelt zich van 2008-2011 als volgt (zie tabellen 4.8 en 4.3):

a. Voor de roos en de chrysant dalen de veilingprijzen van 2008 naar 2009 met 10 - 15\% (kredietcrisis) terwijl de afzet van de roos nog iets stijgt (0.3\%) en die van de chrysant daalt. In 2010 en 2011 stijgen de prijzen van roos en chrysant met ca. 5\%. De afzet van de roos stijgt nog enigszins en die van de chrysant daalt. Voor de phalaenopsis is in 2008 de veilingprijs aanmerkelijk lager dan in 2007 (een daling van $€ 4.87$ naar $€ 4.06$ onder een toename van de afzet van ruim 50\%). In 2009 daalt deze verder tot $€ 3.45$ bij een toename van de afzet van 30\%. In 2010 stijgt de prijs weer naar $€ 3.74$ met een toename van de afzet van $5 \%$ en in 2011 naar $€ 3.95$ terwijl de afzet weer toeneemt met $5 \%$.

b. De gemiddelde uitbetaalprijzen voor de drie vruchtgroenten gaan in 2009 en 2011 door de gevolgen van krediet- en EHEC-crisis met zo'n 10 - 20\% naar beneden. In 2010 is er sprake van een aanmerkelijk herstel, vooral voor de tomaat. 


\subsubsection{Voorlopige conclusies}

Hieronder volgen de voorlopige conclusies. De indeling hiervan is naar bestuurlijk-organisatorische, commerciële en financieel-economische aspecten. De conclusies zijn per sector respectievelijk afzetorganisatie opgesteld waarbij eerst aandacht wordt geschonken aan de gevoerde strategieën (de gedragsvariabelen $\mathrm{G}$ ) en daarna aan de behaalde resultaten (de resultaatsvariabelen R). Ook is gekeken naar de mate van beïnvloeding van de marktstructuur (S) door het marktgedrag $(G)$ (vice versa) en de gevolgen hiervan voor het marktresultaat $(R)$.

\section{- Bestuurlijk-organisatorische conclusies}

Periode 2003-2008

VTN/Coforta/The Greenery heeft met haar strategie van horizontale en verticale concentratie niet bereikt wat haar in 1996 voor ogen stond: een grotere horizontale en verticale bundeling van de afzet van verse groenten en fruit tussen de Nederlandse veilingen en groothandels-/ exportbedrijven. De horizontale concentratie is in 2008 weer op het niveau van voor de fusie terechtgekomen en de beoogde grotere samenwerking en horizontale bundeling van de afzet tussen de afzetorganisaties in groenten en fruit in Nederland is niet behaald. De zoektocht naar een juiste integratie van productie- en handelsactiviteiten met een efficiënte en effectieve structuur (zie appendix A) is nog niet ten einde en het is de vraag of zo'n integratie wel goed mogelijk is, gezien de vaak tegenstrijdige belangen. VTN/The Greenery heeft onderschat dat zij met haar strategie van verticale concentratie en het afsluiten van een deel van de groothandelsmarkten in Nederland en Europa de concurrentie enorm aanwakkerde, waardoor bedrijfsresultaten vaak negatief werden beïnvloed en het vertrek van leden /bedrijven extra werd gestimuleerd. De zakelijke aanpak van VTN/The Greenery wekte de indruk dat het handelsbelang van The Greenery voorging op het coöperatieve belang van de (kleine) leden/bedrijven. VTN/The Greenery leed hierdoor verlies aan 'goodwill'. Het aantal leden is vanaf de fusie met meer dan 10.000 gedaald, van ongeveer 12.000 in 1996 tot 4000 in het jaar 2000 naar 1150 in 2008. Het aantal werknemers is vanaf de overname en integratie van de handelshuizen in 1998 bijna gehalveerd (van 3204 naar 1661). In deze periode is de gemiddelde veilingomzet per lid gestegen van 100.000 naar 650.000 euro.

Beide bloemenveilingen tonen in de aanloop naar en ten tijde van de fusie 2007/2008 een stabiel leiderschap van directie en bestuur en een duidelijke strategie met positieve resultaten. Zij geven een goed voorbeeld van een zorgvuldig gevoerde strategie van horizontale concentratie en het bundelen van de belangen van de bloemenveilingen en hun leden in de sierteeltsector. FloraHolland gaat hierin aan kop sinds de fusie tussen Bloemenveilingen Holland te Naaldwijk/Berkel en Flora Rijnsburg per 1 januari 2002 en neemt ook het initiatief voor de nieuwe fusiebesprekingen met de VBA in 2006 en 2007. Zowel bij FloraHolland als bij de VBA is er een voortdurende daling van het aantal werknemers: voor FloraHolland van 2003-2007 van 2287 naar 2114 en voor de VBA van 1699 naar 1515. In 2008 ligt het totale aantal werknemers voor FloraHolland nieuw op 3555. Het aantal leden daalt voor Flora-Holland van 2003-2007 van 4000 naar 3000 en voor de VBA van 3000 naar 2000. In 2008 ligt het totale aantal leden voor FloraHolland nieuw op 
5124. De gemiddelde veilingomzet per lid is voor alle bloemenveilingen in Nederland (VBN) van 1990-2000 gestegen van $€ 240.000$ naar $€ 365.000$ en is daarna meer dan verdubbeld tot ruim $€ 800.000$ in 2008 .

Periode 2009-2011

In de crisisperiode 2009-2011 vonden bij VTN/The Greenery weer grote veranderingen plaats in strategie, organisatie en resultaten. Een wijziging van de naam The Greenery U.A. in Coforta U.A. en een aparte positionering van coöperatie en handelshuis moest de aanbodbundeling met nieuwe telers en telersverenigingen vergemakkelijken. Een nieuwe onderneming, Coforta Verkoop b.v., werd opgericht. Hiermee kregen de leden een keuzemogelijkheid voor het afzetkanaal van hun producten: via The Greenery naar met name de Europese retail of via het nieuwe verkoopbedrijf Coforta Verkoop b.v. naar de Nederlandse groothandel en exporteur. Ook nu wekte VTN/Coforta/The Greenery de indruk het handelsbelang voorop te stellen. In 2011 bleek dit model voor een viertal telersverenigingen te eenzijdig, 81 leden traden uit. Het verlies aan 'eigen telers'-omzet voor The Greenery bedroeg naar raming $216 \mathrm{mln}$. euro, 34\% van de omzet uit de producten van de leden in 2011. In deze periode daalde het aantal werknemers (in fte's) van 1661 naar 1507 en het aantal leden van 1150 naar 885. De gemiddelde veilingomzet per lid aangesloten bij VTN/Coforta/The Greenery steeg van 650.000 naar 720.000 euro.

Ook voor FloraHolland nieuw was de crisisperiode 2009-2011 een testcase. Ondanks de recessie werd er op bestuurlijk-organisatorisch gebied een aantal belangrijke stappen gezet. Een nieuwe structuur werd ingevoerd voor meer ledenbetrokkenheid en strakkere regels werden ingesteld voor het tegengaan van de afzet buiten de veiling om (BVO). Aandacht werd besteed aan de verdere virtualisering van het veilproces, het product-/marktmanagement, een versterkt risicobeheer en duurzaam ondernemen. Op het gebied van horizontale concentratie 'over de grenzen heen' kwam er uitbreiding. De nieuwe joint venture Veiling Rhein-Maas, tussen FloraHolland en het Duitse Landgard, liet in het eerste volledige jaar 2011 een bevredigende veilingomzet zien. Ook de integratie in 2009/2010 van het aanbod van de overgenomen importveiling TFA door FloraHolland verliep goed en versterkte de marktplaats. Voor zover er verticaal beleid werd ontwikkeld gericht op de (internationale) retailorganisaties, werkte en werkt FloraHolland goed samen met de groothandel/export zonder bedreiging van uitschakeling van deze belangrijke partij. In deze periode daalde het aantal werknemers bij FloraHolland met bijna 10\% en het aantal leden/ bedrijven met 4\%. De gemiddelde veilingomzet per lid steeg van 800.000 naar 850.000 euro.

\section{- Commerciële conclusies}

Periode 2003-2008

De prijsvorming van glasgroenten in de sector en ook bij VTN/The Greenery was niet optimaal en verliep via een ondoorzichtig proces. De prijsdoelstelling luidde: het realiseren per product van een marktconforme uitbetaalprijs (Jaarverslag VTN 2006, p. 5). De oorspronkelijke en voor de leden belangrijke veilingdoelstelling 'het verkrijgen van de hoogste opbrengst voor de producten van de leden' was losgelaten. VTN/The Greenery streefde als handelsorganisatie naar een 
scherpe inkoopprijs voor producten van zowel leden als niet-leden. Een onmogelijke positie om de oorspronkelijke doelstelling voor de huidige leden waar te maken.

Er was een voortdurende onevenwichtigheid tussen aanbod en vraag. Concentratie dan wel een betere samenwerking en afstemming van het aanbod door afzetorganisaties en telersverenigingen vond onvoldoende plaats en de concurrentie was groot. De in 1996 en 1998 uitgevoerde horizontale en verticale fusie door VTN/The Greenery had geen stabiele en rendabele uitbetaalprijzen opgeleverd. Voor zover er sprake was van vaste uitbetaalprijzen over langere termijn waren dit vaste lage prijzen, meestal onder het kostprijsniveau van de gemiddelde glasgroenteteler. De gemiddelde veilingprijs voor vruchtgroenten is door de fusie in 1996 niet erg veranderd. The Greenery besteedde veel aandacht aan de wensen van de grote Nederlandse en Europese retailers. Men investeerde in sorteer-, opslag-, koel- en transportcapaciteit om een vaste leverancierspositie (preferred supplier) bij het GWB te krijgen. Optimale logistiek in de verssector vereiste hoge investeringen in voorraden, koel- en transportcapaciteit en magazijnen. Het is de vraag of The Greenery dit op Europese schaal blijvend kan waarmaken, mede gezien haar lastige financiële positie en laag eigen vermogen.

De bloemenveilingen in Nederland hanteerden als belangrijkste dagelijkse verkoopmethode voor sierteeltproducten het klokveilen. Ook in 2008 werd voldaan aan de voorwaarden hiervoor. De omzetaandelen klok en bemiddeling lagen in de jaren 2003-2006 voor FloraHolland op 70:30 en bij de VBA op 67:33. Bij FloraHolland nieuw verschoven deze aandelen in 2008 naar 65:35. Er vond een langzame verschuiving plaats van minder klokomzet naar meer omzet via bemiddeling, vooral bij de potplanten. Aandacht voor deze verschuiving en het versterken van de klokpositie was van belang. Voor de deelnemers aan het veilproces waren scherpe veiltarieven en goede opbrengstprijzen eveneens van belang. De verkoopprovisie lag bij FloraHolland en de VBA in 2003/2004 gemiddeld op 3 - 3,5\% en verschoof bij beide veilingen naar een lager niveau in 2006/2007 (2,5 - 3\%). In 2008 lag dit percentage bij FloraHolland nieuw op 2.4\%. Het percentage heffingen lag hier in 2003/2004 ca. 1\% onder en werd in 2007/2008 op een enigszins hoger niveau gebracht, evenals de overige inkomsten. Gemiddeld lagen de totale jaarinkomsten voor beide veilingen op ongeveer $10 \%$ van de jaarlijkse productopbrengst. De conclusie over de prijsvorming is mede gebaseerd op de stabiele (theoretische) jaarprijzen voor de roos en de chrysant van 2003-2007. Deze prijsvorming vond voor de meeste producten redelijk optimaal plaats en verliep via een transparant proces tegen scherpe verkooptarieven van de veiling. Voor de meeste productgroepen, zowel bij de snijbloemen als de potplanten en tuinplanten werd het grootste gedeelte $(>50 \%)$ via de klok geveild en was er dagelijks een betrouwbare referentieprijs voor bemiddelingstransacties en persoonlijke verkoop. Een en ander zorgde dagelijks voor een goede match van aanbod en vraag en een 'schone' markt. 
Periode 2009-2011

De prijzen van glasgroenten in 2009 en 2011 waren mede door de gevolgen van krediet- en EHEC-crisis zeer laag en tastten de inkomenspositie van veel telers aan. In 2010 was er sprake van prijsherstel. De lage prijzen voor de teler leidden tot een groeiende groep telers die pleitte voor een verdere bundeling van het aanbod ten behoeve van een betere prijsvorming.

De veilingprijzen voor de roos en de chrysant lagen in 2008 en 2009 door de gevolgen van de kredietcrisis op een lager niveau (-10 tot $-15 \%)$. Opvallend was dat de afzet van de roos nog enigszins steeg. De handel en de consument leken te kiezen voor de goedkopere soorten (o.a. import) en bezuinigden op de prijs. In 2010 en 2011 herstelden de prijzen zich weer enigszins. De veilingprijs voor de phalaenopsis moest in 2008 en 2009 ook een flinke veer laten en was aanmerkelijk lager dan in 2007. In 2010 en 2011 was er ook hier sprake van enig herstel.

De omzetaandelen klok en bemiddeling verschoven van 2008-2011 van 65:35 naar 57:43. Voortdurende aandacht voor het versterken van de klokpositie, vooral bij de verkoop van potplanten, bleef belangrijk. De verkoopprovisie lag bij FloraHolland in 2008 op gemiddeld 2.4\%. In 2011 lag dit tarief op $2.1 \%$. Het percentage heffingen lag in 2008 op $2.7 \%$ en werd in 2011 op een lager niveau gebracht $(2.4 \%)$, evenals de overige inkomsten. Gemiddeld daalden de totale jaarinkomsten van FloraHolland van 2008-2011 van 10 naar 9\% van de jaarlijkse productopbrengst.

- Financieel-economische conclusies

Periode 2003-2008

De financiële positie van VTN/The Greenery op de Europese markt van verse groenten, fruit en paddenstoelen in 2008 was niet sterk. Zij had vanaf 1996 jaarlijks een fluctuerende omzet tussen de 1.1 en 1.6 mld. euro met een variatiemogelijkheid van 25 tot $30 \%$. De aanvoer van producten van eigen leden/bedrijven is met eenzelfde percentage teruggelopen en de ontvangen provisieinkomsten zijn gehalveerd. De positie op de Nederlandse markt was stabiel, op de belangrijkste Europese markten lastig. De Duitse markt was wisselend en teruglopend met veel concurrentie van eigen producenten en import uit andere EU-lidstaten. De positie op de Engelse markt en overige EU-markten was stabiel tot groeiende en de marktpositie in de VS en Japan was wisselend. Ook de liquiditeits- en solvabiliteitsfactoren waren niet hoog. De solvabiliteit is wel verbeterd en de ratio eigen vermogen kwam uit op $10.3 \%$ van het balanstotaal. Het aansprakelijk vermogen daalde enigszins, van 41.1 naar 38,7 \%. Het rendement op het totale vermogen lag in de beginperiode van VTN/The Greenery zeer laag. Vanaf 2001 is dit enigszins verbeterd. Het schommelde in de periode 2001 - 2008 tussen de 0.4 en 3.0\%. Dit is een laag niveau, zeker gezien het ondernemersrisico dat VTN/The Greenery met haar nieuwe activiteiten als vers-provider liep en gaat lopen. Ook de hoogte van de solvabiliteitsratio eigen vermogen liet te wensen over. VTN/The Greenery had als financiële doelstelling in haar jaarverslagen van de afgelopen jaren vermeld staan dat zij deze ratio jaarlijks met twee procentpunten wilde laten stijgen. Helaas is dat in 2008 niet gelukt en werd eenzelfde ratio EV als in 2007 gerealiseerd. 
Beide bloemenveilingen lieten in deze periode een goede financiële ontwikkeling zien op de Europese markt van sierteeltproducten. De veilingomzet van FloraHolland groeide van 2003-2007 jaarlijks met ruim 5\% en die van de VBA met bijna 3\%. De inkomsten uit dienstverlening van FloraHolland groeiden, die van de VBA bleven gelijk. Rendement en solvabiliteitsratio's lagen op een laag, maar aanvaardbaar niveau, voor FloraHolland enigszins hoger dan die van de VBA. Beide veilingen lieten ten tijde van de fusie in september 2007 een financieel sterke positie zien en streden op het scherp van de snede om hun positie jaarlijks te verbeteren en een goed resultaat te behalen. FloraHolland slaagde hierin het best.

Bovenstaande uitkomsten geven aan dat het rendement voor de bloemenveilingen over de afgelopen jaren op een laag niveau lag. Hoewel FloraHolland geen winstbeogende instelling is, zou het rendementspercentage op het niveau van de kapitaalmarktrente moeten liggen.

Periode 2009-2011

In deze periode daalde de netto-omzet van Coforta/The Greenery tot een laag niveau van 1.1 mld. euro in 2011. Tussen krediet- en EHEC-crisis gaf 2010 een herstel tot $1.263 \mathrm{mln}$. euro. Het rendement op het totale vermogen was in 2011 negatief. Posities op de Nederlandse, Engelse en Duitse markten verslechterden, de overige EU-markten bleven redelijk op peil.

Door een kostenbewust beleid is de solvabiliteit en het risicodragend vermogen toch gestegen.

De veilingomzet van FloraHolland daalde in 2009 (jaar van de kredietcrisis) met ongeveer 5\% en kwam in 2010 en 2011 net boven het niveau van 2008 uit. De inkomsten uit diensten van FloraHolland daalden. Er vond echter een grotere daling van de kosten dan de opbrengsten plaats en het rendement en de solvabiliteit werden in deze periode toch verbeterd. 

BEDRIJFSONDERZOEK GLASTUINBOUW IN NEDERLAND, DEELSECTOR GLASGROENTEN 


\section{$5.1 \quad$ Inleiding}

In dit hoofdstuk staat het bedrijfsonderzoek in de deelsector glasgroenten centraal, in hoofdstuk 6 en 7 volgt het bedrijfsonderzoek in de deelsectoren glassnijbloemen en -potplanten. Behandeld worden de belangrijkste gedrags- en resultaatsvariabelen op microniveau, de structuur- en resultaatsvariabelen op mesoniveau en het mogelijke verband tussen variabelen van marktgedrag en marktresultaat met behulp van een enkelvoudige $\chi 2$-analyse. In hoofdstuk 8 volgt een meervoudige econometrische analyse in de drie sectoren.

De onderzoeksvraag richt zich op het opsporen van betekenisvolle verbanden tussen belangrijke variabelen van marktgedrag, marktstructuur en marktresultaat van de glastuinbouwbedrijven binnen deze sectoren.

Het betreft de volgende variabelen uit het analysemodel van figuur 2.4 in hoofdstuk 2:

Marktgedrag

- productdifferentiatie

- bedrijfstypen/afzetmethoden

- horizontale concentratie

- voorwaartse verticale concentratie (=integratie)

- investeringen/innovaties

- bedrijfsomvang/kostenniveau

- toe- en uittreding

Marktresultaat

- jaaromzet + groei

- jaarprijzen

- brutomarge[(P-GTK)/P] *100

- aandeel eigen vermogen in \% totaal (EV/TV)*100

Marktstructuur

- concentratieontwikkeling

- productdifferentiatie

- toetredingsdrempels (investeringen)

Voorafgaand aan het bedrijfsonderzoek vond een vooronderzoek plaats in de vorm van een autoriteitenonderzoek (zie appendix 5A). Op basis van dit autoriteitenonderzoek is per sector een plan van aanpak opgesteld, bestaande uit een kwalitatief en een kwantitatief gedeelte. Het kwalitatieve deel richt zich op het in kaart brengen van het glastuinbouwcomplex in Nederland en het formuleren en testen van de onderzoeksvragen. Het kwantitatieve deel bestaat uit een vragenlijstonderzoek met aanvullende interviews, waarmee belangrijke bedrijfsinformatie is verkregen over onder meer assortimentskeuze, bedrijfstype en -omvang, afzetmethode en -kosten, opbrengsten, rendement en behaalde uitbetaalprijzen (zie appendix 5B). In de volgende paragraaf zal worden beschreven op welke manier het bedrijfsonderzoek in de praktijk is uitgevoerd. 


\subsection{Methode bedrijfsonderzoek glasgroenten}

Het doel van het bedrijfsonderzoek is het verkrijgen van voldoende betrouwbare en representatieve informatie van de glastuinbouwbedrijven per deelsector, ter beantwoording van de in hoofdstuk 2 paragraaf 2.6.2 genoemde onderzoeksvragen op micro- en mesoniveau. Het bedrijfsonderzoek in de sector glasgroenten is gestart in 2006, met deelrapportages in 2006 en 2007.

\section{Onderzoekspopulatie}

Voor dit onderzoek zijn 80 glastuinders benaderd vanuit een door LTO Groeiservice beschikbaar gesteld adressenbestand van tomaten- en paprikatelers, verspreid over de belangrijke concentraties glastuinbouwgebieden in Nederland (Westland, Oostland, Midden- Nederland, Venlo e.o. en West- en Midden-Brabant). Deze ondernemers zijn gebeld met een verzoek om mee te werken aan een mondeling interview van maximaal een uur, op basis van een vooraf toe te sturen vragenlijst (zie appendix 5B). In deze vragenlijst werd allereerst aan elke tuinder gevraagd zijn bedrijfstype aan te geven. Daarna volgde een dertigtal specifieke vragen over algemene bedrijfskenmerken, assortiment, omzet- en kostenontwikkeling, personeel en bedrijfsuitrusting, marketing/ verkoop en prijsvorming. Hierbij werd verwezen naar een aantal toonbladen ter verduidelijking van het begrip bedrijfstype, de kostenopbouw in de bedrijfskolom en de prijsontwikkeling in de voorafgaande jaren. Uiteindelijk zijn 42 vraaggesprekken gehouden met 22 tomaten- en 20 paprikatelers. De beantwoording van de vragen is in meerderheid volledig geweest. Op enkele vragen over in het verleden geïnvesteerde bedragen of de verhouding eigen en vreemd vermogen bleef men het antwoord soms schuldig of werd een schatting genoemd.

\section{Steekproefomvang en representativiteit}

De steekproefomvang is vastgesteld op basis van de populatieontwikkeling glastuinbouwbedrijven en afzetorganisaties voor de twee belangrijkste vruchtgroenten tomaat en paprika in de sector glasgroenten. Deze gekozen steekproef tomaten- en paprikabedrijven is beoordeeld op betrouwbaarheid en representativiteit (zie appendix 5C).

Samenvattend kan het volgende worden gesteld. Het aantal respondenten van de steekproef ten opzichte van het totaal aantal glasgroentebedrijven bedraagt ruim 2\% (42 van de 1958 bedrijven). Het totale areaal van de 42 onderzochte bedrijven bedraagt 245 ha. en heeft een aandeel in de bedrijfsoppervlakte glasgroenten in Nederland van 5.5\% (245 ha./4500 ha.).

Bezien naar het areaalaandeel van de onderzochte productgroep tomaat is dit ongeveer $11 \%$ (154 ha./1396 ha.).Voor de glaspaprika (91 ha./1236 ha.) bedraagt dit 7\%. Gezien de beperkte omvang van de steekproef en de niet geheel representatieve verdeling van de respondenten over de verschillende afzetorganisaties en productiegebieden dienen de resultaten van het onderzoek met enige voorzichtigheid te worden gehanteerd. 


\section{Onderzoeksuitkomsten}

In de paragraaf 5.3 worden de onderzoeksresultaten van het bedrijfsonderzoek behandeld, waar mogelijk in volgorde van de vragen zoals geformuleerd in de vragenlijst. Aan de hand van een aantal frequentietabellen worden de belangrijkste bedrijfskundige en financieel-economische kenmerken van de bedrijven per sector, per productgroep en per bedrijfstype beschreven. Daarna worden met behulp van de chi-kwadraat analyse de enkelvoudige verbanden getoetst tussen de gedrags- en resultaatsvariabelen en wordt een overzicht gegeven van die variabelen die of een betekenisvol of een opvallend niet-betekenisvol verband laten zien. Voor een overzicht van de tabellen en de toelichting hierop verwijzen we u naar appendix 5D.

\subsection{Analyse en resultaten glasgroentebedrijven}

In paragraaf 5.3.1 wordt de analyse van de gedrags- en resultaatsvariabelen besproken, in paragraaf 5.3.2 de analyse van de structuur- en resultaatsvariabelen.

\subsubsection{Analyse gedrags- en resultaatsvariabelen (microniveau)}

In deze paragrafen worden de belangrijkste gedrags- en resultaatsvariabelen uit het bedrijfsonderzoek van de sector glasgroenten besproken (Veerman, 2007). Zoals gezegd komen deze in volgorde van sector, productgroepen en bedrijfstypen aan bod en worden de mogelijke verbanden tussen de genoemde variabelen daarna behandeld.

\subsubsection{Onderzoeksresultaten glasgroenten (sector)}

Het vraaggesprek en de vragenlijst van het bedrijfsonderzoek is ingedeeld naar algemene bedrijfskenmerken, de organisatie van marketing- en verkoopactiviteiten, prijsvorming, effectiviteit en efficiency van de marketing- en verkoopstrategie en sectorale ontwikkelingen. We behandelen de belangrijkste onderzoeksresultaten in deze volgorde.

\section{Kenmerken bedrijf en sector}

Een belangrijk kenmerk van het glasgroentebedrijf is de bedrijfsoppervlakte glas in hectare en de hiermee jaarlijks te realiseren omzet en winst. In 2006 is het verschil in omvang en resultaat tussen de onderzochte bedrijven groot. De populatie ligt iets onder de 2000 bedrijven met een gemiddelde oppervlakte van bijna $2.5 \mathrm{ha}$. Uit dit onderzoek (zie tabel 5.1) blijkt dat er zeer kleine bedrijven ( $<1$ ha.) en zeer grote bedrijven ( $>30$ ha.) actief zijn. Van de 42 onderzochte bedrijven ligt de gemiddelde bedrijfsgrootte met 5.8 ha., met een spreiding van ruim 33 ha. tussen het kleinste en het grootste bedrijf, ruim boven het populatiegemiddelde ${ }^{6}$. Van de bedrijven heeft $25 \%$ een omvang tot en met 1.5 ha., $50 \%$ omvat 3 ha. of meer. De schaalgrootte van bedrijven in de glasgroenten neemt rond $2005 / 2006$ jaarlijks fors toe.

6 Als we de twee grootste bedrijven/respondenten niet meetellen komt het gemiddeld glasopp. op 4.6 ha. en de omzet in 2005 en 2006 op $€ 1.6$ en $€ 1.9 \mathrm{mln}$. 
Tabel 5.1 Belangrijke kenmerken bedrijven sector glasgroenten (tomaat en paprika)

\begin{tabular}{|c|c|c|c|c|c|c|}
\hline$(n)=42$ & $\begin{array}{l}\text { Bedrijfs- } \\
\text { opp. glas } \\
2006 \\
\text { in ha. }\end{array}$ & $\begin{array}{l}\text { Omzet } \\
2005 \\
(x \in 1 \\
\text { mln.) }\end{array}$ & $\begin{array}{l}\text { Omzet } \\
2006 \\
(x € 1 \\
\text { mln.) }\end{array}$ & $\begin{array}{l}\text { Brutomarge } \\
\text { begroot } \\
2006 \\
{[(\mathrm{P}-\mathrm{GTK}) / \mathrm{P}]} \\
* 100 ; \mathrm{n}=39\end{array}$ & $\begin{array}{l}\text { Brutomarge } \\
\text { realisatie } \\
2006 \\
{[(\mathrm{P}-\mathrm{GTK}) / \mathrm{P}]} \\
* 100 ; \mathrm{n}=41\end{array}$ & $\begin{array}{l}\text { Aandeel } \\
\text { eigen verm. } \\
\text { (EV/TV) } \\
* 100 \\
\mathrm{n}=30\end{array}$ \\
\hline Gemiddelde & 5.8 ha. & 2.2 & 2.5 & $5.9 \%$ & $8.0 \%$ & $49.8 \%$ \\
\hline Standaardfout gem. (s.e.) & $1.1 \mathrm{ha}$. & 0.5 & 0.5 & $0.6 \%$ & $2.0 \%$ & $4.4 \%$ \\
\hline Standaardafwijking (s) & 7.1 ha. & 3.2 & 3.3 & $3.6 \%$ & $12.7 \%$ & $24.3 \%$ \\
\hline Minimum & 0.8 ha. & 0.3 & 0.3 & $2.5 \%$ & $-33.3 \%$ & $10.0 \%$ \\
\hline Maximum & 34.0 ha. & 15.5 & 16.0 & $15.0 \%$ & $26.6 \%$ & $90.0 \%$ \\
\hline Spreiding & 33.2 ha. & 15.3 & 15.8 & $12.5 \%$ & $59.9 \%$ & $80.0 \%$ \\
\hline Scheefheid/stand. fout & $2.4 / 0.4$ & $3.1 / 0.4$ & $2.8 / 0.4$ & $1.0 / 0.4$ & $-1.2 / 0.4$ & $0.2 / 0.4$ \\
\hline
\end{tabular}

$[(\mathrm{P}-\mathrm{GTK}) / \mathrm{P}] * 100=[(\text { prijs-gem. totale kosten }) / \text { prijs }]^{*} 100 ; \mathrm{s}=\sqrt{ } \sum\left(\mathrm{x}_{\mathrm{i}}-\overline{\mathrm{X}}\right)^{2} / \mathrm{n}-1 ;$ s.e. $=\mathrm{s} / \sqrt{ } \mathrm{n}$

Evenals de bedrijfsoppervlakte tonen de omzetcijfers 2005 en 2006 en de gerealiseerde brutomarge een grote spreiding. De gemiddelde omzet in 2005 is $€ 2.2 \mathrm{mln}$. met een spreiding van $€ 0.25 \mathrm{mln}$. tot $€ 15.5 \mathrm{mln}$. In 2006 lag de gemiddelde omzet een fractie hoger op $€ 2.5 \mathrm{mln}$. met een minimum van $€ 0.3$ en een maximum van $€ 16.0 \mathrm{mln}$. Het aandeel eigen vermogen in procenten van het totaal ligt in 2006 op bijna 50\% (30 respondenten).

Marketing en verkoop

De belangrijkste vragen betreffen de keuze van de marketing- en verkooporganisatie, de omvang van het verkoopapparaat en de verkoopkosten en de mate van tevredenheid hierover. Deze aspecten worden in onderstaande paragrafen achtereenvolgens behandeld.

\section{Organisatie marketing en verkoop}

Sinds het fusieproces van de groente- en fruitveilingen in Nederland in 1995/1996 is een groot aantal bedrijven gestopt dan wel veranderd van afzetorganisatie en afzetmethode (zie hoofdstuk 4 tabel 4.1). De uitkomsten van het bedrijfsonderzoek laten zien dat in 2006 ruim $40 \%$ van de glasgroentetelers is aangesloten bij VTN/The Greenery in Barendrecht en bijna $17 \%$ bij veiling ZON in Noord-Limburg (tabel 5.2). Dit zijn de voormalige coöperatieve veilingen met de kleinste bedrijven. Ruim 30\% van de respondenten heeft via een gezamenlijk opgerichte telersvereniging gekozen voor een eigen organisatie van de afzet. Vaak heeft men een vaste relatie met een specifiek handelshuis zoals VDT/VDN, BGB /Haluco, Unistar/Van Rijn e.a. De grootste onafhankelijk van de voormalige veilingorganisaties en private handelshuizen opererende afzetorganisatie is FresQ (10\% van de respondenten) met voornamelijk grote glasgroentetelers die hun eigen afzet regelen (Red Star Trading van Gebr. Van der Kaaij, Seasun van Gebr. Gresnigt e.a.). 
Tabel 5.2 Organisatie marketing en verkoop van de onderzochte bedrijven (2005/2006)

\begin{tabular}{|l|c|r|r|r|r|}
\hline $\begin{array}{l}\text { Organisatie van de afzet } \\
\text { via: }\end{array}$ & $\begin{array}{l}\text { Aantal } \\
\text { leden/bedrijven }\end{array}$ & $\begin{array}{l}\text { Aandeel } \\
\text { in } \%\end{array}$ & $\begin{array}{l}\text { Gem. opp. } \\
\text { in ha. }\end{array}$ & $\begin{array}{l}\text { Totale } \\
\text { opp. in ha. }\end{array}$ & $\begin{array}{l}\text { Aandeel } \\
\text { in \% }\end{array}$ \\
\hline The Greenery & 17 & 40.5 & 3.0 & 51.6 & 21.1 \\
\hline ZON & 7 & 16.7 & 2.2 & 15.3 & 6.2 \\
\hline VDN & 3 & 7.1 & 2.6 & 7.9 & 3.2 \\
\hline Haluco & 4 & 9.5 & 10.9 & 43.6 & 17.9 \\
\hline Bakker Barendrecht & 1 & 2.4 & 3.5 & 3.5 & 1.5 \\
\hline Van Rijn & 2 & 4.8 & 13.8 & 27.6 & 11.3 \\
\hline FresQ & 4 & 9.5 & 19.4 & 77.5 & 31.8 \\
\hline QPI & 1 & 2.4 & 2.6 & 2.6 & 1.2 \\
\hline Zaltbommel/VDN & 2 & 4.8 & 5.3 & 10.5 & 4.3 \\
\hline Bochi & 1 & 2.3 & 3.7 & 3.7 & 1.5 \\
\hline Totaal & 42 & 100.0 & & 243.8 & 100.0 \\
\hline
\end{tabular}

\section{Omvang verkoopapparaat en -kosten}

The Greenery en ZON hebben door de relatief grote omvang van het assortiment en omzetaandeel in groenten en fruit het grootste verkoopapparaat ( 5 of meer fte's). Bij zelfstandig opererende telersverenigingen is dit veel kleiner $(0<2 \mathrm{fte}$ 's) en wordt een groot deel van deze werkzaamheden verricht door het handelshuis. De grotere zelfstandige glasgroentebedrijven onder FresQ-vlag zitten ertussenin $(3<5$ fte's). Bij de vraag naar argumenten om voor een bepaalde verkooporganisatie te kiezen wordt door de 42 bedrijven $17 \mathrm{x}$ het realiseren van goede uitbetaalprijzen genoemd. Ook het 'samenwerken met een betrouwbare partner' en het 'historisch zo gegroeid' worden veelvuldig genoemd (beide $16 \mathrm{x}$ ). Hpartner on mee samen te werken en H.md, op de voet gevolgd door F. hier tussen in met 3-<5 fte De verkoopkosten van de bedrijven zijn gemiddeld 3\% van de omzet en variëren tussen de 0.5 en $5.5 \%$ (tabel 5.3). Bijna $40 \%$ geeft een percentage van 2.0-2.5\% op en ruim 20\% zit tussen de 4.5 en $5.5 \%$. Dit is sterk afhankelijk van de omvang van de bedrijfsomzet en de diensten die de verkooporganisaties bieden.

Tabel 5.3 Gemiddelde sectorale verkoopkosten in \% omzet

\begin{tabular}{|l|c|}
\hline Aantal respondenten & 41 \\
\hline Aantal gemist & 1 \\
\hline Gem. verkoopkosten alle glasgroentebedrijven (in \%) & 3.0 \\
\hline Standaardfout gemiddeld (in \%) & 0.2 \\
\hline Standaardafwijking (in \%) & 1.3 \\
\hline Minimum & 0.5 \\
\hline Maximum & 5.5 \\
\hline
\end{tabular}

Bij de vraag naar welke diensten er door het verkoopapparaat werden geleverd, werd door de 42 bedrijven in ruim $75 \%$ van de gevallen gekozen voor verkopen, opslag en verzending. Het sorteren en verpakken wordt door henzelf gedaan, als dat aan de orde is. Uitbesteding van sorteren en verpakken komt bij ongeveer $10 \%$ van de respondenten voor en wordt meestal als kostbaar gezien. Ook wordt debiteurenbewaking in een drietal gevallen genoemd als onderdeel van de verkoopdienstverlening. Bij navraag blijkt dat sommige handelshuizen (o.a. Haluco) wel scherpe verkooptarieven aanbieden, maar het risico van niet- tijdige betaling aan de teler laten. Ook is het ophalen van de producten bij de teler en het aanleveren bij de groothandel niet altijd opgenomen in de tarieven van de handelshuizen. 
The Greenery maakt reclame met zogenaamde gratis ophaaldiensten en veiling ZON berekent hiervoor volgens telers via haar dochter LOZON hoge tarieven.

3. Mate van tevredenheid over de verkooporganisatie

$55 \%$ van de bedrijven is tevreden tot zeer tevreden over de verkooporganisatie, $12 \%$ ontevreden tot zeer ontevreden en 33\% zit ertussenin. Bedrijfstype A1 (zie paragraaf 5.3.1.3) is het meest ontevreden, waarschijnlijk in verband met de relatief hoge verkoopkosten die de afzetorganisatie in rekening brengt, en de vaak lager uitvallende uitbetaalprijzen (zie tabel 5.12 en 5.13). Als maatregelen om de tevredenheid te vergroten worden genoemd een betere prijs- en kwaliteitsverhouding ( $7 x)$, een transparante prijsvorming $(7 x)$ en herinvoeren van de veilingklok met concentratie van het aanbod $(8 \mathrm{x})$.

\section{Prijsvorming}

Voor het door de ondernemer te behalen rendement op investeringen is een goede prijsvorming en het realiseren van een gemiddelde jaarlijkse uitbetaalprijs boven de gemiddelde kosten van groot belang. Helaas is dat voor veel bedrijven lang niet altijd het geval. Naast de keuze van een onderscheidend assortiment en efficiënte productiemiddelen hangt dit nauw samen met de organisatie van de afzet en het marketing- en verkoopbeleid dat wordt gevoerd. De vragen hierover in het bedrijfsonderzoek betreffen:

1. de gekozen verkoopwijze en de hoogte van de jaarlijkse gemiddelde uitbetaalprijzen;

2. de mate van tevredenheid, de verbetermogelijkheden en de vormen van samenwerking;

3. de acties bij lage prijzen en de mening over het P8-initiatief van paprikatelers ${ }^{7}$ ).

1. Verkoopwijze en gemiddelde uitbetaalprijzen

De onderzoeksuitkomsten in tabel 5.4 laten zien dat de verkoopwijze van de producten voor twee derde gedeelte plaatsvindt via bemiddeling en steeds minder via de klok, waarvan de laatste in gebruik is bij de veiling ZON. Het overige deel van de verkoop gaat via de telersvereniging (ca. $24 \%$ ) en via de teler zelf (ca. 12\%, bijv. FresQ).

Tabel 5.4 Verkoopwijze producten (2005/2006)

\begin{tabular}{|l|r|r|}
\hline & Aantal bedrijven & Aandeel in \% \\
\hline Via bemiddeling veiling & 19 & 45 \\
\hline Via telersvereniging & 10 & 24 \\
\hline Directe verkoop door de teler & 5 & 12 \\
\hline Deel klok, deel bemiddeling & 8 & 19 \\
\hline Totaal & 42 & 100 \\
\hline
\end{tabular}

7 P8 vertegenwoordigt de gezamenlijke belangen van de Nederlandse paprikatelers. Doel is het versterken van de marktpositie. De leden van P8 zijn telersverenigingen van paprika's. De belangrijkste taak van P8 is het uitvoeren van marketingactiviteiten voor de paprika (www.p-acht.nl). 
De gemiddelde (netto) uitbetaalprijzen voor tomaat en paprika van 2003-2006 tonen een wisselend beeld. 2003 was voor beide producten een goed jaar (30 respondenten), 2004 en 2005 tonen een sterke terugval. In 2006 is weer sprake van enig herstel. Voor een overzicht van de gemiddelde (netto) uitbetaalprijzen voor tomaat en paprika van 2003-2006 verwijzen we naar de tabellen 5.5 en 5.6 .

\section{Tevredenheid uitbetaalprijs}

De onderzoeksresultaten laten zien dat ongeveer $60 \%$ van de respondenten de uitbetaalprijs matig vindt, $26 \%$ vindt deze goed. Op de vraag hoe de prijs verbeterd zou kunnen worden, werd een verhoogde concentratie van het aanbod het meeste genoemd $(15 \mathrm{x})$.

Ten aanzien van de samenwerking tussen telers, onder meer ten behoeve van een betere prijsvorming, gaf meer dan $25 \%$ aan deze samenwerking nog steeds via de grootste afzetorganisatie, The Greenery, te zoeken. 15\% zocht deze samenwerking via zijn telersvereniging resp. ZON Verkoopdiensten en $12 \%$ via P8, het landelijk overleg van paprikatelers. $15 \%$ van de respondenten werkte niet samen.

\section{Acties bij lage prijzen en P8-bundelingsinitiatief}

Lage prijzen en het P8-bundelingsinitiatief laten zien dat van de 42 onderzochte bedrijven bijna $40 \%$ (meestal bij The Greenery en ZON aangesloten telers) vindt dat zijn afzetorganisatie hier acties moet ondernemen door bijvoorbeeld klanten te benaderen of een marktgebied te zoeken met nog enige extra vraag. $20 \%$ heeft geen idee en denkt dit verlies voor eigen rekening te moeten nemen (doordraaien). Een aantal bedrijven denkt in de P8-samenwerking een mogelijkheid te vinden om dit tegen te gaan. Alle respondenten die bekend zijn met dit initiatief (P8) staan hier positief tegenover.

Effectiviteit en efficiency van gehanteerde marketing- en verkoopmethoden $24 \%$ van de respondenten vindt dat een goede afstemming van aanbod en vraag het meest effectief werkt. Segmentatie in de markt en een juiste verhouding van voorverkoop en dagmarkt (50/50) scoren daarna het hoogst (elk 14\%).

Bij efficiency scoort ketenverkorting het hoogst (57\%). Schaalvergroting (19\%) en uitgekiende logistiek (17\%) komen als tweede en derde.

\section{Belangrijke bedrijfs- en sectorontwikkelingen}

De beantwoording van de vraag naar belangrijke ontwikkelingen in de glastuinbouw laten zien dat de telers het meest worstelen met de keuze voor grootschalig- of kleinschaligheid. Moeten ze doorgaan met een grootschaliger opererend glastuinbouwbedrijf met bijbehorende risico's of is er voor het kleinere bedrijf ook nog een toekomst? 


\subsubsection{Productsoorten (tomaat en paprika)}

$\mathrm{Na}$ de bespreking van de onderzoeksuitkomsten op sectorniveau worden nu de belangrijkste resultaten uit de voorgelegde vragenlijst per productsoort in tabelvorm gegroepeerd, geanalyseerd en toegelicht. Het betreft de beantwoording van de vragen over:

1. uitbetaalprijzen 2003-2006

2. omzetontwikkeling 2005/2006

3. bedrijfsoppervlakte in ha. glas

4. brutomarge 2006

5. concentratieontwikkeling (C4) per productsoort.

Ad 1. Uitbetaalprijzen 2003-2006

De onderzoeksuitkomsten van de (netto) uitbetaalprijzen voor de tomaat en paprika van 20032006 in onderstaande tabellen 5.5 en 5.6 geven aan dat de gemiddelde uitbetaalprijs een hoge prijsfluctuatie kent ( $\mathrm{p}_{\max } / \mathrm{p}_{\min }$ ligt tussen de 1.4 en 1.6). Dit hangt nauw samen met het soort en type product, het wisselend verloop van aanbod en vraag gedurende het seizoen en de mate van concurrentie op de belangrijkste Noord-Europese markten. De minimumprijs zakt nogal eens onder het kostprijsniveau van het product. De prijsvariatie bij de tomaat is, gezien de grotere verschillen in geteeld producttype, groter dan bij de paprika. Opvallend is dat de maximumprijs minder fluctueert dan de minimumprijs. Dit kan wijzen op overaanbod en op scherpe prijsonderhandelingen op het minimumprijsniveau met een sterke positie van de groot- en detailhandel. Het jaar 2003 was voor beide producten een goed jaar. 2004 toont een sterke terugval voor de tomaat, terwijl de daling bij de paprika minder is. In 2005 zijn de rollen omgedraaid: de gemiddelde prijs voor de tomaat herstelt zich, maar de paprika daalt tot een zeer laag niveau, een absoluut dieptepunt. In 2006 is weer sprake van een redelijk herstel, zowel voor de tomaat als voor de paprika.

Tabel 5.5 Gemiddelde uitbetaalprijzen tomaat 2003, 2004, 2005 en 2006

\begin{tabular}{|c|c|c|c|c|c|}
\hline $\begin{array}{l}\text { Productsoort: } \\
\text { tomaat }\end{array}$ & $\begin{array}{c}\text { gem. } \\
\text { uitbetaalprijs in } \\
\text { eurocent p. } \mathrm{kg} \\
2003 \\
\end{array}$ & $\begin{array}{c}\text { gem. } \\
\text { uitbetaalprijs in } \\
\text { eurocent p. kg } \\
2004 \\
\end{array}$ & $\begin{array}{c}\text { gem. } \\
\text { uitbetaalprijs in } \\
\text { eurocent p. kg } \\
2005 \\
\end{array}$ & $\begin{array}{c}\text { gem. } \\
\text { uitbetaalprijs in } \\
\text { eurocent p. kg } \\
2006 \\
\end{array}$ & $\begin{array}{l}\text { prijsfluctuatie- } \\
\text { coëfficient } \\
\left(\mathrm{p}_{\max } / \mathrm{p}_{\min }\right)\end{array}$ \\
\hline Gemiddelde prijs & 97 & 60 & 83 & 86 & 1.60 \\
\hline Standaardfout & 8 & 6 & 7 & 7 & \\
\hline Standaard afw. & 29 & 26 & 34 & 32 & \\
\hline Minimum & 77 & 46 & 50 & 68 & 1.67 \\
\hline Maximum & 165 & 160 & 200 & 190 & 1.25 \\
\hline $\begin{array}{l}\text { Aantal } \\
\text { respondenten }\end{array}$ & 14 & 18 & 22 & 21 & \\
\hline Aantal gemist & 8 & 4 & 0 & 1 & \\
\hline
\end{tabular}


Tabel 5.6 Gemiddelde uitbetaalprijzen paprika 2003, 2004, 2005 en 2006

\begin{tabular}{|c|c|c|c|c|c|}
\hline $\begin{array}{l}\text { Productsoort: } \\
\text { paprika }\end{array}$ & $\begin{array}{c}\text { gem. } \\
\text { uitbetaalprijs in } \\
\text { eurocent p. kg } \\
2003 \\
\end{array}$ & $\begin{array}{c}\text { gem. } \\
\text { uitbetaalprijs in } \\
\text { eurocent p. kg } \\
2004\end{array}$ & $\begin{array}{c}\text { gem. } \\
\text { uitbetaalprijs in } \\
\text { eurocent p. kg } \\
2005\end{array}$ & $\begin{array}{c}\text { gem. } \\
\text { uitbetaalprijs in } \\
\text { eurocent p. kg } \\
2006 \\
\end{array}$ & $\begin{array}{l}\text { prijsfluctuatie- } \\
\text { coëfficient } \\
\left(\mathrm{p}_{\max } / \mathrm{p}_{\min }\right)\end{array}$ \\
\hline Gemiddelde prijs & 148 & 128 & 99 & 140 & 1.49 \\
\hline Standaard fout & 4 & 1 & 7 & 4 & \\
\hline Standaard afw. & 14 & 7 & 9 & 11 & \\
\hline Minimum & 118 & 117 & 83 & 111 & 1.42 \\
\hline Maximum & 170 & 145 & 130 & 160 & 1.31 \\
\hline $\begin{array}{l}\text { Aantal } \\
\text { respondenten }\end{array}$ & 16 & 19 & 19 & 18 & \\
\hline Aantal gemist & 3 & 0 & 0 & 1 & \\
\hline
\end{tabular}

Tabel 5.7 geeft een vergelijk met de gemiddelde prijzen van het Productschap Tuinbouw (PT) voor alle tomaten resp. paprika's. Hieruit blijkt dat in bijna alle gevallen het gemiddelde prijsniveau van de door de respondenten opgegeven uitbetaalprijzen boven de gemiddelde PT-prijzen ligt. Dit wordt veroorzaakt door een aantal respondenten met een assortiment in een hoger prijssegment (zie ook de prijzen per bedrijfstype in tabel 5.12 en 5.13).

Tabel 5.7 Vergelijk gemiddelde jaarprijzen Productschap Tuinbouw (PT) en onderzoeksresultaat voor de tomaat en paprika

\begin{tabular}{|l|l|l|l|l|c|}
\hline & 2003 & 2004 & 2005 & 2006 & $\begin{array}{c}\text { prijsfluctuatie- } \\
\text { coëfficient } \\
\left(\mathrm{p}_{\max } / \mathrm{p}_{\min }\right)\end{array}$ \\
\hline PT gem. jaarprijs alle tomaten & 89 & 57 & 75 & $78 \mathrm{~V}$ & 1.56 \\
\hline $\begin{array}{l}\text { Gem. prijs tomaat uit } \\
\text { onderzoeksresultaat }\end{array}$ & 97 & 60 & 83 & 86 & 1.60 \\
\hline & & & & & $136 \mathrm{~V}$ \\
\hline PT gem. jaarprijs alle paprika's & 138 & 125 & 100 & 140 & 1.38 \\
\hline $\begin{array}{l}\text { Gem. prijs paprika uit } \\
\text { onderzoeksresultaat }\end{array}$ & 148 & 128 & 99 & & 1.49 \\
\hline
\end{tabular}

$\mathrm{V}=$ Voorlopig

\section{Ad 2, 3 en 4. Omzetontwikkeling, bedrijfsoppervlakte en brutomarge}

De onderzoeksuitkomsten die naar productsoort zijn gemeten, worden gepresenteerd in tabel 5.8. Hierin is zichtbaar dat het gemiddelde tomatenbedrijf in Nederland bijna twee keer zo groot is als het paprikabedrijf. Dat geldt zowel voor bedrijfsoppervlakte glas als omzet. De gemiddelde omzet van het tomatenbedrijf ontwikkelt zich van $€ 2.9 \mathrm{mln}$. in 2005 naar $€ 3.2 \mathrm{mln}$. in 2006 . Het kleinere paprikabedrijf laat een gemiddelde omzet in 2005 van $€ 1.4 \mathrm{mln}$. en $€ 1.8 \mathrm{mln}$. in 2006 zien. Gesplitst naar tomaat en paprika komen de begrote marges bij de tomaat uit op 5.2\% en bij de paprika op 6.5\%. De gerealiseerde brutomarge in 2006 ligt bij de tomaat en paprika op een gelijk niveau $(8.0 \%)$. 
Tabel 5.8 Belangrijke bedrijfskenmerken per productsoort 2005/2006

\begin{tabular}{|c|c|c|c|c|c|}
\hline Productsoorten & $\begin{array}{l}\text { Bedrijfsopp. } \\
\text { glas } 2006 \text { in } \\
\text { ha. }\end{array}$ & $\begin{array}{l}\text { Omzet } 2005 \\
(\mathrm{x} € 1 \mathrm{mln} .)\end{array}$ & $\begin{array}{l}\text { Omzet } 2006 \\
(\mathrm{x} € 1 \mathrm{mln} .)\end{array}$ & $\begin{array}{l}\text { Brutomarge in } \\
\% \text { begroot } \\
2006[(\mathrm{P}- \\
\text { GTK }) / \mathrm{P}] * 100\end{array}$ & $\begin{array}{l}\text { Brutomarge in } \\
\% \text { realisatie } \\
2006[(\mathrm{P}- \\
\text { GTK }) / \mathrm{P}] * 100\end{array}$ \\
\hline \multicolumn{6}{|l|}{ Tomaat $(n=22)$} \\
\hline Gemiddelde & 7.0 & 2.9 & 3.2 & $5.2(n=21)$ & $8.0(n=19)$ \\
\hline Standaardfout & 1.9 & 0.9 & 0.9 & 0.6 & 3.5 \\
\hline Standaardafwijking & 8.7 & 4.0 & 4.1 & 2.7 & 14.1 \\
\hline Minimum & 1.0 & 0.4 & 0.4 & 2.5 & -33.3 \\
\hline Maximum & 34.0 & 15.5 & 16.0 & 12.5 & 26.6 \\
\hline \multicolumn{6}{|l|}{ Paprika $(n=20)$} \\
\hline Gemiddelde & 4.5 & 1.4 & 1.8 & 6.5 & 8.0 \\
\hline Standaardfout & 1.1 & 0.4 & 0.4 & 0.9 & 2.3 \\
\hline Standaardafwijking & 4.8 & 1.6 & 1.8 & 4.2 & 10.2 \\
\hline Minimum & 1.0 & 0.3 & 0.3 & 2.5 & -5.7 \\
\hline Maximum & 18.0 & 6.0 & 6.5 & 15.0 & 25.0 \\
\hline
\end{tabular}

$[(\mathrm{P}-\mathrm{GTK}) / \mathrm{P}] * 100=[(\text { prijs-gem. totale kosten }) / \text { prijs }]^{*} 100$

\section{Ad 5. Concentratieontwikkeling per productsoort}

In tabel 5.9 wordt de berekening getoond van de horizontale concentratiegraad (C4) onder de glastomaten- en de glaspaprikabedrijven. Ondanks de forse groei in schaalvergroting bij de glastuinbouwbedrijven over de afgelopen decennia ligt de omvang in bedrijfsoppervlakte glas van de vier grootste bedrijven uit de steekproef in 2006 nog niet boven de 100 ha. De C4 voor tomaten ligt op ruim $6 \%$ en voor paprika's op $4 \%$. Er is in de glasgroenten dus nog steeds sprake van een lage concentratie van bedrijven. In tabel 5.15 en 5.16 wordt deze $\mathrm{C} 4$ berekend per bedrijfstype en per wel of niet voorwaarts geïntegreerd glasgroentebedrijf (VVI-bedrijf).

Tabel 5.9 Meting concentratieontwikkeling (C4) van glasgroentebedrijven (bedrijfsopp. glas in ha. per productsoort tomaat en paprika) (2006)

\begin{tabular}{|l|l|r|r|r|r|r|r|r|}
\hline $\begin{array}{l}\text { Productsoort }+ \\
\text { areaal populatie } \\
\text { tomaat en } \\
\text { paprika in ha. }\end{array}$ & $\begin{array}{l}\text { Bedrijfs- } \\
\text { opper- } \\
\text { vlakte } \\
\text { steekprf. } \\
\text { gem. }\end{array}$ & $\begin{array}{c}\text { Stan- } \\
\text { daard- } \\
\text { fout } \\
\text { gem. }\end{array}$ & $\begin{array}{l}\text { Stan- } \\
\text { daard- } \\
\text { afwij- } \\
\text { king }\end{array}$ & $\begin{array}{l}\text { Aantal } \\
\text { respon } \\
\text { denten } \\
\text { (n) }\end{array}$ & $\begin{array}{l}\text { Som } \\
\text { bedrijfs } \\
\text {-opp. } \\
\text { steek- } \\
\text { proef }\end{array}$ & $\begin{array}{l}\text { Mini- } \\
\text { mum }\end{array}$ & $\begin{array}{l}\text { Concen- } \\
\text { tratiegraad } \\
\text { (C4) } \\
\text { mum }\end{array}$ \\
\hline Tom. 1481 ha. & 7.0 & 1.9 & 8.7 & 22 & 153.1 & 1.0 & 34.0 & $\begin{array}{l}89.9 / 1481= \\
6.1 \%\end{array}$ \\
\hline Papr. 1214 ha. & 4.5 & 1.1 & 4.8 & 20 & 90.8 & 0.8 & 18.0 & $\begin{array}{l}50.3 / 1214= \\
4.1 \%\end{array}$ \\
\hline Tot. 2695 ha. & 5.8 & 1.1 & 7.1 & 42 & 243.8 & 0.8 & 34.0 & \\
\hline
\end{tabular}

$\mathrm{C} 4=$ Concentratiegraad vier grootste glasgroentebedrijven per productsoort, gemeten in opp. glas in ha. 


\subsubsection{Bedrijfstypen (A1 t/m A4)}

De onderzoeksuitkomsten hiervoor zijn besproken op sector- en productniveau. In deze paragraaf worden ze per bedrijfstype geanalyseerd en toegelicht. De bedrijven zijn onder te verdelen in vier bedrijfstypen: A1-veilingteler, A2-veilingtelersvereniging, A3-zelfstandige teler en A4zelfstandige telersvereniging. Een nadere omschrijving van deze bedrijfstypen staat in toonblad 1 van de vragenlijst (zie appendix 5B). De A1- en A2-bedrijven hebben de organisatie van de afzet in handen gegeven van de afzetorganisaties VTN/The Greenery en ZON. Als lid van deze coöperatieve afzetorganisatie zijn zij verticaal geïntegreerd met het groothandelsbedrijf dat de verdere afzet regelt inclusief de prijsonderhandelingen met de detailhandel. Dit wordt voorwaartse verticale integratie genoemd en de geïntegreerde bedrijven VVI-bedrijven. De A3- en A4-bedrijven hebben dit meestal zelf of in telersverenigingsverband georganiseerd met een of meer groothandelaren/exporteurs. Deze bedrijven noemen we niet-VVI-bedrijven.

Hieronder volgen in tabel $5.10 \mathrm{t} / \mathrm{m} 5.16$ de onderzoeksresultaten per bedrijfstype.

Het betreft:

1.omzetontwikkeling 2005/2006, brutomarge 2006 begroot en gerealiseerd en aandeel eigen vermogen in percentage totale vermogen $(\mathrm{EV} / \mathrm{TV}) * 100$;

2. keuze afzetorganisatie, verkoopkosten en de mate van tevredenheid;

3. gemiddelde uitbetaalprijzen per productsoort en bedrijfstype;

4. concentratieontwikkeling (C4) per bedrijfstype.

Ad 1. Omzetontwikkeling 2005/2006

De onderzoeksuitkomsten laten in tabel 5.10 zien dat bedrijfstype A1 de laagste gemiddelde bedrijfsomzet realiseert van $€ 0.6 \mathrm{mln}$. euro met een spreiding van $€ 0.3$ tot $€ 1.5 \mathrm{mln}$. (2005/2006). Bijna $60 \%$ van deze bedrijven scoort een omzet van $€ 0.5 \mathrm{mln}$. of lager. Een aantal van deze bedrijven heeft het moeilijk en overweegt, mede gezien de bedrijfsresultaten en gebrek aan een opvolger, binnen enkele jaren te stoppen. Type A2 ziet meer perspectief. De gemiddelde omzet ontwikkelt zich hier van $€ 1.6 \mathrm{mln}$. in 2005 naar $€ 2.0 \mathrm{mln}$. in 2006 met een flinke spreiding van $€ 1$ - $€ 5 \mathrm{mln}$.. De bedrijfsomzet is redelijk evenwichtig verdeeld tussen de laagste en hoogste omzet. Een aantal van deze bedrijven is aan het uitbreiden in oppervlakte glas hetgeen zorgt voor een extra toename van de omzet. Bedrijfstype A3 telt maar vier bedrijven. De hoge gemiddelde omzet van $€ 6.6$ tot $€ 7.3 \mathrm{mln}$. wordt sterk beïnvloed door één respondent met een grote bedrijfsomvang (€ 15.5 - $€ 16.0 \mathrm{mln}$.).

Type A4 geeft een evenwichtiger beeld. Hier hebben respondenten een gemiddelde omzet van $€ 3.2 \mathrm{mln}$. in 2005 en $€ 3.6 \mathrm{mln}$. in 2006 met een minder grote spreiding. Deze ondernemers investeren het meest in nieuwe bedrijfsuitrusting en -uitbreiding, bezitten de nieuwste bedrijven en behalen de hoogste gemiddelde omzet (op de uitzonderlijke A3-respondent na). 
Tabel 5.10 Belangrijke bedrijfskenmerken per bedrijfstype in 2005/2006

\begin{tabular}{|c|c|c|c|c|c|}
\hline Bedrijfstype & $\begin{array}{l}\text { Omzet } \\
(\mathrm{x} € 1 \mathrm{mln} .) \\
\text { realisatie } \\
2005 \\
\end{array}$ & $\begin{array}{l}\text { Omzet } \\
(\mathrm{x} € 1 \mathrm{mln} .) \\
\text { realisatie } 2006\end{array}$ & $\begin{array}{l}\text { Brutomarge } \\
2006 \text { in } \% \\
\text { begroot }[(\mathrm{P}- \\
\text { GTK }) / \mathrm{P}] * 100\end{array}$ & $\begin{array}{l}\text { Brutomarge } \\
2006 \text { in } \% \\
\text { realisatie }[(\mathrm{P}- \\
\mathrm{GTK}) / \mathrm{P}] * 100\end{array}$ & $\begin{array}{l}\text { Aandeel eigen en } \\
\text { totale vermogen) } \\
(\mathrm{EV} / \mathrm{TV})^{*} 100 \\
\mathrm{n}=30\end{array}$ \\
\hline A1 (14 respondenten) & & & $\begin{array}{l}\text { A1(14 } \\
\text { resp.) }\end{array}$ & $\begin{array}{l}\text { A1(13 } \\
\text { resp.) }\end{array}$ & $\begin{array}{l}\mathrm{A} 1(10 \\
\text { resp.) }\end{array}$ \\
\hline Gemiddelde & 0.6 & 0.6 & 5.0 & 4.1 & 58.5 \\
\hline Standaardfout gem. & 0.1 & 0.1 & 0.7 & 3.8 & 9.3 \\
\hline Standaardafwijking & 0.2 & 0.3 & 2.6 & 14.9 & 29.5 \\
\hline Minimum & 0.3 & 0.3 & 2.5 & -25.0 & 15.0 \\
\hline Maximum & 0.9 & 1.5 & 10.0 & 20.0 & 90.0 \\
\hline A2 (12 respondenten) & & & $\begin{array}{l}\text { A2(12 } \\
\text { resp.) }\end{array}$ & $\begin{array}{l}\text { A2(11 } \\
\text { resp.) }\end{array}$ & A2 (7 resp.) \\
\hline Gemiddelde & 1.6 & 2.0 & 5.2 & 8.2 & 40.9 \\
\hline Standaardfout gem. & 0.2 & 0.3 & 0.9 & 4.6 & 7.1 \\
\hline Standaardafwijking & 0.7 & 1.1 & 3.1 & 15.4 & 18.7 \\
\hline Minimum & 0.8 & 1.0 & 2.5 & -33.3 & 30.0 \\
\hline Maximum & 2.7 & 4.9 & 12.5 & 26.6 & 80.0 \\
\hline A3 (4 resp.) $\left.{ }^{*}\right)$ & & & A3 (4 resp.) & A3 (4 resp.) & A3 (3 resp.) \\
\hline Gemiddelde & 6.6 & 7.3 & 6.3 & 9.8 & 54.3 \\
\hline Standaardfout gem. & 3.2 & 3.3 & 1.3 & 3.9 & 10.7 \\
\hline Standaardafwijking & 6.4 & 6.5 & 2.5 & 7.9 & 18.5 \\
\hline Minimum & 0.3 & 0.3 & 2.5 & -1.6 & 33.0 \\
\hline Maximum & 15.5 & 16.0 & 7.5 & 16.5 & 65.0 \\
\hline A4 (12 respondenten) & & & $\begin{array}{l}\text { A4(11 } \\
\text { resp.) }\end{array}$ & $\begin{array}{l}\text { A4(11 } \\
\text { resp.) }\end{array}$ & $\begin{array}{l}\text { A4(10 } \\
\text { resp.) }\end{array}$ \\
\hline Gemiddelde & 3.2 & 3.6 & 7.5 & 11.1 & 46.0 \\
\hline Standaardfout gem. & 1.1 & 1.0 & 1.5 & 3.3 & 7.5 \\
\hline Standaardafwijking & 3.7 & 3.6 & 5.0 & 15.7 & 23.7 \\
\hline Minimum & 0.4 & 0.6 & 2.5 & -5.7 & 10.0 \\
\hline Maximum & 13.5 & 13.5 & 15.0 & 26.0 & 85.0 \\
\hline
\end{tabular}

\section{Brutomarge 2006 en aandeel eigen vermogen}

De gemiddeld begrote en gerealiseerde brutomarges in 2006 komen voor alle respondenten uit op $+5.9 \%$ en $+8.0 \%$. Als we de resultaten splitsen naar bedrijfstype, dan liggen de begrote marges voor alle bedrijfstypen dicht bij elkaar in de buurt, tussen de 5 (A1) en $7.5 \%$ (A4). De gerealiseerde brutomarges verschillen veel meer. Deze ligt bij A1 bijna vijf procentpunten lager dan bij de overige bedrijfstypen. Opvallend is ook de grote spreiding hierin.

Het aandeel eigen vermogen in procenten van het totaal ligt in 2006 op bijna 50\% (30 respondenten). Als we de resultaten splitsen naar bedrijfstype, dan scoort A1 het hoogst met 58.5\% en A2 het laagst met $41 \%$. Vanuit A2 gezien is het verschil betekenisvol.

Ad 2. Keuze afzetorganisatie, verkoopkosten en de mate van tevredenheid

De onderzoeksuitkomsten van bedrijfstype A1 (tabel 5.11) laten zien dat deze respondenten de kleinere veilingtelers zijn, aangesloten bij VTN/The Greenery uit Barendrecht en veiling ZON uit Venlo. Deze afzetorganisaties regelen de gehele marketing en verkoop voor deze bedrijven tegen een bepaalde afzetprovisie. A1-telers betalen gemiddeld de hoogste verkoopkosten (3.7\%), 
met een spreiding van 1.8 tot $5.5 \%$. Van deze bedrijven zit nog dertig procent aanzienlijk boven het gemiddelde, zij betalen 5 tot $5.5 \%$ van de omzet.

De A2-bedrijven zijn eveneens bijna alle, rechtstreeks of via een telersvereniging, aangesloten bij deze afzetorganisaties. Een tweetal A2-telers heeft de afzet uitbesteed aan veiling Zaltbommel/VDN. Bedrijfstype A2 betaalt gemiddeld 2.8\% en heeft een spreiding van 2 tot $5 \%$. Hier betaalt ongeveer $60 \%$ van de bedrijven $2.5 \%$ van de omzet aan verkoopkosten.

Beide bedrijfstypen zijn in meerderheid tevreden (57\% resp. bijna $67 \%$ is zeer tevreden tot tevreden, $20 \%$ resp. $12 \%$ is ontevreden tot zeer ontevreden).

De onderzoeksresultaten van bedrijfstype A3/A4 geven aan dat deze bedrijven de verkoop zelf doen (FresQ-leden) of dat ze via hun telersvereniging een specifieke relatie hebben met een handelshuis dat geheel of grotendeels de marketing en verkoop verzorgt (BGB/Haluco, VDT/ VDN, FPO/Van Rijn, Tradition/Bocchi, Batavia/Bakker e.a.). Type A3 betaalt gemiddeld 3\% van de omzet met een spreiding van 2 tot $5 \%$, type A4 gemiddeld $2.5 \%$ met een spreiding van 0.5 tot $5 \%$. De twee grootste bedrijven van dit type betalen $2 \%$ of minder. De respondenten van bedrijfstype A4 zijn relatief het meest tevreden (bijna 70\% is zeer tevreden tot tevreden) en de vier respondenten van type $\mathrm{A} 3$ het minst.

Tabel 5.11 Keuze afzetorganisatie, gem. verkoopkosten (\% omzet) en mate van tevredenheid

\begin{tabular}{|c|c|c|c|c|c|c|c|c|}
\hline \multirow[b]{2}{*}{ Bedrijfstype } & \multirow{2}{*}{$\begin{array}{l}\text { Aantal } \\
\text { aangeslo- } \\
\text { ten } \\
\text { bedrijven }\end{array}$} & \multirow{2}{*}{\multicolumn{2}{|c|}{$\begin{array}{l}\text { Verkoopkosten } \\
\text { in \% omzet }\end{array}$}} & \multicolumn{4}{|c|}{ Mate van tevredenheid } & \multirow[b]{2}{*}{$\begin{array}{l}\text { Zeer } \\
\text { ontevreden }\end{array}$} \\
\hline & & & & $\begin{array}{l}\text { Zeer } \\
\text { tevreden }\end{array}$ & Tevreden & $\begin{array}{l}\text { Tevreden/ } \\
\text { Ontevre- } \\
\text { den }\end{array}$ & $\begin{array}{l}\text { Ontevre- } \\
\text { den }\end{array}$ & \\
\hline A1 (14 resp.) & & Gem. & 3.7 & 1 & 6 & 4 & 2 & 1 \\
\hline Greenery & 9 & Stand. fout & 0.3 & & & & & \\
\hline \multirow[t]{3}{*}{$\mathrm{ZON}$} & 5 & Stand. afw & 1.2 & & & & & \\
\hline & & Min. & 1.8 & & & & & \\
\hline & & Max. & 5.5 & & & & & \\
\hline A2 (12 resn) & & Gem & 28 & 1 & 6 & 4 & & 1 \\
\hline Greenery & 8 & Stand. fout & 0.2 & & & & & \\
\hline $\mathrm{ZON}$ & 2 & Stand. afw & 0.8 & & & & & \\
\hline \multirow[t]{2}{*}{ Zaltbommel / VDN } & $\frac{2}{2}$ & Min. & 2.0 & & & & & \\
\hline & & Max. & 5.0 & & & & & \\
\hline A3 (4 resp.) & & Gem. & 30 & & 1 & 2 & 1 & \\
\hline Van Rijn & 1 & Stand. fout & 1.0 & & & & & \\
\hline \multirow[t]{3}{*}{ FresQ } & 3 & Stand. afw & 1.7 & & & & & \\
\hline & & Min. & 2.0 & & & & & \\
\hline & & Max. & 5.0 & & & & & \\
\hline & & & & & & & & \\
\hline A4 (12 resp.) & & Gem. & 2.5 & 1 & 7 & 4 & & \\
\hline Van Rijn & 1 & Stand. fout & 0.4 & & & & & \\
\hline FresQ & 1 & Stand. afw & 1.5 & & & & & \\
\hline VDN & 3 & Min. & 0.5 & & & & & \\
\hline Haluco & 4 & Max. & 5.0 & & & & & \\
\hline BakkerBarendrecht & 1 & & & & & & & \\
\hline QPI & 1 & & & & & & & \\
\hline Bochi & 1 & & & & & & & \\
\hline & & & & & & & & \\
\hline
\end{tabular}


Ad 3. De gemiddelde uitbetaalprijzen per productsoort naar bedrijfstype

De gemiddelde uitbetaalprijzen die worden gepresenteerd in de tabellen 5.12 en 5.13, laten per productsoort naar bedrijfstypen gemeten grote verschillen zien. Zoals is opgemerkt, hangt dit samen met soort en type product, de organisatie van de marketing en verkoop van het bedrijf en het verloop van de marktsituatie. Bij de tomaat scoort bedrijfstype A1 in bijna alle jaren gemiddeld het laagst, wat betreft de uitbetaalprijs en bedrijfstype A4 het hoogst. Bij de paprika's is dit voor type A1, behalve in 2006, eveneens het geval, zij het dat hier bedrijfstype A3 (slechts 1 respondent) het hoogst scoort. Bedrijfstype A2 scoort bij de paprika in alle jaren hoger dan type A1 en A4. Een vergelijk met de gemiddelde PT-prijzen (tabel 5.14 ) geeft aan dat voor de tomaat bij bedrijfstype A1 de gemiddelde uitbetaalprijs lager is en bij type A2 en A4 hoger. Bij de paprika is dit, behalve in 2004 en 2006, vergelijkbaar, maar de verschillen zijn minder groot dan bij de

Tabel 5.12 Gemiddelde uitbetaalprijzen tomaat per bedrijfstype 2003, 2004, 2005 en 2006

\begin{tabular}{|c|c|c|c|c|c|}
\hline $\begin{array}{l}\text { Productsoort: } \\
\text { tomaat }\end{array}$ & $\begin{array}{c}\text { gem. } \\
\text { uitbetaalprijs } \\
\text { in eurocent p. } \\
\mathrm{kg} \\
2003\end{array}$ & $\begin{array}{l}\text { gem. } \\
\text { uitbetaalprijs } \\
\text { in eurocent p. } \\
\mathrm{kg} \\
2004\end{array}$ & $\begin{array}{c}\text { gem. } \\
\text { uitbetaalprijs } \\
\text { in eurocent p. } \\
\mathrm{kg} \\
2005\end{array}$ & $\begin{array}{c}\text { Gem. } \\
\text { uitbetaalprijs } \\
\text { in eurocent p. } \\
\mathrm{kg} \\
2006\end{array}$ & $\begin{array}{l}\text { Prijsfluctuatie- } \\
\text { coëfficient } \\
\left(\mathrm{p}_{\max } / \mathrm{p}_{\min }\right)\end{array}$ \\
\hline A1 (aantal resp.) & 3 & 5 & 7 & 6 & \\
\hline Aantal gemist & 4 & 2 & 0 & 1 & \\
\hline Gemiddelde prijs & 82.7 & 51.8 & 70.4 & 74.7 & 1.60 \\
\hline Standaardafw. & 5.5 & 4.7 & 3.6 & 2.7 & \\
\hline Standaardfout & 3.2 & 2.1 & 1.4 & 1.1 & \\
\hline Minimum & 79 & 46 & 66 & 70 & 1.72 \\
\hline Maximum & 89 & 57 & 75 & 77 & 1.56 \\
\hline A2 (aantal resp.) & 4 & 6 & 8 & 8 & \\
\hline Aantal gemist & 4 & 2 & 0 & 0 & \\
\hline Gemiddelde prijs & 102.0 & 57.8 & 89.3 & 89.5 & 1.76 \\
\hline Standaardafw. & 42.2 & 8.0 & 44.9 & 40.7 & \\
\hline Standaardfout & 21.1 & 3.3 & 15.9 & 14.4 & \\
\hline Minimum & 77 & 47 & 68 & 70 & 1.64 \\
\hline Maximum & 165 & 68 & 200 & 190 & $1.21 *)$ \\
\hline A3 (aantal resp.) & 2 & 2 & 2 & 2 & \\
\hline Aantal gemist & 0 & 0 & 0 & 0 & \\
\hline Gemiddelde prijs & 87 & 56 & 64 & 74 & 1.55 \\
\hline Standaardafw. & 5.6 & 7.1 & 19.8 & 8.5 & \\
\hline Standaardfout & 4.0 & 5.0 & 14.0 & 6.0 & \\
\hline Minimum & 83 & 51 & 50 & 68 & 1.66 \\
\hline Maximum & 91 & 61 & 78 & 80 & 1.49 \\
\hline A4 (aantal resp.) & 5 & 5 & 5 & 5 & \\
\hline Aantal gemist & 0 & 0 & 0 & 0 & \\
\hline Gemiddelde prijs & 104.8 & 73.8 & 96.4 & 100.2 & 1.42 \\
\hline Standaardafw. & 33.0 & 48.4 & 40.0 & 40.3 & \\
\hline Standaardfout & 14.8 & 21.6 & 17.9 & 18.0 & \\
\hline Minimum & 80 & 46 & 67 & 76 & 1.74 \\
\hline Maximum & 160 & 160 & 165 & 170 & 1.06 \\
\hline
\end{tabular}

$\left.{ }^{*}\right)$ Max. prijs conchita 2005/max. prijs conchita 2003, in 2004 geen prijsnotering bekend; 
tomaat. Er lijkt bij de tomaat een betekenisvol prijsverschil te bestaan, kijkend vanuit het A1assortiment (voornamelijk ronde en trostomaat) naar de andere bedrijfstypen. Deze bedrijfstypen laten echter een grotere spreiding zien door een breder assortiment van speciale producten met een hoger prijsniveau.

Als we de uitbetaalprijs over de periode 2003-2006 volgen, dan kent deze een hoge prijsfluctuatie die per bedrijfstype aanmerkelijke verschillen laat zien. De coëfficiënt $\mathrm{p}_{\max } / \mathrm{p}_{\min }$ ligt bij type A4 op een lager niveau (1.4) dan bij A2 (1.8). Dit laatste kan iets zeggen over de scherpe prijsonderhandelingen die vooral op het niveau van veilingtelers plaatsvinden. Deze minimumprijs zakt vooral bij deze bedrijfstypen (A1/A2) nogal eens onder het kostprijs-niveau van het product. Ook is de prijsvariatie bij de tomaat, gezien de grotere verschillen in geteeld producttype, groter dan bij de paprika. Wat verder opvalt bij de tomaat is de hogere prijsfluctuatie van de minimumprijs ten opzichte van de maximumprijs, dit in tegenstelling tot de paprika. Overaanbod en scherpe prijsonderhandelingen op het minimum prijsniveau met een sterke positie van de groot- en detailhandel kunnen hieraan ten grondslag liggen.

Tabel 5.13 Gemiddelde uitbetaalprijzen paprika per bedrijfstype 2003, 2004, 2005 en 2006

\begin{tabular}{|c|c|c|c|c|c|}
\hline $\begin{array}{l}\text { Productsoort: } \\
\text { Paprika }\end{array}$ & $\begin{array}{c}\text { gem. } \\
\text { uitbetaalprijs } \\
\text { in eurocent p. } \\
\mathrm{kg} \\
2003\end{array}$ & $\begin{array}{l}\text { gem. } \\
\text { uitbetaalprijs } \\
\text { in eurocent } \mathrm{p} \text {. } \\
\mathrm{kg} \\
2004\end{array}$ & $\begin{array}{c}\text { gem. } \\
\text { uitbetaalprijs } \\
\text { in eurocent p. } \\
\text { kg } \\
2005\end{array}$ & $\begin{array}{l}\text { Gem. } \\
\text { uitbetaalprijs } \\
\text { in eurocent } \mathrm{p} \text {. } \\
\mathrm{kg} \\
2006\end{array}$ & $\begin{array}{l}\text { Prijsfluctuatie- } \\
\text { coëfficient } \\
\left(\mathrm{p}_{\max } / \mathrm{p}_{\min }\right)\end{array}$ \\
\hline A1 (aantal resp.) & 6 & 7 & 7 & 7 & \\
\hline Aantal gemist & 1 & 0 & 0 & 0 & \\
\hline Gemiddelde prijs & 136.8 & 127.0 & 95.6 & 138.9 & 1.45 \\
\hline Standaardafw. & 15.9 & 8.6 & 8.6 & 12.9 & \\
\hline Standaardfout & 6.5 & 3.3 & 3.2 & 4.9 & \\
\hline Minimum & 118 & 118 & 83 & 111 & 1.42 \\
\hline Maximum & 161 & 145 & 105 & 150 & 1.53 \\
\hline A2 (aantal resp.) & 3 & 4 & 4 & 4 & \\
\hline Aantal gemist & 1 & 0 & 0 & 0 & \\
\hline Gemiddelde prijs & 155.3 & 129.3 & 99.5 & 144.0 & 1.56 \\
\hline Standaardafw. & 4.6 & 5.1 & 2.5 & 11.2 & \\
\hline Standaardfout & 2.6 & 2.6 & 1.3 & 5.6 & \\
\hline Minimum & 150 & 124 & 96 & 135 & 1.56 \\
\hline Maximum & 158 & 136 & 102 & 160 & 1.57 \\
\hline A3 (aantal resp.) & 1 & 1 & 1 & 1 & \\
\hline Aantal gemist & 0 & 0 & 0 & 0 & \\
\hline Gemiddelde prijs & 170.0 & 135.0 & 130.0 & 145.0 & 1.31 \\
\hline A4 (aantal resp.) & 6 & 7 & 7 & 6 & \\
\hline Aantal gemist & 1 & 0 & 0 & 1 & \\
\hline Gemiddelde prijs & 153.0 & 127.7 & 98.7 & 136.5 & 1.55 \\
\hline Standaardafw. & 7.6 & 5.4 & 2.2 & 11.0 & \\
\hline Standaardfout & 3.1 & 2.1 & 0.8 & 4.5 & \\
\hline Minimum & 140 & 117 & 95 & 124 & 1.47 \\
\hline Maximum & 160 & 135 & 100 & 150 & 1.60 \\
\hline
\end{tabular}


Tabel 5.14 Vergelijk gemiddelde jaarprijzen Productschap Tuinbouw (PT) en onderzoeksresultaat per bedrijfstype voor de tomaat en paprika

\begin{tabular}{|l|l|l|l|l|c|}
\hline & 2003 & 2004 & 2005 & 2006 & $\begin{array}{c}\text { Prijsfluctuatie- } \\
\text { coëfficient } \\
\left(\mathrm{p}_{\text {max }} / \mathrm{p}_{\text {min }}\right)\end{array}$ \\
\hline $\begin{array}{l}\text { PT gemiddelde jaarprijs } \\
\text { alle tomaten }\end{array}$ & 89 & 57 & 75 & $\left.78^{*}\right)$ & 1.56 \\
\hline $\begin{array}{l}\text { Gemiddelde prijs } \\
\text { tomaat uit } \\
\text { onderzoeksresultaat }\end{array}$ & 97 & 60 & 83 & 86 & 1.62 \\
\hline Bedrijfstype A1 & 83 & 52 & 70 & 75 & 1.60 \\
\hline Bedrijfstype A2 & 102 & 58 & 89 & 90 & 1.76 \\
\hline Bedrijfstype A3 & 87 & 56 & 64 & 74 & 1.55 \\
\hline Bedrijfstype A4 & 105 & 74 & 96 & 100 & 1.42 \\
\hline & & & & $136 *)$ & 1.38 \\
\hline $\begin{array}{l}\text { PT gemiddelde jaarprijs } \\
\text { alle paprika's }\end{array}$ & 138 & 125 & 100 & 140 & 1.49 \\
\hline $\begin{array}{l}\text { Gemiddelde prijs } \\
\text { paprika uit } \\
\text { onderzoeksresultaat }\end{array}$ & 148 & 128 & 99 & 139 & \\
\hline Bedrijfstype A1 & 137 & 127 & 96 & 139 & 1.45 \\
\hline Bedrijfstype A2 & 155 & 129 & 100 & 144 & 1.56 \\
\hline Bedrijfstype A3 & 170 & 135 & 130 & 145 & 1.55 \\
\hline Bedrijfstype A4 & 153 & 128 & 99 & 137 & \\
\hline
\end{tabular}

$*)=$ Voorlopig

Ad 4. Concentratieontwikkeling(C4) per bedrijfstype en per wel of niet voorwaarts geïntegreerd glasgroentebedrijf (VVI-bedrijfstype)

In de tabel 5.15 wordt de horizontale concentratiegraad (C4) berekend per bedrijfstype. Evenals bij de $\mathrm{C} 4$ per productsoort is per bedrijfstype sprake van een lage concentratiegraad, variërend van 4.0 tot 5.2\%. In tabel 5.16 hebben we de twee groepen veilingtelers (A1 en A2) samengevoegd tot één nieuwe groep. Deze groep veilingtelers bestaat uit bedrijven die alle verticaal geïntegreerd zijn in de afzetorganisatie met de groothandel (het zogenoemde VVI-bedrijfstype). Ook de twee groepen zelfstandige telers (A3 en A4) zijn samengevoegd als groep bedrijven die niet-verticaal geïntegreerd zijn met de groothandel (het zogenoemde niet-VVI-bedrijfstype). Met deze twee nieuwe groepen trekken we in tabel 5.16 een vergelijking tussen de leden/bedrijven (26 resp.) van VTN/The Greenery en ZON, verticaal geïntegreerd met de groothandel, en de niet-verticaal geïntegreerde bedrijven (16 resp.). De berekening laat een gemiddelde bedrijfsoppervlakte zien per wel of niet-VVI-bedrijfstype van 3 en 10.4 ha. glas. Dit betekenisvolle verschil (7.4 ha.) geeft aan dat de bedrijfsomvang van het zelfstandig opererende glasgroentebedrijf (A3/ A4) aanmerkelijk groter is dan de bij de voormalige groenteveilingen aangesloten leden. Een belangrijke reden hiervoor is het verlagen van de gemiddelde (vaste) kosten, van belang om de hogere kosten van de marketing- en verkoopfunctie inclusief de logistiek te kunnen opbrengen. De concentratiegraad (C4), in 2006 op een laag niveau van 3.5\% resp. 5.2\% (tabel 5.16), zal de komende jaren nog kunnen toenemen, evenals het verschil tussen deze twee (VVI) bedrijfstypen. 
Uitgaande van een optimale bedrijfsomvang van gemiddeld 4 ha. (Kwin Glastuinbouw 2010, p. 17) zal er bij een areaalomvang tomaten en paprika van ongeveer 3000 ha. een structurele ruimte zijn voor totaal 750 bedrijven. Bij de areaalverhouding VVI-type en niet-VVI-type van $1: 2$ betekent dit op termijn een structurele ruimte voor het VVI-bedrijfstype van 1000 ha. met 250 bedrijven en voor het niet-VVI-type een areaal van 2000 ha. met 500 bedrijven. Rekening houdende met de grotere bedrijfsomvang van het niet-VVI-bedrijfstype (gemiddeld 8-10 ha.) zal dit laatste aantal bedrijven in werkelijkheid nog aanzienlijk lager kunnen uitvallen $(<=250$ bedrijven). Dit betekent dat de werkelijke concentratie in de totale glasgroenteteelt op termijn nog kan toenemen en het totaal aantal glasgroentebedrijven dalen tot 500 of minder.

Tabel 5.15 Meting horizontale concentratie (C4) in 2006 per bedrijfstype glasgroenten (tomaat en paprika) in oppervlakte glas (ha.)

\begin{tabular}{|l|r|r|r|r|r|r|r|l|}
\hline $\begin{array}{l}\text { Type bedrijf }+ \\
\text { areaal populatie } \\
\text { tomat en } \\
\text { paprika in ha. }\end{array}$ & $\begin{array}{l}\text { Bedrijfs- } \\
\text { opper- } \\
\text { vlakte } \\
\text { steekprf. } \\
\text { gem. }\end{array}$ & $\begin{array}{c}\text { Stan- } \\
\text { daard- } \\
\text { fout } \\
\text { gem. }\end{array}$ & $\begin{array}{l}\text { Stan- } \\
\text { daard } \\
\text { afwij- } \\
\text { king }\end{array}$ & $\begin{array}{l}\text { Aantal } \\
\text { respon } \\
\text { denten } \\
\text { (n) }\end{array}$ & $\begin{array}{l}\text { Som } \\
\text { bedrijfs } \\
\text {-opp. } \\
\text { steekpr }\end{array}$ & $\begin{array}{l}\text { Mini- } \\
\text { mum }\end{array}$ & $\begin{array}{l}\text { Maxi } \\
\text { mum }\end{array}$ & $\begin{array}{l}\text { Concen- } \\
\text { tratiegraad } \\
\text { (C4) }\end{array}$ \\
\hline A1. 245 ha. & 1.6 & 0.2 & 0.8 & 14 & 22.3 & 1.0 & 4.0 & $\begin{array}{l}9.8 / 245= \\
4.0 \%\end{array}$ \\
\hline A2. 610 ha. & 4.6 & 0.8 & 2.7 & 12 & 55.1 & 2.3 & 12.2 & $\begin{array}{l}29.6 / 610= \\
4.8 \%\end{array}$ \\
\hline A3. 750 ha. & 17.0 & 6.8 & 13.6 & 4 & 67.8 & 0.8 & 34.0 & $95.7 / 1840$ \\
\hline A4. 1090 ha. & 8.2 & 2.2 & 7.5 & 12 & 98.6 & 1.5 & 26.7 & $5.2 \% *)$ \\
\hline Tot. 2695 ha. & 5.8 & 1.1 & 7.1 & 42 & 243.8 & 0.8 & 34.0 & \\
\hline
\end{tabular}

C4= Concentratiegraad vier grootste glasgroentebedrijven per bedrijfstype, gemeten in opp. glas; $\left.{ }^{*}\right)$ Bedrijfstype A3 en A4 zijn samengevoegd vanwege het kleine aantal A3 resp. met het grootste bedrijf in opp. glas (34 ha.)

Tabel 5.16 Meting horizontale concentratie(C4) in 2006 per wel/niet-VVI-bedrijfstype glasgroenten in oppervlakte glas (ha.)

\begin{tabular}{|l|l|r|r|r|r|r|r|r|}
\hline $\begin{array}{l}\text { Type bedrijf, } \\
\text { wel of niet- } \\
\text { verticaal voor- } \\
\text { waarts geïnt- } \\
\text { greerd (VVI) }\end{array}$ & $\begin{array}{l}\text { Bedrijfs- } \\
\text { opper- } \\
\text { vlakte } \\
\text { steekprf. } \\
\text { gem. }\end{array}$ & $\begin{array}{c}\text { Stan- } \\
\text { daard- } \\
\text { fout } \\
\text { gem. }\end{array}$ & $\begin{array}{l}\text { Stan- } \\
\text { daard } \\
\text { afwij- } \\
\text { king }\end{array}$ & $\begin{array}{l}\text { Aantal } \\
\text { respon } \\
\text { denten } \\
\text { (n) }\end{array}$ & $\begin{array}{l}\text { Som } \\
\text { bedrijfs } \\
\text {-opp. }\end{array}$ & $\begin{array}{l}\text { Mini- } \\
\text { mum }\end{array}$ & $\begin{array}{l}\text { Maxi- } \\
\text { mum }\end{array}$ & $\begin{array}{l}\text { Concen- } \\
\text { tratiegraad } \\
\text { (C4) }\end{array}$ \\
\hline $\begin{array}{l}\text { VVI } \\
\text { A1+A2=855 }\end{array}$ & 3.0 & 0.5 & 2.4 & 26 & 77.4 & 1.0 & 12.2 & $\begin{array}{l}29.6 / 855= \\
3.5 \%\end{array}$ \\
\hline $\begin{array}{l}\text { Niet-VVI } \\
\text { A3+A4=1840 } \\
\text { ha. }\end{array}$ & 10.4 & 2.4 & 9.6 & 16 & 166.4 & 0.8 & 34.0 & $\begin{array}{l}95.7 / 1840= \\
5.2 \%\end{array}$ \\
\hline Tot. 2695 ha. & 5.8 & 1.1 & 7.1 & 42 & 243.8 & 0.8 & 34.0 & \\
\hline
\end{tabular}

C4= Concentratiegraad vier grootste glasgroentebedrijven per bedrijfstype, gemeten in opp. glas; 


\subsubsection{Mogelijk verband tussen marktgedrag en -resultaat ( $\chi 2$-analyse)}

In de vorige paragrafen zijn de belangrijkste onderzoeksresultaten van de sector, de onderscheiden productgroepen en de bedrijfstypen weergegeven. In deze paragraaf worden de verbanden tussen gedragsvariabelen en behaalde resultaten besproken aan de hand van een aantal kruistabellen waarbij de chi-kwadraatanalyse is toegepast (Huizingh, 2010). Getoetst wordt of er een significant verband bestaat. Bij elke toetsing wordt de chi-kwadraatwaarde $\left(\chi^{2}\right)$ aangegeven met het aantal vrijheidsgraden (DF=Degrees of Freedom) en de overschrijdingskans p (bij 95\% betrouwbaarheid). Hoewel bij een aantal toetsen niet werd voldaan aan alle voorwaarden voor een betrouwbare toets (de aanwezigheid van cellen met een te lage frequenties) zijn deze wel meegenomen in de analyse. Bij de analyse van de horizontale concentratiegraad $(\mathrm{C} 4)$ wordt eveneens gebruik gemaakt van kruistabellen zonder deze test.

De te behandelen marktgedragsvariabelen zijn:

- productsoorten

- type glastuinbouwbedrijf

- verkoopwijze producten

- moderniteit bedrijf

- bedrijfsoppervlakte (in hectare glas)

- marketing en verkoop

- voorwaartse verticale integratie

- horizontale concentratie

- investeringen/innovaties

- bedrijfsomvang/kostenniveau

- toe- en uittreding sector

De marktresultaatsvariabelen zijn:

- jaaromzet + groei

- jaarprijzen

- brutomarge $[(\mathrm{P}-\mathrm{GTK}) / \mathrm{P}] * 100$

- aandeel eigen vermogen in $\%$ totaal $(\mathrm{EV} / \mathrm{TV}) * 100$

In tabel 5.17 wordt een overzicht gegeven van de onderzochte verbanden tussen de hierboven genoemde variabelen met een al dan niet significant resultaat. Alle getoetste variabelen worden in appendix 5D aan de hand van kruistabellen (tabellen $5.18 \mathrm{t} / \mathrm{m} 5.47$ ) geanalyseerd en toegelicht. In een aantal gevallen zijn ter vergroting van het inzicht andere dan de genoemde resultaatsvariabelen getoetst. 
Tabel 5.17 Overzicht uitkomsten chi-kwadraattest variabelen marktgedrag, -structuur en -resultaat

\begin{tabular}{|c|c|c|c|c|}
\hline $\begin{array}{l}\text { Tabel } \\
\text { nr. }\end{array}$ & Gedragsvariabele & Resultaatsvariabele*) & Testwaarden & $\begin{array}{l}\text { Signifi- } \\
\text { cantie } \\
\text { (ja/nee) }\end{array}$ \\
\hline 5.18 & Type glastuinbouwbedrijf & Producttypen tomaat & $\begin{array}{l}\mathrm{n}=22 ; \chi 2=31.656 \\
\mathrm{DF}=21 ; \mathrm{p}<0.063\end{array}$ & $\begin{array}{l}\text { Ja } \\
(p=0.1)\end{array}$ \\
\hline 5.19 & Type glastuinbouwbedrijf & $\begin{array}{l}\text { Investeringsniveau ( } € \times 1 \\
\text { mln.) }\end{array}$ & $\begin{array}{l}\mathrm{n}=31 ; \chi 2=37.372 \\
\mathrm{DF}=15 ; \mathrm{p}<0.001\end{array}$ & $\mathrm{Ja}$ \\
\hline 5.20 & Type glastuinbouwbedrijf & Verkoopkosten in \% omzet & $\begin{array}{l}\mathrm{n}=41 ; \chi 2=24.018 \\
\mathrm{DF}=15 ; \mathrm{p}<0.065\end{array}$ & $\begin{array}{l}\text { Ja } \\
(p=0.1)\end{array}$ \\
\hline 5.21 & Type glastuinbouwbedrijf & Omzet gerealiseerd in 2006 & $\begin{array}{l}\mathrm{n}=42 ; \chi 2=45.721 \\
\mathrm{DF}=18 ; \mathrm{p}<0.000\end{array}$ & $\mathrm{Ja}$ \\
\hline 5.22 & Type glastuinbouwbedrijf & $\begin{array}{l}\text { Brutomarge gerealiseerd } \\
2006\end{array}$ & $\begin{array}{l}\mathrm{n}=39 ; \chi 2=16.370 \\
\mathrm{DF}=12 ; \mathrm{p}<0.175\end{array}$ & Nee \\
\hline 5.23 & Type glastuinbouwbedrijf & $\begin{array}{l}\text { Aandeel eigen vermogen in } \\
\% \text { totaal }\left(\mathrm{EV} / \mathrm{TV}^{*} 100\right) 2006\end{array}$ & $\begin{array}{l}\mathrm{n}=30 ; \chi 2=16.133 \\
\mathrm{DF}=12 ; \mathrm{p}<0.185\end{array}$ & Nee \\
\hline 5.24 & Verkoopwijze producten & Omzet gerealiseerd in 2006 & $\begin{array}{l}\mathrm{n}=42 ; \chi 2=45.202 \\
\mathrm{DF}=30 ; \mathrm{p}<0.037\end{array}$ & $\mathrm{Ja}$ \\
\hline 5.25 & Moderniteit bedrijf & Omzet gerealiseerd in 2006 & $\begin{array}{l}\mathrm{n}=42 ; \chi 2=45.756 \\
\mathrm{DF}=25 ; \mathrm{p}<0.007\end{array}$ & $\mathrm{Ja}$ \\
\hline 5.26 & Bedrijfsopp. glas in ha. & Verkoopwijze producten & $\begin{array}{l}\mathrm{n}=42 ; \chi 2=36.280 \\
\mathrm{DF}=15 ; \mathrm{p}<0.002\end{array}$ & $\mathrm{Ja}$ \\
\hline 5.27 & Bedrijfsopp. glas in ha. & Moderniteit bedrijf & $\begin{array}{l}\mathrm{n}=42 ; \chi 2=45.756 \\
\mathrm{DF}=25 ; \mathrm{p}<0.007\end{array}$ & $\mathrm{Ja}$ \\
\hline 5.28 & $\begin{array}{l}\text { Organisatie marketing en } \\
\text { verkoop }\end{array}$ & Bedrijfsopp. glas in ha. & $\begin{array}{l}\mathrm{n}=42 ; \chi 2=80.160 \\
\mathrm{DF}=45 ; \mathrm{p}<0.001\end{array}$ & $\mathrm{Ja}$ \\
\hline 5.29 & $\begin{array}{l}\text { Organisatie marketing en } \\
\text { verkoop }\end{array}$ & $\begin{array}{l}\text { Brutomarge gerealiseerd } \\
\text { in } 2006\end{array}$ & $\begin{array}{l}\mathrm{n}=39 ; \chi 2=16.649 \\
\mathrm{DF}=27 ; \mathrm{p}<0.939\end{array}$ & Nee \\
\hline 5.30 & $\begin{array}{l}\text { Organisatie marketing en } \\
\text { verkoop }\end{array}$ & Verkoopkosten in $\%$ omzet & $\begin{array}{l}\mathrm{n}=41 ; \chi 2=69.911 \\
\mathrm{DF}=45 ; \mathrm{p}<0.010\end{array}$ & $\mathrm{Ja}$ \\
\hline 5.31 & VVI-bedrijfstype & Omzet gerealiseerd in 2006 & $\begin{array}{l}\mathrm{n}=42 ; \chi 2=11.939 \\
\mathrm{DF}=3 ; \mathrm{p}<0.008\end{array}$ & $\mathrm{Ja}$ \\
\hline 5.32 & VVI-bedrijfstype & $\begin{array}{l}\text { Brutomarge gerealiseerd in } \\
2006\end{array}$ & $\begin{array}{l}\mathrm{n}=39 ; \chi 2=2.403 \\
\mathrm{DF}=3 ; \mathrm{p}<0.493\end{array}$ & Nee \\
\hline 5.33 & VVI-bedrijfstype & Bedrijfsopp. glas in ha. & $\begin{array}{l}\mathrm{n}=42 ; \chi 2=17.219 \\
\mathrm{DF}=5 ; \mathrm{p}<0.004\end{array}$ & $\mathrm{Ja}$ \\
\hline 5.34 & VVI-bedrijfstype & $\begin{array}{l}\text { Investeringsniveau in } € \times 1 \\
\text { mln. }\end{array}$ & $\begin{array}{l}\mathrm{n}=31 ; \chi 2=11.933 \\
\mathrm{DF}=5 ; \mathrm{p}<0.036\end{array}$ & $\mathrm{Ja}$ \\
\hline 5.35 & VVI-bedrijfstype & $\begin{array}{l}\text { Aandeel eigen vermogen in } \\
\% \text { totaal }(\mathrm{EV} / \mathrm{TV} * 100) 2006\end{array}$ & $\begin{array}{l}\mathrm{n}=30 ; \chi 2=2.618 \\
\mathrm{DF}=4 ; \mathrm{p}<0.624\end{array}$ & Nee \\
\hline $\begin{array}{l}5.36- \\
5.44\end{array}$ & $\begin{array}{l}\text { Concentratiegraad (C4) } \\
\text { bedrijfsopp. glas in ha. }\end{array}$ & $\begin{array}{l}\text { Omzet en brutomarge } \\
\text { gerealiseerd in } 2005 / 2006\end{array}$ & n.v.t. & n.v.t. \\
\hline 5.45 & Investeringen in $€ \times 1 \mathrm{mln}$. & $\begin{array}{l}\text { Brutomarge gerealiseerd } \\
\text { in } 2006\end{array}$ & $\begin{array}{l}\mathrm{n}=28 ; \chi 2=16.055 \\
\mathrm{DF}=15 ; \mathrm{p}<0.378\end{array}$ & Nee \\
\hline 5.46 & Bedrijfsopp. glas in ha. & Productiekosten in $€$ per $\mathrm{m}^{2}$ & $\begin{array}{l}\mathrm{N}=42 ; \chi 2=19.448 \\
\mathrm{DF}=20 ; \mathrm{p}<0.493\end{array}$ & Nee \\
\hline 5.47 & Bedrijfsopp. glas in ha. & $\begin{array}{l}\text { Brutomarge gerealiseerd in } \\
2006\end{array}$ & $\begin{array}{l}\mathrm{N}=39 ; \chi 2=22.671 \\
\mathrm{DF}=15 ; \mathrm{p}<0.091\end{array}$ & $\begin{array}{l}\text { Ja } \\
(p=0.1)\end{array}$ \\
\hline
\end{tabular}

*) Niet alle te toetsen variabelen zijn resultaatsvariabelen 


\subsubsection{Structuur- en resultaatsvariabelen (mesoniveau)}

Hier worden de onderscheiden structuur- en resultaatsvariabelen van de sector glasgroenten besproken, deels voortkomend uit de onderzoeksresultaten van het sectoronderzoek en onderzoek afzetorganisaties (zie hoofdstuk 3 en 4) en deels vanuit het bedrijfsonderzoek. Zoals wordt aangegeven in het analysemodel van figuur 2.4 in hoofdstuk 2 , vindt er een voortdurende wederzijdse beïnvloeding plaats van marktgedragsvariabelen $(\mathrm{G})$ naar marktstructuurvariabelen (S). Behandeld worden de concentratieontwikkeling bij producenten, afzetorganisaties en groothandel/export, de productdifferentiatie, de toetredingsdrempels en de mogelijke verbanden van deze variabelen met de resultaatsvariabelen omzet, productie- en exportwaarde, prijzen, brutomarge en solvabiliteit.

\subsubsection{Horizontale concentratie}

\section{Producenten}

In onderstaande tabel 5.48 zijn de uitkomsten van het sector- en bedrijfsonderzoek betreffende de ontwikkeling van de concentratiegraad (C4) met de resultaatsvariabele gemiddelde brutomarge 2006 samengevoegd (tabel 3.54 en 5.36 t/m 5.44). De C4- opp. glas ligt voor de vier grootste tomaten- en paprikabedrijven, zoals eerder aangegeven, op een laag niveau van ruim 6 en $4 \%$.

Tabel 5.48 Ontwikkeling concentratie (C4) en brutomarge producenten glasgroenten 2004-2010 met onderzoeksresultaten sector- en bedrijfsonderzoek

\begin{tabular}{|c|c|c|c|c|}
\hline $\begin{array}{l}\text { Concentratiegraad (C4 in \%) } \\
\text { glasgroenten }\end{array}$ & 2004 & 2006 & 2007 & 2008 \\
\hline $\begin{array}{l}\text { Sectoronderzoek*) producenten } \\
\text { glasgroenten }(\mathrm{C} 4 \text { in \%): }\end{array}$ & & & & \\
\hline -Tomaat & 6.5 & 5.0 & & 10.0 \\
\hline -Paprika & 4.4 & 4.0 & & 5.0 \\
\hline -Komkommer & 6.1 & & & 5.0 \\
\hline $\begin{array}{l}\text {-Glasgroenten } \\
\text { (alle bedrijven op basis van areaal) }\end{array}$ & 5.7 & 5.0 & & 6.5 \\
\hline $\begin{array}{l}\text { Bedrijfsonderzoek producenten } \\
\text { glasgroenten }(\mathrm{C} 4 \text { in \%): }\end{array}$ & & & & \\
\hline -Tomaat & & 6.1 & & \\
\hline -Paprika & & 4.1 & & \\
\hline -VVI-bedrijfstype (A1/A2) & & 4.8 & & \\
\hline -niet-VVI-bedrijfstype (A3/A4) & & 5.2 & & \\
\hline -Туре A1 & & 4.0 & & \\
\hline -Type A2 & & 4.8 & & \\
\hline $\begin{array}{l}\text { Bedrijfsonderzoek producenten } \\
\text { glasgroenten (brutomarge in \%): }\end{array}$ & & & & \\
\hline -Tomaat & & 13.2 & & \\
\hline -Paprika & & 7.0 & & \\
\hline -VVI-bedijfstype (A1/A2) & & 7.3 & & \\
\hline -niet-VVI-bedrijfstype (A3/A4) & & 8.3 & & \\
\hline -Type A1 & & -1.9 & & \\
\hline -Type A2 & & 7.3 & & \\
\hline
\end{tabular}


De gemiddelde brutomarge van deze bedrijven in 2006 bedraagt bij de glastomaten $13.2 \%$ en bij de glaspaprika 7.0\%. Als we deze vergelijking maken naar wel/niet-VVI-bedrijfstype (A1/A2 resp. A3/A4), dan zien we ook hier een lage C4-opp. glas (4.8- 5.2\%) met een brutomarge van 7.3 resp. 8.3\%. Als laatste vergelijken we de C4-opp. glas en de gemiddelde brutomarge per vier grootste bedrijven van het type A1 en A2. Bedrijfstype A1 heeft het zwaar in de scherpe concurrentiestrijd en scoort in 2006 een negatieve gemiddelde brutomarge (-1.9\%), A2 komt uit op $7.3 \%$. De in hoofdstuk 3 getrokken conclusie wordt met de uitkomsten van het bedrijfsonderzoek verder onderbouwd en ligt hiermee in lijn. De concentratiegraad van de vier grootste producenten (C4) in de glasgroenten ligt op een laag niveau. Er is een geringe toename bij de producenten van glasgroenten van 5.7\% naar 6.5\% over de periode 2003-2008 met de hoogste concentratie in het gewas tomaat $(10 \%)$. Deze toename is van weinig invloed op het sector- en bedrijfsresultaat (productiewaarde, prijzen glasgroenten en brutomarge).

\section{Afzetorganisaties en groothandel/export}

Voor de ontwikkeling van de concentratiegraad over deze periode bij de afzetorganisaties en de groothandel/export en de invloed hiervan op sectorresultaten wordt verwezen naar hoofdstuk 3 paragraaf 3.5.2.3 (tabel 3.54) en hoofdstuk 4 paragraaf 4.2.5.1 (tabel 4.5).

\subsubsection{Voorwaartse verticale integratie}

In paragraaf 4.2.5.2 van het vorige hoofdstuk is deze gedragsvariabele uitvoerig besproken en zijn tevens de (negatieve) gevolgen voor de marktstructuur en -situatie voor de sector glasgroenten geschetst. De verkleining van de groothandelsmarkten in Nederland en aangrenzende buurlanden is beschreven evenals de scherpe concurrentie die hierdoor ontstond. In het bedrijfsonderzoek glasgroenten is geprobeerd deze fragmentatie van groothandelsmarkten nader te analyseren en vast te stellen aan de hand van de meest relevante gedrags- en resultaatsvariabelen van wel en niet-voorwaarts verticaal geïntegreerde bedrijven (VVI-bedrijven). Hieronder volgen de belangrijkste onderzoeksuitkomsten.

1. Er is een betekenisvol verschil tussen de gemiddelde bedrijfsomvang in opp. glas van het wel of niet-VVI-bedrijfstype (tabel 5.16 en 5.33). Dit geeft aan dat de bedrijfsomvang van het bij The Greenery of ZON aangesloten bedrijf (A1/A2) aanmerkelijk kleiner is dan het zelfstandig opererende glasgroentebedrijf (A3/A4).

2. Het VVI-bedrijfstype (A1/A2) behaalt gemiddeld een betekenisvol lagere omzet dan het nietVVI-bedrijfstype (A3/A4) (tabel 5.31).

3. Er is geen betekenisvol verschil in de gerealiseerde brutomarge tussen het VVI-bedrijfstype en het niet-VVI-bedrijfstype (tabel 5.32).

4. Er is een betekenisvol verschil in gemiddeld investeringsniveau ( $€$ x $1 \mathrm{mln}$.) tussen het VVIbedrijfstype en het niet-VVI-bedrijfstype, het niet-VVI-type investeert aanzienlijk meer (tabel 5.34).

5. Er is geen betekenisvol verschil in aandeel eigen vermogen in \% van het totale vermogen tussen het VVI-bedrijfstype (A1 en A2) en niet-VVI-bedrijfstype (A3 en A4) (tabel 5.35). 
Een belangrijk argument dat vaak wordt gehanteerd bij de vergroting van de bedrijfsomvang van het glastuinbouwbedrijf is dat dit kan leiden tot een toename van 'economies of scales' resp. 'economies of scope'. Men gaat er hierbij vanuit dat productie op grotere schaal de gemiddelde (vaste) kosten verlaagt, een efficiëntieslag, mede van belang om de hogere kosten van de marketing- en verkoopfunctie inclusief de logistiek te kunnen opbrengen. De vraag is echter of de hogere productie ook leidt tot hogere prijzen c.q. hogere opbrengsten (de effectiviteitsslag). Bovenstaande onderzoeksuitkomsten geven aan dat er voor meer bedrijfstypen (klein en groot) in de glasgroenten een redelijk rendement is te behalen.

De concurrentiemonitor glasgroente (Van Galen et al., LEI-rapport 2010-051, pp. 25, 26) laat op basis van onderzoek over de economische bedrijfsomvang 2006-2008 uit het Bedrijven-Informatienet vergelijkbare resultaten zien.

\subsubsection{Productdifferentiatie}

In tabel 5.47a (zie appendix 5D) wordt de ontwikkeling van areaal en aantal bedrijven van de drie belangrijkste glasgroenten getoond, met voor de tomaat en de paprika tevens een splitsing in producttypen. Bij de komkommer is dit niet het geval. De productdifferentiatie bij dit gewas is in tegenstelling tot de tomaat en paprika beperkt. De komkommer is een tamelijk homogeen product, heeft weinig onderscheidend vermogen en moet op de buitenlandse markten de concurrentie aan met (Zuid-)Europese producten van een lagere prijsklasse. Wat de drie gewassen wel gemeenschappelijk hebben, zijn optimale teeltomstandigheden in moderne kassen met een hoge fysieke productie per hectare. Nederlandse producenten behalen hierdoor aanmerkelijk hogere opbrengsten per vierkante meter dan hun Europese concurrenten, de prijsvorming blijft echter onzeker (Van Galen et al., LEI-rapport-2010-051, pp. 40, 41). De meeste tomaten die momenteel in Nederland worden geteeld zijn trostomaten. Daarnaast worden ronde tomaten, vleestomaten en cherrytomaten onderscheiden. De laatste jaren is sprake van een grotere verscheidenheid. Nieuwe rassen worden ontwikkeld door de veredelingsbedrijven en telers kunnen kiezen uit meer rassen. Hetzelfde geldt voor de paprika's die worden geteeld in verschillende kleuren en vormen (blok, punt en mini). Van de totale teeltoppervlakte bestaat meer dan de helft uit rode paprika's (CBS Landbouwtelling).

De uitkomsten van het bedrijfsonderzoek en de analyse van de relevante gedrags- en resultaatsvariabelen ten aanzien van productdifferentiatie leveren het volgende op: er lijkt een verband te bestaan tussen bedrijfstype en de keuze van het producttypen tomaat. (tabel 5.18). Bedrijfstype A1 en A2 (veilingtelers en -telersverenigingen) kiezen voornamelijk voor de ronde of de trostomaat (convenience), bedrijfstype A3 en A4 kiezen in meerderheid voor de specialere soorten tomaat (specialties).

\subsubsection{Toetredingsdrempels (investeringen)}

Toetreding tot de sector glasgroenten in Nederland in de periode 2005-2010 is geen eenvoudige zaak en de investeringsdrempels zijn hoog. Toetreding tot de sector vond nauwelijks plaats, uittreding des te meer. In deze periode is jaarlijks tien tot vijftien procent van de bedrijven gestopt. 
De investeringen in nieuwe moderne kassen inclusief inrichting en grond zijn hoog en het behalen van voldoende rendement is onzeker, mede gezien de sterke concurrentie op de belangrijkste markten, de banken- en kredietcrisis in 2008/2009 en het voortdurende lage consumentenvertrouwen in Europa. Toch is in 2007 meer dan een half mln. euro per bedrijf geïnvesteerd (tabel 5.49 ) in met name glasopstanden, gebouwen, machines, installaties en grond. Innovatieve telers zien nog steeds nieuwe mogelijkheden, ook in een periode van laagconjunctuur (Van Galen et al., LEI-rapport-2010-051, pp. 31, 32).

Tabel 5.49 Investeringen binnen glasgroentebedrijven in Nederland, in 1000 euro per bedrijf in de periode $2004-2008$

\begin{tabular}{|l|c|c|c|c|c|}
\hline Investeringen glasgroenten & 2004 & 2005 & 2006 & 2007 & 2008 \\
\hline $\begin{array}{l}\text { Brutoinvesteringen a) } \\
\text { waarvan }\end{array}$ & 206 & 196 & 122 & 506 & 398 \\
\hline -grond b) & 78 & 82 & -74 & 103 & 21 \\
\hline -gebouwen (incl. glasopstanden) & 57 & 46 & 73 & 141 & 189 \\
\hline -werktuigen, installaties en & 54 & 50 & 106 & 238 & 170 \\
machines & & & & 2 & 3 \\
\hline -plantopstanden & 17 & 17 & 16 & 22 & 15 \\
\hline -overig & & 2 & 1 & & 2 \\
\hline
\end{tabular}

Bron: Informatienet LEI, rapport 2010-051, tabel 2.2; a) Brutoinvesteringen: investeringen-desinvesteringen;

b) Inclusief investeringen in grond en erfpachtrecht.

Het opzetten van een nieuw bedrijf in glasgroenten vergt hoge investeringen. Investeringen in een nieuw glastomatenbedrijf (met WKK-installatie) lopen uiteen van 115 en 103 euro per $\mathrm{m}^{2}$ kas voor een bedrijf van 4 ha. in 2008 en 2010, tot 105 en 95 euro per $\mathrm{m}^{2}$ bij een bedrijf van 10 ha. In totaal komt een gemiddeld bedrijf van 4 ha. op een investering van 4.6 en $4.1 \mathrm{mln}$. euro in 2008 en 2010. Dit bedrag is exclusief de aanschaf van grond (locatiegebonden). Daarnaast moet een groter bedrijf doorgaans investeren in sorteer- en verpakkingsmachines. De investering daarvoor bedraagt voor een bedrijf van 4 ha. ongeveer 110 duizend euro (Vermeulen, 2008 en 2010). In de praktijk betreft nieuwbouw ook uitbreiding en herbouw van bestaande kassen, vaak op grotere oppervlaktes. Bovenstaande investeringskosten gelden voor de opzet van een nieuw bedrijf. Het omschakelen vanuit een bestaande teelt vergt minder kosten, is afhankelijk van het type bedrijf, de aanwezige kas en de aanwezigheid van een WKK-installatie. Omschakeling vanuit een vergelijkbare teelt duurt circa 1-2 maanden. Omschakeling vindt doorgaans plaats tussen twee teeltrondes, wanneer de kas is leeg geruimd. In de praktijk vindt omschakeling daarom vooral plaats in de periode vanaf de tweede helft van oktober tot januari. Omschakeling duurt korter als het een bestaand (tomaten) bedrijf is met een ander productsegment en langer als het 
geen vruchtgroentebedrijf (tomaten, paprika, komkommer) is. De bouw van een nieuw bedrijf duurt doorgaans een half tot driekwart jaar. Dit betreft de bouwperiode vanaf het moment dat de nodige vergunningen en de grond zijn verworven. Het verkrijgen van de vergunningen kan lange tijd (tot vele jaren) in beslag nemen (Van Galen et al., LEI nota 11-056, p. 10).

In voorgaande paragrafen (tabellen 5.19 en 5.34) is vastgesteld dat het investeringsniveau voor kleinere bedrijven (type A1, veilingteler) significant lager ligt dan dat van de grotere bedrijven (type A2 en A4). Een belangrijke vraag is of dit hogere investeringsniveau ook een hoger resultaat bewerkstelligt. In tabel 5.45 wordt dit verband getoetst. Twee derde van de respondenten heeft deze vraag beantwoord. Hieruit komt naar voren dat er geen betekenisvol verband lijkt te zijn tussen de hoogte van het investeringsniveau en de gerealiseerde brutomarge in 2006. Dat wijst mogelijk op een beperkte innovativiteit van de investeringen.

\subsection{Voorlopige conclusies}

Hieronder volgen de voorlopige conclusies over de onderzoeksuitkomsten van het marktgedrag (G) en het marktresultaat (R) van de glasgroentebedrijven. De indeling hiervan is naar bestuurlijk-organisatorische, commerciële en financieel-economische aspecten en zoveel mogelijk opgesteld in volgorde van de onderzoeksrapportage in dit hoofdstuk.

De variabelen van de marktstructuur $(S)$ en marktresultaat $(R)$ worden daarna behandeld. waarbij de voortdurende onderlinge beïnvloeding van gedrag, structuur en resultaat (vice versa) een belangrijke rol speelt.

\subsubsection{Conclusies marktgedrag en -resultaat}

Op grond van de uitkomsten van het bedrijfsonderzoek naar het marktgedrag en -resultaat in de sector glasgroenten (tomaat en paprika) kunnen we nu het volgende concluderen.

- Bestuurlijk-organisatorische en financieel-economische conclusies

\section{Strategische keuze bedrijfsomvang}

Een belangrijke beleidskeuze van het glasgroentebedrijf is de keuze in oppervlakte glas (ha.) en de hiermee jaarlijks te realiseren omzet en winst. De schaalgrootte van de bedrijven in de glasgroenteteelt neemt nog steeds aanzienlijk toe. De grootste productgroepen (tomaat, paprika en komkommer) laten vanaf 2000-2006 een jaarlijkse daling zien van het aantal bedrijven met 5 tot $10 \%$ (zie tabel 5.47a appendix 5D). In 2006 is het verschil in omvang en resultaat tussen de onderzochte bedrijven groot. De totale populatie ligt iets onder de 2000 bedrijven met een gemiddelde oppervlakte van bijna 2.5 ha. Er zijn zeer kleine bedrijven $(<1$ ha.) en zeer grote bedrijven ( $>30$ ha.) actief. Van de 42 onderzochte bedrijven ligt de gemiddelde bedrijfsgrootte met 5.8 ha. en een spreiding van ruim 33 ha. tussen het kleinste en het grootste bedrijf, ruim boven het populatiegemiddelde. Evenals de bedrijfsoppervlakte tonen de omzetcijfers 2005 en 
2006 en de gerealiseerde brutomarge een grote spreiding. De gemiddelde omzet in 2005 is $€ 2.2$ mln. met een spreiding van $€ 0.25 \mathrm{mln}$. tot $€ 15.5 \mathrm{mln}$. In 2006 lag de gemiddelde omzet een fractie hoger op $€ 2.5 \mathrm{mln}$. met een minimum van $€ 0.3$ en een maximum van $€ 16.0 \mathrm{mln}$. Als we de twee grootste bedrijven niet meetellen, komt het gemiddelde glasoppervlak op 4.6 ha. en de omzet in 2005 en 2006 op $€ 1.6$ en $€ 1.9 \mathrm{mln}$. De gerealiseerde brutomarge in 2006 ligt gemiddeld op $8.0 \%$.

\section{Strategische keuze productsoort}

Bezien naar productsoorten tomaat en paprika is het gemiddelde tomatenbedrijf in Nederland in 2006 bijna twee keer zo groot als het paprikabedrijf. Dat geldt zowel voor de bedrijfsoppervlakte glas als de omzet. De gemiddelde omzet van het tomatenbedrijf ontwikkelt zich van $€ 2.9 \mathrm{mln}$. in 2005 naar $€ 3.2 \mathrm{mln}$. in 2006 . Het kleinere paprikabedrijf laat een gemiddelde omzet zien van $€ 1.4 \mathrm{mln}$. in 2005 en $€ 1.8 \mathrm{mln}$. in 2006 . De gerealiseerde brutomarge in 2006 ligt bij de tomaat en paprika op een gelijk niveau $(8.0 \%)$.

\section{Strategische keuze bedrijfstype A1-A4}

Bezien naar bedrijfstype realiseert type A1, de kleinere veilingteler, de laagste gemiddelde bedrijfsomzet van $€ 0.6 \mathrm{mln}$. euro (2005/2006). Bijna $60 \%$ van deze bedrijven scoort een omzet van $€ 0.5 \mathrm{mln}$. of lager. Een aantal van deze bedrijven heeft het moeilijk en overweegt, mede gezien de bedrijfsresultaten en het gebrek aan een opvolger, binnen enkele jaren te stoppen. Bedrijfstype A2, de grotere veilingteler, tevens aangesloten bij een veilingtelers-vereniging, ziet meer perspectief. De gemiddelde omzet ontwikkelt zich hier van $€ 1.6 \mathrm{mln}$. in 2005 naar $€$ $2.0 \mathrm{mln}$. in 2006. Een aantal van deze bedrijven breidt uit in oppervlakte glas, wat zorgt voor een extra toename van de omzet. Bedrijfstype A3, de zelfstandige teler, telt vier bedrijven. De hoge gemiddelde omzet van $€ 6.6$ tot $€ 7.3 \mathrm{mln}$. wordt sterk beïnvloed door één respondent met een grote bedrijfsomvang ( $€ 15.5$ - $€ 16.0 \mathrm{mln}$.). Bedrijfstype A4, de telers aangesloten bij een zelfstandige telersvereniging, geeft een evenwichtiger beeld. Hier hebben respondenten een gemiddelde omzet van $€ 3.2 \mathrm{mln}$. in 2005 en $€ 3.6 \mathrm{mln}$. in 2006 . Deze ondernemers investeren het meest in nieuwe bedrijfsuitrusting en -uitbreiding, bezitten de nieuwste bedrijven en behalen de hoogste gemiddelde omzet. De gemiddeld gerealiseerde brutomarge in $2006 \mathrm{komt}$ voor alle respondenten uit op $8 \%$. Gesplitst naar bedrijfstype liggen de gerealiseerde brutomarges tussen de 4 (A1) en $11 \%$ (A4).

Het onderzoek naar de mogelijke verbanden tussen bedrijfstype en behaalde resultaten komt tot de volgende opvallende uitkomsten:

- er lijkt een verband te bestaan tussen bedrijfstype en producttype tomaat. Bedrijfstype A1 en A2 kiezen voornamelijk voor de ronde of de trostomaat (convenience), bedrijfstype A4 kiest in meerderheid voor de specialere soorten tomaat (specialties);

- er is een voor de hand liggend betekenisvol verband tussen bedrijfstype en de hoogte van omzet en investeringsniveau. Bij de kleinere bedrijven (type A1) ligt dit op een lager niveau dan bij de grotere bedrijven (type A2 en A4). Ten aanzien van de moderniteit van het bedrijf blijkt 
dat naarmate het bedrijf een recenter bouwjaar heeft, het in de meeste gevallen uitbreidt en een hogere jaaromzet behaalt;

- naarmate het bedrijf groter is in omzet, betaalt het een lager percentage verkoopprovisie;

- er is geen betekenisvol verband tussen bedrijfstype en gerealiseerde brutomarge.

\section{Concentratieontwikkeling per productsoort en bedrijfstype}

Ondanks de groei in schaalvergroting bij de glasgroentebedrijven over de afgelopen decennia ligt de omvang in bedrijfsoppervlakte glas van de vier grootste bedrijven uit de steekproef in 2006 nog niet boven de 100 ha. De horizontale concentratiegraad C4 voor tomaten ligt op ruim $6 \%$ en voor paprika's op 4\%. Per bedrijfstype A1t/m A4 varieert deze C4 van 3.5 tot 5.2\%. Er is bij de productiebedrijven sprake van een lage horizontale concentratie.

Als we de twee groepen veilingtelers (A1 en A2) samenvoegen tot één nieuwe groep (zie tabel 5.16) dan zijn dit alle verticaal geïntegreerde bedrijven, samen met de groothandel in één afzetorganisatie ondergebracht (het zogenoemde VVI-bedrijfstype). Ook de twee groepen zelfstandige telers (A3 en A4) zijn samengevoegd als groep bedrijven die niet-verticaal geïntegreerd zijn met de groothandel (het zogenoemde niet-VVI-bedrijfstype). Het (markt) aandeel van deze twee groepen wel en niet-voorwaarts geïntegreerde bedrijven in het areaal glasgroenten (tomaat en paprika) verhoudt zich ongeveer als 30\%:70\% en is een maatstaf voor de verticale concentratie in de markt van glasgroenten. De gemiddelde bedrijfsoppervlakte van deze twee nieuwe groepen geeft een betekenisvol verschil van 7.4 ha. De gemiddelde bedrijfsomvang in ha. glas alsook de omzet (zie tabel 5.34) en het investeringsniveau (tabel 5.37) van het zelfstandig opererende glasgroentebedrijf (A3/A4) is aanmerkelijk groter dan van de aangesloten bedrijven bij de voormalige veilingen. Hiermee probeert bedrijfstype A3/A4 tot een verlaging van de gemiddelde kosten te komen, van belang om de kosten van de marketing- en verkoopfunctie inclusief de logistiek te kunnen opbrengen. De verwachting is dat dit verschil in bedrijfsomvang in ha. glas en omzet tussen deze twee bedrijfstypen de komende jaren nog zal toenemen en hiermee ook de horizontale concentratie in de totale glasgroenteteelt. Hierbij kan het aantal glasgroentebedrijven op termijn nog aanzienlijk dalen tot 500 of minder. Verder valt bij de vergelijking van dit (VVI-) bedrijfstype op dat er geen betekenisvol verschil is in de gerealiseerde brutomarge van beide types (zie tabel 5.35). Dat is een opvallende conclusie. Het betekent dat het streven naar productie op grote schaal niet in alle gevallen leidt tot een verlaging van gemiddelde kosten en dat ook bedrijven van kleinere omvang een positieve brutomarge kunnen behalen. Dit is in lijn met voorgaande conclusies uit punt 3 (zie ook tabel 5.25).

\section{Investeringen/innovaties}

In het voorgaande is vastgesteld dat het investeringsniveau voor kleinere bedrijven lager ligt dan dat van de grotere bedrijven. De vraag is of een hoger investeringsniveau ook een hoger resultaat bewerkstelligt. Er lijkt geen betekenisvol verband te zijn tussen de hoogte van het investeringsniveau en de gerealiseerde brutomarge in 2006 (tabel 5.45). De investeringen in de glastuinbouw vinden in veel gevallen meer procesgericht dan marktgericht plaats. Er wordt minder geïnves- 
teerd in een product- of diensteninnovatie die een hogere opbrengstprijs oplevert (bijv. de introductie van een nieuw ras), maar meer in middelen die een verlaging van de productiekosten en de gemiddelde kostprijs beogen.

\section{Bedrijfsomvang/kostenniveau}

De afgelopen jaren is de schaalgrootte van het glastuinbouwbedrijf flink toegenomen, mede in de veronderstelling dat de gemiddelde totale kosten hierdoor zouden dalen. Bedrijven met een grotere oppervlakte glas hebben echter procentueel gemeten niet een betekenisvol lagere kostprijs per $\mathrm{m}^{2}$ dan kleinere bedrijven (tabel 5.46). Dit geldt zowel voor tomaten- als paprikabedrijven. In het verlengde hiervan ligt de ontwikkeling van de brutomarge. Deze mag geacht worden te

Schaalvergroting niet altijd rendabel (29 maart 2011):

Middelgrote tuinbouwbedrijven weten nagenoeg hetzelfde rendement te halen als grote tuinderijen. Schaalvergroting leidt niet per definitie tot kostenverlaging. De bedrijfseconomische verschillen met kleine bedrijven zijn wel aanzienlijk. Dat blijkt uit het onderzoek schaalvergroting van het LEI, dat vorige week gepresenteerd werd.

verbeteren door uitbreiding en vernieuwing van het glastuinbouwbedrijf. Dit lijkt inderdaad het geval te zijn. De onderzoeksuitkomsten (tabel 5.47) lijken een betekenisvol verband aan te geven, echter wel met een enigszins lagere betrouwbaarheid van $90 \%$.

\section{- Commerciële en financieel-economische conclusies}

1. De organisatie van de marketing- en verkoopactiviteiten is per type glastuinbouwbedrijf zeer verschillend en onderhevig aan veel veranderingen. Sinds het horizontale en verticale fusieproces van de groente- en fruitveilingen in Nederland in 1995/1996 is een groot aantal bedrijven gestopt dan wel veranderd van afzetorganisatie en afzetmethode. De uitkomsten van het bedrijfsonderzoek laten zien dat in 2006 nog bijna 60\% van de glasgroentetelers is aangesloten bij VTN/The Greenery in Barendrecht en veiling ZON in Noord-Limburg. Dit zijn de voormalige coöperatieve veilingen met de kleinste bedrijven. Ruim 30\% van de respondenten heeft via een gezamenlijk opgerichte telersvereniging gekozen voor een eigen organisatie van de afzet. Vaak heeft men een meer of minder vaste relatie met een specifiek handelshuis zoals VDT/VDN, BGB /Haluco, Unistar/Van Rijn e.a.. De grootste onafhankelijk van de voormalige veilingorganisaties en private handelshuizen opererende afzetorganisatie in 2006 is FresQ (10\% van de respondenten), met voornamelijk grote glasgroentetelers die hun eigen afzet regelen (Red Star Trading van Van der Kaaij, Seasun van Gresnigt, Lans Tomaten e.a.). Inmiddels is in 2012/2013 de positie van FresQ en haar leden drastisch veranderd en zijn deze bedrijven toegetreden tot een nieuwe zelfstandige telersvereniging Harvest House (zie paragraaf 3.5.2 en de appendices 3A en 4B). 
2. The Greenery en ZON hebben door de relatief grote omvang van het assortiment en omzetaandeel in groenten en fruit het grootste verkoopapparaat ( 5 of meer fte's). Bij zelfstandig opererende telersverenigingen is dit veel kleiner $(0<2 \mathrm{fte}$ 's) en wordt een groot deel van deze werkzaamheden verricht door het handelshuis. De grotere zelfstandige glasgroentebedrijven onder FresQ-vlag zitten ertussenin ( $3<5$ fte's). De bedrijven met het laagste percentage verkoopkosten (ca. 25\%) bevinden zich vooral bij de handelsbedrijven Van Rijn, Bakker Barendrecht, Haluco en telersvereniging FresQ. Dit zijn de grotere bedrijven in opp. glas. De kleinere bedrijven met het hoogste percentage verkoopkosten bevinden zich voornamelijk bij The Greenery (hier betaalt 60\% van de respondenten meer dan 3\% van de omzet aan verkoopkosten). Er is een betekenisvol verschil in percentage verkoopkosten, gemeten naar bedrijfsomvang in ha. glas en omzet (tabel 5.20) Naarmate deze omvang groter is, liggen de verkoopkosten in percentage van de omzet lager.

3. Er lijkt een betekenisvol verband te zijn tussen de keuze van de organisatie van de afzet(marketing en verkoop) en de bedrijfsomvang in ha.(tabel 5.28). Bij VTN/The Greenery en vooral ZON zijn verhoudingsgewijs meer kleinere bedrijven aangesloten dan bij de handelshuizen Haluco en Van Rijn en telersvereniging FresQ. De verkoopwijze van de producten vindt voor twee derde gedeelte plaats via bemiddeling en steeds minder via de klok, nog af en toe in gebruik bij veiling ZON. Het overige deel van de verkoop gaat via de telersvereniging (ca. 24\%) en via de teler zelf (ca. 12\%, bijv. FresQ). Er lijkt een verband te bestaan tussen de verkoopwijze van de producten en de gerealiseerde jaaromzet: verkoop via de telersvereniging en directe verkoop tonen een groter omzetaandeel, klok en bemiddeling een kleiner aandeel (tabel 5.24). De toetsing van de bedrijfsomvang in opp. glas met de wijze van verkoop laat hetzelfde zien: bedrijven van kleinere omvang (tot 3 ha.) kiezen vaker voor bemiddeling door veiling of klok/deel bemiddeling (bijna $82 \%$ ), terwijl de grotere bedrijven (7.6 ha. en meer ) kiezen voor verkoop via telersvereniging dan wel voor directe verkoop (100\% resp. 85\%).

4. Er is geen verband tussen de gekozen afzetorganisatie en gerealiseerde brutomarge (5.29) De afzetorganisatie heeft weinig of geen invloed op het individuele bedrijfsresultaat van de leden. Dit wordt voornamelijk door de producent zelf bepaald.

5. De tevredenheid over de verkooporganisaties in de sector glasgroenten is als volgt: $55 \%$ van de bedrijven is tevreden tot zeer tevreden over de verkooporganisatie, $12 \%$ is ontevreden tot zeer ontevreden en $33 \%$ zit hiertussen. Bedrijfstype A1 is het meest ontevreden in verband met de relatief hoge verkoopkosten en de vaak lage uitbetaalprijzen.

6. De gemiddelde uitbetaalprijzen laten per productsoort naar bedrijfstypen gemeten grote verschillen zien (tabel 5.14). Zoals is opgemerkt, hangt dit samen met soort en type product, de organisatie van de marketing en verkoop van het bedrijf en het verloop van de marktsituatie. Bij de tomaat scoort bedrijfstype A1 in bijna alle jaren gemiddeld het laagst, wat betreft de uitbetaalprijs en bedrijfstype A4 het hoogst. Bij de paprika is dit voor type A1 eveneens het geval, 
behalve in 2006. Bedrijfstype A3 (slechts één respondent) scoort hier het hoogst. Bedrijfstype A2 scoort bij de paprika in alle jaren hoger dan type A1 en A4. Er lijkt bij de tomaat een betekenisvol prijsverschil te bestaan, kijkend vanuit het A1-assortiment (voornamelijk ronde en trostomaat) naar de andere bedrijfstypen. Deze bedrijfstypen laten echter een grotere spreiding zien door een breder assortiment van speciale producten met een hoger prijsniveau.

\subsubsection{Conclusies marktstructuur en -resultaat}

Op grond van de uitkomsten van het bedrijfsonderzoek naar marktstructuur en -resultaat kunnen we het volgende concluderen.

\subsubsection{Horizontale concentratie}

- De concentratiegraad van de vier grootste producenten (C4) in de glasgroenten ligt op een laag niveau. Er is een geringe toename bij de producenten van glasgroenten van $5.7 \%$ naar $6.5 \%$ over de periode $2003-2008$ met de hoogste concentratie (10\%) in het gewas tomaat (zie tabel 5.48). Onderstaande tabel 5.50 toont de hoogte van de $\mathrm{C} 4$ per onderscheiden bedrijfstype met de hoogte van de gemiddelde brutomarge. Hoewel de toename van de $\mathrm{C} 4$ gering is en op dit lage niveau van weinig invloed lijkt te zijn op het sector- en bedrijfsresultaat (productiewaarde, prijzen glasgroenten en brutomarge) valt op dat bij een hogere C4-waarde ook steeds een hogere brutomarge wordt bereikt.

Tabel 5.50 Concentratiegraad (C4) en brutomarge 2006 naar onderscheiden bedrijfstypen *)

\begin{tabular}{|l|c|c|}
\hline Onderscheiden bedrijfstypen & $\begin{array}{c}\text { Concentratiegraad (C4 in \%) in } \\
\text { 2006 producenten glasgroenten }\end{array}$ & $\begin{array}{l}\text { Gemiddelde brutomarge (in \%) } \\
\text { gerealiseerd door deze bedrijven }\end{array}$ \\
\hline -Tomaat & 6.1 & 13.2 \\
\hline -Paprika & 4.1 & 7.0 \\
\hline -VVI-bedrijfstype & 4.8 & 7.3 \\
\hline -niet-VVI-bedrijfstype & 5.2 & 8.3 \\
\hline -Bedrijfstype A1 & 4.0 & -1.9 \\
\hline -Bedrijfstype A2 & 4.8 & 7.3 \\
\hline
\end{tabular}

VVI = Voorwaartse Verticale Integratie; ${ }^{*}$ ) Onderzoeksresultaten C4 producenten glasgroenten uit tabel $5.39 \mathrm{t} / \mathrm{m}$ 5.44

\subsubsection{Voorwaartse verticale integratie}

- Het (markt)aandeel van de twee groepen wel en niet-voorwaarts geïntegreerde bedrijven in het areaal glasgroenten (tomaat en paprika) verhoudt zich ongeveer als 30\%:70\% en is een maatstaf voor de verticale concentratie in de groothandelsmarkt van glasgroenten (zie tabel 5.16).

- De gemiddelde bedrijfsomvang in oppervlakte glas en omzet van de bij VTN/The Greenery of $\mathrm{ZON}$ aangesloten bedrijven (A1/A2) is aanmerkelijk kleiner dan het zelfstandig opererende glasgroentebedrijf (A3/A4). Hetzelfde geldt voor het gemiddeld investeringsniveau ( $€$ x $1 \mathrm{mln}$.). 
- Er is geen betekenisvol verschil in de gerealiseerde brutomarge tussen de bij VTN/The Greenery of ZON aangesloten bedrijven (A1/A2) en de zelfstandig opererende glasgroentebedrijven (A3/A4). Voor meerdere bedrijfstypen (klein en groot) is in de glasgroenten een redelijk rendement te behalen. Dit stemt overeen met de uitkomsten van de concurrentiemonitor glasgroenten (Van Galen et al., LEI-rapport 2010-051, pp. 25, 26).

\subsubsection{Productdifferentiatie}

- De productdifferentiatie bij de glasgroenten in Nederland is niet erg breed. Het assortiment van de komkommer is het smalst, dat van de tomaat het breedst en de paprika bevindt zich hiertussen. In het algemeen kan worden gezegd dat productdifferentiatie tot een hogere brutomarge leidt.

- De uitkomsten van het bedrijfsonderzoek gaven aan dat er een betekenisvol verband lijkt te bestaan tussen bedrijfstype en producttypen tomaat. Bedrijfstype A1 en A2 (veilingtelers en -telersverenigingen) kiezen voornamelijk voor de ronde of de trostomaat (convenience), bedrijfstype A3 en A4 kiezen in meerderheid voor de specialere soorten tomaat (specialties).

\subsubsection{Toetredingsdrempels (investeringen)}

- Toetreding tot de sector glasgroenten in Nederland is geen eenvoudige zaak en de investeringsdrempels zijn hoog. Eerder is aangegeven dat in de periode 2005-2010 jaarlijks tien tot vijftien procent van de bedrijven stopte. Toetreding tot de sector vond nauwelijks plaats, uittreding des te meer. Investeringen in nieuwe kassen inclusief inrichting en grond zijn hoog en het behalen van voldoende rendement is onzeker, gezien de sterke concurrentie op de belangrijkste markten, de banken- en kredietcrisis in 2008/2009 en het voortdurende lage consumentenvertrouwen in Europa.

- De uitkomsten van het bedrijfsonderzoek geven aan dat het investeringsniveau in 2006 voor kleinere bedrijven (type A1, veilingteler) aanmerkelijk lager ligt dan dat van de grotere bedrijven (type A2 en A4). Een belangrijke vraag is of dit hogere investeringsniveau ook een hoger resultaat bewerkstelligt. Dit mogelijk verband is getoetst. Uit deze toetsing komt naar voren dat er geen betekenisvol verband lijkt te zijn tussen de hoogte van de investeringen en de gerealiseerde brutomarge in 2006. Een aanvullende vraag blijft hoe innovatief deze investeringen zijn. 
5.5 Bedrijfs- en marktkarakteristieken sectoren glastuinbouw 2006-2008

De centrale vraag van het onderzoek is of verschillen in marktstructuur (S) van de sectoren en marktgedrag $(\mathrm{G})$ van de grootste afzetorganisaties en de glastuinbouwbedrijven betekenisvolle verschillen in marktresultaten $(\mathrm{R})$ opleveren.

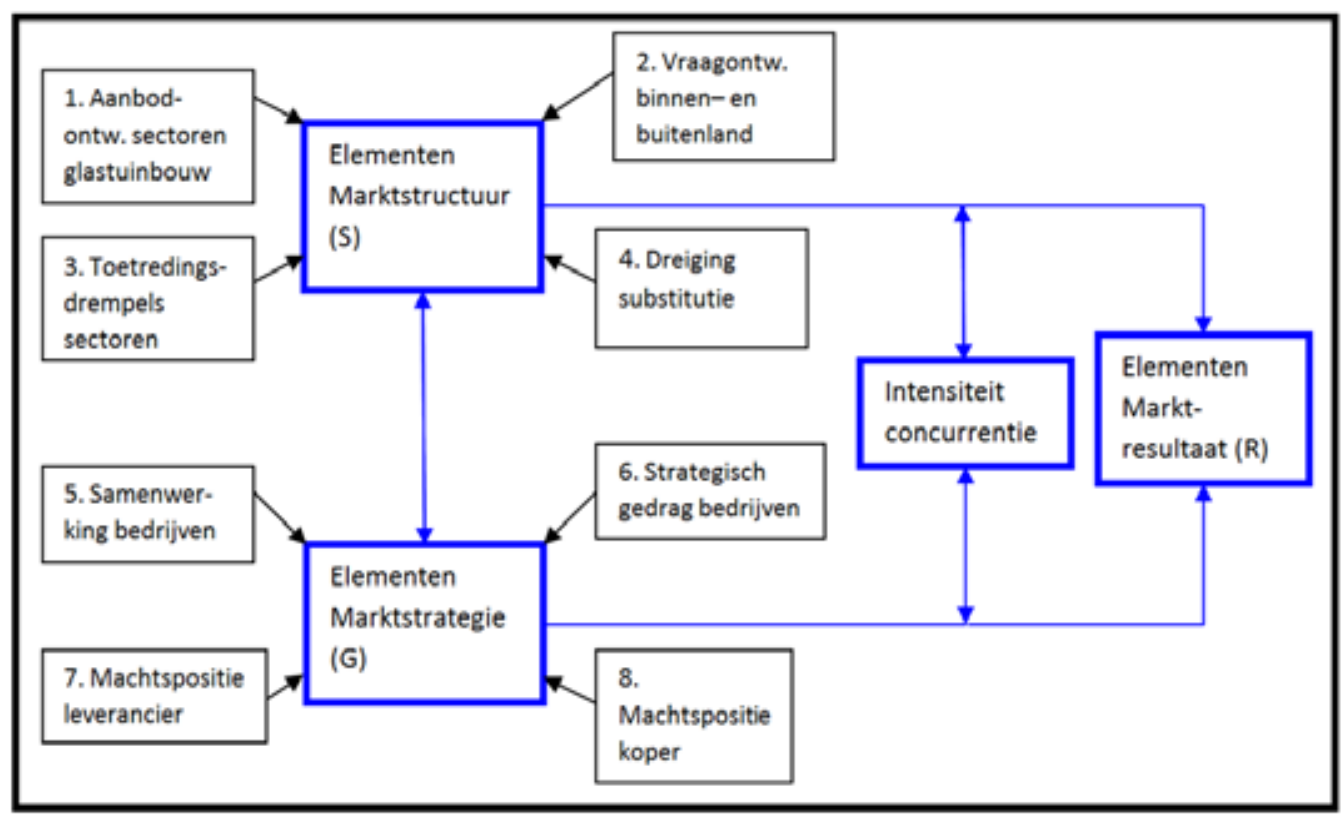

Figuur 1.1 Conceptueel model: concurrentie, concentratie en rentabiliteit sectoren glastuinbouw in Nederland

Het bovenstaande conceptueel model (figuur 1.1 in hoofdstuk 1) en het analysemodel in hoofdstuk 2 (figuur 2.4) geven aan welke bedrijfs- en marktgegevens nodig zijn om de relevante variabelen van marktstructuur, -gedrag en -resultaat per sector in kaart te brengen en mogelijke verbanden te toetsen. Onderstaande tabel 5.50 geeft een overzicht van de belangrijkste gegevens 2006-2008 van marktstructuur en marktresultaten in de drie sectoren glastuinbouw(S en R). Deze gegevens komen grotendeels voort uit het sectoronderzoek ( $\mathrm{H} \mathrm{3}$ ) en het onderzoek afzetorganisaties ( $\mathrm{H}$ 4). Tabel 5.51 geeft een overzicht van gegevens uit het bedrijfsonderzoek glasgroenten (zie hoofdstuk 5) betreffende het marktgedrag en de marktresultaten ( $G$ en $R$ ). In hoofdstuk 6 en 7 wordt deze tabel aangevuld met de gegevens uit het bedrijfsonderzoek sectoren glassnijbloemen en -potplanten. Het bedrijfsonderzoek is gehouden in 2006, 2007 en 2008 en de onderzoeksuitkomsten per sector staan los van elkaar. Mogelijke verbanden tussen marktstructuur, marktgedrag en marktresultaat worden per sector onderzocht. Om een indruk te krijgen van de verschillen tussen de sectoren worden bedrijfs- en marktkarakteristieken naast elkaar geplaatst. 
Tabel 5.50 Onderzoeksresultaten sector- en bedrijfsonderzoek marktstructuur en marktresultaat sectoren glastuinbouw 2006-2008

\begin{tabular}{|c|c|c|c|}
\hline $\begin{array}{l}\text { Bedrijfs- en markt- } \\
\text { karakteristieken sector } \\
\text { (mesoniveau) }\end{array}$ & $\begin{array}{l}\text { Sector glasgroenten (A) } \\
\text { Onderzoek } 2006 \\
-\mathrm{N}=2000 ; 4500 \text { ha. }\end{array}$ & $\begin{array}{l}\text { Sector glassnijbloemen (B) } \\
\text { Onderzoek } 2007 \\
-\mathrm{N}=2600 ; 3000 \text { ha. }\end{array}$ & $\begin{array}{l}\text { Sector glaspotplanten }(C) \\
\text { Onderzoek } 2008 \\
-\mathrm{N}=1000 ; 1431 \text { ha. }\end{array}$ \\
\hline $\begin{array}{l}\text { Omvang actuele markt }(\mathrm{Ma}) \text { in } \\
2006-2008 \\
(\text { met groei in \%) }\end{array}$ & $\begin{array}{l}\text { - productiewaarde }(\mathrm{x} € 1 \mathrm{mln} .) \\
\text {-2006: } 1.350(+1 \%) \\
\text {-2007: } 1.340(-1 \%) \\
\text {-2008: } 1.270(-5 \%)\end{array}$ & $\begin{array}{ll}\text { - productiewaarde }(\mathrm{x} € 1 \mathrm{mln} .) \\
-2006: & 2.277(+3 \%) \\
-2007: & 2.294(+1 \%) \\
-2008: & 2.158(-6 \%)\end{array}$ & $\begin{array}{l}\text { - productiewaarde }(\mathrm{x} € 1 \\
\text { mln.) } \\
-2006: 1.624(+7 \%) \\
-2007: 1.768(+9 \%) \\
-2008: 1.847(+5 \%)\end{array}$ \\
\hline $\begin{array}{l}\text { Omvang relevante markt }(\mathrm{Mr}) \\
2006+\text { groei }\end{array}$ & $\begin{array}{l}-2006: 1.350(x € 1 \mathrm{mln} .) \\
(+0 \mathrm{mln} .)\end{array}$ & $\begin{array}{l}-2006: 2.327(x € 1 \mathrm{mln} .) \\
(+ \text { ca. } 50 \mathrm{mln} .)\end{array}$ & $\begin{array}{l}-2006: 1.754(\mathrm{x} \in 1 \mathrm{mln} .) \\
(+ \text { ca. } 130 \mathrm{mln} .)\end{array}$ \\
\hline Verzadigingsgraad $\mathrm{V}(\mathrm{Ma} / \mathrm{Mr})$ & $-1.350 / 1.350=1.0$ & $-2.277 / 2.327=0.98$ & $-1.624 / 1.754=0.93$ \\
\hline $\begin{array}{l}\text { Aantal producenten } \\
\text { Horizontale concentratie**) }\end{array}$ & $\begin{array}{l}-\mathrm{N}=2000(2006) \\
-2006: \mathrm{C} 45 \% \\
-2008: \mathrm{C} 46.5 \%\end{array}$ & $\begin{array}{l}-\mathrm{N}=2600(2007) \\
-2007: \mathrm{C} 4 \quad 5.5 \% \\
-2008: \mathrm{C} 4 \quad 7 \%\end{array}$ & $\begin{array}{l}-\mathrm{N}=1000(2008) \\
-2007: \mathrm{C} 4 \quad 6.5 \% \\
-2008: \mathrm{C} 4 \quad 6.5 \% \\
\end{array}$ \\
\hline $\begin{array}{l}\text { Aantal afzetorganisaties } \\
\text { Horizontale concentratie }\end{array}$ & $\begin{array}{l}-10-15 \text { (VTN/ZON/Telersver.) } \\
-2006: \mathrm{C} 472 \% \\
-2008: \mathrm{C} 466 \% \\
\end{array}$ & $\begin{array}{l}-2 \text { (FH/Plantion) } \\
-2007: \text { C2 } 100 \%\end{array}$ & $\begin{array}{l}-2 \text { (FH/Plantion) } \\
-2008: \mathrm{C} 2100 \%\end{array}$ \\
\hline $\begin{array}{l}\text { Aantal grooth./exp.//imp. } \\
\text { Horizontale concentratie**) }\end{array}$ & $\begin{array}{l}-1110 \\
-2006: \mathrm{C} 10 \quad 72 \% \\
-2008: \mathrm{C} 10 \quad 67 \%\end{array}$ & $\begin{array}{l}\text {-ca. } 700 \\
-2007: \text { C8 } 58 \% \\
-2008: \text { C } 85 \%\end{array}$ & $\begin{array}{ll}\text {-ca. } 300 & \\
-2008: \text { C8 } & 59 \% \\
-2009: \text { C8 } & 60 \%\end{array}$ \\
\hline $\begin{array}{l}\text { Gem. gewogen jaarprijzen } \\
\text { alle producten (eurocent per } \\
\mathrm{kg} \text { of st.) }\end{array}$ & $\begin{array}{l}\text {-2006: } 97 \mathrm{ct} \\
\text {-2007: } 103 \mathrm{ct} . \\
\text {-2008: } 101 \mathrm{ct} .\end{array}$ & $\begin{array}{l}-2006: 22 \text { ct. } \\
-2007: 23 \text { ct. } \\
-2008: 22 \text { ct. }\end{array}$ & $\begin{array}{l}\text {-2006: } 117 \text { ct. } \\
\text {-2007: } 127 \text { ct. } \\
\text {-2008: } 129 \text { ct. }\end{array}$ \\
\hline Exportwaarde $\left.(x € 1 \mathrm{mln} .)^{*}\right)$ & $\begin{array}{l}\text {-2006: } 3.420 \\
-2007: 3.620 \\
-2008: 3.718\end{array}$ & $\begin{array}{l}\text {-2006: } 3.237 \\
-2007: 3.373 \\
-2008: 3.243\end{array}$ & $\begin{array}{ll}-2006: & 1.777 \\
-2007: & 1.858 \\
-2008: & 1.854\end{array}$ \\
\hline Exportaandeel *) & $\begin{array}{l}-2006: 68 \% \text { (glas)groenten } \\
-2007: 68 \% \\
-2008: 70 \%\end{array}$ & $\begin{array}{l}\text {-2006: } 88 \% \text { (glas)snijbloemen } \\
\text {-2007: } 90 \% \\
-2008: 87 \%\end{array}$ & $\begin{array}{l}\text {-2006: } 73 \% \\
\text { (glas)potplanten } \\
-2007: 70 \% \\
-2008: 66 \%\end{array}$ \\
\hline Importwaarde $\left.(x € 1 \mathrm{mln} .)^{*}\right)$ & $\begin{array}{ll}-2006: & 1.000 \text { (schatting) } \\
-2007: & 1.000 \text { (schatting) } \\
-2008: & 985\end{array}$ & $\begin{array}{l}\text {-2006: } 664 \\
-2007: 702 \\
-2008: 827 \\
\end{array}$ & $\begin{array}{ll}-2006: & 318 \\
-2007: & 348 \\
-2008: & 379\end{array}$ \\
\hline Importaandeel *) & $\begin{array}{ll}-2006: & 18 \% \text { (glas)groenten } \\
-2007: & 18 \% \\
-2008: & 11 \%\end{array}$ & $\begin{array}{l}\text {-2006: } 23 \% \text { (glas)snijbloemen } \\
-2007: 23 \% \\
-2008: 28 \%\end{array}$ & $\begin{array}{l}-2006: 16 \% \\
\text { (glas)potplanten } \\
-2007: 17 \% \\
-2008: 17 \% \\
\end{array}$ \\
\hline Markttoetreding & $\begin{array}{l}\text {-deels open/deels gesloten } \\
(70 / 30)\end{array}$ & -open & -open \\
\hline $\begin{array}{l}\text { Verticale concentratie (VVI) } \\
\text { afzetorganisatie/veilingen }\end{array}$ & $\begin{array}{l}\text {-VTN/The Greenery en ZON: } \\
\text { ca. } 30 \%\end{array}$ & -nihil & -nihil \\
\hline 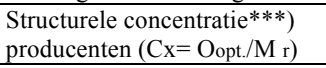 & $\begin{array}{l}-2.5 \mathrm{mln} . / 1.350 \mathrm{mln} .= \\
1 / 540\end{array}$ & $\begin{array}{l}-2.6 \mathrm{mln} . / 2.377 \mathrm{mln} .= \\
1 / 895\end{array}$ & $\begin{array}{l}-4.9 \mathrm{mln} . / 1.750 \mathrm{mln} .= \\
1 / 350\end{array}$ \\
\hline $\begin{array}{l}\text { Feitelijke concentratie } \\
\text { producenten }\end{array}$ & $-1 / 2000$ & $-1 / 2600$ & $-1 / 1000$ \\
\hline \multicolumn{4}{|c|}{$\begin{array}{l}\text { *) export- en importwaarden groenten, snijbloemen en potplanten betreffen verse producten onder glas en uit de } \\
\left.\text { volle grond; }{ }^{* *}\right) \mathrm{C} 4=\text { Concentratiegraad van de vier grootste bedrijven }=\text { het aandeel in bedrijfsoppervlakte of } \\
\left.\text { omzet van deze bedrijven in het totaal, } \mathrm{C} 10=\text { Concentratiegraad tien grootste bedrijven etc.; }{ }^{* *}\right) \text { de structurele } \\
\text { concentratie }\left(\mathrm{C}_{\mathrm{x}}\right) \text { is de verhouding gemiddelde (optimale) ondernemingsomvang }(\mathrm{O}) \text { en de relevante } \\
\text { marktomvang }\left(\mathrm{M}_{\mathrm{r}}\right) \text {. }\end{array}$} \\
\hline
\end{tabular}


Tabel 5.51 Onderzoeksresultaten sector- en bedrijfsonderzoek marktgedrag en marktresultaat sector glasgroenten 2006-2008

\begin{tabular}{|c|c|c|c|}
\hline $\begin{array}{l}\text { Bedrijfs- en markt- } \\
\text { karakteristieken sectoren } \\
\text { (microniveau) }\end{array}$ & $\begin{array}{l}\text { Sector glasgroenten (A) } \\
\text { Onderzoek } 2006 \\
-\mathrm{N}=2000 ; 4500 \text { ha. } \\
\text {-n=42; } 244 \text { ha. } \\
\text {-tomaat/paprika }\end{array}$ & $\begin{array}{l}\text { Sector glassnijbloemen (B) } \\
\text { Onderzoek } 2007 \\
-\mathrm{N}=2600 ; 3000 \text { ha. } \\
\text { (Onderzoeksresultaten: zie } \\
\text { hoofdstuk 6) }\end{array}$ & $\begin{array}{l}\text { Sector glaspotplanten (C) } \\
\text { Onderzoek } 2008 \\
-\mathrm{N}=1000 ; 1431 \text { ha. } \\
\text { (Onderzoeksresultaten: zie } \\
\text { hoofdstuk 7) }\end{array}$ \\
\hline Gem. leeftijd bedrijf & -13 jaar & & \\
\hline $\begin{array}{l}\text { Bedrijfstypen } 1 \mathrm{t} / \mathrm{m} 4 \text {, } \\
\text { aandelen absoluut en relatief }\end{array}$ & $\begin{array}{lrr}\text {-A1 } & 14 & 33 \\
\text {-A2 } & 12 & 29 \\
\text {-A } 3 & 4 & 10 \\
\text {-A4 } & \underline{12} & \underline{28} \\
\text { tot. } & \frac{12}{42} & 100 \%\end{array}$ & & \\
\hline $\begin{array}{l}\text { Bedrijfsomvang in opp. glas (gem. } \\
\text { met minimum en maximum in ha.) }\end{array}$ & $\begin{array}{ll}\text {-gem. } & 5.8 \\
\text {-min. } & 0.8 \\
\text {-max. } & 34.0\end{array}$ & & \\
\hline $\begin{array}{l}\text { Bedrijfsomvang in omzet } 2006 \\
\text { met minimum en maximum ( } € \times 1 \\
\text { mln.) }\end{array}$ & $\begin{array}{lr}\text {-gem. } & 2.5 \\
\text {-min. } & 0.3 \\
\text {-max. } & 16.0\end{array}$ & & \\
\hline $\begin{array}{l}\text { Brutomarge [( Prijs }- \text { GTK }) / \text { Prijs] } \\
\text { x 100) } 2006 \text { met minimum en } \\
\text { maximum }\end{array}$ & $\begin{array}{lr}\text {-gem. } & 8.0 \\
\text {-min. } & -33.0 \\
\text {-max. } & 26.6 \\
\end{array}$ & & \\
\hline $\begin{array}{l}\text { Brutomarge [( Prijs - GTK)/Prijs] } \\
\mathrm{x} 100) \text { per bedrijfstype in } 2006\end{array}$ & $\begin{array}{rr}\text {-A1 } & 4.5 \\
-\mathrm{A} 2 & 9.1 \\
-\mathrm{A} 3 & 11.2 \\
\text {-A4 } & 9.8\end{array}$ & & \\
\hline $\begin{array}{l}\text { Solvabiliteit(EV/TV*100) } \\
\text {-per sector en per bedrijfstype }\end{array}$ & $\begin{array}{ll}\text {-sector } & 49.8 \\
\text {-A1 } & 58.5 \\
\text {-A2 } & 40.9 \\
\text {-A3 } & 54.3 \\
\text {-A4 } & 46.0 \\
\end{array}$ & & \\
\hline $\begin{array}{l}\text { Afzetorganisaties: aandeel in \% } \\
\text { totaal respondenten }\end{array}$ & $\begin{array}{ll}\text {-VTN } & 40 \\
\text {-ZON } & 16 \\
\text {-Eigen Verkoop } & 14 \\
\text {-Telersvereniging } & 30 \\
\end{array}$ & & \\
\hline $\begin{array}{l}\text { Eigen Verkoop: aandeel in \% } \\
\text { totaal respondenten }\end{array}$ & $\begin{array}{l}\text {-Via telersver. } 30 \%+\text { E.V. } 0-< \\
15 \% \text {. }\end{array}$ & & \\
\hline $\begin{array}{l}\text { Veilingprovisie in \% omzet + } \\
\text { min./max. }\end{array}$ & $\begin{array}{ll}\text {-gem. } & 3.0 \\
\text {-min. } & 0.5 \\
\text {-max. } & 5.5 \\
\end{array}$ & & \\
\hline $\begin{array}{l}\text { Eigen Verkoop (kosten) } \\
\text { in } \% \text { omzet }+ \text { min. / max. }\end{array}$ & $\begin{array}{ll}\text {-gem. } & 3.0 \\
\text {-min. } & 0.5 \\
\text {-max. } & 5.5\end{array}$ & & \\
\hline $\begin{array}{l}\text { Verkoopmethode: aandeel in \% } \\
\text { totaal respondenten }\end{array}$ & $\begin{array}{ll}\text {-BB } & 64 \\
\text {-Telersver. } & 24 \\
\text {-EV } & 12 \\
\end{array}$ & & \\
\hline $\begin{array}{l}\text { Marktontwikkeling } \\
(\% \text { jaarlijkse groei) }\end{array}$ & $\begin{array}{l}-05 / 06:+1-2 \% \\
-06 / 07:-1-2 \% \\
-07 / 08:-5-6 \% \\
\end{array}$ & & \\
\hline $\begin{array}{l}\text { Prijsvorming } \\
\text { (opinie telers) }\end{array}$ & $\begin{array}{l}\text {-2005/2006: } \\
\text {-matig }(60 \%) \\
\text {-goed }(26 \%)\end{array}$ & & \\
\hline $\begin{array}{l}\text { Prijsontwikkeling min. } \rightarrow \text { max. } \\
\text { (eurocent per kg/st.) } \\
\text { (gem. gew. jaarprijzen) }\end{array}$ & $\begin{array}{lc}\text {-periode } & 2003-2006: \\
\text {-tomaat } & 60-97 \\
\text {-paprika } & 99-148 \\
\text { (onstabiele ontwikkeling) } \\
\end{array}$ & & \\
\hline $\begin{array}{l}\text { Tevredenheid over } \\
\text { afzetorganisatie }\end{array}$ & $\begin{array}{l}-55 \% \text { tevreden } / \mathrm{z} \text {. tevr. } \\
-33 \% \text { tevreden/ontevr. } \\
-12 \% \text { ontevreden/zeer } \\
\text { ontevreden }\end{array}$ & & \\
\hline
\end{tabular}



BEDRIJFSONDERZOEK GLASTUINBOUW IN NEDERLAND, DEELSECTOR GLASSNIJBLOEMEN 



\subsection{Inleiding}

Dit hoofdstuk behandelt de uitkomsten van het bedrijfsonderzoek in de deelsector glassnijbloemen. Vergelijkbaar met hoofdstuk 5 gaat het om het in kaart brengen van de ontwikkeling van de belangrijkste gedrags- en resultaatsvariabelen op microniveau, de structuur- en resultaatsvariabelen op mesoniveau en het enkelvoudige verband tussen marktgedrag en -resultaat, te meten met de $\chi 2$-analyse (zie ook het analysemodel en de variabelen van figuur 2.4 in hoofdstuk 2). In hoofdstuk 7 wordt verslag gedaan van eenzelfde bedrijfsonderzoek in de deelsector glaspotplanten en in hoofdstuk 8 volgt de meervoudige econometrische analyse in de drie sectoren. Het plan van aanpak en de gehanteerde vragenlijst bij dit deelonderzoek is qua opzet en terminologie grotendeels gelijk aan die van de sector glasgroenten (zie appendix 6A voor de verschillen). Hetzelfde geldt voor de praktische uitvoering van het onderzoek dat hierna wordt beschreven.

\subsection{Methode bedrijfsonderzoek glassnijbloemen}

Doel van het onderzoek is het verkrijgen van voldoende betrouwbare en representatieve informatie van de bedrijven, nu uit de sector glassnijbloemen, ter beantwoording van de in hoofdstuk 2 paragraaf 2.6.2 genoemde onderzoeksvragen. Dit deel van het bedrijfsonderzoek is uitgevoerd in 2007 , met een deelrapportage in juli 2008.

Onderzoekspopulatie glassnijbloemen

Voor dit deelonderzoek zijn 100 glastuinders benaderd vanuit een door LTO Groeiservice beschikbaar gesteld adressenbestand, verspreid over de belangrijkste concentraties glastuinbouw (rozen- en chrysantenbedrijven) in Nederland te weten Westland, Oostland, Midden-Nederland regio Bommelerwaard, Noord-Holland regio Aalsmeer en regio Heerhugowaard. Evenals bij de glasgroenten is het doel om naast het in kaart brengen van bedrijfstype en algemene bedrijfskenmerken, inzicht te krijgen in de ontwikkeling van kosten, opbrengsten, prijzen en andere zaken op individueel bedrijfsniveau. De bedrijven in de sector glassnijbloemen zijn onderverdeeld in vier bedrijfstypen: B1-veilingteler, B2-veilingtelers-vereniging, B3-zelfstandige teler en B4zelfstandige telersvereniging. De omschrijving van deze bedrijfstypen staat in toonblad 1 van de vragenlijst (zie appendix 6A). De B1- en B2-bedrijven hebben de organisatie van de afzet in handen gegeven van hun afzetorganisaties, de bloemenveilingen. In 2006 zijn er nog vier bloemenveilingen in Nederland. De twee grootste, FloraHolland en de VBA, fuseren in 2007 tot het nieuwe FloraHolland. In 2009/2010 gaan de twee kleinste (Veiling Vleuten en VON te Bemmel) op in de nieuwe bloemenveiling Plantion in Ede (zie hoofdstuk 3). Het doel was om ongeveer 40 vraaggesprekken te houden in de periode september - december 2007, verdeeld over de vier te onderscheiden bedrijfstypen B1 t/m B4 in de rozen- en chrysantenteelt. Dit is deels gelukt. Van bedrijfstype B3 en B4 is in de sector glassnijbloemen nauwelijks sprake (slechts twee respondenten). 44 respondenten zijn bereid gevonden aan de hand van de per e-mail toegezonden vragenlijst het mondelinge interview te voeren. Totaal waren dit 21 rozen- en 23 chrysantente- 
lers. De beantwoording van de vragen is in meerderheid volledig geweest. In appendix 6B wordt een overzicht gegeven van de totale populatie glastuinbouw en glassierteelt in Nederland en de diverse ontwikkelingen in aantal bedrijven, areaal en prijs- en afzetgegevens, voor zowel de glassnijbloemen in het geheel als voor de roos en de chrysant in het bijzonder.

Steekproefomvang en representativiteit glassnijbloemen

De steekproefomvang is vastgesteld op basis van de populatieontwikkeling glastuinbouwbedrijven in de sector snijbloemen voor de twee belangrijkste gewassen, de roos en de chrysant. Deze gekozen steekproef rozen- en chrysantenbedrijven is beoordeeld op betrouwbaarheid en representativiteit (zie appendix 6B).

Samenvattend kan hierover het volgende worden gemeld. Het aandeel van het aantal respondenten van het onderzoek ten opzichte van het totaal aantal bedrijven bedraagt 1.7\% (44 van de ca. 2600 bedrijven). Het totale areaal van deze 44 onderzochte bedrijven bedraagt 149 ha. en heeft een aandeel in de totale bedrijfsoppervlakte glassnijbloemen in Nederland (2007) van 5\% (149 ha. ten opzichte van ongeveer 3000 ha., zie tabel 1.2).

Het aandeel van de onderzochte productgroepen roos en chrysant (zie tabel 1.2 en 1.3) bedraagt voor de roos ongeveer 9\% (69 ha. glasroos ten opzichte van 754 ha. totaal) en voor de chrysant $13 \%$ ( 80 ha. glaschrysant ten opzichte van 600 ha. totaal).

Gezien de beperkte omvang van deze steekproef en de niet geheel representatieve verdeling van de respondenten over de verschillende productiegebieden (zie tabel 1.3) dienen de resultaten van het onderzoek met enige voorzichtigheid te worden gehanteerd.

\section{Onderzoeksuitkomsten}

In paragraaf 6.3 worden de onderzoeksresultaten van het bedrijfsonderzoek glassnijbloemen behandeld, waar mogelijk in volgorde van de vragen zoals geformuleerd in de vragenlijst (zie appendix 6A). Aan de hand van een aantal frequentietabellen worden de belangrijkste bedrijfskundige en financieel-economische kenmerken van de bedrijven per sector, per productgroep en per bedrijfstype beschreven. Daarna worden de met behulp van de chi-kwadraatanalyse getoetste enkelvoudige verbanden tussen de gedrags- en resultaatsvariabelen besproken en wordt een overzicht gegeven van die variabelen die een meer of minder betekenisvol verband laten zien. Met deze onderzoeksuitkomsten dienen de in hoofdstuk 2 geformuleerde vragen op micro- en mesoniveau te worden beantwoord. Deze kruistabellen en de toelichting hierop staan in appendix 6C. 


\subsection{Analyse en resultaten glassnijbloemenbedrijven}

In paragraaf 6.3.1 wordt de analyse van de gedrags- en resultaatsvariabelen besproken, in paragraaf 6.3.2 de analyse van de structuur- en resultaatsvariabelen.

\subsubsection{Analyse gedrags- en resultaatsvariabelen (microniveau)}

Hierna worden de belangrijkste gedrags- en resultaatsvariabelen uit het bedrijfsonderzoek van de sector glassnijbloemen geanalyseerd en besproken (Veerman, 2008). Ze komen in volgorde van sector, productgroepen en bedrijfstypen aan bod. De mogelijke verbanden tussen de genoemde variabelen worden daarna behandeld.

\subsubsection{Onderzoeksresultaten glassnijbloemen (sector)}

Het vraaggesprek en de vragenlijst van het bedrijfsonderzoek (zie appendix 6A) is ingedeeld naar algemene bedrijfskenmerken, de organisatie van marketing- en verkoopactiviteiten, prijsvorming, effectiviteit en efficiency van de marketing- en verkoopstrategie en sectorale ontwikkelingen. De belangrijkste onderzoeksresultaten worden in deze volgorde behandeld.

\section{Kenmerken bedrijf en sector}

Ook bij de glassnijbloemen is de bedrijfsoppervlakte glas in ha. een belangrijk kenmerk voor de te realiseren jaarlijkse omzet en winst. Hoewel minder spectaculair dan in de glasgroenten is er sprake van een voortdurende toename van de gemiddelde bedrijfsomvang en een grote variatie in omvang en resultaat van de onderzochte bedrijven. De populatie ligt in 2007 op 2600 bedrijven en een gemiddelde oppervlakte van 1.2 ha. De onderzoeksuitkomsten (zie tabel 6.1) geven aan dat er kleine en grote bedrijven actief zijn. Van de 44 onderzochte bedrijven is de gemiddelde bedrijfsomvang 3.4 ha. met een spreiding van 0.6 ha. tot 13 ha. Bijna $44 \%$ heeft een omvang tot en met 2.5 ha., $56 \%$ een omvang groter dan 2.5 ha. De gemiddelde omzet in 2005 is $€ 2.4$ mln. met een spreiding van $€ 0.2 \mathrm{mln}$. tot $€ 10 \mathrm{mln}$. Hiervan heeft $55 \%$ een jaaromzet van $€ 2$ mln. en kleiner, $45 \%$ heeft een omzet groter dan $€ 2 \mathrm{mln}$., oplopend tot $€ 10 \mathrm{mln}$. In 2006 lag de gemiddelde omzet op $€ 2.6 \mathrm{mln}$. met een minimum van $€ 0.2$ en een maximum van $€ 15 \mathrm{mln}$. De

Tabel 6.1 Belangrijke kenmerken bedrijven sector glassnijbloemen (roos en chrysant)

\begin{tabular}{|c|c|c|c|c|c|c|}
\hline$(n)=44$ & $\begin{array}{l}\text { Bedrijfs- } \\
\text { opp. glas } \\
2006 \\
\text { in ha. }\end{array}$ & $\begin{array}{l}\text { Omzet } \\
2005 \\
(\mathrm{x} € 1 \\
\mathrm{mln} .)\end{array}$ & $\begin{array}{l}\text { Omzet } \\
2006 \\
(x \in 1 \\
\text { mln.) }\end{array}$ & $\begin{array}{l}\text { Brutomarge } \\
\text { begroot } \\
2006 \\
{[(\mathrm{P}-\mathrm{GTK}) / \mathrm{P}]} \\
* 100 ; \mathrm{n}=39\end{array}$ & $\begin{array}{l}\text { Brutomarge } \\
\text { realisatie } \\
2006 \\
{[(\mathrm{P}-\mathrm{GTK}) / \mathrm{P}]} \\
* 100 ; \mathrm{n}=41 \\
\end{array}$ & $\begin{array}{l}\text { Aandeel eigen } \\
\text { verm. } 2006 \\
(\mathrm{EV} / \mathrm{TV}) * 100 \\
\mathrm{n}=29\end{array}$ \\
\hline Gemiddelde & 3.4 ha. & 2.4 & 2.6 & $8.0 \%$ & $11.1 \%$ & $44.0 \%$ \\
\hline Standaardfout gem. (s.e.) & 0.4 ha. & 0.3 & 0.4 & $1.2 \%$ & $1.4 \%$ & $3.9 \%$ \\
\hline Standaardafwijking (s) & 2.5 ha. & 2.0 & 2.5 & $8.0 \%$ & $9.3 \%$ & $21.2 \%$ \\
\hline Minimum & 0.6 ha. & 0.2 & 0.2 & $-10.0 \%$ & $-12.5 \%$ & $10.0 \%$ \\
\hline Maximum & 13.0 ha. & 10.0 & 15.0 & $35.0 \%$ & $39.1 \%$ & $100.0 \%$ \\
\hline Spreiding & 12.4 ha. & 9.8 & 14.8 & $45.0 \%$ & $51.6 \%$ & $90.0 \%$ \\
\hline Scheefheid/stand. Fout & $1.8 / 0.4$ & $2.3 / 0.4$ & $3.4 / 0.4$ & $1.4 / 0.4$ & $0.7 / 0.4$ & $0.7 / 0.4$ \\
\hline
\end{tabular}

$[(\mathrm{P}-\mathrm{GTK}) / \mathrm{P}] * 100=[($ prijs-gem. totale kosten $) /$ prijs $] * 100 ; \mathrm{s}=\sqrt{ } \sum\left(\mathrm{x}_{\mathrm{i}}-\overline{\mathrm{X}}\right)^{2} / \mathrm{n}-1 ;$ s.e. $=\mathrm{s} / \sqrt{ } \mathrm{n}$ 
brutomarges begroot en gerealiseerd voor de 44 respondenten komen gemiddeld uit op 8 en $11 \%$ met eveneens een grote spreiding.

Het aandeel eigen vermogen in procenten van het totaal is bij twee derde van de bedrijven bekend en ligt gemiddeld in 2006 op een niveau van 44\% (29 resp.).

$55 \%$ van de bedrijven valt onder type B1, ruim 40\% onder type B2 en twee bedrijven gedeeltelijk onder type B3 of B4. De helft van de bedrijven is opgericht in 1997 of eerder. Het oudste dateert van 1980, het jongste van 2007. De gemiddelde bedrijfsleeftijd is 11 jaar.

\section{Marketing en verkoop}

De belangrijkste vragen betreffen de keuze van de marketing- en verkooporganisatie, de omvang van het verkoopapparaat en de -kosten en de mate van tevredenheid hierover. Deze aspecten worden in onderstaande punten achtereenvolgens behandeld.

\section{Organisatie marketing en verkoop}

Alle 44 onderzochte bedrijven zijn aangesloten bij FloraHolland te Naaldwijk en de vestigingen in Aalsmeer, Bleiswijk, Rijnsburg, Eelde en Venlo. Een aantal van de grootste bedrijven zet zijn producten af op meer veilpunten in overleg met het management van deze vestigingen. Reeds voor de fusie van september 2007 tussen FloraHolland Naaldwijk en VBA Aalsmeer waren deze bedrijven van beide veilingen lid. Bijna 30\% van de respondenten werkt samen met een via de veiling opgerichte telersvereniging en probeert via een eigen verkoopfunctionaris de afzet extra te stimuleren. Een tweetal bedrijven in de chrysantenteelt heeft met medeweten van de veiling een eigen verkooporganisatie opgezet, die deels rechtstreeks met de groothandel/export en het grootwinkelbedrijf zaken doet. Voorts is er een bedrijf dat toestemming heeft een deel van de afzet te leveren aan de Duitse veiling Landgard.

Tabel 6.2 Organisatie marketing en verkoop van de onderzochte bedrijven

\begin{tabular}{|l|r|r|}
\hline Organisatie van de afzet via: & Aantal bedrijven & \multicolumn{1}{|c|}{ Aandeel in \% } \\
\hline FloraHolland veilen/bemiddelen & 28 & 63.6 \\
\hline FloraHolland + telersvereniging (EV) & 13 & 29.5 \\
\hline FloraHolland + eigen verkoop (EV) & 2 & 4.6 \\
\hline FloraHolland + eigen verkoop (EV) Landgard & 1 & 2.3 \\
\hline Totaal & 44 & 100.0 \\
\hline
\end{tabular}

\section{Omvang verkoopapparaat en -kosten}

FloraHolland heeft door de afzet van een breed assortiment bloemen en planten een groot verkoopapparaat (bemiddelingsbureau). Bij de in samenwerking met de veiling opgezette telersverenigingen is dit veel kleiner, meestal niet meer dan één verkoper. Ongeveer $30 \%$ van de respondenten beschikt zowel over het verkoopapparaat van de veiling als over de eigen verkoper, in dienst bij de telersvereniging. De belangrijkste argumenten om voor een bepaalde bloemenveiling of andere verkooporganisatie te kiezen zijn: historisch zo gegroeid (33x genoemd) en realiseert goede uitbetaalprijzen (19x genoemd). Hierbij waren meer antwoorden mogelijk, maximaal drie. 
De via de veiling betaalde provisie, gemeten als percentage van de omzet, bedraagt gemiddeld $6 \%$ en varieert tussen de 3 en $10 \%$ (tabel 6.3). De ene helft van de respondenten geeft een percentage van $3-5.5 \%$ op en de andere helft zit boven de $5.5 \%$. Dit is afhankelijk van de bedrijfsomzet en de diensten die de veiling biedt. Van de 44 onderzochte bedrijven gaat het in ruim $60 \%$ van de gevallen om verkopen, opslag en verzending. Deze bedrijven doen het sorteren en verpakken zelf, als dat aan de orde is. Ruim 30\% maakt alleen gebruik van verkopen en doet de overige zaken zelf. De kosten EV, gemeten als percentage van de omzet, bedraagt gemiddeld $0.9 \%$ en varieert tussen de 0.1 en $4 \%$ (10 respondenten).

Tabel 6.3 Gemiddelde veilingprovisie en kosten eigen verkoop in \% omzet

\begin{tabular}{|l|c|c|}
\hline$(\mathrm{n})=44$ & $\begin{array}{l}\text { Veilingprovisie } \\
\text { (in \% omzet) }\end{array}$ & $\begin{array}{l}\text { Eigen verkoop (EV) } \\
\text { (in \% omzet) } \\
\mathrm{n}=10\end{array}$ \\
\hline Gemiddelde & 6.1 & 0.9 \\
\hline Standaardfout (s.e.) & 0.2 & 0.4 \\
\hline Standaardafwijking (s) & 1.7 & 1.2 \\
\hline Minimum & 3.0 & 0.1 \\
\hline Maximum & 10.0 & 4.0 \\
\hline
\end{tabular}

\section{Mate van tevredenheid over de verkooporganisatie}

$75 \%$ van de respondenten kiest voor tevreden tot zeer tevreden, $25 \%$ kiest voor tevreden/ontevreden. Als maatregelen om de tevredenheid te vergroten wordt door $40 \%$ van de respondenten een actievere opstelling van de verkoper van het bemiddelingsbureau genoemd. Andere mogelijke maatregelen zijn het verhogen van collectieve reclame (meer Holland Promotie), het klantgerichter werken, het verlagen van de concurrerende import en het verbeteren van de informatie en communicatie naar groothandel, exporteurs en grootwinkelbedrijven.

\section{Prijsvorming}

Een gemiddelde jaarlijkse uitbetaalprijs (voor begripsomschrijving zie bijlage 2) boven de gemiddelde kosten is ook in de sector glassnijbloemen van groot belang. Voor veel bedrijven is dit niet altijd het geval. Veel beleidszaken worden verschillend ingezet en zorgen voor een grote variatie in resultaten. Hierbij gaat het om product- en assortimentskeuze, kwaliteit en efficiëntie van mensen en middelen, een goede organisatie van de afzet en een gericht marketing- en verkoopbeleid.

In de praktijk van het dagelijks ondernemen kunnen ook invloeden van buitenaf zorgen voor verschillen in resultaat. Voorbeelden hiervan zijn de grote variaties in mogelijkheden van grondaankoop en in grondprijzen in de ene of andere regio of provincie in Nederland.

Vaste lasten kunnen hierdoor aanmerkelijke verschillen opleveren. Ook de verschillen in concurrentiegevoeligheid van de gekozen productsoort in relatie tot de toelating van buitenlandse concurrenten kunnen zorgen voor een daling van resultaten en een verandering van productsoort en -typen. Zowel bij de roos als anjer zijn er veel voorbeelden van (kleine) arbeidsintensieve gewassen uit Nederland die het onderspit dolven ten opzichte van lager geprijsde importproducten. 
De vragen in het bedrijfsonderzoek over de onderscheiden beleidszaken en behaalde resultaten betreffen onder meer:

1. de gekozen verkoopwijze en de hoogte van de jaarlijkse gemiddelde uitbetaalprijzen;

2. de mate van tevredenheid, de verbetermogelijkheden en de vormen van samenwerking;

3. de acties bij lage prijzen en de mening over de in september 2007 gerealiseerde fusie tussen FloraHolland en de VBA.

\section{Verkoopwijze en gemiddelde uitbetaalprijzen}

In tabel 6.4 wordt een overzicht gegeven van de door de respondenten gehanteerde verkoopwijzen. Bij de onderzochte bedrijven (rozen- en chrysantentelers) vinden deze voor $25 \%$ plaats via alleen de klok en voor $64 \%$ deels voor de klok en deels via bemiddeling. Hierbij is de klok toonaangevend en ruim in de meerderheid (van 50\% oplopend tot $95 \%$ ) en bemiddeling in de minderheid (van 50\% dalend tot 5\%). Ongeveer 10\% van de respondenten heeft naast de veiling (klok en bemiddeling) nog een derde verkoopkanaal ontwikkeld, alleen of in samenwerking met de telersvereniging. De veiling is hiervan in alle gevallen op de hoogte en staat dit in onderling overleg mondjesmaat toe.

Tabel 6.4 Verkoopwijze producten

\begin{tabular}{|l|r|r|}
\hline & Aantal bedrijven & Aandeel in \% \\
\hline via klokverkopen op veiling & 11 & 25.0 \\
\hline $\begin{array}{l}\text { via klok (A) en bemiddeling (B) } \\
\text { veiling }\end{array}$ & 28 & 63.6 \\
\hline A,B,C (verkoop via telersvereniging) & 1 & 2.3 \\
\hline A,B,D (eigen verkoop) & 2 & 4.5 \\
\hline A,C,D & 1 & 2.3 \\
\hline A,D & 1 & 2.3 \\
\hline Totaal & 44 & 100.0 \\
\hline
\end{tabular}

Een overzicht van de uitbetaalprijzen voor roos en chrysant (2004-2007) wordt gegeven in de volgende paragraaf (tabellen 6.5, 6.6 en 6.7) bij de analyse per productsoort.

2. Tevredenheid uitbetaalprijs, verbetermogelijkheden en samenwerking

Bijna $60 \%$ van de respondenten vindt de uitbetaalprijs matig, $34 \%$ vindt deze goed en $7 \%$ slecht. Op de vraag hoe deze te verbeteren werd het meeste genoemd 1-op-1-levering aan retail en meer Holland Promotie (elk 7x genoemd). Een betere prijs/kwaliteitverhouding werd 6x genoemd. Onder anders vielen onder meer verlagen import, beperkt uitgiftebeleid nieuwe producten en verven/afzet chrysanten via Intergreen. Vijf respondenten hadden geen idee hoe dit te doen. Ten aanzien van de samenwerking bij de afzet tussen telers, onder meer ten behoeve van een betere prijsvorming, geeft $30 \%$ aan deze samenwerking voornamelijk via veiling FloraHolland te zoeken (klok en bemiddeling). Ruim 34\% zegt niet specifiek samen te werken met anderen en brengt onder eigen naam de productie voor de klok. 32\% werkt samen in een telersvereniging, zoals bijvoorbeeld Decorum Company (Flowers), TOP Flowers, Holland Combi Roses en andere verenigingen, vaak geïnitieerd door de veredelaar, stekleverancier of adviseur (Florpartners). 
Topflowers is inmiddels opgeheven en Zento is toegetreden tot Gro4U. Deze laatste organisatie bestaat momenteel uit zeven telersverenigingen (Vakblad voor de Bloemisterij, nr. 19, 10 mei 2013). De twee respondenten die overblijven (4\%), verkeren in een bijzondere situatie. De een schakelt binnen een jaar over van chrysanten op potplanten en de ander zoekt de samenwerking verticaal. Het levert de producten via haar transportbedrijf World Satter Flowers (WSF) rechtstreeks aan groothandel/exporteur Intergreen, met melding aan FloraHolland.

\section{Acties en mening over fusie bloemenveilingen}

Bij een te laag prijsniveau door overaanbod zoekt 34\% van de respondenten extra afzet via de handelskanalen. Ruim $27 \%$ kiest op langere termijn voor productontwikkeling en introductie van nieuwe rassen via de veredelaar of stekleverancier en bijna 10\% kiest voor extra promotie. Advies vragen aan het bemiddelingsbureau van FloraHolland en verhogen van de kwaliteit worden daarnaast nog genoemd als te ondernemen acties. Ook een combinatie van de genoemde acties komt regelmatig voor in deze situatie. Slechts één respondent heeft geen idee wat te doen, een ander denkt aan doordraai en een derde noemt onderzoek als eerste te ondernemen actie. De fusie tussen VBA Aalsmeer en FloraHolland Naaldwijk wordt door 84\% van de respondenten als goed betiteld, bijna 9\% vindt de fusie matig en een enkeling schort zijn mening op (anders) of vindt de fusie slecht.

Effectiviteit en efficiency van de gehanteerde marketing- en verkoopmethoden $68 \%$ van de respondenten vindt concentratie van het aanbod via de klok de meest effectieve verkoopmethode. $23 \%$ kiest voor een combinatie van verkoop via klok en telersvereniging met afzet onder eigen naam. 9\% kiest voor een combinatie van bemiddeling en directe afzet, eventueel onder jaarcontract met de handel. Hieronder valt ook het kopen op afstand (KOA).

Kijken we naar de efficiency dan wordt bemiddelen met 55\% als de meest efficiënte verkoopmethode gezien. Directe levering aan de retail scoort hier 21\% (met een verplichte administratieve melding aan FloraHolland) en het klokveilen scoort 18\%.

\section{Belangrijke bedrijfs- en sectorontwikkelingen}

De meest genoemde ontwikkeling in de sector glassnijbloemen is energiemanagement (36\%). Dit heeft direct te maken met de recente overstap van bijna alle rozen- en chrysantentelers op de belichte teelt en de aanschaf van een WKK-installatie. Scherpe inkoop van gas en elektra en teruglevering van stroom aan het net kan een aanmerkelijke verlaging van de energiekosten per $\mathrm{m}^{2}$ opleveren. De aanschaf van de juiste capaciteit en een optimaal management van deze kostbare installaties inclusief planning stroomproductie en -levering vereist veel kennis van zaken en is risicovol vanwege prijsfluctuaties. Een aantal telers noemt naast management van energie zaken als verticale integratie, verkopen via internet, nichemarketing en vergroting van de schaal van productie en afzet. Ruim 34\% noemt heel specifieke onderwerpen als concurrentieontwikkeling van de import (rozen uit o.a. Kenia), ruimtelijke ordeningsplannen van gemeenten en provincie, innovatieontwikkeling zoals kas als energiebron, ledverlichting, mobiele teelt, plantrobot en andere nieuwe zaken. 


\subsubsection{Productsoorten (roos en chrysant)}

$\mathrm{Na}$ de onderzoeksuitkomsten op sectorniveau worden nu de resultaten per productsoort toegelicht. Het betreft de vragen over:

1. uitbetaalprijzen 2004-2007;

2. bedrijfsoppervlakte in ha. glas 2006;

3. omzetontwikkeling 2006/2007;

4. brutomarge 2006;

5. concentratieontwikkeling $(\mathrm{C} 4)$ per productsoort.

\section{Ad 1. Uitbetaalprijzen 2004-2007}

De gemiddelde uitbetaalprijzen voor roos en chrysant van 2004-2007 staan vermeld in onderstaande tabellen 6.5 en 6.6 en betreffen een breed en diep assortiment rozen en chrysanten. Er is sprake van een stabiele ontwikkeling van het gemiddelde prijsniveau met een licht stijgend verloop en een lage prijsfluctuatie ( $\mathrm{p}_{\max } / \mathrm{p}_{\min }$ ligt tussen de 1.1 en 1.2). Dit hangt samen met de keuze van het soort en type product, het wisselend verloop van aanbod en vraag gedurende het seizoen en de mate van concurrentie op de belangrijkste Noord-Europese markten. De prijsvariatie van de roos is groter dan die van de chrysant. Dit geeft aan dat het assortiment roos aanmerkelijk breder en dieper is. De prijsfluctuatie van de gemiddelde, de maximum- en de minimumprijs bij beide snijbloemen over de beschouwde periode, is laag. Dit wijst op een evenwichtige ontwik-

Tabel 6.5 Gemiddelde uitbetaalprijzen roos 2004, 2005, 2006 en 2007(P)

\begin{tabular}{|l|c|c|c|c|c|}
\hline $\begin{array}{l}\text { Productsoort: } \\
\text { Roos }\end{array}$ & $\begin{array}{c}\text { gem. } \\
\text { uitbetaalprijs in } \\
\text { eurocent p. st. } \\
2004\end{array}$ & $\begin{array}{c}\text { gem. } \\
\text { uitbetaalprijs in } \\
\text { eurocent p. st. } \\
2005\end{array}$ & $\begin{array}{c}\text { gem. } \\
\text { uitbetaalprijs in } \\
\text { eurocent p. st. } \\
2006\end{array}$ & $\begin{array}{c}\text { gem. } \\
\text { uitbetaalprijs in } \\
\text { eurocent p. st. } \\
2007(\mathrm{P})\end{array}$ & $\begin{array}{c}\text { Prijs- } \\
\text { fluctuatie- } \\
\text { coëfficient } \\
\left(\mathrm{p}_{\max } / \mathrm{p}_{\min }\right)\end{array}$ \\
\hline Gemiddelde prijs & 0.37 & 0.39 & 0.39 & 0,41 & 1.11 \\
\hline Standaardfout & 0.05 & 0.04 & 0.03 & 0.03 & \\
\hline Standaard afw. & 0.14 & 0.15 & 0.13 & 0.12 & 1.21 \\
\hline Minimum & 0.19 & 0.22 & 0.23 & 0.22 & 1.11 \\
\hline Maximum & 0.67 & 0.70 & 0.67 & 0.63 & \\
\hline Aantal respondenten & 9 & 14 & 19 & 20 & \\
\hline Aantal gemist & 12 & 7 & 2 & 1 & \\
\hline
\end{tabular}

Tabel 6.6 Gemiddelde uitbetaalprijzen chrysant 2004, 2005, 2006 en 2007(P)

\begin{tabular}{|l|c|c|c|c|c|}
\hline $\begin{array}{l}\text { Productsoort: } \\
\text { Chrysant }\end{array}$ & $\begin{array}{c}\text { gem. } \\
\text { uitbetaalprijs in } \\
\text { eurocent p. st. } \\
2004\end{array}$ & $\begin{array}{c}\text { gem. } \\
\text { uitbetaalprijs in } \\
\text { eurocent p. st. } \\
2005\end{array}$ & $\begin{array}{c}\text { gem. } \\
\text { uitbetaalprijs in } \\
\text { eurocent p. st. } \\
2006\end{array}$ & $\begin{array}{c}\text { gem. } \\
\text { uitbetaalprijs in } \\
\text { eurocent p. st. } \\
2007(\mathrm{P})\end{array}$ & $\begin{array}{c}\text { Prijs- } \\
\text { fluctuatie- } \\
\text { coëfficient } \\
\left(\mathrm{p}_{\max } / \mathrm{p}_{\min }\right)\end{array}$ \\
\hline Gemiddelde prijs & 0.25 & 0.25 & 0.27 & 0.27 & 1.08 \\
\hline Standaardfout & 0.02 & 0.02 & 0.02 & 0.01 & \\
\hline Standaard afw. & 0.08 & 0.06 & 0.07 & 0.07 & 1.11 \\
\hline Minimum & 0.19 & 0.21 & 0.21 & 0.20 & 1.16 \\
\hline Maximum & 0.43 & 0.45 & 0.47 & 0.50 & \\
\hline Aantal respondenten & 13 & 18 & 22 & 23 & \\
\hline Aantal gemist & 10 & 5 & 1 & 0 & \\
\hline
\end{tabular}


Tabel 6.7 Vergelijk gemiddelde jaarprijzen PT en onderzoeksresultaat voor roos en chrysant

\begin{tabular}{|l|l|l|l|l|c|}
\hline & 2004 & 2005 & 2006 & 2007 & $\begin{array}{c}\text { Prijs- } \\
\text { fluctuatie- } \\
\text { coëfficient } \\
\left(\mathrm{p}_{\max } / \mathrm{p}_{\min }\right)\end{array}$ \\
\hline $\begin{array}{l}\text { PT gem. jaarprijs roos } \\
\text { grootbloemig }\end{array}$ & 0,26 & 0,26 & 0,27 & & 1,04 \\
\hline $\begin{array}{l}\text { Gem. prijs roos uit } \\
\text { onderzoeksresultaat }\end{array}$ & 0,37 & 0,39 &, 39 & $0,41(\mathrm{P})$ & 1,11 \\
\hline & & & & & \\
\hline PT gem. jaarprijs troschrysant & 0,20 & 0,22 & 0,24 & & 1,20 \\
\hline $\begin{array}{l}\text { Gem. prijs chrysant uit } \\
\text { onderzoeksresultaat }\end{array}$ & 0,25 & 0,25 & 0,27 & $0,27(\mathrm{P})$ & 1,08 \\
\hline
\end{tabular}

$\mathrm{P}=$ Prognose

keling van aanbod en vraag in deze periode op de belangrijke groothandelsmarkten in Europa en op goede prijsonderhandelingen tussen telers met hun afzetorganisaties en de groot- en detailhandel. Wat opvalt in tabel 6.7 is het verschil tussen de prijzen uit het onderzoeksresultaat roos en chrysant met de door het PT geregistreerde gemiddelde jaarprijzen. Bij de roos liggen deze PT-prijzen gemiddeld 10-12 eurocent per stuk lager en bij de chrysant 3-5 eurocent. Dit wordt veroorzaakt door de lagere uitbetaalprijzen van de geïmporteerde snijbloemen. Bij de rozentelers in Nederland heeft een grote omschakeling van kleinbloemige naar grootbloemige rozenteelt plaatsgevonden en worden de veel arbeid kostende kleinbloemige rozen steeds meer vanuit Kenia en andere landen ingevoerd.

Ad 2, 3 en 4. Ontwikkeling bedrijfsoppervlakte, omzet en brutomarge per product

De onderzoeksuitkomsten van bedrijfsoppervlakte, omzet en brutomarge naar productsoort gemeten, worden gepresenteerd in tabel 6.8. De oppervlakte glas van het gemiddeld rozenbedrijf in Nederland is iets kleiner dan het chrysantenbedrijf terwijl de omzet groter is. Deze omzet ontwikkelt zich van $€ 2.6 \mathrm{mln}$. in 2005 naar $€ 3.0 \mathrm{mln}$. in 2006. In 2005 laat het chrysantenbedrijf

Tabel 6.8 Belangrijke bedrijfskenmerken per productsoort 2006/2007

\begin{tabular}{|c|c|c|c|c|c|}
\hline Productsoorten & $\begin{array}{l}\text { Bedrijfsopp. } \\
\text { glas } 2006 \text { in } \\
\text { ha. }\end{array}$ & $\begin{array}{l}\text { Omzet } 2005 \\
(x \in 1 \mathrm{mln} .)\end{array}$ & $\begin{array}{l}\text { Omzet } 2006 \\
(x \in 1 \mathrm{mln} .)\end{array}$ & $\begin{array}{l}\text { Brutomarge in } \\
\% \text { begroot } \\
2006[(\mathrm{P}- \\
\text { GTK }) / \mathrm{P}] * 100\end{array}$ & $\begin{array}{l}\text { Brutomarge in } \\
\% \text { realisatie } \\
2006[(\mathrm{P}- \\
\text { GTK }) / \mathrm{P}] * 100\end{array}$ \\
\hline $\operatorname{Roos}(\mathrm{n}=21)$ & & $(n=19)$ & & & \\
\hline Gemiddelde & 3.3 & 2.6 & 3.0 & 10.8 & 13.3 \\
\hline Standaardfout & 0.7 & 0.6 & 0.7 & 2.3 & 2.7 \\
\hline Standaardafwijking & 3.1 & 2.6 & 3.3 & 10.3 & 12.3 \\
\hline Minimum & 0.6 & 0.2 & 0.2 & -10.0 & -12.5 \\
\hline Maximum & 13.0 & 10.0 & 15.0 & 35.0 & 39.1 \\
\hline \multicolumn{6}{|l|}{ Chrysant $(n=23)$} \\
\hline Gemiddelde & 3.5 & 2.1 & 2.2 & 5.4 & 9.1 \\
\hline Standaardfout & 0.4 & 0.2 & 0.3 & 0.8 & 1.0 \\
\hline Standaardafwijking & 2.0 & 1.2 & 1.2 & 3.8 & 4.7 \\
\hline Minimum & 0.6 & 0.3 & 0.3 & 2.5 & 0.1 \\
\hline Maximum & 7.8 & 4.7 & 5.0 & 15.0 & 17.1 \\
\hline
\end{tabular}

$[(\mathrm{P}-\mathrm{GTK}) / \mathrm{P}] * 100=[($ prijs-gem. totale kosten $) /$ prijs $] * 100$ 
een gemiddelde omzet zien van $€ 2.1 \mathrm{mln}$. en in 2006 van $€ 2.2 \mathrm{mln}$. De omzetspreiding bij de rozen ligt hoger dan bij de chrysanten en er komen relatief meer kleine bedrijven voor: 33\% van de rozentelers heeft een bedrijfsomvang tot 1.5 ha., terwijl dit bij de chrysant $17 \%$ is. De brutomarge begroot ligt bij de roos op 10.8\% en bij de chrysant op 5.4\%. De brutomarge gerealiseerd op $13.3 \%$ resp. op $9.1 \%$. Ook hier is, evenals bij oppervlakte glas en omzet, sprake van een grote spreiding, voor de rozenteelt het grootst.

\section{Ad 5. Concentratieontwikkeling per productsoort}

In tabel 6.9 wordt de berekening getoond van de horizontale concentratiegraad (C4) onder de glasrozen- en de -chrysantenbedrijven. Ondanks de groei in schaalvergroting bij de glastuinbouwbedrijven over de afgelopen decennia ligt de omvang in bedrijfsoppervlakte glas van de vier grootste bedrijven uit de steekproef in 2006 nog niet boven de 100 ha. De C4 voor rozen ligt in 2006 op $4.8 \%$ en voor chrysanten op $4.3 \%$. Er is in de glassnijbloemen evenals in de glasgroenten sprake van een lage horizontale concentratie onder de producenten. In tabel 6.13 wordt deze $\mathrm{C} 4$ berekend per bedrijfstype.

Tabel 6.9 Meting concentratieontwikkeling (C4) van glassnijbloemen per productsoort

\begin{tabular}{|l|l|l|l|l|l|l|l|l|}
\hline $\begin{array}{l}\text { Productsoort } \\
\text { en areaalopp. } \\
\text { populatie roos } \\
\text { en chrysant in } \\
\text { ha. (2006) }\end{array}$ & $\begin{array}{l}\text { Bedrijfs- } \\
\text { opper- } \\
\text { vlakte } \\
\text { steekprf. } \\
\text { gem. }\end{array}$ & $\begin{array}{l}\text { Stan- } \\
\text { daard- } \\
\text { fout } \\
\text { gem. }\end{array}$ & $\begin{array}{l}\text { Stan- } \\
\text { daard- } \\
\text { afwij- } \\
\text { king }\end{array}$ & $\begin{array}{l}\text { Aantal } \\
\text { respon } \\
\text { denten } \\
\text { (n) }\end{array}$ & $\begin{array}{l}\text { Som } \\
\text { bedrijfs- } \\
\text { opp. } \\
\text { steekprf }\end{array}$ & $\begin{array}{l}\text { Mini- } \\
\text { mum }\end{array}$ & $\begin{array}{l}\text { Maxi- } \\
\text { mum }\end{array}$ & Concen- \\
Roos \\
ha.
\end{tabular}

$\mathrm{C} 4=$ Concentratiegraad vier grootste glassnijbloemenbedrijven per productsoort, gemeten in opp. glas in ha. 


\subsubsection{Bedrijfstypen (B1 t/m B4)}

De onderzoeksuitkomsten uit de paragrafen hiervoor zijn besproken op sector- en productniveau. In deze paragraaf worden ze per bedrijfstype geanalyseerd en toegelicht. De B1 - en B2-bedrijven hebben de organisatie van de afzet in handen gegeven van hun afzetorganisaties, de bloemenveilingen (paragraaf 6.2.1). Bedrijfstype B3 en B4 komen nauwelijks voor in de sector glassnijbloemen (twee respondenten). Hieronder volgen in tabel $6.10 \mathrm{t} / \mathrm{m} 6.12$ de onderzoeksresultaten per bedrijfstype. Het betreft:

1. omzetontwikkeling 2005/2006, brutomarge 2006 begroot en gerealiseerd en aandeel eigen en totale vermogen $(\mathrm{EV} / \mathrm{TV})^{*} 100$;

2. keuze afzetorganisatie, veilingprovisie en de mate van tevredenheid;

3. verkoopwijze en gemiddelde uitbetaalprijzen per productsoort en bedrijfstype;

4. concentratieontwikkeling (C4) per bedrijfstype.

\section{Ad 1. Omzetontwikkeling 2005/2006}

De onderzoeksuitkomsten laten in tabel 6.10 zien dat bedrijfstype B1(Veilingteler) een gemiddelde bedrijfsomzet realiseert van $€ 1.8 \mathrm{mln}$. in 2005 en $€ 1.8 \mathrm{mln}$. in 2006 . De spreiding in omzet varieert van $€ 0.2 \mathrm{mln}$. voor het kleinste tot $€ 3.6 \mathrm{mln}$. voor het grootste bedrijf $(2005 / 2006)$. Bij de roos scoort $50 \%$ van de bedrijven een omzet van $€ 1.0 \mathrm{mln}$. of lager. Het chrysantenbedrijf is enigszins groter: $50 \%$ scoort een omzet van $€ 1.5$ of lager.

Bij bedrijfstype B2 (Veilingtelersvereniging) is de gemiddelde bedrijfsomzet $€ 3.1 \mathrm{mln}$. in 2005

Tabel 6.10 Omzet, brutomarge en aandeel eigen vermogen per bedrijfstype

\begin{tabular}{|c|c|c|c|c|c|}
\hline $\begin{array}{l}\mathrm{n}=44 \\
\text { Bedrijfstype }\end{array}$ & $\begin{array}{l}\text { Omzet } \\
(\mathrm{x} € 1 \mathrm{mln} .) \\
\text { realisatie } 2005\end{array}$ & $\begin{array}{l}\text { Omzet } \\
(\mathrm{x} € 1 \mathrm{mln} .) \\
\text { realisatie } 2006\end{array}$ & $\begin{array}{l}\text { Brutomarge } \\
2006 \text { in } \% \\
\text { begroot }[(\mathrm{P}- \\
\text { GTK }) / \mathrm{P}] * 100\end{array}$ & $\begin{array}{l}\text { Brutomarge } \\
2006 \text { in } \% \\
\text { realisatie }[(\mathrm{P}- \\
\mathrm{GTK}) / \mathrm{P}] * 100\end{array}$ & $\begin{array}{l}\text { Aandeel eigen } \\
\text { en totale } \\
\text { vermogen) } \\
(\mathrm{EV} / \mathrm{TV})^{*} 100 \\
2006\end{array}$ \\
\hline B1 (24 resp.) & & & & & (16 resp.) \\
\hline Gemiddelde & 1.8 & 1.8 & 8.6 & 12.4 & 52 \\
\hline Standaardfout gem. & 0.2 & 0.2 & 2.0 & 2.2 & 6 \\
\hline Standaardafwijking & 1.1 & 1.2 & 9.8 & 10.9 & 23 \\
\hline Minimum & 0.2 & 0.2 & $-10.0 *)$ & $\left.-12.5^{*}\right)$ & 20 \\
\hline Maximum & 3.6 & 3.6 & 35.0 & 39.1 & 100 \\
\hline B1,B3 (1 resp.) & & & & & (1 resp.) \\
\hline Gemiddelde & 4.7 & 5.0 & 7.5 & 4.5 & 60 \\
\hline B2 (18 resp.) & (16 resp.) & & & & (12 resp.) \\
\hline Gemiddelde & 3.1 & 3.6 & 7.1 & 9.6 & 33 \\
\hline Standaardfout gem. & 0.7 & 0.8 & 1.4 & 1.6 & 4 \\
\hline Standaardafwijking & 2.6 & 3.4 & 5.8 & 7.0 & 13 \\
\hline Minimum & 1.3 & 1.3 & 2.5 & 0.1 & 10 \\
\hline Maximum & 10.0 & 15.0 & 22.5 & 22.0 & 50 \\
\hline \multicolumn{6}{|l|}{ B2,B4 (1 resp.) } \\
\hline Gemiddelde & 2.2 & 2.2 & 10.0 & 13.0 & \\
\hline
\end{tabular}

$\left.[(\mathrm{P}-\mathrm{GTK}) / \mathrm{P}] * 100=[(\text { prijs-gem. totale kosten }) / \mathrm{prijs}]^{*} 100 ; *\right)$ een B1-respondent met een verliesgevende teelt van kleinbloemige rozen schakelt na een laatste jaar over op een nieuw grootbloemig ras. 
en $€ 3.6 \mathrm{mln}$. in 2006. De spreiding bij dit bedrijfstype is aanmerkelijk groter dan bij B1. Ze varieert in 2005 van $€ 1.3$ tot $€ 10.0 \mathrm{mln}$. en in 2006 van $€ 1.3$ tot $€ 15.0 \mathrm{mln}$. Bij de roos behaalt $33 \%$ van de B2-bedrijven een omzet tot $€ 1.7 \mathrm{mln}$. en $67 \%$ een omzet $>€ 1.7 \mathrm{mln}$. Bij de chrysant ligt dit percentage op $43 \%$ en $57 \%$ bij een vergelijkbare omzet als de roos (€ $1.7 \mathrm{mln}$.). De bedrijfsomzet in 2005 en 2006 is niet evenredig verdeeld tussen de laagste en hoogste omzet. Een klein aantal bedrijven (type B2 bij roos, type B1 bij chrysant) is flink aan het uitbreiden in bedrijfsoppervlakte en zorgt voor een extra toename van de bedrijfsomzet.

Brutomarge en aandeel eigen vermogen

De gemiddeld begrote en gerealiseerde brutomarges in 2006 komen voor alle respondenten uit op $+8.0 \%$ en $+11.1 \%$. Bij splitsing van de resultaten naar bedrijfstype liggen de begrote marges voor alle bedrijfstypen dicht bij elkaar in de buurt, tussen de 7.1 en $10.0 \%$. De brutomarges gerealiseerd liggen tussen $4.5 \%$ en $13.0 \%$. B1 scoort met $12.4 \%$ hoger dan B2 met $9.6 \%$. Het gemiddeld aandeel eigen vermogen van de sector in procenten van het totaal ligt in 2006 op $44 \%$ (29 resp.). Bij splitsing naar bedrijfstype varieert dit percentage van 33 tot $60 \%$. Bedrijfstype B1 scoort een betekenisvol hoger percentage dan type B2 (zie tabel 6.22, met 90\% betrouwbaarheid, $\mathrm{p}<0.062$ ). In tegenstelling tot het gestelde in het artikel "Investeren in telersvereniging loont" uit het Vakblad voor de Bloemisterij (2010), komt B1 (de veilingteler) in dit deelonderzoek tot gemiddeld hogere resultaten dan type B2 (lid telersvereniging).

Ad 2. Keuze afzetorganisatie, veilingprovisie en de mate van tevredenheid

De respondenten van bedrijfstype B1 zijn alle trouwe veilingtelers, aangesloten bij Flora-Holland Naaldwijk of Aalsmeer. In $80 \%$ of meer van de gevallen regelt de bloemenveiling via klok en bemiddeling de gehele marketing en verkoop voor de bedrijven tegen een bepaalde provisie. Deze ligt tussen 3.0 en 9.5\% van de omzet, afhankelijk van de diensten die men afneemt plus een relatief lage vergoeding voor het lidmaatschap van deze organisatie. Bij de roos is er een en bij de chrysant zijn er twee respondenten die naast FloraHolland nog een extra verkoper inzetten of een eigen afzet-bv hebben opgericht (met medeweten van de veiling).

Bij de B2-telers is het aantal bedrijven dat extra verkoop inzet in samenwerking met de telersvereniging vanzelfsprekend groter dan bij het B1-bedrijfstype. Bij de roos ligt dit op bijna 40\% van de respondenten, bij de chrysant aanmerkelijk hoger $(86 \%)$.

De respondenten van bedrijfstype B1 betalen gemiddeld de hoogste provisie, uitgedrukt in een percentage van de omzet, namelijk $6.5 \%$, met een spreiding van 4.0 tot $10.0 \%$ (zie tabel 6.11 ). Bijna $40 \%$ van deze bedrijven zit aanzienlijk boven het gemiddelde, zij betalen tot $10 \%$ van de omzet hieraan. Bedrijfstype B2 betaalt gemiddeld 5.7\% en heeft een spreiding van 4.0 tot $8.0 \%$. Hier betaalt ongeveer $28 \%$ van de bedrijven meer dan $5.7 \%$ van de omzet aan provisie. De respondenten van bedrijfstype B2 zijn relatief het meest tevreden (bijna $78 \%$ is tevreden tot zeer tevreden). Respondenten van bedrijfstype B1 zijn iets minder tevreden (67\% is tevreden). Uitgesplitst naar productsoort zijn chrysantentelers het meest tevreden, van bedrijfstype B1 is ruim $70 \%$ tevreden en van bedrijfstype B2 bijna $86 \%$ (tevreden en zeer tevreden). Rozentelers 
Tabel 6.11 Keuze afzetorganisatie, gemiddelde veilingprovisie (\% omzet) en mate van tevredenheid

\begin{tabular}{|c|c|c|c|c|c|c|c|c|c|}
\hline \multirow[b]{2}{*}{$\begin{array}{l}\text { Bedrijfstype/ } \\
\text { Productsoort }\end{array}$} & \multirow[b]{2}{*}{$\begin{array}{l}\text { Organisatie } \\
\text { van de afzet }\end{array}$} & \multirow[b]{2}{*}{$\begin{array}{l}\text { Aan- } \\
\text { tal } \\
\text { resp. }\end{array}$} & \multirow{2}{*}{\multicolumn{2}{|c|}{$\begin{array}{l}\text { Veilingprovisie } \\
\text { in } \% \text { omzet }\end{array}$}} & \multicolumn{5}{|c|}{ Mate van tevredenheid } \\
\hline & & & & & $\begin{array}{l}\text { Zeer } \\
\text { tevre- } \\
\text { den }\end{array}$ & $\begin{array}{l}\text { Tevre- } \\
\text { den }\end{array}$ & $\begin{array}{l}\text { Tevreden/ } \\
\text { ontevre- } \\
\text { den }\end{array}$ & $\begin{array}{l}\text { Onte- } \\
\text { vreden }\end{array}$ & $\begin{array}{l}\text { Zeer } \\
\text { onter } \\
\text { den }\end{array}$ \\
\hline B1 (24 resp.) & & & Gem. & 6.5 & & & & & \\
\hline \multirow[t]{3}{*}{ Roos (10) } & FH & 8 & Stand. fout & 0.3 & & 6 & 4 & & \\
\hline & $\mathrm{FH}+$ Ver. & 1 & Stand. Afw & 1.7 & & & & & \\
\hline & FH + Afzetbv & 1 & Min. & 4.0 & & & & & \\
\hline \multirow[t]{3}{*}{ Chrysant(14) } & FH & 12 & Max. & 10.0 & & 10 & 4 & & \\
\hline & FH + Ver. & 1 & & & & & & & \\
\hline & FH + Landgard & 1 & & & & & & & \\
\hline Subtotaal & & 24 & & & & 16 & 8 & & \\
\hline & & & & & & & & & \\
\hline \multicolumn{10}{|l|}{ B1,B3 (1 resp.) } \\
\hline Chrysant & FH + Afzetbv & 1 & Gem. & 4.0 & & 1 & & & \\
\hline & & & & & & & & & \\
\hline \multirow{2}{*}{ Roos (11) } & $\mathrm{FH}$ & & Gem. & 5.1 & & 8 & 3 & & \\
\hline & FH + Ver. & 4 & Stand. afw & 1.3 & & & & & \\
\hline \multirow[t]{2}{*}{ Chrysant (7) } & FH & 1 & Min. & 4.0 & 1 & 5 & 1 & & \\
\hline & $\mathrm{FH}+$ Ver. & 6 & Max. & 8.0 & & & & & \\
\hline Subtotaal & & 18 & & & 1 & 13 & 4 & & \\
\hline & & & & & & & & & \\
\hline B2,B4 (1 resp.) & FH + Ver. & 1 & Gem. & 3.0 & & 1 & & & \\
\hline Totaal B1-B4 & & 44 & & & 1 & 31 & 12 & & \\
\hline
\end{tabular}

bedrijftype B1 zijn het minst tevreden (40\% is tevreden/ontevreden).

Dat rozentelers van het bedrijfstype B1(veilingtelers) het minst tevreden zijn, ondanks de hogere resultaten in brutomarge en aandeel eigen vermogen, kan worden veroorzaakt door de toenemende groei en concurrentie van de door de veiling toegelaten importrozen.

Ad 3. Verkoopwijze en gemiddelde uitbetaalprijzen per productsoort en bedrijfstype

Verkoopwijze roos en chrysant per type bedrijf

De respondenten van bedrijfstype B1 Veilingteler (tabel 6.12) geven aan dat hun product in meerderheid via de klok wordt verkocht. Voor de roos is dat $60 \%$ alleen via de klok en $40 \%$ via de klok en bemiddeling. Voor de chrysant is dat $100 \%$ via de klok en bemiddeling. Respondenten van het bedrijfstype B2 roos verdelen hun afzet over de klok, klok en bemiddeling en verkoper telersvereniging, voor de chrysant gaat $100 \%$ via klok en bemiddeling. Twee chrysantentelers hebben naast de afzet via de veiling nog een eigen directe afzet-bv richting handel, met medeweten van de bloemenveiling. 
Tabel 6.12 Verkoopwijze producten per bedrijfstype B1 t/m B4 en productsoort

\begin{tabular}{|l|l|l|c|c|}
\hline Type glastuinbouwbedrijf & Productsoort & Verkoopwijze & $\begin{array}{c}\text { Aantal } \\
\text { bedrijven }\end{array}$ & $\begin{array}{c}\text { Aan- } \\
\text { deel } \\
\text { in \% }\end{array}$ \\
\hline B1 Veilingteler & roos & Via klokverkopen op veiling & 6 & 60 \\
\hline & & Via klok en bemiddeling & 4 & 40 \\
\hline Subtotaal & chrysant & Via klok en bemiddeling & 14 & 100 \\
\hline B1, B3 & & & 24 & \\
\hline B2Veilingtelersvereniging & chrysant & Anders & 1 & \\
\hline & & Via klokverkopen op veiling & 4 & 36 \\
\hline & & Via klok en bemiddeling & 4 & 36 \\
\hline & $\begin{array}{l}\text { Via klok, bemiddeling en } \\
\text { telersvereniging }\end{array}$ & 3 & 28 \\
\hline Subtotaal & chrysant & Via klok en bemiddeling & 7 & 100 \\
\hline B2,B4 & & & 18 & \\
\hline Totaal B1-B4 & chrysant & Anders & 1 & \\
\hline & & & 44 & 100 \\
\hline
\end{tabular}

Gemiddelde uitbetaalprijzen per productsoort en bedrijfstype

Uit de tabellen 6.13 en 6.14 is, behalve de genoemde opmerkingen per productsoort (tabel 6.5 en 6.6), op te maken dat de gemiddelde uitbetaalprijs per type bedrijf per jaar flink kan verschillen. Bij de roos scoort bedrijfstype B1 (veilingteler) in alle jaren gemiddeld de hoogste uitbetaalprijs. Bij de chrysant is dit eveneens het geval met B1.

In 2005 is er het grootste prijsverschil tussen bedrijfstype B1 en B2 met betrekking tot de roos (€ 0.42 ten opzichte van $€ 0.33$ ). In 2007 zijn de uitbetaalprijzen bijna gelijk ( $€ 0.42$ ten opzichte van $€ 0.41)$. Bij de chrysant is het verschil tussen bedrijfstype B1 en B2 kleiner dan bij de roos: in 2004 het grootst ( $€ 0.27$ ten opzichte van $€ 0.22$ ) en in 2005 het kleinst ( $€ 0.26$ ten opzichte van $€ 0.24)$. Een vergelijk met de gemiddelde PT-prijzen geeft aan dat de prijzen uit de onderzoeksresultaten in alle jaren hoger scoren. Een verklaring hiervoor kan zijn dat in de PT-prijzen ook de lagere uitbetaalprijzen van de geïmporteerde producten zijn opgenomen.

De grote prijsvariatie $\left(\mathrm{p}_{\max }-\mathrm{p}_{\min }\right)$ van de roos bij de veilingtelers (B1) laat zien dat hier een breed assortiment van verschillende typen unieke rozen voor de klok komt, wat resulteert in een gemiddeld stabiel prijsniveau van 2005-2007. Bij de telersverenigingen (B2) is het aangevoerde assortiment rozen minder breed en is de prijsvariatie ook minder groot. Voor de chrysant is er een enigszins vergelijkbare situatie, zij het dat het assortiment chrysanten niet zo breed is als dat van de roos en er minder verschillende typen chrysanten zijn (Vakblad voor de Bloemisterij, staalkaart 2009). Dit blijkt ook uit de kleinere prijsvariatie van de chrysant ten opzichte van de roos, zowel bij de veilingtelers (B1) als de telersvereniging (B2). De prijsfluctuatie van de gemiddelde, de maximum- en de minimumprijs is bij alle bedrijfstypen laag met uitzondering van het bedrijfstype B2, afzet roos. Er is sprake van een evenwichtige ontwikkeling van aanbod en vraag in deze periode op de groothandelsmarkten in Europa en goede prijsonderhandelingen tussen telers, hun afzetorganisaties en de groot- en detailhandel. 
Tabel 6.13 Gemiddelde uitbetaalprijzen roos per bedrijfstype 2004, 2005, 2006 en 2007(P)

\begin{tabular}{|c|c|c|c|c|c|}
\hline $\begin{array}{l}\text { Productsoort: } \\
\text { Roos } \\
\text { B1: } n=10 \\
\text { B2: } n=11\end{array}$ & $\begin{array}{c}\text { gem. } \\
\text { uitbetaalprijs } \\
\text { in euro p. st. } \\
2004\end{array}$ & $\begin{array}{c}\text { gem. } \\
\text { uitbetaalprijs } \\
\text { in euro p. st. } \\
2005\end{array}$ & $\begin{array}{c}\text { gem. } \\
\text { uitbetaalprijs } \\
\text { in euro p. st. } \\
2006\end{array}$ & $\begin{array}{c}\text { gem. } \\
\text { uitbetaalprijs } \\
\text { in euro p. st. } \\
2007(\mathrm{P})\end{array}$ & $\begin{array}{l}\text { Prijsfluctuatie- } \\
\text { coëfficient } \\
\left(\mathrm{p}_{\max } / \mathrm{p}_{\min }\right)\end{array}$ \\
\hline B1-Aantal resp. & 6 & 9 & 10 & 9 & \\
\hline Aantal gemist & 4 & 1 & 0 & 1 & \\
\hline Gemiddelde prijs & 0.38 & 0.42 & 0.41 & 0.42 & 1.15 \\
\hline Standaardafw. & 0.18 & 0.16 & 0.16 & 0.14 & \\
\hline Standaardfout & 0.07 & 0.06 & 0.05 & 0.05 & \\
\hline Minimum & 0.19 & 0.22 & 0.23 & 0.22 & 1.21 \\
\hline Maximum & 0.67 & 0.70 & 0.67 & 0.63 & 1.11 \\
\hline B2-Aantal resp. & 3 & 5 & 9 & 11 & \\
\hline Aantal gemist & 8 & 6 & 2 & 0 & \\
\hline Gemiddelde prijs & 0.34 & 0.33 & 0.37 & 0.41 & 1.24 \\
\hline Standaardafw. & 0.01 & 0.09 & 0.10 & 0.11 & \\
\hline Standaardfout & 0.01 & 0.04 & 0.03 & 0.03 & \\
\hline Minimum & 0.33 & 0.25 & 0.24 & 0.27 & 1.37 \\
\hline Maximum & 0.35 & 0.48 & 0.53 & 0.55 & 1.57 \\
\hline
\end{tabular}

$\mathrm{P}=$ Prognose

Tabel 6.14 Gemiddelde uitbetaalprijzen chrysant per bedrijfstype 2004, 2005, 2006 en

\begin{tabular}{|c|c|c|c|c|c|}
\hline $\begin{array}{l}\text { Productsoort: } \\
\text { Chrysant } \\
\text { B1: } n=14 \\
\text { B2: } n=11 \\
\text { B1, B3: } n=1 \\
\text { B2, B4: } n=1\end{array}$ & $\begin{array}{l}\text { gem. } \\
\text { uitbetaalprijs } \\
\text { in euro p. st. } \\
2004\end{array}$ & $\begin{array}{l}\text { gem. } \\
\text { uitbetaalprijs } \\
\text { in euro p. st. } \\
2005\end{array}$ & $\begin{array}{c}\text { gem. } \\
\text { uitbetaalprijs } \\
\text { in euro p. st. } \\
2006\end{array}$ & $\begin{array}{c}\text { gem. } \\
\text { uitbetaalprijs } \\
\text { in euro p. st. } \\
2007(\mathrm{P})\end{array}$ & $\begin{array}{c}\text { Prijsfluctuatie- } \\
\text { coëfficient } \\
\left(\mathrm{p}_{\max } / \mathrm{p}_{\min }\right)\end{array}$ \\
\hline B1 (aantal resp.) & 7 & 11 & 13 & 14 & \\
\hline Aantal gemist & 7 & 3 & 1 & 0 & \\
\hline Gemiddelde prijs & 0.27 & 0.26 & 0.28 & 0.28 & 1.08 \\
\hline Standaardafw. & 0.10 & 0.08 & 0.09 & 0.09 & \\
\hline Standaardfout & 0.04 & 0.02 & 0.03 & 0.02 & \\
\hline Minimum & 0.20 & 0.21 & 0.22 & 0.20 & 1.10 \\
\hline Maximum & 0.43 & 0.45 & 0.47 & 0.50 & 1.16 \\
\hline B1,B3 (aant. resp) & 0 & 1 & 1 & 1 & \\
\hline Gemiddelde prijs & & 0.22 & 0.22 & 0.22 & 1.00 \\
\hline B2 (aantal resp.) & 3 & 5 & 9 & 11 & \\
\hline Aantal gemist & 8 & 6 & 2 & 0 & \\
\hline Gemiddelde prijs & 0.22 & 0.24 & 0.24 & 0.25 & 1.14 \\
\hline Standaardafw. & 0.01 & 0.02 & 0.02 & 0.02 & \\
\hline Standaardfout & 0.01 & 0.01 & 0.01 & 0.01 & \\
\hline Minimum & 0.20 & 0.22 & 0.21 & 0.23 & 1.15 \\
\hline Maximum & 0.24 & 0.26 & 0.27 & 0.28 & 1.17 \\
\hline B2,B4 (aant. resp) & 1 & 1 & 1 & 1 & \\
\hline Gemiddelde prijs & 0.19 & 0.22 & 0.23 & 0.22 & 1.21 \\
\hline
\end{tabular}

$\mathrm{P}=$ Prognose 
Tabel 6.15 Vergelijk gemiddelde jaarprijzen PT en onderzoeksresultaat 2004, 2005, 2006 en 2007 ( P) per bedrijfstype voor roos en chrysant

\begin{tabular}{|l|l|l|l|l|l|}
\hline & 2004 & 2005 & 2006 & $2007(\mathrm{P})$ & $\begin{array}{l}\text { Prijsfluctuatie- } \\
\text { coëfficient } \\
\left(\mathrm{p}_{\max } / \mathrm{p}_{\min }\right.\end{array}$ \\
\hline $\begin{array}{l}\text { Gem. jaarprijs PT roos } \\
\text { grootbl.*) }\end{array}$ & 26 & 26 & 27 & & 1.11 \\
\hline $\begin{array}{l}\text { Gem. prijs roos uit } \\
\text { onderzoeksresultaat (tabel 6.16) }\end{array}$ & 0.37 & 0.39 & 0.39 & $0.41(\mathrm{P})$ & \\
\hline Bedrijfstype B1 roos & 0.38 & 0.42 & 0.41 & 0.42 & 1.15 \\
\hline Bedrijfstype B2 roos & 0.34 & 0.33 & 0.37 & 0.41 & 1.24 \\
\hline Bedrijfstype B1, B3 & $\mathrm{nvt}$ & $\mathrm{nvt}$ & $\mathrm{nvt}$ & $\mathrm{nvt}$ & \\
\hline Bedrijfstype B2, B4 & $\mathrm{nvt}$ & $\mathrm{nvt}$ & $\mathrm{nvt}$ & $\mathrm{nvt}$ & \\
\hline & & & & & \\
\hline Gem. jaarprijs PT troschrysant & 20 & 22 & 24 & & \\
\hline $\begin{array}{l}\text { Gem. prijs chrysant uit } \\
\text { onderzoeksresultaat (tabel 6.16) }\end{array}$ & 0.25 & 0.25 & 0.27 & $0.27(\mathrm{P})$ & 1.08 \\
\hline Bedrijfstype B1 chrysant & 0.27 & 0.26 & 0.28 & 0.28 & 1.08 \\
\hline Bedrijfstype B2 chrysant & 0.22 & 0.24 & 0.24 & 0.25 & 1.14 \\
\hline Bedrijfstype B1, B3 & $\mathrm{nvt}$ & $\mathrm{nvt}$ & $\mathrm{nvt}$ & $\mathrm{nvt}$ & \\
\hline Bedrijfstype B2, B4 & $\mathrm{nvt}$ & $\mathrm{nvt}$ & $\mathrm{nvt}$ & $\mathrm{nvt}$ & \\
\hline
\end{tabular}

\section{Ad 4. Concentratieontwikkeling (C4) per bedrijfstype}

In tabel 6.16 wordt de horizontale concentratiegraad (C4) berekend per bedrijfstype. Evenals bij de C4 per productsoort is per bedrijfstype sprake van een lage concentratiegraad, variërend van 3.7 tot $4.7 \%$. De berekening laat een gemiddelde bedrijfsoppervlakte zien per bedrijfstype B1 en B2 van 2.8 en 4.1 ha. glas. Dit levert een betekenisvol verschil op $(\mathrm{p}<0.006)$ en geeft aan dat de bedrijfsomvang van een in telersvereniging opererend glassnijbloemenbedrijf (B2) aanmerkelijk groter is dan die van de veilingteler (B1). Evenals in de glasgroentesector speelt het oogmerk van verlaging van de gemiddelde (vaste) kosten een grote rol, van belang om de extra kosten van de marketing- en verkoopfunctie van de telersvereniging te kunnen opbrengen. De concen-

Tabel 6.16 Meting horizontale concentratie (C4) in 2006 per bedrijfstype glassnijbloemen in oppervlakte glas

\begin{tabular}{|c|c|c|c|c|c|c|c|c|}
\hline $\begin{array}{l}\text { Type bedrijf en } \\
\text { areaal populatie } \\
\text { roos en } \\
\text { chrysant in ha. }\end{array}$ & $\begin{array}{l}\text { Bedrijfs- } \\
\text { opper- } \\
\text { vlakte } \\
\text { steekprf. } \\
\text { gem. }\end{array}$ & $\begin{array}{l}\text { Stan- } \\
\text { daard- } \\
\text { fout } \\
\text { gem. }\end{array}$ & $\begin{array}{l}\text { Stan- } \\
\text { daard- } \\
\text { afwij- } \\
\text { king }\end{array}$ & $\begin{array}{c}\text { Aantal } \\
\text { respon } \\
- \\
\text { denten } \\
\text { (n) }\end{array}$ & $\begin{array}{l}\text { Som } \\
\text { bedrijfs } \\
\text {-opp. } \\
\text { steekpr }\end{array}$ & $\begin{array}{l}\text { Mini- } \\
\text { mum }\end{array}$ & $\begin{array}{l}\text { Maxi- } \\
\text { mum }\end{array}$ & $\begin{array}{l}\text { Concen- } \\
\text { tratiegraad } \\
\text { (C4) }\end{array}$ \\
\hline B1 642 ha.*) & 2.8 & 0.4 & 1.9 & 25 & 70.8 & 0.6 & 6.0 & $\begin{array}{l}25.8 / 642= \\
4.0 \%\end{array}$ \\
\hline B2. 709 ha. $\left.{ }^{*}\right)$ & 4.1 & 0.7 & 2.9 & 19 & 77.9 & 1.5 & 13.0 & $\begin{array}{l}36.3 / 709= \\
5.1 \%\end{array}$ \\
\hline Tot. 1351 ha. & 3.4 & 0.4 & 2.5 & 44 & 148.7 & 0.6 & 13.0 & \\
\hline
\end{tabular}

$\mathrm{C} 4=$ Concentratiegraad vier grootste glassnijbloemenbedrijven per bedrijfstype, gemeten in opp. glas

*) Bedrijfstype B1, B3 en B2, B4 zijn samengevoegd met B1 en B2 vanwege slechts één respondent. 
tratiegraad (C4), in 2006 op een niveau van $4.0 \%$ resp. 5.1\%, zal de komende jaren nog kunnen toenemen, evenals het verschil tussen deze twee bedrijfstypen. Uitgaande van een optimale bedrijfsomvang van gemiddeld 4 ha. (Kwin Glastuinbouw 2010) zal er bij een totale areaalomvang roos en chrysant van ongeveer 1000 ha. op termijn een structurele ruimte zijn voor ongeveer 250 bedrijven. Dit betekent dat de werkelijke concentratie in de totale glassnijbloementeelt op termijn nog zal toenemen en het aantal rozen- en chrysantentelers, in 2006 bestaande uit 425 rozen- en 334 chrysantenbedrijven, nog aanzienlijk zal dalen.

\subsubsection{Mogelijke verbanden tussen marktgedrag en -resultaat}

In de vorige paragrafen zijn de belangrijkste onderzoeksresultaten van de sector, de te onderscheiden productgroepen en de bedrijfstypen weergegeven. In deze paragraaf worden de mogelijke verbanden tussen gedrags- en resultaatsvariabelen besproken aan de hand van een aantal kruistabellen waarbij de chi-kwadraatanalyse is toegepast (Huizingh, 2010). Getoetst wordt of er een significant verband bestaat. Bij elke toetsing wordt de chi-kwadraatwaarde $\left(\chi^{2}\right)$ aangegeven met het aantal vrijheidsgraden ( $\mathrm{DF}=$ Degrees of Freedom) en de overschrijdingskans $\mathrm{p}$ (bij $95 \%$ betrouwbaarheid). Hoewel bij een aantal toetsen niet werd voldaan aan alle voorwaarden voor een betrouwbare toets (de aanwezigheid van cellen met te lage frequenties) geven zij wel een bepaalde trend aan die van belang is voor de analyse. Bij de analyse van de horizontale concentratiegraad (C4) wordt eveneens gebruik gemaakt van kruistabellen, echter zonder de chi-kwadraattest.

De te behandelen marktgedragsvariabelen zijn:

1. productsoorten

2. type glastuinbouwbedrijf

3. verkoopwijze producten

4. moderniteit bedrijf

5. bedrijfsoppervlakte glas (in ha.)

6. marketing en verkoop

7. voorwaartse verticale integratie (VVI)

8. horizontale concentratie

9. investeringen/innovaties

10 bedrijfsomvang/kostenniveau

11. toe- en uittreding sector

De marktresultaatsvariabelen zijn:

1. jaaromzet + groei

2. jaarprijzen

3. brutomarge $[(\mathrm{P}-\mathrm{GTK}) / \mathrm{P}] * 100$

4. aandeel eigen vermogen in $\%$ totaal $(\mathrm{EV} / \mathrm{TV}) * 100$ 
In tabel 6.17 wordt een overzicht gegeven van de onderzochte verbanden tussen de hierboven genoemde variabelen met een al dan niet significant resultaat. Alle getoetste variabelen worden in appendix $\mathrm{C}$ met behulp van de in de tabel genoemde kruistabellen (tabellen $6.18 \mathrm{t} / \mathrm{m} \mathrm{6.38}$ ) geanalyseerd en toegelicht. De significante en enkele niet-significante en vermeldenswaardige resultaten, van belang voor de analyse, worden na dit overzicht beschreven.

In een aantal gevallen zijn ter vergroting van het inzicht andere dan de genoemde resultaatsvariabelen getoetst.

Tabel 6.17 Overzicht chi-kwadraattest variabelen marktgedrag en marktresultaat

\begin{tabular}{|c|c|c|c|c|}
\hline $\begin{array}{l}\text { Tabel } \\
\text { nr. }\end{array}$ & Gedragsvariabele & $\begin{array}{l}\text { Structuur- en } \\
\text { resultaatsvariabelen }\end{array}$ & Testwaarden & $\begin{array}{l}\text { Signifi- } \\
\text { cantie } \\
\text { (ja/nee) }\end{array}$ \\
\hline 6.18 & Productsoort & $\begin{array}{c}\text { Brutomarge } 2006 \\
\text { (gerealiseerd) }\end{array}$ & $\begin{array}{l}n=44 ; \chi 2=11.127 \\
D F=4 ; p<0.025\end{array}$ & $\mathrm{Ja}$ \\
\hline 6.19 & Type glastuinbouwbedrijf & Veilingprovisie in \% omzet & $\begin{array}{l}\mathrm{n}=44 ; \chi 2=50.990 \\
\mathrm{DF}=12 ; \mathrm{p}<0.000\end{array}$ & $\mathrm{Ja}$ \\
\hline 6.20 & Type glastuinbouwbedrijf & Omzet gerealiseerd in 2006 & $\begin{array}{l}\mathrm{n}=42 ; \chi 2=45.721 \\
\mathrm{DF}=18 ; \mathrm{p}<0.000\end{array}$ & $\mathrm{Ja}$ \\
\hline 6.21 & Type glastuinbouwbedrijf & $\begin{array}{l}\text { Brutomarge gerealiseerd } \\
2006\end{array}$ & $\begin{array}{l}\mathrm{n}=44 ; \chi 2=8.899 \\
\mathrm{DF}=12 ; \mathrm{p}<0.712\end{array}$ & Nee \\
\hline 6.22 & Type glastuinbouwbedrijf & $\begin{array}{l}\text { Aandeel eigen vermogen } \\
(\mathrm{EV}) \text { in } \% \text { totale verm. (TV) }\end{array}$ & $\begin{array}{l}\mathrm{n}=29 ; \chi^{2}=14.859 \\
\mathrm{DF}=8 ; \mathrm{p}<0.062\end{array}$ & $\begin{array}{l}\text { Ja, } \\
\mathrm{p}>90 \%\end{array}$ \\
\hline 6.23 & Verkoopwijze producten & Omzet gerealiseerd in 2006 & $\begin{array}{l}\mathrm{n}=44 ; \chi 2=13.797 \\
\mathrm{DF}=12 ; \mathrm{p}<0.314\end{array}$ & Nee \\
\hline 6.24 & Verkoopwijze producten & Veilingprovisie in \% omzet & $\begin{array}{l}\mathrm{n}=44 ; \chi 2=25.145 \\
\mathrm{DF}=12 ; \mathrm{p}<0.014\end{array}$ & $\mathrm{Ja}$ \\
\hline 6.25 & Verkoopwijze producten & $\begin{array}{l}\text { Brutomarge gerealiseerd } \\
2006\end{array}$ & $\begin{array}{l}\mathrm{n}=44 ; \chi 2=9.959 \\
\mathrm{DF}=12 ; \mathrm{p}<0.620\end{array}$ & Nee \\
\hline 6.26 & Moderniteit bedrijf & Omzet gerealiseerd in 2006 & $\begin{array}{l}\mathrm{n}=44 ; \chi 2=16.669 \\
\mathrm{DF}=8 ; \mathrm{p}<0.034\end{array}$ & $\mathrm{Ja}$ \\
\hline 6.27 & Moderniteit bedrijf & $\begin{array}{l}\text { Brutomarge gerealiseerd } \\
2006\end{array}$ & $\begin{array}{l}\mathrm{n}=44 ; \chi 2=18.039 \\
\mathrm{DF}=8 ; \mathrm{p}<0.021\end{array}$ & $\mathrm{Ja}$ \\
\hline 6.28 & Moderniteit bedrijf & Bedrijfsopp. glas in ha. & $\begin{array}{l}\mathrm{n}=44 ; \chi 2=20.903 \\
\mathrm{DF}=12 ; \mathrm{p}<0.052\end{array}$ & $\mathrm{Ja}$ \\
\hline 6.29 & Bedrijfsopp. glas in ha. & $\begin{array}{l}\text { Veilingprovisie in \% v.d. } \\
\text { omzet }\end{array}$ & $\begin{array}{l}\mathrm{n}=44 ; \chi 2=17.429 \\
\mathrm{DF}=24 ; \mathrm{p}<0.830\end{array}$ & Nee \\
\hline 6.30 & Bedrijfsopp. glas in ha. & Investeringen ( $€ \times 1 \mathrm{mln})$. & $\begin{array}{l}\mathrm{n}=37 ; \chi 2=38.401 \\
\mathrm{DF}=16 ; \mathrm{p}<0.001\end{array}$ & $\mathrm{Ja}$ \\
\hline 6.31 & Bedrijfsopp. glas in ha. & Productiekosten in $€$ per $\mathrm{m}^{2}$ & $\begin{array}{l}\mathrm{n}=44 ; \chi^{2}=19.566 \\
\mathrm{DF}=16 ; \mathrm{p}<0.240\end{array}$ & Nee \\
\hline 6.32 & Bedrijfsopp. glas in ha. & $\begin{array}{l}\text { Brutomarge gerealiseerd } \\
2006\end{array}$ & $\begin{array}{l}\mathrm{n}=44 ; \chi 2=29.734 \\
\mathrm{DF}=16 ; \mathrm{p}<0.019\end{array}$ & $\mathrm{Ja}$ \\
\hline 6.33 & $\begin{array}{l}\text { Organisatie marketing en } \\
\text { verkoop }\end{array}$ & Omzet gerealiseerd in 2006 & $\begin{array}{l}\mathrm{n}=44 ; \chi 2=14.941 \\
\mathrm{DF}=12 ; \mathrm{p}<0.245\end{array}$ & Nee \\
\hline 6.34 & $\begin{array}{l}\text { Organisatie marketing en } \\
\text { verkoop }\end{array}$ & $\begin{array}{l}\text { Brutomarge gerealiseerd } \\
\text { in } 2006\end{array}$ & $\begin{array}{l}\mathrm{n}=44 ; \chi 2=12.664 \\
\mathrm{DF}=12 ; \mathrm{p}<0.394\end{array}$ & Nee \\
\hline 6.35 & $\begin{array}{l}\text { Organisatie marketing en } \\
\text { verkoop }\end{array}$ & Verkoopkosten in $\%$ omzet & $\begin{array}{l}\mathrm{n}=44 ; \chi 2=9.957 \\
\mathrm{DF}=12 ; \mathrm{p}<0.620\end{array}$ & Nee \\
\hline $\begin{array}{l}6.36- \\
6.37 \\
\end{array}$ & $\begin{array}{l}\text { Concentratiegraad (C4) } \\
\text { bedrijfsopp. glas in ha. }\end{array}$ & $\begin{array}{l}\text { Omzet en brutomarge } \\
\text { gerealiseerd in } 2005 / 2006\end{array}$ & n.v.t. & n.v.t. \\
\hline 6.38 & $\begin{array}{l}\text { Investeringsniveau (€ x } 1 \\
\text { mln.) }\end{array}$ & $\begin{array}{l}\text { Brutomarge gerealiseerd } \\
2006\end{array}$ & $\begin{array}{l}\mathrm{n}=37 ; \chi 2=23.314 ; \\
\mathrm{DF}=24 ; \mathrm{p}<0.501\end{array}$ & Nee \\
\hline
\end{tabular}




\subsubsection{Structuur- en resultaatsvariabelen sector (mesoniveau)}

In de volgende paragrafen worden de onderscheiden structuur- en resultaatsvariabelen van de sector glassnijbloemen besproken, deels voortkomend uit de onderzoeksresultaten van het sectoronderzoek en onderzoek afzetorganisaties (zie hoofdstuk 3 en 4) en deels vanuit het bedrijfsonderzoek. Zoals wordt aangegeven in het analysemodel van figuur 2.4 in hoofdstuk 2, vindt er een voortdurende wederzijdse beïnvloeding plaats van marktgedragsvariabelen naar marktstructuurvariabelen. Behandeld worden de concentratieontwikkeling bij producenten, afzetorganisaties en groothandel/export, de productdifferentiatie, de toetredingsdrempels en de mogelijke verbanden van deze variabelen met de resultaatsvariabelen omzet, productie- en exportwaarde, prijzen, brutomarge en solvabiliteit.

\subsubsection{Horizontale concentratie}

\section{Producenten}

In tabel 6.39 zijn de uitkomsten van het sector- en bedrijfsonderzoek betreffende de horizontale concentratiegraad van de vier grootste bedrijven (C4) met de resultaatsvariabele gemiddelde brutomarge 2006 samengevoegd (tabel 3.54, 6.36 en 6.37). De C4-oppervlakte glas, per productsoort voor de vier grootste rozen- en chrysantenbedrijven gemeten, ligt op een laag niveau en bedraagt in 20064.8 en 4.2\%. De gemiddelde brutomarge 2006 bedraagt voor de rozen $10.8 \%$ en voor de chrysanten 7.0\%. Per bedrijfstype bekeken ligt deze C4 voor het B1-bedrijfstype op $4.3 \%$ met een gemiddelde brutomarge van $5.0 \%$ en het B2-type op $4.8 \%$ met een brutomarge van $13.8 \%$. De vier grootste B1-leden (veilingtelers) telen allen chrysanten en de vier grootste

Tabel 6.39 Concentratie (C4) en brutomarge producenten glassnijbloemen 2004-2010

\begin{tabular}{|c|c|c|c|c|c|c|}
\hline $\begin{array}{l}\text { Concentratiegraad (C4 in \%) } \\
\text { Glassnijbloemen }\end{array}$ & 2006 & 2007 & 2008 & 2009 & 2010 & 2011 \\
\hline $\begin{array}{l}\text { Sectoronderzoek*) producenten } \\
\text { glassnijbloemen (C4 in \%): } \\
\text {-Roos } \\
\text {-Chrysant } \\
\text {-Potplantentelers (C4 in \%) } \\
\text {-Groene planten } \\
\text {-Bloeiende planten } \\
\text { (alle bedrijven op basis van areaal) }\end{array}$ & & $\begin{array}{l}6.0 \\
5.0 \\
6.0 \\
7.0\end{array}$ & $\begin{array}{l}8.0 \\
6.0 \\
6.0 \\
6.5\end{array}$ & $\begin{array}{r}10.0 \\
7.0 \\
6.0 \\
6.0\end{array}$ & & \\
\hline $\begin{array}{l}\text { Bedrijfsonderzoek producenten } \\
\text { glassnijbloemen (C4 in \%): } \\
\text {-Roos } \\
\text {-Chrysant } \\
\text {-Bedrijfstype B1 } \\
\text {-Bedrijfstype B2 }\end{array}$ & $\begin{array}{l}4.8 \\
4.2 \\
4.3 \\
4.8\end{array}$ & & & & & \\
\hline $\begin{array}{l}\text { Bedrijfsonderzoek producenten } \\
\text { glassnijbloemen (brutomarge in \%): } \\
\text {-Roos (C4-resp.) } \\
\text {-Chrysant (C4-resp.) } \\
\text {-Bedrijfstype B1(C4-resp.) } \\
\text {-Bedrijfstype B2(C4-resp.) }\end{array}$ & $\begin{array}{r}10.8 \\
7.0 \\
5.0 \\
13.8 \\
\end{array}$ & & & & & \\
\hline
\end{tabular}

*) Onderzoeksresultaten sectoronderzoek producenten glassierteelt (H3, deel tabel 3.55) 
B2-leden (veilingtelersvereniging) zijn rozentelers. Het B1-bedrijfstype scoort met een iets lagere C4-waarde een lagere brutomarge dan bedrijfstype B2 (8.8\%). Gemeten over alle B1- en B2-respondenten is dit margeverschil minder groot (3.8\%).

De in hoofdstuk 3 getrokken conclusie wordt met de uitkomsten van het bedrijfsonderzoek verder onderbouwd en ligt hiermee in lijn. De C4-waarde in de glassnijbloemen ligt op een laag niveau. Er is een geringe toename bij de producenten van glassnijbloemen van ongeveer 4 naar $10 \%$ over de periode 2006-2009 met de hoogste concentratie bij de roos. Deze toename is van weinig invloed op het sector- en bedrijfsresultaat.

Voor de ontwikkeling van de concentratiegraad over deze periode bij de afzetorganisaties en de groothandel/export en de invloed hiervan op sectorresultaten wordt verwezen naar tabel 3.55 en tabel 4.9 in hoofdstuk 3 en 4.

\subsubsection{Voorwaartse verticale integratie}

In de voorgaande paragraaf is de structuurvariabele voorwaartse verticale integratie ook opgenomen als gedragsvariabele. Zoals eerder is gezegd, zijn er weinig voorbeelden te geven van glassierteeltbedrijven die verticaal zijn geïntegreerd met de groothandel/export of die plannen daartoe hebben. Wel zijn er vele voorbeelden van verticale samenwerking tussen producenten, afzetorganisaties, groothandels/exporteurs en grootschalige detaillisten, vooral bij de grotere potplantenbedrijven, waarbij niet de zeggenschap over de bedrijfsvoering wordt overgedragen. In hoofdstuk 4 en 5 is deze gedrags- en structuurvariabele bij de rapportage afzetorganisaties en bedrijfsonderzoek glasgroenten nadrukkelijk aan de orde geweest.

De kenmerkende verschillen en de problematiek van het afzetsysteem in de twee sectoren wordt nogmaals kort besproken. Aangegeven is wat de gevolgen zijn van voorwaartse verticale integratie voor de marktstructuur en -situatie voor de sector glasgroenten. De verkleining van de groothandelsmarkten in Nederland en aangrenzende buurlanden is beschreven, evenals de scherpe concurrentie die hierdoor ontstond. Mede hierdoor is er in Nederland in de glasgroentesector een ondoorzichtige marktsituatie ontstaan waarbij geen sprake meer is van openbare, vrije en transparante prijsvorming. Hierdoor is een goede dagelijkse match van vraag en aanbod van het versproduct praktisch onmogelijk. Voor een versproduct als glasgroenten is dit geen goede zaak. Door de onzekerheid van het tijdstip van de oogst en de beperkte houdbaarheid daarna is het dagelijks vereffenen van overschotten en tekorten een noodzaak. Hierbij is naast verticale handel (producent, groothandel, detaillist) ook horizontale handel nodig tussen marktpartijen aan vraag- en aanbodzijde onderling. Door het ontstaan van de vele verticale afzetketens, soms bijna letterlijk vastgeklonken, zijn de nodige zijwaartse (horizontale) transactiemogelijkheden om vraag en aanbod beter op elkaar aan te sluiten en de markt op te schonen, moeilijk geworden. Het resultaat is dat er te grote overschotten of tekorten ontstaan, een niet stabiele prijsvorming en -ontwikkeling en in bepaalde perioden van het jaar onnodig veel derving. 
In de sector glassnijbloemen speelt een vergelijkbaar probleem als in de glasgroenten. Ook hier is sprake van een versproduct met een onzeker oogsttijdstip en een korte houdbaarheids-tijd. De handel in versproducten heeft voor producten die niet direct zijn doorverkocht vanaf het koopmoment een prijs- en kwaliteitsprobleem. De kwaliteit neemt af en wie wil er een prijs betalen boven de inkoopprijs. Tot op heden hebben de gezamenlijke Nederlandse siertelers het coöperatieve afzetsysteem met de organisatie van een aantal effectieve marktplaatsen onder één bestuur in stand kunnen houden en zelfs tot bijna 100\% deelname kunnen brengen. Het voordeel hiervan is een dagelijks openbaar en transparant prijsvormingssysteem dat voor aanvoerders en kopers uit de gehele EU vrij toegankelijk is en kansen biedt op reële prijsvorming en prijzen. Deze dagelijks variërende prijs is tevens een noodzakelijke referentieprijs voor aanvullende grotere transacties tussen grotere marktpartijen. Van voorwaartse verticale integratie zijn er geen voorbeelden voorhanden van glassnijbloementelers die verticaal zijn geïntegreerd met de groothandel/export. Wel zijn er voorbeelden van verticale samenwerking tussen producent, afzetorganisatie, groothandel/export en grootschalige detaillisten, vooral bij de grotere potplantenbedrijven.

\subsubsection{Productdifferentiatie}

In de sector glassierteelt is de productdifferentiatie van snijbloemen en potplanten groot. De roos bestaat bijvoorbeeld uit drie soorten: de grootbloemige roos, de kleinbloemige en de trosroos. Iedere soort kent tenminste 15 verschillende cultivars en tien verschillende kleuren (Vakblad voor de Bloemisterij, jaarlijkse staalkaart snijbloemen en potplanten, 22 mei 2009).

Veredelingsbedrijven werken nauw samen met producenten en de groot- en detailhandel bij de ontwikkeling van nieuwe producten en concepten. Dergelijke producten en concepten bieden de detailhandel, groothandel, teler en veredelaar de mogelijkheid zich als gehele bedrijfskolom te onderscheiden. Op deze manier kan een nieuwe cultivar een stevige marktpositie veroveren en stimuleert de detailhandel herhalingsaankopen. Het aantal snijbloemenbedrijven daalde in 2011 met 3\% tot circa 1.450 (tabel 6.40). Deze daling is minder groot dan voorgaande jaren. In 2010 waren de bedrijfsresultaten beter dan in 2009 en dat gaf hoop op een verder herstel. Het areaal snijbloemen daalde mede hierdoor zeer beperkt met ongeveer 20 ha. tot iets onder de 2.600 ha. Het areaal nam minder hard af dan het aantal bedrijven. Het areaal roos daalde opnieuw. In 2011 gingen de voorlopige cijfers uit van een daling van 8\% hetgeen een halvering van het areaal betekent tussen 2000 en 2011.

Tabel 6.40 Ontwikkeling aantal glassnijbloemenbedrijven en areaal snijbloemen

\begin{tabular}{|l|l|l|l|l|l|}
\hline & 2000 & 2009 & 2010 & $2011(\mathrm{P})$ & $\begin{array}{l}\text { Mutatie } \\
2010 / 11 \\
\text { in \% }\end{array}$ \\
\hline Aantal snijbloemenbedrijven & 3280 & 1730 & 1500 & 1450 & -3.3 \\
\hline Areaal snijbloemenbedrijven & 3920 & 2870 & 2600 & 2580 & -0.8 \\
\hline -waarvan roos & 930 & 530 & 500 & 460 & -8.0 \\
\hline -waarvan chrysant & 770 & 490 & 500 & 510 & +2.0 \\
\hline -waarvan gerbera & 250 & 220 & 180 & 180 & - \\
\hline
\end{tabular}

Bron: CBS Landbouwtelling, bewerking LEI rapport 2012-064, gegevens 2011 zijn voorlopig (P) 
De gedrags- en structuurvariabele productdifferentiatie betreft het productbeleid en het productontwikkelingsbeleid in brede zin dat vanaf 2004 is gevoerd door de twee grootste bloemenveilingen FloraHolland en VBA en haar leden snijbloemen- en potplantentelers.

In 2004 zegt FloraHolland het volgende over haar bedrijfsstrategie:

'FloraHolland wil de afzetketen van bloemisterijbedrijven beter laten presteren. Om dit te bereiken wil FH een breed aanbod van bloemisterijproducten uit binnen- en buitenland aan de veilingklokken en aan het bemiddelingsbureau binden.' (Jaarverslag 2005, p. 15).

$\mathrm{Zij}$ somt een reeks van strategische maatregelen op om haar marktplaatsen en dienstverlening (veilen en bemiddelen) te versterken door middel van enerzijds het aanbieden van een breed en diep assortiment aantrekkelijke bloemisterijproducten en anderzijds het aantrekken van een jaarrond koopkrachtige vraag voor deze producten. FloraHolland is een dienstverlenend bedrijf dat met name verkoop- en logistieke diensten aanbiedt. Het gaat om het aanbod van aantrekkelijke producten en diensten die extra waarde toevoegen aan het geheel van de transactie. De vraag is ook hier wat de invloed is van het assortiment producten en diensten op de concurrentiepositie van FloraHolland, het onderscheidend vermogen ten opzichte van andere aanbieders en het resultaat. Is er een verband tussen de inzet van nieuwe producten en diensten en de behaalde resultaten? Verwezen wordt naar voorbeelden uit jaarverslagen 2004-2008 van nieuw ontwikkelde producten en diensten door FloraHolland en de VBA, alleen of in samenwerking met derden (paragraaf 4.3.5.3 en 4.3.5.4).

De onderzoeksuitkomsten van het bedrijfsonderzoek glassnijbloemen betreffende het assortiment geteelde producten (Veerman, 2008) laten het volgende zien:

1. Veel rozentelers in Nederland zijn de afgelopen jaren door de concurrentie van importrozen (Kenia, Ethiopië e.a.) overgeschakeld op grootbloemige, middelgrootbloemige en trosrozen (specialties). Producttypen die door respondenten van zowel bedrijfstype B1 als B2 zijn gekozen, zijn onder andere rassen als Grand Prix, Passion, Red Naomi, Avalanche, Vivaldi. Met investeringen in het bedrijfsproces (WKK + belichte teelt) en jaarrond productie zijn dit de strategische wapens voor de toekomst. Kleinbloemige teelt komt nog wel voor, maar dan meestal in combinatie met grootbloemig of middelgrootbloemig.

2. In de chrysantenteelt kiezen de veilingtelers in vier gevallen voor de pluischrysant (specialties), de overigen voor de troschrysant, waarbij de rassen Euro, Anastasia en Reagan koploper zijn. De leden van een veilingtelersvereniging kiezen allen voor de troschrysant waarvan een aantal voor trosspecialties. Ook in de chrysantenteelt is en wordt geïnvesteerd in het bedrijfsproces (WKK + belichte teelt) en jaarrond productie.

3. Er lijkt een verband te bestaan tussen productsoort en gerealiseerde brutomarge: de onderzochte glasrozenbedrijven realiseren in 2006 een betekenisvol hogere brutomarge dan de glaschrysantenbedrijven. Zoals eerder is aangegeven kan dit verschil worden veroorzaakt door functieverschillen van het product. De chrysant heeft meer aspecten van een gebruiksproduct en de roos meer aspecten van een geschenkproduct. 


\subsubsection{Toetredingsdrempels (investeringen)}

Toetreding tot de sector glassnijbloemen in Nederland is evenals in de glasgroenten een kostbare zaak en ook hier zijn de investeringsdrempels hoog. In de voorgaande paragraaf is onder toe-en uittreding sector aangegeven dat van 2005-2010 er een vergroting plaatsvond van de gemiddelde bedrijfsomvang van 1.1 tot 1.6 ha. glasoppervlakte. Jaarlijks stopte 5 tot $10 \%$ van de bedrijven. Toetreding tot de sector vond nauwelijks plaats, uittreding meer. Toch wordt er nog steeds geinvesteerd in de overblijvende bedrijven. Van 2001-2005 stijgt de gemiddelde investering per bedrijf vooral in machines, werktuigen en installaties (van ongeveer 50.000 naar 80.000 euro). In de periode 2004-2008 blijven de investeringen in de glastuinbouw op een stabiel niveau van 150.000 euro, ondanks de fluctuaties in omzet en inkomen. In 2007 en 2008 is er onder andere in groenlabelkassen geïnvesteerd in verband met de strenger wordende regelgeving. In 2009 en 2010 was het investeringsniveau laag door de gevolgen van de kredietcrisis. In 2011 was er een groei van de investeringen waarneembaar, vooral in de potplantensector en in beperktere mate bij de snijbloemen. Ondanks de EHEC-crisis werd er ook in de glasgroenten geïnvesteerd. Het gemiddelde investeringsniveau (alle sectoren glastuinbouw) ligt in 2011 op bijna 170.000 euro per bedrijf, 20.000 euro boven het voortschrijdend vijfjaargemiddelde over de periode 20072011. Innovatieve telers zien nog steeds nieuwe mogelijkheden, ook in een periode van kredieten EHEC-crisis (Van der Meulen et al., 2012, pp. 128,129).

Het opzetten van een nieuw bedrijf in de sector glassnijbloemen vraagt hoge investeringen. Een nieuw glasrozenbedrijf (met WKK-installatie) vergt in 2010 een investering van ongeveer 130 euro per $\mathrm{m}^{2}$ kas voor een bedrijf van 2 ha. in 2010 , tot 115 euro per $\mathrm{m}^{2}$ bij een bedrijf van 10 ha. In totaal komt een gemiddeld glasrozenbedrijf van 2 ha. uit op een investering van bijna 3 mln. en een bedrijf van 4 ha. op bijna $5 \mathrm{mln}$. euro. Dit bedrag is inclusief de benodigde bedrijfsmiddelen, maar exclusief de aanschaf van grond. De grondprijs varieert per gebied in Nederland en is sterk locatiegebonden. Deze investeringen gelden voor de opzet van een nieuw bedrijf. Het omschakelen vanuit een bestaande teelt vergt minder kosten, is afhankelijk van het type bedrijf, de aanwezige kas en de aanwezigheid van een WKK-installatie (Vermeulen, 2010).

Er is vastgesteld dat er geen betekenisvol verband aanwezig is tussen bedrijfstype en investeringsniveau. In tabel 6.38 wordt getoetst of een hoger investeringsniveau ook een hoger resultaat bewerkstelligt. 37 van de 44 respondenten hebben deze vraag beantwoord. Evenals in de glasgroenten is er geen betekenisvol verband te constateren tussen de hoogte van de investeringen en de gerealiseerde brutomarge in 2006. Hogere investeringen van bedrijven blijken ook in de sector siertuinbouw niet (direct) tot hogere resultaten te leiden.

Zoals eerder is aangegeven hangt dit vooral af van de uniekheid van de investering. De concurrentie in de sector glassnijbloemen is hoog en bedrijven zullen trachten innovatieve investeringen te imiteren om aldus een deel van het (extra) resultaat te verwerven. 


\subsection{Voorlopige conclusies}

Hieronder volgen de voorlopige conclusies uit het onderzoek naar marktgedrag en marktresultaat van de glassnijbloemenbedrijven. Evenals bij de glasgroenten is de indeling naar bestuurlijkorganisatorische, commerciële en financieel-economische aspecten. Marktstructuur en marktresultaat worden daarna behandeld tezamen met de onderlinge beïnvloeding van marktgedrag en -structuur (vice versa).

\subsubsection{Marktgedrag en -resultaat}

Op grond van de uitkomsten van het bedrijfsonderzoek naar het marktgedrag en -resultaat in de sector glassnijbloemen (roos en chrysant) kunnen we het volgende concluderen.

- Bestuurlijk-organisatorische en financieel-economische conclusies

\section{Strategische keuze bedrijfsomvang}

Ook in de sector glassnijbloemen is sprake van een voortdurende toename van de gemiddelde bedrijfsomvang en een grote variatie in omvang en resultaat van de onderzochte bedrijven. De schaalgrootte van de bedrijven neemt nog steeds toe. De productgroepen roos en chrysant laten vanaf 2001-2010 een jaarlijkse daling zien van het aantal bedrijven met 5 tot 10\%. Het areaal van de roos daalt met een vergelijkbaar percentage en ligt in 2010 op 460 ha., onder het areaal van de chrysant. Deze daling wordt veroorzaakt door de toenemende concurrentie van de buitenlandse import, met name uit Kenia en Ethiopië. Het areaal chrysant stabiliseert vanaf 2009 en ligt in 2010 iets boven de 500 ha. Het gemiddelde rozenbedrijf is dan gestegen van 1.1 naar 1.8 ha., het chrysantenbedrijf van 1.4 naar 1.8 ha. In 2007 bestaat de populatie glassnijbloementelers uit 2600 bedrijven met een gemiddelde oppervlakte van 1.2 ha.

De onderzoeksuitkomsten geven aan dat er kleine en grote bedrijven actief zijn. Van de 44 onderzochte bedrijven is de gemiddelde bedrijfsomvang 3.4 ha. met een spreiding van 0.6 ha. tot 13 ha. De gemiddelde omzet in 2005 is $€ 2.4 \mathrm{mln}$. met een spreiding van $€ 0.2 \mathrm{mln}$. tot $€ 10 \mathrm{mln}$. In 2006 is deze gestegen tot $€ 2.6 \mathrm{mln}$. met een spreiding van $€ 0.2$ tot $€ 15 \mathrm{mln}$.

Het onderzoek naar mogelijke verbanden tussen bedrijfsomvang en behaalde resultaten laat zien dat er bij de glassnijbloemen ook voor het kleinere bedrijf nog veel mogelijkheden zijn:

- bedrijven met een kleinere oppervlakte glas behaalden in 2006 een significant hogere brutomarge;

- bedrijven met een grotere oppervlakte glas laten geen significant lagere kostprijs per $\mathrm{m}^{2}$ zien dan kleinere bedrijven;

- bedrijven met een grotere oppervlakte glas betalen geen significant lagere veilingprovisie.

\section{Strategische keuze productsoort}

Bezien naar productsoorten roos en chrysant is het gemiddelde rozenbedrijf in Nederland iets kleiner dan het chrysantenbedrijf, terwijl de omzet groter is. Deze omzet ontwikkelt zich van 
$€ 2.6 \mathrm{mln}$. in 2005 naar $€ 3.0 \mathrm{mln}$. in 2006 . Het chrysantenbedrijf laat een gemiddelde omzet in 2005 zien van $€ 2.1 \mathrm{mln}$. en in 2006 van $€ 2.2 \mathrm{mln}$. De omzetspreiding bij de rozen ligt hoger dan bij de chrysanten en er komen relatief meer kleine bedrijven voor (33\% van de rozentelers heeft een bedrijfsomvang tot 1.5 ha., terwijl dit bij de chrysant $17 \%$ is). De brutomarge begroot ligt bij de roos op 10.8 en bij de chrysant op 5.4\%, de brutomarge gerealiseerd op 13.3 resp. 9.1\%. Ook hier is, evenals bij bedrijfsoppervlakte en omzet, sprake van een grote spreiding, voor de rozentelers het grootst.

Het onderzoek naar mogelijke verbanden tussen keuze productsoort en behaalde resultaten komt tot de volgende uitkomst:

- de rozenbedrijven realiseren in 2006 een betekenisvol hogere brutomarge dan de chrysantenbedrijven.

\section{Strategische keuze bedrijfstype}

Van de vier bedrijfstypen valt 55\% onder het bedrijfstype B1, ruim $40 \%$ onder type B 2 en slechts twee bedrijven gedeeltelijk onder type B3 of B4. Veilingteler B1 realiseert een gemiddelde bedrijfsomzet van $€ 1.8 \mathrm{mln}$. in 2005 en 2006 . Deze omzet varieert van $€ 0.2 \mathrm{mln}$. voor het kleinste tot $€ 3.6 \mathrm{mln}$. voor het grootste bedrijf. Bij B2 is de gemiddelde bedrijfsomzet $€ 3.1 \mathrm{mln}$. in 2005 en $€ 3.6 \mathrm{mln}$. in 2006. De spreiding bij B2 is groter en varieert in 2005 van $€ 1.3$ tot $€ 10.0 \mathrm{mln}$. en in 2006 van $€ 1.3$ tot $€ 15.0 \mathrm{mln}$.

De gerealiseerde brutomarge ligt tussen $4.5 \%$ en $13.0 \%$ en komt gemiddeld uit op $11 \%$. Bedrijfstype B1 behaalt met $12.4 \%$ een hogere marge dan type B2 met 9.6\%. Het aandeel eigen vermogen voor alle respondenten ligt in 2006 gemiddeld op 44\%. Naar bedrijfstype bezien scoort B1 een betekenisvol hoger percentage (52\%) dan type B2 (33\%).

Het onderzoek naar mogelijke verbanden tussen keuze bedrijfstype en resultaten geeft de volgende uitkomsten:

- er is een betekenisvol verband tussen type bedrijf en te betalen veilingprovisie. B2 betaalt een betekenisvol lager percentage veilingprovisie dan bedrijfstype B1;

- er is een betekenisvol verband tussen bedrijfstype en het gerealiseerde aandeel eigen vermogen. Bij type B1 ligt dit op een hoger niveau dan bij B2;

- er is een betekenisvol verband tussen moderniteit van het bedrijf en behaalde bedrijfsomzet: naarmate het bedrijf een recenter bouwjaar heeft, breidt het in de meeste gevallen uit en behaalt een hogere jaaromzet;

- er is geen betekenisvol verband tussen bedrijfstype en gerealiseerde brutomarge in 2006;

- er is geen betekenisvol verband tussen bedrijfstype en de hoogte van het investeringsniveau.

Bedrijfstype B1(de veilingteler) komt in dit onderzoek tot gemiddeld hogere resultaten dan bedrijfstype B2 (lid telersvereniging). Dit strookt niet met de conclusies in het artikel 'Investeren in telersvereniging loont" uit het Vakblad voor de Bloemisterij (2010). 


\section{Concentratieontwikkeling bedrijven}

De horizontale concentratiegraad (C4) onder de bedrijven in de sector glassnijbloemen ligt in 2006 op een laag niveau. Voor roos en chrysant ligt deze C4 tussen 4 en 5\%, voor bedrijfstype B1 en B2 tussen 5 en 7\%. Deze uitkomsten zijn in lijn met de uitkomsten van het sectoronderzoek (zie hoofdstuk 3). Er is een geringe toename naar 10\% over de periode 2006-2009 met de hoogste concentratie in het gewas roos. Deze toename lijkt van weinig invloed op het sector- en bedrijfsresultaat (productiewaarde, prijzen snijbloemen, brutomarge).

Ondanks de lage concentratiegraad op dit moment, is de verwachting dat deze de komende jaren toch zal toenemen en het aantal bedrijven aanzienlijk zal dalen (tabel 6.16).

Opvallend is voorts het verschil in brutomarge tussen de vier grootste bedrijven en de gemiddelde brutomarge van alle bedrijven: bedrijven van kleinere omvang boeken vergelijkbare en soms betere resultaten. De brutomarge, gerealiseerd in 2006 bij de vier grootste rozentelers bedraagt $10.8 \%$ ten opzichte van gemiddeld $13.3 \%$ voor alle respondenten. Bij de chrysantentelers is dit ook het geval. Hier ligt het gemiddelde ruim vier procentpunten hoger.

\section{Investeringen/innovaties}

In de periode 2004-2008 blijven de investeringen in de glastuinbouw op een stabiel niveau van gemiddeld 150.000 euro per bedrijf. In 2007 en 2008 is er onder andere in groenlabelkassen geïnvesteerd in verband met de strenger wordende regelgeving. In 2009 en 2010 was het investeringsniveau laag door de gevolgen van de kredietcrisis. In 2011 was er een groei waarneembaar, vooral in de potplantensector en in beperktere mate bij de snijbloemen.

Het onderzoek naar mogelijke verbanden tussen bedrijfstype en investeringen resp. investeringen en brutomarge laat het volgende zien:

- er is geen betekenisvol verband tussen bedrijfstype en de hoogte van het investeringsniveau;

- er is geen betekenisvol verband tussen de hoogte van de investeringen en de gerealiseerde brutomarge in 2006. Hogere investeringen van bedrijven leiden niet (direct) tot hogere resultaten. Concurrerende bedrijven beschikken snel over de informatie om de innovatie te beantwoorden en eventueel te imiteren.

\section{- Commerciële en financieel-economische conclusies}

\section{Organisatie marketing en verkoop}

Alle onderzochte bedrijven zijn aangesloten bij FloraHolland te Naaldwijk met vestigingen te Aalsmeer, Bleiswijk, Rijnsburg, Eelde en Venlo (inmiddels Veiling Rhein-Maas in Straelen-Herongen, in samenwerking met Landgard te Duitsland). Een aantal van de grootste bedrijven zet zijn producten af op meer veilpunten in goed overleg met het management van deze vestigingen. Ruim $60 \%$ van de bedrijven heeft de marketing- en verkoopactiviteiten volledig uitbesteed aan de veiling en $30 \%$ beschikt zowel over het verkoopapparaat van de veiling als over de eigen verkoper, in dienst bij de telersvereniging. Ongeveer 10\% heeft naast de veiling (klok en bemiddeling) nog een 
derde verkoopkanaal ontwikkeld, alleen of in samenwerking met de telersvereniging. De veiling is hiervan op de hoogte en staat dit in goed overleg beperkt toe. FloraHolland beschikt voor de afzet van bloemen en planten over een groot verkoopapparaat. Dit is bij de telersvereniging veel kleiner, meestal niet meer dan één verkoper. De via de veiling betaalde provisie, gemeten als percentage van de omzet, bedraagt gemiddeld $6 \%$ en varieert tussen de 3 en 10\%. De kosten EV, gemeten als percentage van de omzet bedraagt gemiddeld $0.9 \%$ en varieert tussen de 0.1 en $4 \%$.

Het bedrijfsonderzoek naar mogelijke verbanden tussen organisatie marketing en verkoop en resultaten geeft aan dat er geen betekenisvolle verbanden zijn tussen deze activiteiten en de omzet, de gerealiseerde brutomarge en de hoogte van de veilingprovisie. Het lijkt erop dat elk bedrijf zijn eigen marketing- en verkoopmix per deelactiviteit (klok, bemiddeling, eigen verkoop) zodanig inzet dat geen significante resultaatsverschillen ontstaan.

Het bedrijfsonderzoek naar mogelijke verbanden tussen verkoopwijze en resultaten geeft de volgende uitkomsten:

- er is een betekenisvol verband tussen verkoopwijze en hoogte veilingprovisie: alleen via de klok verkopen betekent het betalen van de hoogste veilingprovisie;

- er blijkt geen betekenisvol verband te zijn tussen de verkoopwijze van de producten en de gerealiseerde jaaromzet, in tegenstelling tot de verwachting dat het vooral de kleinere bedrijven zijn die hun producten via de klok afzetten.

- er is geen betekenisvol verband tussen de verkoopwijze producten en de gerealiseerde brutomarge in 2006. Wel valt op dat van de bedrijven die hun producten via de veilingklok verkopen, er vier van de tien bedrijven de hoogste marge behalen (40\%) en dat bij klok en bemiddeling dit er slechts twee van de 29 (7\%) zijn. Het verkopen van snijbloemen via de veilingklok kan, ondanks de hogere te betalen provisie voor het verkopen via de klok, meer resultaat opleveren in de vorm van hogere prijzen en brutomarges. De uitbetaalprijzen 2004-2007 laten zien dat het B1bedrijfstype (de veilingteler) zowel bij de roos als bij de chrysant de hoogste prijzen realiseert.

\section{Mate van tevredenheid}

$75 \%$ van de respondenten is tevreden tot zeer tevreden over zijn verkooporganisatie, $25 \%$ is tevreden/ontevreden. $40 \%$ noemt een actievere opstelling van de verkoper van het bemiddelingsbureau als de belangrijkste maatregel om de tevredenheid te vergroten.

\section{De gemiddelde uitbetaalprijzen per productsoort en bedrijfstype}

De gemiddelde uitbetaalprijs per type bedrijf laat jaarlijks verschillen zien. Zowel bij de roos als bij de chrysant scoort bedrijfstype B1 in alle jaren gemiddeld de hoogste uitbetaalprijs.

In 2005 bestaat het grootste verschil tussen bedrijfstype B1 en B2 roos, in 2007 zijn de uitbetaalprijzen bijna gelijk. Bij de chrysant is het verschil tussen bedrijfstype B1 en B2 kleiner, in 2004 het grootst.

De grote prijsvariatie $\left(\mathrm{p}_{\max }-\mathrm{p}_{\min }\right)$ van de roos bij de veilingtelers laat zien dat hier een breed assortiment van verschillende typen unieke rozen voor de klok komt, wat resulteert in een gemid- 
deld stabiel prijsniveau van 2005-2007. Bij de telersverenigingen is het aangevoerde assortiment rozen minder breed en is de prijsvariatie ook minder groot. Voor de chrysant is er een enigszins vergelijkbare situatie, zij het dat het assortiment chrysanten niet zo breed is als dat van de roos en het aantal verschillende typen chrysanten kleiner. Dit blijkt ook uit de kleinere prijsvariatie van de chrysant ten opzichte van de roos, zowel bij B1- als B2-telers.

De prijsfluctuatie van de gemiddelde, de maximum- en de minimumprijs is bij alle bedrijfstypen laag, met uitzondering van het B2-bedrijfstype afzet roos. Er is sprake van een redelijk evenwichtige ontwikkeling van aanbod en vraag in deze periode op de belangrijke groothandelsmarkten in Europa en goede prijsonderhandelingen tussen telers met hun afzetorganisaties en de groot- en detailhandel.

\subsubsection{Marktstructuur en -resultaat}

Op grond van de uitkomsten van het bedrijfsonderzoek naar marktstructuur en -resultaat kunnen we over de onderscheiden variabelen het volgende concluderen.

\subsubsection{Horizontale concentratie}

De concentratiegraad van de vier grootste producenten in de glassnijbloemen ligt op een laag niveau. Er is een geringe toename van ongeveer 4.5 naar 8.5\% over de periode 2006-2009 met de hoogste concentratie (10\%) in het gewas roos. Hoewel de toename van de $\mathrm{C} 4$ gering is en op dit lage niveau van weinig invloed lijkt te zijn op het sector- en bedrijfsresultaat, valt op dat bij een hogere C4-waarde (roos) in veel gevallen een hogere brutomarge wordt bereikt (zie tabel 6.39). De horizontale concentratie onder de afzetorganisaties is bijna $100 \%$. FloraHolland heeft een marktaandeel van ongeveer $97.5 \%$ en Plantion $2.5 \%$ (tabel 4.9 ).

\subsubsection{Voorwaartse verticale integratie}

Voorbeelden van voorwaartse verticale integratie van glassnijbloementelers zijn niet voorhanden. Wel zijn er voorbeelden van verticale samenwerking tussen producenten, afzetorganisatie, groothandels/exporteurs en grootschalige detaillisten, vooral bij de grotere potplantenbedrijven.

\subsubsection{Productdifferentiatie}

De productdifferentiatie van snijbloemen en potplanten is groot. De Nederlandse sierteeltsector is innovatief en heeft een grote variëteit aan producten. Veredelingsbedrijven werken samen met producenten en de groot- en detailhandel bij de ontwikkeling van nieuwe producten en concepten. Hoewel het areaal en aantal snijbloementelers in Nederland daalt en de concurrentie met buitenlandse aanvoerders zowel op de eigen bloemenveiling als op de groothandelsmarkten in Europa toeneemt, zien producenten en veiling kans jaarrond een in volume stabiel en in soorten breed en diep assortiment snijbloemen aan te bieden tegen concurrerende prijzen. De afzetorganisaties met hun leden/producenten slagen er aldus in de vermindering in aanvoer van de Nederlandse snijbloemen op te vangen met een toename van import. Hierbij zijn vaak ook Nederlandse telers met een buitenlandse vestiging betrokken. 
Het bedrijfsonderzoek naar mogelijke verbanden geeft aan dat er een betekenisvol verband bestaat tussen productsoort en brutomarge 2006. Rozentelers realiseren een hogere brutomarge dan de chrysantentelers.

\subsubsection{Toetredingsdrempels (investeringen)}

Toetreding tot de sector glassnijbloemen in Nederland is een kostbare zaak en de investeringsdrempels zijn hoog. In de periode 2005-2010 vond nauwelijks toetreding tot de sector plaats, meer uittreding. Het gemiddelde investeringsniveau (alle sectoren glastuinbouw) ligt in 2011 op bijna 170.000 euro per bedrijf, 20.000 euro boven het voortschrijdend vijfjaargemiddelde over de periode 2007-2011. Innovatieve telers zien nog steeds nieuwe mogelijkheden, ook in een periode van kredietcrisis.

Het bedrijfsonderzoek naar mogelijke verbanden tussen bedrijfstype en investeringsniveau geeft aan dat er geen betekenisvol verband is tussen deze twee variabelen. Dit is tegengesteld aan de verwachtingen en wordt veroorzaakt door een aantal grotere chrysantenbedrijven/ veilingtelers die onder bedrijfstype B1 vallen.

Er blijkt geen betekenisvol verband te zijn tussen investeringsniveau en gerealiseerde brutomarge 2006. Hogere investeringen van bedrijven blijken bij de glassnijbloemen niet (direct) tot hogere resultaten te leiden.

6.5 Bedrijfs- en marktkarakteristieken sectoren glastuinbouw 2006-2008

De centrale vraag van het onderzoek is of verschillen in marktstructuur van de sectoren en marktgedrag van de grootste afzetorganisaties en de glastuinbouwbedrijven betekenisvolle verschillen in marktresultaten opleveren. 


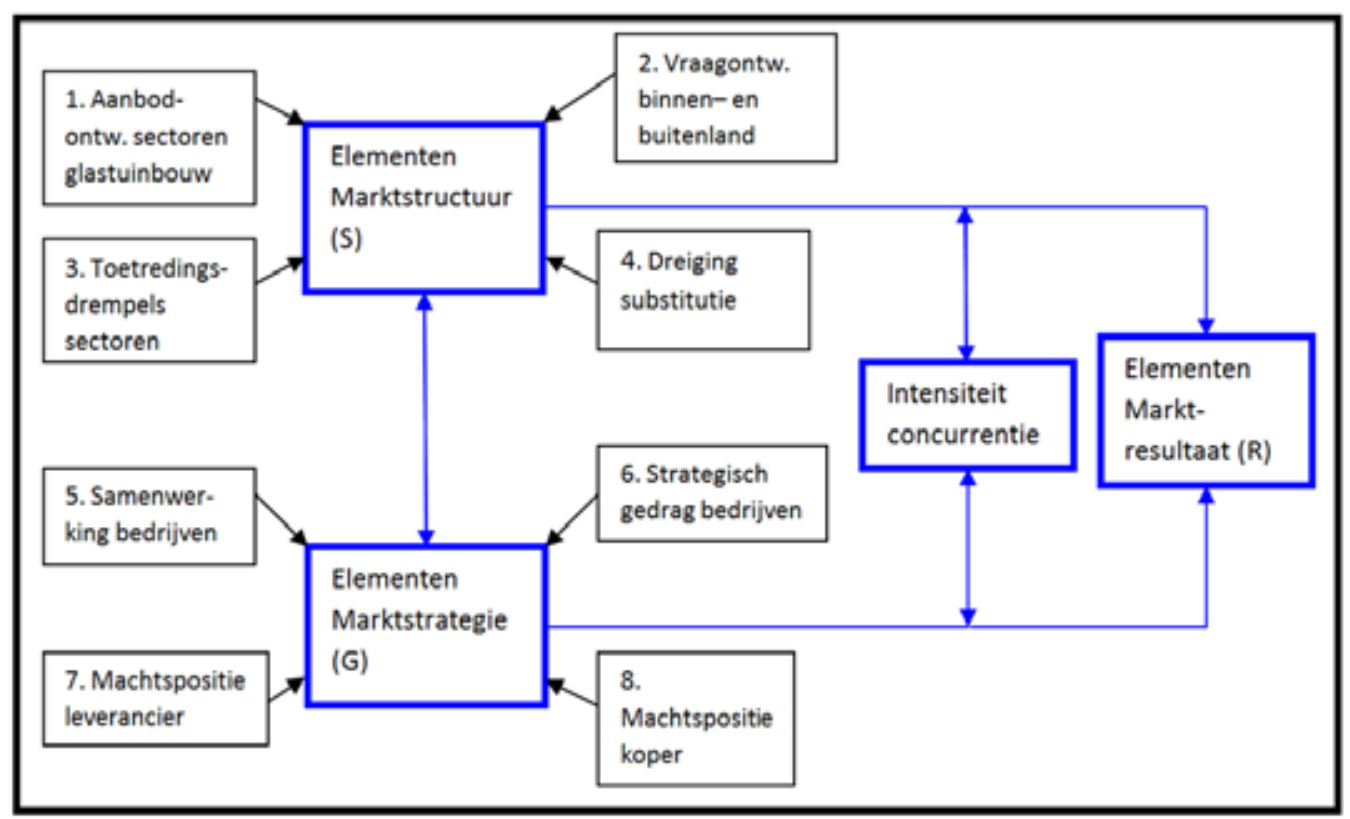

Figuur 1.1 Conceptueel model: concurrentie, concentratie en rentabiliteit sectoren glastuinbouw in Nederland

Het bovenstaande conceptueel model (figuur 1.1 in hoofdstuk 1) en het analysemodel in hoofdstuk 2 (figuur 2.4) geven aan welke bedrijfs- en marktgegevens nodig zijn om de relevante variabelen van marktstructuur, -gedrag en -resultaat per sector in kaart te brengen en mogelijke verbanden te toetsen. Onderstaande tabel 6.41 geeft een overzicht van de belangrijkste gegevens 2006-2008 van marktstructuur en marktresultaten in de drie sectoren glastuinbouw (S en R). Deze gegevens komen grotendeels voort uit het sectoronderzoek (H 3 ) en het onderzoek afzetorganisaties ( $\mathrm{H} 4)$. Tabel 6.42 geeft een overzicht van gegevens betreffende het marktgedrag en de marktresultaten ( $\mathrm{G}$ en $\mathrm{R}$ ) uit het bedrijfsonderzoek glasgroenten met ernaast de gegevens van de glassnijbloemen. In hoofdstuk 7 volgen de gegevens uit het bedrijfsonderzoek glaspotplanten. Het bedrijfsonderzoek is gehouden in 2006, 2007 en 2008 en de onderzoeksuitkomsten per sector staan los van elkaar. Mogelijke verbanden tussen marktstructuur, marktgedrag en marktresultaat worden per sector onderzocht. Om een indruk te krijgen van de verschillen tussen de sectoren worden bedrijfs- en marktkarakteristieken naast elkaar geplaatst. 
Tabel 6.41 Onderzoeksresultaten sector, afzetorganisaties en producenten marktstructuur en marktresultaat sectoren glastuinbouw 2006-2008

\begin{tabular}{|c|c|c|c|}
\hline $\begin{array}{l}\text { Bedrijfs- en markt- } \\
\text { karakteristieken sector } \\
\text { (mesoniveau) }\end{array}$ & $\begin{array}{l}\text { Sector glasgroenten }(A) \\
\text { Onderzoek } 2006 \\
-N=2000 ; 4500 \text { ha. }\end{array}$ & $\begin{array}{l}\text { Sector glassnijbloemen (B) } \\
\text { Onderzoek } 2007 \\
-\mathrm{N}=2600 ; 3000 \text { ha. }\end{array}$ & $\begin{array}{l}\text { Sector glaspotplanten }(C) \\
\text { Onderzoek } 2008 \\
-\mathrm{N}=1000 ; 1431 \text { ha. }\end{array}$ \\
\hline $\begin{array}{l}\text { Omvang actuele markt (Ma) } \\
-2006 \\
-2007 \\
-2008 \\
(\text { met groei in \%) }\end{array}$ & $\begin{array}{l}\text { - productiewaarde }(x \in 1 \mathrm{mln} .) \\
\text {-2006: } 1.350(+1 \%) \\
-2007: 1.340(-1 \%) \\
-2008: 1.270(-5 \%)\end{array}$ & $\begin{array}{ll}\text { - productiewaarde }(\mathrm{x} \in 1 \mathrm{mln} .) \\
-2006: & 2.277(+3 \%) \\
-2007: & 2.294(+1 \%) \\
-2008: & 2.158(-6 \%)\end{array}$ & $\begin{array}{l}\text { - productiewaarde }(\mathrm{x} \in 1 \mathrm{mln} .) \\
-2006: 1.624(+7 \%) \\
-2007: 1.768(+9 \%) \\
-2008: 1.847(+5 \%)\end{array}$ \\
\hline $\begin{array}{l}\text { Omvang relevante markt }(\mathrm{Mr}) \text { - } \\
2006 \\
(+ \text { groei })\end{array}$ & $\begin{array}{l}\text { - productiewaarde }(x \in 1 \mathrm{mln} .) \\
\text {-2006: } 1.350(x \in 1 \mathrm{mln} .) \\
(+0 \mathrm{mln} .)\end{array}$ & $\begin{array}{l}\text { - productiewaarde }(\mathrm{x} \in 1 \mathrm{mln} .) \\
\text {-2006: } 2.327(\mathrm{x} \in 1 \mathrm{mln} .) \\
\text { (+ ca. } 50 \mathrm{mln} .)\end{array}$ & $\begin{array}{l}\text { - productiewaarde }(\mathrm{x} \in 1 \mathrm{mln} .) \\
\text {-2006: } 1.754(\mathrm{x} \in 1 \mathrm{mln} .) \\
(+ \text { ca. } 130 \mathrm{mln} .)\end{array}$ \\
\hline Verzadigingsgraad V (Ma/Mr) & $-1.350 / 1.350=1.0$ & $-2.277 / 2.327=0.98$ & $-1.624 / 1.754=0.93$ \\
\hline $\begin{array}{l}\text { Aantal producenten } \\
\text { horizontale concentratie**) }\end{array}$ & $\begin{array}{l}-\mathrm{N}=2000(2006) \\
-2006: \mathrm{C} 45 \% \\
-2008: \mathrm{C} 46.5 \%\end{array}$ & $\begin{array}{l}-\mathrm{N}=2600(2007) \\
-2007: \mathrm{C} 4 \quad 5.5 \% \\
-2008: \mathrm{C} 4 \quad 7 \%\end{array}$ & $\begin{array}{l}-\mathrm{N}=1000(2008) \\
-2007: \mathrm{C} 4 \quad 6.5 \% \\
-2008: \mathrm{C} 4 \quad 6.5 \%\end{array}$ \\
\hline $\begin{array}{l}\text { Aantal afzetorganisaties } \\
\text { horizontale concentratie }\end{array}$ & $\begin{array}{l}-10-15 \text { (VTN/ZON/Telersver.) } \\
-2006: \text { C4 72\% } \\
-2008: \text { C4 } 66 \%\end{array}$ & $\begin{array}{l}-2(\mathrm{FH} / \mathrm{Plantion}) \\
-2007: \mathrm{C} 2100 \%\end{array}$ & $\begin{array}{l}-2(\mathrm{FH} / \mathrm{Plantion}) \\
-2008: \mathrm{C} 2100 \%\end{array}$ \\
\hline $\begin{array}{l}\text { Aantal grooth./exp./imp. } \\
\text { horizontale concentratie**) }\end{array}$ & $\begin{array}{l}-1110 \\
-2006: C 10 \quad 72 \% \\
-2008: C 10 \quad 67 \%\end{array}$ & $\begin{array}{l}\text {-ca. } 700 \\
-2007: \text { C8 } 58 \% \\
-2008: \text { C } 859 \% \\
\end{array}$ & $\begin{array}{l}\text {-ca. } 300 \\
\text {-2008: C8 } 59 \% \\
\text {-2009: C8 } 60 \%\end{array}$ \\
\hline $\begin{array}{l}\text { Gem. gewogen jaarprijzen alle } \\
\text { producten (eurocent per kg of } \\
\text { st.) }\end{array}$ & $\begin{array}{l}\text {-2006: } 97 \mathrm{ct} \\
-2007: 103 \mathrm{ct} \\
-2008: 101 \mathrm{ct} .\end{array}$ & $\begin{array}{l}-2006: 22 \mathrm{ct} \\
-2007: 23 \mathrm{ct} \\
-2008: \quad 22 \mathrm{ct} .\end{array}$ & $\begin{array}{l}-2006: 117 \mathrm{ct} . \\
-2007: 127 \mathrm{ct} . \\
-2008: 129 \mathrm{ct} .\end{array}$ \\
\hline Exportwaarde $(x \in 1 \mathrm{mln}) *)$. & $\begin{array}{l}-2006: 3.420 \\
-2007: 3.620 \\
-2008: 3.718 \\
\end{array}$ & $\begin{array}{l}-2006: 3.237 \\
-2007: 3.373 \\
-2008: 3.243 \\
\end{array}$ & $\begin{array}{l}-2006: 1.777 \\
-2007: 1.858 \\
-2008: 1.854 \\
\end{array}$ \\
\hline Exportaandeel $*$ ) & $\begin{array}{l}-2006: 68 \% \text { (glas)groenten } \\
-2007: 68 \% \\
-2008: 70 \%\end{array}$ & $\begin{array}{l}-2006: 88 \% \text { (glas)snijbloemen } \\
-2007: 90 \% \\
-2008: 87 \%\end{array}$ & $\begin{array}{l}\text {-2006: } 73 \% \text { (glas) potplanten } \\
-2007: 70 \% \\
-2008: 66 \%\end{array}$ \\
\hline Importwaarde (x $€ 1$ mln.) $*)$ & $\begin{array}{l}\text {-2006: } 1.000 \text { (schatting) } \\
-2007: 1.000 \text { (schatting) } \\
-2008: \quad 985 \\
\end{array}$ & $\begin{array}{l}-2006: 664 \\
-2007: 702 \\
-2008: 827 \\
\end{array}$ & $\begin{array}{ll}-2006: & 318 \\
-2007: & 348 \\
-2008: & 379 \\
\end{array}$ \\
\hline Importaandeel *) & $\begin{array}{ll}-2006: & 18 \% \text { (glas)groenten } \\
-2007: & 18 \% \\
-2008: & 11 \%\end{array}$ & $\begin{array}{l}-2006: 23 \% \text { (glas)snijbloemen } \\
-2007: 23 \% \\
-2008: 28 \%\end{array}$ & $\begin{array}{l}\text {-2006: } 16 \% \text { (glas)potplanten } \\
-2007: 17 \% \\
-2008: 17 \%\end{array}$ \\
\hline Markttoetreding & $\begin{array}{l}\text {-deels open/deels gesloten } \\
(70 / 30)\end{array}$ & -open & -open \\
\hline $\begin{array}{l}\text { Verticale concentratie } \\
\text { afzetorganisatie/veilingen }\end{array}$ & $\begin{array}{l}\text {-VTN/The Greenery en ZON: } \\
\text { ca. } 30 \%\end{array}$ & -nihil & -nihil \\
\hline $\begin{array}{l}\text { Structurele concentratie } * * *) \\
\text { producenten }(\mathrm{Cx}=\text { Oopt./M r) }\end{array}$ & $\begin{array}{l}-2.5 \mathrm{mln} . / 1.350 \mathrm{mln} .= \\
1 / 540 \text { (gem. omzet: zie H5) }\end{array}$ & $\begin{array}{l}-2.6 \mathrm{mln} . / 2.327 \mathrm{mln} .= \\
1 / 895 \text { (gem. omzet: zie H6) }\end{array}$ & $\begin{array}{l}-4.9 \mathrm{mln} . / 1.750 \mathrm{mln} .= \\
1 / 350 \text { (gem. omzet: zie H7) }\end{array}$ \\
\hline $\begin{array}{l}\text { Feitelijke concentratie } \\
\text { producenten }\end{array}$ & $-1 / 2000$ & $-1 / 2600$ & $-1 / 1000$ \\
\hline
\end{tabular}

*) export- en importwaarden groenten, snijbloemen en potplanten betreffen verse producten onder glas en uit de volle grond; **) $\mathrm{C} 4=$ Concentratiegraad van de vier grootste bedrijven $=$ het aandeel in bedrijfsoppervlakte of omzet van deze bedrijven in het totaal, $\mathrm{C} 10=$ Concentratiegraad tien grootste bedrijven etc. ; $* * *)$ de structurele concentratie $\left(\mathrm{C}_{\mathrm{x}}\right)$ is de verhouding gemiddelde (optimale) ondernemingsomvang $(\mathrm{O})$ en de relevante marktomvang $\left(\mathrm{M}_{\mathrm{r}}\right)$. 
Tabel 6.42 Onderzoeksresultaten sector- en bedrijfsonderzoek marktgedrag en marktresultaat sector glasgroenten en -snijbloemen 2006-2008

\begin{tabular}{|c|c|c|c|}
\hline $\begin{array}{l}\text { Bedrijfs- en markt- } \\
\text { karakteristieken sectoren } \\
\text { (microniveau) }\end{array}$ & $\begin{array}{l}\text { Sector glasgroenten }(A) \\
\text { Onderzoek } 2006 \\
-\mathrm{N}=2000 ; 4500 \text { ha. } \\
-\mathrm{n}=42 ; 244 \text { ha. } \\
\text {-tomaat/paprika }\end{array}$ & $\begin{array}{l}\text { Sector glassnijbloemen (B) } \\
\text { Onderzoek } 2007 \\
-\mathrm{N}=2600 ; 3000 \text { ha. } \\
\text {-n=44; } 149 \text { ha. } \\
\text {-roos/chrysant }\end{array}$ & $\begin{array}{l}\text { Sector glaspotplanten }(\mathrm{C}) \\
\text { Onderzoek } 2008 \\
-\mathrm{N}=1000 ; 1431 \text { ha. } \\
\text { (Onderzoeksresultaten: zie } \\
\text { Hoofdstuk 7) }\end{array}$ \\
\hline Gem. leeftijd bedrijf & -13 jaar & -11 jaar & \\
\hline $\begin{array}{l}\text { Bedrijfstypen } 1 \mathrm{t} / \mathrm{m} 4 \text {, } \\
\text { aandelen absoluut en relatief }\end{array}$ & $\begin{array}{lrr}-A 1 & 14 & 33 \\
-A 2 & 12 & 29 \\
-A 3 & 4 & 10 \\
-A 4 & 12 & \underline{28} \\
\text { tot. } & \frac{42}{100} \%\end{array}$ & $\begin{array}{lrr}-B 1 & 24 & 56 \\
-B 2 & 18 & 40 \\
-B 1,3 & 2 & 4 \\
-B 4 & & \\
\text { tot. } & \overline{44} & \overline{100} \%\end{array}$ & \\
\hline $\begin{array}{l}\text { Bedrijfsomvang in opp. glas } \\
\text { (gem. met minimum en } \\
\text { maximum in ha.) }\end{array}$ & $\begin{array}{lr}\text {-gem. } & 5.8 \\
\text {-min. } & 0.8 \\
\text {-max. } & 34.0\end{array}$ & $\begin{array}{lr}\text {-gem. } & 3.4 \\
\text {-min. } & 0.6 \\
\text {-max. } & 13.0\end{array}$ & \\
\hline $\begin{array}{l}\text { Bedrijfsomvang in omzet } \\
2006 \text { met minimum en } \\
\text { maximum ( } € \text { x } 1 \mathrm{mln} .)\end{array}$ & $\begin{array}{lr}\text {-gem. } & 2.5 \\
\text {-min. } & 0.3 \\
\text {-max. } & 16.0\end{array}$ & $\begin{array}{lr}\text {-gem. } & 2.6 \\
\text {-min. } & 0.2 \\
\text {-max. } & 15.0\end{array}$ & \\
\hline $\begin{array}{l}\text { Brutomarge[( Prijs - GTK) } \\
\text { /Prijs] x 100) met minimum en } \\
\text { maximum }\end{array}$ & $\begin{array}{lr}\text {-gem. } & 8.0 \\
\text {-min. } & -33.3 \\
\text {-max. } & 26.6\end{array}$ & $\begin{array}{ll}\text {-gem. } & 11.0 \\
-\min . & -5.5 \\
-\max . & 39.1\end{array}$ & \\
\hline $\begin{array}{l}\text { Brutomarge [( Prijs - } \\
\text { GTK)/Prijs] x 100) } \\
\text { per bedrijfstype in } 2006\end{array}$ & $\begin{array}{lr}\text {-A1 } & 4.5 \\
\text {-A2 } & 9.1 \\
\text {-A3 } & 11.2 \\
\text {-A4 } & 9.8\end{array}$ & $\begin{array}{lr}\text {-B1 } & 12.4 \\
-\mathrm{B} 2 & 9.6 \\
-\mathrm{B} 3 & \\
-\mathrm{B} 4 & \end{array}$ & \\
\hline $\begin{array}{l}\text { Solvabiliteit(EV/TV*100) } \\
\text {-per sector en per bedrijfstype }\end{array}$ & $\begin{array}{ll}\text {-sector } & 49.8 \\
\text {-A1 } & 58.5 \\
\text {-A2 } & 40.9 \\
\text {-A3 } & 54.3 \\
\text {-A4 } & 46.0\end{array}$ & $\begin{array}{ll}\text {-sector } & 44.0 \\
-\mathrm{B} 1 & 52.0 \\
-\mathrm{B} 2 & 33.0 \\
-\mathrm{B} 1,3 & 60.0 \\
-\mathrm{B} 4 & \end{array}$ & \\
\hline $\begin{array}{l}\text { Afzetorganisaties: aandeel in } \\
\% \text { totaal respondenten }\end{array}$ & $\begin{array}{ll}\text {-VTN } & 40 \\
\text {-ZON } & 16 \\
\text {-Eigen Verkoop } & 14 \\
\text {-Telersvereniging } & 30 \\
\end{array}$ & $\begin{array}{l}-2(\mathrm{FH} / \text { Plantion }) \\
-2007: \mathrm{C} 2100 \%\end{array}$ & \\
\hline $\begin{array}{l}\text { Eigen Verkoop: aandeel in \% } \\
\text { totaal respondenten }\end{array}$ & $\begin{array}{l}\text {-Via telersver. } 30 \%+\text { E.V. } \\
0-<15 \% \text {. }\end{array}$ & $\begin{array}{l}\text { - Via telersver. } 30 \%+ \\
\text { E.V. } 0-<5 \% \text { (melding FH) }\end{array}$ & \\
\hline $\begin{array}{l}\text { Veilingprovisie in \% omzet }+ \\
\text { min./max. }\end{array}$ & $\begin{array}{ll}\text {-gem. } & 3.0 \\
\text {-min. } & 0.5 \\
\text {-max. } & 5.5\end{array}$ & $\begin{array}{lr}\text {-gem. } & 6.0 \\
\text {-min. } & 3.0 \\
\text {-max. } & 10.0\end{array}$ & \\
\hline $\begin{array}{l}\text { Eigen Verkoop (kosten) } \\
\text { In } \% \text { omzet }+ \text { min. } / \text { max. }\end{array}$ & $\begin{array}{ll}\text {-gem. } & 3.0 \\
\text {-min. } & 0.5 \\
\text {-max. } & 5.5\end{array}$ & $\begin{array}{ll}\text {-gem. } & 0.9 \\
\text {-min. } & 0.1 \\
\text {-max. } & 4.0\end{array}$ & \\
\hline $\begin{array}{l}\text { Verkoopmethode: aandeel in } \\
\% \text { totaal respondenten }\end{array}$ & $\begin{array}{ll}\text {-BB } & 64 \\
\text {-Telersver. } & 24 \\
-E V & 12\end{array}$ & $\begin{array}{ll}\text {-Klok } & 25 \\
- \text { Klok/BB } & 64 \\
-\mathrm{EV} & 11\end{array}$ & \\
\hline $\begin{array}{l}\text { Marktontwikkeling } \\
\text { (\% jaarlijkse groei) }\end{array}$ & $\begin{array}{l}-05 / 06:+1-2 \% \\
-06 / 07:-1-2 \% \\
-07 / 08:-5-6 \%\end{array}$ & $\begin{array}{ll}-05 / 06: & +3 \% \\
-06 / 07: & +1 \% \\
-07 / 08: & -6 \%\end{array}$ & \\
\hline $\begin{array}{l}\text { Prijsvorming } \\
\text { (opinie telers) }\end{array}$ & $\begin{array}{l}\text {-2005/2006: } \\
\text {-matig }(60 \%) \\
\text {-goed }(26 \%)\end{array}$ & $\begin{array}{l}\text {-2006/2007: } \\
\text {-matig }(60 \%) \\
\text {-goed }(34 \%)\end{array}$ & \\
\hline $\begin{array}{l}\text { prijsontwikkeling min/max } \\
\text { (eurocent per kg/st.) } \\
\text { (gem. gew. jaarprijzen) }\end{array}$ & $\begin{array}{lc}\text {-periode } & 2003 \\
\text {-tomaat } & 2006: \\
\text {-paprika } & 90-97 \\
\text { (onstabiele ontwikkeling) }\end{array}$ & $\begin{array}{lr}\text {-periode } & 2003-2008: \\
\text {-roos } & 37-41 \\
\text {-chrysant } & 25-27 \\
\text { (stabiele ontwikkeling) }\end{array}$ & \\
\hline $\begin{array}{l}\text { Tevredenheid over } \\
\text { afzetorganisatie }\end{array}$ & $\begin{array}{c}-55 \% \text { tevreden } / \text { z. tevr. } \\
-33 \% \text { tevreden/ontevr. } \\
-12 \% \text { ontevreden/zeer } \\
\text { ontevreden }\end{array}$ & $\begin{array}{l}-75 \% \text { tevreden } \\
-25 \% \text { tevreden/ontevreden }\end{array}$ & \\
\hline
\end{tabular}


BEDRIJFSONDERZOEK GLASTUINBOUW IN NEDERLAND, DEELSECTOR GLASPOTPLANTEN 



\subsection{Inleiding}

Dit hoofdstuk behandelt het bedrijfsonderzoek glaspotplanten. Ook hier is de onderzoeksvraag gericht op het achterhalen van betekenisvolle verbanden tussen de onderscheiden variabelen van marktgedrag, marktresultaat en marktstructuur van de producenten in deze sector (zie hoofdstuk 2,5 en 6 en het analysemodel van figuur 2.4). In hoofdstuk 8 volgt de meervoudige econometrische analyse van de drie sectoren. Het plan van aanpak en de gehanteerde vragenlijst is qua opzet grotendeels gelijk aan dat van de sector glasgroenten en -snijbloemen (zie appendix 7A voor de verschillen). Hetzelfde geldt voor de praktische uitvoering van het onderzoek dat hierna wordt beschreven.

\subsection{Methode bedrijfsonderzoek glaspotplanten}

Doel van het onderzoek is het verkrijgen van voldoende betrouwbare en representatieve informatie van de glastuinbouwbedrijven in de deelsector, ter beantwoording van de in hoofdstuk 2 paragraaf 2.6.2 genoemde onderzoeksvragen op micro- en mesoniveau. Het bedrijfsonderzoek glaspotplanten is uitgevoerd in 2008, met een deelrapportage in mei 2009.

\section{Onderzoekspopulatie}

In de sector potplanten zijn in totaal ongeveer 80 glastuinders van groene en bloeiende planten benaderd (respons 50\%) vanuit een adressenbestand van LTO Groeiservice. Deze telers waren verspreid over de glastuinbouwgebieden Westland, Oostland e.o., Leiden e.o. en de regio Aalsmeer. De ondernemers zijn bezocht en ondervraagd aan de hand van de eerder toegestuurde vragenlijst. Deze vragenlijst is grotendeels vergelijkbaar met die van de sector snijbloemen behalve het verschil in productsoorten (zie appendix 6A en 7A). Er zijn 44 vraaggesprekken gehouden met 21 groene potplantentelers en 23 bloeiende potplantentelers. De beantwoording van de vragen is meestal goed verlopen. Soms bleef men het antwoord schuldig of werd een schatting genoemd. De resultaten worden in volgorde van de gevraagde onderdelen van de vragenlijst weergegeven. In appendix 7B volgt een overzicht van de omvang en ontwikkeling van de populatie bedrijven in Nederland. Hier wordt ook de omvang en verhouding van de steekproefelementen ten opzichte van de populatie gegeven.

\section{Steekproefomvang en representativiteit}

De steekproefomvang is vastgesteld op basis van de populatieontwikkeling glastuinbouwbedrijven en afzetorganisaties in de sector potplanten voor de twee belangrijkste groepen, de groene en de bloeiende planten. Deze gekozen steekproef is beoordeeld op betrouwbaarheid en representativiteit (zie appendix 7B). Het aandeel van het aantal respondenten van het onderzoek ten opzichte van het totaal aantal bedrijven bedraagt 4.4\% (44 van de ca. 1000 bedrijven). Het totale areaal van de 44 onderzochte bedrijven bedraagt 185 ha. en heeft een aandeel in het totale areaal glaspotplanten in Nederland (2008) van bijna 13\% (185 ha. ten opzichte van 1431 ha.). Wanneer 
we de geografische verdeling van het areaal over de regio's in Nederland bezien, ligt bijna $80 \%$ van het areaal in het Westen van Nederland, in de provincies Noord-Holland en Zuid-Holland met clusters rondom de bloemenveilingen in het Westland, Oostland en Aalsmeer. De steekproef is getrokken uit het ledenbestand potplantentelers van LTO Groeiservice waarvan ongeveer $80 \%$ woonachtig is in deze gebieden. Gezien het grote aandeel in het totale areaal en aantal potplantenbedrijven en de genoemde clustervorming, is het bedrijfsonderzoek gericht op respondenten in het Westen van Nederland. Gezien de beperkte omvang van de steekproef en de niet geheel representatieve verdeling van de respondenten over de verschillende productiegebieden (zie tabellen 1.3 en 1.4 in appendix 7B) dienen de resultaten van het onderzoek met enige voorzichtigheid te worden gehanteerd.

\section{Onderzoeksuitkomsten}

In paragraaf 7.3 worden de onderzoeksresultaten van het bedrijfsonderzoek glaspotplanten behandeld, in volgorde van de vragen in de vragenlijst (appendix 7A). Aan de hand van een aantal frequentietabellen worden de belangrijkste bedrijfskundige en financieel-economische kenmerken van de bedrijven per sector, per productgroep en per bedrijfstype beschreven. Daarna worden de met behulp van de chi-kwadraatanalyse getoetste enkelvoudige verbanden tussen de gedrags- en resultaatsvariabelen besproken en wordt een overzicht gegeven van die variabelen die een betekenisvol of een opvallend niet-betekenisvol verband laten zien. Met deze onderzoeksuitkomsten dienen de in hoofdstuk 2 geformuleerde vragen op micro- en mesoniveau te worden beantwoord. Een overzicht van deze kruistabellen en de toelichting hierop staan in appendix 7C.

\subsection{Analyse en resultaten glaspotplantenbedrijven}

In paragraaf 7.3.1 wordt de analyse van de gedrags- en resultaatsvariabelen besproken, in paragraaf 7.3.2 volgt de analyse van de structuur- en resultaatsvariabelen.

\subsubsection{Analyse gedrags- en resultaatsvariabelen (microniveau)}

Hieronder worden de belangrijkste gedrags- en resultaatsvariabelen uit het bedrijfsonderzoek van de sector glaspotplanten besproken (Veerman, 2009). Zoals gezegd komen deze in volgorde van sector, productgroepen en bedrijfstypen aan bod en worden de mogelijke verbanden tussen de genoemde variabelen daarna behandeld.

\subsubsection{Onderzoeksresultaten glaspotplanten (sector)}

Het vraaggesprek en de vragenlijst van het bedrijfsonderzoek (zie appendix 7A) is ingedeeld naar algemene bedrijfskenmerken, de organisatie van marketing- en verkoopactiviteiten, prijsvorming, effectiviteit en efficiëntie van de marketing- en verkoopstrategie en sectorale ontwikkelingen. We behandelen de belangrijkste onderzoeksresultaten in deze volgorde. 


\section{Kenmerken bedrijf en sector}

Evenals in de glassnijbloemen is bij de glaspotplanten de bedrijfsoppervlakte glas in ha. een belangrijk kenmerk voor de te realiseren jaarlijkse omzet en winst. Er is sprake van een toename van de gemiddelde bedrijfsomvang en een grote variatie in omvang en resultaat van de onderzochte bedrijven. De populatie ligt in 2008 op ruim 1000 bedrijven en een gemiddelde oppervlakte van 1.4 ha. De onderzoeksuitkomsten (zie tabel 7.1) geven aan dat er kleine en grote bedrijven actief zijn. Van de 44 onderzochte bedrijven is de gemiddelde bedrijfsomvang 4.2 ha. met een spreiding van 0.2 ha. tot 25 ha. De gemiddelde omzet in 2006 is $€ 4.9 \mathrm{mln}$. met een spreiding van $€ 0.3 \mathrm{mln}$. tot $€ 35 \mathrm{mln}$. In 2007 lag de gemiddelde omzet op $€ 5.3 \mathrm{mln}$. met eenzelfde spreiding als in 2006. De brutomarges begroot en gerealiseerd voor de 44 respondenten zijn gelijk en komen gemiddeld uit op 8.6\% met eveneens een grote spreiding. Het aandeel eigen vermogen in procenten van het totaal ligt in 2006 op 42.3\% (14 respondenten). Van de vier typeringen glaspotplantenbedrijf valt $57 \%$ onder het type $\mathrm{C} 1$, veilingteler met kleinschalige afzet via de veilingorganisatie met tevens in meerderheid een zelfstandige eigen verkoop (EV). Bijna 40\% valt onder het type $\mathrm{C} 2$, veilingteler met grootschaliger afzet via de veiling, met in telersverenigingsverband de eigen verkoop, soms zelfstandig. Twee C1-bedrijven uit de steekproef (3 - 4\%) vallen gedeeltelijk onder het type $\mathrm{C} 3$ resp. $\mathrm{C} 4$ met eigen afzet rechtstreeks aan een handelsorganisatie. Van de bedrijven is ruim de helft opgericht in 1991 of eerder. Het oudste bedrijf dateert van 1970, het jongste van 2008. De gemiddelde bedrijfsleeftijd is 17 jaar.

Tabel 7.1 Kenmerken bedrijven sector glaspotplanten (groen en bloeiend)

\begin{tabular}{|c|c|c|c|c|c|c|}
\hline$(n)=44$ & $\begin{array}{l}\text { Bedrijfs- } \\
\text { opp. glas } \\
2006 \\
\text { In ha. }\end{array}$ & $\begin{array}{l}\text { Omzet } \\
2006 \\
(x \in 1 \\
\text { mln.) }\end{array}$ & $\begin{array}{l}\text { Omzet } \\
2007 \\
(x € 1 \\
\text { mln. })\end{array}$ & $\begin{array}{l}\text { Brutomarge } \\
\text { begroot } 2006 \\
{[(\mathrm{P}-\mathrm{GTK}) / \mathrm{P}]} \\
* 100 ; \mathrm{n}=41\end{array}$ & $\begin{array}{l}\text { Brutomarge } \\
\text { realisatie } 2006 \\
{[(\mathrm{P}-\mathrm{GTK}) / \mathrm{P}]} \\
* 100 ; \mathrm{n}=41\end{array}$ & $\begin{array}{l}\text { Aandeel eigen } \\
\text { verm. } 2006 \\
(\mathrm{EV} / \mathrm{TV}) \\
* 100) ; \mathrm{n}=14\end{array}$ \\
\hline Gemiddelde & 4.2 ha. & 4.9 & 5.3 & $8.6 \%$ & $8.6 \%$ & $42.3 \%$ \\
\hline Standaardfout gem. (s.e.) & 0.7 ha. & 0.7 & 0.8 & $1.3 \%$ & $0.9 \%$ & $7.0 \%$ \\
\hline Standaardafwijking (s) & 4.5 ha. & 6.4 & 6.8 & $8.0 \%$ & $5.8 \%$ & $26.0 \%$ \\
\hline Minimum & 0.2 ha. & 0.3 & 0.3 & $-5.0 \%$ & $-5.5 \%$ & $10.0 \%$ \\
\hline Maximum & 25.0 ha. & 35.0 & 35.0 & $22.5 \%$ & $24.1 \%$ & $100.0 \%$ \\
\hline Spreiding & 24.8 ha. & 34.7 & 34.7 & $37.5 \%$ & $29.6 \%$ & $90.0 \%$ \\
\hline Scheefheid/standaardfout & & & & & & \\
\hline
\end{tabular}

$[(\mathrm{P}-\mathrm{GTK}) / \mathrm{P}] * 100=[(\text { prijs-gem. totale kosten }) / \text { prijs }]^{*} 100 ; \mathrm{s}=\sqrt{ } \sum\left(\mathrm{x}_{\mathrm{i}}-\overline{\mathrm{X}}\right)^{2} / \mathrm{n}-1 ;$ s.e. $=\mathrm{s} / \sqrt{ } \mathrm{n}$

\section{Marketing en verkoop}

De belangrijkste vragen betreffen de keuze van de marketing- en verkooporganisatie, de omvang van het verkoopapparaat en de -kosten en de mate van tevredenheid hierover. De onderzoeksresultaten worden hieronder behandeld.

\section{Organisatie marketing en verkoop}

De 44 onderzochte potplantenbedrijven zijn aangesloten bij FloraHolland te Naaldwijk met vestigingen in Aalsmeer, Bleiswijk, Rijnsburg, Eelde en Venlo. Evenals bij de snijbloemen zet een klein aantal grote bedrijven zijn producten af op meerdere veilpunten, in overleg met het management. Bijna 89\% van de respondenten (tabel 7.2) heeft naast de veiling als verkooporgani- 
satie tevens een eigen verkoper of een verkoper in samenwerking met collega-bedrijven. 11\% laat de verkoop volledig over aan de veiling (klok en/of bemiddeling). Ruim 36\% van de respondenten werkt samen in een met behulp van de veiling opgerichte telersvereniging en probeert via een of meer door de vereniging aangetrokken verkoopfunctionarissen de eigen afzet extra te stimuleren. Slechts een enkel groot bedrijf heeft met medeweten van de veiling een eigen afzetbv opgericht die voor een deel rechtstreeks met de groothandel/export en het grootwinkelbedrijf zaken doet, ook in aan potplanten verwante producten.

Tabel 7.2 Organisatie marketing en verkoop van de onderzochte bedrijven

\begin{tabular}{|l|r|r|}
\hline Organisatie van de afzet via: & Aantal bedrijven & \multicolumn{1}{|c|}{ Aandeel in \% } \\
\hline FloraHolland veilen/bemiddelen & 5 & 11.4 \\
\hline FloraHolland + telersvereniging (EV) & 16 & 36.4 \\
\hline FloraHolland + eigen verkoop (EV) & 23 & 52.2 \\
\hline Totaal & 44 & 100.0 \\
\hline
\end{tabular}

\section{Omvang verkoopapparaat en -kosten}

FloraHolland heeft door de grote omvang van het brede en diepe aangevoerde assortiment bloemen en planten een groot verkoopapparaat (bemiddelingsbureau FloraHolland Connect). Dit is bij de individuele bedrijven en de in samenwerking met de veiling opgezette telersverenigingen veel kleiner. $75 \%$ van de respondenten besteedt aan de eigen verkoop tussen de $0<2$ personen, bijna $16 \%$ heeft hiervoor tussen de $3<5$ personen beschikbaar en 3 respondenten $(7 \%)$ hebben meer dan 5 personen. $89 \%$ van de respondenten kan zowel over het uitgebreide verkoopapparaat van de veiling beschikken als over de eigen verkoper, in dienst van het bedrijf of de coöperatieve telersvereniging. De meest genoemde argumenten om voor een bepaalde verkooporganisatie te kiezen zijn H. Historisch zo gegroeid (31 van de 44), E. Betrouwbare partner om mee samen te werken $(20 \mathrm{x})$ en D. Stevige positie in de markt $(14 \mathrm{x})$.

De via de veiling betaalde provisie, gemeten als percentage van de omzet bedraagt gemiddeld $6.7 \%$ en varieert tussen de 3 en $12 \%$ (tabel 7.3 ). De ene helft van de respondenten geeft een percentage van $3.1<6.5 \%$ op en de andere helft zit op $6.5 \%$ of meer. Een en ander is afhankelijk van de bedrijfsomzet en de diensten die de veiling biedt. Van de 44 onderzochte bedrijven gaat het in ruim $80 \%$ van de gevallen om verkopen, opslag en verzending. Deze bedrijven doen het sorteren en verpakken zelf, als dat nodig is. Bijna 16\% maakt alleen gebruik van verkopen en

Tabel 7.3 Gemiddelde veilingprovisie en kosten eigen verkoop in \% omzet

\begin{tabular}{|l|c|c|}
\hline$(\mathrm{n})=44$ & $\begin{array}{l}\text { Veilingprovisie } \\
\text { (in \% omzet) }\end{array}$ & $\begin{array}{l}\text { Kosten eigen verkoop } \\
\text { (EV) (in \% omzet) } \\
\mathrm{n}=43\end{array}$ \\
\hline Gemiddelde & 6.7 & 2.2 \\
\hline & & \\
\hline Standaardfout (s.e.) & 0.3 & 0.2 \\
\hline Standaardafwijking (s) & 2.0 & 1.2 \\
\hline Minimum & 3.1 & 0.5 \\
\hline Maximum & 12.0 & 5.0 \\
\hline
\end{tabular}


in bijna 5\% van de gevallen is alleen sprake van administratieve melding van de verkoop. De eigen verkoop $(\mathrm{EV})$, gemeten als percentage van de omzet, bedraagt gemiddeld $2.2 \%$ en varieert tussen de 0.5 en $5 \%$.

3. Mate van tevredenheid over de verkooporganisatie

$50 \%$ van de respondenten is tevreden over de verkooporganisatie, $39 \%$ is tevreden/ontevreden en $9 \%$ ontevreden. Als maatregelen om de tevredenheid te vergroten wordt een actievere opstelling van de verkoper van het bemiddelingsbureau genoemd door ruim $20 \%$ van de respondenten. Andere mogelijke maatregelen zijn het verhogen van collectieve reclame (meer Holland Promotie), het klantgerichter werken en het verbeteren van de informatie en communicatie naar groothandelaren/exporteurs en retail.

\section{Prijsvorming}

Een gemiddelde jaarlijkse uitbetaalprijs boven de gemiddelde kosten is ook in de sector glaspotplanten van groot belang. Evenals in de snijbloemen komt hier veel voor kijken. Product- en assortimentskeuze, kwaliteit en efficiëntie van mensen en middelen, een goede organisatie van de afzet met een gericht marketing- en verkoopbeleid kan per bedrijf heel verschillend worden ingezet en zorgt voor een variatie in resultaten.

De vragen in het bedrijfsonderzoek hierover betreffen:

1. de gekozen verkoopwijze en de hoogte van de jaarlijkse gemiddelde uitbetaalprijzen;

2. de mate van tevredenheid, de verbetermogelijkheden en de vormen van samenwerking;

3. de acties bij lage prijzen en de mening over de in september 2007 gerealiseerde fusie tussen

FloraHolland en de VBA.

1. Verkoopwijze en gemiddelde uitbetaalprijzen

In tabel 7.4 wordt een overzicht gegeven van de door de respondenten gehanteerde verkoopwijzen. De verkoopwijze van de producten vindt voor ruim $18 \%$ plaats via de klok en bemiddeling, voor ruim $43 \%$ via klok, bemiddeling en verkoop door de telersvereniging en voor bijna 39\% via klok, bemiddeling en eigen verkoop. Bij de potplanten varieert de klokverkoop tussen 4 en $80 \%$. De klokverkopen (in omzet) hebben hierbij een gemiddeld aandeel van $31 \%$, het aandeel bemiddeling incl. eigen verkoop in omzet bedraagt 69\%. De klok heeft naast zijn prijsvormende functie ook een belangrijke introductiefunctie voor nieuwe producten. Bijna $82 \%$ van de respondenten heeft naast de veiling (klok en/of bemiddeling) nog de eigen verkoopfunctie ontwikkeld, alleen of in samenwerking met de telersvereniging. De veiling is hiervan in praktisch alle gevallen op de hoogte door de meldingsplicht van de verkopen.

Tabel 7.4 Verkoopwijze producten

\begin{tabular}{|l|r|r|}
\hline & Aantal bedrijven & Aandeel in \% \\
\hline Via klok en bemiddeling & 8 & 18 \\
\hline Via klok, bemiddeling en telersvereniging) & 19 & 43 \\
\hline Via klok, bemiddeling en eigen verkoop) & 17 & 39 \\
\hline Totaal & 44 & 100 \\
\hline
\end{tabular}


Een overzicht van de gemiddelde uitbetaalprijzen voor een aantal potplanten/respondenten (2005-2008) wordt gegeven in de volgende paragraaf (tabellen 7.5 en 7.6) bij de analyse per productsoort. Hier wordt de opgegeven uitbetaalprijs per productsoort en potmaat voor de phalaenopsis nader geanalyseerd (voor andere producten, zie Veerman, 2009).

2. Tevredenheid uitbetaalprijs en verbetermogelijkheden

Bijna $64 \%$ van de respondenten vindt de uitbetaalprijs matig, $18 \%$ slecht en $11 \%$ goed. Op de vraag hoe deze verbeterd zou kunnen worden, worden het meeste genoemd een betere match van vraag en aanbod $(14 \mathrm{x})$ en conceptontwikkeling/innovatie $(13 \mathrm{x}) .5$ respondenten hadden geen idee hoe dit zou kunnen. Ten aanzien van de samenwerking tussen telers, onder andere ten behoeve van een betere prijsvorming, gaf $18 \%$ aan deze samenwerking nog steeds via veiling FloraHolland te zoeken. Ruim 34\% zegt niet samen te werken met anderen en $48 \%$ werkt middels een telersvereniging samen (Decorum Company, Floramotion, Ficus For Ever, Air So Pure, ID Plant, Comfort Plant e.a.).

\section{Acties en mening over fusie bloemenveilingen}

Bij een te laag prijsniveau door overaanbod zoekt ruim 36\% van de respondenten extra afzet via de handelskanalen. Eveneens ruim 36\% kiest voor aanbodbeperking en/of vertragen van de oogst, bijna 7\% kiest voor productontwikkeling en introductie van nieuwe rassen en bijna $14 \%$ kiest voor extra waarde toevoegen resp. kwaliteitsverhoging. De fusie tussen VBAAalsmeer en FloraHolland Naaldwijk wordt door bijna $73 \%$ van de respondenten als goed betiteld, ruim $20 \%$ vindt de fusie matig en $7 \%$ slecht. Zicht op lagere veilingkosten (verkoopkosten en logistiek) en een hogere concentratie van aanbod en vraag liggen aan deze fusie ten grondslag.

Effectiviteit en efficiëntie van de gehanteerde marketing- en verkoopmethoden

\section{- Effectiviteit}

Ruim 52\% van de respondenten vindt directe afzet via eigen verkoop (EV) of verkoop via de telersvereniging de meest effectieve verkoopmethode voor potplanten. 30\% kiest voor verkoop via bemiddelingsbureau in combinatie met eigen verkoop. Ongeveer 14\% kiest voor een combinatie van eigen verkoop en concentratie via bemiddelingsbureau en/of klok. Productontwikkeling en ontwikkeling klantconcept wordt als laatste genoemd.

\section{- Efficiëntie}

Directe levering aan de retail via eigen verkoop (EV) en verkoop via bemiddelingsbureau FloraHolland scoren hier het hoogst met elk 34\% van de respondenten. Concentratie via veilingklok staat op de derde plaats (16\%). Klok en bemiddeling, eventueel met levering van grote partijen, scoort ruim $11 \%$. 
Belangrijke bedrijfs- en sectorontwikkelingen

De onderzoeksuitkomsten laten het volgende zien. Het meest genoemd zijn de vele innovaties en de positieve verwachtingen over markt- en vraagontwikkeling ( 2 x 9 resp.). Een aantal telers noemt naast energiemanagement zaken als optimalisatie van de bedrijfsomvang, toename inkoopmacht grootwinkelbedrijf op de Europese markt, kwaliteitsverhoging Nederlands product, nichemarketing en verkopen via internet.

\subsubsection{Productsoorten}

$\mathrm{Na}$ de onderzoeksuitkomsten op sectorniveau worden nu de resultaten per productsoort toegelicht. Het betreft de vragen over:

1. uitbetaalprijzen 2005-2008

2. bedrijfsoppervlakte in ha. glas 2006

3. omzetontwikkeling 2006/2007

4. brutomarge 2006

5. concentratieontwikkeling (C4) per productsoort.

\section{Ad 1. Uitbetaalprijzen 2005-2008}

Gegeven het brede en vaak unieke assortiment potplanten en potmaten dat wordt geteeld, zijn er per productsoort of producttype geen of weinig zinvolle prijsvergelijkingen tussen de bedrijven te maken. Slechts voor een achttal phalaenopsistelers (tabel 7.5) worden de uitkomsten van de

Tabel 7.5 Gem. uitbetaalprijs per type potplant (phalaenopsis) 2005, 2006, 2007 en 2008(P*)

\begin{tabular}{|c|c|c|c|c|c|}
\hline $\begin{array}{l}\text { Productsoort: } \\
\text { Phalaenopsis }\end{array}$ & $\begin{array}{l}\text { gem. } \\
\text { uitbetaalprijs in } \\
\text { euro p. st. } \\
2005\end{array}$ & $\begin{array}{l}\text { gem. } \\
\text { uitbetaalprijs in } \\
\text { euro p. st. } \\
2006\end{array}$ & $\begin{array}{c}\text { gem. } \\
\text { uitbetaalprijs in } \\
\text { euro p. st. } \\
2007\end{array}$ & $\begin{array}{l}\text { gem. } \\
\text { uitbetaalprijs in } \\
\text { euro p. st. } \\
2008\left(\mathrm{P}^{*}\right)\end{array}$ & $\begin{array}{c}\text { Prijs- } \\
\text { fluctuatie- } \\
\text { coëfficient } \\
\left(\mathrm{p}_{\max } / \mathrm{p}_{\min }\right)\end{array}$ \\
\hline Gemiddelde prijs & 5.31 & 5.36 & 5.33 & 4.85 & 1.11 \\
\hline \multicolumn{6}{|l|}{ Standaardfout } \\
\hline Standaardafw. & 0.62 & 0.61 & 0.97 & 1.01 & \\
\hline Minimum & 4.50 & 4.50 & 4.36 & 4.00 & 1.13 \\
\hline Maximum & 6.00 & 6.25 & 7.25 & 7.00 & 1.21 \\
\hline Aantal respondenten & 7 & 7 & 8 & 8 & \\
\hline Aantal gemist & 1 & 1 & 0 & 0 & \\
\hline
\end{tabular}

$* \mathrm{P}=$ prognose

Tabel 7.6 Vergelijk gem. jaarprijzen PT en onderzoeksresultaat voor phalaenopsis

\begin{tabular}{|l|l|l|l|l|c|}
\hline & 2005 & 2006 & 2007 & 2008 & $\begin{array}{l}\text { Prijs- } \\
\text { fluctuatie- } \\
\text { coëfficient } \\
\left(\mathrm{p}_{\max } / \mathrm{p}_{\min }\right.\end{array}$ \\
\hline $\begin{array}{l}\text { PT gem. jaarprijs } \\
\text { phalaenopsis op pot }\end{array}$ & $€ 4.90$ & $€ 5.11$ & $€ 4.86$ & & 1.05 \\
\hline $\begin{array}{l}\text { Gem. prijs phalaenopsis uit } \\
\text { onderzoeksresultaat }\end{array}$ & $€ 5.31$ & $€ 5.36$ & $€ 5.33$ & $€ 4.85\left(\mathrm{P}^{*}\right)$ & 1.11 \\
\hline
\end{tabular}

$* \mathrm{P}=$ Prognose 
gemiddelde uitbetaalprijzen besproken. In 2005, 2006 en 2007 verschillen deze weinig van elkaar, in 2008 ligt de gemiddelde prijs een stuk lager. De prijzen lopen uiteen van $€ 5.36-4.85$ en liggen in alle jaren op een hoger niveau dan het door het Productschap Tuinbouw geregistreerde gemiddelde jaarprijsniveau van $€ 5.11-4.90$ (zie tabel 7.6).

Ad 2, 3 en 4. Ontwikkeling bedrijfsoppervlakte, omzet en brutomarge per productsoort

De onderzoeksuitkomsten van bedrijfsoppervlakte, omzet en brutomarge naar productsoort gemeten, worden gepresenteerd in tabel 7.7. De gemiddelde oppervlakte en omzet van het groene potplantenbedrijf is het kleinst en bedraagt minder dan de helft van het bloeiende potplantenbedrijf. De productsoorten groen en bloeiend en anders betreffen gemiddeld de grotere potplantenbedrijven, die hun kracht zoeken in de combinatie van seizoensplanten, met eventueel de levering van jong plant- en perkgoed. Deze bedrijven laten een grote spreiding in oppervlakte zien, van 1.0 - 25.0 ha., met hieronder één grootschalig potplantenbedrijf met een breed en zeer divers assortiment. De gemiddelde omzet van het groene potplantenbedrijf bedraagt in 2006 en $2007 € 1.7 \mathrm{mln}$. Deze bedrijfsomzet is significant lager dan van de andere productsoorten $(\mathrm{p}<$ 0.024 , zie tabel 7.7). De omzet van het bloeiende potplantenbedrijf ligt in 2006 op $€ 6.8 \mathrm{mln}$. en in 2007 op $€ 7.9 \mathrm{mln}$. Voor groen en bloeiend ligt deze gemiddeld op $€ 5.3 \mathrm{mln}$. in 2006 en $€ 5.5$ mln. in 2007 met een spreiding van 1.2 - 13.5 mln. euro. Voor 'anders' op $€ 9.5 \mathrm{mln}$. in 2006 en 2007 met een spreiding in beide jaren van 0.9 - $35.0 \mathrm{mln}$. euro. Deze laatste groep bestaat uit vier bedrijven waaronder één grootschalig bedrijf.

Bij de potplanten groen ligt de begrote brutomarge op bijna 10\% en de gerealiseerde in 2006 op $11.5 \%$. Bij de bloeiende potplanten zijn deze cijfers lager, de begrote marge ligt op 7 en de gerealiseerde marge op 5.9\%. Groen en bloeiend ligt op bijna $10 \%$ begroot en $7.5 \%$ gerealiseerd en potplanten anders op bijna $11 \%$ begroot en $9.5 \%$ gerealiseerd. Evenals bij bedrijfsoppervlakte en omzet laat de gerealiseerde brutomarge een grote spreiding in resultaten zien. Telers van uitsluitend groene planten laten de hoogst gerealiseerde brutomarge zien. Dit levert een significant verschil op met dat van de bloeiende potplanten $(\mathrm{p}<0.070$, zie tabel 7.7). Groene planten hebben vaak het kenmerk van een specialty, een uniek product zoals ficus, varen, palm e.a. Bloeiende potplanten, vooral de kleinere, handzamer producten die via het grootwinkelbedrijf worden verkocht, hebben meer het kenmerk van een convenience, een gebruiksproduct met een lagere brutomarge.

Het aandeel eigen vermogen is opgegeven door slechts 14 respondenten en ligt in 2006 voor de sector op gemiddeld $42.3 \%$ (zie tabel 7.1). Uitgesplitst naar productsoort varieert dit van $63.3 \%$ voor de planten groen, $42.7 \%$ voor bloeiend, $31 \%$ voor groen en bloeiend $10 \%$ voor anders. Gezien het lage aantal respondenten per productsoort en de grote spreiding in de onderzoeksuitkomsten is de betrouwbaarheid van deze laatste cijfers beperkt. 
Tabel 7.7 Belangrijke bedrijfskenmerken per productsoort 2006/2007

\begin{tabular}{|c|c|c|c|c|c|c|}
\hline Productsoorten & $\begin{array}{r}\text { Bedrijfsopp. } \\
\text { glas } 2006 \text { in } \\
\text { ha. }\end{array}$ & $\begin{array}{r}\text { Omzet } \\
2006 \\
(x € 1 \mathrm{mln} .)\end{array}$ & $\begin{array}{r}\text { Omzet } \\
2007 \\
(\mathrm{x} \in 1 \mathrm{mln} .)\end{array}$ & $\begin{array}{r}\text { Brutomarge in } \\
\% \text { begroot } \\
2006 \\
{[(\mathrm{P}-\mathrm{GTK}) / \mathrm{P}]} \\
* 100\end{array}$ & $\begin{array}{r}\text { Brutomarge in } \\
\% \text { realisatie } \\
2006 \\
{[(\mathrm{P}-\mathrm{GTK}) / \mathrm{P}]} \\
* 100\end{array}$ & $\begin{array}{l}\text { Aandeel eigen } \\
\text { vermogen } \\
2006 \text { in \% } \\
(\mathrm{EV} / \mathrm{TV})^{*} 100 \\
\mathrm{n}=14\end{array}$ \\
\hline Potplanten groen & $\mathrm{n}=16$ & $\mathrm{n}=16$ & $\mathrm{n}=16$ & $\mathrm{n}=15$ & $\mathrm{n}=16$ & $\mathrm{n}=3$ \\
\hline Gemiddelde & 1.9 & 1.7 & 1.7 & 9.7 & 11.5 & 63.3 \\
\hline Standaardfout & 0.4 & 0.4 & 0.4 & 1.4 & 1.7 & 23.3 \\
\hline Standaardafwijking & 1.7 & 1.5 & 1.5 & 5.5 & 6.6 & 40.4 \\
\hline Minimum & 0.2 & 0.3 & 0.3 & 0.5 & -5.5 & 20.0 \\
\hline Maximum & 6.0 & 6.0 & 6.0 & 22.5 & 24.1 & 100.0 \\
\hline Potplanten bloeiend & $\mathrm{n}=15$ & $\mathrm{n}=15$ & $\mathrm{n}=15$ & $\mathrm{n}=15$ & $\mathrm{n}=15$ & $\mathrm{n}=7$ \\
\hline Gemiddelde & 4.8 & 6.8 & 7.9 & 6.9 & 5.9 & 42.7 \\
\hline Standaardfout & 0.9 & 1.4 & 1.6 & 1.5 & 1.0 & 6.9 \\
\hline Standaardafwijking & 3.7 & 5.3 & 6.2 & 6.0 & 3.8 & 18.1 \\
\hline Minimum & 0.8 & 1.0 & 1.0 & -5.0 & -2.9 & 25.0 \\
\hline Maximum & 12.0 & 20.0 & 5.0 & 20.0 & 11.1 & 80.0 \\
\hline $\begin{array}{l}\text { Potplanten groen en } \\
\text { bloeiend }\end{array}$ & $n=9$ & $\mathrm{n}=9$ & $\mathrm{n}=9$ & $n=8$ & $\mathrm{n}=9$ & $\mathrm{n}=3$ \\
\hline Gemiddelde & 5.7 & 5.3 & 5.6 & 9.7 & 7.4 & 31.0 \\
\hline Standaardfout & 1.0 & 1.5 & 1.5 & 1.7 & 2.1 & 11.6 \\
\hline Standaardafwijking & 2.9 & 4.6 & 4.6 & 5.1 & 6.2 & 20.1 \\
\hline Minimum & 2.0 & 1.2 & 1.2 & 5.0 & -2.5 & 10.0 \\
\hline Maximum & 9.0 & 13.5 & 13.8 & 20.0 & 16.6 & 50.0 \\
\hline $\begin{array}{l}\text { Anders, potplanten in } \\
\text { combinatie met jonge } \\
\text { en tuinplanten }\end{array}$ & $\mathrm{n}=4$ & $\mathrm{n}=4$ & $\mathrm{n}=4$ & $\mathrm{n}=3$ & $n=4$ & $\mathrm{n}=1$ \\
\hline Gemiddelde & 7.4 & 9.5 & 9.5 & 10.8 & 9.4 & 10.0 \\
\hline Standaardfout & 5.9 & 8.5 & 8.5 & 2.2 & 1.6 & \\
\hline Standaardafwijking & 11.8 & 17.0 & 17.0 & 3.8 & 3.1 & \\
\hline Minimum & 1.0 & 0.9 & 0.9 & 7.5 & 5.9 & \\
\hline Maximum & 25.0 & 35.0 & 35.0 & 15.0 & 13.3 & \\
\hline
\end{tabular}

$[(\mathrm{P}-\mathrm{GTK}) / \mathrm{P}] * 100=[($ prijs-gem. totale kosten $) /$ prijs $] * 100 ; \mathrm{s}=\sqrt{ } \sum\left(\mathrm{x}_{\mathrm{i}^{-}} \overline{\mathrm{X}}\right)^{2} / \mathrm{n}-1 ;$ s.e. $=\mathrm{s} / \sqrt{ } \mathrm{n}$

\section{Ad 5. Concentratieontwikkeling per productsoort}

In tabel 7.8 wordt de berekening getoond van de horizontale concentratiegraad (C4) onder de groene en bloeiende potplantenbedrijven. Er worden vier productgroepen onderscheiden: groene planten, bloeiende planten, groen en bloeiend en anders (pot- en tuinplanten). Omdat de populatiecijfers van deze verdeling niet bekend zijn, is hiervoor de verdeling van de steekproef gehanteerd. De C4-waarde voor alle potplantenbedrijven ligt in 2006 op een laag niveau (4\%), ondanks de aanwezigheid van een aantal bedrijven boven de 10 ha. glas. De C4 voor groene planten wordt in 2006 geschat op 11\%, bloeiend op 7\%, groen en bloeiend op 8\% en anders op $15 \%$. De laatste C4-waarde betreft de groep pot- en tuinplanten waaronder één bedrijf van 25 ha. groot. Tabel 7.14 toont de $\mathrm{C} 4$ per bedrijfstype. 
Tabel 7.8 Meting concentratieontwikkeling (C4) potplanten per productsoort (2006)

\begin{tabular}{|c|c|c|c|c|c|c|c|c|}
\hline $\begin{array}{l}\text { Productsoort }+ \\
\text { areaal populatie } \\
\text { groene en } \\
\text { bloeiende } \\
\text { potplanten in } \\
\text { ha. }(2006)\end{array}$ & $\begin{array}{l}\text { Bedrijfs- } \\
\text { opper- } \\
\text { vlakte } \\
\text { steekprf. } \\
\text { gem. }\end{array}$ & $\begin{array}{l}\text { Stan- } \\
\text { daard- } \\
\text { fout } \\
\text { gem. }\end{array}$ & $\begin{array}{l}\text { Stan- } \\
\text { daard- } \\
\text { afwij- } \\
\text { king }\end{array}$ & $\begin{array}{l}\text { Aantal } \\
\text { respon- } \\
\text { denten } \\
\text { (n) }\end{array}$ & $\begin{array}{l}\text { Som } \\
\text { bedrijfs- } \\
\text { opp. } \\
\text { steek- } \\
\text { proef }\end{array}$ & $\begin{array}{l}\text { Mini- } \\
\text { mum }\end{array}$ & $\begin{array}{l}\text { Maxi- } \\
\text { mum }\end{array}$ & $\begin{array}{l}\text { Concen- } \\
\text { tratiegraad } \\
\text { (C4) }\end{array}$ \\
\hline Groen $\quad 210$ & 1.9 & 0.4 & 1.7 & 16 & 30.5 & 0.2 & 6.0 & $\begin{array}{l}23 / 210= \\
11 \%\end{array}$ \\
\hline Bloeiend 560 & 4.8 & 1.0 & 3.7 & 15 & 71.8 & 0.8 & 12.0 & $\begin{array}{l}39 / 560= \\
7 \%\end{array}$ \\
\hline $\begin{array}{l}\text { Groen en } \\
\text { bloeiend } 420\end{array}$ & 5.7 & 1.0 & 2.9 & 9 & 51.6 & 2.0 & 9.0 & $\begin{array}{l}34 / 420= \\
8 \%\end{array}$ \\
\hline Anders $\quad 210$ & 7.4 & 5.9 & 11.8 & 4 & 29.5 & 1.0 & 25.0 & $\begin{array}{l}30 / 210= \\
15 \%\end{array}$ \\
\hline Totaal 1400 & 4.2 & 0.4 & 2.5 & 44 & 183.4 & 0.2 & 25.0 & $\begin{array}{l}57 / 1400= \\
4 \%\end{array}$ \\
\hline
\end{tabular}

$\mathrm{C} 4=$ Concentratiegraad vier grootste glaspotplantenbedrijven per productsoort, gemeten in opp. glas in ha.

\subsubsection{Bedrijfstypen ( $\mathrm{C} 1 \mathrm{t} / \mathrm{m} \mathrm{C} 4)$}

De onderzoeksuitkomsten uit de paragrafen hiervoor zijn besproken op sector- en productniveau. In deze paragraaf worden ze per bedrijfstype geanalyseerd en toegelicht. De C1 - en C2-bedrijven hebben de organisatie van de afzet voor een groter of kleiner deel in handen gegeven van hun afzetorganisaties, de bloemenveilingen (paragraaf 7.3.1.1). $\mathrm{C} 1$ is de kleinere veilingteler, $\mathrm{C} 2$ het wat grotere bedrijf, lid van een vereniging van veilingtelers. Bedrijfstype $\mathrm{C} 3$, de van de veiling onafhankelijke teler en $\mathrm{C} 4$, lid van een onafhankelijke telersvereniging, komen weinig voor in de sector glaspotplanten (twee respondenten). Hieronder volgen in tabel $7.9 \mathrm{t} / \mathrm{m} 7.14$ de onderzoeksresultaten per bedrijfstype. Het betreft:

1. omzetontwikkeling 2006/2007, brutomarge 2006 begroot en gerealiseerd en aandeel eigen en totale vermogen $(\mathrm{EV} / \mathrm{TV})^{*} 100$;

2. keuze afzetorganisatie, veilingprovisie en de mate van tevredenheid;

3. verkoopwijze, aandeel klokverkopen in percentage van de omzet en gemiddelde uitbetaalprijzen per bedrijfstype;

4. concentratieontwikkeling (C4) per bedrijfstype. 
Ad 1. Omzetontwikkeling, brutomarge en aandeel eigen vermogen

Tabel 7.9 Omzet, brutomarge en aandeel eigen vermogen per bedrijfstype

\begin{tabular}{|c|c|c|c|c|c|}
\hline $\begin{array}{l}\mathrm{N}=44 \\
\text { Bedrijfstype }\end{array}$ & $\begin{array}{l}\text { Omzet } \\
(\mathrm{x} € 1 \mathrm{mln} .) \\
\text { realisatie } 2006\end{array}$ & $\begin{array}{l}\text { Omzet } \\
(x \in 1 \mathrm{mln} .) \\
\text { realisatie } 2007\end{array}$ & $\begin{array}{l}\text { Brutomarge } \\
2006 \text { in } \% \\
\text { begroot }[(\mathrm{P}- \\
\text { GTK }) / \mathrm{P}] * 100\end{array}$ & $\begin{array}{l}\text { Brutomarge } \\
2006 \text { in } \% \\
\text { realisatie }[(\mathrm{P}- \\
\mathrm{GTK}) / \mathrm{P}] * 100\end{array}$ & $\begin{array}{l}\text { Aandeel eigen } \\
\text { en totale } \\
\text { vermogen) } \\
(\mathrm{EV} / \mathrm{TV}) * 100 \\
2006\end{array}$ \\
\hline C1 (11 resp.) & & & $\mathrm{n}=9$ & $\mathrm{n}=11$ & $\mathrm{n}=5$ \\
\hline Gemiddelde & 1.5 & 1.6 & 9.6 & 8.9 & 43.6 \\
\hline Standaardfout gem. & 0.5 & 0.5 & 1.2 & 2.0 & 9.8 \\
\hline Standaardafwijking & 1.8 & 1.8 & 4.4 & 6.7 & 22.1 \\
\hline Minimum & 0.3 & 0.3 & 2.5 & -2.9 & 10.0 \\
\hline Maximum & 7.0 & 7.0 & 15.0 & 20.0 & 70.0 \\
\hline C1,3 (14 resp.) & & & & & $\mathrm{n}=4$ \\
\hline Gemiddelde & 4.9 & 5.3 & 8.6 & 8.6 & 44.5 \\
\hline Standaardfout gem. & 1.2 & 1.6 & 1.8 & 0.9 & 12.2 \\
\hline Standaardafwijking & 4.7 & 5.1 & 6.0 & 3.0 & 24.4 \\
\hline Minimum & 0.3 & 0.3 & -5.0 & 5.0 & 25.0 \\
\hline Maximum & 18.0 & 20.0 & 20.0 & 14.3 & 80.0 \\
\hline \multicolumn{6}{|l|}{$\mathrm{C} 1,3,4$ (1 resp.) } \\
\hline Gemiddelde & 35.0 & 35.0 & 10.0 & 10.0 & \\
\hline \multicolumn{6}{|l|}{ C1,4 (1 resp.) } \\
\hline Gemiddelde & 2.7 & 3.0 & & -2.5 & \\
\hline C2 (14 resp.) & & & & & $\mathrm{n}=4$ \\
\hline Gemiddelde & 6.1 & 7.1 & 9.3 & 8.9 & 40.8 \\
\hline Standaardfout gem. & 1.5 & 1.8 & 1.8 & 2.2 & 20.3 \\
\hline Standaardafwijking & 5.2 & 6.0 & 6.3 & 7.6 & 40.6 \\
\hline Minimum & 0.7 & 0.8 & 0.5 & -5.5 & 10.0 \\
\hline Maximum & 16.0 & 17.5 & 22.5 & 24.1 & 100.0 \\
\hline C2,3 (3 resp.) & & & & & $\mathrm{n}=1$ \\
\hline Gemiddelde & 1.6 & 1.6 & 4.2 & 8.4 & 33.0 \\
\hline Standaardfout gem. & 0.5 & 0.5 & 0.8 & 1.2 & \\
\hline Standaardafwijking & 0.6 & 0.6 & 1.4 & 2.1 & \\
\hline Minimum & 1.0 & 0.9 & 2.5 & 6.0 & \\
\hline Maximum & 2.0 & 2.0 & 5.0 & 10.0 & \\
\hline
\end{tabular}

$[(\mathrm{P}-\mathrm{GTK}) / \mathrm{P}] * 100=[($ prijs-gem. totale kosten $) /$ prijs $] * 100 ; \mathrm{s}=\sqrt{ } \sum\left(\mathrm{x}_{\mathrm{i}}-\overline{\mathrm{X}}\right)^{2} / \mathrm{n}-1 ;$ s.e. $=\mathrm{s} / \sqrt{ } \mathrm{n}$

Het gemiddeld aandeel eigen vermogen van de sector in procenten van het totaal ligt in 2006 op 42.3\%. Bij splitsing naar bedrijfstype varieert dit percentage van 33 tot 44.5 .

Het bedrijfstype heeft in de sector potplanten minder invloed op het resultaat dan in andere sectoren van de glastuinbouw. Het valt op dat productsoort hierop meer van invloed is.

Ad 2. Keuze afzetorganisatie, veilingprovisie en de mate van tevredenheid

Eerder is aangegeven dat alle 44 onderzochte bedrijven zijn aangesloten bij FloraHolland en dat een aantal van de grootste zijn producten afzet op meerdere veilpunten. Bijna $89 \%$ hiervan heeft naast de veiling als verkooporganisatie tevens een eigen verkoper in dienst, alleen of in samenwerking met andere bedrijven via de telersvereniging. 
Tabel 7.10 Keuze afzetorganisatie, gemiddelde veilingprovisie ( $\%$ omzet) en mate van tevredenheid

\begin{tabular}{|c|c|c|c|c|c|c|c|c|c|}
\hline \multirow[b]{2}{*}{$\begin{array}{l}\text { Bedrijfstype/ } \\
\text { Productsoort }\end{array}$} & \multirow[b]{2}{*}{$\begin{array}{l}\text { Organisatie } \\
\text { van de afzet }\end{array}$} & \multirow[b]{2}{*}{$\begin{array}{l}\text { Aan- } \\
\text { tal } \\
\text { resp. }\end{array}$} & \multirow{2}{*}{\multicolumn{2}{|c|}{$\begin{array}{l}\text { Veilingprovisie } \\
\text { in } \% \text { omzet }\end{array}$}} & \multicolumn{5}{|c|}{ Mate van tevredenheid } \\
\hline & & & & & $\begin{array}{l}\text { Zeer } \\
\text { tevre- } \\
\text { den }\end{array}$ & $\begin{array}{l}\text { Tevre- } \\
\text { den }\end{array}$ & $\begin{array}{l}\text { Tevreden/ } \\
\text { ontevre- } \\
\text { den }\end{array}$ & $\begin{array}{l}\text { Onte- } \\
\text { vreden }\end{array}$ & $\begin{array}{l}\text { Zeer } \\
\text { ontevre- } \\
\text { den }\end{array}$ \\
\hline \multirow[t]{5}{*}{ C1 (11 resp.) } & & & Gem. & 8.0 & & & & & \\
\hline & $\mathrm{FH}$ & 4 & Stand.fout & 0.3 & & & & & \\
\hline & $\mathrm{FH}+\mathrm{EV}$ & 6 & Stand.afw & 2.0 & & & & & \\
\hline & FH + Ver. & 1 & Min. & 5.5 & & & & & \\
\hline & subtotaal & 11 & Max. & 12.0 & & 7 & 4 & & \\
\hline \multirow[t]{5}{*}{$\mathrm{C} 1,3$ (14 resp.) } & & & Gem. & 5.5 & & & & & \\
\hline & FH & 1 & Stand.fout & 0.3 & & & & & \\
\hline & $\mathrm{FH}+\mathrm{EV}$ & 13 & Stand.afw & 1.3 & & & & & \\
\hline & subtotaal & 14 & Min. & 3.1 & & 6 & 6 & 2 & \\
\hline & & & Max. & 7.5 & & & & & \\
\hline $\mathrm{C} 1,3,4$ & $\mathrm{FH}+\mathrm{EV}$ & 1 & Gem. & 4.5 & & 1 & & & \\
\hline $\mathrm{C} 1,4$ & $\mathrm{FH}+$ Ver. & 1 & Gem. & 6.5 & & & & & \\
\hline \multirow[t]{5}{*}{ C2 (14 resp.) } & & & Gem. & 7.1 & & 8 & 5 & 1 & \\
\hline & $\mathrm{FH}+\mathrm{EV}$ & 2 & Stand.fout & 0.6 & & & & & \\
\hline & $\mathrm{FH}+$ Ver. & 12 & Stand.afw & 2.0 & & & & & \\
\hline & Subtotaal & 14 & Min. & 5.0 & & & & & \\
\hline & & & Max. & 12.0 & & & & & \\
\hline & & & & & & & & & \\
\hline \multirow{5}{*}{ C2,3 (3 resp.) } & $\mathrm{FH}+\mathrm{EV}$ & 1 & Gem. & 6.3 & & & & & \\
\hline & $\mathrm{FH}+$ Ver. & 2 & Stand.fout & 1.2 & & & & & \\
\hline & Subtotaal & 3 & Stand.afw & 2.0 & & 1 & 1 & 1 & \\
\hline & & & Min. & 6.0 & & & & & \\
\hline & & & Max. & 7.0 & & & & & \\
\hline Totaal C1-C4 & & 44 & & & & 23 & 16 & 4 & \\
\hline
\end{tabular}

$\mathrm{EV}=$ Eigen verkoop; Ver. $=$ Telersvereniging met eigen verkoper

\section{Veilingprovisie}

Veilingprovisie en kosten eigen verkoop (EV) liggen gemiddeld op 6.7\% en 2.2\% (zie tabel 7.3). Bezien naar bedrijfstype betaalt $\mathrm{C} 1$ met gemiddeld $8 \%$ de hoogste provisie. $36 \%$ van deze bedrijven zit nog aanzienlijk boven dit gemiddelde, tot $12 \%$ van de omzet wordt hieraan betaald. De kosten EV zijn bij dit type het laagst en bedragen gemiddeld 1.9\%.

Bedrijfstype $\mathrm{C} 1,3$ heeft een gemiddelde provisie van 5.5\%. Deze bedrijven betalen de laagste provisie, $50 \%$ betaalt $5 \%$ of minder. De kosten EV bedragen gemiddeld $2.4 \%$. Bedrijfstype C2 betaalt gemiddeld $7.1 \%$ provisie en $2.1 \%$ kosten EV.

Bedrijfstype C2,3 betaalt gemiddeld $6.3 \%$ provisie en $3.7 \%$ kosten EV.

Bedrijfstype $\mathrm{C} 1,4$ en $\mathrm{C} 1,3,4$ betalen een provisie van $6.5 \%$ en $4.5 \%$. De kosten EV bedragen 0.5 en $2 \%$ van de omzet. 
Mate van tevredenheid

De tevredenheid van alle respondenten over hun verkooporganisatie luidt: $50 \%$ is tevreden, $39 \%$ tevreden/ontevreden en $9 \%$ is ontevreden. Per bedrijfstype bekeken toont tabel 7.10 dat type $\mathrm{C} 1$ het meest tevreden is (bijna $64 \%$ is tevreden en $36 \%$ is tevreden/ontevreden). Bedrijfstype $\mathrm{C} 1,3$ laat zien dat hier de tevredenheid minder is. $43 \%$ van dit bedrijfstype is tevreden en $43 \%$ tevreden/ontevreden, terwij1 14\% ontevreden is. Het type $\mathrm{C} 2$ zit tussen de bovenstaande waarderingen in. $57 \%$ van dit bedrijfstype is tevreden, $36 \%$ tevreden/ontevreden, terwij1 $7 \%$ ontevreden is. Bij de combinatie van bedrijfstype $\mathrm{C} 2,3$ is het verschil in waardering gelijk verdeeld over de drie respondenten, de een is tevreden, de ander tevreden/ontevreden en de derde is ontevreden. Typen C1,4 en C1,3,4 antwoorden met 'anders' (moeilijk in te schatten) respectievelijk tevreden.

Ad3. Verkoopwijze, aandeel klokverkopen en gem. uitbetaalprijzen per bedrijfstype

De verkoopwijze in de sector potplanten is de laatste jaren aan sterke veranderingen onderhevig. Sinds de introductie van het digitale Kopen Op Afstand (KOA) vindt een verdere verschuiving plaats van klokverkoop naar bemiddeling en eigen verkoop. In tabel 7.11 wordt aangegeven per bedrijfstype en verkoopwijze hoeveel in 2007 het percentage omzet via klokverkoop bedraagt.

Tabel 7.11 Verkoopwijze producten per bedrijfstype $\mathrm{C} 1 \mathrm{t} / \mathrm{m} \mathrm{C} 4$

\begin{tabular}{|c|c|c|c|c|}
\hline Type glastuinbouwbedrijf & Verkoopwijze & $\begin{array}{r}\text { Aantal } \\
\text { bedrijven }\end{array}$ & $\begin{array}{c}\text { Aan- } \\
\text { deel } \\
\text { in } \% \\
\end{array}$ & $\begin{array}{l}\text { Klok- } \\
\text { verkoop } \\
\text { in } \% \\
\text { omzet }\end{array}$ \\
\hline \multirow[t]{3}{*}{ C1 Veilingteler } & Via klok en bemiddeling & 5 & 46 & Gem. 48.2 \\
\hline & Via klok, bemiddeling en Ver. & 3 & 27 & Min. 20.0 \\
\hline & Via klok, bemiddeling en EV & 3 & 27 & Max. 80.0 \\
\hline Subtotaal & & 11 & 100 & s.e. $=7.1$ \\
\hline \multirow[t]{2}{*}{$\mathrm{C} 1,3$ Veilingteler $+\mathrm{EV}$} & Via klok en bemiddeling & 2 & 14 & Gem. 17.3 \\
\hline & Via klok, bemiddeling en EV & 12 & 86 & Min. 4.0 \\
\hline \multirow[t]{2}{*}{ Subtotaal } & & 14 & 100 & Max. 50.0 \\
\hline & & & & s.e. $=3.9$ \\
\hline $\mathrm{C} 1,3,4$ & Via klok, bemiddeling en Ver. & 1 & 100 & 9.0 \\
\hline $\mathrm{C} 1,4$ & Via klok, bemiddeling en Ver. & 1 & 100 & 60.0 \\
\hline \multirow[t]{3}{*}{ C2 Veilingtelersvereniging } & Via klok en bemiddeling & 1 & 7 & Gem. 30.4 \\
\hline & Via klok en bemiddeling en Ver. & 12 & 86 & Min. $\quad 5.0$ \\
\hline & Via klok, bemiddeling en EV & 1 & 7 & Max. 60.0 \\
\hline Subtotaal & & 14 & 100 & s.e. $=5.0$ \\
\hline \multirow[t]{2}{*}{$\mathrm{C} 2,3$} & Via klok en bemiddeling en Ver. & 2 & 67 & Gem. 28.3 \\
\hline & Via klok, bemiddeling en EV & 1 & 33 & Min. $\quad 5.0$ \\
\hline \multirow[t]{2}{*}{ Subtotaal } & & 3 & 100 & Max. 50.0 \\
\hline & & & & s.e. $=13.0$ \\
\hline \multirow[t]{4}{*}{ Totaal C1-C4 } & & 44 & 100 & Gem. 30.7 \\
\hline & & & & Min. 4.0 \\
\hline & & & & Max. 80.0 \\
\hline & & & & s.e. $=3.3$ \\
\hline
\end{tabular}

$\mathrm{EV}=$ Eigen Verkoop; Ver.= Telersvereniging 
Voor alle 44 respondenten is in tabel 7.4 te zien dat de verkoopwijze van de producten voor ruim $18 \%$ plaatsvindt alleen via de klok en bemiddeling, voor ruim $43 \%$ via klok, bemiddeling en verkoop door de telersvereniging en voor bijna 39\% via klok, bemiddeling en eigen verkoop. In het geheel van de veilingverkopen voor potplanten is de klokverkoop in de minderheid (gemiddeld $31 \%$ aandeel in de omzet) en bemiddeling in de meerderheid (69\% omzetaandeel).

In tabel 7.11 bezien we de resultaten naar de verschillende bedrijfstypen en kunnen we het volgende concluderen. Bij het bedrijfstype $\mathrm{C} 1$ vindt de verkoopwijze van de producten voor bijna $46 \%$ plaats alleen via de klok en bemiddeling, voor ruim $27 \%$ via klok, bemiddeling en verkoop door de telersvereniging en voor ruim $27 \%$ via klok, bemiddeling en eigen verkoop. Hier is het aandeel klokverkoop het hoogst en bedraagt gemiddeld ruim $48 \%$, met een spreiding van 20 tot $80 \%$. Bij bedrijfstype $\mathrm{C} 1,3$ verschuift de verkoopwijze naar veel meer eigen verkoop door het individuele bedrijf ( $86 \%$ ) en veel minder klok en bemiddeling (14\%). Het aandeel klokverkoop bedraagt hier gemiddeld ruim $17 \%$ met een spreiding van 4 tot $50 \%$. Bij het type $\mathrm{C} 2$ gaat de verkoopwijze naar meer verkoop via de telersvereniging $(86 \%)$ en nog minder klok/bemiddeling (7\%) en eigen verkoop (7\%). Hier bedraagt het aandeel klokverkoop gemiddeld ruim 30\%, met een spreiding van 5 tot $60 \%$. Resumerend is te concluderen dat in de potplantensector de verkoopwijze van FloraHolland steeds verder verschuift van klok naar bemiddeling/administratieve melding met meer eigen verkoop door het individuele bedrijf respectievelijk verkoop via de telersvereniging.

Gemiddelde uitbetaalprijzen per type bedrijf

Aangegeven is bij productsoort (tabel 7.5) dat door het unieke assortiment potplanten en potmaten er naar productsoorten geen of weinig zinvolle prijsvergelijkingen zijn te trekken. Datzelfde geldt voor bedrijfstypen. Voor productsoort bloeiende potplanten phalaenopsis is een uitzondering gemaakt. Voor een 8-tal phalaenopsistelers van bedrijfstype $\mathrm{C} 1, \mathrm{C} 1,3$ en $\mathrm{C} 2$ worden in tabel 7.12 de gemiddelde uitbetaalprijzen getoond en vergeleken. Het blijkt dat bij de verkoop

Tabel 7.12 Gem. uitbetaalprijs phalaenopsis per bedrijfstype 2005, 2006, 2007 en 2008(P*)

\begin{tabular}{|c|c|c|c|c|c|}
\hline $\begin{array}{l}\text { Bedrijfstype } \\
\text { C1-C4 }\end{array}$ & $\begin{array}{c}\text { gem. } \\
\text { uitbetaalprijs } \\
\text { in euro p. st. } \\
2005\end{array}$ & $\begin{array}{c}\text { gem. } \\
\text { uitbetaalprijs } \\
\text { in euro p. st. } \\
2006\end{array}$ & $\begin{array}{c}\text { gem. } \\
\text { uitbetaalprijs } \\
\text { in euro p. st. } \\
2007\end{array}$ & $\begin{array}{c}\text { gem. } \\
\text { uitbetaalprijs } \\
\text { in euro p. st. } \\
2008\left(\mathrm{P}^{*}\right)\end{array}$ & $\begin{array}{c}\text { Prijsfluctuatie- } \\
\text { coëfficient } \\
\left(\mathrm{p}_{\max } / \mathrm{p}_{\min }\right)\end{array}$ \\
\hline $\begin{array}{l}\text { C1 Veilingteler } \\
\text { (1 respondent) }\end{array}$ & 4.60 & 4.95 & 4.50 & 4.00 & 1.23 \\
\hline $\begin{array}{l}\text { C1,3 Veilingteler }+\mathrm{EV} \\
(5 / 6 \text { respondenten })\end{array}$ & 5.32 & 5.32 & 5.35 & 4.90 & 1.09 \\
\hline $\begin{array}{l}\text { C2 Veilingtelersvereniging } \\
\text { (1 respondent) }\end{array}$ & 6.00 & 6.00 & 6.00 & 5.40 & 1.11 \\
\hline C1-C3 gemiddelde prijs & 5.31 & 5.36 & 5.33 & 4.85 & 1.10 \\
\hline Standaarddeviatie & 0.62 & 0.61 & 0.97 & 1.01 & \\
\hline Standaardfout & 0.23 & 0.23 & 0.34 & 0.36 & \\
\hline Minimumprijs & 4.50 & 4.50 & 4.36 & 4.00 & 1.13 \\
\hline Maximumprijs & 6.00 & 6.25 & 7.25 & 7.00 & 1.21 \\
\hline Aantal respondenten & 7 & 7 & 8 & 8 & \\
\hline Aantal gemist & 1 & 1 & 0 & 0 & \\
\hline
\end{tabular}


Tabel 7.13 Vergelijk gem. jaarprijzen PT en onderzoeksresultaat voor phalaenopsis

\begin{tabular}{|l|l|l|l|l|c|}
\hline & 2005 & 2006 & 2007 & $2008\left(\mathrm{P}^{*}\right)$ & $\begin{array}{c}\text { Prijsfluctuatie- } \\
\text { coëfficient } \\
\left(\mathrm{p}_{\max } / \mathrm{p}_{\min }\right)\end{array}$ \\
\hline $\begin{array}{l}\text { PT gemiddelde jaarprijs } \\
\text { phalaenopsis op pot }\end{array}$ & $€ 4.90$ & $€ 5.11$ & $€ 4.86$ & & 1.05 \\
\hline $\begin{array}{l}\text { Gemiddelde prijs phalaenopsis uit } \\
\text { onderzoeksresultaat }\end{array}$ & $€ 5.31$ & $€ 5.36$ & $€ 5.33$ & $€ 4.85$ & 1.11 \\
\hline
\end{tabular}

PT=Productschap Tuinbouw

van phalaenopsis meestal wordt gekozen voor bedrijfstype $\mathrm{C} 1,3$ hetgeen het belang van de eigen verkoopfunctie onderstreept. Bedrijfstype $\mathrm{C} 1$ scoort lager met de gemiddelde uitbetaalprijs en $\mathrm{C} 2$ scoort hoger. Op basis van één respondent is geen betrouwbare vergelijking tussen de verschillende bedrijfstypen te trekken. De gemiddelde uitbetaalprijzen voor de phalaenopsis in 2005, 2006, 2007 en 2008 lopen uiteen van $€ 5.36$ - 4.85 en liggen in alle jaren op een hoger niveau dan het door het Productschap Tuinbouw geregistreerde gemiddelde jaarprijsniveau van $€ 5.11-4.90$ (zie tabel 7.13).

De grote prijsvariatie $\left(\mathrm{p}_{\max }-\mathrm{p}_{\text {min }}\right.$ ) van de phalaenopsis bij bedrijfstypen $\mathrm{C} 1, \mathrm{C} 1,3$ en $\mathrm{C} 2$ laat zien dat er door de bedrijven een breed assortiment van verschillende unieke producttypen wordt aangeboden. De prijsfluctuaties van de gemiddelde, de minimum- en de maximumprijs liggen tussen de 10 en $20 \%$ en tenderen vanaf 2008 naar een hoger niveau. Er is vanaf 2008 sprake van een te snelle groei van het aanbod ten opzichte van de vraag op de belangrijkste groothandelsmarkten in Europa, hetgeen de uitbetaalprijzen onder druk heeft gezet. Dit heeft gezorgd voor een toename van de omzet van phalaenopsis (productie- en handelswaarde) op sectorniveau maar niet in een toename van het individuele bedrijfsresultaat.

\section{Ad 4. Concentratieontwikkeling (C4) per bedrijfstype}

In tabel 7.14 wordt de horizontale concentratiegraad (C4) berekend per bedrijfstype. Omdat type $\mathrm{C} 3$ en $\mathrm{C} 4$ alleen voorkomt in de combinatie met $\mathrm{C} 1$ of $\mathrm{C} 2$, zijn deze samengevoegd met bedrijfstype $\mathrm{C} 1,3, \mathrm{C} 1,3,4, \mathrm{C} 1,4$ en $\mathrm{C} 2,3$. Ongeveer $10 \%$ van het areaal teelt tevens tuinplanten. Evenals bij de $\mathrm{C} 4$ per productsoort is per bedrijfstype sprake van een lage concentratiegraad, variërend van 5.3 tot $5.7 \%$. De gemiddelde bedrijfsoppervlakte per bedrijfstype $\mathrm{C} 1$ en $\mathrm{C} 2$ bedraagt 3.7 resp. 4.8 ha. glas. Het C1-gemiddelde wordt sterk beïnvloed door het C1,4-bedrijf met een omvang van 25 ha. Het gemiddelde C1-bedrijf exclusief dit bedrijf bedraagt 2.9 ha. Dit laatste gemiddelde levert een betekenisvol verschil op met het C2-bedrijf. Het geeft aan dat de gemiddelde bedrijfsomvang van een in telersvereniging opererend glaspotplantenbedrijf (C2) aanmerkelijk groter is dan de veilingteler (C1). Evenals in de glassnijbloemen en glasgroentesector is de belangrijkste reden hiervan het verlagen van de vaste kosten en het hiermee opvangen van de extra kosten van de marketing- en verkoopfunctie van de telersvereniging. De concentratiegraad (C4), in 2006 op een niveau van ruim 6\%, zal de komende jaren nog kunnen toenemen, evenals het verschil tussen deze twee bedrijfstypen. Uitgaande van het eerder genoemde optimale bedrijf van gemiddeld 4 ha. glasoppervlakte (KWIN Glastuinbouw 2010) zal er bij een totale areaal 
omvang potplanten onder glas van 1400 ha. op termijn een structurele ruimte zijn voor ongeveer 350 bedrijven. Dit betekent dat de werkelijke concentratie in de totale potplantenteelt onder glas op termijn nog kan toenemen en het aantal bedrijven, bestaande uit ruim 1000 in 2008, nog aanzienlijk kan dalen.

Tabel 7.14 Meting concentratieontwikkeling (C4) potplanten per bedrijfstype (2006)

\begin{tabular}{|l|c|c|c|c|c|c|c|c|}
\hline $\begin{array}{l}\text { Type bedrijf en } \\
\text { areaal populatie } \\
\text { potplanten }\end{array}$ & $\begin{array}{l}\text { Bedrijfs- } \\
\text { opper- } \\
\text { vlakte } \\
\text { steekprf. } \\
\text { gem. }\end{array}$ & $\begin{array}{c}\text { Stan- } \\
\text { daard- } \\
\text { fout } \\
\text { gem. }\end{array}$ & $\begin{array}{l}\text { Stan- } \\
\text { daard- } \\
\text { afwij- } \\
\text { king }\end{array}$ & $\begin{array}{l}\text { Aantal } \\
\text { respon- } \\
\text { denten } \\
\text { (n) }\end{array}$ & $\begin{array}{l}\text { Som } \\
\text { bedrijfs- } \\
\text { opp. } \\
\text { steekprf. }\end{array}$ & $\begin{array}{l}\text { Mini- } \\
\text { mum }\end{array}$ & $\begin{array}{l}\text { Maxi- } \\
\text { mum }\end{array}$ & $\begin{array}{l}\text { Concen- } \\
\text { tratiegraad } \\
\text { (C4) }\end{array}$ \\
\hline C1 770 ha. & $\left.3.7^{* *}\right)$ & 1.0 & 5.0 & 27 & 101.6 & 0.2 & 25.0 & $\begin{array}{l}46.3 / 770 \\
=6.0 \%\end{array}$ \\
\hline C2 630 ha. & 4.8 & 0.9 & 3.7 & 17 & 81.8 & 1.1 & 12.0 & $\begin{array}{c}41.0 / 630 \\
=6.5 \%\end{array}$ \\
\hline Tot. 1400 ha. $\left.{ }^{*}\right)$ & 4.2 & 0.7 & 4.5 & 44 & 183.4 & 0.2 & 25.0 & \\
\hline
\end{tabular}

$\mathrm{C} 4=$ Concentratiegraad vier grootste bedrijven per bedrijfstype $\mathrm{C} 1$ of $\mathrm{C} 2$, gemeten in opp. glas in ha.;

*) Bedrijfstype $\mathrm{C} 1,3, \mathrm{C} 1,3,4, \mathrm{C} 1,4$ en $\mathrm{C} 2,3$ zijn samengevoegd met $\mathrm{C} 1$ en $\mathrm{C} 2$. Ongeveer $10 \%$ van het areaal teelt tevens tuinplanten.**) Zonder het C1,4-bedrijfstype (25.0 ha.) daalt het C1-gemiddelde naar 2.9 ha., hetgeen een betekenisvol verschil oplevert met $\mathrm{C} 2(\mathrm{p}<0.10)$.

\subsubsection{Mogelijk verband tussen marktgedrag en -resultaat ( $\chi 2$-analyse)}

In de vorige paragrafen zijn de belangrijkste onderzoeksresultaten van de sector, de productsoorten en bedrijfstypen weergegeven. Deze paragraaf behandelt de mogelijke verbanden tussen gedrags- en resultaatsvariabelen aan de hand van een aantal kruistabellen waarbij de chi-kwadraatanalyse is toegepast (Huizingh, 2010). Getoetst wordt of er een significant verband bestaat. Bij elke toetsing wordt de chi-kwadraatwaarde $(\chi 2)$ aangegeven met het aantal vrijheidsgraden (DF=Degrees of Freedom) en de overschrijdingskans p (bij 95\% betrouwbaarheid). Hoewel bij een aantal toetsen niet werd voldaan aan alle voorwaarden voor een betrouwbare toets (de aanwezigheid van cellen met te lage frequenties) geven zij wel een bepaalde trend aan die van belang is voor de analyse. Bij de analyse van de horizontale concentratiegraad (C4) wordt eveneens gebruikgemaakt van kruistabellen, maar zonder de chi-kwadraattest.

De te behandelen marktgedragsvariabelen zijn:

1. productsoorten

2. type glastuinbouwbedrijf

3. verkoopwijze producten

4. moderniteit bedrijf

5. bedrijfsoppervlakte glas (in ha.)

6. marketing en verkoop

7. voorwaartse verticale integratie

8. horizontale concentratie

9. investeringen/innovaties

10. bedrijfsomvang/kostenniveau

11. toe- en uittreding sector 
Tabel 7.15 Overzicht chi-kwadraattest variabelen marktgedrag en marktresultaat

\begin{tabular}{|c|c|c|c|c|}
\hline $\begin{array}{l}\text { Tabel } \\
\text { nr. }\end{array}$ & Gedragsvariabele & $\begin{array}{l}\text { Structuur- en } \\
\text { resultaatsvariabelen }\end{array}$ & Testwaarden & $\begin{array}{l}\text { Signifi- } \\
\text { cantie } \\
\text { (ja/nee) }\end{array}$ \\
\hline 7.16 & Productsoort & Omzet 2006 & $\begin{array}{l}\mathrm{n}=44 ; \chi 2=20.757 \\
\mathrm{DF}=12 ; \mathrm{p}<0.054\end{array}$ & $\begin{array}{l}\mathrm{Ja}, \mathrm{p} \\
>90 \%\end{array}$ \\
\hline 7.17 & Productsoort & Omzet 2007 & $\begin{array}{l}\mathrm{n}=44 ; \chi 2=27.602 \\
\mathrm{DF}=15 ; \mathrm{p}<0.024\end{array}$ & $\mathrm{Ja}$ \\
\hline 7.18 & Productsoort & $\begin{array}{c}\text { Brutomarge 2006 } \\
\text { (gerealiseerd) }\end{array}$ & $\begin{array}{l}\mathrm{n}=44 ; \chi 2=23.735 \\
\mathrm{DF}=15 ; \mathrm{p}<0.070\end{array}$ & $\begin{array}{l}\text { Ja, p } \\
>90 \%\end{array}$ \\
\hline 7.19 & Type glastuinbouwbedrijf & $\begin{array}{l}\text { Investeringsniveau ( } € \times 1 \\
\mathrm{mln} \text {.) }\end{array}$ & $\begin{array}{l}\mathrm{n}=37 ; \chi 2=32.228 \\
\mathrm{DF}=20 ; \mathrm{p}<0.041\end{array}$ & $\mathrm{Ja}$ \\
\hline 7.20 & Type glastuinbouwbedrijf & Omzet gerealiseerd in 2007 & $\begin{array}{l}\mathrm{n}=42 ; \chi 2=36.995 \\
\mathrm{DF}=25 ; \mathrm{p}<0.058\end{array}$ & $\begin{array}{l}\text { Ja, p } \\
>90 \%\end{array}$ \\
\hline 7.21 & Type glastuinbouwbedrijf & $\begin{array}{l}\text { Brutomarge gerealiseerd } \\
2006\end{array}$ & $\begin{array}{l}\mathrm{n}=44 ; \chi 2=37.072 \\
\mathrm{DF}=25 ; \mathrm{p}<0.057\end{array}$ & $\begin{array}{l}\text { Ja, p } \\
>90 \%\end{array}$ \\
\hline 7.22 & Verkoopwijze producten & Omzet gerealiseerd in 2006 & $\begin{array}{l}\mathrm{n}=44 ; \chi^{2}=20.062 \\
\mathrm{DF}=10 ; \mathrm{p}<0.029\end{array}$ & $\mathrm{Ja}$ \\
\hline 7.23 & Verkoopwijze producten & Omzet gerealiseerd in 2007 & $\begin{array}{l}\mathrm{n}=44 ; \chi 2=20.455 \\
\mathrm{DF}=10 ; \mathrm{p}<0.025\end{array}$ & $\mathrm{Ja}$ \\
\hline 7.24 & Verkoopwijze producten & Veilingprovisie in $\%$ omzet & $\begin{array}{l}\mathrm{n}=44 ; \chi 2=23.376 \\
\mathrm{DF}=8 ; \mathrm{p}<0.003\end{array}$ & $\mathrm{Ja}$ \\
\hline 7.25 & Verkoopwijze producten & $\begin{array}{l}\text { Brutomarge gerealiseerd } \\
2006\end{array}$ & $\begin{array}{l}\mathrm{n}=44 ; \chi 2=15.472 \\
\mathrm{DF}=10 ; \mathrm{p}<0.116\end{array}$ & Nee \\
\hline 7.26 & Moderniteit bedrijf & Omzet gerealiseerd in 2006 & $\begin{array}{l}\mathrm{n}=44 ; \chi 2=16.669 \\
\mathrm{DF}=8 ; \mathrm{p}<0.034\end{array}$ & $\mathrm{Ja}$ \\
\hline 7.27 & Moderniteit bedrijf & Omzet gerealiseerd in 2007 & $\begin{array}{l}\mathrm{n}=44 ; \chi 2=32.928 \\
\mathrm{DF}=20 ; \mathrm{p}<0.034\end{array}$ & $\mathrm{Ja}$ \\
\hline 7.28 & Moderniteit bedrijf & Bedrijfsopp. glas in ha. & $\begin{array}{l}\mathrm{n}=44 ; \chi 2=29.764 \\
\mathrm{DF}=20 ; \mathrm{p}<0.074\end{array}$ & $\begin{array}{l}\mathrm{Ja}, \\
\mathrm{p}>90 \%\end{array}$ \\
\hline 7.29 & Moderniteit bedrijf & $\begin{array}{l}\text { Brutomarge gerealiseerd } \\
2006\end{array}$ & $\begin{array}{l}\mathrm{n}=44 ; \chi 2=19.803 \\
\mathrm{DF}=20 ; \mathrm{p}<0.470\end{array}$ & Nee \\
\hline 7.30 & Bedrijfsopp. glas in ha. & $\begin{array}{l}\text { Veilingprovisie in \% v.d. } \\
\text { omzet }\end{array}$ & $\begin{array}{l}\mathrm{n}=44 ; \chi 2=26.378 \\
\mathrm{DF}=20 ; \mathrm{p}<0.154\end{array}$ & Nee \\
\hline 7.31 & Bedrijfsopp. glas in ha. & Investeringen ( $€ \times 1 \mathrm{mln})$. & $\begin{array}{l}\mathrm{n}=37 ; \chi 2=38.401 \\
\mathrm{DF}=16 ; \mathrm{p}<0.001\end{array}$ & $\mathrm{Ja}$ \\
\hline 7.32 & Bedrijfsopp. glas in ha. & Productiekosten in $€$ per $\mathrm{m}^{2}$ & $\begin{array}{l}\mathrm{n}=44 ; \chi 2=34.505 \\
\mathrm{DF}=30 ; \mathrm{p}<0.261\end{array}$ & Nee \\
\hline 7.33 & Bedrijfsopp. glas in ha. & $\begin{array}{l}\text { Brutomarge gerealiseerd } \\
2006\end{array}$ & $\begin{array}{l}\mathrm{n}=44 ; \chi 2=19.441 \\
\mathrm{DF}=25 ; \mathrm{p}<0.776\end{array}$ & Nee \\
\hline 7.34 & $\begin{array}{l}\text { Organisatie marketing en } \\
\text { verkoop }\end{array}$ & Omzet gerealiseerd in 2006 & $\begin{array}{l}\mathrm{n}=44 ; \chi 2=23.103 \\
\mathrm{DF}=10 ; \mathrm{p}<0.010\end{array}$ & $\mathrm{Ja}$ \\
\hline 7.35 & $\begin{array}{l}\text { Organisatie marketing en } \\
\text { verkoop }\end{array}$ & Omzet gerealiseerd in 2007 & $\begin{array}{l}\mathrm{n}=44 ; \chi 2=25.584 \\
\mathrm{DF}=10 ; \mathrm{p}<0.004\end{array}$ & $\mathrm{Ja}$ \\
\hline 7.36 & $\begin{array}{l}\text { Organisatie marketing en } \\
\text { verkoop }\end{array}$ & $\begin{array}{l}\text { Brutomarge gerealiseerd } \\
\text { in } 2006\end{array}$ & $\begin{array}{l}\mathrm{n}=44 ; \chi 2=12.763 \\
\mathrm{DF}=10 ; \mathrm{p}<0.237\end{array}$ & Nee \\
\hline 7.37 & $\begin{array}{l}\text { Organisatie marketing en } \\
\text { verkoop }\end{array}$ & Veilingprovisie in $\%$ omzet & $\begin{array}{l}\mathrm{n}=44 ; \chi 2=21.864 \\
\mathrm{DF}=8 ; \mathrm{p}<0.005\end{array}$ & $\mathrm{Ja}$ \\
\hline 7.38 & $\begin{array}{l}\text { Totale verkoopkosten in \% } \\
\text { omzet }\end{array}$ & $\begin{array}{l}\text { Brutomarge gerealiseerd } \\
2006\end{array}$ & $\begin{array}{l}\mathrm{n}=44 ; \chi 2=31.614 \\
\mathrm{DF}=20 ; \mathrm{p}<0.048\end{array}$ & $\mathrm{Ja}$ \\
\hline 7.39 & Veilingprovisie in \% omzet & $\begin{array}{l}\text { Brutomarge gerealiseerd } \\
2006\end{array}$ & $\begin{array}{l}\mathrm{n}=44 ; \chi 2=22.721 \\
\mathrm{DF}=20 ; \mathrm{p}<0.090\end{array}$ & $\begin{array}{l}\mathrm{Ja}, \\
\mathrm{p}>90 \%\end{array}$ \\
\hline $\begin{array}{l}7.40- \\
7.41 \\
\end{array}$ & $\begin{array}{l}\text { Concentratiegraad (C4) } \\
\text { bedrijfsopp. glas in ha. }\end{array}$ & $\begin{array}{l}\text { Omzet en brutomarge } \\
\text { gerealiseerd in } 2006 / 2007\end{array}$ & n.v.t. & n.v.t. \\
\hline 7.42 & $\begin{array}{l}\text { Investeringsniveau }(€ \times 1 \\
\mathrm{mln} .)\end{array}$ & $\begin{array}{l}\text { Brutomarge gerealiseerd } \\
2006\end{array}$ & $\begin{array}{l}\mathrm{n}=37 ; \chi 2=23.314 \\
\mathrm{DF}=24 ; \mathrm{p}<0.501\end{array}$ & Nee \\
\hline
\end{tabular}


De marktresultaatsvariabelen zijn:

1. jaaromzet + groei

2 jaarprijzen

3. brutomarge $[(\mathrm{P}-\mathrm{GTK}) / \mathrm{P}] * 100$

4. aandeel eigen vermogen in $\%$ totaal $(\mathrm{EV} / \mathrm{TV}) * 100$

In tabel 7.15 wordt een overzicht gegeven van de onderzochte verbanden tussen de hierboven genoemde variabelen met een al dan niet significant resultaat. Alle getoetste variabelen worden in appendix $\mathrm{C}$ met behulp van de in de tabel genoemde kruistabellen (tabellen $7.16 \mathrm{t} / \mathrm{m} \mathrm{7.42)}$ geanalyseerd en toegelicht. De significante en enkele niet significante en vermeldenswaardige resultaten, van belang voor de analyse, worden hier beschreven.

\subsubsection{Structuur- en resultaatsvariabelen (mesoniveau)}

In de volgende paragrafen worden de onderscheiden structuur- en resultaatsvariabelen van de sector glaspotplanten besproken, deels voortkomend uit de onderzoeksresultaten van het sectoronderzoek en onderzoek afzetorganisaties (zie hoofdstuk 3 en 4) en deels vanuit het bedrijfsonderzoek. Zoals wordt aangegeven in het analysemodel van figuur 2.4 in hoofdstuk 2, vindt er een voortdurende wederzijdse beïnvloeding plaats van marktgedragsvariabelen naar marktstructuurvariabelen. Behandeld worden de concentratieontwikkeling bij producenten, afzetorganisaties en groothandel/export, de productdifferentiatie, de toetredingsdrempels en de mogelijke verbanden van deze variabelen met de resultaatsvariabelen omzet, productie- en exportwaarde, prijzen, brutomarge en solvabiliteit.

\subsubsection{Horizontale concentratie}

Producenten

In tabel 7.43 zijn de uitkomsten van het sector- en bedrijfsonderzoek betreffende de horizontale concentratiegraad van de vier grootste bedrijven (C4) met de resultaatsvariabele gemiddelde brutomarge 2006 samengevoegd (tabel 3.54, 7.40 en 7.41). De C4-oppervlakte glas, gemeten per productsoort van de vier grootste bedrijven die groene en bloeiende potplanten telen, ligt op een laag niveau en bedraagt in 200611 en 7\%. De gemiddelde C4-brutomarge 2006 bedraagt voor groene planten 9.6 en voor bloeiende planten 3.5\%. Voor alle respondenten ligt de brutomarge groene planten op 11 en bloeiend op bijna $6 \%$.

Per bedrijfstype bekeken ligt de C4-oppervlakte glas voor het C1-bedrijfstype op $6.0 \%$ met een C4-brutomarge van $4.8 \%$ en het C2-type op $6.5 \%$ met een C4-brutomarge van $4.7 \%$.

Het C1-bedrijfstype scoort aldus met een iets lagere $\mathrm{C} 4$-waarde een brutomarge vergelijkbaar met type $\mathrm{C} 2$. Gemeten over alle respondenten $\mathrm{C} 1$ en $\mathrm{C} 2$ ligt de brutomarge ruim vier procentpunt hoger dan de C4-brutomarge (8.9\%). De conclusies van hoofdstuk 3 worden met de uitkomsten van dit bedrijfsonderzoek glaspotplanten verder onderbouwd en liggen hiermee in lijn. De C4waarde in de glaspotplanten ligt op een laag niveau. Er is een daling van de $\mathrm{C} 4$ bij groene en een stabilisatie bij bloeiende potplanten over de periode 2006-2009 van 11 en 7\% naar 6\%. Deze C4-waarde lijkt tot op heden van weinig invloed op het sector- en bedrijfsresultaat. 
Voor de ontwikkeling van de concentratiegraad over deze periode bij de afzetorganisaties en de groothandel/export en de invloed hiervan op sectorresultaten wordt verwezen naar tabel 3.55 en tabel 4.9 in hoofdstuk 3 en 4.

Tabel 7.43 Concentratie (C4) en brutomarge producenten glaspotplanten 2004-2010

\begin{tabular}{|c|c|c|c|c|c|c|}
\hline $\begin{array}{l}\text { Concentratiegraad (C4 in \%) } \\
\text { Glaspotplanten }\end{array}$ & 2006 & 2007 & 2008 & 2009 & 2010 & 2011 \\
\hline $\begin{array}{l}\text { Sectoronderzoek*) producenten } \\
\text {-Potplantentelers (C4 in \%) } \\
\text {-Groene potplanten } \\
\text {-Bloeiende potplanten } \\
\text { (alle bedrijven op basis van areaal) }\end{array}$ & & $\begin{array}{l}6.0 \\
7.0\end{array}$ & $\begin{array}{l}6.0 \\
6.5\end{array}$ & $\begin{array}{l}6.0 \\
6.0\end{array}$ & & \\
\hline $\begin{array}{l}\text { Bedrijfsonderzoek producenten } \\
\text { glaspotplanten }(\mathrm{C} 4 \text { in \%): } \\
\text {-Groene potplanten } \\
\text {-Bloeiende potplanten } \\
\text {-Bedrijfstype C1 } \\
\text {-Bedrijfstype C2 }\end{array}$ & $\begin{array}{r}11.0 \\
7.0 \\
6.0 \\
6.5\end{array}$ & & & & & \\
\hline $\begin{array}{l}\text { Bedrijfsonderzoek producenten } \\
\text { glaspotplanten (brutomarge in \%): } \\
\text {-Groene potplanten (C4-resp.) } \\
\text {-Bloeiende potplanten (C4-resp.) } \\
\text {-Bedrijfstype C1(C4-resp.) } \\
\text {-Bedrijfstype C2(C4-resp.) }\end{array}$ & $\begin{array}{l}9.6 \\
3.5 \\
4.8 \\
4.7 \\
\end{array}$ & & & & & \\
\hline
\end{tabular}

*) Onderzoeksresultaten sectoronderzoek producenten glaspotplanten (H3, deel tabel 3.55)

\subsubsection{Voorwaartse verticale integratie}

In de voorgaande paragraaf is de structuurvariabele voorwaartse verticale integratie ook opgenomen als gedragsvariabele. Er zijn weinig voorbeelden van bedrijven in de sector glassnijbloemen en -potplanten die verticaal zijn geïntegreerd met de groothandel/export of die plannen daartoe hebben. Wel zijn er voorbeelden van verticale samenwerking tussen producenten, afzetorganisaties, groothandels/exporteurs en grootschalige detaillisten, vooral bij de grotere potplantenbedrijven. Hierbij wordt echter niet de zeggenschap over de bedrijfsvoering overgedragen. In hoofdstuk 4, 5 en 6 is deze gedrags- en structuurvariabele bij de rapportage afzetorganisaties en bedrijfsonderzoek glasgroenten en -snijbloemen aan de orde geweest. In paragraaf 6.3.2.2 zijn de kenmerkende verschillen en de problematiek van het afzetsysteem in de sectoren glasgroenten en -snijbloemen nogmaals naast elkaar besproken. Aangegeven is wat de gevolgen zijn geweest van voorwaartse verticale integratie voor de marktstructuur en marktsituatie in de sector glasgroenten. Beschreven is de verkleining van de groothandelsmarkten in Nederland en aangrenzende buurlanden, evenals de scherpe concurrentie en ondoorzichtige marktsituatie die hierdoor is ontstaan met het einde van een openbare, vrije en transparante prijsvorming. In de glasgroenten is hierdoor een goede dagelijkse match van vraag en aanbod van het versproduct in Nederland en België praktisch onmogelijk geworden (Bunte, 2009). In de sector glassnijbloemen en -potplanten wordt dit probleem tot op heden opgelost door veilingorganisatie FloraHolland met een prijsvormingssysteem dat vrije toegang biedt aan aanvoerders en kopers uit de 
gehele EU met gelijke kansen op reële prijsvorming en prijzen. De dagelijks variërende prijs is tevens een noodzakelijke referentieprijs voor aanvullende transacties tussen grote marktpartijen. Hoewel planten langer houdbaar zijn dan snijbloemen, is ook bij pot- en perkplanten sprake van een versproduct met een onzeker oogsttijdstip en een relatief korte houdbaarheidstijd in het logistieke traject. De grotere bedrijven in deze sector moeten zich realiseren dat bij de levering van grote uniforme partijen aan bouwmarkten en grootwinkelbedrijven in Europa een openbaar en transparant systeem van prijsvorming, zoals momenteel door FloraHolland beschikbaar wordt gesteld, van groot belang is voor de sector en het individuele bedrijf. Dit individuele bedrijf wordt benaderd door grote afnemers die graag rechtstreeks zaken willen doen zonder bemoeienis van een veilingorganisatie die mede de belangen van haar leden behartigt. Bedacht moet worden dat je als leverancier nooit de enige bent en altijd een relatief kleine partij blijft ten opzichte van grote Europese winkelketens. Verkoop via FloraHolland geeft naast de informatieve (prijs) ondersteuning een snelle en veilige betalingsregeling, een goede debiteurenbewaking en de mogelijkheid per productgroep geconcentreerd op te treden en bij te lage vraagprijzen de verkoop aan te houden.

\subsubsection{Productdifferentiatie}

Evenals in de sector glassnijbloemen is de productdifferentiatie bij de glaspotplanten groot. In de verkoopstatistieken van FloraHolland worden de potplanten verdeeld in drie productgroepen: groene en bonte kamerplanten (1), bloeiende kamerplanten (2) en perk- en kuipplanten (3). Elke productgroep kent een top 5 tot top 10 aan subgroepen die een goed deel van de omzet voor hun rekening nemen. Voorts is er een grote variatie in potmaat, plantgrootte en -vorm en toegevoegde waarde in soort pot en verpakking. Bij de groene en bonte kamerplanten zijn dracaena, ficus, hedera, palmen, cactussen/succulenten en varens de belangrijkste subgroepen. Bij bloeiende kamerplanten zijn dit phalaenopsis, anthurium, kalanchoë, rosa, chrysant, hortensia, spathiphyllum, cyclaam en guzmania. Bij perk- en kuipplanten zijn dit viola, pelargonium, osteospermum, petunia, impatiens, begonia, lobelia, fuchsia, tagetes en verbena (Vakblad voor de Bloemisterij, jaarlijkse staalkaart snijbloemen en potplanten, 22 mei 2009 e.v.).

Veredelingsbedrijven werken nauw samen met producenten en de groot- en detailhandel bij de ontwikkeling van nieuwe producten en concepten. Het aantal pot- en perkplantenbedrijven daalde in 2012 met ruim 3\% tot circa 860 met een licht toenemend areaal tot 1800 ha. De gemiddelde

Tabel 7.44 Ontwikkeling aantal bedrijven en areaal (pot- en perkplanten onder glas)

\begin{tabular}{|l|r|r|r|r|r|}
\hline & \multicolumn{2}{|l|}{2000} & 2005 & $2012(\mathrm{P})$ & $\begin{array}{l}\text { Mutatie } \\
2011 / 12 \\
\text { in \% }\end{array}$ \\
\hline Aantal bedrijven & 1680 & 1410 & 890 & 860 & -3.4 \\
\hline Areaal onder glas & 1760 & 1930 & 1790 & 1800 & +0.6 \\
\hline -waarvan bloeiende planten & 680 & 790 & 870 & 870 & - \\
\hline -waarvan groene planten & 580 & 590 & 490 & 480 & -2.0 \\
\hline -waarvan perkplanten & 500 & 550 & 430 & 450 & +4.6 \\
\hline
\end{tabular}

Bron: CBS Landbouwtelling, bewerking LEI rapport 2012-064, gegevens 2012 zijn voorlopig (P) 
bedrijfsomvang kwam zo op 2.1 ha. Sinds 2000 is het aantal bedrijven bijna gehalveerd terwijl het totale areaal zich tamelijk stabiel ontwikkelt (tabel 7.44). Het areaal bloeiende planten is hiervan inmiddels het grootst, het areaal groene planten is gedaald en het areaal perkplanten schommelt tussen 400 en 500 ha.

In paragraaf 6.3.2.3 is aangegeven hoe het productbeleid en de productontwikkeling vanaf 2004 door de bloemenveilingen FloraHolland en VBA en haar leden snijbloemen- en potplantentelers gestalte werd gegeven (Jaarverslag FloraHolland 2005, p. 15). Als voorbeelden werden genoemd nieuw ontwikkelde producten en diensten door FloraHolland en VBA, alleen of in samenwerking met derden.

De onderzoeksuitkomsten van het bedrijfsonderzoek glaspotplanten betreffende het assortiment geteelde producten laten het volgende zien:

1. Van de 44 onderzochte bedrijven telen er zestien uitsluitend groene planten, vijftien bloeiende planten, negen groen en bloeiend en vier groen en/of bloeiend in combinatie met jonge planten of tuinplanten. In het verslag onderzoeksresultaten glaspotplanten is in tabel 8 aangegeven welke typen producten er worden geteeld (Veerman, 2009).

- In de groene planten wordt vaak de combinatie gezocht met kuip- en tuinplanten om jaarrond voldoende teeltcapaciteit te kunnen benutten (kuip- en tuinplanten in voorjaar en zomer en groene planten in najaar en vroege voorjaar tot aan begin lente). Men specialiseert zich meestal in bepaalde rassen en typen met bepaalde potmaten. In de groene planten zijn dit o.a. de volgende producten: ficus, dracaena, palmen, varens, schefflera, diefenbachia, aglaonema, hedera e.a.

- In de bloeiende potplanten bestaat het assortiment uit de phalaenopsis, anthurium, bromelia, vriesea, calathea, cyclaam, begonia, st.paulia, azalea e.a.

- Een aantal bedrijven, ook van kleinere omvang, heeft een combinatie van telen en levering eindproduct aan de veiling èn het opkweken en leveren van plantmateriaal aan collegatelers, bijv. dracaena, palmen, varens, nolina e.a.

2. Er is een betekenisvol verband tussen de gekozen productsoort en de door deze bedrijven in 2006 en 2007 gerealiseerde omzet. Telers van groene potplanten zijn gemiddeld de kleinste bedrijven en behalen een betekenisvolle lagere jaaromzet dan telers van bloeiende potplanten $(p<0.054$ en $p<0.004)$. Opvallend is wel dat deze telers in 2006 een betekenisvol hogere brutomarge realiseren dan de telers van de overige productsoorten $(p<0.070)$. Groene planten hebben meer het kenmerk van een specialty, met vaak verkoop via bloemist en tuincentrum. Bloeiende potplanten hebben vaak het kenmerk van een convenience, een gebruiksproduct, met verkoop via het grootwinkelbedrijf (zie ook tabel 7.7). 


\subsubsection{Toetredingsdrempels (investeringen)}

Toetreding tot de sector glaspotplanten in Nederland is in vergelijking met de glassnijbloemen een nog kostbaarder zaak en de investeringsdrempels voor een nieuw bedrijf zijn nog hoger. In de voorgaande paragraaf is onder toe- en uittreding sector aangegeven dat van 2005-2010 er een vergroting plaatsvond van de gemiddelde bedrijfsomvang van 1.1 tot 1.5 ha. glasoppervlakte. Jaarlijks stopte gemiddeld 5\% van de bedrijven. Toetreding tot de sector vond weinig plaats, een enkel glastuinbouwbedrijf stapte vanuit de sector glassnijbloemen over naar de glaspotplanten. In die sector is ook de afgelopen jaren redelijk geïnvesteerd. In paragraaf 6.3.2.4 is onder toetredingsdrempels aangegeven dat het investeringsgedrag in de drie sectoren van de glastuinbouw over de periode 2004-2008 zich stabiel ontwikkelde. In 2009 en 2010 waren de investeringen laag ten gevolge van de kredietcrisis, in 2011 groeiden ze, met name in de potplantensector. In 2011 lag het niveau voor de drie sectoren glastuinbouw gemiddeld op bijna 170.000 euro per bedrijf.

Het opzetten van een nieuw bedrijf in de sector glaspotplanten vergt zeer hoge investeringen. Een nieuw potplantenbedrijf met roltafels, eb- en vloedsysteem en recirculatie (met WKK-installatie) vergde in 2010 een investering van ongeveer 250 euro per $\mathrm{m}^{2}$ kas voor een bedrijf van 2 ha., tot 225 euro per $\mathrm{m}^{2}$ bij een bedrijf van 10 ha. In totaal komt een gemiddeld potplantenbedrijf van 2 ha. uit op een investering van bijna $5 \mathrm{mln}$. en een bedrijf van 4 ha. op $9.5 \mathrm{mln}$. euro. Dit bedrag is inclusief de benodigde bedrijfsmiddelen, maar exclusief de aanschaf van grond. De grondprijs varieert per gebied in Nederland en is sterk locatiegebonden. Deze investeringen gelden voor de opzet van een nieuw bedrijf. Het omschakelen vanuit een bestaande teelt vergt minder kosten, is afhankelijk van het type bedrijf, de aanwezige kas en de aanwezigheid van een WKK-installatie (Vermeulen, 2010).

In tabel 7.19 is vastgesteld dat er een betekenisvol verband aanwezig is tussen bedrijfstype en investeringsniveau: bedrijfstype $\mathrm{C} 1$ Veilingteler investeert betekenisvol minder dan bedrijfstype $\mathrm{C} 2$, lid van de veilingtelersvereniging.

De vraag is of een hoger niveau van investeringen ook een hoger resultaat bewerkstelligt. In tabel 7.42 wordt dit verband getoetst. Evenals in de glasgroenten en -snijbloemen blijkt ook hier dat er geen betekenisvol verband is tussen de hoogte van de investeringen en de gerealiseerde brutomarge in 2006. Hogere investeringen van bedrijven blijken niet (direct) tot hogere resultaten te leiden en concurrerende bedrijven zullen trachten snel innovatieve investeringen te imiteren om aldus een deel van het (extra) resultaat te verwerven. 


\subsection{Voorlopige conclusies}

Hieronder volgen de voorlopige conclusies uit het onderzoek naar marktgedrag en marktresultaat van de glaspotplantenbedrijven. Evenals bij de glassnijbloemen is de indeling naar bestuurlijk-organisatorische, commerciële en financieel-economische aspecten. Marktstructuur en marktresultaat worden daarna behandeld tezamen met de onderlinge beïnvloeding van marktgedrag en marktstructuur (vice versa).

\subsubsection{Conclusies marktgedrag en -resultaat}

Op grond van de uitkomsten van het bedrijfsonderzoek naar het marktgedrag en -resultaat in de sector glaspotplanten kunnen we de volgende conclusies trekken.

- Bestuurlijk-organisatorische en financieel-economische conclusies

\section{Strategische keuze bedrijfsomvang}

Ook bij de glaspotplanten is de bedrijfsoppervlakte glas in ha. een belangrijk kenmerk voor de te realiseren jaarlijkse omzet en winst. Evenals bij de glasgroenten en -snijbloemen is er een voortdurende toename van de gemiddelde bedrijfsomvang en een grote variatie in omvang en resultaat van de onderzochte bedrijven. In 2005 ligt de populatie op ruim 1400 bedrijven, het areaal op 1900 ha. en is de gemiddelde bedrijfsomvang 1.4 ha. In 2012 zijn er nog 860 bedrijven op een areaal van 1800 ha. met een gemiddelde omvang van 2.2 ha.

Van de 44 onderzochte bedrijven is de gemiddelde bedrijfsomvang 4.2 ha. met een spreiding van 0.2 ha. tot 25 ha. De gemiddelde omzet in 2006 is $€ 4.9 \mathrm{mln}$. met een spreiding van $€ 0.3 \mathrm{mln}$. met een maximum van $€ 35 \mathrm{mln}$. In 2007 lag de gemiddelde omzet op $€ 5.3 \mathrm{mln}$. met eenzelfde spreiding als in 2006. De brutomarge gerealiseerd voor de 44 respondenten komt gemiddeld uit op $8.6 \%$ met eveneens een grote spreiding. Het aandeel eigen vermogen in procenten van het totaal ligt in 2006 gemiddeld op $42.3 \%$.

Het onderzoek naar mogelijke verbanden tussen bedrijfsomvang en behaalde resultaten laat zien dat er ook bij de glaspotplanten voor het kleinere bedrijf veel mogelijkheden zijn:

- bedrijven met een kleine en grote oppervlakte glas behaalden in 2006 vergelijkbare brutomarges;

- bedrijven met een kleinere oppervlakte glas laten geen significant hogere kostprijs per $\mathrm{m}^{2}$ zien dan de grotere bedrijven;

- bedrijven met een kleinere oppervlakte glas betalen geen significant hogere veilingprovisie.

Wat verder opvalt, is dat de oudste bedrijven een vergelijkbare brutomarge behalen met de laatst gerealiseerde. Deze oudste bedrijven zijn kwekers van groene planten die vaak ook leverancier zijn van het uitgangsmateriaal en/of leverancier van tuinplanten. 


\section{Strategische keuze productsoort}

Bezien naar productsoorten is het groene potplantenbedrijf in Nederland aanzienlijk kleiner dan het bloeiende potplantenbedrijf. De gemiddelde oppervlakte en omzet van het groene bedrijf bedraagt minder dan de helft van het bloeiende bedrijf. De productsoorten groen en bloeiend en anders betreffen gemiddeld de grotere bedrijven, die hun kracht zoeken in de combinatie van seizoensplanten, met eventueel de levering van jong plant- en perkgoed. Deze bedrijven laten een grote spreiding in oppervlakte zien, van 1.0 - 25.0 ha., met één grootschalig potplantenbedrijf met een breed en zeer divers assortiment.

De gemiddelde omzet van het groene potplantenbedrijf bedraagt in 2006 en $2007 € 1.7 \mathrm{mln}$. Deze bedrijfsomzet is significant lager dan de andere productsoorten. Het bloeiende potplantenbedrijf ligt in 2006 op $€ 6.8 \mathrm{mln}$. en in 2007 op $€ 7.9 \mathrm{mln}$. Voor groen en bloeiend ligt dit gemiddeld op $€ 5.3 \mathrm{mln}$. in 2006 en $€ 5.5 \mathrm{mln}$. in 2007 met een spreiding van $1.2-13.5 \mathrm{mln}$. euro en voor anders op $€ 9.5 \mathrm{mln}$. in 2006 en 2007 met een spreiding in beide jaren van $0.9-35.0 \mathrm{mln}$. euro. Deze laatste groep bestaat uit vier bedrijven. Bij de groene potplanten ligt de gerealiseerde brutomarge in 2006 op $11.5 \%$. Bij de bloeiende potplanten ligt dit cijfer lager, op 5.9\%. Groen en bloeiend ligt op $7.5 \%$ en potplanten anders op 9.5\%. Evenals bij bedrijfsoppervlakte en omzet laat de gerealiseerde brutomarge een grote spreiding in resultaten zien. Telers van groene planten laten de hoogst gerealiseerde brutomarge zien. Dit levert een significant verschil op met dat van de bloeiende potplanten.

Het onderzoek naar mogelijke verbanden tussen keuze productsoort en behaalde resultaten komt tot de volgende uitkomst. Er is een betekenisvol verband tussen de gekozen productsoort en de door deze bedrijven in 2006 en 2007 gerealiseerde omzet. Telers van groene potplanten zijn gemiddeld de kleinste bedrijven en behalen een betekenisvolle lagere jaaromzet dan telers van bloeiende potplanten $(p<0.054$ en $p<0.004)$. Opvallend is dat deze telers in 2006 een betekenisvol hogere brutomarge realiseren dan de telers van de overige productsoorten $(\mathrm{p}<0.070)$.

\section{Strategische keuze bedrijfstype}

Van de vier typeringen valt $57 \%$ onder het type $\mathrm{C} 1$, bijna $40 \%$ onder type $\mathrm{C} 2$ en slechts twee onder het type $\mathrm{C} 3$ en $\mathrm{C} 4$ met rechtstreekse afzet aan een handelsorganisatie. $\mathrm{C} 1$ realiseert de laagste gemiddelde bedrijfsomzet, namelijk $€ 1.5 \mathrm{mln}$. in 2006 en $€ 1.6 \mathrm{mln}$. in 2007.

Type $\mathrm{C} 1,3$ heeft een hogere gemiddelde bedrijfsomzet namelijk $€ 4.9 \mathrm{mln}$. in 2006 en $€ 5.3 \mathrm{mln}$. in 2007. Bij type C2 is de gemiddelde bedrijfsomzet $€ 6.1 \mathrm{mln}$. in 2006 en $€ 7.1 \mathrm{mln}$. in 2007. De combinatie van type $\mathrm{C} 2,3$ heeft een gemiddelde omzet van $€ 1.6 \mathrm{mln}$. en de overige twee respondenten $\mathrm{C} 1,4$ en $\mathrm{C} 1,3,4$ hebben een omzet van $€ 2.7 \mathrm{mln} . / € 3.0 \mathrm{mln}$. $(2006 / 2007)$ en $€ 35$ $\mathrm{mln} .(2006 / 2007)$. De gemiddeld gerealiseerde brutomarge in 2006 voor alle respondenten komt uit op $8.6 \%$. Bij splitsing van de resultaten naar bedrijfstype liggen de gerealiseerde brutomarges dicht bij elkaar, tussen 8.3 en 10\%. Het gemiddeld aandeel eigen vermogen ligt in 2006 op $42.3 \%$. Bij splitsing naar bedrijfstype varieert dit percentage van 33 tot $44.5 \%$. 
Het onderzoek naar mogelijke verbanden tussen keuze bedrijfstype en resultaten laat het volgende zien:

- er is een (verwacht) betekenisvol verband tussen type bedrijf en gerealiseerde omzet. Type C2 behaalt een significant hogere omzet dan type $\mathrm{C} 1(\mathrm{p}<0.058)$;

- er is een betekenisvol verband tussen bedrijfstype en de gerealiseerde brutomarge $(\mathrm{p}<0.057)$.

Bij type $\mathrm{C} 1,3$ ligt dit op een hoger niveau dan bij $\mathrm{C} 1$ en $\mathrm{C} 2$. Evenals in de sector snijbloemen realiseert het kleinste bedrijfstype $\mathrm{C} 1$ (de veilingteler) een hogere brutomarge dan type $\mathrm{C} 2$, vooral bij extra inzet van een eigen verkoper (C1,3) (zie hoofdstuk 6 tabel 6.19).

Dit strookt niet met de conclusies in het artikel 'Investeren in telersvereniging loont' uit het Vakblad voor de Bloemisterij (23 juli 2010, p. 18).

\section{Concentratieontwikkeling bedrijven}

De horizontale concentratiegraad (C4) onder de bedrijven in de sector glaspotplanten ligt in 2006 op een laag niveau. Voor groen en bloeiend ligt deze $\mathrm{C} 4$ op 11 en $7 \%$, voor bedrijfstype $\mathrm{C} 1$ en C2 op 6 en 6.5\%. Deze uitkomsten liggen in lijn met de uitkomsten van het sectoronderzoek (zie hoofdstuk 3). Er is geen toename van de horizontale concentratie over de periode 2006-2009, de concentratie ontwikkelt zich tamelijk stabiel en is van weinig invloed op het sector- en bedrijfsresultaat (productiewaarde, prijzen snijbloemen, brutomarge).

Evenals bij de ontwikkeling van de $\mathrm{C} 4$ per productsoort is bij de $\mathrm{C} 4$ per bedrijfstype het verschil in brutomarge te zien tussen de vier grootste bedrijven en de gemiddelde brutomarge van alle respondenten. Gemeten over alle respondenten $\mathrm{C} 1$ en $\mathrm{C} 2$ ligt de brutomarge ruim vier procentpunt hoger dan de C4-brutomarge. Bedrijven van kleinere omvang boeken vergelijkbare en soms betere resultaten. Strategische keuzen ten aanzien van productsoort en -type, bedrijfstype en -omvang, de organisatie van de afzet, de kosten van grond, energie en arbeid zijn factoren van invloed op het meer of juist minder succesvol ondernemen.

\section{Investeringen/innovaties}

In de periode 2004-2008 blijven de investeringen in de glastuinbouw op een stabiel niveau van gemiddeld 150.000 euro per bedrijf. In 2007 en 2008 is er onder andere in groenlabelkassen geïnvesteerd in verband met de strenger wordende regelgeving. In 2009 en 2010 was het investeringsniveau lager door de gevolgen van de kredietcrisis. In 2011 was er een groei waarneembaar, vooral in de potplantensector en in beperktere mate bij de snijbloemen (Van der Meulen et al., 2012, pp. 128,129).

Het onderzoek naar mogelijke verbanden tussen bedrijfstype en investeringen resp. investeringen en brutomarge laat het volgende zien:

- er is een (verwacht) betekenisvol verband tussen bedrijfstype en de hoogte van het investeringsniveau. Bedrijfstype $\mathrm{C} 1$ investeert betekenisvol minder dan bedrijfstype $\mathrm{C} 2$;

- er is geen betekenisvol verband tussen de hoogte van de investeringen en de gerealiseerde brutomarge in 2006. Hogere investeringen van bedrijven blijken niet (direct) tot hogere resultaten te leiden. Dit is eveneens het geval in de sectoren glasgroenten en -snijbloemen. 


\section{- Commerciële en financieel-economische conclusies}

\section{Organisatie marketing en verkoop}

Alle onderzochte bedrijven zijn aangesloten bij FloraHolland te Naaldwijk met vestigingen te Aalsmeer, Bleiswijk, Rijnsburg, Eelde en Venlo (inmiddels Veiling Rhein-Maas in StraelenHerongen, in samenwerking met Landgard te Duitsland). Een aantal van de grootste bedrijven zet zijn producten af op meer veilpunten in goed overleg met het management van deze vestigingen. Bijna $89 \%$ van de respondenten (tabel 7.2) heeft naast de veiling als verkooporganisatie tevens een eigen verkoper of een verkoper in samenwerking met collega-bedrijven. $11 \%$ laat de verkoop volledig over aan de veiling (klok en/of bemiddeling). Ruim 36\% van de respondenten werkt samen in een met behulp van de veiling opgerichte telersvereniging en probeert via een of meer door de vereniging aangetrokken verkoopfunctionarissen de eigen afzet extra te stimuleren. Slechts een enkel groot bedrijf heeft met medeweten van de veiling een eigen afzet-bv opgericht die voor een deel rechtstreeks met de groothandel/export en het grootwinkelbedrijf zaken doet, ook in aan potplanten verwante producten. FloraHolland heeft door de grote omvang van het brede en diepe aangevoerde assortiment bloemen en planten een groot verkoopapparaat (bemiddelingsbureau FloraHolland Connect), bij de individuele bedrijven en de in samenwerking met de veiling opgezette telersverenigingen is dit veel kleiner. Eigen verkoop ontwikkelt zich vooral sterk bij de productsoort bloeiende planten met een breed en diep assortiment (bijv. phalaenopsis).

De via de veiling betaalde provisie, gemeten als percentage van de omzet, bedraagt gemiddeld $6.7 \%$ en varieert tussen de 3 en $12 \%$. De kosten EV van de teler bedraagt gemiddeld $2.2 \%$ van de omzet en varieert tussen de 0.5 en $5 \%$.

Het bedrijfsonderzoek naar mogelijke verbanden tussen organisatie marketing en verkoop en resultaten geeft de volgende uitkomsten:

- er is een betekenisvol verband tussen de organisatie van de marketing en verkoop en de gerealiseerde jaaromzet in 2006 en 2007. Naarmate de omzet hoger is, maakt men naast de verkoopdiensten van FloraHolland (klok en bemiddeling) meer gebruik van een eigen verkoper. Deze eigen verkoper per bedrijf of telersvereniging lijkt de omzet te stimuleren.

De bedrijven met de laagste omzet (11\%) besteden de marketing- en verkoopactiviteiten in zijn geheel uit aan FloraHolland. Van de overige bedrijven maakt 53\% gebruik van de diensten van FloraHolland met tevens een eigen verkoper. 36\% doet ditzelfde met de verkoopfunctionaris onder de vlag van een telersvereniging waarvan men lid is;

- er blijkt geen betekenisvol verband te zijn tussen de organisatie van de marketing en verkoop en de gerealiseerde brutomarge in 2006. Wel valt op dat alle vijf respondenten die hun marketing en verkoop in zijn geheel uitbesteden aan FloraHolland een brutomarge scoren die hoger is dan $5.1 \%$. Twee van deze vijf scoren tussen 10 en $15 \%$ en twee hoger dan $15 \%$;

- bedrijven die de organisatie van marketing en verkoop in zijn geheel uitbesteden aan FloraHolland betalen een betekenisvol hogere veilingprovisie dan de bedrijven die gebruik maken van veilingbemiddeling met eigen verkoop en verkoop via de telersvereniging. 
Het bedrijfsonderzoek naar mogelijke verbanden tussen verkoopwijze en resultaten geeft de volgende uitkomsten:

- er is een betekenisvol verband tussen de verkoopwijze van de producten en de gerealiseerde jaaromzet in 2006 en 2007. Veilingtelers (verkoopwijze 1) behalen een significant lagere omzet dan leden van de telersvereniging (verkoopwijze 2) en telers met een eigen verkoper (verkoopwijze 3);

- er is een betekenisvol verband tussen verkoopwijze en hoogte veilingprovisie: alleen via de klok verkopen betekent het betalen van de hoogste veilingprovisie;

- hoewel niet significant is er toch wel enig verband tussen de verkoopwijze van de producten en de brutomarge gerealiseerd in 2006. Veilingtelers (verkoopwijze 1) behalen een gemiddeld hogere brutomarge dan leden van de telersvereniging (verkoopwijze 2) en telers met een eigen verkoper (verkoopwijze 3).

Een vraag die nog overblijft is de invloed van hogere totale verkoopkosten en veilingprovisie op de brutomarge. De analyse hiervan leidt tot de volgende conclusies:

- bedrijven met hogere totale verkoopkosten (waarvan het grootste deel veilingprovisie) behalen een hogere brutomarge;

- bedrijven die een hogere veilingprovisie betalen behalen een hogere brutomarge $(p<0.09)$.

\section{Mate van tevredenheid}

$50 \%$ van de respondenten is tevreden over de verkooporganisatie, $9 \%$ ontevreden en $39 \%$ is tevreden/ontevreden. Als maatregel om de tevredenheid te vergroten wordt door ruim $20 \%$ van de respondenten genoemd een actievere opstelling van de verkoper van het bemiddelingsbureau. Andere mogelijke maatregelen zijn het verhogen van collectieve reclame (meer Holland Promotie), het klantgerichter werken en het verbeteren van de informatie en communicatie naar groothandelaren/exporteurs en retail. Naar bedrijfstype verdeeld is $\mathrm{C} 1$ het meest tevreden (bijna $64 \%$ is tevreden en $36 \%$ is tevreden/ontevreden). Bij type $\mathrm{C} 1,3$ is de tevredenheid minder: $43 \%$ is tevreden en $43 \%$ tevreden/ontevreden terwij 1 14\% ontevreden is. Type C 2 zit tussen de bovenstaande waarderingen in.

3. De gemiddelde uitbetaalprijzen per productsoort en bedrijfstype

Door het brede en diepe assortiment potplanten en potmaten zijn er naar productsoort en bedrijfstype weinig zinvolle prijsvergelijkingen te maken. Voor een achttal phalaenopsistelers van bedrijfstype $\mathrm{C} 1$ is een uitzondering gemaakt. Het blijkt dat bij de verkoop van phalaenopsis meestal wordt gekozen voor bedrijfstype $\mathrm{C} 1,3$ hetgeen het belang van de eigen verkoopfunctie onderstreept. Bedrijfstype C1 scoort lager met de gemiddelde uitbetaalprijs en C2 scoort hoger. Op basis van één respondent is geen betrouwbare vergelijking tussen de verschillende bedrijfstypen te trekken. De gemiddelde uitbetaalprijzen voor de phalaenopsis lopen van 2005-2008 uiteen van $€ 5.36-4.85$ en liggen in alle jaren op een hoger niveau dan het door het Productschap Tuinbouw geregistreerde gemiddelde jaarprijsniveau. De grote prijsvariatie van de phalaenopsis bij bedrijfstypen $\mathrm{C} 1, \mathrm{C} 1,3$ en $\mathrm{C} 2$ laat zien dat er door de bedrijven een breed assortiment van ver- 
schillende unieke producttypen wordt aangeboden. De prijsfluctuaties van de gemiddelde, de minimum- en de maximumprijs liggen tussen de 10 en $20 \%$ en tenderen vanaf 2008 naar een hoger niveau. Er is vanaf 2008 sprake van een te snelle groei van het aanbod ten opzichte van de vraag op de belangrijkste groothandelsmarkten in Europa hetgeen de uitbetaalprijzen onder druk zet.

\subsubsection{Conclusies marktstructuur en -resultaat}

Op grond van de uitkomsten van het bedrijfsonderzoek naar marktstructuur en -resultaat kunnen we over de onderscheiden variabelen het volgende concluderen.

\subsubsection{Horizontale concentratie}

De concentratiegraad van de vier grootste producenten in de glaspotplanten ligt op een laag niveau. Er is een stabilisatie van rond de $6 \%$ voor groene en bloeiende potplantentelers over de periode 2006-2009 met in 2006 een hogere concentratie (11\%) in groene potplanten. Het valt op dat bij een hogere C4-waarde (groene potplanten) in 2006 ook een hogere brutomarge wordt bereikt. De horizontale concentratie van de afzetorganisaties in de sector is bijna $100 \%$. FloraHolland heeft een marktaandeel van ongeveer 97.5\% en Plantion $2.5 \%$.

\subsubsection{Voorwaartse verticale integratie}

Voorbeelden van voorwaartse verticale integratie van glaspotplantentelers zijn nauwelijks aanwezig. Wel zijn er veel voorbeelden van verticale samenwerking tussen producenten, afzetorganisatie, groothandels/exporteurs en grootschalige detaillisten, vooral bij de grotere bedrijven. Hierbij behoudt elke schakel in de bedrijfskolom een zelfstandige bedrijfsvoering en zeggenschap in de organisatie van de afzet van glaspotplanten via de keten van (Nederlandse) producent naar (Europese) consument.

\subsubsection{Productdifferentiatie}

De productdifferentiatie van potplanten is evenals bij snijbloemen groot. Er is een grote variëteit aan producten en leveranciers van (nieuw) plantmateriaal werken nauw samen met producenten en de groot- en detailhandel bij de ontwikkeling van nieuwe producten en concepten. Sinds 2000 is het aantal potplantenbedrijven bijna gehalveerd terwijl het totale areaal zich stabiel ontwikkelt. Het areaal bloeiende planten is hiervan inmiddels het grootst, het areaal groene planten is gedaald en het areaal perkplanten schommelt tussen 400 en 500 ha.

Het onderzoek naar mogelijke verbanden tussen keuze productsoort en behaalde resultaten (paragraaf 7.4.1) geeft aan dat er een betekenisvol verband is tussen de gekozen productsoort en de door deze bedrijven in 2006 en 2007 gerealiseerde omzet. Telers van groene potplanten zijn gemiddeld de kleinste bedrijven en behalen een betekenisvolle lagere jaaromzet dan telers van bloeiende potplanten. Opvallend is dat deze telers in 2006 een betekenisvol hogere brutomarge realiseren dan de telers van de overige productsoorten. 


\subsubsection{Toetredingsdrempels (investeringen)}

Toetreding tot de sector glaspotplanten in Nederland is in vergelijking met de glassnijbloemen een nog kostbaarder zaak en de investeringsdrempels voor een nieuw bedrijf zijn nog hoger. In de voorgaande paragraaf is onder toe- en uittreding sector aangegeven dat er van 2005-2010 een vergroting plaatsvond van de gemiddelde bedrijfsomvang van 1.1 tot 1.5 ha. glasoppervlakte. Jaarlijks stopte in die periode gemiddeld 5\% van de bedrijven. Toetreding tot de sector vond weinig plaats, een enkel glastuinbouwbedrijf stapte vanuit de sector snijbloemen over naar de potplanten. De meest recente gegevens van het LEI geven aan dat er in 2012 nog 860 potplantenbedrijven in Nederland actief zijn op een areaal van 1800 ha. met een gemiddelde bedrijfsomvang van 2.2 ha. De pot- en perkplantenbedrijven zijn de laatste jaren binnen de glastuinbouw over het algemeen de best renderende bedrijven. In de sector glaspotplanten wordt behoorlijk geïnvesteerd. Het gemiddelde niveau van investeringen (alle sectoren) ligt in 2011 op bijna 170.000 euro per bedrijf. Een aantal telers ziet nog steeds voldoende mogelijkheden voor het doen van nieuwe investeringen.

Het bedrijfsonderzoek naar mogelijke verbanden tussen bedrijfstype, investeringsniveau en brutomarge geeft de volgende uitkomsten:

- er een betekenisvol verband aanwezig tussen bedrijfstype en investeringsniveau, bedrijfstype $\mathrm{C} 1$ investeert betekenisvol minder dan bedrijfstype $\mathrm{C} 2$;

- ook in de sector glaspotplanten lijkt geen betekenisvol verband aanwezig tussen de hoogte van de investeringen en de gerealiseerde brutomarge in 2006. Hogere investeringen van bedrijven lijken niet (direct) tot hogere resultaten te leiden.

7.5 Bedrijfs- en marktkarakteristieken sectoren glastuinbouw 2006-2008 in samenhang

De centrale vraag van het onderzoek is of verschillen in marktstructuur van de sectoren en marktgedrag van de grootste afzetorganisaties en de glastuinbouwbedrijven betekenisvolle verschillen in marktresultaten opleveren. 


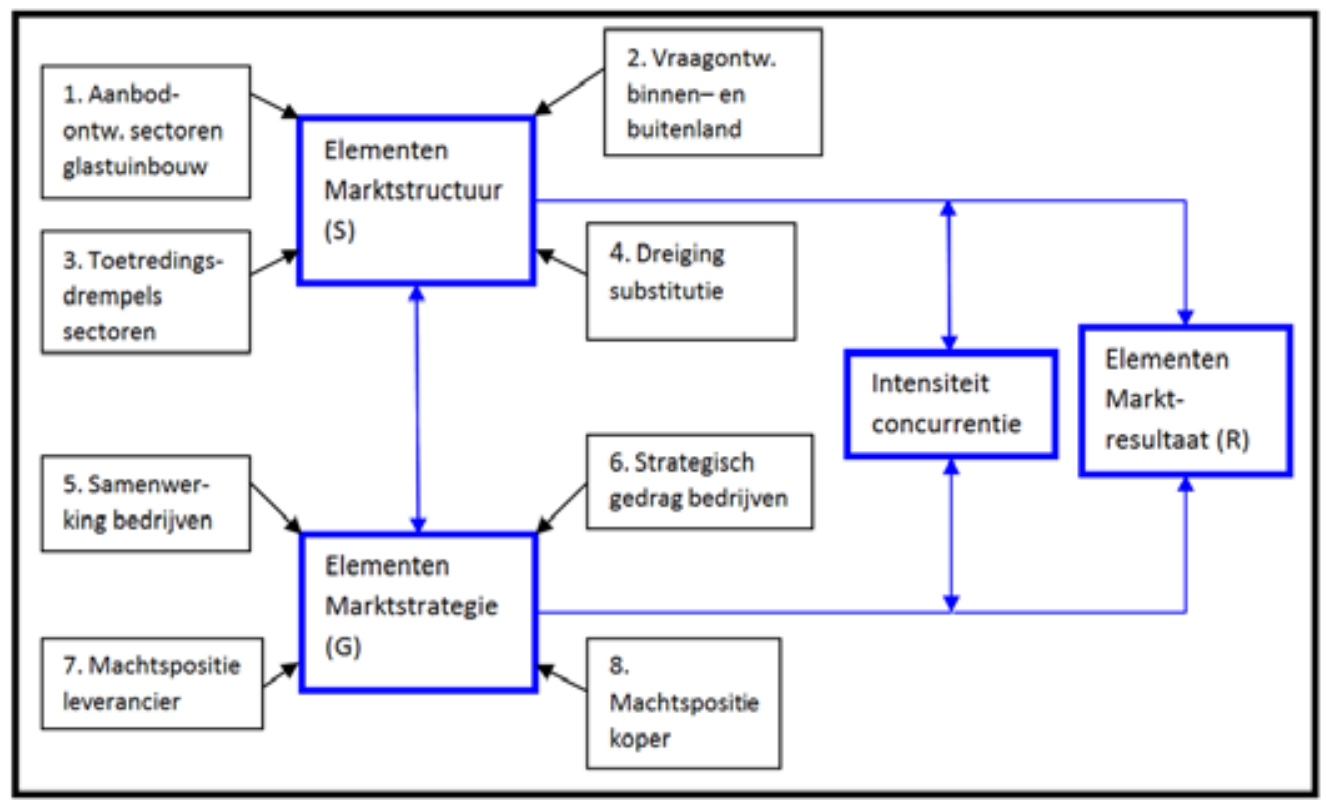

Figuur 1.1 Conceptueel model: concurrentie, concentratie en rentabiliteit sectoren glastuinbouw in Nederland

Het bovenstaande conceptueel model (figuur 1.1 in hoofdstuk 1) en het analysemodel in hoofdstuk 2 (figuur 2.4) geven aan welke bedrijfs- en marktgegevens nodig zijn om de relevante variabelen van marktstructuur, -gedrag en -resultaat per sector in kaart te brengen en mogelijke verbanden te toetsen. Onderstaande tabel 7.45 geeft een overzicht van de belangrijkste gegevens 2006-2008 van marktstructuur en marktresultaten in de drie sectoren glastuinbouw (S en R). Deze gegevens komen grotendeels voort uit het sectoronderzoek (hoofdstuk 3 ) en het onderzoek afzetorganisaties (hoofdstuk 4). Tabel 7.46 geeft een overzicht van gegevens betreffende het marktgedrag en de marktresultaten ( $\mathrm{G}$ en $\mathrm{R}$ ) uit het bedrijfsonderzoek glasgroenten (hoofdstuk 5) met ernaast de gegevens glassnijbloemen en -potplanten uit hoofdstukken 6 en 7. De bedrijfsonderzoeken zijn gehouden in 2006, 2007 en 2008 en de onderzoeksuitkomsten per sector staan los van elkaar. Mogelijke verbanden tussen marktstructuur, marktgedrag en marktresultaat worden per sector onderzocht. Om een indruk te krijgen van de verschillen tussen de sectoren zijn de belangrijkste kenmerken van sector, bedrijf en markt naast elkaar geplaatst. 
Tabel 7.45 Onderzoeksresultaten sector, afzetorganisaties en producenten marktstructuur en marktresultaat sectoren glastuinbouw 2006-2008

\begin{tabular}{|c|c|c|c|}
\hline $\begin{array}{l}\text { Bedrijfs- en markt- } \\
\text { karakteristieken sector } \\
\text { (mesoniveau) }\end{array}$ & $\begin{array}{l}\text { Sector glasgroenten (A) } \\
\text { Onderzoek } 2006 \\
-\mathrm{N}=2000 ; 4500 \text { ha. }\end{array}$ & $\begin{array}{l}\text { Sector glassnijbloemen (B) } \\
\text { Onderzoek } 2007 \\
-\mathrm{N}=2600 ; 3000 \text { ha. }\end{array}$ & $\begin{array}{l}\text { Sector glaspotplanten }(\mathrm{C}) \\
\text { Onderzoek } 2008 \\
-\mathrm{N}=1000 ; 1431 \text { ha. }\end{array}$ \\
\hline $\begin{array}{l}\text { Omvang actuele markt (Ma) } \\
-2006 \\
-2007 \\
-2008 \\
\text { (met \% groei t.o.v. vorig jaar) }\end{array}$ & $\begin{array}{l}\text { - productiewaarde }(\mathrm{x} \in 1 \mathrm{mln} .) \\
-2006: 1.350(+1 \%) \\
-2007: 1.340(-1 \%) \\
-2008: 1.270(-5 \%)\end{array}$ & $\begin{array}{ll}\text { - productiewaarde }(\mathrm{x} \in 1 \mathrm{mln} .) \\
-2006: & 2.277(+3 \%) \\
-2007: & 2.294(+1 \%) \\
-2008: & 2.158(-6 \%)\end{array}$ & $\begin{array}{l}\text { - productiewaarde }(\mathrm{x} \in 1 \mathrm{mln} .) \\
-2006: 1.624(+7 \%) \\
-2007: 1.768(+9 \%) \\
-2008: 1.847(+5 \%)\end{array}$ \\
\hline $\begin{array}{l}\text { Omvang relevante markt }(\mathrm{Mr}) \text { - } \\
2006 \\
(+ \text { groei in mln.euro })\end{array}$ & $\begin{array}{l}\text { - productiewaarde }(\mathrm{x} \in 1 \mathrm{mln} .) \\
-2006: 1.350(\mathrm{x} \in 1 \mathrm{mln} .) \\
(+0 \mathrm{mln} .)\end{array}$ & $\begin{array}{l}\text { - productiewaarde }(\mathrm{x} \in 1 \mathrm{mln} .) \\
-2006: 2.327(\mathrm{x} \in 1 \mathrm{mln} .) \\
(+ \text { ca. } 50 \mathrm{mln} .)\end{array}$ & $\begin{array}{l}\text { - productiewaarde }(\mathrm{x} \in 1 \mathrm{mln} .) \\
\text {-2006: } 1.754(\mathrm{x} \in 1 \mathrm{mln} .) \\
\text { (+ ca. } 130 \mathrm{mln} .)\end{array}$ \\
\hline Verzadigingsgraad V (Ma/Mr) & $-1.350 / 1.350=1.0$ & $-2.277 / 2.327=0.98$ & $-1.624 / 1.754=0.93$ \\
\hline $\begin{array}{l}\text { Aantal producenten } \\
\left.\text { Horizontale concentratie }{ }^{* *}\right)\end{array}$ & $\begin{array}{l}-\mathrm{N}=2000(2006) \\
-2006: C 45 \% \\
-2008: C 46.5 \%\end{array}$ & $\begin{array}{l}-\mathrm{N}=2600(2007) \\
-2007: \mathrm{C} 4 \quad 5.5 \% \\
-2008: \mathrm{C} 4 \quad 7 \%\end{array}$ & $\begin{array}{l}-\mathrm{N}=1000(2008) \\
-2007: \mathrm{C} 4 \quad 6.5 \% \\
-2008: \mathrm{C} 4 \quad 6.5 \%\end{array}$ \\
\hline $\begin{array}{l}\text { Aantal afzetorganisaties } \\
\text { Horizontale concentratie }\end{array}$ & $\begin{array}{l}-10-15 \text { (VTN/ZON/Telersver.) } \\
-2006: \text { C4 72\% } \\
-2008: \text { C4 66\% }\end{array}$ & $\begin{array}{l}-2(\mathrm{FH} / \text { Plantion }) \\
-2007: \mathrm{C} 2100 \%\end{array}$ & $\begin{array}{l}-2(\mathrm{FH} / \text { Plantion }) \\
-2008: \mathrm{C} 2100 \%\end{array}$ \\
\hline $\begin{array}{l}\text { Aantal grooth./exp./imp. } \\
\text { Horizontale concentratie**) }\end{array}$ & $\begin{array}{l}-1110 \\
-2006: C 10 \quad 72 \% \\
-2008: C 10 \quad 67 \% \\
\end{array}$ & $\begin{array}{l}\text {-ca. } 700 \\
-2007: \text { C8 } 58 \% \\
-2008: \text { C8 } 59 \% \\
\end{array}$ & $\begin{array}{l}\text {-ca. } 300 \\
-2008: \text { C8 } 59 \% \\
-2009: \text { C8 } 60 \% \\
\end{array}$ \\
\hline $\begin{array}{l}\text { Gem. gewogen jaarprijzen alle } \\
\text { producten (eurocent per kg of st.) }\end{array}$ & $\begin{array}{l}\text {-2006: } 97 \mathrm{ct} \\
-2007: 103 \mathrm{ct} \\
-2008: 101 \mathrm{ct} .\end{array}$ & $\begin{array}{l}-2006: 22 \mathrm{ct} . \\
-2007: 23 \mathrm{ct} . \\
-2008: 22 \mathrm{ct} .\end{array}$ & $\begin{array}{l}-2006: 117 \mathrm{ct} \\
-2007: 127 \mathrm{ct} \\
-2008: 129 \mathrm{ct} .\end{array}$ \\
\hline Exportwaarde $\left.(x \in 1 \mathrm{mln} .)^{*}\right)$ & $\begin{array}{l}-2006: 3.420 \\
-2007: 3.620 \\
-2008: 3.718 \\
\end{array}$ & $\begin{array}{l}-2006: 3.237 \\
-2007: 3.373 \\
-2008: 3.243 \\
\end{array}$ & $\begin{array}{ll}-2006: & 1.777 \\
-2007: & 1.858 \\
-2008: & 1.854 \\
\end{array}$ \\
\hline Exportaandeel *) & $\begin{array}{l}-2006: 68 \% \text { (glas)groenten } \\
-2007: 68 \% \\
-2008: 70 \%\end{array}$ & $\begin{array}{l}-2006: 88 \% \text { (glas)snijbloemen } \\
-2007: 90 \% \\
-2008: 87 \%\end{array}$ & $\begin{array}{l}-2006: 73 \% \text { (glas)potplanten } \\
-2007: 70 \% \\
-2008: 66 \%\end{array}$ \\
\hline Importwaarde $\left.(\mathrm{x} \in 1 \mathrm{mln} .)^{*}\right)$ & $\begin{array}{ll}-2006: & 1.000 \text { (schatting) } \\
-2007: & 1.000 \text { (schatting) } \\
-2008: & 985 \\
\end{array}$ & $\begin{array}{l}-2006: 664 \\
-2007: 702 \\
-2008: 827 \\
\end{array}$ & $\begin{array}{ll}-2006: & 318 \\
-2007: & 348 \\
-2008: & 379 \\
\end{array}$ \\
\hline Importaandeel *) & $\begin{array}{ll}-2006: & 18 \% \text { (glas)groenten } \\
-2007: & 18 \% \\
-2008: & 11 \% \\
\end{array}$ & $\begin{array}{l}-2006: 23 \% \text { (glas)snijbloemen } \\
-2007: 23 \% \\
-2008: 28 \%\end{array}$ & $\begin{array}{l}\text {-2006: } 16 \% \text { (glas)potplanten } \\
-2007: 17 \% \\
-2008: 17 \%\end{array}$ \\
\hline Markttoetreding & $\begin{array}{l}\text {-deels open/deels gesloten } \\
(70 / 30)\end{array}$ & -open & -open \\
\hline $\begin{array}{l}\text { Verticale concentratie } \\
\text { afzetorganisatie/veilingen }\end{array}$ & $\begin{array}{l}\text {-VTN/The Greenery en ZON: } \\
\text { ca. } 30 \%\end{array}$ & -nihil & -nihil \\
\hline $\begin{array}{l}\text { Structurele concentratie } * * *) \\
\text { producenten }(\mathrm{Cx}=\text { Oopt./M r) }\end{array}$ & $\begin{array}{l}-2.5 \mathrm{mln} . / 1.350 \mathrm{mln} .= \\
1 / 540 \text { (gem. omzet: zie H5) }\end{array}$ & $\begin{array}{l}-2.6 \mathrm{mln} . / 2.327 \mathrm{mln} .= \\
\text { 1/895 (gem. omzet: zie H6) }\end{array}$ & $\begin{array}{l}-4.9 \mathrm{mln} . / 1.750 \mathrm{mln} .= \\
1 / 350 \text { (gem. omzet: zie H7) }\end{array}$ \\
\hline $\begin{array}{l}\text { Feitelijke concentratie } \\
\text { producenten }\end{array}$ & $-1 / 2000$ & $-1 / 2600$ & $-1 / 1000$ \\
\hline
\end{tabular}

*) export- en importwaarden groenten, snijbloemen en potplanten betreffen verse producten onder glas en uit de volle grond; **) C4 = Concentratiegraad van de vier grootste bedrijven $=$ het aandeel in bedrijfsoppervlakte of omzet van deze bedrijven in het totaal, $\mathrm{C} 10=$ Concentratiegraad tien grootste bedrijven etc. ; ***) de structurele concentratie $\left(\mathrm{C}_{\mathrm{x}}\right)$ is de verhouding gemiddelde (optimale) ondernemingsomvang $(\mathrm{O})$ en de relevante marktomvang $\left(\mathrm{M}_{\mathrm{r}}\right)$. 
Tabel 7.46 Resultaten sector- en bedrijfsonderzoek marktgedrag en marktresultaat sector glasgroenten, glassnijbloemen en glaspotplanten 2006-2008

\begin{tabular}{|c|c|c|c|}
\hline $\begin{array}{l}\text { Bedrijfs- en } \\
\text { marktkarakteristieken } \\
\text { sectoren } \\
\text { (microniveau) }\end{array}$ & $\begin{array}{l}\text { Sector glasgroenten (A) } \\
\text { Onderzoek } 2006 \\
-\mathrm{N}=2000 ; 4500 \text { ha. } \\
-\mathrm{n}=42 ; 244 \text { ha. } \\
\text {-tomaat/paprika }\end{array}$ & $\begin{array}{l}\text { Sector glassnijbloemen(B) } \\
\text { Onderzoek } 2007 \\
-\mathrm{N}=2600 ; 3000 \text { ha. } \\
-\mathrm{n}=44 ; 149 \text { ha. } \\
\text {-roos/chrysant }\end{array}$ & $\begin{array}{l}\text { Sector glaspotplanten (C) } \\
\text { Onderzoek } 2008 \\
-\mathrm{N}=1000 ; 1431 \text { ha. } \\
\text { (Onderzoeksresultaten: zie } \\
\text { hoofdstuk } 7 \text { ) }\end{array}$ \\
\hline Gem. leeftijd bedrijf & -13 jaar & -11 jaar & -17 jaar \\
\hline $\begin{array}{l}\text { Bedrijfstypen } 1 \mathrm{t} / \mathrm{m} 4 \text {, } \\
\text { aandelen absoluut en relatief }\end{array}$ & $\begin{array}{lrr}\text {-A1 } & 14 & 33 \\
\text {-A2 } & 12 & 29 \\
\text {-A3 } & 4 & 10 \\
\text {-A4 } & \frac{12}{42} & \frac{28}{00} \\
\text { tot. } & \frac{10}{42} & \end{array}$ & $\begin{array}{lrr}\text {-B1 } & 24 & 56 \\
\text {-B2 } & 18 & 40 \\
\text {-B3 } & 1 & 2 \\
\text {-B4 } & \underline{1} & \underline{2} \\
\text { tot. } & 44 & 100 \%\end{array}$ & $\begin{array}{lrr}-\mathrm{C} 1 & 25 & 57 \\
-\mathrm{C} 2 & 17 & 39 \\
-\mathrm{C} 3 & 1 & 2 \\
-\mathrm{C} 4 & 1 & 2 \\
\text { tot. } & 44 & 100 \%\end{array}$ \\
\hline $\begin{array}{l}\text { Bedrijfsomvang in opp. glas } \\
\text { (gem. met minimum en } \\
\text { maximum in ha.) }\end{array}$ & $\begin{array}{lr}\text {-gem. } & 5.8 \\
\text {-min. } & 0.8 \\
\text {-max. } & 34.0 \\
\end{array}$ & $\begin{array}{lr}\text {-gem. } & 3.4 \\
\text {-min. } & 0.6 \\
\text {-max. } & 13.0 \\
\end{array}$ & $\begin{array}{lr}\text {-gem. } & 4.2 \\
\text {-min. } & 0.2 \\
\text {-max. } & 25.0 \\
\end{array}$ \\
\hline $\begin{array}{l}\text { Bedrijfsomvang in omzet } \\
2006 \text { met minimum en } \\
\text { maximum ( } € \text { x } 1 \mathrm{mln} .)\end{array}$ & $\begin{array}{lr}\text {-gem. } & 2.5 \\
\text {-min. } & 0.3 \\
\text {-max. } & 16.0 \\
\end{array}$ & $\begin{array}{lr}\text {-gem. } & 2.6 \\
\text {-min. } & 0.2 \\
\text {-max. } & 15.0 \\
\end{array}$ & $\begin{array}{lr}\text {-gem. } & 4.9 \\
\text {-min. } & 0.3 \\
\text {-max. } & 35.0 \\
\end{array}$ \\
\hline $\begin{array}{l}\text { Brutomarge[( Prijs }- \text { GTK }) \\
\text { /Prijs] x 100) met minimum } \\
\text { en maximum }\end{array}$ & $\begin{array}{lr}\text {-gem. } & 8.0 \\
\text {-min. } & -33.3 \\
\text {-max. } & 26.6\end{array}$ & $\begin{array}{ll}\text {-gem. } & 11.0 \\
\text {-min. } & -5.5 \\
\text {-max. } & 39.1\end{array}$ & $\begin{array}{lr}\text {-gem. } & 8.6 \\
\text {-min. } & -5.5 \\
\text {-max. } & 24.1\end{array}$ \\
\hline $\begin{array}{l}\text { Brutomarge [( Prijs - } \\
\text { GTK)/Prijs] x 100) } \\
\text { per bedrijfstype in } 2006\end{array}$ & $\begin{array}{lr}\text {-A } 1 & 4.5 \\
\text {-A2 } & 9.1 \\
\text {-A3 } & 11.2 \\
\text {-A4 } & 9.8 \\
\end{array}$ & $\begin{array}{ll}-B 1 & 12.4 \\
-B 2 & 9.6 \\
-B 3 & - \\
-B 4 & - \\
\end{array}$ & $\begin{array}{ll}-\mathrm{C} 1 & 8.9 \\
-\mathrm{C} 2 & 8.9 \\
-\mathrm{C} 1,3 & 8.6 \\
-\mathrm{C} 3 / \mathrm{C} 4 & - \\
\end{array}$ \\
\hline $\begin{array}{l}\text { Solvabiliteit(EV/TV*100) } \\
\text {-per sector en per } \\
\text { bedrijfstype }\end{array}$ & $\begin{array}{ll}\text {-sector } & 49.8 \\
\text {-A1 } & 58.5 \\
\text {-A2 } & 40.9 \\
\text {-A3 } & 54.3 \\
\text {-A4 } & 46.0\end{array}$ & $\begin{array}{ll}\text {-sector } & 44.0 \\
-\mathrm{B} 1 & 52.0 \\
-\mathrm{B} 2 & 33.0 \\
\text {-B 1,3 } & 60.0 \\
\text {-B3/B4 } & -\end{array}$ & $\begin{array}{ll}\text {-sector } & 42.3 \\
-\mathrm{C} 1 & 43.6 \\
-\mathrm{C} 2 & 44.5 \\
-\mathrm{C} 1,3 & 40.8 \\
-\mathrm{C} 3 / \mathrm{C} 4 & -\end{array}$ \\
\hline $\begin{array}{l}\text { Afzetorganisaties: aandeel in } \\
\% \text { totaal respondenten }\end{array}$ & $\begin{array}{ll}\text {-VTN } & 40 \\
\text {-ZON } & 16 \\
\text {-Eigen Verkoop } & 14 \\
\text {-Telersvereniging } & 30 \\
\end{array}$ & -FH $\quad 100$ & $-\mathrm{FH}$ \\
\hline $\begin{array}{l}\text { Eigen Verkoop: aandeel in } \\
\% \text { totaal respondenten }\end{array}$ & $\begin{array}{l}\text {-Via telersver. } 30 \%+ \\
\text { E.V. } 0-<15 \% .\end{array}$ & $\begin{array}{l}\text { - Via telersver. } 30 \%+ \\
\text { E.V. } 0-<5 \% \text { (melding FH) }\end{array}$ & $\begin{array}{l}\text { - via telersver. } 36 \%+\text { E.V. } \\
89 \% \text { (melding FH) }\end{array}$ \\
\hline $\begin{array}{l}\text { Veilingprovisie in \% omzet } \\
+ \text { min./max. }\end{array}$ & $\begin{array}{ll}\text {-gem. } & 3.0 \\
\text {-min. } & 0.5 \\
\text {-max. } & 5.5 \\
\end{array}$ & $\begin{array}{lr}\text {-gem. } & 6.0 \\
\text {-min. } & 3.0 \\
\text {-max. } & 10.0 \\
\end{array}$ & $\begin{array}{cc}\text {-gem. } & 6.7 \\
\text {-min. } & 3.1 \\
\text {-max. } & 12.0 \\
\end{array}$ \\
\hline $\begin{array}{l}\text { Eigen Verkoop (kosten) } \\
\text { in } \% \text { omzet }+\min . / \max .\end{array}$ & $\begin{array}{ll}\text {-gem. } & 3.0 \\
\text {-min. } & 0.5 \\
\text {-max. } & 5.5\end{array}$ & $\begin{array}{ll}\text {-gem. } & 0.9 \\
\text {-min. } & 0.1 \\
\text {-max. } & 4.0\end{array}$ & $\begin{array}{ll}\text {-gem. } & 2.2 \\
\text {-min. } & 0.5 \\
\text {-max. } & 5.0\end{array}$ \\
\hline $\begin{array}{l}\text { Verkoopmethode: aandeel in } \\
\% \text { totaal respondenten }\end{array}$ & $\begin{array}{ll}\text {-BB } & 64 \\
\text {-Telersver. } & 24 \\
\text {-EV } & 12\end{array}$ & $\begin{array}{ll}- \text {-Klok } & 25 \\
- \text { Klok/BB } & 64 \\
- \text { EV } & 11\end{array}$ & $\begin{array}{ll}\text {-Klok/BB } & 18 \\
\text {-Klok/BB/Tel. } & 43 \\
\text {-Klok/BB/EV } & 39\end{array}$ \\
\hline $\begin{array}{l}\text { Marktontwikkeling } \\
\text { (\% jaarlijkse groei) }\end{array}$ & $\begin{array}{l}-05 / 06:+1-2 \% \\
-06 / 07:-1-2 \% \\
-07 / 08:-5-6 \%\end{array}$ & $\begin{array}{l}-05 / 06:+3 \% \\
-06 / 07:+1 \% \\
-07 / 08:-6 \%\end{array}$ & $\begin{array}{l}-05 / 06:+7 \% \\
-06 / 07:+8 \% \\
-07 / 08:+9 \%\end{array}$ \\
\hline $\begin{array}{l}\text { Prijsvorming } \\
\text { (opinie telers) }\end{array}$ & $\begin{array}{l}\text {-2005/2006: } \\
\text {-matig }(60 \%) \\
\text {-goed }(26 \%)\end{array}$ & $\begin{array}{l}\text {-2006/2007: } \\
\text {-matig }(60 \%) \\
\text {-goed }(34 \%)\end{array}$ & $\begin{array}{l}\text {-2006/2007: } \\
\text {-matig }(64 \%) \\
\text {-goed }(11 \%)\end{array}$ \\
\hline $\begin{array}{l}\text { Prijsontwikkeling } \min / \max \\
\text { (eurocent per kg./st.) } \\
\text { (gem. gew. jaarprijzen) }\end{array}$ & 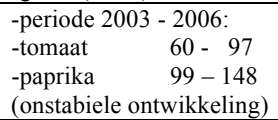 & $\begin{array}{lr}\text {-periode } & 2003-2008: \\
\text {-roos } & 37-41 \\
\text {-chrysant } & 25-27 \\
\text { (stabiele ontwikkeling) }\end{array}$ & $\begin{array}{l}\text {-phalaenopsis } € 4.57-5.11 \\
\text { (periode } 2003-07,2008 \\
\text { daling tot } € 4.06 \text { door } \\
\text { overaanbod/vraagdaling) }\end{array}$ \\
\hline $\begin{array}{l}\text { Tevredenheid over } \\
\text { afzetorganisatie }\end{array}$ & $\begin{array}{l}-55 \% \text { tevreden } / \text { z. tevr. } \\
-33 \% \text { tevreden/ontevr. } \\
-12 \% \text { ontevreden } / \text { zeer } \\
\text { Ontevreden }\end{array}$ & $\begin{array}{l}-75 \% \text { tevreden } \\
-25 \% \text { tevreden/ontevreden }\end{array}$ & $\begin{array}{l}-50 \% \text { tevreden } \\
-39 \% \text { tevreden/ontevreden } \\
-9 \% \text { ontevreden }\end{array}$ \\
\hline
\end{tabular}


Uit de tabellen 7.45 en 7.46 zijn de volgende ontwikkelingen te constateren:

1. De deelsector glasgroenten (A) heeft in oppervlakte glas gemiddeld de grootste bedrijven, de deelsector glaspotplanten (C) scoort op gemiddelde omzet het hoogst (bijna twee keer de omzet van het glasgroentebedrijf).

2. De gemiddelde brutomarge voor alle bedrijfstypen ligt in 2006 het hoogst in de deelsector glassnijbloemen. Splitsen we dit uit naar de verschillende bedrijfstypen dan scoort in de glasgroenten het type A4 het hoogst en in de glassnijbloemen het type B1. Opvallend is het verschil met het A1-bedrijf dat met de brutomarge hier bijna acht procentpunten onder blijft.

3. De gemiddelde solvabiliteit van de bedrijven is in de sector glasgroenten enigszins hoger dan die in de sector glassnijbloemen (50 versus 44\%), type A1 scoort bij de glasgroenten het hoogst en B1,3 bij de glassnijbloemen (60 versus 58.5\%).

4. De prijsvorming in de glasgroentesector (A) is niet transparant in tegenstelling tot die in de glassnijbloemen- en -potplantensector (B en $C$ ) waar het klokveilen en de geamalgameerde prijsvorming bij bemiddeling nog steeds een centrale rol spelen en er ook voor de kleinere veilingteler een goede prijsvorming wordt gerealiseerd (zie de verschillen in onderstaande tabel 7.47).

5. De eigen verkoop speelt in de potplantensector een belangrijke rol, altijd echter naast de centrale verkoop en afrekening (veilen en/of bemiddelen) door FloraHolland. De veilingprovisie ligt hier gemiddeld het hoogst. In de glasgroenten vindt de eigen verkoop door onafhankelijke telers veel minder plaats en bij de snijbloemen komt dit, met melding aan de veiling, sporadisch voor. De totale gemiddelde verkoopkosten (provisie en eigen verkoop) liggen het laagst bij de glasgroenten.

6. Bij de glassnijbloemen ontwikkelen zich de gemiddelde veilingprijzen voor roos en chrysant (alle soorten) in de aanloop naar de veilingfusie stabiel, in tegenstelling tot de glasgroenten waar de jaarprijzen sterk wisselen. Bij de glaspotplanten is de gemiddelde veilingprijs voor phalaenopsis veel minder stabiel.

7. De structurele concentratie ligt in alle sectoren aanmerkelijk hoger dan de feitelijke concentratie. In de glasgroenten gaat het proces van schaalvergroting het snelst en bedraagt de verhouding tussen deze twee factoren 3.7, in de glassnijbloemen 2.9 en in de glaspotplanten 2.8. 
Tabel 7.47 Gem. jaarprijzen 2005/2006 glasgroenten en -snijbloemen bedrijfstype 1 en 2

\begin{tabular}{|l|l|l|l|l|}
\hline & 2005 & 2006 & 2005 & 2006 \\
\hline & Tomaat & Tomaat & Roos & Roos \\
\hline Gem. prijs uit onderzoeksresultaat & 83 & 86 & 39 & 39 \\
\hline Bedrijfstype 1 & 70 & 75 & 42 & 41 \\
\hline Bedrijfstype 2 & 89 & 90 & 33 & 37 \\
\hline & Paprika & Paprika & Chrysant & Chrysant \\
\hline Gem. prijs uit onderzoeksresultaat & 99 & 140 & 25 & 27 \\
\hline Bedrijfstype 1 & 96 & 139 & 26 & 28 \\
\hline Bedrijfstype 2 & 100 & 144 & 24 & 24 \\
\hline
\end{tabular}

Samengevoegde onderzoeksresultaten tabellen 5.22 en 6.24

Uit tabel 7.47 blijkt dat de kleinere veilingteler B1 een aanmerkelijk hoger resultaat behaalt bij de prijsvorming 2005/2006 dan zijn grotere collega-bedrijven type B2. In de sector glasgroenten is de situatie juist andersom. Hier behaalt de kleinere veilingteler A1 van VTN/The Greenery over deze jaren juist een lager resultaat.

\subsection{Conceptueel model in de sectoren glasgroenten en glassierteelt}

In bijlage 5 is aan de hand van de verschillende onderzoeksuitkomsten een nadere invulling gegeven aan het conceptueel model (zie figuur 1.1 en tabellen 7.45 en 7.46).

Een inschatting is gemaakt van de ontwikkeling van marktstructuur en marktgedrag inclusief de wisselwerking in de sectoren, de hoogte van de concurrentie-intensiteit en de invloed hiervan op het resultaat. Hieruit is op te maken dat de concurrentie-intensiteit in de sector glasgroenten aanmerkelijk hoger is dan die in de sector glassnijbloemen en -potplanten wat zich uit in gemiddeld lagere resultaten voor de betreffende afzetorganisaties en hun leden.

Het verschil wordt vooral veroorzaakt door :

1. verzadigingsverschijnselen in de betreffende sectoren

2. verschillen in aantal productgroepen en productdifferentiatie

3. periodieke overcapaciteit

4. verschillen in (prijs)beleid tussen concurrenten in de sectoren en een gebrek aan horizontale bundeling van het dagelijkse aanbod van verse glasgroenten (countervailing power) tegenover het Europese grootwinkelbedrijf. 
BEDRIJFSONDERZOEK GLASTUINBOUW NEDERLAND, MEERVOUDIGE ECONOMETRISCHE ANALYSE 



\subsection{Inleiding}

In dit hoofdstuk wordt het meervoudig verband onderzocht tussen een aantal verklarende en te verklaren gedrags- en resultaatsvariabelen op het niveau van het glasgroente-, -snijbloemen- en -potplantenbedrijf. Na de enkelvoudige analyse in de voorgaande hoofdstukken wordt nu verder gezocht naar verklarende variabelen die meer informatie over een specifiek verband kunnen geven. Hiermee wordt, mede op basis van de uitkomsten van de eerder verrichte analyse, een aantal nieuw opgestelde hypothesen getoetst. Deze zijn ontwikkeld met behulp van het SGR-model met een uitbreiding van de eerder behandelde variabelen van marktstructuur en marktgedrag.

\subsection{Methode onderzoek en analyse}

Meervoudige regressieanalyse

$\mathrm{Na}$ de behandeling van de resultaten van de enkelvoudige analyse volgt nu de meervoudige regressieanalyse. De uitbreiding van het onderzoek betreft de omvang en richting van het verband tussen kenmerken van het bedrijfstype, ondernemerstype, de organisatie van de afzet en ontwikkeling van de gerealiseerde brutomarge (Lerner Index) [Lerner, 1934].

Voor het schatten van omvang en richting van de mogelijke verbanden tussen de verschillende variabelen wordt verwezen naar onderstaande hypothesen en functies (1) en (2).

\subsection{Toelichting hypothesen en modelspecificatie}

\subsubsection{Hypothesen}

- H1A Telersverenigingen hebben een positieve invloed op de ondernemingsprestaties.

Dit geldt met name voor glasgroentebedrijven, omdat hier telersverenigingen zich richten op marketingbeslissingen.

- H1B Verkoopcoöperaties (The Greenery, ZON, FloraHolland) hebben een positieve invloed op de ondernemingsprestaties.

Telersverenigingen voor glasgroenten ontwikkelden zich vanaf 1990 en later steeds meer tot complete marketingorganisaties. Grote telers ontwikkelden speciale producten met een eigen merknaam zoals de productgroep cherrytomaten. Andere grote zelfstandige telers en telersverenigingen startten een samenwerking met grootwinkelbedrijven, het organiseren van promotieactiviteiten, speciale verpakkingen onder merknaam (privat label), kwaliteitscontrole etc. Telersverenigingen investeerden hiertoe met name in logistieke middelen. In verband met de hieraan verbonden risico's en de noodzaak directe afspraken te maken met het grootwinkelbedrijf omzeilden zij de traditionele verkoopcoöperaties/veilingen, zoals The Greenery, en onderhandelden zelf met hun eindafnemers. Telers wilden zelf hun financiële risico's onder controle houden, omdat ze niet het vertrouwen hadden dat The Greenery dat zou kunnen of willen (Bij- 
man en Hendrikse, 2003). Het aantal diensten nam vooral toe door de verticale integratie van de groothandel en nieuwe logistieke activiteiten. Het grote aantal te vermarkten producten en aangeboden diensten, evenals het verschil tussen kleine en grote telers maakte een juist te heffen provisie lastig. Telers die de tarieven te hoog vonden, gingen op zoek naar alternatieven (Bijman en Hendrikse, 2003).

Telersverenigingen van snijbloementelers zijn meer gericht op het uitwisselen van informatie over het productieproces. Er is minder noodzaak de productaanvoer te combineren om te kunnen voldoen aan de vraag van grote klanten, onder andere omdat de bloemist/winkelier nog steeds het belangrijkste distributiekanaal is in Nederland en Duitsland.

Individuele telers zijn niet anoniem op de Nederlandse bloemenveiling, omdat snijbloemen worden verkocht op telersnaam.

Verkoopcoöperaties (The Greenery, ZON, FloraHolland) voorzien hun leden van een keur van diensten waaronder dagelijkse prijsonderhandelingen, kredietmanagement, verzekeringen, logistiek en kwaliteitscontrole. Belangrijk is te zien dat lidmaatschap van een telersvereniging en van een verkoopcoöperatie elkaar niet uitsluiten. Er zijn veel telersverenigingen die samenwerken met hun verkoopcoöperatie. Telersverenigingen die niet langer aangesloten zijn bij een verkoopcoöperatie hebben vaak een relatie met een commerciële groothandel die vergelijkbare diensten aanbiedt.

- H2 Verkoop via de veilingklokken heeft een positieve invloed op de Lerner Index.

Klokverkoop is gericht op het behalen van de hoogste prijzen en winsten voor de producten van de leden; onderhandelen is gericht op veiligheid en ketenefficiëntie.

Verwacht mag worden dat het veilproces een hogere prijs realiseert dan onderhandelingen. De theoretische literatuur geeft aan dat veilen resulteert in hogere prijzen dan onderhandelingen met een beperkt aantal kopers (Bulow and Klemperer, 1996). Toenemende concurrentie is belangrijker dan onderhandelingsvaardigheden of de kracht van monopolie. Empirische resultaten op Franse vismarkten tonen eveneens dat een toename van het aantal klanten in veilingverkopen leidt tot een verhoging van de prijzen (Guillotreau and Jiménez-Toribio, 2011). Helstad et al. (2005) tonen aan dat veilingprijzen voor Noorse vis hoger zijn dan prijzen bij directe verkoop.

- H3 Jonge, moderne bedrijven presteren beter dan oudere bedrijven, omdat hun bedrijfsmiddelen meer up-to-date zijn.

De productiviteit van arbeid en overige factoren is meestal hoger bij jonge, moderne bedrijven. Dit geeft lagere variabele kosten en een toename van de brutowinstmarge. Vaste kosten, waaronder rente en afschrijving zullen vaak hoger zijn. 
- H4 Grote bedrijven presteren beter dan kleine bedrijven, omdat zij een efficiëntere en effectievere schaalgrootte bereiken.

Van grotere bedrijven mag worden verwacht dat zij een bepaalde economische schaalgrootte zullen bereiken waardoor zij efficiënter zullen produceren. Katchova (2010) en Bonanno et al. (2013) vonden bewijs dat grotere bedrijven financieel beter presteerden dan kleinere bedrijven. Onderzoek wees uit dat er beperkte economische schaalgrootte is in de Nederlandse glastuinbouw.

- H5A Bedrijven met meer ondernemers in de bedrijfsleiding presteren beter, omdat zij een hogere arbeidsspecialisatie kunnen bereiken.

- H5B Bedrijven met meer ondernemers in de bedrijfsleiding presteren slechter, omdat zij meer coördinatieproblemen en conflicterende belangen hebben.

Moderne glastuinbouwbedrijven hebben een meer dan gemiddelde omvang en functies die de noodzakelijke vaardigheden van één glastuinbouwbedrijf overtreffen. Bedrijven onder leiding van een groter managementteam presteren beter omdat zij zich gemakkelijker kunnen specialiseren in bijvoorbeeld: productie, energie, marketing en personeelszaken (HRM).

Een groter managementteam kan echter leiden tot meer coördinatieproblemen en conflicten.

- H6A Jongere ondernemers presteren beter dan oudere, omdat ze beter zijn opgeleid.

- H6B Oudere ondernemers presteren beter dan jongere, omdat ze meer ervaring hebben.

Katchova (2010) en Bonanno et al. (2013) concludeerden dat het financiële beleid van bedrijven met jonge ondernemers minder goed werd uitgevoerd dan het financieel beleid van oudere ondenemers bij langer gevestigde bedrijven. Jonge ondernemers komen vaak minder aantrekkelijke financiële voorwaarden overeen en moeten onderdelen en vaardigheden van het vakgebied en hoe om te gaan met de verschillende risico's nog leren.

Aan de andere kant zijn jonge ondernemers vaak beter opgeleid, creatiever en eerder bereid hun bedrijven te vernieuwen en snel aan te passen aan de voortdurend veranderende wensen van moderne grootwinkelbedrijven, consumenten en maatschappij.

Bovenstaande hypothesen worden getoetst op significantie met behulp van een aantal opgestelde regressievergelijkingen (Huizingh, 2010). Leidraad bij deze opzet is het artikel van Setiawan et al. (2013) waarin een verdere invulling wordt gegeven aan het SGR-model. In dit model zijn regressievergelijkingen opgenomen met de te verklaren en verklarende variabelen voor onderzoek en de analyse van de Indonesische voedsel- en drankindustrie. De te verklaren variabele is de bruto winstmarge, gemeten met behulp van de Lerner Index. 
De Lerner Index wordt gerelateerd aan diverse verkoopstrategieën en bedrijfs- en ondernemerskenmerken in de drie sectoren van de Nederlandse glastuinbouw (zie onderstaande functies (1) en (2).

Functie (1) $\quad \frac{\mathrm{L}=\mathrm{P}-\mathrm{MC}}{\mathrm{P}}=\frac{\text { Brutomarge }}{\text { Omzet }}=\mathrm{F}(\mathrm{TE}, \mathrm{VC}, \mathrm{SM})$

Functie (2) $\quad \mathrm{TE}=\mathrm{F}$ (omvang, leeftijd, moderniteit, investeringen)

Onderstaand de omschrijving van afgekorte variabelen in functie (1)

- $\mathrm{TE}=$ Technische Efficiëntie $=$ Kosten per $\mathrm{m}^{2}$

- $\mathrm{L}=$ Lerner Index $=$ Brutomarge $=\left(\right.$ Omzet per $\mathrm{m}^{2}-$ Kosten per $\left.\mathrm{m}^{2}\right) /\left(\right.$ Omzet per $\left.\mathrm{m}^{2}\right)$

- $\mathrm{VC}=$ Verticale Coördinatiemeting

- $\mathrm{SM}=$ Sales Method $=$ Verkoopmethode

\subsubsection{Modelspecificatie}

In dit onderzoek zijn schattingen van verkoopprijzen van producenten en kosten per $\mathrm{m}^{2}$ gebruikt om de Lerner Index af te leiden. Bonanno et al. (2013) calculeerden de Lerner Index voor agrarische bedrijven in SSC's (Short Supply Chains) in Italië aan de hand van omzet- en winstgegevens uit het Farm Accountancy Data Network (FADN). Zij schatten een uitgebreide versie van onderstaande vergelijking (1).

(1) $\quad \mathrm{L}_{\mathrm{i}}=\frac{\mathrm{P}_{\mathrm{i}}-\mathrm{MC}}{\mathrm{P}_{\mathrm{i}}}=\alpha_{0}+\alpha_{1} \mathrm{X}_{\mathrm{ij}}+\alpha_{2} \mathrm{Y}_{\mathrm{ik}}+\varepsilon_{\mathrm{i}}$

De Lerner Index voor bedrijf $\mathrm{i}$ als een functie van de producentenprijs $\mathrm{P}_{\mathrm{i}}$ en marginale kosten $\mathrm{MC}_{\mathrm{i}}$ hangt af van bedrijfskenmerken $\mathrm{j}$ : $\mathrm{X}_{\mathrm{ij}}$ en verkoopstrategieën $\mathrm{k}$ : $\mathrm{Y}_{\mathrm{ik}}$. Zoals gewoonlijk zijn de $\alpha$ 's de te schatten parameters en vertegenwoordigt $\varepsilon_{\mathrm{i}}$ de foutenterm of residu. De verkoopkenmerken betreffen het lidmaatschap van een traditionele verkoopcoöperatie (The Greenery, ZON, FloraHolland) en/of telersvereniging en het gebruikmaken van het veilingmechanisme van de bloemenveiling. De kenmerken van de onderneming en ondernemer betreffen technische efficiëntie (TE), bedrijfsomvang en leeftijd van het bedrijf en van de ondernemer. Het meten van de technische efficiëntie ten behoeve van de econometrische schatting is gedaan op basis van de kosten per $\mathrm{m}^{2}$. Omdat direct gebruik van deze variabele in de eerste vergelijking (1) een simultaniteitsprobleem zou veroorzaken, is de TE-parameter eerst afzonderlijk bepaald met de methode van de kleinste kwadraten (OLS) en herplaatst door middel van een instrumentele variabele:

$$
\mathrm{TE}_{\mathrm{i}}=\beta_{0}+\beta_{1} \mathrm{X}_{\mathrm{ij}}+\eta_{\mathrm{i}}
$$

De $\beta$ 's zijn de te schatten parameters en $\eta$ vertegenwoordigt de foutenterm of residu. De kenmerken zijn hier bedrijfsomvang, bedrijfs- en ondernemersleeftijd, investeringsomvang en solvabi- 
liteitsratio (EV/TV). Van bedrijven die investeren mag worden verwacht dat ze lagere variabele kosten hebben en hogere brutomarges dan bedrijven die niet investeren. Het verband tussen eigen vermogen en technische efficiëntie is ingewikkelder. Telers die veel winst maakten in het verleden zijn in staat om te investeren in kostenefficiëntie, omdat ze veel eigen vermogen bezitten. Maar een laag eigen vermogen kan ook veroorzaakt zijn door hoge investeringen in kostenefficiëntie in het nabije verleden.

Zoals eerder gezegd is de modelspecificatie vergelijkbaar met die van Setiawan et al. (2013). Setiawan et al. analyseren brutomarge op het niveau van de industrie van Indonesië. Setiawan et al.'s systeem is meer uitgewerkt. Er zijn vergelijkingen opgenomen voor de variabelen prijsstarheid en industriële concentratie. Prijsstarheid is niet relevant voor groenten en snijbloemen, omdat beide markten gekenmerkt kunnen worden als dagmarkten (spotmarkten). Industriële concentratie is natuurlijk relevant, maar hier niet opgenomen, omdat gegevens zijn gebruikt op producentenniveau en niet op sectorniveau. Onze analyse is gericht op lidmaatschap van een traditionele verkoopcoöperatie en/of een telersvereniging en het gebruik van het veilproces van de bloemenveiling. Het systeem van vergelijkingen is opgelost door het gebruik van een tweefasenmodel. Vergelijking (2) is geschat met behulp van de methode van de kleinste kwadraten (OLS). De voorspelde waarden zijn gebruikt in de OLS-schatting van vergelijking (1). Omdat de meeste geselecteerde parameters niet significant waren bij de eerste schatting, zijn bij de achtereenvolgende schattingen de minst significante variabelen een voor een vervallen totdat alleen significante variabelen overbleven.

\subsection{Resultaten econometrisch onderzoek}

De data verkregen uit het bedrijfsonderzoek uit de periode 2006-2008 zijn gebruikt om de in de voorgaande paragraaf toegelichte hypothesen nader te toetsen. In de tabellen $1 \mathrm{~A}$ en $1 \mathrm{~B}$ wordt een overzicht gegeven van de voor de econometrische analyse gebruikte variabelen van de glasgroente- en glassnijbloemensector. In tabel 2 worden de belangrijkste uitkomsten van de beide regressieanalyses naast elkaar getoond. De analyse in de sector glaspotplanten is op een vergelijkbare manier uitgevoerd. De conclusies hiervan zijn vermeld in paragraaf 8.6. 
Tabel 1A Variabelen producenten glasgroenten met gemiddelde waarde en standaarddeviatie

\begin{tabular}{|l|l|l|l|}
\hline & $\mathrm{N}$ & Mean & Std. Dev. \\
\hline Bedrijfsleeftijd & 42 & 12.02 & 6.13 \\
\hline Bedrijfsomvang & 42 & 5.81 & 7.14 \\
\hline Aantal ondernemers & 42 & 1.62 & 0.88 \\
\hline Leeftijd ondernemers & 42 & 37.62 & 12.16 \\
\hline Lid verkoopcoöperatie & 42 & 0.62 & 0.49 \\
\hline Lid telersvereniging & 42 & 0.57 & 0.50 \\
\hline Tomaten Dummy & 42 & 0.52 & 0.51 \\
\hline Lerner Index & 40 & 8.03 & 12.63 \\
\hline Kosten & 42 & 38.38 & 5.45 \\
\hline Technische efficiëntie & 29 & 40.40 & 6.86 \\
\hline Investeringen & 31 & 5.23 & 9.04 \\
\hline EV/TV-ratio & 30 & 49.80 & 24.35 \\
\hline Listwise? Ja & 29 & & \\
\hline
\end{tabular}

Tabel1B Variabelen producenten glassnijbloemen met gemiddelde waarde en standaarddeviatie

\begin{tabular}{|l|l|l|l|}
\hline & $\mathrm{N}$ & Mean & Std. Dev. \\
\hline Bedrijfsleeftijd & 46 & 19.76 & 6.52 \\
\hline Bedrijfsomvang & 46 & 3.23 & 2.41 \\
\hline Aantal ondernemers & 46 & 1.52 & 0.66 \\
\hline Leeftijd ondernemer & 36 & 43.06 & 8.89 \\
\hline Lid telersvereniging & 46 & 0.41 & 0.50 \\
\hline Veilen dummy & 46 & 0.35 & 0.48 \\
\hline Lerner Index & 43 & 11.36 & 11.44 \\
\hline Kosten & 46 & 68.54 & 17.34 \\
\hline Technische efficiëntie & 38 & 68.88 & 6.65 \\
\hline 8Investeringen & 38 & 5.80 & 8.30 \\
\hline EV/TV ratio & 30 & 44.53 & 21.06 \\
\hline Listwise? Ja & 22 & & \\
\hline
\end{tabular}

Toelichting tabellen

Het aantal waarnemingen onder glasgroentetelers betreft 42 bedrijven. Van deze 42 bedrijven zijn 26 telers lid van een verkoopcoöperatie en 16 telers niet. Daarnaast zijn 24 telers lid van een telersvereniging en 18 niet. Van de 42 bedrijven gebruiken 8 het veilingmechanisme voor de verkoop van glasgroenten en 34 niet. De groep van 8 bedrijven is te klein voor de analyse.

Het aantal waarnemingen onder glassnijbloementelers betreft 46 bedrijven. Van deze 46 bedrijven zijn 19 telers lid van een telersvereniging en 27 telers niet. Van de 46 bedrijven gebruiken 16 exclusief het veilingmechanisme voor de verkoop van verse snijbloemen en 30 telers gebruiken een mix van verkoopmethoden. 
Onderzocht is of het lidmaatschap van een telersvereniging of van een verkoopcoöperatie in de sectoren van de glastuinbouw zich voldoende uitbetaalt.

Technische efficiëntie werd gemeten in de eerste fase van de 2SLS-procedure (Two Stage Least Squares Regression) volgens de methode van de kleinste kwadraten (OLS). De voorspelde TEwaarden zijn opgenomen in de vergelijking van de Lerner Index. Kosten per $\mathrm{m}^{2}$ zijn geregresseerd met de beschikbare verklarende variabelen: bedrijfsomvang en -leeftijd, het aantal ondernemers, de leeftijd van de directeur, de investeringszin en de solvabiliteit. Een dummy is opgenomen voor het telen van de tomaat. De voorspelde waarde is gebruikt voor de herschatte Lerner Index.

De onderzoeksresultaten van het tweefasenmodel (2SLS) staan in tabel 2. De uitkomsten illustreren het verschil tussen de sectoren glasgroenten en -snijbloemen. Alleen het teken (-) van de richting van de TE-parameter komt overeen voor beide typen telers. Hoe hoger de technische efficiëntie, hoe lager de kosten per $\mathrm{m}^{2}$. In de glasgroentesector geeft het lidmaatschap van een telersvereniging de hoogste brutomarge. In de sierteeltsector is het de klok van de bloemenveiling die de hoogste brutomarge biedt. Merk op dat in de glasgroentesector het veilen via de klok sterk is afgenomen en geen verklarende variabele meer is. De traditionele verkoopcoöperaties (The Greenery, ZON, FloraHolland) hebben met hun bemiddelingsactiviteiten in beide sectoren weinig of geen positieve invloed op de financiële uitkomsten van het verkoopproces.

Ondernemingsomvang heeft een positieve invloed op de brutomarge in de glasgroentesector, maar niet in de glassierteelt. Dit lijkt tegenstrijdig, maar komt overeen met het feit dat de productie en verkoop van homogene glasgroenten aanmerkelijk wordt verhoogd door een toename van schaalgrootte, terwijl voor de productie en verkoop van snijbloemen juist productdifferentiatie belangrijker is. Er zijn meer glassnijbloementelers die 'niche' variëteiten produceren op kleine schaal en hiermee hogere brutomarges bereiken. Elke variëteit brengt hogere vaste kosten met zich mee die alleen kunnen worden goedgemaakt door hogere brutomarges (Sutton, 1995). Dit

Tabel 2 Tweefasenmodel (incl. TE) met schatting van de Lerner Index (data 2006)

\begin{tabular}{|l|l|l|}
\hline & Vegetables & Cut flowers \\
\hline $\mathrm{N}$ & 28 & 22 \\
\hline $\mathrm{R}^{2}$ & 36.1 & 68,1 \\
\hline Adj. $\mathrm{R}^{2}$ & 24,9 & 60,6 \\
\hline & & \\
\hline Constante & 0.428 & 0.470 \\
\hline Bedrijfsleeftijd & & \\
\hline Bedrijfsomvang & $0.007^{*}$ & $-0.028^{* *}$ \\
\hline Aantal ondernemers & $-0.074^{* * *}$ & \\
\hline Leeftijd ondernemer & & $0.006^{* *}$ \\
\hline Lid verkoopcoöperatie & & \\
\hline Lid telersvereniging & $0.100^{* *}$ & \\
\hline Klok Bloemenveiling & & $0.099^{* * *}$ \\
\hline Tomaten Dummy & & \\
\hline Technische Efficiëntie(kosten) & $-0.009^{*}$ & $-0.006^{* * *}$ \\
\hline
\end{tabular}


wordt extra ondersteund door het gebruik van de klok van de bloemenveiling. De snijbloemen krijgen een podium en worden verkocht op telersnaam.

Een toename van het aantal ondernemers heeft een negatieve invloed op de ontwikkeling van de brutomarge in beide sectoren. Dit doet vermoeden dat management in teamverband de brutomarge doet dalen, waarschijnlijk door een gebrek aan coördinatie en conflicten. Dit effect kan op termijn verdwijnen wanneer telers de juiste partners weten te vinden om mee samen te werken. Het verband tussen de leeftijd van de ondernemer en de ontwikkeling van de brutomarge is positief in de sector glassnijbloemen: oudere telers presteren beter dan jongere door hun grotere ervaring.

\subsection{Samenvatting resultaten}

De resultaten van het econometrisch onderzoek in paragraaf 8.4 tonen aan dat de traditionele verkoopcoöperaties (The Greenery, ZON, FloraHolland) nauwelijks of geen invloed hebben op de door de bedrijven in de sectoren glasgroenten en glassierteelt gerealiseerde brutomarges. Telersverenigingen hebben een positieve invloed op de brutomarges van bedrijven in de sector glasgroenten en bloemenveiling FloraHolland heeft met haar klokveilen een positieve invloed op de brutomarges van bedrijven in de sector glassnijbloemen. Beide resultaten zijn een indicatie dat de marketingstrategieën voor de producenten/glastuinders in deze sectoren ertoe doen. Telersverenigingen, vooral in de glasgroenten, zijn opgezet om marketingstrategieën te ontwikkelen. In de sector glassnijbloemen en -potplanten nemen individuele telers zelf de productie- en marketingbeslissingen en verkopen hun producten onder eigen naam. Hun productie is nooit anoniem. Ook de economische schaalgrootte verschilt tussen beide sectoren. Schaalvergroting verlaagt veelal de productiekosten in de sector glasgroenten en is nodig om de producten tegen een lagere prijs te kunnen verkopen. Zelfs al zijn de producten onderscheidend en volledig naar de wensen van het moderne grootwinkelbedrijf, een kostenstrategie is tot op zekere hoogte onvermijdelijk. In de sierteeltsector zijn meer mogelijkheden 'niche' producten op kleinere schaal te verkopen en een hogere brutomarge te behalen. Brutomarge wordt vergroot door technische efficiëntie. En technische efficiëntie hangt af van de investeringsgeneigdheid en de beschikbaarheid van voldoende eigen vermogen (de solvabiliteitsratio). Meer inzicht in de relatie tussen investeringen, de financiële situatie en technische efficiëntie van het glastuinbouwbedrijf is hiervoor nodig. 


\subsection{Conclusies}

\subsubsection{Samenvattende conclusie sector glasgroenten}

De uitkomsten van de econometrische analyse laten ons zien dat in de glasgroentesector deelname aan een telersvereniging gemiddeld betere resultaten oplevert dan deelname aan een traditionele verkoopcoöperatie. Het zijn vooral de ondernemers met nieuwe ideeën over bedrijfsorganisatie en verticale samenwerking die met gemiddeld grotere en modernere bedrijven de beste resultaten boeken.

\subsubsection{Samenvattende conclusie sector glassnijbloemen}

Veilingtelers die exclusief via de bloemenveiling hun producten veilen, realiseren gemiddeld een hogere brutomarge dan telers die naast veilen ook andere verkoopmethoden gebruiken. Hierbij levert deelname aan een telersvereniging gemiddeld betere resultaten op dan niet-deelname en behalen kleine bedrijven hogere brutomarges dan grote. Oudere ondernemers presteren beter dan jongere. De klok van de bloemenveiling is de beste garantie voor hogere brutomarges. Het blijkt in de snijbloemensector dat schaalvergroting van de productie minder effect heeft op de brutomarge dan het produceren van 'niche' producttypen. Hierbij speelt de verkoopmethode via de klok een belangrijke rol. Bedrijven met 'niche' producten hebben hogere vaste kosten waarbij een hogere brutomarge het financieren gemakkelijker maakt.

\subsubsection{Samenvattende conclusie sector glaspotplanten}

Voor de glaspotplanten, waar de aard van het product duidelijk verschilt van de korter houdbare glasgroenten en glassnijbloemen, zijn te weinig gegevens beschikbaar om conclusies te trekken. 




\subsection{Conclusies onderzoek sectoren, afzetorganisaties en producenten}

In dit hoofdstuk worden de conclusies van de deelonderzoeken onderscheiden in sectorale conclusies, conclusies afzetorganisaties en conclusies producenten glastuinbouw.

De variabelen van de sectoren en afzetorganisaties zijn, voor zover mogelijk, aangevuld met de resultaten van 2011-2015 (zie paragraaf 3.5.2 en de appendices A en B van hoofdstuk 3 en 4).

\subsubsection{Conclusies sectoronderzoek voedingstuinbouw en siertuinbouw}

De sectoranalyse van hoofdstuk 3 leidt tot de volgende conclusies:

\section{Conclusie ontwikkeling sectorvariabelen}

De structuurvariabelen binnenlands aandeel, export- en importaandeel en de resultaatsvariabelen productiewaarde, exportwaarde en importwaarde laten in de drie sectoren glastuinbouw vanaf 1980-heden over de meeste jaren een positieve ontwikkeling zien. De productie- en exportwaarde weet tot aan de kredietcrisis in 2009 een steeds hoger niveau te bereiken. Na de terugval in 2009

Tabel 9.1 Ontwikkeling sectorvariabelen glastuinbouw 1980-2005, 2006-2010 en 2011-2016

\begin{tabular}{|c|c|c|c|}
\hline Soort variabele & Glasgroenten & Glassnijbloemen & Glaspotplanten \\
\hline $\begin{array}{l}\text { Resultaats- en structuur- } \\
\text { variabelen sectoren }\end{array}$ & & & \\
\hline $\begin{array}{lc}\text {-Productiewaarde } & (\mathrm{x} \in 1 \mathrm{mld}) \\
\text { Periode } & 1980-2005 \\
\text { Idem } & 2006-2010 \\
\text { Idem } & 2011-2016 \\
& \\
\text {-Binnenlands } & \text { aandeel 2006-2010 }\end{array}$ & $\begin{array}{l}0.7-1.2 ; \text { groeifactor } 1.7 \\
1.3-1.5 \\
1.2-1.4 \\
82 \%-94 \%\end{array}$ & $\begin{array}{l}0.8-2.2 ; \text { groeifactor } 2.8 \\
2.3-2.1 \\
2.0-2.2 \\
77 \%-75 \%\end{array}$ & $\begin{array}{l}0.2-1.5 ; \text { groeifactor } 7 \\
1.6-2.0 \\
2.0-2.0 \\
84 \%-86 \%\end{array}$ \\
\hline $\begin{array}{lr}\text {-Importwaarde } & (\mathrm{x} \in 1 \mathrm{mld}) \\
\text { Periode } & 1980-2005 \\
\text { Idem } & 2006-2010 \\
\text { Idem } & 2011-2016 \\
& \\
\text {-Importaandeel } & 2006-2010\end{array}$ & $\begin{array}{l}0.1-1.0 ; \text { groeifactor } 10 \\
1.0-1.0 \\
1.1-1.1 \\
18 \%-6 \%\end{array}$ & $\begin{array}{l}0.07-0.65 ; \text { groeifactor } 9 \\
0.7-0.7 \\
0.7-0.9 \\
23 \%-25 \%\end{array}$ & $\begin{array}{l}0.04-0.3 ; \text { groeifactor } 7 \\
0.3-0.3 \\
0.4-0.4 \\
16 \%-14 \%\end{array}$ \\
\hline $\begin{array}{lr}\text {-Exportwaarde } & (\mathrm{x} \in 1 \mathrm{mld}) \\
\text { Periode } & 1980-2005 \\
\text { Idem } & 2006-2010 \\
\text { Idem } & 2011-2016 \\
& \\
\text {-Exportaandeel } & 2006-2010\end{array}$ & $\begin{array}{l}0.9-3.9 ; \text { groeifactor } 4 \\
3.4-3.9 \\
3.8-4.4 \\
68 \%-72 \%\end{array}$ & $\begin{array}{l}0.7-3.1 ; \text { groeifactor } 4.5 \\
3.2-3.2 \\
3.5-3.5 \\
88 \%-91 \%\end{array}$ & $\begin{array}{l}0.2-1.7 ; \text { groeifactor } 8 \\
1.8-2.0 \\
2.0-2.2 \\
73 \%-68 \%\end{array}$ \\
\hline $\begin{array}{l}\text {-Aantal afzetorganisaties *) } \\
\text {-Horizontale concentratie *) } \\
\text { Periode 2006-2008 } \\
\text { Idem 2015-2016 } \\
\text {-Aantal grooth./exp./imp.*) } \\
\text {-Horizontale concentratie *) } \\
\text { Periode 2006-2010 } \\
\text { Idem 2015-2016 }\end{array}$ & $\begin{array}{l}10-15 \text { (COF-The Greenery } \\
\text { /ZON/Telersverenigingen) } \\
\text { C4 } 72 \%-66 \% \\
\text { C6 } 60 \% \\
1110 \\
\text { C10 } 72 \%-66 \% \\
\text { C10 > } 60 \%\end{array}$ & $\begin{array}{l}2 \text { (FH/Plantion) } \\
\text { C2 } 100 \% \\
\text { C2 } 100 \% \\
\text {-ca. } 700 \\
\text { C8 } 58 \%-59 \% \\
\text { C8 }>60 \%\end{array}$ & $\begin{array}{l}2 \text { (FH/Plantion) } \\
C 2100 \% \\
C 2100 \% \\
\text {-ca. } 300 \\
C 858 \%-59 \% \\
C 8>60 \%\end{array}$ \\
\hline
\end{tabular}

*) C-4 = Concentratiegraad van de 4 grootste bedrijven in bedrijfsopp. of omzet als aandeel van het totaal, C-10 idem voor de 10 grootste bedrijven etc. 
is er in 2010 en de jaren erna sprake van een aanmerkelijk herstel. De sector glassnijbloemen laat weliswaar een daling zien van het areaal en de productie in Nederland, maar die wordt, naast een toename van de overige import, opgevangen door een rechtstreekse aanvoer van vooral rozen en chrysanten vanuit sub-Sahara Afrika.

In onderstaande tabel 9.1 wordt over drie perioden het verloop van de resultaatsvariabelen aangegeven met voor de eerste periode, 1980-2005, tevens de hoogte van de groeifactor.

Van 2006-2010 wordt de resultaats- en structuurvariabele van het eerste en het laatste jaar getoond. De tussenliggende waarden staan vermeld in de tabellen 3.51, 3.52 en 3.53 van hoofdstuk 3. Van het jaar 2011 en 2016 zijn alleen de resultaatsvariabelen opgenomen.

In het tweede deel van de tabel staat de horizontale concentratie van de afzetorganisaties/telersverenigingen en de groothandel/export vermeld over de periode 2006-2008 en 2015-2016.

De sector siertuinbouw toont van 1980 tot 2009 een stabielere ontwikkeling dan de voedingstuinbouw met jaarlijks hogere groeicijfers, mede veroorzaakt door de sterke groei van de potplanten in deze periode. Vanaf 2009 vermindert de groei van de sector glassnijbloemen en daalt het areaal roos en chrysant in Nederland drastisch. De kleinbloemige, arbeidsintensieve soorten snijbloemen worden voor een groot deel vervangen door een toenemende invoer vanuit zuidelijk Afrika en andere landen. Alle sectoren profiteren van een groeiende import-/re-exportfunctie van fruit, snijbloemen en potplanten vanuit Nederland naar aangrenzende landen en handelspartners.

\section{Conclusie ontwikkeling horizontale concentratie}

Ondanks de sterke toename van de schaalgrootte in de glastuinbouw is de concentratie onder producenten laag met een concentratiegraad van de vier grootste bedrijven van $6 \%-10 \%$.

Dit betekent bij directe verkoop aan de groothandel/detailhandel vaak een afhankelijke positie met weinig verkoopmacht. Bij een grotere productdifferentiatie zal die kunnen toenemen.

In tabel 9.1 is aangegeven dat de concentratiegraad onder afzetorganisaties/telersverenigingen en de groothandel/export aanmerkelijk groter is dan die onder producenten.

In de siertuinbouw nemen bloemenveiling FloraHolland en Plantion met marktaandelen in 2010 van $98 \%$ en $2 \%$ bijzondere posities in (C2 is $100 \%$ ).

In de voedingstuinbouw hebben de vier grootste afzetorganisaties (FresQ, The Greenery, Komosa en ZON) van 2009 tot 2012 een concentratiegraad (C4) tussen de 50\% en 60\%.

De positie van FresQ en haar voormalige leden is in 2012-2013 volledig veranderd.

In 2015 is door de zes grootste Nederlandse afzetorganisaties/telersverenigingen de Federatie Vruchtgroenteorganisaties (FVO) opgericht. Dit betekent dat er momenteel in de glasgroentesector een concentratiegraad (C6) van ruim $60 \%$ is ontstaan. Deze concentratie is redelijk in evenwicht met die van de groothandel/export waar de tien grootste exporteurs $(\mathrm{C} 10)$ een aandeel van $60 \%-70 \%$ hebben. 


\section{Conclusie productdifferentiatie}

In de glasgroenten is de productdifferentiatie van de belangrijkste vruchtgroenten laag. De komkommer als tamelijk homogeen product, heeft het op de Europese markt het zwaarst.

De tomaat en de paprika, die een breder assortiment kennen en zich gemakkelijker kunnen onderscheiden, ondervinden toch bijna evenveel concurrentie als de komkommer. Dit blijkt uit de gerealiseerde uitbetaalprijzen 2005-2009 waar duidelijk wordt dat de trostomaat zich nauwelijks meer onderscheidt van de ronde tomaat. De trostomaat wordt tegenwoordig als een commodity beschouwd, gelijk aan de losse tomaat. De nieuwe niches zijn de kleine cherry trostomaatjes zoals de Tommy's en de Subliem. Toch heeft de Nederlandse tomaat in de EU de afgelopen jaren aan marktaandeel gewonnen door de mogelijkheid van jaarrond aanbod, een voorsprong in kwaliteit op Spanje en Marokko en het creëren van toegevoegde waarde door middel van een breed assortiment producten, verpakkingen en merken. Al vanaf 2012 is Nederland de grootste exporteur wereldwijd van tomaten.

In de glassierteelt is de productdifferentiatie van snijbloemen en potplanten vele malen groter dan in de glasgroenten. Dit grotere onderscheid tussen producten zorgt voor minder scherpe concurrentie die van invloed is op de resultaten. Zowel bij snijbloemen als bij potplanten levert dit een stabielere en vaak hogere prijs op.

\subsubsection{Conclusies onderzoek afzetorganisaties voedingstuinbouw en siertuinbouw}

\section{Afzetorganisatie Coforta/The Greenery}

Coforta/The Greenery heeft met haar strategie van horizontale en verticale concentratie niet bereikt wat haar in 1996 voor ogen stond: een grotere horizontale en verticale bundeling van de afzet van de Nederlandse veilingen en groothandels-/exportbedrijven. De zoektocht naar een juiste integratie van productie en handel met een efficiënte en effectieve structuur is niet ten einde en recent weer ter hand genomen met een nieuwe verkooporganisatie. De financiële positie van Coforta/The Greenery op de Europese markt van verse groenten, fruit en paddenstoelen is nog steeds niet sterk. De positie op de Nederlandse markt is stabiel, op de belangrijkste Europese markten lastig. De positie op de Engelse markt was tot 2016 redelijk, maar is na het Brexit-besluit tamelijk onzeker, evenals de marktposities in de VS en Japan. Het rendement op het totale vermogen ligt laag. In 2015 en 2016 doet zich na de crisisjaren 2009, 2011 en 2013 een voorzichtig herstel voor. In 2015 wordt eenzelfde hoogte van de omzet als in 2014 gerealiseerd en een nettowinst van $4 \mathrm{mln}$. euro. In 2016 daalt de omzet met ruim 7\% en stijgt de netto winst tot 9 $\mathrm{mln}$. euro. Het rendement op gemiddeld geïnvesteerd vermogen is weer positief en het aansprakelijk vermogen is gestegen. Modernisering van de coöperatie is ingezet met de vernieuwing van de verkooporganisatie per 1 januari 2016. Ook de nieuwe horizontale samenwerking binnen de in 2015 opgerichte Federatie Vruchtgroenteorganisaties met de grootste afzetorganisaties /telersverenigingen en binnen het GroentenFruithuis met Frugi Venta biedt nieuwe mogelijkheden voor de toekomst (zie appendices A en B hoofdstuk 3 en 4). 


\section{Bloemenveiling FloraHolland}

Bloemenveilingen FloraHolland en VBA tonen in de aanloop naar en tijdens de fusie 20072008 een duidelijke strategie met positieve resultaten. $\mathrm{Zij}$ geven een goed voorbeeld van een zorgvuldig uitgevoerde strategie van horizontale concentratie en bundeling van belangen van de bloemenveilingen en hun leden. Voor FloraHolland is de crisisperiode 2009-2011 een testcase waar ze goed doorheen komt. Op het gebied van horizontale concentratie over de grenzen zijn er uitbreidingen: een nieuwe joint venture Veiling Rhein-Maas, opgericht samen met het Duitse Landgard, en een integratie in 2009-2010 van de importveiling TFA. Beide zijn een aanwinst voor de marktplaats. Voor zover er verticaal beleid wordt ontwikkeld gericht op de internationale retail, werkt FloraHolland samen met de exporteur zonder bedreiging van integratie of uitschakeling. FloraHolland hanteert als belangrijkste dagelijkse verkoopmethode voor sierteeltproducten het klokveilen, fysiek en digitaal. Zowel bij snijbloemen als pot- en tuinplanten wordt een groot deel van de productgroepen via de klok geveild en wordt tevens getracht tot een betrouwbare referentieprijs voor bemiddeling en persoonlijke verkoop te komen. Aandacht voor het versterken van de klokpositie, vooral bij de verkoop van potplanten, is belangrijk. De veilingomzet van FloraHolland daalt in 2009, jaar van de kredietcrisis, met ongeveer 5\% en komt in 2010 en 2011 net boven het niveau van 2008 uit. De inkomsten uit diensten van FloraHolland dalen. Er vindt echter een grotere daling van de kosten dan de opbrengsten plaats en het rendement en de solvabiliteit verbeteren in deze periode toch. In 2012 realiseert FloraHolland een hogere productomzet dan in 2011, de jaarinkomsten dalen echter. In 2013 presteert de sierteeltsector redelijk, de productomzet van FloraHolland stijgt licht, maar de kosten zijn hoger dan de inkomsten en FloraHolland lijdt een exploitatieverlies. 2014 is een jaar van licht herstel en FloraHolland sluit 2015 af met een stijging van de productomzet en een minieme daling van de opbrengsten. De totale kosten dalen met meer en het resultaat na belasting stijgt tot $12 \mathrm{mln}$. euro. Voor de meeste kwekers en klanten was 2015 een positief verlopen jaar. Het feit dat de handel heeft besloten weer bij te dragen aan de promotie van bloemen en planten door Bloemenbureau Holland is zeer positief. In het kader van de nieuwe strategie FloraHolland 2020 wordt gewerkt aan versterking en vergroting van de fysieke en digitale marktplaatsen.

De overige resultaten 2013-2016 van beide afzetorganisaties zijn opgenomen in hoofdstuk 4 appendix 4B.

\subsubsection{Conclusies bedrijfsonderzoek producenten glastuinbouw}

Onderstaand worden de belangrijkste conclusies van de mogelijke verbanden tussen de variabelen van marktgedrag en -resultaat van producenten in de glastuinbouw toegelicht.

Mogelijke verbanden producenten glasgroenten

1.Er lijkt een verband tussen bedrijfs- en producttype: veilingtelers produceren voornamelijk de ronde of trostomaat, zelfstandige telers kiezen in meerderheid de speciale soorten tomaat. Dit beïnvloedt prijs- en inkomensvorming. De brutomarge van de kleine veilingteler en grote zelfstandige teler verschilt aanzienlijk maar niet-significant (4\% versus $11 \%$ ).

2. Bedrijven met een grotere oppervlakte glas hebben geen betekenisvol lagere kostprijs per $\mathrm{m}^{2}$ 
dan kleinere bedrijven. Verondersteld wordt dat de brutomarge verbetert door uitbreiding en vernieuwing van het bedrijf. De onderzoeksuitkomsten lijken dit te bevestigen. Uitbreiding en vernieuwing zijn meer zinvol gezien vanuit margeverbetering, dan alleen kostenverlaging.

3. Er is een betekenisvol verband tussen de organisatie van de afzet en de bedrijfsomvang. Bij The Greenery en vooral ZON zijn verhoudingsgewijs meer kleine bedrijven aangesloten dan bij de (voormalige) handelshuizen Haluco en Van Rijn en telersvereniging FresQ.

4. Er is geen betekenisvol verband tussen de traditionele afzetorganisatie en de gerealiseerde brutomarge. De afzetorganisatie heeft weinig invloed op het bedrijfsresultaat van de leden. Dit wordt voornamelijk door de producent zelf bepaald. Met het stoppen van klokveilen en de overstap naar bemiddeling is met name de positie van de kleinere veilingteler verzwakt.

Mogelijke verbanden producenten glassnijbloemen

1. De kleine veilingteler in de snijbloemen realiseert een verwachte lagere omzet en betaalt een hogere provisie dan de grote veilingteler, lid telersvereniging. Hoewel er geen betekenisvol verband is tussen bedrijfstype en gerealiseerde brutomarge, kan het klokveilen leiden tot hogere prijzen en een hogere brutomarge. Behalve het hogere prijsniveau realiseren kleine veilingtelers een hoger vermogensresultaat dan de grote bedrijven ${ }^{10}$.

2. Rozenbedrijven realiseren een betekenisvol hogere brutomarge dan chrysantenbedrijven door het bredere en diepere assortiment van de roos ten opzichte van de chrysant.

Het verband tussen bedrijfsoppervlakte en behaalde resultaten laat zien dat kleine snijbloementelers onder glas dezelfde of betere resultaten behalen dan de grote.

3. Er zijn geen betekenisvolle verbanden tussen de organisatie van de afzet en de omzet, de gerealiseerde brutomarge en de hoogte van de veilingprovisie. Het lijkt erop dat elk bedrijf zijn eigen marketing- en verkoopmix per deelactiviteit (klok, bemiddeling, eigen verkoop) zodanig inzet dat geen significante resultaatsverschillen ontstaan. Het verkopen van snijbloemen via de veilingklok levert goede resultaten op. Kleine en grote snijbloementelers realiseren vergelijkbare brutomarges.

Mogelijke verbanden producenten glaspotplanten

1 De kleine veilingteler, met of zonder eigen verkoop, realiseert een verwachte lagere omzet, maar een hogere brutomarge dan de grote veilingteler, lid van de telersvereniging.

Oude en nieuwe bedrijven behalen vergelijkbare brutomarges.

2. Hogere investeringen van bedrijven blijken niet (direct) tot hogere resultaten te leiden. Er zijn meer innovatieve investeringen nodig die prijzen en brutomarge verbeteren.

3 . Er is een betekenisvol verband tussen de organisatie van de afzet en verkoopwijze en de gerealiseerde jaaromzet: grote potplantenbedrijven zetten naast de verkoopdiensten van de veiling meer eigen verkoop in, in eigen dienst of in dienst van de telersvereniging.

10 Bedrijfstype B1(de veilingteler) komt in dit onderzoek tot gemiddeld hogere resultaten dan bedrijfstype B2 (lid telersvereniging). Dit strookt niet met de conclusies in het eerder genoemde artikel 'Investeren in telersvereniging loont" uit het Vakblad voor de Bloemisterij, 23 juli 2010, p. 18. 
Uitbesteden van de gehele verkoop aan FloraHolland is vooral voor de kleine teler effectief en vergroot de kans op het behalen van een hogere brutomarge. Hij betaalt een hoge provisie, maar behaalt een hoge brutomarge door het positieve verband tussen provisie en brutomarge.

\subsection{Conclusies econometrisch onderzoek producenten glastuinbouw}

\subsubsection{Producenten glasgroenten}

De uitkomsten van de econometrische analyse laten ons zien dat in de glasgroentesector deelname aan een telersvereniging gemiddeld betere resultaten oplevert dan deelname aan een traditionele marketingcoöperatie. Het zijn vooral de jonge ondernemers met nieuwe ideeën over bedrijfsorganisatie en verticale samenwerking die met gemiddeld grote en moderne bedrijven de beste resultaten boeken.

\subsubsection{Producenten glassnijbloemen}

Veilingtelers die exclusief via de bloemenveiling hun producten veilen, realiseren gemiddeld een hogere brutomarge dan telers die naast veilen ook andere verkoopmethoden gebruiken. Hierbij levert deelname aan een telersvereniging gemiddeld betere resultaten op dan niet-deelname en behalen kleine bedrijven hogere brutomarges dan grote. Oudere ondernemers presteren beter dan jonge. De klok van de bloemenveiling is de beste garantie voor hogere brutomarges. Het blijkt in de snijbloemensector dat schaalvergroting van de productie minder effect heeft op de brutomarge dan het produceren van 'niche' producttypen. Hierbij speelt de verkoopmethode via de klok een belangrijke rol. Bedrijven met 'niche' producten hebben hogere vaste kosten waarbij een hogere brutomarge het financieren gemakkelijker makt.

\subsection{Slotconclusie}

De slotconclusie ter beantwoording van de hoofdvraag kan bevestigend zijn en luidt als volgt. Het verschil in marktstructuur en marktgedrag in de sectoren glasgroenten en glasbloemen kan een betekenisvolle oorzaak zijn om het verschil in marktresultaat te verklaren.

Als we de positie en resultaten van de kleine veilingteler in de glasgroenten volgen na de integratie van de groothandel in de bedrijfsvoering van de afzetorganisatie, dan zien wij een productiebedrijf in de knel met gemiddeld lagere resultaten voor zowel de kleine veilingteler als zijn afzetorganisatie ten opzichte van de zelfstandige teler en zijn telersvereniging.

In de glassnijbloemen is de positie en het resultaat van de kleine veilingteler/klokveiler juist beter in vergelijking met eigen verkoop of verkoop via een telersvereniging. 
De uitkomsten van dit onderzoek geven aan dat in de sector glasgroenten de zelfstandige telersvereniging, die al dan niet met de klassieke coöperaties samenwerkt, maar in ieder geval een eigen marketingbeleid ontwikkelt, de beste resultaten boekt. In de sector glassnijbloemen worden voor de veilingklok de hoogste marges behaald. Voor de sector glaspotplanten, waar de aard van het product duidelijk verschilt van de korter houdbare glasgroenten en glassnijbloemen, zijn te weinig gegevens beschikbaar om conclusies te trekken.

\subsection{Onderzoeksmethodologie}

Centraal in dit onderzoek staat het conceptueel model van figuur 1.1, ontstaan uit een samenvoeging van het analysemodel voor bedrijfstakken van Porter, dat van Daems en het SGR-model van De Jong. Als te onderzoeken sector in de tuinbouw is gekozen voor de glastuinbouw en daarvan de deelsectoren glasgroenten, glassnijbloemen en glaspotplanten. Als belangrijkste productgroepen in de glasgroente is gekozen voor tomaat en paprika, in de glassnijbloemen voor roos en chrysant en in de potplanten voor de groepen groen en bloeiend.

Op basis van dit conceptueel model heeft een selectie van variabelen plaatsgevonden op het niveau van de sectoren, de afzetorganisaties en de producenten die zowel theoretisch als praktisch nader zijn onderzocht. Het gaat om die structuur- en gedragsvariabelen die bepalend zijn voor de mate van concurrentie en de gerealiseerde resultaten. Deze variabelen zijn geselecteerd uit het overzicht van nader te onderzoeken elementen genoemd in hoofdstuk 1 paragraaf 1.3 en toegevoegd in bijlage 5 van dit proefschrift. De basis voor de keuze is de veronderstelde dynamische marktwerking van deze variabelen in het concurrentie- en concentratieproces van de bedrijfstak en de sectoren (zie Marijs en Hulleman, 2003: 112).

\section{Onderzoek sectoren}

De variabelen die grotendeels de structuur van de sector en het resultaat op sectorniveau bepalen, zijn: de hoogte van de concentratiegraad onder producenten, afzetorganisaties en groothandel/ exporteurs, de productdifferentiatie, de hoogte van de toetredingsdrempels/ investeringen, het binnenlands aandeel, het importaandeel en het exportaandeel. Sectorale resultaatsvariabelen zijn de gerealiseerde productiewaarde, export- en importwaarde, groei, gemiddelde jaarprijzen en -rendement. Deze gegevens en kerncijfers zijn verkregen uit jaarverslagen, studies en rapporten van de overkoepelende organisaties uit de tuinbouw. Bij het volgen en vergelijken van de cijfermatige ontwikkeling in de tabellen zijn, voor zover mogelijk en beschikbaar, de volgende jaren gekozen: 1980, 1990, 2000, 2005 - 2010, $2011 \mathrm{t} / \mathrm{m}$ 2016. Soms was dit niet mogelijk. Het Productschap Tuinbouw heeft in zijn publicaties bij sommige overzichten bepaalde jaren weggelaten. De ontwikkelingen in de jaren 2011 t/m 2016 zijn in hoofdstuk 9 kort toegelicht.

\section{Onderzoek afzetorganisaties}

Dit onderzoek betreft het strategisch afzetbeleid, de ontwikkeling van horizontale en verticale concentratie, de mate van productdifferentiatie en de hoogte van de (innovatieve) investeringen. 
Afzonderlijke studies naar de hoofdzaken van de strategie, ontwikkeling van de organisatie en resultaten zijn gemaakt vanuit de beleidsplannen en jaarverslagen 2003 - 2010 van VTN/Coforta/The Greenery in de voedingstuinbouw en VBA/FloraHolland in de siertuinbouw. Getoetst zijn de verbanden met jaarprijzen, jaaromzet en rendement. Ook hier zijn de jaren 2011 t/m 2016 in hoofdstuk 9 toegevoegd aan de conclusies.

Bedrijfsonderzoeken deelsectoren en econometrische onderzoek

Het bedrijfsonderzoek is gehouden in de periode 2006 - 2008 met jaarlijks aansluitende deelrapportages en samenvattingen van de onderzoeksresultaten. Deze samenvattingen zijn toegestuurd aan de deelnemende bedrijven. Per sector zijn 80 - 100 glastuinders benaderd vanuit een door LTO Groeiservice beschikbaar gesteld adressenbestand, verspreid over de belangrijke concentraties glastuinbouw in Nederland. Deze ondernemers zijn gebeld met een verzoek om mee te werken aan een mondeling interview van maximaal een uur, op basis van een vooraf toegestuurde vragenlijst. Per deelonderzoek zijn ruim 40 vraaggesprekken met telers gehouden. De beantwoording van de vragen is in meerderheid volledig geweest. Op enkele vragen over in het verleden verrichte investeringen of de verhouding eigen en vreemd vermogen bleef men het antwoord schuldig of werd een schatting genoemd. De omvang van de steekproef is vastgesteld op basis van de ontwikkeling van de populatie glastuinders en afzetorganisaties. Gezien de beperkte omvang van de steekproef en de verdeling van de respondenten over de productiegebieden dienen de resultaten van het onderzoek met enige voorzichtigheid te worden gehanteerd (zie de appendices in hoofdstuk 5, 6 en 7).

In 2015/2016 is een econometrisch onderzoek uitgevoerd naar meervoudige verbanden tussen gedrags- en resultaatsvariabelen voor de drie sectoren. De uitbreiding en aanvulling van het bedrijfsonderzoek betreft met name het vaststellen van de omvang en richting van het mogelijke verband tussen kenmerken van het gekozen bedrijfstype, ondernemerstype en organisatie van de afzet en de ontwikkeling van de gerealiseerde brutomarge (Lernerindex).

Gebruiksfuncties en ervaringen conceptueel model

Het conceptueel model heeft in dit onderzoek de volgende theoretische en praktische functies op bedrijfstak- en bedrijfsniveau.

De theoretische functies zijn:

- het beschrijven en selecteren van de belangrijkste te onderzoeken elementen van marktstructuur, marktgedrag en marktresultaat en het rangschikken van deze elementen in onafhankelijke en afhankelijke variabelen;

- het globaal toetsen van de theoretische verbanden tussen deze variabelen en het benoemen van de verwachtingen;

- het bepalen van de daadwerkelijk te toetsen variabelen met behulp van de uitkomsten van het sectoronderzoek en het onderzoek onder de afzetorganisaties en het bedrijfsonderzoek onder producenten, aangevuld met een meervoudige econometrische analyse op deze data. 
De praktische functies zijn:

- het beschrijven van de gekozen onafhankelijke en afhankelijke variabelen;

- het toetsen van de werkelijke verbanden tussen deze variabelen en het vastleggen van de onderzoeksuitkomsten;

- het trekken van conclusies en het doen van aanbevelingen;

- het inschatten van markttypering, -ontwikkeling en concurrentie intensiteit per sector.

Het conceptueel onderzoeksmodel heeft voor- en nadelen.

De voordelen zijn:

- het model is duidelijk in de weergave van problematiek en methode van analyse;

- het model is te gebruiken voor analyse van de bedrijfskolom, bedrijfstak, sector en markt;

- het model is te gebruiken voor analyse op macro-, meso- en microniveau;

- het model is handig in gebruik bij selectie en toetsing van de relevante onafhankelijke en afhankelijke variabelen.

De nadelen zijn:

- niet alle geselecteerde hoofdvariabelen vertegenwoordigen evenveel onderliggende elementen. Sommige boxen vertegenwoordigen veel variabelen en andere slechts een enkele (zie de voorbeelden van box 1 en box 4);

- het model is lastig gelijktijdig op meer niveaus te gebruiken;

- het model is minder geschikt voor het meten van de externe concurrentie.

De voordelen wegen naar onze mening zwaarder dan de nadelen, dus stellen wij voor vanaf heden het bijvoeglijk naamwoord conceptueel vóór onderzoeksmodel te laten vervallen.

\subsection{Discussie}

Voor alle drie de sectoren in de glastuinbouw geldt dat de bovengenoemde conclusies en verbanden laten zien dat er, ondanks grote verschillen in resultaat op individueel bedrijfsniveau, er toch sprake kan zijn van positieve resultaten op sectorniveau. Terwijl er flinke aantallen glastuinders in elke sector jaarlijks afhaken, blijft de sector als geheel in productie- en exportwaarde redelijk op niveau. Zijn het de variabelen van de marktstructuur die hierin het grootste aandeel hebben of die van het marktgedrag van de belangrijkste afzetorganisaties en/of de individuele glastuinbouwbedrijven? Of spelen 'economies of scale' en 'scope' bij productie, inkoop/verkoop en logistiek in ons 'doorvoerland' de belangrijkste rol? Het lijkt erop dat het vooral de marktgedragingen zijn van de belangrijkste afzetorganisaties/telersverenigingen en groothandelaren/exporteurs met hun posities op binnen- en buitenlandse markten, die hierin het grootste aandeel hebben of kunnen hebben. Wederzijdse beïnvloeding van marktstructuur en marktgedrag en effecten van verwantschap in verkoop en logistiek van Nederlandse en geïmporteerde verse tuinbouwproducten voor binnen- en buitenlandse markten spelen hierbij een grote rol. Een grondige jaarlijkse 
afstemming van aanbod en vraag tussen afzetorganisaties/telersverenigingen en groothandel/ export met een onafhankelijke en transparante prijsvorming vergemakkelijkt het oplossen van problemen van overschot en tekort. Het gezamenlijk optrekken en samenwerken hierbij en bij grote investeringsprojecten en het bevorderen van het innovatieve vermogen van de glastuinders en de groothandel/export kan in alle drie sectoren tot verbetering van resultaten leiden. Hierbij is aandacht voor en ondersteuning van kleinere bedrijven en het opleiden van hun ondernemers van groot belang. Een van de opvallendste uitkomsten van dit onderzoek is het grote verschil in positie van en geboden mogelijkheden aan kleine bedrijven en hun ondernemers in de deelsectoren glastuinbouw. Voor de gehele glastuinbouw en haar spelers, zowel voor producenten als voor groothandelaren/exporteurs, blijft een open en toegankelijke markt met een dynamische wisselwerking tussen structuur en gedrag van groot belang voor het realiseren van voldoende marktresultaat. Kenmerken van een goede marktstructuur voor producent en groothandel/export zijn de aanwezigheid van voldoende aanbieders van en vragers naar productgroepen met differentiaties en innovaties. Daarnaast zijn een horizontale concentratie van het aanbod van afzetorganisaties die zich kan meten met de concentratie aan koperzijde, een goede verticale samenwerking zonder integratie met de groot- en detailhandel en een concurrerend kostenniveau van groot belang. 


\section{Referenties}

- Bain, J.S.(1959). Industrial organization. John Wiley \& Sons, New York.

- Baltussen, W., Kornelis, M., Van Galen, M., Logatcheva, K., Van Horne, P., Smit, A., Janssens, S., De Smet, A., Van Zelst, N., Immink, V., Oosterkamp, E., Gerbrandy, A., Van Bockel, W. \& Pham, T.(2014). Prijsvorming van voedsel, Ontwikkelingen van prijzen in acht Nederlandse ketens van versproducten. Nota 14-112, LEI, Den Haag.

- Bonanno, A., Cambalo, L., Caracciolo, F. \& Pascucci, S.(2013). Farms' performance and short supply chains in Italy, an econometric analysis, AIEAA Conference, Para, 6-7 June 2013.

- Bunte, F.H.J., Kuiper, W.E., Galen, M.A. van \& Goddijn, S.T.(2003). Macht en prijsvorming in Agrofoodketens. Rapport 5.03.01, LEI, Den Haag.

- Bunte, F.H.J.(2009). Prijsvorming glastuinbouw. Nota 09-02, LEI, Den Haag.

- Bulow, J. \& Klemperer, P.(1996). Auctions versus negotiations. American Economic Review 86 (1), pp. 180-194.

- Bijman, W.J.J.(2002). Essays on Agricultural Co-operatives; Governance Structure in Fruit and Vegetables Chains. Erasmus University, Rotterdam.

- Bijman, J., \& Hendrikse, G.(2003). Co-operatives in chains: institutional restructuring in the Dutch fruit and vegetables industry, Chain and Network Science, pp. 95-107.

- Bijman, W.J.J.(2004). De organisatie van samenwerking: van horizontaal naar verticaal, en verder. Wageningen Universiteit, Leerstoelgroep Bedrijfskunde, Stichting Agro Keten Kennis, 's-Hertogenbosch.

- Bijman, W.J.J.(2002). Effecten van verticale coördinatie en internationalisatie op de Nederlandse land- en tuinbouw, Tijdschrift voor Sociaal Wetenschappelijk Onderzoek van de Landbouw. Jg. 17, nr. 3, Wageningen Universiteit i.s.m. Stichting Agro Keten Kennis, 's-Hertogenbosch.

- Carlton, D.W. \& Perloff, J.M.(2005). Modern Industrial Organization. Fourth Edition, Pearson Addison-Wesley, Boston.

- Caves, R.E.(1964). American industry: structure, conduct, performance. Prentice Hall, Englewood Cliffs, New Jersey.

- Caves, R.E.(1980). Industrial organization, corporate strategy and structure. Journal of Economic Literature. Jg. 18, pp. 64-92.

- Daems, H. \& Douma, S.W.(1985). Concurrentie: analyse en strategie. Kluwer, Deventer/ Antwerpen.

- Douma, S.W. \& Schreuder, H.(1991). Economic approaches to organizations. Prentice Hall, London.

- Galbraith, J.K.(1980). American capitalism. The concept of countervailing power. Boston (Mass.).

- Galen, M.A. van, Ruijs, M.N.A., Dijkxhoorn, Y. \& Smit, P.(2010). Bedrijfskolom en marktstructuur van tomaten; Addendum bij Prijsvorming van voedingsproducten. Nota 11-056, LEI, Den Haag.

- Galen, M.A. van, Ruijs, M.N.A., Dijkxhoorn, Y. \& Bakker, T.(2010). Concurrentiemonitor glasgroenten. Rapport 2010-051, LEI, Den Haag.

- Guillotreau, P. \& Jiménez-Toribio R.(2006). The impact of electronic clock auction systems 
on shellfish prices: econometric evidence from a structural change model. Journal of Agricultural Economics, Vol. 57, No. 3, 2006, pp. 523-546

- Guilotreau, P. \& Jiménez-Toribio, R.(2011). The price effect of expanding fish auction markets. Journal of Economic Behavior \& Organization, 211-225.

- Helstad, K., Vassdal, T., Trondsen, T. \& Young, J.A.(2005). Price links between auction and direct sales of fresh and frozen fish in North Norway (1997-2003). Marine Resource Economics 20 (3), pp. 305-322.

- Heybroek, A.M.A. \& Hack, M.(1992). Visie op de internationale concurrentiekracht in de bloemisterij. LEI-DLO en Rabobank Nederland.

- Heybroek, A.M.A., Kleijn, E.J.H.M. de \& Tap, H.(1992). Visie op de internationale concurrentiekracht in de groente. LEI-DLO en Rabobank Nederland.

- Huizingh, E.(2004). Inleiding SPSS 12.0 voor Windows. Academic Service, Sdu Uitgevers, Den Haag.

- Huizingh, E.(2006). Inleiding SPSS 14.0 voor Windows. Academic Service, Sdu Uitgevers, Den Haag.

- Huizingh, E.(2010). Inleiding SPSS 19.0 voor Windows. Academic Service, Sdu Uitgevers, Den Haag.

- Jacquemin, A.P.(1987). The new industrial organization: market forces and strategic behaviour. Clarendon Press, Oxford.

- Jacquemin, A.P. \& Jong, H.W. de,(1977). European Industrial Organization. MacMillan Press, London.

- Jong, H.W. de,(1971). Marktanalyse en markttheorie. Stenfert Kroese, Leiden.

- Jong, H.W. de,(1972). Dynamische concentratietheorie. Stenfert Kroese, Leiden.

- Jong, H.W. de,(1985). Dynamische markttheorie. Tweede druk, Stenfert Kroese, Leiden.

- Jong, H.W. de,(1989). Dynamische markttheorie. Vierde druk, Stenfert Kroese, Leiden.

- Jong, H.W. de,(1993). The structure of European industry. Third edition, Kluwer Academic Publishers, Dordrecht.

- Jong, H.W. de,(1996). Algemene en industrieel-economische beschouwingen. In: Nentjes, A.(red.)(1996). Marktwerking versus coördinatie; Preadviezen. Koninklijke Vereniging voor de Staatshuishoudkunde, Uitgeverij Lemma, Utrecht.

- Katchova, A.L.(2010). An analysis of the financial performance of beginning farmers, Agricultural \& applied Economics Association 2010, AAEA, CAES \& WAEA Joint Annual Meeting, Denver, Colorado, July 25-27, 2010.

- Keuning, D. \& Eppink, D.J.(1986). Management en organisatie. Derde druk, Stenfert Kroese, Leiden.

- Kolkman, W.A.(1999). Dynamiek in de groente- en fruitsector van 1990 tot 1998; een nieuw logistiek concept. Productschap Tuinbouw.

- Kyriakopoulos, K.(2000). The Market Orientation of Cooperative Organisations; Learning Strategies and Structures for Integrating Firm and Members, Nyenrode University.

- Leeflang, P.S.H. \& Beukenkamp, P.A.(1993). Probleemgebied marketing, een managementbenadering. Derde druk, Stenfert Kroese, Houten. 
- Marijs, A.J. \& Hulleman, W.(2003). Meso-economie en de bedrijfsomgeving, een bedrijfstakanalyse. Derde druk, Wolters-Noordhoff, Groningen/Houten.

- Mason, E.S.(1957). Economic concentration and the monopoly problem. Harvard University Press, Cambridge.

- Meulen, H.A.B. van der, Bommel, K. van, Vermeulen, P. \& Zijlstra, J.(2007). Bedrijfsovername grote glastuinbouwbedrijven. Rapport 6.07.19, LEI, Den Haag.

- Meulen, H.A.B. van der, Everdingen, W.H. \& Smit, A.B.(2012). Actuele ontwikkeling van resultaten en inkomens in de land- en tuinbouw in 2012. Rapport 2012-064, LEI, Den Haag.

- Meulen, H.A.B. van der, Everdingen, W.H. van, Smit, A.B. \& Silvis, H.(2013). Actuele ontwikkeling van resultaten en inkomens in de land-en tuinbouw in 2013. Rapport 2013-060, LEI, Wageningen UR.

- Penning, Wout,(1997) student HES Rotterdam, The Greenery International b.v.; een evaluatie van een evolutie in de afzet van groente en fruit. Productschap Tuinbouw.

- Porter, M.E.(1992). Concurrentie strategie; analysemethoden voor bedrijfstakken \& industriele concurrentie. Tweede druk, L.J. Veen B.V., Amsterdam/Antwerpen.

- Porter, M.E.(1998). Competitive strategy; techniques for analyzing industries and competitors. Free Press, New York.

- Porter, M.E.(1981). The contributions of industrial organization to strategic management. Academy of Management Review, jg. 6, nr. 4, pp. 609-620.

- Porter, M.E.(1998). Competitive advantage; creating and sustaining superior performance. The Free Press, New York.

- Porter, M.E.(1990). The competitive advantage of nations. The Free Press, New York.

- Rogier, J.J.H.(1998). De wisselwerking tussen organisatie en markt; ontwerp van een instrument voor ondernemers die hun besturing willen balanceren. Groningen, pp. 72-75, 98.

- Setiawan, M., Emvalomatis, G. \& Oude Lansink, A.(2013). Structure, conduct and performance: evidence from the Indonesian food and beverages industry. Empiral Economics 45, pp. 1149-1165.

- Scherer, F.M.(1980). Industrial market structure and economic performance. Houghton Mifflin, Boston.

- Schumpeter, J.A.(1954). History of economic analysis. Oxford University Press, New York.

- Sutton, J.(1995). Sunk costs and market structure; Price completion, advertising and the evolution of concentration, Cambridge MA: MIT Press.

- Veldman, J. et al.(2004). Exportmanagement. Vijfde druk, Stenfert Kroese/Wolters-Noordhoff, Groningen, pp. 67-117.

- Verdoorn, P.J.(1971). Het commercieel beleid bij verkoop en inkoop. Tweede druk, Stenfert Kroese, Leiden, pp. 343-360.

- Verhage, B.(2004). Grondslagen van de Marketing. Vierde druk, Stenfert Kroese/WoltersNoordhoff, Groningen/Houten, pp. 900-994.

- Williamson, O.E.(1975). Markets and hierarchie: analysis and antitrust implication; : a study in the economics of internal organization. New York/London.

- Winship, C. \& Mare, R.D.(1984), Regression models with ordinal variables, American Sociological Review 49, pp. 512-525. 
Jaarverslagen en jaaroverzichten, beleidsplannen, vakbladen, onderzoeksverslagen, internet documenten

- Jaarverslagen en jaaroverzichten Vereniging van Bloemenveilingen in Nederland (VBN) 1980, 1990, 2000 en 2005-2007

- Bloemenveiling Aalsmeer, Jaarverslagen 2003, 2004, 2005 en 2006.

- FloraHolland Naaldwijk, Jaarverslagen 2003, 2004, 2005 en 2006.

- FloraHolland Naaldwijk/Aalsmeer, Jaarverslagen 2007-2016 (na fusie van september 2007).

- Jaarverslagen VTN/Coforta/The Greenery 1995-2016

- Jaarverslagen Frugi Venta/GroentenFruit Huis 2003-2016.

- Productschap Tuinbouw (PT), jaarverslagen, jaaroverzichten en kengetallen 1980, 1990, 1995, 2000-2013.

- Uitgerekend De Tuinbouw, uitgave Productschap Tuinbouw 2002.

- Hoofdbedrijfschap Agrarische Groothandel (HBAG), commissie Bloemen \& Planten, commissie Groenten \& Fruit, jaarverslagen, jaaroverzichten en kengetallen 1980, 1990, 1995, 2000-2013.

- Economisch Instituut voor het Midden- en kleinbedrijf (EMI), Jaarboek detailhandel, Zoetermeer, 2007.

- Fusierapport Bloemenveiling Aalmeer en FloraHolland, Samengaan voor de toekomst, 2007.

- Strategische visie P 2020 ‘Bakens verzetten', Beleidsplan FloraHolland.

- VGB-visie op de sierteeltgroothandel 2010-2020, Dynamiek in perspectief, april 2010.

- Willegen, van, et al.(2010), Typisch Groothandel; vergelijking 2010-2009.

- Willegen, van, et al.(2014), Typisch Groothandel; vergelijking 2008-2013.

- Beleidsplan 2005-2008, Frugi Venta Groenten en Fruit Handelsplatform Nederland, Gezonde Handel

- Vakblad voor Groenten \& Fruit, Teelt in Beeld, bijlage voorjaar 2004, 2006, 2008 en 2009.

- Vakblad voor Groenten \& Fruit, week 9, 2011 en week 10, 2011: Pleidooi voor ontkoppelen van VTN en het handelsbedrijf The Greenery en introductie van transparantere uitbetaalprijzen.

- Vakblad voor Groenten \& Fruit, 29 maart 2011: Schaalvergroting niet altijd rendabel.

- Vakblad voor Groenten \& Fruit, oktober 2011: Uittreding bij Coforta/The Greenery van vier telersverenigingen en 81 glasgroentetelers per 1 januari 2012.

- Vakblad voor Groenten \& Fruit, 9 augustus 2013: De Belgische fusieveiling Belorta uit Mechelen wil geen 'Nederlandse fouten' maken.

- Vakblad voor Groenten \& fruit, 4 april 2014: Sector is zwak in vernieuwing.

- Vakblad voor Groenten \& fruit, 25 juli 2014: Veel bewegingen in de afzet missen centraal doel.

- Vakblad voor de Bloemisterij nr. 16, 22 april 2005: Provisie FloraHolland kan omlaag.

- Vakblad voor de Bloemisterij nr. 28, 15 juli 2005: Rozentelers over hun toekomst.

- Vakblad voor de Bloemisterij nr. 35, 2 september 2005: Bloemenbureau voorspelt forse exportgroei tot 2014.

- Vakblad voor de Bloemisterij, Staalkaart snijbloemen en potplanten, jaarlijkse bijlage, mei 2009. 
- Vakblad voor de Bloemisterij, 23 juli 2010: Investeren in telersvereniging loont.

- Vakblad voor de Bloemisterij week 6, 2011: FloraHolland wordt geen Greenery.

- Vakblad voor de Bloemisterij week 26, 2013: Grote glastuinbouwbedrijven hebben in financieel slechtere jaren grotere problemen dan kleine bedrijven.

- Agrarische Hogeschool Delft, studierichting Tuinbouw, Syllabus Afzet van Nederlandse tuinbouwproducten, november 1992, pp. 13-33.

- Veerman, C.P.(2006). Autoriteitenonderzoek glasgroenten, samenvatting met voorlopige conclusie. (http://proefschrift.online/kees-veerman/)

- Veerman, C.P.(2010). Resultaten Beleidsonderzoek Bloemenveilingen in Nederland 19802008. (http://proefschrift.online/kees-veerman/)

- Veerman, C.P.(2010). Resultaten Beleidsonderzoek VTN/The Greenery 1995-2008. (http:// proefschrift.online/kees-veerman/)

- Veerman, C.P.(2007). Onderzoeksresultaten bedrijfsonderzoek glasgroenten. (http://proefschrift.online/kees-veerman/)

- Veerman, C.P.(2008). Onderzoeksresultaten bedrijfsonderzoek glassnijbloemen. (http://proefschrift.online/kees-veerman/)

- Veerman, C.P.(2009). Onderzoeksresultaten bedrijfsonderzoek glaspotplanten. (http://proefschrift.online/kees-veerman/)

- Verzamelen van Keteninformatie ten behoeve van een doelmatiger afzet, Methode, E.H. Poot, Uitgave Proefstation voor Bloemisterij en Glasgroenten, Rapport 253.

- Vermeulen, P.C.M. (red.)(2008). Kwantitatieve Informatie voor de Glastuinbouw(Kwin) 2008; Groenten-Snijbloemen-Potplanten. Rapport 185. WUR Glastuinbouw, Wageningen.

- Vermeulen, P.C.M. (red.)(2010). Kwantitatieve Informatie voor de Glastuinbouw(Kwin) 2010; Groenten-Snijbloemen-Potplanten. Editie 21. WUR Glastuinbouw, Wageningen.

- Vermeulen, P.C.M. (red.)(2012). Kwantitatieve Informatie voor de Glastuinbouw(Kwin) 20122013; Groenten-Snijbloemen-Potplanten. Editie 22. WUR Glastuinbouw, Wageningen.

- Woerden, S.C. van (red.)(2005). Kwantitatieve Informatie voor de Glastuinbouw(Kwin) 2005 2006; Groenten-Snijbloemen-Potplanten. Rapport PPO 594, WUR Glastuinbouw, Wageningen.

- LEI-DLO, VEK-Adviesgroep, Rabobank Nederland, NFO-Trendbox, Iquip BV:

a. De kleur van samenwerking; ontwikkelingen in de sierteelt: van solisme naar partnerschap in ketens, 10 december 2001.

b. De smaak van samenwerking; ontwikkelingen in de voedingtuinbouw, van solisme naar partnerschap in ketens, 10 december 2001.

c. De onbegrensde tuinbouw, Instrumenten in de concurrentiestrijd: internationale ketens en netwerken, 15 april 2002.

d. Kiemkracht, De evolutie van de sector uitgangsmateriaal: van autonomie naar partner in Business, 15 april 2002.

- LEI-DLO en PPO Glastuinbouw, Op Kop, Internationale concurrentiepositie en strategie Nederlandse Glastuinbouw, 2004.

- Persbericht LNV: Landbouw en voedingscluster meest concurrerend van de Nederlandse eco- 
nomie. Uit: rapport De sterke Nederlandse clusters volgens de Porter-methodiek, anno 2003, (www9.minlnv.nl/servlet).

- Bedrijfsresultaten en inkomens van land- en tuinbouwbedrijven, BINternet, LEI 2008-2009, (www3.lei.wur.nl/binternet2/showtable).

- Platform FloriLog en FloriLog-regie, werkplan 2005 (www.florilog.nl).

- Vruchtgroenten Nederland, Concurrentiedruk neemt toe, concurrentieanalyse vruchtgroente 2015, (www.vruchtgroente.nl).

- Nieuwe samenwerking DPA en Frugi Venta in GroentenFruitHuis per 1 januari 2014 (www. groentenfruithuis.nl). 
Bijlage 1 - SCP-model

Structure, Conduct, and Performance (Carlton en Perloff, 2005, p. 4)

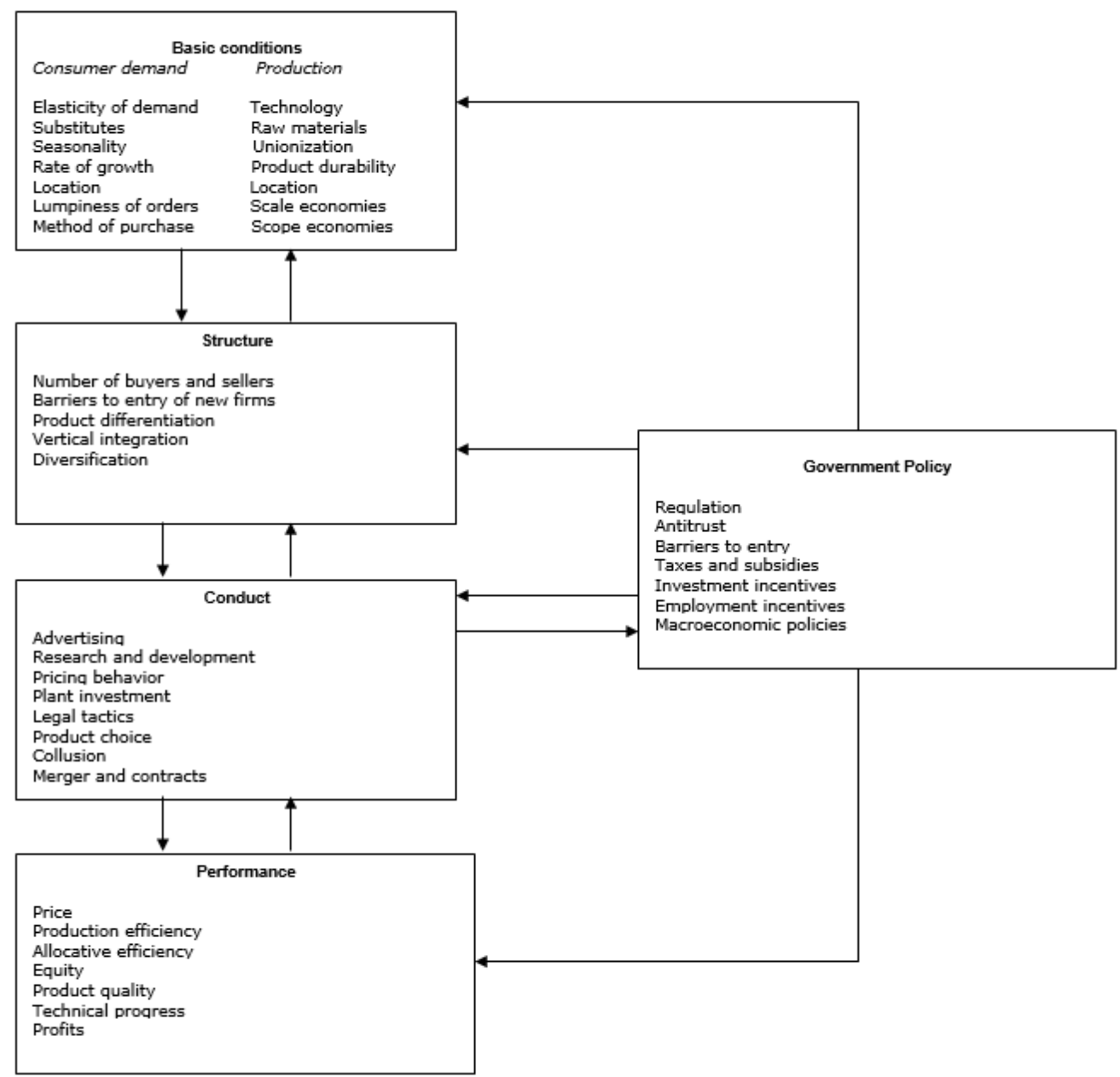


Bijlage 2 - Begripsomschrijvingen

\section{- Afzet}

De verkoop en distributie door ondernemingen van verse (glas)tuinbouwproducten in eenheden (stuks of $\mathrm{kg}$ ) gemeten via de diverse schakels van de bedrijfskolom van kweker tot consument.

\section{- Afzetmethode}

De door ondernemingen resp. diverse schakels in de bedrijfskolom gekozen methode bij de verkoop en distributie van verse (glas)tuinbouwproducten van kweker tot consument.

\section{- Bedrijfstak}

De Jong (1989, p. 76) definieert een bedrijfstak als het geheel van de ondernemingen die op directe wijze met elkaar in horizontale relatie (concurrentie en anderszins) treden. Met het begrip relatie doelt De Jong op de parameterinterdependentie. Parameterinterdependentie fungeert als criterium voor de afbakening van een 'gelijksoortig' product en van de bedrijfstak. Daems (1985, p. 38) definieert een bedrijfstak als een verzameling van ondernemingen of filialen van ondernemingen die gelijksoortige producten produceren op basis van een gelijksoortige technologie.

\section{- Bedrijfskolom}

De opeenvolgende bedrijfstakken (schakels in de bedrijfskolom) die een product doorloopt van oerproducent tot eindgebruiker.

\section{- Concentratie}

Het begrip concentratie wordt in Dynamische Markttheorie van De Jong (1989, p. 8) omschreven als zeggenschap van de ene onderneming over de andere. Deze concentratie kan drie grondvormen aannemen te weten horizontaal, verticaal en diagonaal.

- Diagonale concentratie kan worden omschreven als de combinatie van verschillende economische handelingen/ondernemingen uit verschillende bedrijfstakken/stadia in de bedrijfskolom onder gemeenschappelijke beslissingsmacht, in de praktijk diversificatie resp. conglomeratie genoemd.

De Jong (1989, p. 226) spreekt van diversificatie als de onderneming nieuwe, nog niet door haar verzorgde markten gaat betreden, waarbij zij gebruik maakt van product-, proces-, materiaal- of klantverwantschappen. Bij conglomeraties zijn deze verwantschappen grotendeels afwezig.

- Horizontale concentratie is het op bedrijfstakniveau samenvoegen van verschillende economische handelingen/ondernemingen onder gemeenschappelijke beslissingsmacht (1989, p. 77).

- Verticale concentratie (= verticale integratie) is de combinatie van opeenvolgende economische handelingen onder gemeenschappelijke beslissingsmacht resp. een vereniging van achter elkaar geschakelde stadia in de bedrijfskolom tot één geheel, voorwaarts of achterwaarts (1989. pp. 183-185). 


\section{- Concentratiegraad}

De absolute concentratiegraad $\mathrm{C}$ meet het aandeel dat de grootste ondernemingen in een markt of bedrijfstak hebben (zie bijlage 3).

\section{- Handelsmarge}

Handelsmarge (groothandel of detailhandel) wordt in Grondslagen van de Marketing (Verhage, 2004 , p. 935) omschreven als het verschil tussen de inkoop- en verkoopprijs van de groothandel resp. de detailhandel. De bruto handelsmarge is het totale verschil tussen de inkoop- en verkoopprijs, de netto handelsmarge is de brutomarge onder aftrek van de gemaakte kosten oftewel de winstmarge.

- Herfindahl-Hirschmann-index (H)

De Herfindahl-Hirschmann-index is de som van de gekwadrateerde marktaandelen $\left(\mathrm{P}_{\mathrm{i}}\right)$ van de $\mathrm{n}$ ondernemingen in de sector:

$$
\mathrm{H}=\sum_{\mathrm{i}=1}^{\mathrm{N}} \mathrm{P}_{\mathrm{i}}{ }^{2}
$$

waarbij de weging is volgens het relatieve marktaandeel. Bij monopolie is de index maximaal, d.w.z. $H=1$, terwijl bij gelijke marktaandelen van alle ondernemingen de index een minimum bereikt.: $H=1 / n$. Een correcte omschrijving van de bedrijfstak is van groot belang. Hoe strenger de definitie, hoe vlugger er sprake is van een gering aantal aanbieders met relatief grote marktaandelen (zie bijlage 3 ).

\section{- Marketingmix}

Marketingmix wordt in Grondslagen van de Marketing (Verhage, 2004, p. 950) omschreven als een uitgekiende, op een of meer doelgroepen afgestemde combinatie van vier met elkaar samenhangende marketinginstrumenten (product, promotie, prijs en distributie) om de markt te bewerken.

\section{- Marketingstrategie}

Marketingstrategie wordt in Grondslagen van de Marketing (Verhage, 2004, p. 951) omschreven als de manier waarop een organisatie binnen de grenzen van haar business-definitie haar marketingdoelstellingen op lange termijn beoogt te verwezenlijken, met beleidsimplicaties voor de te voeren producten, de te bewerken doelgroepen en de positionering op de markt. Zie ook hieronder de begripsomschrijving Visie, missie en (marketing)doelstellingen.

\section{- Markt}

De markt wordt in Grondslagen van de Marketing (Verhage, 2004, p. 951) omschreven als het totaal aantal kopers van een bepaald product in een bepaalde periode en een bepaald gebied, die 
gezamenlijk voor de totale vraag zorgen waarop het totaal van de aanbieders in diezelfde periode en hetzelfde gebied met hun producten en diensten inspelen.

- Marktaandeel

Het marktaandeel wordt in Grondslagen van de Marketing (Verhage, 2004, p. 951) omschreven als de verkopen van een bedrijf over een bepaalde periode in verhouding tot de verkopen van alle aanbieders over diezelfde periode op dezelfde markt (gebied), uitgedrukt als percentage in omzetwaarde (euro's) dan wel afzet (aantallen product).

- Marktontwikkeling

Het dynamische van de dynamische markttheorie uit zich in de marktontwikkeling. Marktontwikkeling (De Jong, 1989, p. 100) is de opeenvolging van verschillende marktsituaties in de groeicyclus. De marktsituaties zijn dwarsdoorsneden van de marktontwikkeling, zij stellen daarin momenten voor die geen permanent karakter, maar wel een zekere eenheid van karakter hebben. Een bepaalde fase kan uiteenlopende marktsituaties bevatten.

- Marktsituatie

De marktsituatie (De Jong, 1989, p. 100) wordt omschreven als het samenhangend geheel van vraag- en aanbodfactoren dat op een gegeven moment of gedurende een korte periode de kenmerken van de markt van een bepaald product toont.

- Marktstructuur

Marktstructuur (De Jong, 1989, p. 101) is het geheel van kenmerken die bij een gegeven marktsituatie de geleding, opbouw en onderlinge betrekkingen van marktpartijen aan de aanbod- en vraagzijde van de markt voorstellen. Het verwijst naar het aantal ondernemingen, de onderlinge grootte, verhoudingen en verbindingen tussen de ondernemingen zoals de mate van concurrentie, beheersing en samenwerking. De marktstructuur wordt gezien als een onderdeel van de marktsituatie. De marktstructuur kan door ondernemers voortdurend worden gevormd en omgevormd, terwijl de marktsituatie conditionerend werkt.

- Omgevingsfactoren

- Macro-economische

Situaties, gebeurtenissen en trends in de maatschappij die van invloed zijn op de mate waarin een onderneming bij het bewerken van de markt haar doelen bereikt. De voornaamste invloeden zijn demografische, economische, politiek/juridische, technologische en sociaal/culturele factoren. Zie Grondslagen van de Marketing (Verhage, 2004, p. 948).

- Meso-economische

De niet-beheersbare partijen in de externe, maar directe omgeving van de onderneming (de bedrijfstak of markt waarop zij actief is) waaronder de toeleveranciers, afnemers, distribuanten, concurrenten en belangengroepen (Verhage, 2004, p. 955).

- Micro-economische

Alle afdelingen en bedrijfsmiddelen die zich buiten de marketingafdeling bevinden, maar wel deel van de organisatie uitmaken. Deze grotendeels beheersbare invloeden in de interne omgeving van een organisatie omvat de beschikbare (commerciële, technische, personele, financiële en natuurlijke) middelen, bedrijfsfuncties en organisatiecultuur (Verhage, 2004, p. 955). 
- Parameterinterdependentie

Parameterinterdependentie (De Jong, 1989, p. 101) is het al dan niet optreden van reacties van de kant van de onafhankelijke ondernemingen op wijzigingen in de parameters (prijs, kwaliteit, reclame, verpakking, enz.) van initiërende ondernemingen.

\section{- Prijs}

Een van de instrumenten van de marketingmix (een opbrengstdrager) die vanuit de koper gezien de tegenwaarde in geld vormt die hij in ruil voor het product aan de verkoper wil betalen (de objectieve prijs) (Verhage, 2004, p. 965).

- prijs producent (producentenprijs)

Prijs per eenheid (st. of $\mathrm{kg}$ ) die de tuinder van de koper voor zijn product ontvangt exclusief belasting, verkoopprovisie, logistieke kosten en verpakking, ook wel uitbetaalprijs voor het product genoemd of prijs af glastuinbouwbedrijf.

- prijs groothandel/exporteur (groothandelsprijs)

Prijs per eenheid (st. of $\mathrm{kg}$ ) die de groothandelaar/exporteur van de koper (meestal detaillist) voor zijn product ontvangt exclusief belasting, logistieke kosten en verpakking, ook wel genoemd prijs af groothandel.

- prijs consumenten (consumentenprijs)

Prijs per eenheid (st. of $\mathrm{kg}$ ) die de consument voor het gekochte product betaalt inclusief belasting, logistieke kosten en verpakking oftewel de verkoopprijs van de detailhandel inclusief alle bijkomende kosten (eindprijs).

\section{- SBI}

Standaard Bedrijfsindeling (SBI), sinds 1993 aangepast aan de Europese standaardindeling. In de SBI worden alle productieve activiteiten van bedrijven en overheid in Nederland ingedeeld in zeventien secties, elk aangeduid met een letter A t/m Q. Elk zelfstandig bedrijfsonderdeel krijgt een viercijferige codering, die aangeeft welke activiteit de onderneming als hoofdactiviteit uitoefent. Het Centraal Bureau voor de Statistiek bepaalt de hoofdactiviteit aan de hand van het zwaartepunt van de toegevoegde waarde. Zo valt het glastuinbouwbedrijf onder de primaire sector, letter A xxxx, sectienr. ..., afdelingsnr...., groepsnr...., bedrijfsklassenr.....

Een complete lijst van bedrijfstakken biedt de bedrijfsindeling van de Kamers van Koophandel 1995, afgekort BIK 95. De KvK leveren de benodigde informatie aan het CBS en maken gebruik van dezelfde viercijferige SBI-codering, maar voegen hieraan vaak nog meer cijfers aan toe (max. 2) om op een specifiek bedrijfstakniveau te komen.

\section{- SGR(SCP)-model}

Stroming in de Industrial Organisation die het SGR-paradigma (Structuur, Gedrag, Resultaat) heeft ontwikkeld dat ervan uitgaat dat de marktstructuur, het marktgedrag en de resultaten van de marktpartijen met elkaar samenhangen. SCP is de Engelse vertaling van SGR: Structure, Conduct, Performance (zie bijlage 1). 
- Verkoopmethoden versproducten (glas)tuinbouw

1. Verkoop door de veiling met gebruikmaking van de veilingklok

We kunnen de volgende vormen van veilen onderscheiden (Agrarische Hogeschool Delft, 1992):

- doorvoerveilen

De producten van iedere kweker worden apart voor de klok langs gevoerd, zodat de kopers direct kunnen zien wat ze kopen en van wie.

- blokveilen

Partijen van een bepaald product, afkomstig van verschillende kwekers, maar van gelijke sortering en kwaliteit, kunnen worden geblokt. Dat wil zeggen dat de partijen als één partij worden geveild. Het blok wordt meestal niet in een keer verkocht maar in gedeelten. Na elke koop gaat de wijzer van de klok opnieuw draaien, net zolang tot het gehele blok verkocht is. De kwekers ontvangen de gemiddelde prijs die voor het blok betaald is.

- voorverkoopveilen

Soms worden producten verkocht met de afspraak dat pas over een bepaalde tijd geleverd wordt. Bij het veilen kan dan een monster aanwezig zijn dat tot na de levering wordt bewaard. Dit is een vorm van administratief veilen. Hieronder verstaat men alle soorten verkopen via een veiling waarbij de producten niet op de veiling worden aangevoerd.

- kopen op afstand (KOA)

Met behulp van de elektronische aanvoerbrief (EAB) wordt het kopen op afstand (KOA) vergemakkelijkt. Met EAB sturen aanvoerders via hun computer alle aanvoergegevens naar FloraHolland. Het resultaat is dat gegevens sneller beschikbaar zijn en de logistieke processen beter kunnen worden gepland. De koper heeft daardoor een beter overzicht over het aanbod voorafgaand aan en tijdens het veilproces. Met KOA wordt de inkoop verlegd van de tribune naar de locatie van de koper. Op een beeldscherm is de inkoop op de virtuele klok te volgen. Dat biedt flexibiliteit, kopers kunnen de processen van prijsvorming beter volgen en op basis daarvan transacties afsluiten. De in 2009 door FloraHolland overgenomen importveiling Tele Flower Auction (TFA) in Amstelveen werkte uitsluitend met kopers op afstand.

2. Verkoop door de veiling zonder gebruik van de veilingklok

De veiling hanteert voor de verschillende productsoorten nog de volgende verkoopmethoden (Agrarische Hogeschool Delft, 1992):

- bemiddeling

Deze vorm van verkoop houdt meestal in dat de bemiddelaars van de veiling als verkoopschakel fungeren tussen de wat grotere telers en de grote kopers. De bemiddelaars proberen enerzijds de aangeboden producten te verkopen, terwijl ze anderzijds voor gevraagde partijen een aanbieder proberen te vinden. De prijs hangt vaak af van wat het product bij de veilingklok opbrengt en wat bij een gegeven vraag en aanbod 'haalbaar' is.

- contractteelt

Bij sommige groente- en fruitgewassen en soms bij bloembollen en boomkwekerijgewassen vindt er contractteelt plaats. De veilingen kunnen dan standaardcontracten opstellen waar zo- 
wel de telers als de kopers zich aan houden. De prijs wordt vooraf bepaald en er zijn aanvullende bepalingen mogelijk waarin bijzondere wensen kunnen worden geregeld.

-cash \& carry

Een groothandelsvorm bij sierteeltproducten, gericht op de kleine kopers voor wie de minimum af te nemen hoeveelheid bij de klok te veel is en/of remmend werkt op de distributie. De cash \& carry's voeren een breed en diep assortiment. Ze zijn op de grote bloemenveilingen gevestigd en worden daar zonder veilingaandeel d.w.z. door groothandelaren 'gerund'. De benodigde producten worden via de klok ingekocht. Bij de kleine veiling is de cash \& carry soms eigendom van de veiling. Deze wil op zo'n manier de kwekers meer aan zich binden. Hier wordt de inkoop bij de kwekers uit de omgeving gedaan.

-uit de hand verkopen

Als er op de veiling geen bemiddelingsbureau aanwezig is, kunnen er zich ook gevallen voordoen waar verkoop zonder gebruik van de klok beter is. De veilingdirecteur neemt dan de rol van bemiddelaar op zich en kan deze verkopen regelen. Ook komt het voor dat kweker en handelaar, als overeenstemming over een verkoop wordt bereikt, dit melden bij hun veiling (voorbeelden van administratieve verkoop).

Het spreekt voor zich dat bij al deze verkoopmethoden, waarbij de veiling betrokken wordt, provisie moet worden betaald over het overeengekomen bedrag, net zoals bij de normale klokverkopen, zij het in mindere mate, afhankelijk van de overeengekomen diensten van de veiling.

- Visie, missie en (marketing)doelstellingen

- Een visie is een managementfilosofie (managementdenkbeelden) over hoe de externe omgeving zich de komende jaren ontwikkelt (de wereld, Europa, Nederland, het marktgebied en de concurrentie) en hoe de onderneming er in de toekomst uit zou moeten zien. Wat wil de onderneming in de toekomst bereiken? (Leeflang, 1993, p. 12).

- De missie omschrijft welke functies de onderneming in de huidige marktsituatie kan en wil vervullen (haar kernactiviteiten) en waarop ze haar bestaansgrond heeft (Verhage, 2004, p. 955). Concreet zijn dit de Product-Markt-Technologie-Combinaties (PMTC) die de onderneming in portefeuille heeft.

- (Marketing)doelstellingen zijn doelstellingen die zijn afgeleid van de ondernemingsdoelen en betrekking hebben op de eindresultaten van een te voeren (marketing)beleid zoals bijvoorbeeld een te behalen omzet of marktaandeel binnen een bepaalde vaste periode, meestal een of meerdere jaren. Zij moeten zoveel mogelijk SMART zijn, d.w.z. Specifiek, Meetbaar, Acceptabel, Realistisch en Tijdgebonden. 
Bijlage 3 - Meetmethoden horizontale en verticale concentratie

Meten van horizontale concentratie

Voor het meten van de horizontale concentratiegraad worden de twee meest gebruikte indices besproken te weten de absolute concentratiegraad $(C)$ en de relatieve concentratiegraad, de Herfindahl-Hirschmann-index(H) (De Jong, 1989, pp. 24-25).

$\mathrm{C}$ meet het aandeel dat de $\mathrm{K}$ grootste ondernemingen in een markt of bedrijfstak hebben:

$\mathrm{K}$

$\mathrm{C}=\sum_{i=1} \mathrm{P}_{\mathrm{i}}(\mathrm{i}=1, \ldots \ldots \mathrm{K}, \mathrm{K}+1, \mathrm{n})$.

Voor K worden als regel de 1, 2, 4, 8 of 12 grootste ondernemingen genomen. $\mathrm{C}$ is de som van de marktaandelen van het aantal grootste ondernemingen $(\mathrm{K})$ en $\mathrm{P}_{\mathrm{i}}$ is het marktaandeel van de i-de onderneming. Zodoende wordt de absolute concentratie gemeten. De relatieve concentratie vestigt de aandacht op de mate van ongelijkheid in grootte van de marktaandelen. De vraag is of de marktstructuur symmetrisch of asymmetrisch is opgebouwd. Dit is o.a. van belang voor de analyse van rivaliteit en samenwerking. De zwakte van de concentratiegraad als maatstaf vloeit enerzijds voort uit de verwaarlozing van het relatieve aspect, anderzijds zijn er bezwaren tegen de index zelf, te weten:

- de index geeft geen uitsluitsel over de verdelingen van de aandelen binnen de groep van de grootste ondernemingen

- de index zegt niets over de verdeling van de marktaandelen en het aantal van de (n-K) ondernemingen

- bij vergelijking tussen bedrijfstakken en in de tijd kunnen zich moeilijk interpreteerbare situaties voordoen: de $\mathrm{C}_{4}$ is bijvoorbeeld in bedrijfstak $\mathrm{A}$ groter dan in bedrijfstak $\mathrm{B}$, terwijl voor de $\mathrm{C}_{8}$ het omgekeerde geldt.

Omdat deze bezwaren de empirisch gevonden resultaten weinig lijken te beïnvloeden, wordt veel met de concentratiegraad gewerkt. De belangrijke voordelen van deze index zijn eenvoud en toepasbaarheid. De horizontale concentratiegraad is tevens een maatstaf voor de concurrentieintensiteit in een sector. De concurrentie-intensiteit wordt dan gedefinieerd als $1 /$ concentratiegraad.

In dit onderzoek wordt met deze index gewerkt bij het vergelijken van concentratie en concurrentie in de deelsectoren van de glastuinbouw. 
De Herfindahl-Hirschmann-index is de som van de gekwadrateerde marktaandelen $\left(\mathrm{P}_{\mathrm{i}}\right)$ van de $\mathrm{n}$ ondernemingen in de sector:

$$
\mathrm{H}=\sum_{\mathrm{i}=1}^{\mathrm{n}} \mathrm{P}_{\mathrm{i}}{ }^{2}
$$

De weging is volgens het relatieve marktaandeel. Bij monopolie is de index maximaal, d.w.z. $\mathrm{H}=1$, terwijl bij gelijke marktaandelen van alle ondernemingen de index een minimum bereikt: $\mathrm{H}=1 / \mathrm{n}$.

Een correcte omschrijving van de bedrijfstak is van groot belang. Hoe preciezer de definitie, hoe vlugger er sprake is van een gering aantal aanbieders met relatief grote marktaandelen.

\section{Voorbeeld 1}

In de deelsector glastomaten in Nederland in 2008 hebben de volgende verkooporganisaties een marktaandeel van achtereenvolgens 30\% (The Greenery), 25\% (FresQ), 10\% (VDN), 10\% $(\mathrm{ZON})$, de overige tien organisaties hebben met elkaar een marktaandeel 25\%. De absolute concentratiegraad van de vier grootste organisaties met het grootste marktaandeel $\left(\mathrm{C}_{4}\right)$ bedraagt dan $75 \%$. De concurrentie-intensiteit is $1 / \mathrm{C}_{4}=1,33$.

\section{Voorbeeld 2}

Stel dat in de deelsector glastomaten in Nederland vijf verkooporganisaties een marktaandeel hebben van ieder 20\%. De Herfindahl-Hirschman-index(HI) bestaat dan uit de som van de kwadraten van die percentages. De index bedraagt: $0,04+0,04+0,04+0,04+0,04=0,20$.

Indien de verdeling echter $50 \%, 25 \%, 10 \%, 10 \%$ en $5 \%$ is, is de uitkomst $0,25+0,0625+0,01$ $+0,01+0,0025=0,335$.

Hoe meer er sprake is van concentratie van de totale omzet bij enkele aanbieders, hoe hoger deze index is. Een verschil van mening over een ongewenste hoogte van de concentratie wordt vooral gevoerd in relatie tot de markt. Hoe nauwer een markt wordt gedefinieerd, hoe eerder een hoge graad van concentratie aanwezig is. De maximale score is 1 , die wordt bereikt bij de situatie dat er slechts één aanbieder is die 100\% van de markt bestrijkt. Bij een groot aantal aanbieders met ongeveer gelijke marktaandelen nadert deze index tot 0 . Bij deze wijze van berekenen wordt dus zowel rekening gehouden met het aantal aanbieders in een bedrijfstak als met de verschillen in marktaandeel.

\section{Meten van verticale concentratie}

De meting van verticale concentratie is niet zonder problemen. De meest bekende maatstaven betreffen de verhouding van de toegevoegde waarde tot de totale omzetten van een onderneming en de verhouding van voorraden tot verkopen (De Jong, 1989, p. 190). Hoe meer stadia van de bedrijfskolom via centralisatie van de beslissingsmacht aan elkaar worden gekoppeld, des te groter zal de verticale concentratie zijn. In verband met de vele moeilijkheden voor het hanteren van bruikbare indices voor het weergeven van verticale concentratie $(1989$, pp. 190,192) stelt 
De Jong voor een verhoudingsgetal hiervoor te gebruiken, het zogenaamde integratiegetal $\mathrm{V}_{\mathrm{i}}=$ $\mathrm{i}-1 / \mathrm{n}-1$ Hierin is $\mathrm{i}$ het aantal geïntegreerde stadia, $\mathrm{n}$ het aantal mogelijk te integreren stadia. Het integratiegetal varieert tussen de waarden 0 en 1 en wordt groter met toenemende integratie. Hiermee kan men vergelijkingen maken tussen ondernemingen in vrij homogene bedrijfstakken of subbedrijfstakken.

Bijvoorbeeld bij een bedrijfskolom van 5 stadia en 2 geïntegreerde stadia is de uitkomst $1 / 4$ en bij 3 geïntegreerde stadia $1 / 2$. De voornaamste problemen zijn het afbakenen van de productiestadia en de selectie van de productieketen. Hiermee kan men vergelijkingen maken tussen ondernemingen in vrij homogene bedrijfstakken of subbedrijfstakken.

\section{Voorbeeld 1:}

We gaan uit van een bedrijfskolom van 7 stadia en 3 of 2 te integreren bedrijfstakken (zie figuur 2.1). Het integratiegetal van de bedrijfskolom glasgroenten bedraagt volgens bovenstaande formule 2/6 =0,33 (integratie van kweker, veiling en groothandel). Dat van de bedrijfskolom glassnijbloemen en -potplanten 1/6 = 0,16 (integratie van kweker en veiling). De Jong hanteert ook het begrip integratiegraad (De Jong, 1989, p. 193). Deze graad meet niet de geïntegreerde stadia in de keten, maar de mate waarin een onderneming bij integratie in voorwaartse en achterwaartse zin de markt uitschakelt. De formule hiervoor luidt: $\mathrm{VI}_{2}=\mathrm{t} / \mathrm{s}+\mathrm{t}$, waarin $\mathrm{t}$ staat voor transacties via de eigen nieuwe ondernemingsafdeling en s voor de via de markt afgewikkelde kopen en verkopen. Dit kengetal geeft een maatstaf voor de mate van volledigheid van de integratie en schommelt evenals het integratiegetal tussen 0 en 1 .

\section{Voorbeeld 2:}

VTN/The Greenery is een verticaal geïntegreerde afzetorganisatie met de Van Dijk Delft Groep en de Fresh Produce Divisie van Perkins Foods plc. In de bedrijfskolom glasgroenten verkocht zij in 2008 gemiddeld 50\% of meer van deze groenten van eigen telers rechtstreeks aan de detailhandel en schakelde daarmee ca. 50\% of meer van de groothandels- en exportmarkt uit. Dit geeft een verticale integratiewaarde (VI-waarde) van tenminste $50 \%(0.5 / 0.5+0.5)$. 
Bijlage 4 - Te onderzoeken structurele en strategische elementen uit figuur 1.1

Elementen marktstructuur sectoren glastuinbouw

1. Aanbod sectoren glastuinbouw (kenmerken en ontwikkeling)

a. aantal, soort en omvang ondernemingen (4 bedrijfstypen)

b. productsoort, productgroepen, product items(homogeen/heterogeen)

c. productietechnologie

d. productiecapaciteit en investeringen

e. vestigingsplaats/regio

f. opbrengsten, kosten, brutomarge, prijzen per eenheid per productsoort en bedrijfstype

g. groeivoet

h. concentratiegraad ondernemingen per sector en per verkooporganisatie

i. verkoop- en afzetmethode

2. Vraag binnen- en buitenlandse markten (kenmerken en ontwikkeling)

a. aantal, soort en omvang ondernemingen (groothandel, exporteurs, detailhandel)

b. productsoort, productgroepen, product items(homogeen/heterogeen)

c. logistieke technologie

d. productiecapaciteit en investeringen

e. geografische, demografische en sociaal-economische factoren

f. opbrengsten, kosten, brutomarge, prijzen per eenheid per productsoort

g. groeivoet

h. concentratiegraad ondernemingen (groothandel, exporteurs, detailhandel)

i. prijs- en margevorming in de bedrijfskolom (teler, afzetorganisatie, groothandel/exporteur, detailhandel)

3. Dreiging toe- en uittreding sectoren glastuinbouw

a. hoogte toetredingsdrempels (investeringen, prijsconcurrentie, technologie)

b. openheid sectoren (vrije toe- en uittreding)

c. transparantie prijsvorming sectoren/markten

d. overheidsbeleid (EU, landelijk en regionaal)

4. Dreiging substitutie sectoren glastuinbouw

a. andere verse producten uit de voedingstuinbouw en de siertuinbouw(glas en volle grond) in Nederland

b. idem geïmporteerd uit landen binnen en buiten de EU

Elementen marktstrategie sectoren glastuinbouw

5. Samenwerking bedrijven

a. streven naar horizontale concentratie productie- of handelsbedrijven (fusie of overname)

b. idem inkoop- of afzetorganisaties (fusie of overname ) 
c. streven naar verticale concentratie(fusie of overname productie- en/of handelsbedrijven v.v.)

d. streven naar horizontale of verticale samenwerking van productie- en handelsbedrijven op contractbasis (een- of meerjarig)

6. Strategisch gedrag bedrijven

a. product- en procesbeleid (assortimentskeuze, product- en procesontwikkeling, innovaties)

b. marketing- en verkoopbeleid (klokverkoop vs. bemiddeling vs. eigen verkoop)

c. interne en externe logistiek (en de mogelijkheden en consequenties van voorwaartse verticale integratie)

7. Machtspositie van de leverancier

a. aanwezigheid inkoopstrategie via inkoopcoöperatie of telersvereniging (countervailing power)

b. verschillen in belang van input: energie, kas, plantmateriaal, meststoffen en gewasbeschermingsmiddelen

c. concentratiegraad leveranciers

d. bedreiging door leverancier van voorwaartse verticale integratie

e. belang, omvang en frequentie van de leveranties

8. Machtspositie van de koper

a. aanwezigheid verkoopstrategie via verkoopcoöperatie of telersvereniging (countervailing power)

b. het belang en de uniekheid van de leverantie voor de koper

c. concentratiegraad onder leveranciers en kopers

d. bedreiging door koper van achterwaartse verticale integratie

e. de aanwezigheid van extra dienstbetoon door de leverancier aan de koper via service providing 
Bijlage 5 - Invulling conceptueel model in de sector glasgroenten en glassierteelt

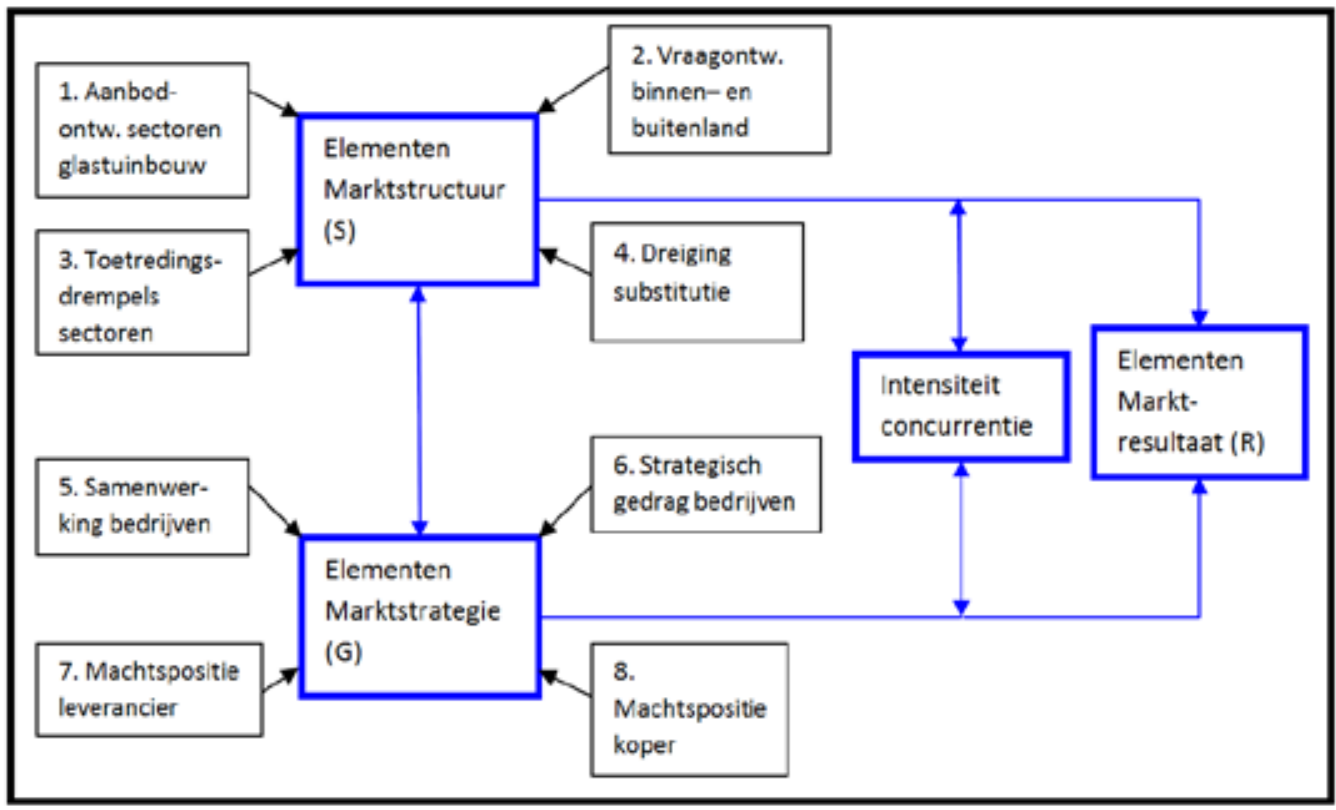

Figuur 1.1 Conceptueel model: concurrentie, concentratie en rentabiliteit sectoren glastuinbouw in Nederland

\section{Sector glasgroenten}

1.1 Toelichting marktstructuur sector glasgroenten (2013-2014)

- Box 1 en 2:

De vraag- en aanbodontwikkeling van Nederlandse glasgroenten verloopt de laatste jaren weinig gecoördineerd en kent jaarrond flinke perioden van overcapaciteit en overschotten in productie en afzet. Het (veiling)verkoopsysteem van verse glasgroenten in de sector is grotendeels vervangen door bemiddeling en persoonlijke verkoop. Het aantal telers is van 2006 tot 2014 gehalveerd tot ongeveer 1000 bedrijven met een lage horizontale concentratie onder producenten. Uitgaande van een stabilisering van de sectoromzet op $1.5 \mathrm{mrd}$. euro en een bedrijfsoptimum van $2.5 \mathrm{mln}$. euro omzet lijkt er op termijn ruimte voor ongeveer 600 glasgroentetelers.

De machtsverhoudingen van de vier grootste afzetorganisaties en tien grootste kopers van glasgroenten op groothandelsniveau lopen niet ver uiteen. Het aantal afzetorganisaties inclusief de GMO-erkende telersverenigingen ligt op ongeveer 15 met een horizontale concentratiegraad (C4) van 60\%. Het aantal groothandelaren inclusief export/import bedraagt ruim 1000 met een horizontale concentratie (C10) van 65\%.

Een groot deel van de handelsactiviteiten verschuift echter naar Europese detailhandelsmarkten 
waar het zeer geconcentreerde Europese grootwinkelbedrijf de inkoopvoorwaarden stelt en de marktmacht in handen heeft.

De productiewaarde ligt op een niveau van ongeveer $1.4 \mathrm{mrd}$. euro en de exportwaarde incl. re-export van groenten en fruit op $3.8 \mathrm{mrd}$. euro. De markt toont tekenen van verzadiging en de glasgroentesector bevindt zich volgens het SGR-model van De Jong (zie tabel 2.4, p. 40) in de rijpheids- en teruggangsfase.

\section{- Box 3:}

Toetredingsdrempels in de sector glasgroenten zijn hoog. Toetreding vergt hoge bedrijfsinvesteringen en eventueel expliciete toestemming van de verticaal geïntegreerde afzetorganisatie. De productsoorten betreffen voornamelijk vruchtgroenten (tomaat, paprika en komkommer) en de productdifferentiatie is niet groot. De kans op succes met winstresultaat is onzeker en hangt vooral af van de uniekheid van het te telen product en het ondernemerschap van de teler. Nieuwe zelfstandige bedrijven kiezen veelal voor extra bedrijfsomvang met een eigen verkoopapparaat. De toetredingsdrang en de concurrentiedruk zullen hierdoor in de sector glasgroenten enigszins lager zijn dan in de sectoren glassnijbloemen en -potplanten waar de benodigde bedrijfsomvang kleiner is en toetreding tot de afzetorganisatie gemakkelijker is te realiseren.

- Box 4:

Dreiging van substitutie van de Nederlandse glasgroenten betreft vooral de geïmporteerde (glas) groenten. De waarde hiervan betreft voornamelijk de geïmporteerde vruchtgroenten uit ZuidEuropese lidstaten, Turkije en Marokko en bedraagt ongeveer $1 \mathrm{mrd}$. euro op jaarbasis waarvan bijna $90 \%$ is bestemd voor re-export.

\subsection{Toelichting marktgedrag sector glasgroenten}

\section{- Box 5 en 6:}

De onderlinge samenwerking in de sector tussen zelfstandige producenten, afzetorganisaties en telersverenigingen beperkt zich tot de noodzakelijke contacten en gaat niet altijd van harte. Het strategisch gedrag is vooral gericht op de wensen van de Europese grootwinkelbedrijven. Een recent artikel van Jeroen Verheul in het Vakblad Groenten \& fruit begint met de volgende aanhef: 'In de afzetketen voor groenten en fruit bewegen partijen veel, maar niet naar elkaar toe. Meerdere strategieën naast elkaar in Nederland houden echte samenwerking tegen. Vernieuwingen zijn er vooral in België en Venlo, weliswaar met de oude veilklok.' (Vakblad nr.15, 25 juli 2014, pp. 6-8). Hij geeft hierin aan dat bij de acht belangrijkste afzetorganisaties in de glasgroenten het commerciële proces bij een ieder verschillend is geregeld. Dit houdt de mogelijkheden van meer samenwerking en mogelijke horizontale fusies tegen.

\section{- Box 7 en 8:}

In de glasgroenten hebben de zaad- en veredelingsbedrijven als leveranciers van de nieuwste rassen vaak (veel) meer marktmacht dan hun afnemers, de relatief kleine glasgroentetelers. Door 
gezamenlijke inkoop via telersvereniging of afzetorganisatie wordt getracht hier inkoopmacht tegenover te stellen. Ook bij de levering van gas en stroom is de machtsverhouding in het voordeel van de grote energiebedrijven. Bij de overige toeleveranciers van tuinbouwbenodigdheden is de marktmacht evenwichtiger verdeeld.

Een groot deel van de handel is verschoven naar detailhandelsniveau. Aan koperszijde is in de glasgroenten de toenemende inkoopmacht van het Europese grootwinkelbedrijf in het oog springend. In de ons omringende grote landen als Duitsland, Engeland, Frankrijk e.a. kent dit type bedrijf een hoge horizontale concentratie en een sterke positie op de consumentenmarkt voor groenten en fruit.

\subsection{Concurrentie-intensiteit en marktresultaat sector glasgroenten}

Er is sprake van een toename van de concurrentie-intensiteit in de glasgroenten wat het sectorresultaat onder druk zet. De concurrentie verschuift gedeeltelijk van Nederlandse en Europese groothandelsmarkten naar detailhandelsmarkten en verscherpt aanzienlijk door het verschil in marktmacht tussen toeleverende telers en hun afzetorganisaties en het steeds geconcentreerder inkopende grootwinkelbedrijf. Andere oorzaken van de toenemende concurrentie en verminderde resultaten zijn verzadigingsverschijnselen in de bedrijfstak, periodieke overcapaciteit en verschillen in (prijs)beleid tussen concurrenten.

\section{Sector glassierteelt (snijbloemen en potplanten)}

\subsection{Toelichting marktstructuur sector glassierteelt (2013-2014)}

\section{- Box 1 en 2:}

De vraag- en aanbodontwikkeling van snijbloemen en potplanten verloopt bij de Nederlandse bloemenveilingen tot op heden tamelijk evenwichtig. De prijsvorming vindt voor de meeste producten op een optimale manier plaats en verloopt via een transparant proces tegen scherpe verkooptarieven van de veiling. Van de meeste productgroepen, zowel bij de snijbloemen als de potplanten en tuinplanten wordt het grootste gedeelte $(>50 \%)$ via de klok geveild en er is dagelijks een betrouwbare referentieprijs voor bemiddelingstransacties en persoonlijke verkoop. Een en ander zorgt voor een goede match van aanbod en vraag en een schone markt.

Het aantal snijbloementelers is van 2006 tot 2014 gehalveerd tot 1300 bedrijven en het aantal potplantentelers ligt op ongeveer 800 (daling 20\%). De horizontale concentratie onder producenten ligt op een laag niveau. Uitgaande van een stabilisering van de sectoromzet snijbloemen op $2.2 \mathrm{mrd}$. euro en een bedrijfsoptimum van $2.6 \mathrm{mln}$. euro omzet is er op termijn ruimte voor ongeveer 850 glassnijbloemenbedrijven. De sectoromzet potplanten groeit jaarlijks nog met een aantal procenten. Uitgaande van een bedrijfsoptimum van $5.0 \mathrm{mln}$. euro en een sectoromzet van $2.0-2.5 \mathrm{mrd}$. euro is hier ruimte voor 400 tot 500 bedrijven. De horizontale concentratie van de twee afzetorganisaties ligt op bijna 100\%, met marktaandelen van 98\% voor FloraHolland en 2\% voor Plantion.

De horizontale concentratie van de acht grootste kopers van glassnijbloemen en -potplanten is ongeveer $60 \%$. Het aantal groothandelaren gespecialiseerd in het vervoer van snijbloemen inclusief 
export/import bedraagt ongeveer 700, in potplanten zijn dit er ongeveer 300. De productiewaarde glassnijbloemen en -potplanten ligt de laatste jaren op een niveau van $2.0-2.2$ mrd. euro en de exportwaarde incl. re-export op 3.2 resp. $2.0 \mathrm{mrd}$. euro. De markt voor snijbloemen toont tekenen van verzadiging, die van potplanten groeit jaarlijks nog met een aantal procenten. De sector glassnijbloemen bevindt zich volgens het SGR-model van De Jong in de rijpheids- en teruggangsfase, de sector glaspotplanten bevindt zich in de gevorderde groeifase (zie tabel 2.4, p. 40).

\section{- Box 3:}

In de sectoren glassnijbloemen en -potplanten zijn toetredingsdrempels tamelijk hoog in de vorm van flinke bedrijfsinvesteringen. Er is een ruime productkeuze mogelijk uit het assortiment snijbloemen of potplanten met een grote differentiatie. De kans op succes met winstresultaat is onzeker en hangt af van de uniekheid van het te telen product en het ondernemerschap van de teler.

\section{- Box 4:}

Dreiging van substitutie van de Nederlandse glassnijbloemen en -potplanten betreft voornamelijk de import. Bij snijbloemen zijn het vooral rozen uit Afrika (Kenia en Ethiopië) en ZuidAmerika (Ecuador en Colombia) en chrysanten uit Brazilië en Italië. Pot- en tuinplanten komen meer uit Europese landen als België, Duitsland, Frankrijk, Italië en Spanje (zie H4, p.89).

\subsection{Toelichting marktgedrag sector glassierteelt}

\section{- Box 5 en 6:}

De samenwerking in de sierteeltsectoren tussen producenten, afzetorganisaties en telersverenigingen verloopt naar tevredenheid van de meeste leden. Ook de samenwerking met de groothandel/export en de grotere ketens in de detailhandel op Europese markten verloopt goed en is niet bedreigend voor de Nederlandse groothandel/ export. Het strategisch gedrag is gericht op de wensen van de groothandelaren/exporteurs en de Europese detailhandel. Hieronder vallen bloemenspeciaalzaken, tuincentra, cash\&carry's, markten, bouwmarkten en grootwinkelbedrijven.

\section{- Box 7 en 8:}

Bij de snijbloemen en potplanten zijn het de leveranciers van uniek plantmateriaal die een sterkere positie hebben dan hun afnemers, de kleinere glassnijbloemen- en potplantentelers. In deze sectoren wordt getracht meer inkoopmacht te organiseren via telersvereniging of afzetorganisatie. Leveranciers van energie hebben eveneens sterkere posities en de meeste marktmacht. Bij de leveranciers van machines, materialen en grondstoffen is de marktmacht tussen leverancier en glastuinder evenwichtiger verdeeld.

De verdeling van de marktmacht tussen afzetorganisatie en groothandelaar/exporteur gaat gelijk op. De positie van het Europese grootwinkelbedrijf is groeiende, maar tot op heden hebben in de meeste landen de bloemist, het tuincentrum, de bouwmarkt en de (streek)markt een vergelijkbare of sterkere positie. 


\subsection{Concurrentie-intensiteit en marktresultaat sectoren glassnijbloemen en -potplanten}

De verhoging van de concurrentie-intensiteit in de sector snijbloemen wordt vooral veroorzaakt door een toename van de import van rozen en chrysanten. Het areaal van deze twee grootste productgroepen in Nederland is vanaf 2000 met zo'n 30 - 40\% gedaald. De import wordt mede gestimuleerd door overheden en Nederlandse bedrijven in het kader van ontwikkelingssamenwerking en een jaarrond aanbod van snijbloemen. Andere oorzaken van de toenemende concurrentie zijn verzadigingsverschijnselen in de markt voor snijbloemen en het gedaalde consumentenvertrouwen, vooral bij de Zuid-Europese lidstaten. Positiever zijn de marktontwikkelingen bij de glaspotplanten. Deze sector neemt nog steeds toe in productie- en exportwaarde en is inmiddels even groot als de sector glassnijbloemen. Beide sectoren beschikken over een grote differentiatie in productgroepen en tonen op de vrije en open Europese groothandelsmarkten een evenwichtige marktontwikkeling van aanbod en vraag met redelijke resultaten. 


\section{Samenvatting}

\section{Inleiding}

De uitbreiding van het marktgebied van de Europese Unie heeft gezorgd voor een forse toename van aanbod van en vraag naar verse glastuinbouwproducten op de Europese markt. Het gevolg is ook een toename van de concurrentie met goedkoper producerende bedrijven uit de nieuwe lidstaten en veranderingen in de productie- en afzetstructuur van de bedrijven. In de glasgroenten leidde dit tot een grootschalige horizontale en verticale fusie tussen de meeste groente- en fruitveilingen in Nederland en een aantal grote exporteurs. VTN/The Greenery werd in 1996-1998 van een coöperatieve veilingorganisatie een handelscoöperatie. In de glassierteelt (snijbloemen en potplanten) vonden alleen horizontale fusies plaats tussen coöperatieve veilingen en bleef de groothandel/export zelfstandig. Momenteel zijn er nog twee bloemenveilingen over: FloraHolland in Aalsmeer/Naaldwijk (marktaandeel 98\%) en Plantion in Ede (2\%).

\section{Centrale onderzoeksvraag}

Dit proefschrift richt zich op de ontwikkeling van marktstructuur, marktstrategie en marktresultaat in de glastuinbouw in Nederland over de afgelopen 35 jaar. De centrale onderzoeksvraag luidt of het verschil in marktstructuur en marktgedrag in de glasgroenten en de glassierteelt een significante oorzaak is om het verschil in marktresultaat (brutomarge) voor de leden/bedrijven en hun afzetorganisaties te verklaren.

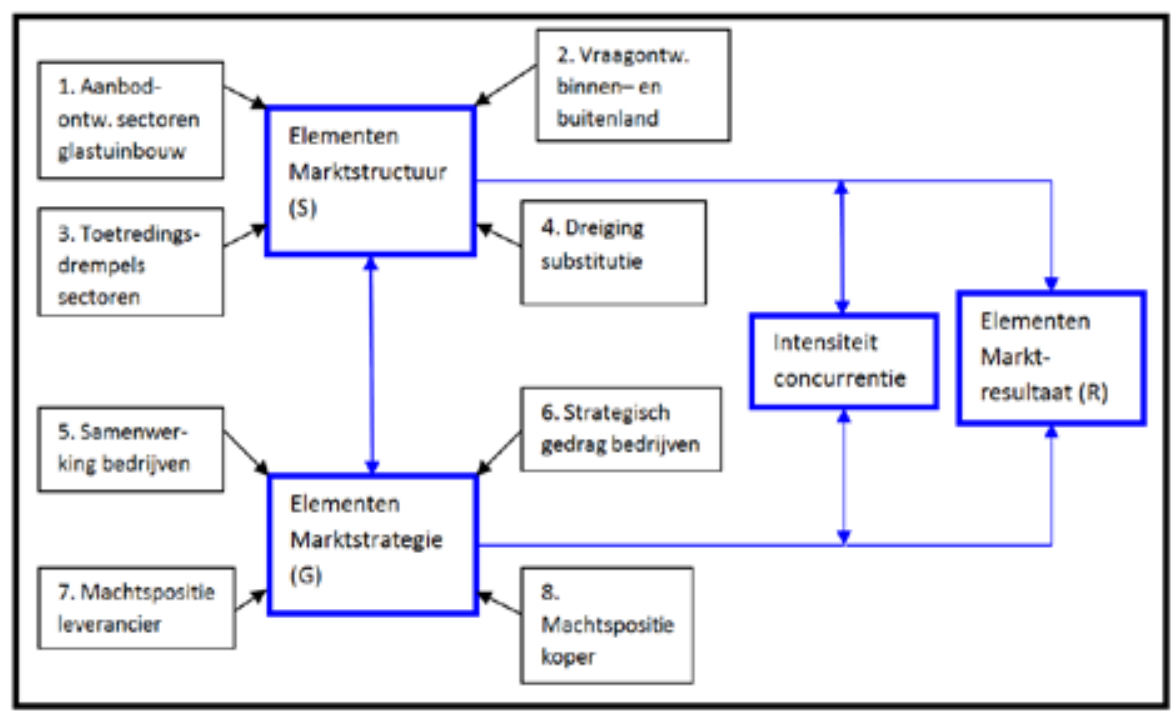

Figuur 1.1 Conceptueel model: concurrentie, concentratie en rentabiliteit sectoren glastuinbouw in Nederland 
Het conceptueel model

In de literatuur is een aantal theorieën en modellen bestudeerd uit de leer van de externe organisatie, Industrial Organisation theorie. Hierin staat de analyse van bedrijfstakken, bedrijfskolom en bijbehorende markten centraal en wordt het verband tussen marktstructuur (S), marktgedrag (G) en marktresultaat (R) nader onderzocht. Toegelicht zijn het statisch SGR-model van Bain, het dynamisch SGR-model van De Jong en de analysemodellen van Porter en Daems. Hieruit is het conceptueel model van concurrentie, concentratie en rentabiliteit voortgekomen voor de analyse van de sectoren in de glastuinbouw (figuur 1.1).

Bedrijfsonderzoek, sectoronderzoek en onderzoek afzetorganisaties

Tussen 2006 en 2008 is een drietal bedrijfsonderzoeken uitgevoerd onder producenten in de glasgroenten, glassnijbloemen en glaspotplanten. Hierbij zijn jaarlijks ruim veertig glastuinders geïnterviewd. Gegevens van bedrijven en meningen van glastuinders betreffende structuur, gedrag en resultaat op bedrijfsniveau zijn geïnventariseerd. Gelijktijdig vond een onderzoek plaats naar de ontwikkeling van de productie en afzet op sectorniveau en het niveau van de belangrijkste afzetorganisaties en de groothandel/export. Deze gegevens zijn geanalyseerd, op geselecteerde variabelen getoetst en voorzien van voorlopige conclusies. De belangrijkste bedrijfs- en marktkarakteristieken en de gerealiseerde onderzoeksresultaten zijn in een aantal bij de betreffende hoofdstukken behorende tabellen en appendices weergegeven. Het bedrijfsonderzoek is in 2015/2016, op basis van de data uit 2006-2008, uitgebreid met een econometrisch onderzoek en een meervoudige analyse van een aantal van de belangrijkste structuur- en gedragsvariabelen ter verklaring van de behaalde resultaten (brutomarge).

Onderzoeksresultaten sectoren

De drie sectoren glastuinbouw tonen over een periode van 35 jaar, behoudens een kleine terugval in 2009 en 2011, door krediet- en EHEC-crisis, een positieve ontwikkeling in productie- en exportwaarde. Door een sterkere groei van de potplanten toont de siertuinbouw gemiddeld hogere

Ontwikkeling resultaatsvariabelen sectoren glastuinbouw van 1980-2016

\begin{tabular}{|c|c|c|c|}
\hline \multirow{2}{*}{\multicolumn{4}{|c|}{\begin{tabular}{|l} 
Soort variabele \\
Resultaatsvariabelen sectoren
\end{tabular}}} \\
\hline & & & \\
\hline $\begin{array}{lc}\text {-Productiewaarde } & (\mathrm{x} \in 1 \mathrm{mld}) \\
\text { Periode } & 1980-2005 \\
\text { Idem } & 2006-2010 \\
\text { Idem } & 2011-2016 \\
& \\
& \\
\text {-Binnenlands } & \text { aandeel } 2006-2010\end{array}$ & $\begin{array}{l}0.7-1.2 ; \text { groeifactor } 1.7 \\
1.3-1.5 \\
1.2-1.4 \\
82 \%-94 \%\end{array}$ & $\begin{array}{l}0.8-2.2 ; \text { groeifactor } 2.8 \\
2.3-2.1 \\
2.0-2.2 \\
77 \%-75 \%\end{array}$ & $\begin{array}{l}0.2-1.5 ; \text { groeifactor } 7 \\
1.6-2.0 \\
2.0-2.0 \\
84 \%-86 \%\end{array}$ \\
\hline $\begin{array}{lc}\text {-Exportwaarde } & (\mathrm{x} \in 1 \mathrm{mld}) \\
\text { Periode } & 1980-2005 \\
\text { Idem } & 2006-2010 \\
\text { Idem } & 2011-2016 \\
& \\
\text {-Exportaandeel } & 2006-2010\end{array}$ & $\begin{array}{l}0.9-3.9 ; \text { groeifactor } 4 \\
3.4-3.9 \\
3.8-4.4 \\
68 \%-72 \%\end{array}$ & $\begin{array}{l}0.7-3.1 \text {; groeifactor } 4.5 \\
3.2-3.2 \\
3.5-3.5 \\
88 \%-91 \%\end{array}$ & $\begin{array}{l}0.2-1.7 ; \text { groeifactor } 8 \\
1.8-2.0 \\
2.0-2.2 \\
73 \%-68 \%\end{array}$ \\
\hline
\end{tabular}


groeicijfers dan de voedingstuinbouw. De productie- en exportwaarde weet tot aan de kredietcrisis in 2009 een steeds hoger niveau te bereiken. De sector glassnijbloemen laat weliswaar een daling zien van het areaal en de productie in Nederland, maar die wordt, naast een toename van de overige import, opgevangen door een rechtstreekse aanvoer van vooral rozen en chrysanten vanuit subSahara Afrika.

Alle sectoren profiteren van de groeiende import-/re-exportfunctie van groente en fruit, snijbloemen en potplanten vanuit Nederland naar de aangrenzende landen en handelspartners in Europa. Het hoge aandeel van de sectorvariabelen binnenlands aandeel en exportaandeel, zowel in glasgroenten, -snijbloemen en -potplanten, werkt stimulerend op de ontwikkeling van productiewaarde, exportwaarde en prijzen.

\section{Onderzoeksresultaten afzetorganisaties}

In de voedings- en siertuinbouw lopen marktgedrag en marktstructuur sinds 1998 flink uiteen. In de glasgroenten is de concentratiegraad van de vier grootste afzetorganisaties (C4) gedaald tot $60 \%$ en op het niveau van voor de fusie terechtgekomen. In 1997 stond deze C4 op 96\%. Ook is het aandeel van telers van VTN/The Greenery in het areaal Nederlandse glasgroenten afgenomen. VTN/The Greenery heeft met haar strategie van horizontale en verticale concentratie niet bereikt wat haar in 1996 voor ogen stond: een grotere horizontale en verticale bundeling van de afzet van de Nederlandse veilingen en groothandels-/exportbedrijven. De zoektocht naar een juiste integratie van productie en handel met een efficiënte en effectieve structuur is niet ten einde en recent weer ter hand genomen met een nieuwe verkooporganisatie. De financiële positie van Coforta(VTN)/The Greenery op de Europese markt van verse groenten, fruit en paddenstoelen is nog steeds niet sterk. Vanaf 1996 is er een jaarlijks fluctuerende omzet tussen de 0.9 en 1.5 mld. euro met een variatiemogelijkheid van 25 tot $30 \%$. De aanvoer van producten van eigen leden/bedrijven en de ontvangen provisie-inkomsten zijn meer dan gehalveerd. De positie op de Nederlandse markt is stabiel, op de belangrijkste Europese markten lastig. Het rendement op het totale vermogen ligt laag. In 2015 en 2016 doet zich na de crisisjaren 2009, 2011 en 2013 een voorzichtig herstel voor.

Bloemenveilingen FloraHolland en VBA tonen in de aanloop naar en tijdens de fusie 2007-2008 een duidelijke strategie met positieve resultaten. Zij geven een voorbeeld van een zorgvuldig uitgevoerde strategie van horizontale concentratie en bundeling van belangen van de bloemenveilingen en hun leden. Voor FloraHolland is de crisisperiode 2009-2011 een testcase waar ze goed doorheen komt. Op het gebied van horizontale concentratie over de grenzen zijn er uitbreidingen: een nieuwe joint venture, Veiling Rhein-Maas, opgericht samen met het Duitse Landgard, en een integratie in 2009-2010 van de importveiling TFA. Beide zijn een aanwinst voor de marktplaats. Voor zover er verticaal beleid wordt ontwikkeld gericht op de internationale retail, werkt FloraHolland samen met de exporteur zonder bedreiging van integratie of uitschakeling. FloraHolland hanteert als belangrijkste dagelijkse verkoopmethode voor sierteeltproducten het klokveilen, fysiek en digitaal. Zowel bij snijbloemen als pot- en tuinplanten wordt een groot deel 
van de productgroepen via de klok geveild en wordt tevens getracht tot een betrouwbare referentieprijs voor bemiddeling en persoonlijke verkoop te komen. Aandacht voor het versterken van de klokpositie, vooral bij de verkoop van potplanten, is belangrijk. De veilingomzet van FloraHolland daalt in 2009, jaar van de kredietcrisis, met ongeveer 5\% en komt in 2010 en 2011 net boven het niveau van 2008 uit. De inkomsten uit diensten van FloraHolland dalen. Er vindt echter een grotere daling van de kosten dan van de opbrengsten plaats en het rendement en de solvabiliteit verbeteren in deze periode toch. In 2012 realiseert FloraHolland een hogere productomzet dan in 2011, de jaarinkomsten dalen echter. In 2013 presteert de sierteeltsector redelijk, de productomzet van FloraHolland stijgt licht, maar de kosten zijn hoger dan de inkomsten en FloraHolland lijdt een exploitatieverlies. 2014 is een jaar van licht herstel, 2015 en 2016 sluiten af met een toename van de productomzet van 3 en $4 \%$. De winst na belasting bedraagt in deze jaren 12 en 3 mln. euro. Voor de meeste kwekers en klanten zijn 2015 en 2016 positief verlopen jaren. Het feit dat de handel heeft besloten weer bij te dragen aan de promotie van bloemen en planten door Bloemenbureau Holland wordt zeer positief ontvangen. In het kader van de nieuwe strategie FloraHolland 2020 wordt gewerkt aan versterking en vergroting van de fysieke en digitale marktplaatsen.

Resultaten producenten glastuinbouw

Op individueel bedrijfsniveau lopen de waargenomen resultaten eveneens uiteen en vindt er tussen glastuinders momenteel een ware veldslag plaats om te overleven. Hierbij lijkt het kleine bedrijf in de glassnijbloemen en -potplanten betere papieren te hebben dan dat in de glasgroenten. De belangrijkste verbanden tussen structuur, gedrag en resultaat in de sectoren worden hieronder vermeld.

- Meest opvallende enkelvoudige verbanden glasgroenten

- Door de relatief hoge verkoop- en logistieke kosten is het kleine bedrijf duurder uit dan de grotere bedrijfstypen. Als de afzetorganisatie daarnaast het principe van kostenmaker = kostendrager toepast, zijn deze bedrijven nog meer in het nadeel.

- Veilingtelers leveren voornamelijk de ronde of trostomaat, zelfstandige telers kiezen in meerderheid de speciale soorten tomaat. Dit beïnvloedt de prijsvorming.

- Kleine en grote veilingtelers verschillen betekenisvol in bedrijfsomvang met zelfstandige telers, maar behalen vergelijkbare brutomarges. Productie op grotere schaal leidt niet altijd tot een verlaging van de gemiddelde kosten en een verbetering van de brutomarge. Het geeft wel een groter risico op overaanbod dat niet tegen redelijke prijzen kan worden verkocht. Grote bedrijven kennen in slechte jaren vaak grotere financiële problemen dan kleine bedrijven.

- De horizontale concentratie onder groentetelers ligt op een laag niveau en hun verkoopmacht is gering. De vier grootste afzetorganisaties hebben een concentratiegraad van ongeveer $60 \%$.

- De verticaal geïntegreerde veilingtelers zijn kleiner van omvang en investeren minder dan niet-geïntegreerde telers. Zij realiseren vergelijkbare brutomarges. De betekenis van de afzetorganisaties voor het realiseren van goede prijzen en voldoende rendement voor de aangesloten leden is betrekkelijk gering. Het belang van scherpe inkoopprijzen voor de eigen 
handelsorganisatie beïnvloedt de brutomarge van de leden.

- Hogere investeringen van bedrijven blijken niet (direct) tot hogere resultaten te leiden.

- Meest opvallende enkelvoudige verbanden glassnijbloemen

- De kleine veilingteler in de snijbloemen realiseert een verwachte lagere omzet en betaalt een hogere provisie dan de grotere veilingteler, lid van een telersvereniging. Hoewel er geen betekenisvol verband is tussen bedrijfstype en gerealiseerde brutomarge kan de hogere veilingprovisie leiden tot hogere prijzen en een hogere brutomarge. Behalve het hogere prijsniveau realiseren de kleinere telers een hoger vermogensresultaat dan de grotere.

- Rozenbedrijven realiseren een hogere brutomarge dan de chrysantenbedrijven door het bredere en diepere assortiment van de roos.

- Het verband tussen bedrijfsoppervlakte en behaalde resultaten laat zien dat kleinere snijbloementelers dezelfde of betere resultaten behalen dan de grotere.

- Horizontale concentratie onder de snijbloementelers ligt evenals bij de groente- en potplantentelers op een laag niveau. De kleine veilingteler heeft weinig verkoopmacht en heeft de afzetorganisatie nodig voor een goede prijsvorming en succesvolle verkoop.

- Er zijn geen betekenisvolle verbanden tussen de organisatie van de afzet en de omzet, de gerealiseerde brutomarge en de hoogte van de veilingprovisie. Het lijkt erop dat elk bedrijf zijn verkoopinstrumenten zodanig inzet dat geen significante resultaatsverschillen ontstaan. Het verkopen van snijbloemen via de veilingklok levert goede resultaten op.

- Meest opvallende enkelvoudige verbanden glaspotplanten

- De kleinere veilingteler, met of zonder eigen verkoop, realiseert een verwachte lagere omzet, maar een hogere brutomarge dan de grotere veilingteler, lid van de telersvereniging.

- Kleinere bedrijven behalen hogere of vergelijkbare resultaten ten opzichte van de grotere. Oude en nieuwe bedrijven behalen vergelijkbare brutomarges.

- Telers van groene planten behalen een betekenisvolle lagere jaaromzet dan telers van bloeiende potplanten. Groene planten zijn wel vaak unieker dan bloeiende planten waardoor telers hogere prijzen en een hogere brutomarge behalen.

- De horizontale concentratie onder potplantentelers ligt evenals bij de snijbloementelers op een laag niveau. Vooral kleinere telers kunnen de afzetorganisatie goed gebruiken voor een goede prijsvorming en succesvolle verkoop.

- Evenals in de andere sectoren blijken hogere investeringen van bedrijven niet (direct) tot hogere resultaten te leiden en zijn er meer innovatieve investeringen nodig die prijzen verhogen en brutomarge verbeteren.

- Er is een betekenisvol verband tussen verkoopwijze en de gerealiseerde jaaromzet: grotere potplantenbedrijven zetten naast de verkoopdiensten van de veiling meer eigen verkoop in, in eigen dienst of in dienst van de telersvereniging.

- Uitbesteden van de gehele verkoop aan FloraHolland is vooral voor de kleine teler effectief en vergroot de kans op het behalen van een hogere brutomarge. Hij betaalt een hoge provisie, maar behaalt door het positieve verband van provisie en marge een hogere brutomarge. 
Resultaten econometrisch onderzoek producenten glastuinbouw

- Meest opvallende meervoudige verbanden glasgroenten

De uitkomsten van de econometrische analyse laten ons zien dat in de glasgroentesector deelname aan een telersvereniging gemiddeld betere resultaten oplevert dan deelname aan een traditionele marketingcoöperatie. Het zijn vooral de jonge ondernemers met nieuwe ideeën over bedrijfsorganisatie en verticale samenwerking die met gemiddeld grote en moderne bedrijven de beste resultaten boeken.

- Meest opvallende meervoudige verbanden glassnijbloemen

Veilingtelers die exclusief via de bloemenveiling hun producten veilen, realiseren gemiddeld een hogere brutomarge dan telers die naast veilen ook andere verkoopmethoden gebruiken. Hierbij levert deelname aan een telersvereniging gemiddeld betere resultaten op dan niet-deelname en behalen kleine bedrijven hogere brutomarges dan grote. Oudere ondernemers presteren beter dan jonge. De klok van de bloemenveiling is de beste garantie voor hogere brutomarges. Het blijkt in de snijbloemensector dat schaalvergroting van de productie minder effect heeft op de brutomarge dan het produceren van 'niche' producttypen. Hierbij speelt de verkoopmethode via de klok een belangrijke rol. Bedrijven met 'niche' producten hebben hogere vaste kosten, maar een hogere brutomarge maakt het financieren gemakkelijker.

\section{Slotconclusie}

De slotconclusie ter beantwoording van de hoofdvraag kan bevestigend zijn en luidt als volgt: het verschil in marktstructuur en marktgedrag in de sectoren glasgroenten en glassnijbloemen kan een betekenisvolle oorzaak zijn om het verschil in marktresultaat te verklaren.

Als we de positie en resultaten van de kleine veilingteler in de glasgroenten volgen na de integratie van de groothandel in de bedrijfsvoering van de afzetorganisatie, dan zien wij een productiebedrijf in de knel met gemiddeld lagere resultaten voor zowel de kleine veilingteler als zijn afzetorganisatie ten opzichte van de zelfstandige teler en zijn telersvereniging.

In de glassnijbloemen is de positie en het resultaat van de kleine veilingteler/klokveiler juist beter in vergelijking met eigen verkoop of verkoop via een telersvereniging.

De uitkomsten van dit onderzoek geven aan dat in de sector glasgroenten de zelfstandige telersvereniging, die al dan niet met de klassieke coöperaties samenwerkt, maar in ieder geval een eigen marketingbeleid ontwikkelt, de beste resultaten boekt. In de sector glassnijbloemen worden voor de veilingklok de hoogste marges behaald. Voor de sector glaspotplanten, waar de aard van het product duidelijk verschilt van de korter houdbare glasgroenten en glassnijbloemen, zijn te weinig gegevens beschikbaar om conclusies te trekken.

Woerden, oktober 2017 


\section{Summary}

\section{Introduction}

The expansion of the market area of the European Union has caused a strong increase of supply and demand of fresh horticulture products of the Dutch glasshouse sector on the European market. Consequently there is increased competition with companies from new European member states, producing against lower prices, as well as changes in production and sales structure. In the Dutch food horticulture sector this led to a large horizontal and vertical merger between most of the auctions and a number of large exporters. From 1996 to 1998 VTN/The Greenery changed from a co-operative auction into a co-operative trade organisation. In the floriculture sector only horizontal mergers took place between co-operative auctions. The wholesalers/exporters remained independent. At present there are two Flower Auctions, FloraHolland te Naaldwijk (market share 98\%) and Plantion in Ede (2\%).

\section{Central research question}

This thesis explores the development of market structure, market strategy and market results in the horticulture glasshouse sector over the last thirty-five years. The central research question is whether the difference in market structure and market strategy in the Dutch sectors of glasshouse vegetables and glasshouse cut flowers and pot plants is a significant cause to explain the difference in market results for the growers and their co-operative organisations.

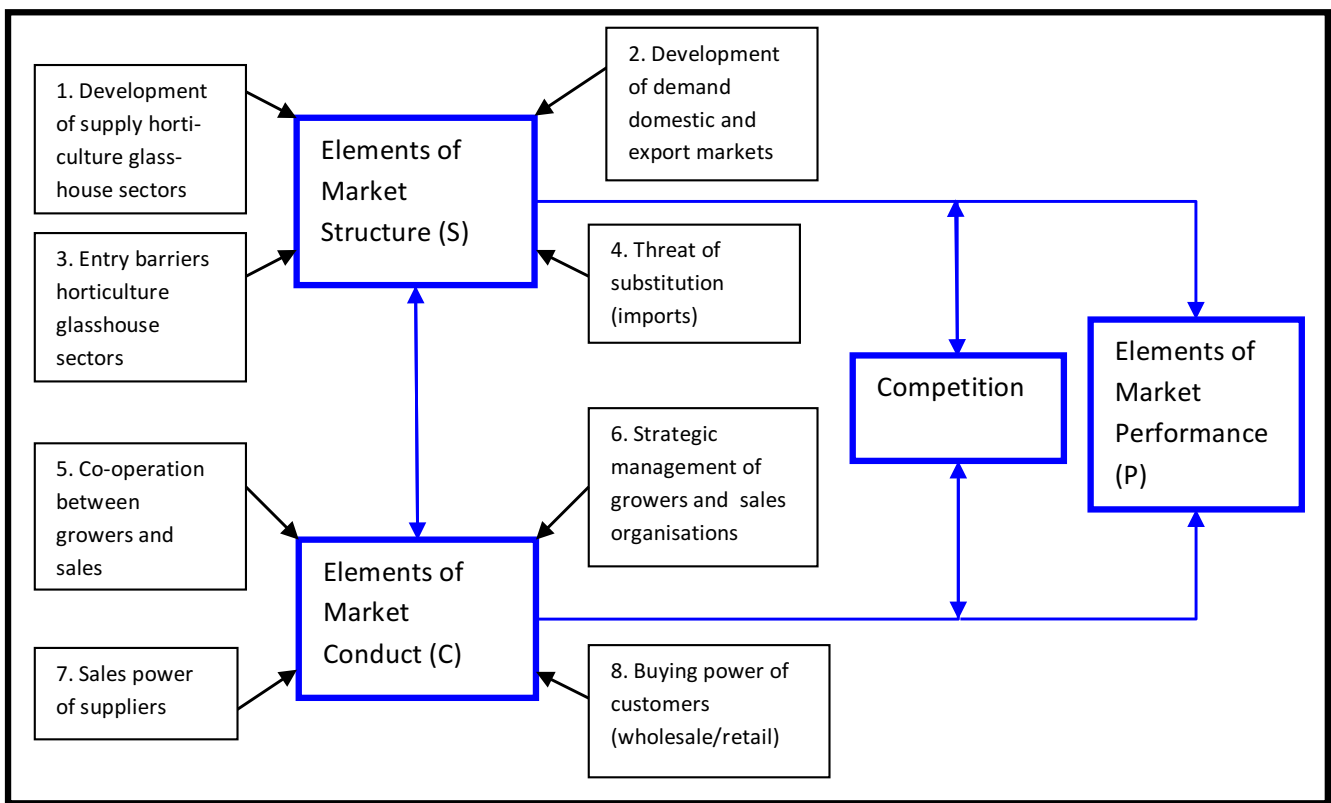

Figure 1.1 Conceptual model: competition, concentration and performance Dutch horticulture glasshouse sectors 
The conceptual model

A number of theories and models have been studied derived from the Industrial Organisation Theory. This theory focuses on the analysis of branches of industries, industry chains and markets involved. It examines the relation between market structure $(\mathrm{S})$, market conduct $(\mathrm{C})$ and market performance (P) through the SCP-model (in Dutch: SGR-model). A description and explanation is given of the static SCP-model of Bain, the dynamic SGR-model of De Jong and the branch-analysing models of Porter and Daems. The conceptual model of competition, concentration and performance (figure 1.1) has been constructed from these models to analyse the Dutch horticulture glasshouse sectors.

Research of producers, sector research and research of auctions/sales organisations

From 2006-2008 three research projects on producers were conducted amongst 40 growers of vegetables, 40 growers of cut flowers and 40 growers of pot plants, all under glass. Data and opinions of growers about their company, market strategy and performance were gathered. In the same period sector research of the development of total production, imports and exports took place in the three sectors of the glasshouse industry on sector level, on the level of sales organisations and the wholesalers/ exporters. The gathered data have been analysed and tested on selected variables. In three different chapters temporary conclusions have been drawn. The most important business and market characteristics and research outcomes are discussed in three separate tables at the end of these three chapters and the associated appendices. The research of producers was expanded in 2015/2016 on the basis of the data of the research 2006-2008 with econometric research and multiple analysis of a number of the most important variables of market structure and market conduct to explain the market results (Lerner Index).

Results of sector research

The three horticulture sectors under glass show a positive development in yearly production and export value over a period of thirty-five years, besides a small decrease in 2009 and 2011, as a result

Development of variables in Dutch horticulture glasshouse sector 1980-2016

\begin{tabular}{|c|c|c|c|}
\hline \multirow{2}{*}{$\begin{array}{l}\text { Sort of variable } \\
\text { Sector variables }\end{array}$} & Vegetables under glass & Cut flowers under glass & Pot plants under glass \\
\hline & & & \\
\hline $\begin{array}{ll}\text {-Production value } & (\mathrm{x} \in 1 \mathrm{mld}) \\
\text { Period } & 1980-2005 \\
\text { Idem } & 2006-2010 \\
\text { Idem } & 2011-2016 \\
& \\
\text {-Domestic share } & 2006-2010\end{array}$ & $\begin{array}{l}0.7-1.2 \text {; growing factor } 1.7 \\
1.3-1.5 \\
1.2-1.4 \\
82 \%-94 \%\end{array}$ & $\begin{array}{l}0.8-2.2 ; \text { growing factor } 2.8 \\
2.3-2.1 \\
2.0-2.2 \\
77 \%-75 \%\end{array}$ & $\begin{array}{l}0.2-1.5 \text {; growing factor } 7 \\
1.6-2.0 \\
2.0-2.0 \\
84 \%-86 \%\end{array}$ \\
\hline $\begin{array}{lr}\text {-Export value } & (\mathrm{x} € 1 \mathrm{mld}) \\
\text { Period } & 1980-2005 \\
\text { Idem } & 2006-2010 \\
\text { Idem } & 2011-2016 \\
& \\
\text {-Exportshare } & 2006-2010\end{array}$ & $\begin{array}{l}0.9-3.9 \text {; growing factor } 4 \\
3.4-3.9 \\
3.8-4.4 \\
68 \%-72 \%\end{array}$ & $\begin{array}{l}0.7-3.1 \text {; growing factor } 4.5 \\
3.2-3.2 \\
3.5-3.5 \\
88 \%-91 \%\end{array}$ & $\begin{array}{l}0.2-1.7 \text {; growing factor } 8 \\
1.8-2.0 \\
2.0-2.2 \\
73 \%-68 \%\end{array}$ \\
\hline
\end{tabular}


of the banking and EHEC crisis. In the Dutch floriculture sector the average growing figures are a bit higher than in the food horticulture sector because of a stronger yearly increase in the production of pot plants. In all three sectors the production and export values are increased almost every year until the banking crisis in 2009. After 2010/2011 the sectors have been recovering.

The sector cut flowers under glass show a decrease of area and production ( $\mathrm{m}^{2}$ glass $)$ in The Netherlands. However, there is an increase of import and direct supply of cut flowers from foreign growers and Dutch companies from the southern part of Africa (roses, chrysanthemums etc.). All sectors profit from the growing import/re-export function of vegetables and fruit, cut flowers and pot plants from The Netherlands to neighbouring countries and trade partners in Europe. The high share of the sector variables domestic share and export share in all three sectors stimulate the development of production value, export value and prices.

Results of research into auctions/sales organisations

In the food horticulture and floriculture sectors there has been quite a difference in market strategy and market structure since 1998. In the sector vegetables under glass the degree of concentration of the four largest sales organisations (C4) has decreased to the level of before the merger $(60 \%)$. In 1997 this figure was $96 \%$. Also the share of growers of VTN/The Greenery in the area of Dutch vegetables under glass has decreased. VTN/The Greenery did not reach her target of 1996 with their strategy of horizontal and vertical concentration: organizing a larger bundling of the turnover of the Dutch auctions and wholesalers/exporters.

The search for a good working integration of horticultural production and trade in one company with an efficient and effective structure has not been completed yet and started in 2016 with a new sales organisation. The financial position of VTN/The Greenery on the European market is not strong. Since 1996 the annual turnover has strongly fluctuated between 0.9 and 1.5 billion euros, with a variation range of 25 to $30 \%$. The supply of their own members halved, just like the income out of commission. The position on the Dutch market is stable, on the most important European markets difficult. The return on investment is low. In 2015 and 2016 a careful recovery started after the difficult years of crisis 2009, 2011 and 2013.

Flower auctions FloraHolland and VBA showed a clear strategy and good results around the merger of 2007. The merger was a good example of a carefully implemented strategy of horizontal concentration, bringing together the interests of the flower auctions and their members. For FloraHolland the period of the crisis 2009-2011 was a test with success.

There was an expansion of horizontal concentration across the borders: a new joint venture auction Rhein-Maas, founded together with the German organisation Landgard and there was an integration with the import auction TFA in Aalsmeer. Both organisations are important for the market position of FloraHolland. In the Dutch floriculture sector under glass there are hardly any examples of vertical concentration of producers or sales organisations with wholesalers/ exporters. There are examples, though, of vertical co-operation between these organisations and international retail, especially with the larger growers of pot plants. 
The auction clock, physical and digital, is the most important sales method the flower auctions use daily. For most products there is a public pricing system. It provides a transparent process of supply and demand against sharp tariffs of the auction. For cut flowers as well as for pot and garden plants a large part of the product groups are sold by way of the auction clock, which mostly ensures a reliable reference price for mediation and personal selling and provides a good match of supply and demand and a 'clean' market. Attention to strengthen the position of the auction clock, especially with the selling of pot and garden plants, is important. The turnover of FloraHolland decreased in 2009 (bank crisis) and increased in 2010 and 2011 just above the level of 2008. Incomes out of services dropped.

As costs decreased more than incomes, profits and solvency improved in this period.

In 2012 FloraHolland realised a turnover increase of 3\% compared to 2011 . However, the incomes out of services decreased. In 2013 the sector performed reasonably. The turnover of FloraHolland increased slightly but costs were higher than incomes and FloraHolland had an exploitation loss. 2014 was a year of slight recovery, 2015 and 2016 ended with an increasing turnover of 3 and 4\%. Profit after tax in these years are 12 and 3 million euros. For most of the growers and customers the results in 2015 and 2016 were positive. The decision of the wholesale/export (VGB) to contribute again in the promotion costs of Bloemenbureau Holland was welcomed very positively. Along with the new strategy of 2020 FloraHolland is working on the strengthening and expansion of the physical and digital market places.

\section{Research results of producers}

On producers level there is also quite a difference in market strategy, structure and results between growers in the sectors of glasshouse vegetables and glasshouse cut flowers and pot plants. At present there is a fierce struggle to survive in each sector. It seems that the small grower of cut flowers and pot plants stands a better chance than the small grower in vegetables. The most striking single relations between structure, conduct and result will be mentioned.

- Most striking single relations glasshouse vegetables

- The small company has relatively higher costs than the larger types. If the sales organisation uses the principle of 'the user pays the total costs made' this burden is rather heavy for the smallest companies.

- Auction growers mainly deliver round or grape tomatoes, the majority of independent growers choose for the special varieties. This influences the pricing process.

- Small and large auction growers differ significantly in business size from independent growers, but realise comparable margins. Large-scale production does not always lead to lower average costs and a better margin, but it does entail a greater risk of too much supply and low prices. Growers with a larger business size are faced with larger financial problems in difficult years than smaller ones.

- Horizontal concentration of the four largest growers of vegetables lies at a low level and their sales power is low. The concentration of the four largest sales organisations is about $60 \%$.

- Vertically integrated auction growers are smaller in business size and invest less than non- integrated independent growers. They realise comparable margins. 
- The importance of the sales organisation to realise good prices and margins for the members' products seems rather small. Sharp purchase prices are of equal importance for the trade organisation and influence the margin of the members.

- Higher investments don't produce higher results (directly). More innovative investments are needed to improve prices and margins.

- Most striking single relations glasshouse cut flowers

- The small auction grower realises an expected smaller turnover and pays higher commission than the larger auction grower, member of a growers organisation. Although there is no significant relation between grower type and realised margin, higher commission can lead to higher prices and margins. Besides the higher price level, smaller growers realise a higher solvency than larger growers.

- Growers of roses under glass realise a higher margin than growers of chrysanthemums because of a wide and deep assortment.

- Small growers of cut flowers show comparable or better results than the larger ones.

- Horizontal concentration of the four largest growers of cut flowers lies, just like the sectors of vegetables and pot plants under glass, at a low level. The small auction grower has little market power and needs the sales organisation for reasonable prices and successful sales.

- There are no significant relations between the organisation of sales and growers' turnover, realised margin and the height of commission. It looks as if every grower uses his own mix of marketing and sales activities in a way that no significant differences in results arise.

- Selling of cut flowers by means of the auction clock gives good results.

- Most striking single relations glasshouse pot plants

- The smaller auction grower, with or without personal selling, realises an expected smaller turnover but a higher margin than the larger auction grower, member of a growers organisation.

- Smaller growers (in $\mathrm{m}^{2}$ glass) get higher results or results comparable to those of the larger ones. Old and new companies get comparable margins.

- Growers of green plants get a significant lower yearly turnover than growers of blooming pot plants. Green plants are often more unique than blooming plants. That is why growers of green plants get higher prices and margins.

- Horizontal concentration of the growers of pot plants lies, just like in the other sectors, at a low level. The small auction grower has little market power and needs the sales organisation for realising reasonable prices and successful sales.

- Like in the other sectors the small grower invests less in his business than the larger ones. Higher investments do not directly produce higher results. More innovative investments are needed to improve prices and margins.

- There is a significant relation between the organisation of sales and the yearly realised turnover: larger growers use more personal selling besides the sales services of the auction, as their own business activity or as an activity of the growers organisation.

Boarding out all sales activities to FloraHolland is effective especially for the small grower 
and enlarges the chance of realising a higher margin. Although he pays a higher commission, he realises a higher margin because of the positive relation between commission and margin.

Producers results through econometric research

- Most striking multiple relations glasshouse vegetables

The results of the econometric analysis show that in the sector glasshouse vegetables membership of a growers association produces better results on average than membership of a traditional marketing corporation. Especially young producers with new ideas about the organisation of the company and vertical co-operation with on average large and modern companies are booking the best results.

- Most striking multiple relations glasshouse cut flowers

Auction growers using the auction clock exclusively to sell their products realise a higher margin on average than growers using other selling methods.

The membership of a growers association produces higher results on average than no membership and smaller companies get higher margins than large ones. Senior growers get higher results than junior growers. The auction clock is the best guarantee for realising higher margins. It seems that in the sector cut flowers a larger scale has less effect on the margin than producing 'niche' product types. For the latter the selling method via the auction clock plays an important role. Companies with 'niche' products have higher fixed costs although a higher margin gives fewer problems when it comes to finance the production.

Final conclusion

The answer to the central question confirms the following: the difference in market structure and market strategy in the Dutch sectors of glasshouse vegetables and glasshouse cut flowers is a significant cause to explain the difference in market results. If we follow the position and the results of the small grower in the sector glasshouse vegetables, we are looking at a producer in a tight spot with lower average results for the grower and his co-operation in comparison with the independent grower and his grower association. In the sector glasshouse cut flowers the position and results of the small auction clock grower is better in comparison with the grower who sells on his own or via a growers association.

The results of this research indicate that in the sector glasshouse vegetables the highest margins are obtained by the independent growers associations, working either cooperativly with the classical co-operations or independent there from but in any case with their own marketing strategy. In the sector glasshouse cut flowers it is the grower selling through the auction clock who gets the highest margins. In the sector glasshouse pot plants, where the type of the product clearly differs from the perishable vegetables and cut flowers, there are too few data to draw conclusions. 
